

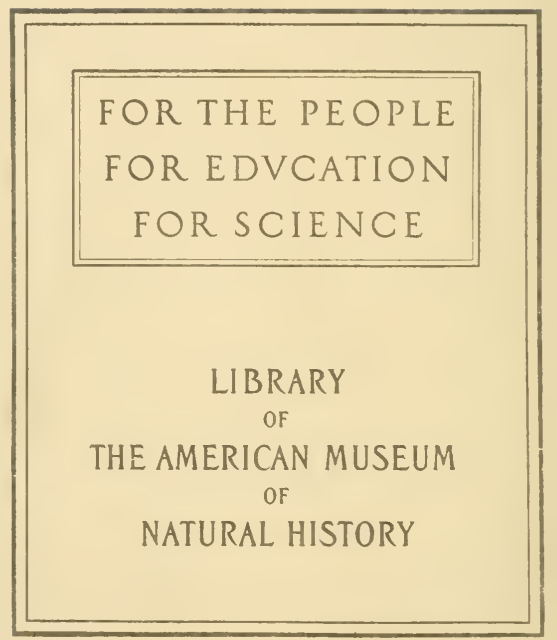








\section{BIRDS OF CALIFORNIA}




\section{By Mrs. WhelLock}

NESTLINGS OF FOREST AND MARSH

With 12 full-page photogravures and nearly 60 text illustrations from original photographs. $12 \mathrm{mo}$. 257 pages. $\$ 1.00$

A. C. Miclurg \& CO. 


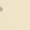




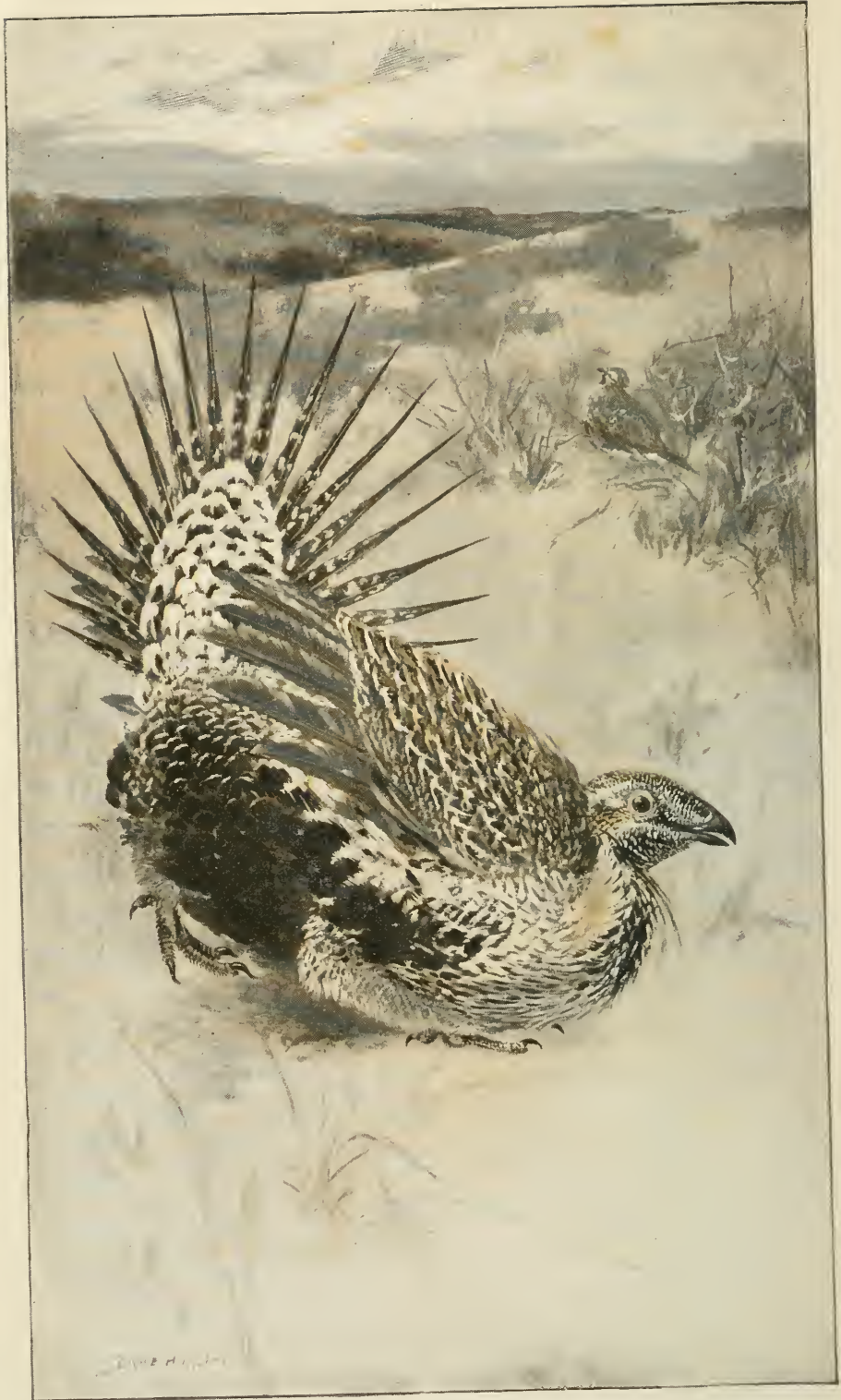

309. Sage Grouse 


\section{BIRDS OF CALIFORNIA}

AN INTROIDUC'TION

TO MORE THAN THREE HUNDRED COMMON BIRDS OF THE STATE AND ADJACENT ISLANDS

WITH A SUPPLEMENTARY LIST OF RARE MIGRANTS, ACCIDENTAL VISITANTS, AND HYPOTHETICAL SUBSPECIES

BY

IRENE GROSVENOR WHEELOCK

AUTHOR OF "NESTLINGS OF FOREST AND MARSH"

$+1, \quad \leq(79 \cdot 4)$

WITH TEN FULL,PAGE PLATES AND SEVENTY-EIGHT DRAWINGS IN THE TEXT BY BRUCE HORSFALL

Third Edition

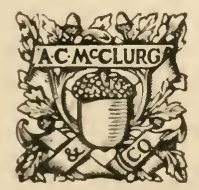

C H I C A G O

A. C. M C C L U R \& C O.

1912 


\section{Copyright}

\section{A. C. McClurg \& Co. \\ 1903}

Published February 20, 1904

$-15.69065 \mathrm{hec} 29$ 
MY MOTHER 



\section{NOTE OF ACKNOWLEDGMENT}

WHILE, in the preparation of this work, I have met with universal kindness from the everhospitable Californians, my especial thanks are due to members of the Cooper Club and to Dr. David Starr Jordan, of Leland Stanford University, for many courtesies extended and kindly encouragement given. For advice and assistance I am also indebted to Mr. Chas. F. Lummis, Mr. Leverett M. Loomis, Mr. John Muir, Mr. Joseph Grinnell, Mr. H. R. Taylor, and the late Chester A. Barlow. But it is to my fellow-student and co-laborer, my husband, Mr. Harry B. Wheelock, that I owe most. With untiring patience he has read manuscript, checked lists, and corrected errors, thereby making it possible. for me to go on in the face of many obstacles.

I. G. W. 



\section{N TRODUCTOR Y}

CALIFORNIA is the land of sunshine, flowers, and bird song. In the great sweep of country from Mexico on the south to Oregon on the north are found climatic conditions ranging from the Aretic circle to the tropics. The valleys blossom with roses, while the mountains are crowned with perpetual snow. Hence we find a flora and fauna as unique as the climate. It is the paradise of the bird-lover as well as of the tomrist. Birds of the Torrid Zone come here; birds of Alaska winter here; birds from the mountains come down into the valleys. There is a constant movement north and south, a lesser one vertically from the warm lowlands to the colder altitudes, or vice versa.

To live among these fascinating feathered folk and not long to know them, one must have eyes that see not and ears deaf to Nature's music. Yet the bird-lover who wishes to enjoy an aequaintance with them without scientific study finds his road beset with difficulties. From the scientific works that seem to him hopelessly abstruse he turns to the "popular" bird book, which is delightful but does, not help him to 
identify his "bird neighbors." It is in the hope of meeting this need and affording an introduction to the birds more commonly found in California that this non-technical work is offered. Keys have been avoided and a simple classification, according to habitat or color, substituted, following the excellent plan used by Neltje Blantjan, which has never been excelled for easy identification.

In selecting these three hundred from the five hundred varieties listed as occurring within the confines of the State and adjacent islands, no arbitrary rule has been followed, the author being guided by her own experience in field work among them. During a test study in 1902, the ground covered was from Mexico to Oregon, and from the islands off the coast to the eastern slope of the Sierra Nevada; and in this, two hundred and forty odd species were commonly met with, while the others were by no means rare. The observations were made in the desert region along the California side of the Colorado River, and at Tia Juana, San Diego, Riverside, Redlands, Pasadena, San Pedro, Santa Catalina, in the Santa Cruz Mountains, Monterey, Pacific Grove, Palo Alto, Alviso, San Francisco Bay region, Martinez, the Farallones, Mt. Tamalpais, Mt. Shasta, Sacramento, Slippery Ford, Lake Tahoe, Fallen Leaf Lake, Eagle Lake, and Lake Tulare. This list is given for the benefit of bird-loving tourists who may wish to do likewise. 
Of the birds occurring in the State and not mentioned in this volume forty are ducks and geese, the rest being either rare migrants or subspecies, confusing to the observer and usually impossible to differentiate without a gun. The seabirds, usually omitted from non-technical bird books in the East, are so conspicuous a part of California Avifauna that no work on the subject would be complete without them.

Field notes begun in 1894, and made with the aid of powerful binoculars, form the basis of the following pages. The books used for reference, wherever the author's personal observations were unsatisfactory, are "Ridgway's Manual of North American Birds," Bendire's "Life Histories," Loomis's "Water Birds of California," Mrs. Bailey's "Manual of Birds of the Western United States," Davie's "Nests and Eggs of North American Birds," "The Condor," "The Auk," "The Nidologist," Nelson's "Report of Birds of Alaska," and Mr. Grinnell's "Check-list of California Birds." The check-list numbers and nomenclature of the American Ornithologist Union have been strictly adhered to.

No originality is claimed for the technical descriptions of the birds, as on this point the author has drawn freely from standard authorities, oftentimes verbatim, when a personal examination of specimens was impossible. 
It has been a difficult matter to collect facts for the breeding range and season because there is no published data on the subject; but the work has been conscientiously done, and every precaution taken to prevent possible errors. The dates given include the earliest and latest at which eggs or newly hatched young are usually found. It will be seen from this that especial attention has been given to the habits of each species during the reproduction period, including nest-building, incubation, care of the young, etc., all of which, unless otherwise accredited, has been taken from the author's own notes.

Long and careful study of the feeding habits of young birds in California and the Eastern United States has led the author to make some statements which may incur the criticism of ornithologists who have not given especial attention to the subject. For instance, - that the young of all macrochires, woodpeckers, perching birds, cuckoos, kingfishers, most birds of prey, and many seabirds are fed by regurgitation from the time of hatching through a period varying in extent from three days to four weeks, according to the species. Furthermore, that birds eating animal flesh or large insects give fresh (unregurgitated) food to their young at a correspondingly earlier stage of development than do those varieties which subsist on small insects or seeds. Also, that exclusive seed eaters are usually fed by regurgitation so long as they remain in 
the nest. Out of one hundred and eighty cases recorded by the author, in every instance where the young were hatched in a naked or semi-naked condition they were fed in this manner for at least three days. In some instances the food was digested, wholly or in part: in others it was probably swallowed merely for convenience in carrying, and was regurgitated in an undigested condition. There seemed to be no definite relation between the duration of the period of regurgitative feeding and the length of time required for the full development of the fledgeling. Young vultures were fed in this way for ten days, and stayed in the nest nine weeks. Young robins received their food by this process three, occasionally four, days, and usually took flight on the fifteenth day. Humming-birds, swallows, and a few others are fed by regurgitation so long as they remain in the nest. Goldfinches, waxwings, and others are nourished in this way, with an occasional meal of raw food, until they are ready to fly. The list is a long one, and as most if not all of these instances are mentioned in their individual biographies, given in this rolume, they need not be cited here. Scientists have long known that pigeons, doves, and humming-birds feed their young in this manner, and the discovery that most species do likewise need cause no surprise.

Irene Grosvenor Wheeluck.

Ситеяо, January I, 1904. 


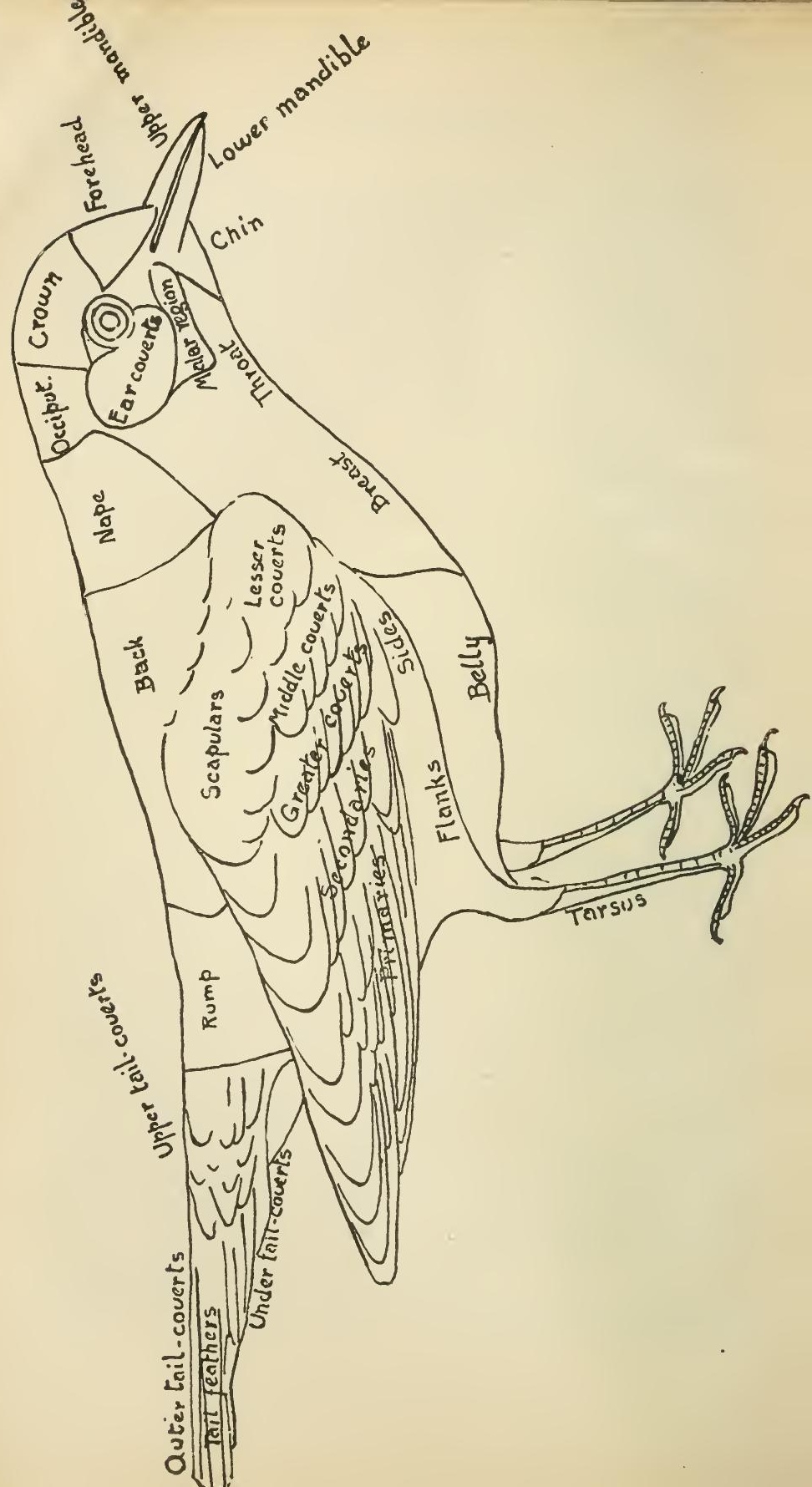




\section{IDENTIFICATION}

THE accompanying chart of a bird will explain the terms used in the descriptions. "Upper parts" refers to the entire upper surface of the body of the bird from the bill to the tail. In the same manner, "Under parts" refers to the under surface.

In identifying, decide first into which class the bird you are observing is likely to belong, - that is, whether land or water birds. If water, whether it is found on the open sea, or near shore, or in bayous or marshes, and whether it is a swimmer or a wader, anc then look for it in the list where you think it may belong. Always ascertain as near as you can the bird's length, and remember, in judging length, that a bird usually looks smaller than he actually measures. If the bird is among the land birds, and is neither a game bird nor a bird of prey, trace it down in the color classification. 


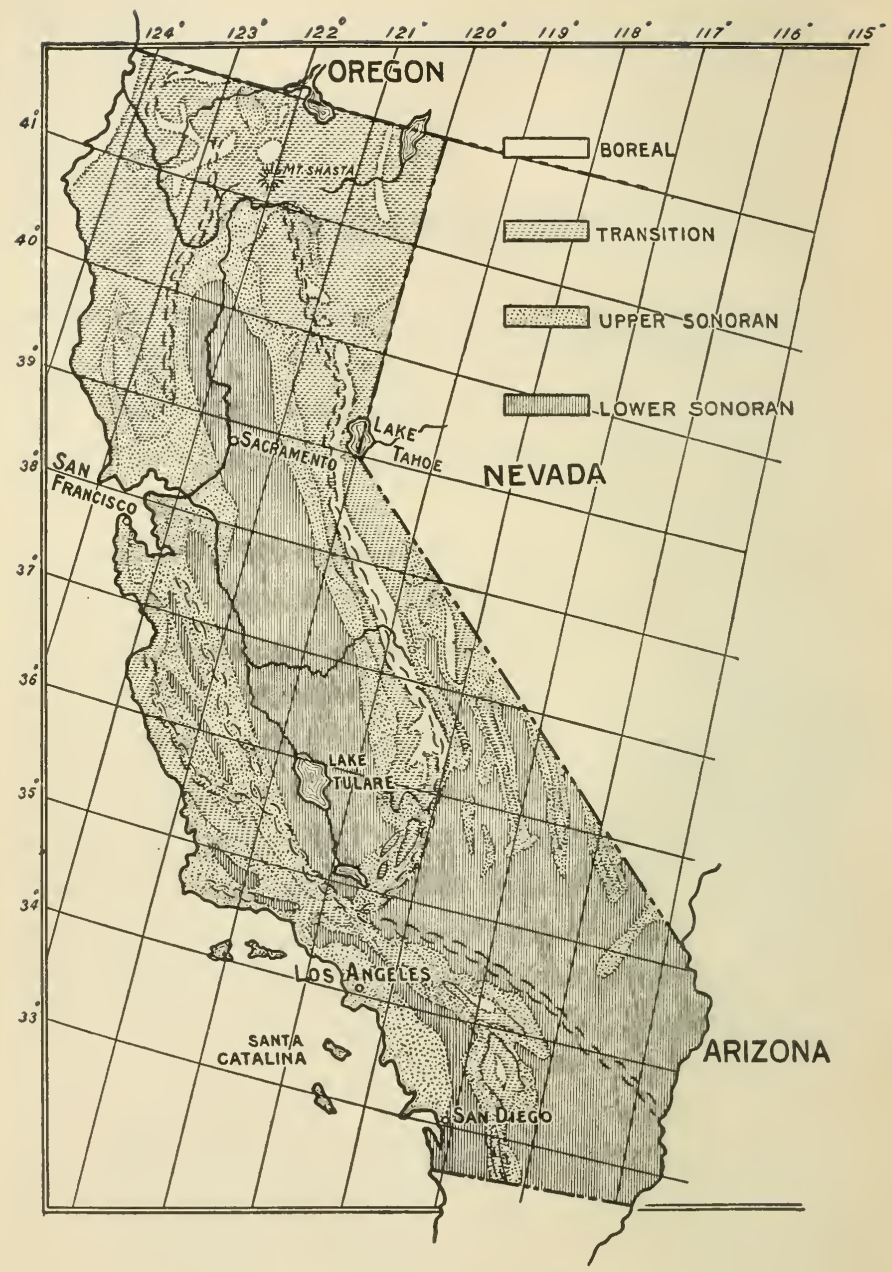




\section{USE OF THE MAP}

The four Life Zones indicated on the accompanying map are those mentioned in the data given under the headings Geographical Distribution and Breeding Range. They represent climatic conditions of temperature in the regions indicated. The "Boreal" extends from the treeless, snowclad summits, far above the timber-line down throngh the coniferous forests. Next in coldness is the "Transition," which begins at the Yellowpines, overlapping the Boreal a little, and containing some species of oaks, buckbrush, manzanita, and some sagebrush. Lying between the Transition and the almost tropical heat of the "Lower Sonoran" is the "Upper Sonoran," where we find the juniper, oaks, piñon pines, and sagebrush. Last of all, the "Lower Sonoran" is the warmest. In it lie the hot valleys and desert regions of California, and here flourish the lire oaks and mesquites. Many California birds migrate from one to another of these zones between breeding seasons, as the birds of the Eastern United States migrate north and south. This changing from lower to higher altitude, or the reverse, is termed vertical migration. 



\section{CON T E N T S}

\section{PAR'T I.-WATER BIRDS}

\section{BIRDS OF THE OPEN SEA}

Tufted Puffin ․ . . . . 3 Black-footed Albatross . . 17

Rhinoceros Anklet . . . . 5 Short-tailed Albatross . . 18

Cassin Auklet . . . . . 6 Pacifie Fulmar . . . . . 19

Ancient Murrelet . . . . 7 Black-vented Shearwater . . 20

Marbled Murrelet . . . . 10 Dark-bodied Shearwater . . 21

Xantus Murrelet . . . . 11 Kaeding Petrel . . . . . 22

Pigeon Guillemot . . . . 12 Black Petrel . . . . . 23

California Murre . . . . 13 Ashy Petrel . . . . . . 24

Parasitic Jaeger . . . . . 16 Man-0'-War Bird . . . . 26

BIRDS FOUND NEAR THE SHORE OR IN BAYS

Loon . . . . . . . . 27 Forster Tern . . . . . . 44

Pacific Loon . . . . . 30 Least Tern . . . . . 45

Red-throated Loon . . . . 31 American Black Tern . . 46

Glaucous-winged Gull . . . 32 Farallone Cormorant . . 48

Western Gull . . . . 31 Brandt Cormorant . . . 50

Herring Gull . . . . . . 37 Baird Cormorant . . . . 52

California Gull . . . . . 39 American White Pelican . . 53

Ringr-billed Gull. . . . . 40 California Brown Pelican . . 55

Heermann frull . . . . . 41 Whistling Swan . . . . 56

Bonaparte Gull . . . . . 42 Trumpeter Swan . . . . 57

Royal Tern . . . . . . 43

BIRIS FOINI) ALONG THE BEACHES

Wilson Phalarope . . . . 5

American $A$ rocet . . . . 60

Black-necked Stilt . . . . 62

Long-billed Dowitcher. . . 63

Least Sandjiper, or Mralow

Oxeye
Pierl-backed Sandpiper, or Ox Bird . . . . . . . 66

Western Samilyiper . . . 67

Sanderling . . . . . 68

Greater Yellow-legs. . $\quad 69$

Wandering Tattler . . . 71 
Spotted Sandpiper .

72 Black-bellied Plover . . 76

Long-billed Curlew, or Sicklebilled Curlew . . . . Hudsonian Curlew, or Jack Curlew Killdeer *. . . . 77 73 Snowy Plover . . . 78 Black Turnstone 。 . . 80 75 Black Oyster-catcher . . . 81

\section{BIRDS FOUND IN BAYOUS AND MARSHES}

Western Grebe .

82 Anthony Green Heron

Anerican Eared Grebe . . 84

Pied-billed Grebe . . . . 86

White-faced Glossy Ibis . . 88

Ameriean Bitteru . . .

Least Bittern . . . . . 91

Treganza Blue Heron, or

Blue Crane

84 Black-crowned Night Heron

97

88 California Clapper Rail . 99

90 Virginia Rail . . . . 101

91 Sora, or Carolina Rail . . 102

California Black Rail . . 104

93 Florida Gallinule, or Red-

American Egret . . . . 94 billed Hnd-hen . . . 105

Snowy Heron . . . . 95 American Coot . . . . . 107

\section{PAR'T II. - LAND BIRDS}

\section{I. - UPLAND GAME BIRDS}

Wilson Snipe . . . . . 111 Gambel Partridge . . . . 122

Mountain Plover . . . . 113 Sierra Sooty Grouse . . . 124

Mountain Partridge . . . 114 Oregon Ruffed Grouse . . 126

Plumed Partridge . . . . 115 Sage Grouse . . . . . . 127

California Partridge . . . 118 Band-tailed Pigeon . . . 130

Valley Partridge . . . . 120 Mourning Dove . . . . 132

\section{II. - BIRDS OF PREY}

California Vulture, or Condor 134 Swainson Hawk . . . . 150

Turkey Vulture . . . . $136 \quad$ Ferruginous Rongh-leg . . 153

White-tailed Kite . . . . 138 Goldeu Eagle . . . . . 154

Marsh Hawk . . . . . 139 Bald Eagle . . . . . . 156

Western Sharp-shinned Duck Hawk. . . . . 158

Hawk . . . . . . 142 Pigeon Hawk . . . . . 159

Cooper Hawk . . . . . 143 Desert Sparrow Hawk . . 161

Prairie Falcon . . . . 145 Fish Hawk, or American

Western Red-tailed Hawk . 147 Osprey . . . . . . . 163

Red-bellied Hawk . . . . 149 American Barn Owl . . 166 
American Long-eared Owl . 168 Pacific Horned Owl . . . 173

Short-eared Owl . . . . 169 Burrowing Owl . . . . 175

California Screech Owl . . 171 Pygmy Owl . . . . . 178

\section{III. - COMMION LAND BIRDS IN COLOR GROUPS}

\section{With Brown Predominating in Plumage}

Road-runner . . . . . 181

California Cuckoo .

Rerl-shafted Flicker

I) usky Poorwill, or California

Poorwill

California Nighthawk

Texan Nighthawk . .

Say Phoebe

Western Wood Pewee

Pallid Horned Lark, or Des-

ert Horned Lark

California Hornerl Lark .

Rinddy Horned Lark . .

Streaked Horned Lark .

Gray-crowned Leucosticte

Pine Siskin, or Pine Finch .

Western Vesper Sparrow.

Western Savanna Sparrow

Bryant Marsh Sparrow.

Belding Marsh Sparrow .

Large-billed Sparrow .

Western Grasshoppersparrow

Western Lark Sparrow

White-crowned Sparrow .

Gambel sparrow, or Intermediate Sparrow

Nuttall sparrow

fiolden-crownel sjarrow.

Western Chipping Sparrow.

Brewer Sparrow

Black-chinned sparrow

Thurber Junco, or Sierra Junco

Point Pinos Juneo .
185

158

192

194

197

199

202

204

208

208

209

209

211

213

215

216

217

218

219

221

$2 \cdot 22$

$2 \cdot 24$

225

225

225

228

230

231

234
Bell Sparrow

Sage Sparrow

Rufous-crowned Sparrow.

Desert Song Sparrow .

Mountain Song Sparrow . . 242

Heerman Song Sparrow . . 243

Samuels Song Sparrow . . 243

Rusty Song Sparrow . . . 244

Lincoln Sparrow . . . . 244

Townsend Sparrow . . . 245

Thick-billed Sparrow . . . 247

Stephens Sparrow . . . . 248

Californian Towlee . . . 248

Anthony Towhee . . . . 250

Green-tailed Towhee . . . 251

Black-headed Grosbeak . . 253

Cliff Swallow . . . . . 256

Rough-winged Swallow . . 258

Cedar Waxwing . . . . 259

American Pipit . . . . . 262

Water Ouzel, or American

Dipper. . . . . . 264

Sage Thrasher . . . . . 268

Californian Thrasher . . . 270

Pasadena Thrasher. . . . $2 \pi 2$

Leconte Thrasher . . . . 273

Crissal Thrasher . . . . 274

Cactus Wren . . . . 276

Rock Wren . . . . . 279

Cañon Wren . . . . 281

Dotted Canon Wren . . . 282

Vigors Wren . . . . 2 2st

Parkman Wren, or Pacitic

House Wren. 
Western Winter Wren

Tule Wren

Interior Tule Wren, or Western Marsh Wren

Californian Creeper . . . 293

Sierra Creeper . . . . . 293

Pallid Wren-tit. . . . . 296

Californian Bush-tit . . . 298

Chestnut-backed Chickadee . 301
Coast Wren-tit . . . . . 302

289 Townsend Solitaire . . 303

Russet-backed Thrush . . 306

Andubon Hermit Thrush, or

Sierra Hernit Thrush . . 307

Dwarf Hernit Thrush . . 309

Western Robin . . . . . 309

Varied Thrush . . . . . 311

\section{IVith Dusky, Gray, and Slate-Colored Plumaye}

\begin{tabular}{|c|c|c|c|c|}
\hline Belted Kingfisher . & & 313 & Western Mockingbird & 340 \\
\hline Vaux Swift. . & & 317 & Slender-billed Nuthatch & 342 \\
\hline Arkansas Kingbird & . & 318 & Red-breasted Nuthatch & 344 \\
\hline Cassin Kingbird . . & & 322 & Pygmy Nuthatch . . & 345 \\
\hline Ash-throated Flycatcher & & 324 & Plain Titmouse. . & 348 \\
\hline Oregon Jay . . . . & & 327 & Mountain Chickarlee . & 350 \\
\hline Clarke Nutcracker. & & 329 & Californian Chickadee & 353 \\
\hline Oregon Junco . . & & 333 & Learl-colored Bush-tit. & 354 \\
\hline Bank Swallow . . & & 334 & Western Gnatcatcher . & 356 \\
\hline White-rumped Shrike & & $336^{\circ}$ & Black-tailed Gnatcatcher & 358 \\
\hline California Shrike. . & & 337 & & \\
\hline
\end{tabular}

\section{Plumage Conspicuously Black and White}

Harris Woodpecker . . . 360

Cabanis Woodpecker . . . 361

Gairdner Woodpecker . . 363

Nuttall Woodpecker . . . 364

White-headed Woodpecker . 366

Arctic Three-toed Woodpecker . . . . . . 368

Williamson Sapsucker . . 370

Northern l'ileated Woodpecker.

Californian Woodpecker . 376

Gila Woodpecker . . . 378
White-throated Swift . 379

Western Black Phœbe . . 381

Black-billed Magpie . . . 383

Yellow-billed Magpie • • 387

White-necked Raven . 389

Bobolink . . . . . . 390

Spurred Towhee . . . . 393

Oregon Towhee. . . . . 394

Lark Bunting . . . . . 396

Phainopepla . . . . . 398

Black-throated Gray Warbler 401

\section{Plumage Black or Iridescent Black}

Black Swift

American Raven

Western Crow
Cowbird .

Brewer Blackbird .

408 Western Martin
415 
Plumage Green, Greenish Gray, and Olive

Black-chinned Hummingbird

Costa Hummingbird

Anna Hummingbird

Rufous Hummingbird

Allen Hummingbird

Calliope Hummingbird

Olive-sided Flycatcher

Western Flycatcher

Traill Flycatcher

Hammond Flycatclier

Wright Flycatcher
Northern Yiolet-green Swallow

433

436

439

441

442

\section{Red Conspicuous in P. umuge}

Red-breasted Sapsucker .

462 Bicolored Blackbird

Lew is Woodpecker . . . 465

Tricolored Blackbird .

475

Vermilion Flycatcher.

466

San Diego Red-winged Blackbird .

Sonoran Redt-winged Blackbird .

California Pine Grosbeak . . 476

California Purple Finch . . 478

Cassin Purple Finch . . . 480

House Finch, or Linnet . . 481

Bendire Crossbill . . . 483

\section{Blue or Metallic Blue Conspicuous in Plumage}

Grinnell Jay

Blue-fronted Jay . . . . 489

California Jay . . . . 490

Piñon Jay . . . . . . 493

Western Blue Grosbeak . . 496

Lazuli Bunting
Barn Swallow . . . . 500

White-bellied Swallow, or Tree Swallow . . . . 502

Westęrn Bluebird . . . 505

Mountain Bluebird . . . $506^{\circ}$

\section{Yellou or Orange Conspicuous in Plumage}

Yellow-headed Blackbird

Western Neadowlark . . 511

Scott Orinle . . . . . . 514

Arizona Hooded Oriole . 517

Bullock Oriole . . . . . 519

Western Eveuing Grosbeak . 523

Willow Goldfinch . . . 525

California Goldfinch
Lawrence Goldfinch

Louisiana Tanager, or Westeru 'l'inagere .

Calaveras Warbler" .

California Yellow Warbler

Yellow-rmuped Warbler, or

Myrtle Warbler

Audubon Warbler . 
Townsend Warbler . . . 540 Long-tailed Chat . . . 549

Hernit Warbler . . . . 542 Golden Pileolated Warbler : 552

Macgillivray Warbler. . . 545 Verdin . . . . . . 554

Pacific Yellow-throat . . . 546

SUPPLEMENTARY LIST . . . . . . . . . . 559

INDEX . . . . . . . . . . . 。 . 569 


\section{LIS'T OF IILUSTRATIONS}

PAGE

SAge Grouse

Frontispiere

Idextification Chate of Bird . . . . . . . . . . . xir

MLA of ZoNes . . . . . . . . . . . . . . . . . Xvi

Tufted Puffis. "As a puppy enjoys a bone" . . . . . . 4

Axcinst Murrelet. "If a white-cap developed near them, they would ahways escape it by diving" . . . . . . . . . . 8

Pigeos Guillemot. "The Baby Guillemot” . . . . . . 12

Ashy Petrel. "The playmate of the grim old sea" . . . . 25

Loos. "The young loous are taken into the water". . . . . 29

WfSTERN GuLL. "The young gull is taught to fish" . . . . 35

American Black Terx. "As it picks dragon-flies from the low rushes" . . . . . . . . . . . . . . . . . $4 \pi$

Brandt Cormorant . . . . . . . . . . To face page 50

Wilson Pilalarope. "Picking up their own food before they were ten hours old" . . . . . . . . . . . . . . . 59

SANDERling. "A game of tag with the ocean" . . . . . . 69

Hudsonian Cerlew. "When alighting" . . . . . . . 75

American Eared Grebe. When tired, they are given a ride on the mother's back . . . . . . . . . . . . . . 85

White-FACED Glossy IBIs. "Watching for minnows in the shallow water" . . . . . . . . . . . . . . . 89

VIRGINi RaIL. "Picking his way cautiously between the tules" 101

Califoria Partidide. "It haunts the canous and slopes" . 119

Moursixg Dove. "A platform of sticks" . . . . . . . 133

California Vulture, or Condor . . . . To face page 134

White-tailed Kite. "Preying upon the field mice" . . . . 139

l'rairie Falcon. "Not even the bald eagle? can strike such terror to a flock of grouse" . . . . . . . . . . . 146 
SwaIssox Hawk. "Wait silently until the prey appears"

Burrowixg OwL. "They converse in soft love notes"

ROAD-RUNNER

To face page

California Cuckoo. "He was busy feasting where the tent caterpillars nested"

Nighthawk. "Crept back as often as she was driven away"

SAY Phøвe. "The industrious little mother repairs the nest"

GRAY-CROWNed Leccosticte. "Searching in the snow for beetles and bugs" .

LARGE-BILLED SPAIROW. "It ham th the wharves and breakwaters"

Western Lark SPARrow. "The singer"

Golden-Crowned Sparrow. "Their food is chiefly weed seeds and winter berries"

Thurber Junco. "They protested with plaintive calls" . . . 232

SAGE Sparrow. "He sings to his mate, not to you" . . . . 238

Desert Sovg Sparrow. "In rain or shine, he is the same jolly fellow".

Townsend Sparrow. "The way he digs for his supper"

Green-TAIled Towhee. "A manner distinctly his own"

BLACK-HEAded Grosbeak. "His little brown throat swelling with music"

AMERICAN Pipit. "Up to the very highest peaks they wander"

Water Ouzel, or Americax Dipper . . . To face page

Leconte Thrasher. "He loves the barrenness of the desert" .

Cactus Wres. "A long, purse-shaped affair"

TUle Wren .

To face page

Sierra Creeper. "He offers his sweetheart a fat grub"

Californian Bush-tit .

To fuce page

Townsfid Solitaire. "Remained there singing when the shadows of evening closed over the scene".

Russer-BACKED Thrush. "Only at twilight and in the earliest dawn may one hear the rich sweet song of this shy singer" .

VAried Thrush. "Silent and shy" . . . . . . . . . 312

Belted Kingfisher. "He strikes again and again" . . . . 315

ARKANSAS KINGBIRD. "Watching with a great show of alertness" 


\section{ILLUSTRATIONS}

XXvii

PAGE

OREGON JAY. "Not a single blue feather"

328

Clarke Nutcracker

329

WhITE-RUMPED SHRIKe. "Impaling their prey on thorns" . .

337

Pygmy Nuthatch. "Both birds worked busily carrying feathers"

347

Plain Titmouse. "Busily carrying short hair, feathers, and wool "

Mountais ChickadeE. "The birds were very fearless"

Black-TAILED Gratcatcher. " He was a bewitching little gray ball of feathers"

CABAxis Woonpecker. "Both sexes share the labors of excavating" .

WIITE-HEADED WOODPECKER. "Where the bark is thickest and roughest"

Northers Pileated Woodpecker. "After a few trials he learns to hammer right merrily" .

Californian Woodpecker . . . . . . . . To face page

White-throaten Swift. "Its nesting site is the most inaccessible cliff"

Bовоцгік. "While his demure sweetheart listens" .

PhaiNopepla .

To face page

Biack-throatrd Gray Warbler. "They lean away over to peer under every leaf" . . . . . . . . . . . . . 403

BLACK SWIFT. "While flying swiftly through the air" . . . 404

Black-CHINed HummingBiRd. "Lit daintily a few inches away" 418

Axxa Hummisimd. "Upon a wire clothes-line, and squeaking right merrily" . .

Callope Humingaird. "It feeds upon the painted cups" .

Norther. Violet-grefe Swallow. "It is a lover of pine woods and mountain forests" .

Gray Vireo. "The hest songster of all the vireos"

Ruby-crownen Kixiser. "Only an expert climber can hope to leep into one "

RED-RREASTED SAPsucker. "The mother watched the attempt to drink the sweet syrup" .

Vermilox Flycatener. "Pouring ont his juy"

San Diego Ren-winged Buachur. “A spirit of reckless during" . 
California Pine Grosbeak. "He seems fairly to revel in the swirling clouds of snow" . . . . . . . . . . . 477

Mexican Crosssill. "Head down, chickadee fashion" . . . 484

Steller JAY. "Nowhere are they welcome". . . . . . 487

California JAY. "The colder the better" . . . . . . . 491

YELLOW-HEADED BLACKBIRD. "Beseechingly from the eradle" 510

Scott Oriole. "He will peer into it with ludicrous earnestness" 516

Louisiana TANAGER. "A dragonfly had been captured for breakfast" . . . . . . . . . . . . . . 532

Aunubon Warbler. "Always in a mad chase for something to eat". . . . . . . . . . . . . . . . . 539

Hermit WARBLER. "With her beak full of cobwebs" . . . 543

LoNG-TAILED Chat. "Where he whistled and sang from dawn until dark" . . . . . . . . . . . . . . . . . 549

Pileolated Warbler. "His song reminds one of the tinkle of a brooklet". . . . . . . . . . . . . . 553

VERDIN. "A retort-shaped affair" . . . . . . . . 555 
- PAR'T I

\section{WATER BIRISS}





\title{
BIRDS OF CALIFORNIA
}

\author{
PART I \\ WA'TER BIRDS
}

\section{BIRDS OF THE OPEN SEA}

\section{TUFTED PUFFIN. - Lunda cirrhata.}

Fanuly: The Auks, Murres, and Puffins.

Length: 15.00 .

Mllults in Summer: Top of head, wings, batk, and tail uniform blackish brown; throat, breast, and belly dark grayish brown ; cheeks, forehead, and chin white; a long silky tuft of yellow feathers, enrved like horns, hanging down and back from each side of the erown, just back of the eyes. End of the bill bright red, base greenish yellow; feet bright red.

Adults in 1 'inter: Tufts wanting; sides of head dusky ; feet and bill duller; horny covering at base of bill replacel by hrown skin.

Jouny Youny: Uniforın dark gray or black.

Geographicul Distribution: Coasts and islands of the North Pacific from

Southern California to Alaska.

Brealing Runge: From the Farallone Islands north to Brhiring Sea.

Brreding Serson: Approximately, June 1 to August 1.

Nest: Usually in crevice in rock; sometimes a burrow is excavaterl in the shale; bare, or lined with coarse weeds.

Eygs: 1; ranging from white to yollowish huff, variously markesl with lilac dots at both ends; or, irregular, indistinet tan-color sjots over entire surface; or, having nondescript zigzag markings. Size $2.81 \times 1.89$.

The name "sea parrot" is applied to all puffius on aceount of their curious parrot-like bill. 'The 'Tufted 
Puffin breeds extensively on the Farallone Islands and, to a limited extent, on Santa Barbara and San Clementi and Point Reyes Islauds. Its single egg is laid in the barest semblance of a nest at the end of a burrow, or in a crevice among the rocks, or often under the shelter of a boulder. Wherever the nest may be it is always valiantly defended, and only in the rare absence of both parents will the collector rob it. The only child receives all the attention proverbially given to only children, for the nest is never left unguarded and the parents make a fierce fight if molested. The young puffin is an oddlooking baby, for it inherits the family bill. Otherwise

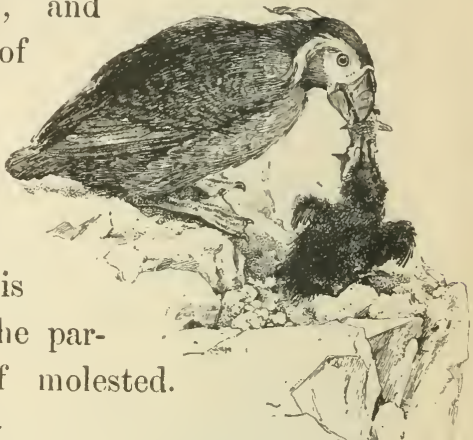

12. Tufted Puffin. "As a puppy enjoys a bone." B.7. it looks like a gray rat crouched at the entrance to its home run. Both adults and young are noisy, constantly growling from their burrows, and croaking when outside; this with their odd bill, white facemask, and drooping yellow ear-tufts, makes them eeric creatures of the sea. Their food consists of fish, mollusks, and crustacea, which they obtain by diving, using both wings and feet to propel themselves under water. This top-heavy bird is exceedingly awkward on land, and especially so when alighting with a fish in its beak, as with a swinging motion it drops its feet very wide apart. In feeding, the parent holds the fish or 
crustacean firmly in its beak, and the young tear bits from it with suarling whines, somewhat as a puppy enjoys a bone.

The young bird dives or is shoved off from the rocks to the water, both parents assisting at the rather startling début and, apparently, breaking the foree of the fall by flying under the little one. One would expect a bird so uncouth and helpless in walking to be particularly graceful on the water, but this is not the case with the puffins, for they swim in such a horizontal position as to scem even more ungraceful than on land.

\section{RHINOCEROS AUKLET. - Cerorhinca monocerata.}

FAnily : The Auks, Murres, and Puffins.

Length: 15.00 .

Adults: Upper parts uniform grayish black ; sides of head, neck, upper neck, and sides dull gray; lower breast and belly white, washed with gray; a row of narrow, pointed white feathers along each side of occiput ; anuther row from base of bill across eleek to ear.

Nuptial Plumage: Base of upper mandible surmounted by a compressed upright horn, the base of which clasps the mandible as a sadille, down to and inclosing the nostrils. In winter this is replaced by leathery skin.

Downy Young: Soft gray-brown.

Geographical Distribution: ('oast and islands of the North Paeific from Behring Sea south to Lower California (resident).

Breeding liange: From Washington northward on islands near the coast. Brecting Sruson: Approximately, June 1 to August 20.

Vest: In crevice or at end of burrow, 2 to 4 feet from entrance, sometimes lined with refuse, but oftener bare.

Eggs: 1 ; chalky white, with faint gray markings. Size $2.70 \times 1 . \$ 2$.

Turs Rhinoceros Anklet is an odd-looking bird, having a short chunky body, with lical set so close to its shoulders as to leave no neck at all, and legs so 
short as to be practically invisible. Floating on the water it scems to have fallen orer on its face and to be unable to right itself, so that it looks much more like a bit of wood than a bird. You glance at it carelessly, never dreaming that it may be alive, when suddenly it dives, leaving no trace. In a moment it reappears at some distance away, only to dive again the instant you turn in its direction. It is perfectly at home on or in the water, although so helpless on land, and can swim a long distance submerged.

Largely nocturnal in habits, migrating and feeding at night; it hides from the sun in burrows or behind rocks during the day, and if brought into the strong light it blinks like an owl. At night it flies swiftly in flocks, with peculiar, plaintive cries, after the manner of the swift. In winter it is found on most of the islands along the coast from Tia Juana and San Diego north. Migrates in flocks about May 1. Is recorded from Santa Catalina.

16. CASSIN AUKLET. - Ptychoramphus aleuticus.

Fanily: The Auks, Murres, and Puffins.

Length: 8.75 .

Adults: Above, dark slate-color, merging into ashy on sides of head and neck ; upper breast and sides slate; lower breast and belly white; a white spot on lower eyelids.

Downy Young: Soft brownish gray.

Geographical Distribution: Pacific coast of North America from Alaska to Lower California.

Breeding Range: From San Benito Islands northward.

Breeding Season: Approximately, April 1 to September 1. 
Nest : In crevices of rocks, under edge of boulders, or in shallow burrow ; unlined.

Eggs: 1 ; greenish white. Size $1.81 \times 1.33$.

LiKe the rhinoceros auklet, Cassin's Auklet is nocturnal in habit, hiding in its burrow by day and coming out in the twilight to feed and fly. Both species are expert swimmers and divers, obtaining in this manner the crustacea which form their chief diet. On stormy nights they may be heard calling to each other abore the thunder of the surf and the fury of the gale. On clear or moonlight nights they flit like huge beetles over the shore, with continual high-keyed notes. With the sereams of the gulls by day and the calls of the auklets by night, the rocky islands of the Pacific coast are never silent.

The Cassin Auklets are resident in small numbers off the coast of Southern California and on the islands of Santa Catalina, Santa Barbara, and Santa Cruz, breeding locally northward along their range. On the Farallones they breed in great numbers, and are also found nesting abundantly on the Netarte Islands and along the rocky coast of British Columbia. Each pair will usually raise three broods, of a single bird each, every season. The young remain in the nest until fully feathered, when they are able to fly, swim, and dive with the ease of adult birds.

\section{ANCIENT MURRELET. - Signthliboramphus antiquus.}

Family : The Auks, Murres, and Puffins.

Length: 10.00 .

Breeding Plumage: Head and throat black; siles of neck, line on each sille of crown to nape, white; upjer lack gray, streakerl laterally with white; back, wings, and tail hownish gray, blackish on primaries; sides sooty brown; breast and belly white. 
Winter Plumage: Throat white; upper parts uniform dark gray; under parts white.

Downy Young: Above, soft dark gray; lower parts and throat white. Geographical Distribution: Coasts of the Northern Pacific from Monterey northward to aretic circle.

Breeding Range: From Sitka northward.

Breeding Season: June and July.

Nest: Unlined, in holes in a bank or shallow burrow.

Egys: 2 ; deep buff, with fine markings of light purplish brown.

Size $2.32 \times 1.47$.

Is "California Water Birds," No. II., Mr. Leverett II. Loomis says concerning the occurrence of the Ancient Murrelet at Monterey in midwinter: "About five hundred yards from the surf a belt of drift kelp extending from Seaside Laboratory around Point Pinos (Pacific Grove, Cal.) had gained an anchorage. The nar-
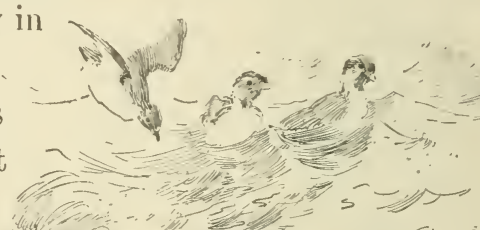
divers and swimmers under water, and voracious in their pursuit of small fry. Unlike marbled murrelets they did not seek safety in flight when pursued. Neither did they dive as soon or remain as long under water when keeping out of the way of the boat. If a whitecap developed near them they wotild always escape it by diving. That this little Auk leaves its summer home in the land of icebergs and comes south in considerable numbers in winter to California has not been generally known to ornithologists."

In April it starts north again, and by May 20 has reached the breeding ground in Alaska. Here it seleets a nesting place, either a deep crevice in the rock, the abandoned burrow of a rabbit, or under the heavily matted grass. Under the grass it burrows its way for two or three feet, and there scratches out a small cavity, lining it carefully with dry grass from the outside. Here two buff eggs are laid. These are brooded by one bird during the day, while the other feels out at sea. At night they change places. The only account of their nesting habits has been given by Mr. Littlejohn, who spent some time with them on an Mlaskan island. He deseribes the squeaky noises made by the nocturnal birds, murrelets, auklets, and petrels, as effectually banishing sleep. "As if not satisfied with the constant babble of their neighbors, the murrelets took especial delight in alighting at the foot of the $\mathrm{\Lambda}$-shaped tent, toe-nailing it up to the ridgepole, resting there a moment, and then sliding down the other sicle." 


\section{MARBLED MURRELET. - Brachyramphus marmoratus.}

Fanily: The Auks, Murres, and Puffins.

Length: 9.75 .

Adults in Summer: Above dusky, barred with rusty browin; under parts white, each feather tipped with umber, producing a mottled effect. Adults in Winter: Above slate-gray with white band across nape; sca!ulars mixed with white, and feathers of back tipped with brownish; lower parts white, more or less mottled with gray.

Young: Above uniform dark gray, with light band on nape more or less distinct. Lower parts white, mottled with gray.

Geographical Distribution: Pacific coast of North America from Southern California to Alaska.

Breeding Range: From Oregon coast northward.

Nest: In burrow in gronnd, or hole in bank, or crevice in cliff.

Eggs: 1 ; buffy, marked with purple-brown. Size $2.14 \times 1.42$.

The Marbled Murrelet is found only in the Pacific Ocean, and breeds in such inaccessible places that little is known of its habits. The adult birds and young are found in numbers about Vancouver Island, but its nesting sites are difficult to find. It is more common along the coast of British Columbia than farther south. The best authorities seem to agree that the nesting habits of this species are like those of the ancient murrelet and their usual breeding grounds only a little farther south. In California they are common near the coast all winter as far south as San Diego. At Monterey we found them exceedingly timid, diving at the slightest alarm and impossible to approach. Their food consists of small invertebrates, which they pick from the rocks at some distance under water. 


\section{XANTUS MURRELET. - Endomychura}

hypoleuca.

Famil: : The Auks, Murres, and Puffins.

Length: 10.00 .

Adults: Upper parts plain slaty gray ; under parts, including cheeks and throat, uniform clear white; lining of wing white; head without ornamental feathers or spines.

Downy Young: Uniform dusky color above, light gray beneath.

Geographical Distribution: Sonthern California to Cape St. Lucas.

Breeding Range: From San Diego sonthward on coast of Southern California and on Coronado Islands.

Breeding Sectson: Approximately, Mareh 1 to June 1.

Nest: In crevices of cliffs; usually lined with coarse grass.

Eggs: 1; light buffy, with gray-brown markings. Size $2.05 \times 1.50$.

The Xantus Murrelet is a common resident along the coast of Southern California as far north as Monterey. Little is known concerning its breeding habits, although it nests on the coast from San Diego south, more abundantly south of the Mexican border. It is numerous out in the open sea south of Coronado Islands during the breeding season, and is said to nest on the Island of San Clementi as well as Coronado. It is found in the Santa Barbara Channel at all seasons of the year, and without doubt a few nest on the Santa Barbara Islands at present, though the breeding ground there is reported as deserted for some years. The nesting habits are probably not unlike those of its Alaskan cousins except as to season. 


\section{PIGEON GUILLEMOT.-Cepphus columba.}

Fanily: The Auks, Murres, and Puffins.

Length: 13.50 .

Adults in Summer: Uniform blackish except wings, where black basal half runs to point, making a black wedge between two white patches; feet red; bill black and slender.

Alults in Winter: White, varied on upjer jarts with black; wings and tail as in summer.

Young: Similar to winter plumage of adult.

Douny Young: Uniform black above, under parts gray.

Geographical Distribution: Coasts and islands of the North Pacific from

Behring Strait to Southern California.

Breeding Renge: From San Nicholas Island northward.

Breeding Secison: Approximately, May 1 to August 1.

Nest: Behind or uncler boulders or in dark places, as near the water as possible.

Eygs : 2 ; light green-blue, thickly marked with lilac, mostly at larger end. Size $2.43 \times 1.62$.

The Pigeon Guillemot, "so like a guillemot and so like a pigeon," is very abundant on the Farallones. It is a pretty, graceful bird, first cousin to the murre, which it somewhat resembles, being of a soft, dark brown color. Two points impress you at first, - its conspicuous scarlet feet, and the broad white band on the wing. Like many sea birds, it stands with the body in a vertical position, supported by the long foot, after the manner of a penguin. Its curious nest is made of pebbles, carried one by one in its bill and deposited in a

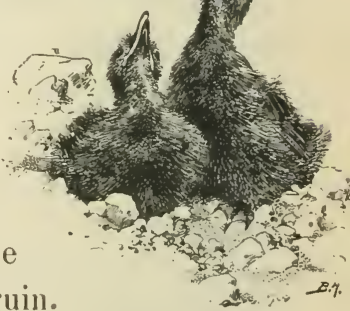

29. "The BaBy Guillemot" cirele in dark crannies of the rocks or hidden under boulders. They seem to serve chiefly as a rim to keep the eggs 
from rolling away. The breeding ground of the Pigcon Guillemot is that also occupied by the gulls, on the lower part of the islands, often near the water's edge. Yet surrounded on every side by the nests of the gulls and living near neighbors with them, they seem to be the only birds which these brigands of the sea do not commonly molest. Probably pigeon eggs are not to their taste. 'The baby Guillemot when first hatelied is covered with thin blackish down on the head, neck, and back, shading to dark gray on the under parts. There is no conspicuous coloring to betray him in the dark nesting place, for eren his feet are dull olive rather than red like those of his father. As with our own land pigeons, the fanily always consists of twins, theoretically a male and a female. Like the land pigeons, also, they are fed by regurgitation; but here the resen:blance cuds, for they learn to dive and swim almost as soon as the down is fairly dry, and become expert in paddling swiftly with their heads submerged, in a unique and very amusing fashion.

\section{0:. CALIFORNIA MURRE-U'ria troile califormica.}

Family: The Auks, Murres, and Puffins.

Lrngth : 17.50 .

Adults in Summer: Upper parts uniform grayish brown; browner on neck and siles of head; under parts white.

Adults in Winter: Upper parts same as in sunmer ; under parts white; throat and siles of head more or less washed with brownish; sides tinged with darker.

Downy Young: Upper parts grayish brown, the head and neck finely streaked with pearl-gray. Under parts white.

Geographical Distribution: Coasts and islands of North Pacific. 
Breeding Range: From Farallones to Alaska.

Breeding Season: Approximately, May to August.

Nest: A bare flat place on cliffs, no lining, no protection.

Eggs: 1 ; pear-shaped; varying from white to buffy, amber, and pale green. May be either unmarked or streaked with brown. In size they vary from $3.50 \times 1.90$ to $2.05 \times 1.45$.

The great Murre rookery of the California coast is on the Farallone Islands; until the last few years their eggs were a common product in the markets of San Francisco. According to figures furnished by Mr. Leverett M. Loomis, the collection of Murre's eggs at the Farallones in 1896 amounted to 7,645 dozen, all of these being shipped to California markets. Mr. Loomis also says: "In 1885 three hundred thousand eggs were gathered. The market became glutted, one cargo being dumped into San Francisco Bay and another abandoned on the island." According to another authority, five hundred thousand eggs were sold in less than two months, - all collected in one limited portion of South Farallone Island, and, "in the opinion of the eggers, not more than one egg in six was gathered." Fortunately the Government has now forbidden the collection of eggs and the molesting of the birds on any portion of these islands, and no one is allowed to land except by permission of the Government Light House Inspector.

Besides being robbed by human enemies, the unfortunate Murres have to wage continual war against the Western gulls, who steal their eggs the moment their backs are turned, or even snatch them from under the mother bird. Possibly for this reason they often choose 
a narrow ledge just wide enough for them to squat upon • when brooding the egrg, where they will have only one side to defend. Since they brood in an almost upright position, the egg resting between the feet, it is difficult to -tell a brooding bircl.

Most ludicrous is their habit of ducking their heads as if in salute, and when this is done by hundreds, one after another, the effect is grotesque indeed. I had thought this the result of excitement at the presence of an enemy, but it continuel when I fancied myself well concealed and no one else in sight. It is usually followed by the departure of a number, who dive with incredible siviftness from the steep rocks to the sea, either from hunger or alarm. Nlthough so awkward and helpless on land, they are at home on or under the water, swimming submerged with great ease and siviftness.

The nesting date of the California Murres differs with different authorities, Mr. Loomis placing it in April, and Mr. Emerson from the middle of May to late in August; my own date is June. This discrepancy is accounted for by the fact that they rear several broods in a year if accident befall the earliest. And as the Western gulls eonsider the young Mure a delicious morsel, the life of any nestling is precarious. When the gulls press too closely, the wise Murres push their one baby off the rock into the water below, darting beneath it with incredible swiftness, and the young Murre, although not ready for the dive, is yet born with its swimming-suit on, and bobs up serenely after a dizay fall. 


\title{
37. PARASITIC JAEGER. - Stercorarius parasiticus.
}

\author{
Family: The Skuas and Jaegers.
}

\section{Length: 17.00 .}

Light Phase of Adults: Top of liead and lores dark grayish brown; rest of head and back of neck straw-color, merging into white on throat; breast and belly white, washed on sides with grayish; back, wings, and tail slaty gray; middle tail-feathers narrow, pointed, and 3.00 longer than the others; tarsi black.

Dark Phase of Adults: Entire plumage dark brownish slate-color, darker on head and lighter on under parts.

Light Phase of Young: Head and neck buffy, streaked with dark ; upper parts dark grayish brown, the feathers tipped with buffy ; under parts buffy, barred with dark.

Dark Phase of Young: Dark grayish brown, darker on wings and tail ; neck, belly, and sides streaked with buffy.

Downy Young: Soft grayish brown above, under parts lighter.

Geographical Distribution: Entire northern hemisphere; south in winter to equator.

Breeding Range: Chiefly within the arctic circle.

Breeding Season: Approximately, June 5 to July 15.

Nest: A mere depression in the ground, rudely lined with grass, dry leaves, or moss; situated on dry upland or rocks near the water.

Eggs: 2 to 4 ; pale greenish brown, spotted thickly with umber at larger end and somewhat over entire surface. Size $2.23 \times 1.62$.

The Parasitic Jaeger occurs commonly as a migrant on the coast of California, though a few remain all winter. Mr. Grimnell reports one taken at Santa Monica, and Dr. Jeffries tells me they are numerous at Santa Catalina in November. They are winter residents in small numbers, also in Oregon, Washington, and British Columbia, and wherever found in sufficient numbers they render life miserable for terns and gulls by snatching their fish from them. At the end of a month's persecution the bodies of the terns become much emaciated from lack of food, 
as nearly every capture is seized by the rapacious Jaegers as soon as raised from the water. Like must bullies, the Jaeger never bothers a gull of its own size, but chooses its victim from the smaller varieties. In the northern regions it destroys eggs and nests of other water-fowl, rarely fishing for itself, but living by thievery.

\section{BLACK-FOOTED ALBATROSS. - Diomedea nigripes.}

Family : The Albatrosses.

Length: 28.50-36.00.

Adults: Upler parts dark brownish gray ; under parts uniform grayish ; tail-coverts and anterior portions of head white; bill dusky brown; feet black.

Young: Similar, but upper tail-coverts dark gray, and little or no white on head.

Geographical Distribution: North Pacific, including west coast of North Ameri'a.

Breeding linnge: Islands of the Pacific near the equator.

Nest: A depression in the guano, lined or edged with a little seaweed. Eggs: 1 ; white.

VERY little is known of the nesting habits of this rover of the high seas. I have been able to find only one record of any nest discovered or any egg taken. It is said to breed on the islands in the middle of the Pacific Ocean toward the equator, in January and February. Its eries are said to resemble cat-calls and to have a particularly doleful somnd heard in the roar of a tempest. Of untiringr flight, it visits the land only to $\mathbf{n}$ sst, and is seldom seen near the coast, preferring the free, bold life on the open sea. 
It has been nicknamed "Gonie" by the fishermen, in supposed allusion to a peculiar croaking noise it makes when feeding.

82. SHORT-TAILED ALBATROSS. - Diomedea albatrus.

FaniLY: The Albatrosses.

Length : $33.00-37.00$.

Adults: White, merging to straw-yellow on head and neck; tailfeathers browuish, primaries having yellow shafts.

Young: Uniform dark brownish gray, merging to blackish on head and neck ; shafts of primaries straw-yellow; bill and feet light brown.

Geographical Distribution: North Pacific; in America from California to Alaska.

Breeding Range: Islands of the Sandwich group and northward to Aleutian Islands.

Nest: The bare ground.

Eggs: 1 ; elliptical ; white. Size $4.20 \times 2.60$.

The Short-tailed Albatross is found on the Pacific Ocean, following the whaling ships to feed on the refuse. Mr. Davie says: "It is easily caught with hook and line, and when taken on board is unable to rise from the deck, as it requires a long range of surface on which to flap its wings."

It is occasionally seen in the Bay of Monterey in December and January, following the whales that frequently come into the harbor, and it is remarkably fearless. A young bird of this species shot by Mr. Loomis was very ferocious, screaming with rage, and trying to bite its wounded wing. When approached by the collector who had shot it, the bird turned its fury upon him. The Chinese fishermen regard these monarchs of the high seas with superstitious awe, feeding them and 
propitiating them with choice bits, in hope of averting danger and winning good luck in their fishing. According to their belief, the whales drive the sardines into the bay to help the Chinese, but the albatross drives the whales.

86 c. PACIFIC FULMAR. - Fulmarus glacialis rodgersi.

Family: The Fulmars and Shearwaters.

Length: 17.00-19.00.

Light Phase: Head, neck, and under parts white; upper parts ashy gray ; primaries and secondaries dark gray-brown.

Dark Phase: Uniform dusky gray above, ashy gray below.

Geographical Distribution: North Pacifie, south on the American cuast to Mexicu.

Breeding Pange: Islands of the Pacifie from the coast of British Columbia to Behring Sea.

Breeding Secusm: June and July.

Nest: In colonies on ledges ant in erevices of steep promontories rising perpendicularly from the sea.

Eggs: 1 ; chalky white. Size $2.85 \times 1.90$.

LikE all the Fulmars, this species is found on the open sea and rarely lands upon the coast. It has been recorded at Monterey, and occurs at most of the islands along the coast of California, Washington, Oregon, and British Columbia. It is very abundant at Santa Catalina in the fall and winter.

Its common names are Goose, Gonie, Gluttonbirl, Giant Petrel. Of these "Gluttonbird" seems to apply to this vulture of the sea. Its food consists of dead flesh, fish, or fowl, as the case may be, upon which it gorges until unable to fly. It is eminently a bird of the open sea, visiting the land seldom except in the breeding season, and usually not flying nearer the coast than five or ten miles. 
All the Fulmars may be distinguished from the gulls in flight by their characteristic wing motions. The wings of the gulls rise and fall rapidly in wide sweeps, and are held more or less at an angle in soaring; the Fulmar wing stroke is slower and apparently (though not really) less powerful.

The Pacific Fulmar feeds its newly hatched young by regurgitation of an amber-colored ill-șmelling oil. It is said by some authorities to eject this as a protection against enemies, also; certainly the odor is sufficiently offensive to prevent any but the most enthusiastic ornithologist from meddling with its domestic affairs.

\section{BLACK-VENTED SHEARWATER. - Puffinus opisthomelas.}

FAnILY : The Fulmars and Shearwaters.

Length: 12.00-15.00.

Adults: Upper parts dark slate-color, merging to gray on head and neck ; under parts white, except lower tail-coverts, which are blackish gray. Dousny Young: Upper parts lark ashy gray ; under parts smoky white. Geographical Distribution: Pacific Ocean, chiefly the southurard coast of Lower California, north to Santa Cruz, California.

Breediny lianye: Islands of the South Pacific, north to Lower California.

RECORDs are claimed of this species as far north as the coast of Oregon. Little is known concerning its nesting habits. Mr. Anthony found adults and young on San Benito Islands in July, and writes that they nest in caves there. ("The Condor," Vol. II. page 29.)

Mr. A. W. Anthoriy in "The Auk," Vol. XIII., has given a full description of the occurrence of these Shear- 
waters off the coast of Southern and Lower California. Here flocks of several thousand birds may be frequently seen hovering over the vast schools of herring that for some reason come near the shore. Mr. Anthony mentions one flock that numbered at least fifty thousand. The presence or absence of the Shearwater near shore is gorerned by the abundance or scarcity of fish; during late July, August, and September the maximum is reached.

The Black-vented Shearwater is supposed to breer during the winter months, south of the equator, and the summer flocks usually contain numbers of young birds.

95. DARK-BODIED SHEARWATER- P'uffinus griseus.

Fanily: The Fulmars and Shearwaters.

Adults: Plumage uniform sooty gray; lighter, sometimes whitish, on chin and throat; under wing-coverts white, transversely nottled with gray at tips; bill blackish.

Geoyraphicril Distribution: South Pacific, north on the American coast, to Queen Charlotte I-lands, British Columbia.

Breeding Range: Islands of the Sointh Pacific.

Nest: A rule structure of twigs, dead leaves, and peat at the end of a burrow three or four feet long; in sicle of a bank. Ejggs: 1 ; clialky white. Size $2.25 \times 1.45$.

Thus Shearwater occurs in great numbers at Monterey and Santa Cruz, California. I have seen a black cloud fully a mile long composed of thousands of dark-bodied Shcarwaters, a few brandt cormorants, and many gulls hovering over the sardines in the Bay of Monterey in Juile. So mumerous were they that the surface of the water was black with them in continual motion as they 
dropped for a catch, or rose each with a fish in its beak, or settled to the water to eat. In this multitude the dark-bodied Shearwaters outnumbered both gulls and cormorants, and the combined noise was indescribable. Mr. Loomis, in his work on the migration of sea birds, as observed at Monterey, proves inferentially that the dark-bodied Shearwaters breed in the south temperate zone during the winter months, coming north as soon as the breeding season is over, and remaining until September. In New Zealand, where this bird breeds abundantly, it excavates a burrow in a bank ahmost exactly like that made by a kingfisher. At the end of this is placed a lining of small sticks, and occasionally a few leaves, or a little moss, and here the one chalky eggr is laid.

105.2. KAEDING PETREL. - Oceanodroma kaedingi.

FAMiLY : The Fulmars and Shearwaters.

Length: $7.25-8.50$.

Adults: Sooty gray, lighter on under parts; upper tail-coverts white; tail-feathers shading to gray at base; tail forked; bill and feet black. Geographical Distribution: North Pacific, south to Sonthern California. Breeding Range: Islands of the Pacific Coast.

Breeding Season: March to September.

Nest : In burrow, or more conmonly in erevices of loose rock; rudely lined with dried grasses.

Eggs: 1; creain white, with wreath of fine purple dots about larger end. Size, $1.34 \times 1.00$.

According to Mrs. Bailey the Leach petrels reported on the coast of California were really the species known 
as Kaeding petrels. There is little to distinguish the two except size, the latter being slightly smaller and darker than the Eastern species. In breeding habits the two are probably identical. Male and female take part in sitting upon the single egg - sometimes one of the pair, sometimes both together. The newly hatched young are fed by regurgitation of a brownish oily fluid. Like the forked-tailed petrel; this species ejects the oil from its throat and stomach if molested. The odor clings to nest, eggrs and young.

107. BLACK PETREL. - Oceanodroma melania.

Fanuly: The Fulmars and Shearwaters.

Length : 8.00-9.00.

Adult: Dusky blackish, lighter on under parts; greater wing-coverts and onter wehs of tertials light ash-color.

Geographical Distribution: South Pacific, northward to Los Angeles County, California.

Breeding Range: Islauts off the coast of southern ('alifornia and southward to the equator.

Breediny Season: July:

Nest: Bare ground, or burrow one to three feet in depth.

Eggs: 1 ; pure white ; elliptical oval. size $1.44 \times 1.08$.

THe Black Petrel, while less common than the anhy, is yet a resident on the ocean adjacent to Southern California Mr. Grimell reports it as far north as silnta Barbara, and as breeding on I Ios Coronados Istands, off San Diego. Like all its family, it eomes to land only to nest, and any acquaintance with it must be made from a bost, or during the breeding season at the islands. It 
is nocturnal in habits, feeding and flying only after darkness has settled over the sea, and enjoying a storm as the robin enjoys the sun. Its notes are a high plaintive call or a queer, low, purring coo. The latter is heard only during the nesting season. The name "Petrel" means Little Peter, and has been given this bird because of its curious habit of skimming over the surface of the water with feet just touching it in a quick, pattering motion, as if trying to walk upon the waves. All the time it flutters its wings like a huge butterfly.

\section{ASHY PETREL. - Oceanodroma homochroa.}

FAmiLY: The Fulmars and Shearwaters.

Length: 8.00-9.00.

Adult: Grayish slate-color, merging to lighter on wing-coverts: quills and tail blackish, merging to ashy slate-color on rump and upper tail-coverts.

Geographical Distribution : Coast of Califormia.

Breeding Range: Islands off the coast of California, including the Farallones and Santa Barbara.

Breeding Season: June and July.

Nest: In crevices under rocks, under driftwood, in stone walls, in burrows.

Eggs: Creamy white, sometimes faintly spotted about the large end. Size $1.19 \times 0.93$.

The Ashy Petrels were breeding abundantly on the South Farallone Islands at the time of a recent visit I made to the spot, but few of the birds were in evidence during the daylight hours. The nests were well hidden under loose rocks, in crevices and in all sorts of crannies; they were betrayed only by their disagreeable odor. In 
common with other petrels these feed their newly hatched young upon the dark oily fluid which they eject through their bills into the throats of the fledgelings, and this is undoubtedly the cause of the unpleasant smell that ever clings to their plumage. The male petrel takes a full share of the labors of incubation, and some authorities aver that, like the phalarope, he does it all. As soon as he is able to fly, the young petrel takes to the sea,

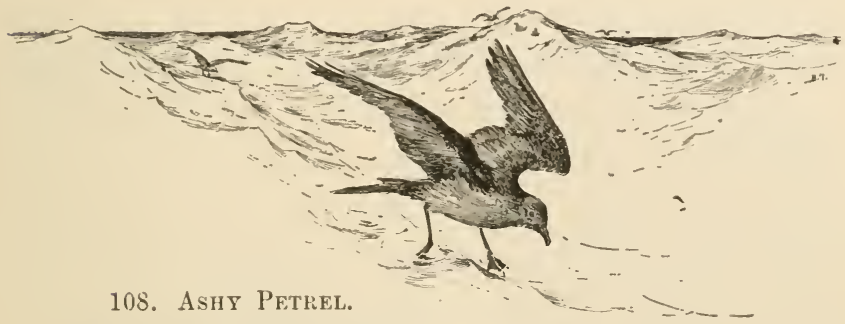

"The playmate of the grim old sea."

never to come ashore until, a year or two later, he wants a wife and a burrow of his own. Think of it - day after day, week aftei week, eating, sleeping, resting on the boundless water! His only refuge from the storm is to fly above or beyond it; his only food is the drift he may pick up. Dancing on the crest of the wave, dashing through the salt spray, he is the ocean's own darling, the playmate of the grim old sea. 


\section{MAN-O'-WAR BIRD. - Fregata aquila.}

Fanily: The Man-o'-War Birds.

Lergth: 39.00 .

Adult IIale: Uniform iridescent black, with greeu and reddish purple reflections; wings very long; tail forked for more than half its length.

Adult Female: Upper parts rusty black; under parts white; wings with gray pateh.

Young: Head, neck, and under parts white; rest of plumage dull blackish.

Dorny Young: Uniform white.

Geographical Distribution: Tropical and subtropical coasts generally; in America north to Florida and Texas, casually through interior along Mississippi River and along Pacific coast to Humboldt Bay, California.

Breeding Rany": Gulf of Mexico and islands off coast of Lower California.

Breeding Season: January to March.

Nest: A slight platform of twigs upon the branches of the mangrove trees at edge of lagoon.

Eggs: 1 ; dull white, unspotted. Size $2.70 \times 1.84$.

Frigate Bird, Frigate Pelican, Man-o'-IVar Bird, and Hurricane Bird are the common names applied to Fregutu aquila by sailors and fishermen. It is regarded by seamen as a weather prophet, always flying higher in clear weather and low before a storm. The name "Man-o'War Bird" doubtless obtains from its resemblance to a black ship as it hangs motionless in midair. Mr. Chapman writes of these birds: "They have a greater expanse of wing in proportion to the weight of their body than any other bird. They rarely alight on the water, but, facing the wind, pass hour's resting motionless on outstretehed wings, sometimes ascending to great heights and calmly soaring far above storms. It is when feeding that their 
marvellous aerial powers are displayed to the best advantage. By swift, indescribably, graceful darts they secure fish which are near the surface, or capture those which have leaped from the water to escape some enemy below. They also pursue gulls and terns, and, forcing them to disgorge their prey, eatch it in midair."

Although rare in California north of Monterey, they are more or less common throughout the coast from that point southward. They are high-handed plunderers of the gulls, meting out to them some punishment for their constant thieving. But it is to the unfortunate fish-hawk that these pirates are most terrible. Reports are given on good authority of the terror exhibited by fish-hawks at the approach of their enemy, who forces them to fish hour by hour until exhausted, and seizes every fish as soon as it is brought up from the water. This frequently results in the death of the hawk by exhaustion and drowning.

BIRDS FOUND NEAR THE SHORE OR $I N B A Y S$

7. LOON. - Ciaria immer.

FaniLy: 'The Loons.

Lenyth : 32.00 .

Adults in Summer: Heal and neck glosiy greenish black ; upper parts, wings, and tail irilesernt black; throat and silles of neck erosied by transverse streaks of white; back and wings spotterl or speckled with white; breast and belly white; sides black, spotted with white; bill black. 
Adults in Winter, and Young: Plunage of upper parts without white; under parts and throat white.

Downy Young: Uniform blackish; belly nearly white.

Geographical Distribution: Northern part of northern hemisphere.

Breeding Range: Northern United States and throughout Canada to the aretic circle.

Breeding Serson: Approximately, June 1 to August 15.

Nest: A slight hollow in the sand near the water; sometimes roughly

lined with dry reeds, sticks, or marsh grass.

Eggs: 2, rarely 3 ; olive, spotted with umber; elliptical. Size $3.50 \times$ 2.20 .

Or the loneliest lakes of California the common Loon, known as Gavia imber, is a regular winter visitant, but he shuns the coast whenever he can. Is this because he likes the taste of fresh-water fish better than that of sea fish? Who knows? Like those of all diving birds, the Loon's stout legs are set well back, and propel its heary body with equal rapidity and ease on or under the water. Its speed in submarine swimming has been estimated to reach eight miles an hour and to continue indefinitely with only the bill exposed. In this he uses only his feet, the wings being folded tightly. All its fish are caught by diving. Awkward and helpless on land, where it uses wings to assist in locomotion, it leaves the water only to nest. Its two greenish gray eggs are laid upon a thin mat of grass in a slight'y hollowed place on the ground, and, in order to be as far as possible removed from neighbors, the site chosen is usually a small grass-covered islet. The young Loons are oval balls of blackish down and are oceasionally taken into the water on the back of the adult bird. Their first attempts at diving are very funny, and with all their efforts they are able to submerge no more than their heads and necks, so that 
they seem to be standing on their heads and paddling their feet in the air. They soon bicome expert swimmers and diver's. Yet under the water as on it, lurk the Loon's enemies. The large pickerel are fond of catching him by the feet, and great mud-turtles wait for a delicious piece of Loon i meat. If he floats serenely on the surface, hawks and gulls are ever ready to swoop down upon him. Fortunate it is for the poor mother that she has but two to guard.

The peculiar ery of the Loon has been well described by Mr. J. H.
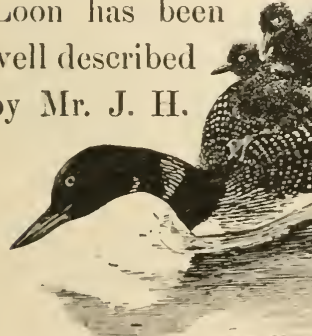

"The young loons are taken into the water."

Langille: "Beginning on the fifth note of the seale, the voice slides through the eighth to the third of the scale above in loud, clear, sonorous tones, which on a dismal evening before a thunderstorm - the lightning already playing along the inky sky - are anything but musical. He has also another mather soft and pleasing utterance, soumling like who-vcho-ucho-uho, the syllables being so rapidly pronomnecel as to sommd almost like a shake of the voice - a sort of weird laughter. 
"Only on a lonely lake in the heart of the woods do you get the startling thrill of the Loon's wilil cry - one clear, piercing note, or a long, quavering, demoniacal langh that to the timid suggests a herd of screaming panthers.".

\section{PACIFIC LOON. - Gavia pacifica.}

Fanily: The Loons.

Length: 27.00 .

Adults in Summer: Upper part of head and nape pale gray, nearly white; sides of head, throat, and fore-neck black, glossed with metallic purple and green ; wings and tail blackish; breast and belly white; sides of neck, wing-coverts, and back black, spotted and streaked with white; sides of belly sometimes finely streaked with black.

Adults in Winter, and Young: Similar to Gavin imber.

Dorrey Young: Dark sooty gray.

Geographical Distribution: Western United States, east to Rocky Mountains, south to Cape St. Lueas, north to arctic circle, east to Hudson Bay.

Breeding Range: From Northern United States to Alaska.

Breeding Season: Approximately, June 1 to August 1.

Nest: Of water grasses, rushes, or decayed vegetation at edge of water.

Eggs: 2 ; varying in color from brown-olive to pale greenish gray. Size $3.00 \times 1.85$.

THis species of the Pacific coast Black-throated Loon corresponds to the Black-throated Loon of Eastern United States, being a trifle paler in coloring but irlentical in habits. It is the most expert of all divers; I have seen one remain under water three minutes by a watch, meanwhile covering a distance of a humdred yards in his submarine swimming. They are very abundant in Monterey Bay all the winter, and I have found a few there as late as June 10, although the regular 
breeding season had begm and they were long sinee due in Canada. The nest of the Pacific Leom is usually a mass of wet, decaying vegetation at the very edge of the water, or sometimes floating among the rushes. Occisionally it is lined with feathers. The bird follows the grebe's fashion of eovering the egg.s during her absence, but does not remain away all day as do the grebes. The Loons are most devoted parents, carrying the little ones pick-a-back as soon as hatcherl, and, in case of attack by hunters, often rising with a great splash between the hunter and their brood, to cover the retreat of the young. The food of all Loons consists largely of fish, although they occasionally relish frogs, and to the newly hatched young the mother brings the larva of water insects obtained by diving. These she liys on the surface for the brood to pick up, insteal of placing them in the bills of the little ones.

\section{RED-THROATED LOON. - Gavia stellata.}

FAMILY: The Loons.

L.negth : 25.50 .

Allults in Summer : Sides of head and neck light brownish gray : throat gray ; a triangular patch of rich chestunt on fore-neck; crown and broal stripe down back of neck finely streaked brownish black and white; back, wings, and tail dark grayish brown, finely specked with white; breast and belly white.

Adults in Wrinter, and Young: Throut and fore-neck white; upper parts blackish, spottel with white.

Douny Foun!: TPuer parts blackish slate; under fiarts lark gray.

Geographical Jistribution: Eutire northern heunisplere, south in winter as far as latitudo $30^{\circ}$.

Brending linny" : The arctic regions.

Breediny Seceson: June 1 to August 1. 
Nest: A slight hollow on ground, close to water; unlined and unprotected.

Eggs: 2; brown or olive, spotted with umber. Size $2.50 \times 1.81$.

THIs is the smallest and handsomest of the loons. It occur's in California from November to late in April, being the last to arrive from the North and the first to leave. In habits it is nearly identical with Garia imber, but is a more northern variety, being more abundant in Canada than in the United States. It has been found breeding in British Columbia fifty miles north of Vancourer. Unlike the common loon, however, it frequents the salt rather than the fresh water, and during the winter montlıs is common along the California coast from Oregon to Mexico. It is the "gray loon" of the fishermen, and its long, wild call as it rises against a breeze and circles under a cloudy sky is always a signal for the boats to seek shelter, for the storm will break and not "blow over."

\section{GLAUCOUS-WINGED GULL. - Larus glaucescens.}

Fanily: The Gulls and Terns.

Length: 25.75 .

Adults in Summer: Head, neck, lower parts, and tail uniform white; mantle dark pearl-gray; feet and legs black.

Adults in Winter: Plumage sinilar to that of summer, but with head and neck tinely mottled or washerl with sooty gray.

Young: J)ark ash-gray, with mantle mixed with perl-gray; head and neck indistinctly streaked with huffy ; unler parts mixed with white.

Dowmy Young: Dull whitish gray ahove, white below ; head, neck, and upper parts marked irregularly with dark gray.

Geographical Distrihution: Pacitic enast of North America from Alaska and Behring Sea; south in wiuter to Southern California.

Breeding Range: Islands of the Pacific coast from Washington northward. 


\section{BIRDS FOUND NEAR SHORE OR IN BAYS 33}

Brecding Season: Approximately, Nay 1 to Augnst 1.

Nest: A bare slight depression in the ground near shore, or a rude affair of seaweeds and grass on shelving rocks or cliffs.

Eggs : 2 to 4 ; from dark olive to white, spotted with light brown and umber. Size $2.88 \times 2.03$.

The Glaucous-winged Gull is one of the most numerous birds on the C'alifornia coast. Mr. Leverett M. Loomis writes of it at Monterey in mirlwinter as follows:

"Whales frequently came into the bay. Often they would be attended by a great train of gulls and pelicans 'feeding upon the slop-over'... In Carmel V'alley near the ocean I found them [the Glaneous-winged Gulls] in company with ITestern gulls following the plough as robins do in the spring in South Carolina. The tameness and familiarity of the water birds on this coast strikingly contrast with the wariness of those of the North Atlantic."

This gull may be known from the others by the long wing-quills of slate-gray tipped with white. Its winter range does not extend so far south as that of some of its congeners, but it is reported all along the California coast from Monterey northward. In nesting habits the Glaueous-winged Gulls resemble the Western gulls; the newly hatehed Gilaucous-winged are the softest, downiest nestlings imagrinable. They are fed upon small fish, refuse from salmon cammeries, - which the parents fly miles to obtain, - and small mollusks. 


\section{WESTERN GULL. - Larus occidentalis.}

FAyILY: The Gulls and Terns.

Length: 25.50 .

Adults in Summer: Head, neck, lower parts, rump, and tail white; mantle dark slaty gray; wing-quills black, with large spots of white. Angle of lower mandible very conspicuons; depth of bill through mandible greater than at base.

Adults in Winter: Plumage similar to that of summer, except that top of head and nape are streaked with dark gray-brown.

Foung: Upper parts brownish gray mottled with white; quills and tailfeathers black, tipped with white; under parts grayish; sides mottled with white.

Dourny Young: Ashy white; head mottled with distinct black patches; upper parts more or less mottled with dark ash.

Geographical Distribution: Pacific coast of North America from Lower California to British Columbia.

Breeding Range: From Coronado Islands to British Columbia; at Santa Catalina, Santa Barbara, and San Clementi.

Breeding Serson: Approximately, Nay 1 to August 1.

Nest: Of weeds; on rocky ledges.

Eggs: 2 to 3 ; light olive, spotter with umber. Size $2.76 \times 1.94$.

Most conspicuous because everywhere present, most interesting because of his very wickedness, is the variety of gull found on the Farallones, and everywhere on the California coast. He is known as Larus occidentalis, and is the only species that breeds on those islands. The pretty herring gulls of our harbors are quite different in habit from this roracious plunderer.

Larus occidentalis is a degenerate. Too lazy to fish for himself, he steals from whomsoever he can. If the victim be a diving bird who has come to the surface with a struggling fish in his beak, the Western Gull will hover over him, compelling him to dive again and again, until, exhausted, he abandons the food he has had no 
time to swallow; then the victor, seizing it quickly, flies away to devour it. Fish brought to the nest of other birds as food for mate or young is stolen by the Western Gulls as soon as laid down, and so expert on the wing are they that but once have I seen punishment overtake them. In this case the bird tried to snatch a fish that had been thrown to a baby seal. Quicker than thought, the seal mother caught the bird by the feet and drew it under the water. In a few moments she rose with the lifeless body, shook it viciously, and tossed it con-

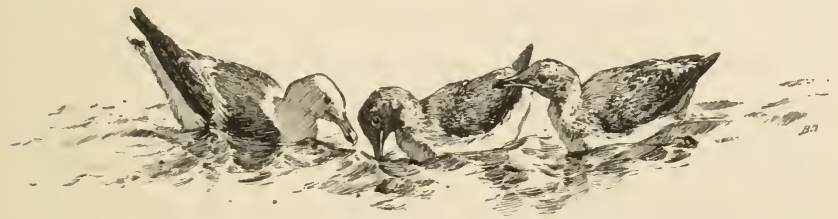

49. Westerix Gull.

The young gull is tanght to fish.

temptuously away. This occurred at Avalon, Santa Catalina, and was witnessed by many spectators at 6 A. M. one May morning. But seals are not usually the victims of these tyrants. Cormorant and murre eggs and young, and even young rabbits, are its farorite bill of fare. Eiggs they will steal in spite of all precautions; a lighthouse keeper tells about covering a pile of eggs closely with a sail-cloth, only to have the gulls work their way under it and carry off every one.

But in spite of all his faults, the Western Gull is devoted to his mate and nestlings, feeding and guarding them with constant eare. Early in May he begins to repair his old nest, stealing material from the cormo- 
rants if he can, bringing it himself if he must. The nest is a large, soft, and warm affair made of dried Farallone weed and oecasionally lined with a few feathers. It is also scrupulously clean. No fish scales, fish bones, or other debris is allowed to remain near it. The young gulls, usually three in number, are beauties, covered with grayish buff down and spotted all over with dots of darker. At three weeks old they are mottled black and light ashy. They show no fear, and will allow a person to handle them, only looking surprise from their bright little eyes. One would never believe that such innocent-looking babies could ever become thieves and cannibals. They stay in the nest longer than most of the young sea birds, not leaving it until their wings are fully feathered and strong. Even then they are not like the parents, for, until a year old, all young gulls are mottled brown and white. The brownish-looking gulls flying with the others on our harbors and rivers are not a different species, but are the immature.

The young gull learns to fish in a unique way. He also learns to steal, but that is another story. He scrambles with fluttering wings down to the water, accompanied by the rest of his family. As soon as he is fairly launched, one of the adult birds brings a small fish, and showing it to him, lets it float on the surface. If the youngster is an apt pupil, he snaps at it and usually gets it. If not, it is snatched up by some adult, for might is right in the sea-bird world. If after losing several in this way he becomes discouraged, he is fed, taken ashore for a sun-bath, and in an hour is back for 
another lesson. In the meantime he watehes his parents filching food from nestlings around him, and as soon as he dares, or ean find a bird more helpless than himself, he tries the plan. He finds it much easier than catching a bobbing sardine in the water, and from that time his career in crime begins.

\section{HERRING GULL. - Larus argentatus.}

Family: The Gulls and Terns.

Length: 23.25 .

Adults in Summer: Head, throat, and uncler parts white ; mantle pearlgray; white tip of first primary separated from large white spot farther up by blotch of black half an inch wille extending to the tip; eyelids yellow; feet pale flesh-color.

Adults in Winter: Similar, but mottled with ash-color on head and neck.

Young: Grayish brown, streaked or mottled on head, neck, and upper parts with dull whitish; quill-eoverts and tail-feathers rusty black.

Inumy Young: Soiled white; head irregularly spotted with black; back, wings, and tail washed with ashy.

Geographical Distribution: North America in general; in summer from latitude $40^{\circ}$ northward; south in winter to Cuba and Lower California.

Brealing Range: Inland lakes from latitude $43^{\circ}$ to the Upper Yukon, Alaska.

Breeding Sereson: Approximately, May 15 to August 1.

Nest: A slight depression in the gromud, lined thinly with grasses; near water.

Eyys : 3 ; varying from blue-white to yellow-brown, blotehed with light and dark brown. Size $2.80 \times 1.75$.

Tuss is a common gull throughout its range, and differs from other species in its abundance around rivers and harbors. It is the gull seen following the ferryboats on San Francisco Bay, perehing on the anchored fishing craft in Monterey harbor, and sitting on the buoys at San Diego, and tormenting the seals at Santa 
Catalina. It is the species best known East and West, following the coastwise vessels as well as those of the Great Lakes, and feeding on the refuse thrown out.

Its name of Herring Gull is probably derived from its habit of following a school of herring, and gorging itself upon them as it flies. To see the countless numbers of gulls and shearwaters hovering over a school of herrings in Monterey Bay is an experience worth a trip across the continent. No words can describe their multitude or their clamor. A compact cloud of them two miles long and half a mile wide, sceming almost like a solid mass of wings, is a common sight in that harbor.

By a curious adaptation of its natural nesting-habits to necessity for self-protection, in localities where its nests have been continually robbed, it has learned to build in trees sixty and seventy feet from the ground. In these cases the nest is a compact structure somewhat resembling a crow's nest, but more often plastered with a small amount of mud and lined with grasses and moss. In fact, it adapts itself to local conditions in placing and constructing its home: guided by some instinctive law, it lays its eggs on the bare ground in one region; it elaborately lines and carefully conceals its nest in another; and, wherever necessary for selfpreservation, it chooses a tall tree.

The young gulls are fascinatingly fat babies covered with fluffy down, and even prettier than ducklings. When hatched in ground nests, they soon learn to run about, and they are taken to the water when a few weeks 
old. It is possible that when the nest is seventy-five feet up in a tree the nestlings, like those of the wood ducks, are carried down by one of the alults.

\section{CALIFORNIA GULL. - Larus californicus.}

F.nuLY: The Gulls and Terns.

Length: 21.50 .

Adults: Head, neck, and under parts white; mantle dark slate-gray; the yellow bill marked with rerl spot, tonching or encircling a black spot near end of lower mandible; iris bright brown; feet light green.

Foung: Head, neck, and lower parts white, washed with brownish gray; upper parts mottled gray and buffy; quills and tail-feathers rusty black.

Downy Young: Light ash-gray, marked with black spots on heal and washerl with dark gray on lack, wings, and tail.

Geographical Distribution: Western North America, chiefly in the interior from Mlaska to Mexico.

Breeding Range: Inland lakes of Oregon, Washington, British Columbia, and Ltah.

Brecding Season: Approximately, Mray 15 to August 15.

Nest: Of sticks and grasses, lined with feathers; on ground, on rocks, or in low sagelrush near water.

Eggs: 3 to 5 ; from blue-white to gray-brown. Size $2.50 \times 1.65$.

The California Gull is a regular winter visitant on the coast, but disalppear's usually about May 1. It breeds abundantly on Lake Malheur, Oregon, on Great Sialt Iake, Utah, and ats far north as Great Slave Laike. It may easily be distinguished from the other species by its smaller size. Mr. Loomis reports it as abundant at Monterey, where it is found in eompany with the western and glancons-winged. During the winter it is common on all the fresh-water marshes as well as the coast, throughout Southern Califoruia. Mrs. Bailey silys, "It 
Pescadero in the low fields near the ocean, hundreds have been seen following the plough." $A$ similar statement has been made of two other varieties, the ringbilled and the short-billed.

54. RING-BILLED GULL. - Larus delanarensis.

FaniLY: The Gulls and Terns.

Length : 19.00 .

Adults in Summer: Head, neck, lower parts, and tail white; mantle pearl-gray; first primary black, with white patch near tip; rest of primaries gray, washed with black on outer web and tipped with white; iris pale yellow; eyelids red; bill greenish yellow, banderl near end with black and tipred with orange ; feet yellowish green. Adults in Winter : Sinilar, but with ashy streaks on head and nape. Young: Upper parts dark ashy, mottled with buff; outer primaries black; upper lialf of tail-feathers pearl-gray, meeting a broad band of black which extends to a narrow white tip; bill yellowish at base, shading into black at tip.

Downy Young: Dull gray-white ; hear spotted with black ; back waslıed with dusky.

Geographical Distribution: Entire North America; south in winter to Cuba and Mexico.

Breeding Rirnge: Northern portions of the United States, and inland lakes of Oregon, Washington, and British Columbia. Breeding Season: Aplroximately, May 1 to August 1. Nest: Of coarse grass ; on ground, near water.

Eggs: 2 to 3 ; buffy gray, spotted with chocolate. Size $2.77 \times 1.67$.

Although the Ring-billed Gull is a more or less locally common species in every part of the United States, it is more abundant on the Atlantic than on the Pacific coast. In habits it is like the herring gull, but may be distinguished by its smaller size, yellowish green feet, and banded bill. Quite un-sea-bird-like, it relishes the larva of marsh insects as well as the adult forms, and during fall migrations it catches them on the wing, 
as do swallows. In some localities it has been seen feeding among the freshly turned furrows of a ploughed field. There is reason to believe that, unlike some nembers of its family, it never robs other birds either of food, eggs, or young, but is content with the small fish and insects it ean pick up on inland marshes and meadows.

\section{HEERMANN GULL. - Larus heermanni.}

\section{Family : The Gulls and Terns.}

Length: 18.75 .

Adults in Summer: Upper parts dark slate-color; head and neck white; under parts dusky gray; wings and tail black, the latter tipped with white; bill scarlet.

Adults in Winter: similar, but hearl rery dark, nearly black.

Douny Young: Dark ash-eolor, the feathers of upper parts elged witlı buffy ; hearl mottlesl.

Immature (Second Year?) : Entire plumage muiform dark ash ; tail black. Geographical Distribution: Pacific coast of North America from British

Columbia south to Panama.

Breeding Ranye: From Coronado Islands northward; does not breed at the Farallones.

Breeding Season: Approximately, May 20 to August 1.

Nest: On ground near water, or on cliffs ; scantily lined with coarse grass or moss.

Eggs: 2 to 3 ; greenish gray, marked with lilac and brown. Size $2.45 \times$ 1.50 .

True Heermam Gull may be readily distinguished from any other species by its darker plumage. It is a eurions sight to see these handsome birds at San Diego Bay and La Jolla following an unlucky pelican who has a fine pouchful of fish. They fly over and around him, darting down to peck at him with their bills mutil he is foreed to disgorge his catch. The dignified and methodical pelican is no match for these swift flyers, and soon yields to the inevitable. I have seen the same pelican 
robbed three times in succession, leave the vicinity with a flock of several gulls following. A close watch failed to discover any other species of gulls at this sport, and I believe the persecutors are invariably the Larus heermamni, although the Western gull is much more apt to conmmit such atrocities. In this locality, however, the Heermann Gulls outnumber the Western three to one. Mr. Grinnell says this is the case also at Los Angeles, while at Monterey Mr. Loomis reports them as varying in proportion at different times during migration.

60. BONAPARTE GULL. - Larus philadelphia.

FaviLY: The Gulls and Terns.

Length: 13.00 .

Adults in Summer: Head and throat dark slate, nearly black; mantle pearly gray ; unler parts, tail, nape, and sides of head white ; wings white, shading to pearl-gray; first primary tipped and eiged on outer web with black; other primaries with broad black transverse spots, forming a bar; feet and legs orange; bill black.

Adults in W'inter: Similar, but head and throat white, back and sides of head gray.

Young: Head white, top and nape washed with gray; under parts and tail white, the tail banded with black near end; back and wingcoverts ashy; primaries hluish gray, narrowly tipped with black.

Geographical Distribution: Whole of North Amierica.

Breeding Range: Northern parts of the United States northward.

Breeding Scason: Approxiniately, June 1 to Angust 1.

Nest: Of sticks and grasses; lined with fibre; always elevated from the gromul in bushes, trees, or high stumps.

Eggs: From greenish to olive-brown, spotted with brown and light purple, chiefly at larger end. Size $1.95 \times 1.34$.

THE distinguishing feature of the Bonaparte Gull is its slate-gray hood in summer, all the other Pacific gulls having light-colored or white heads. Its appearance as 
it flies toward you may have suggested its name, for it is not unlike the black cocked hat and white expanse of bosom so characteristic of the portraits of that monarch.

It is found throughout North America, being rather more abundant on the Atlantic than the Pacific coant. Its food is small fish, which it procures by diving from the air to the surface of the water, not beneath it. Swift and graceful in flight, of small and clegant form, it seems rather to belong to the terns than to the gulls. Its breeding grounds are in the far north, through the wooded districts of Mlaska and as far south as Manitoba. In November and May these gulls pass through California as migrants, a few remaining at San Diego Bay throughout December and returning there in March.

\section{ROYAL TERN. - Sterna maxima. \\ Family: The Gulls and Terns.}

Length: 18.21.

Adults in Spring: Top of head and nape glossy black, feathers lengthened to form a crest; upper parts pearl-gray, merging to white on tail and at back of neck; under parts, including throat and sides of neck, pure white; bill briglit orange; feet black.

Adults after Brceding Season and in Winter: Similar, but black on heal and crest mixed with white; bill prale orange.

Young: Similar to winter adults, but upper parts more or less mottled with dusky brown; tail dusky near tip; crest slightly dereloped; top of head dusky, mixed with white.

Douny Young: Like downy young of S. caspia.

Geogrmphical Distribution: Tropical America and warmer prarts of North America, to latitude $40^{\circ}$, casually northward to Massachusetts and the Great Lakes. Common constwise in Califernia at all seasons.

Breeding Runge: On $\Lambda$ tlantic coast from New Jersey southwurd; on Gulf coast from Texas to Florida; at San Mignel Island on tho Pacitic coast. 
Nest: A shallow depression scooped in the sand of a beach.

Eggs: 2 to 4 ; narrower and more pointed than those of Caspian tern; grayish, spotted with brown and purple. Size $2.67 \times 1.70$.

\section{Concerning the Royal Tern, Mr. Frank M. Chapman} writes: "It is a strong, active bird on the wing, and a reckless, dashing diver, frequently disappearing beneath the surface in catching its prey. The slow-flying pelicans are at its mercy, and it often deftly robs them of their well-earned gains.

"All the terns are to be known from the gulls by the very different mamner in which they hold their bills. A tern points its bill directly downward and looks, as Coues says, like a big mosquito, while a gull's bill points forward in the plane of its body."

\section{FORSTER TERN. - Sterna forsteri.}

Family : The Gulls and Terns.

Lenigth: 15.10 .

Adults in Summer: Top of liearl and nape jet black ; upper parts pearlgray; under parts, including throat and sides of neck, uniform white; bill dull orange, tipped with dusky; feet deep orange.

Adults in Winter: Similar, but head white, tinged witl gray on nape, and white dusky patch around eyes and ear-coverts; bill brownish, merging to black at tip ; feet brownish.

Young: Similar to winter adults, but with top of head, nape, back, and wings washed with dark umber; distinctly darker at end of tail ; sides of head dissky brownish.

Downy Young: Upper parts pale buffy lrown, coarsely mottled with black; under parts, except throat, white.

Geographical Distribution: North America generally; south in winter to Brazil.

Breeding Range: On Pacific coast from Washington to Lower California ; common at Lake Tahoe, Eagle and Elsinore Lakes, California.

Breeding Season: Approximately, May 1 to July 20. 
Nest : Made of flags or marsh vegetation; lined with weeds; in wet marshy place, or floating among rushes.

Eggs: 2 or 3 from pure white to pale green or brown-gray, irregularly spotted with several shades of brown and purple. Size $1.85 \times 1.35$.

Dr. BREwER calls this species "pre-eminently a marsh tern," and says that its monotonous cry closely resembles the call note of a logrgerhead shrike. It is found nesting in colonies in company with gull-billed terns and Bonaparte gulls in suitable localities throughout its breeding range, but chiefly on large lakes in the interior. Its food consists of mimnows, insects, and refuse floating on the water.

\section{LEAST TERN. - Sterna antillarum. \\ Family: The Gulls and Terns.}

Length: $8.50-9.75$.

Adults in Summer: Upper parts pearl-gray; under parts white; forehead white; crown, lores, and nape jet black; bill yellow, usually tipped with black; feet orange.

Adults in Winter: Similar, but lores and crown white; nape black; bill black.

Young: Similar to winter adults, but upper parts mottled with blackish and buffy.

Downy Young: Upper parts pale buffy gray, finely mottled with dusky; head distinctly marked with irregular black speckles; under parts white.

Geographical Distribution : Northern Sonth America, north to California, Minnesota, New England, and casually to Labrador.

Breeding liange: Breeds locally nearly throughout its range. In California as far north as Ballona Beach, Los Angreles County.

Breeding Season: Approximately, May 1 to July 15.

Nest: Scarcely perceptible hollow in the bare sand of the beach; unlined. Eygg: 2 or 3 ; greenish gray, spotted with liglit and lark brown, and light purple. Oceasionally these markings form a wreath at the larger end. Size $1.25 \times 0.95$.

SEa Swallow and Little Striker are the common names applied to this little tern, although sea swallow 
is used of all terns. The Least Tern is said to feed upon insects, and has the peculiar darting, skimming flight of swallows; hence the appellation "sea swallow" is particularly appropriate to it. Its call note is a highkeyed squeal or squeak, and it utters this note almost continuously while on the wing.

Throughout the coast of Southern California these Terns are found nesting on the narrow strip of beach between the tide marsh and the sea. Along the old sea drive, a few miles southward from Coronado Beach, it is not uncommon to find their eggs laid on the bare sand, at the edge of the salt marsh, well out of reach of the tide; but so perfectly do they harmonize with their environment that the searcher may, and usually does, pass them by, unless the distress of the parent bird or the flushing of the mother from the nest betrays its location. Even more difficult to find are the newly hatched young, which are little balls of down scarcely larger than a walnut, and seem to melt into the color of the sand even after you have discovered them. Crouched motionless among the pebbles, they do not even wink until your hand almost closes over them, when, presto! they scud off with most surprising speed.

\section{AMERICAN BLACK TERN. - Hydrochelidon nigra surinamensis.}

FaniLY: The Gulls and Terns.

Length: 9.00-10.00.

Adults in Summer: Head, neck, and under parts black; upper parts uniform slate-gray; bill and feet black. 


\section{BIRDS FOUND NEAR SHORE OR IN BAYS tr}

Adults in Winter: Head, neck, and under parts white; upper parts deep pearl-gray.

Young: Similar to winter adults, but feathers of back tipped with brownish, and sides washed with slaty.

Downy Young: Upper parts dull dark brown, coarsely mottled with black; top of head, throat, and breast plain blackish brown; side of head dull whitish; belly white, washed with dark gray.

Geographical Distribution: Temperate and tropical America, from Alaska to Brazil and Chili.

Brealing Range: Interior of United States from latitude $39^{\circ}$ northward.

On Pacific coast breeds abundantly in Oregon and California.

Breeding Season: Approximately, from . Way 10 to August 1.

Nest: The eggs are laik on a mat of reeds and decaying vegetation float-

ing among rushes of a marsh, in shallow water ; or oceasionally on bare ground of a mud flat.

Eggs: 2 or 3; brownish green, thickly spotted with dark and light brown and light purple, mostly about the larger end. Size 1.35 $\times 0.95$.

True Black Tern has long wings and a short tail which, with its dark coloring, renders it easily dis-

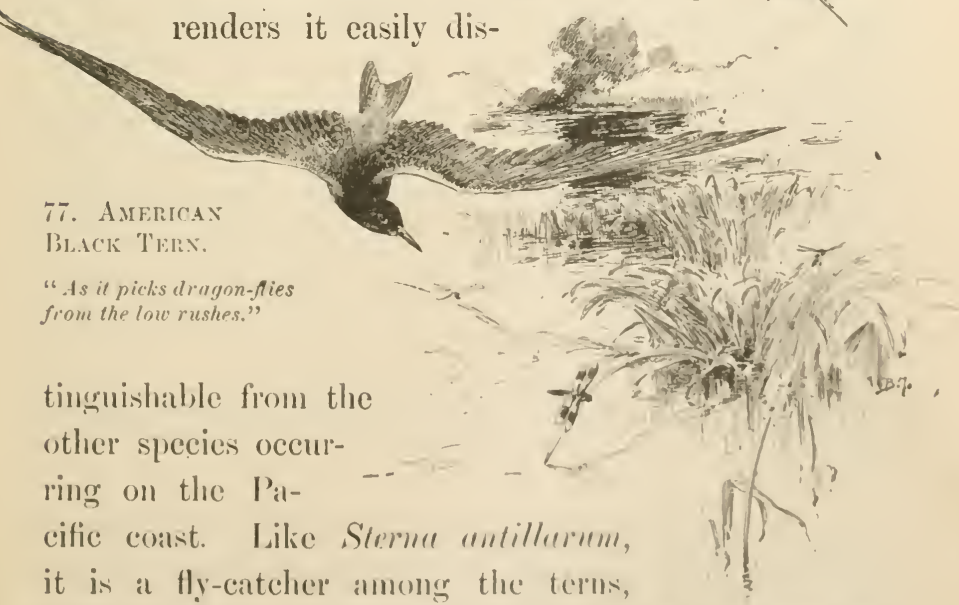
feeding almost entirely on aquatic insects and dragonflies. It darts and skims over the marshes with the 
grace and agility of a swallow, scarcely pausing in its flight, as it picks dragon-flies from the low rushes or catches them in midair. Fish proper it scorns. Crayfish forms some part of its diet, though possibly only a small part. It is found circling over a marshy meadow as well as above the more open water of the lakes, and its nesting site is not infrequently an almost dry pool. The choice of these often seems to be a mere matter of whim, but probably is determined by the abundance of insect life in the locality.

\section{0 c. FARALLONE CORMORANT. - Phalacrocorax auritus albociliatus.}

\section{Fanily : The Cormorants.}

Length: $25.00-31.00$.

Adults: Greenish black merging to grayish brown on back and wings.

All the feathers of these parts borlered with black, producing a scaled effect.

Nuptial Plumage: On each side of head behind the eve there is a small tuft of long, curved, whitish feathers ; gular sac bright orange.

Young: Head and neck brownish gray shading to light on chin, and dark on top of head; under parts brownish, darker on siles; gular sac yellow.

Geographical Distribution: California, sonth to Cape St. Lucas and the Revilla Gigedo Islands.

Breeding Range: Farallone Islands.

Breeding Season: May and June.

Nest : A loosely constructed mat of kelp, seaweed, and sometimes twigs. Eggs: From 4 to 5; light greenish, covered with chalky film. Size $2.40 \times 1.54$

The Farallone Cormorant may be recognized from the other species on the Farallone Islands by the long white tufts over the eyes. In nesting habits it is identical with Brandt's cormorant, nor can the eggs of the two species 
be distinguished by an expert. Both nest in colonies on the South Farallone, and Mr. Corydon Chamberlin, in the "Nidologist," 1895, reports a rookery at Clear' Lake, California. Early in May it constructs a shallow nest, about a foot in diameter, lined with Farallone weed and kelp. Occasionally one attempts to carry a long, bulky-looking string of the latter, which trails behind him as he flies, making him look like a winged polliwog. They mould these nests to a roundness by sitting on them, turning awkwardly about and working the kelp) into place with feet and bill, but with none of the fluttering movements of wings and tail apparent in the nestbuilding of land birds. After the nest is begun, one or the other of the parent birds is constantly present, and even then it is a hard struggle to keep the Western grulls from stealing the nesting material as fast as it is brought. The newly hatched Cormorants lack the down of most young sea-birds and are not handsome babies, their fat bodies and grotesque long necks being covered with a leathery-looking black skin. My observations eonvinee me that they are fed by regurgitation for the first twentyfour hours or longer" this is, if possible, a more ludierous process of "pumping " thin in the ease of young herons." After this regurgitation period eomes a time when live fish is brought to the nest and torn or elewed by the adults before being given to the nestlings. As soon as the latter are able to manage live fish, small carp are popped into their throats hearl first, and swallowed with curious gulpings. Each meal is followed by a rest time,

1 See Branit Cormorant. 
when the half-grown Cormorant sits shrugged up into a discouraged-looking bunch, or lolls listlessly against his fellow nestlings. Around (and beneath the nest if - in a tree) are bits of fish and other debris, showing that the supply often exceeds the demand.

\section{BRANDT CORMORANT. - Phalacrocorax penicillatus.}

Family : The Cormorants.

Length: 35.00 .

Adults: Head and neck iridescent black, with a patch of whitish surrounding base of gular sac; under parts iridescent dark green; scapulars and wing-coverts dark green, edged with black.

Nuptial Plumage: Uppermost scapulars and sides of neck ornamented with long stiff white filaments; gular sac blue.

Young: Head, neck, and rump dark brown; rest of upper parts paler brown; under parts dusky brown, paler on throat.

Geographical Distribution: Pacific coast of North America from Cape St. Lueas to Washington.

Breeding Range: Islands of the Pacific from Lower California to Washington.

Breeding Season: Approximately, May 1 to July 20.

Nest and Egys: Identical in appearance with those of Farallone cormorant. Size $2.40 \times 1.50$.

This is the most common cormorant of the California coast, and may be distinguished by its stiff white feathers on sides of neck and by its blue gular sac. Rookeries are found on seal rocks near Cypress Point, Monterey, at Santa Cruz, and on the Farallones. These birds nest in colonies on the steepest crags and ledges of those islands. About the middle of May they may be seen carrying seaweed and kelp to their chosen site. There they fashion a new shallow, bowl-shaped nest, which becomes cemented with guano; or perhaps they redecorate an old one 


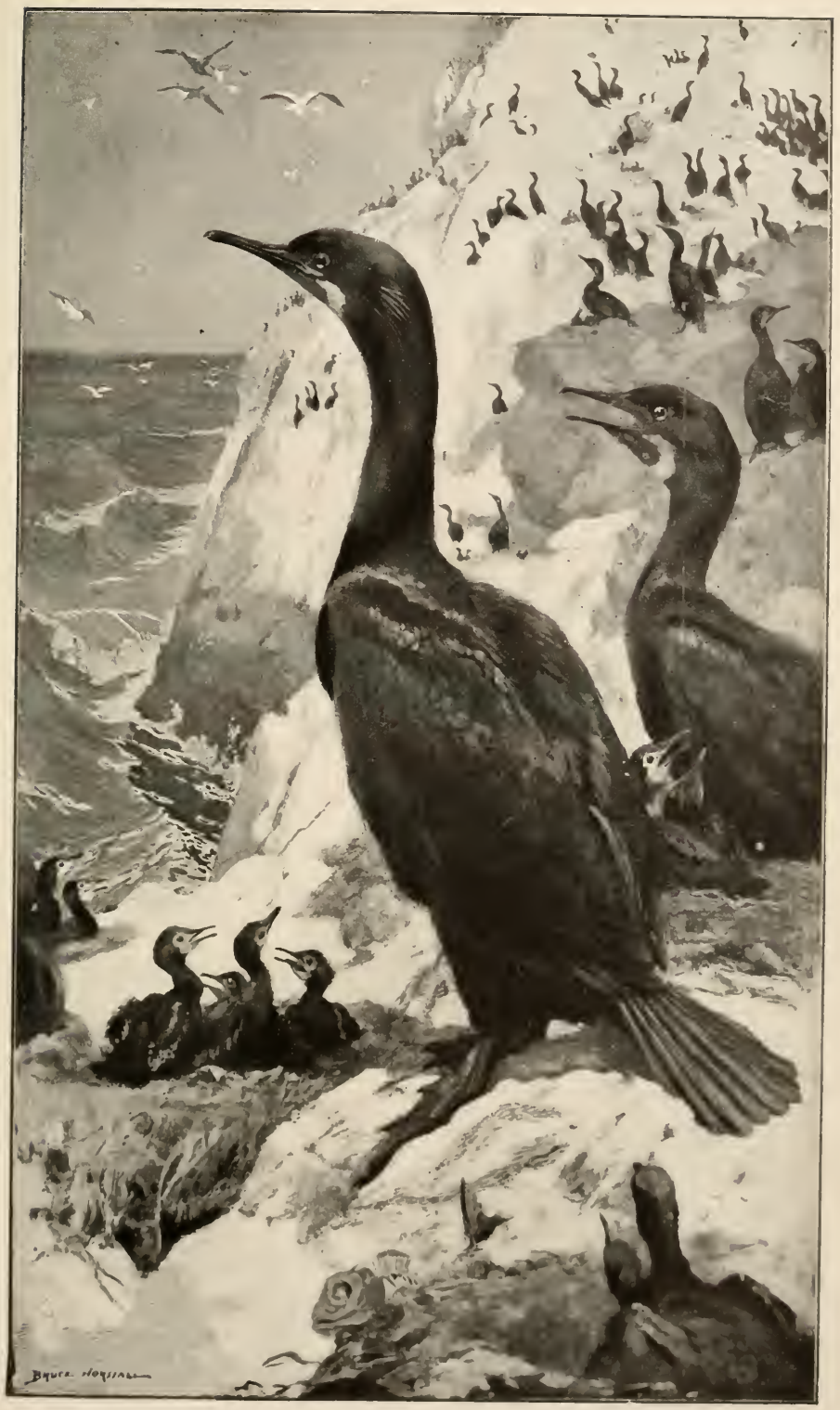

122. BRandT Commurant 

with fresh sea moss. From the amount of guano used, and the solidity with which most of these structures had become cemented to the rock, - indeed, they seemed a part of the rock itself, - I judged that they had been handed down from one cormorant generation to another, for many years. Yet each season sees them carefully redecorated on the outside with new, bright-colored seaweed. This weed is seldom picked up on the rocks, but is freshly pulled from the bed of the ocean near shore, the birds diving in some places more than fifty feet. Upon timing one, I found it was under water two and one half minutes; it then reappeared with a bill full of scarlet algæe. Here again the mischievous gulls are in evidence, and the poor Cormorant must guard his gayly trimmed nest, or every bit of his hard-earned moss will be stolen. After the five chalky green eggrs are laid his vigilance must never relax, for cormorant eggs and cormorant babies are the most delicious morsels in a sea gull's menu. So the great awkward birds are ever craning their long necks this way and that, watching before, behind, on every side, for the whitewinged robbers. The effect is that, from any point of view, a cormorant rookery is a weird sight. As the days go by, the pretty nests blossom one by one with newly hatehed Cormorants, the very homeliest of all created things. Their ungrainly bodies are encased in a naked, greasy black skin, and their preternaturally long necks end in immense months, so that they resemble huge polliwogs. Like polliwogs, also, they are ever wriggling. For the first few days the soung Cormorants 
are fed by regurgitation - a curious process, always alarming to the observer. The mother squats at the side of the nest, and immediately four or five long black necks are stretched up like finger's of a black kid glove split at the end. These wave helplessly about, until she selects one and thrusts her bill far down the split, which is the throat of the young. She then violently shakes the baby, thereby emptying the food from her mouth into his. Later on small fish are torn and given them. ${ }^{1}$

\section{3 b. BAIRD CORMORANT. - Phalacrocorax} pelagicus resplendens.

Fanily: The Cormorants.

Length : 34.00-40.00.

Adults : Feathers of forehead advancing to base of culinen; gular sac and naked lores dull coral-red or reddish brown; heal and neck glossy violet-black, more purplish toward head, changing gradually through green-blue to glossy bronze-green on under parts; scapular's and wing-coverts dark green, tinged with bronze. Back dark green.

Nuptial Plumage: Neck and rump ornamented with narrow white filament-like feathers; tlanks with a large patch of pure white.

Young: Uniform brownish dusky, merging to grayish on lead; the upper parts darker, with glossy greenish reflections.

Domny Young: Covered with down of a uniform dark sooty gray (Ridgeway).

Georgraphical Distribution: Pacific coast of North America from Washington south to Cape st. Lucas, and Mazatlan, Mexico.

Breeding Range: Islands near the coast of California and Washington. Breeding Season: Approximately, June 1 to July 15.

Nest: Of rock moss or kelp on leilges of perpendicular rock.

Eggs: 4 ; pale bluish green, with lime deposit on surface. Size $2.19 \times 1.44$.

The Baird Cormorants are less common and more timid than either of the foregoing species. They may

1 See Farallone Cormorants. 
be recognized by a white patch on each flank. They breed in very small rookeries of ten or a dozen pairs, instead of several hundred as is the case with Brandt cormorants, - and are frequently found nesting alone. Their site is usually the most inaccessible rocks in the vicinity. Frequently, so narrow is the ledge chosen that the young are crowded off and are killed by the fall to the water or rocks below. Each season the old nests are used, being repaired with kelp or relined with fresh sea moss. Baird Cormorants, though so retiring, are particularly courageous in defence of their nests and young, and are eitler so devoted to the former or so stupid that they will return after being robbed and brood upon the empty nest. Their nests are constructed with greater eare than those of the other species mentioned, and are lined with the more delicate varieties of sea moss as well as the coarse kelp. They become cemented into a more or less solid mass and also glued to the rock with guano. Some of them are so solid as to warrant the opinion that they have been in use many years. The feeding habits of this species are like those of the Brandt and Farallone cormorants.

\section{AMERICAN WHITE PELICAN - Pelecamus erythrorlyynchos.}

FamiLy: The Pelicans.

Lenyth: 4 1!-6 feet.

Adult Nuptial Plumayr: Entirely white, quills black, whitish at hase; a pendant crest of pale yellow featlers, nul a horuy protuluerance on top of bill ; ponch and bill reddish ; feet bright red. 
Adults in Winter: Similar to above, but lacking the crest and the horny protuberance on bill. Pouch, bill, and feet lemon-yellow.

Young: Plumage white, merging to brownish gray on top of head; bill, pouch, and feet pale lemon.

Geographical Distribution: Temperate North America, sonth in winter to Ulexico ; common on the coast of California.

Breeding Range: Southeastern Oregon, Red River valley in British Columbia; lakes of the interior west of Mississippi River, and from Utah northward.

Breeding Season: Approximately, April 15 to August.

Nest: A pile of sand heaped up about 8 inches high and 14 inches

in diameter, sometimes lined with sticks and slightly hollowed out

on top. Usually on dry sandy beach of an island.

Eggs: 2, rarely 4 ; chalky white. Size $3.45 \times 2.30$.

The American White Pelican has become a comparatively rare bird east of the Mississippi River, but is abundant throughout the coast of Southern and Central California and on Santa Barbara Island. Mr. Grimnell reports it breeding at Eagle Lake. It feeds while on or in the water, scooping the fish in its bill when swimming or wading, seldom diving for them from the air, and always tossing the catch until it can be swallowed head first. Crustacea are rarely if ever eaten by this species, and they will travel many miles for fish rather than eat frogs.

"Often a flock will band together and, by beating their wings, drive a school of fishes into the shallows, where they gather up large numbers at every scoop of their big bag. The water taken is allowed to drain out of the corners, and the fish are swallowed. If the bird is fishing to feed her young, she still does the same, and afterwards disgorges the fish; for she could not fly if her pouch were filled with fishes." 1

1 Mrs. Eckstrom, in "The Bird Book." 
It is the White Peliean that the gulls torment so by stealing his hard-earned catch time after time. And the Pelican, always of dignified and care-burdened mien, looks conically disconsolate over losing his dinner in this fashion. Yet he makes no attempt to defend himself, for he has no chance; the quick gulls have seized the booty and fled before his slow brain and slower body can move to resent the robbery.

\subsection{CALIFORNIA BROWN PELICAN. - Pelecanus occidentalis californicus.}

Faurly: The Pelicans.

Length: $4 \frac{1}{2}-5$ feet.

Nuptial Plumage: Head and chin white, the top of head tinged with straw-yellow; a chestnut patch more or less lengthened to crest on back of head; neck chestnut, merging to seal-brown; upper parts, including wings and tail, silver gray, more or less streaked with sealbrown; under parts dark brownish, streaked with white; pouch and feet red.

Adults in Winter: Similar, but entire head and neck white, somewhat tinged with straw-color; pouch and feet dull olive.

Young: Head, neck, and upper parts light-brownish gray, tipped with paler; under parts white, washed with brownish gray on sides.

Geogruphical Distribution: Pacific coast from British Columbia to the Galapagos.

Breeding Range: Islands off coast of Lower California and Mexico.

Breeding Season: May and June.

Nest: Usually on the ground, sometimes in the mangrove trees; a loosely constructed, rather bulky mass of sticks and weed-stalks ; lined with grass.

Eiggs: 2 to 5 ; chalky white. Size $3.00 \times 2.01$.

The California Brown Pelican is abundant throughout California, especially from Santa Cruz southward. At almost any time of the day during the fall, winter, and early spring, a flock of them may be seen lazily 
flying along the coast over the water in pelican fashion, one behind another. Their flight is characteristic, being five or six wing-strokes taken by all simultaneously, followed by a soaring, which lasts until the leader gives the signal for more wing-strokes. Back and forth up and down the coast, always in pelican single file, the line broken only when one dives to the water for an especially tempting fish. At the inlet on the west side of the isthmus of Santa Catalina, the early morning hours are vocal with the noise of their fishing. Plunk! plunk! - they dive one by one from various heights, striking the water with a heavy splash that can be heard several hundred feet. Mr. Gosse says that these Pelieans invariably turn a somersault under the surface of the water; for they descend diagonally, and the head emerges in the opposite direction.

Although shown a young Brown Pelican which the owner said he had taken from the nest on Santa Catalina Islands, I found that the fishermen there agreed with Mr. Grimell that no pelicans nested nearer than Los Coronados Islands. As they return to the same breeding ground year after year, the rookery would certainly have been discovered, no matter how inaccessible.

\section{WHISTLING SWAN. - Olor columbianus.}

Family : The Ducks, Geese, and Swans.

Length: About $4 \frac{1}{2}$ feet.

Adults: Uniform white; basal portion of bill white, with lores black, the latter usually with a small yellow spot.

Young: Light grayish; bill pinkish; feet light. 
Geographical Distribution: Whole of Forth America.

Breeding Range: Aretie regions.

Breeding Season: June, July, and possilly May.

Nest: "The eggrs are usually laid on a tussock surrounded with water, and so near it that the female sometimes sits with her feet in the water." 1

Eggs: 3 to 6 ; grayish white, stainet with rusty. Size $4.19 \times 2.72$.

Triss beautiful bird is found in the United States only in winter and while migrating in spring and fall. It is rare in California, but a few remain through the winter in the interior of the northern part of the State. The peculiar call note is kept up while the birds are migrating; it resembles the "honk" of wild geese, but is shriller and more metallic in tone. Heard overhead in a small valley shut in by mountains, it has a weird, vibrant quality.

\section{TRLMPETER SWAN. - Olor bucinator.}

Fanily: The Ducks, Geese, and Swans.

Length: $5-5 \frac{1}{2}$ feet.

Adults: Plumage uniform white; bill and lores jet black.

Foung: Grayish brown, browner on head and neek.

Geogruphical Distribution : Interior of North America, west to the Pacific coast; rare or casual on the Atlantic.

Erreding liange: Interior of the Northem Luited States northward. Breeding Sicasom: May and June.

Nest : On high ground; of grasses and moss; lined with down and feather's. Eygs: 2 to 6 ; white. size $4.30 \times 2.60$.

A Not uncommon bird in California during the winter and early spring. It is found somewhat back from the coast in the fresh-water sloughs. Aceording to Mr. Shields, the ery of the Trumpeter Swan resembles the tones of the French horn. Certainly it is a different 
sound from the shrill notes of the preceding species, being deeper and more mellow. It is a more common bird in Southern California, and may be heard, as well as seen, in large flocks migrating during the early spring and late fall. It trumpets, however, at dusk and daybreak, for an hour at a time without ceasing, and is particularly noisy at nesting time when feeding its young; the united clamor carrics the news of its presence at the nest to listeners a mile or two away. Although the arctic regions are the breeding ground of this bird, a few pairs are said by Mr. Lockhart to breed on the Saskatchewan River in British Columbia.

\section{BIRDS FOUND ALONG THE $B E A C H E S$}

\section{WILSON PHALAROPE. - Steganopus tricolor.}

Family : The Phalaropes.

Length: Female, 10.00 ; male, 9.00 , a little smaller than a robin.

Male in Breeding Plumage: Upper parts grayish brown, brownest on crown and merging to reddish brown on sides of neck in a more or less distinct stripe; line over eye and under parts white, tinged with buff on throat and breast.

Female in Breeding Plumage: Back and crown slaty gray ; a black stripe on sides of head and neck merging to red-brown on shoulders; line over eye and under parts white, tinged with light brown on chest and lower part of throat.

Adults in Winter: Upper parts dusky gray ; under parts white, washed with grayish on chest and siłes.

Downy Young: Light cinnamon-brown above, paler below, merging to white on under parts. Line of black through crown and nape to back of neck. Three black stripes on lower back. 
Geographical Distribution: From British Columbia, south in winter to Brazil.

Breding Range: Breeds locally throughout the United States from latitude $35^{\circ}$ northward. At Lake Tahoe and other points in California.

Breeding Season: May 20 to July 15.

Nest : A slight depression in the ground; lined with grass.

Eggs: 3 or 4 ; buffy, marked with umber. Size $1.30 \times 1.60$.

Wilson Phalaropes present some unique features of bird life. The female is an inch or more longer than the male and larger in proportion. She is more conspicuously marked, and is the handsomer of the two, a condition rarely found avifauna. Although so

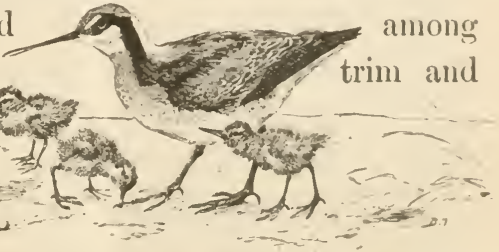

224. Wilsoy Phalatiofe.

"Picking up their oun food before they were ten hours old."

dainty, she is naturally, perhaps, somewhat overhearing in her domestic relations, refusing to consider her master in anything. She does all the wooing, and woe to the unfortunate male if two females place their choice upon him. No roice will he have in the matter, for the more persistent or the stronger will win, and he must follow her. To do him justice, he seems to admire her fully as much because she is aggressive. Once the choice is made his daily life is cut out for him. He must make the nest in which madam combescends to lay three or four buff eggs spotted with dark brown. After that the entire care of incubation and rearing the brood devolves upon him. In one instance at least. I 
am positive that the mother was not near the nest at any time after the eggs were laid. The male brooded continually, leaving only when necessary to obtain food. Almost as soon as the down was dry on the chicks they ran out of the nest like little sandpipers, and followed him about up and down the beach, picking up their own food, before they were ten hours old, and the second day they were swimming in the shallow water as gayly as any of the adult birds.

The Phalaropes are not rare along the eastern part of California, and doubtless nest in other marshes than those bordering some parts of Lake Tahoe. They breed there quite abundantly, and their sandpiper-like cries mingle with the plaintive notes of the killdeer whenever anyone enters the nesting place. Like the killdeer, also, the Phalarope will fly restlessly back and forth over its home, revealing by its very anxiety what it is most anxious to conceal. Wilson Phalarope is exclusively an American species, and is less common on the coasts than in the interior.

225. AMERICAN AVOCET. - Recurirostra americana.

Fanily: The Arocets and Stilts.

Length: 17.00 .

Adults in Summer: Head, neck, shoulders, and ehest uniform light reddish brown, merging to buff at base of bill ; rump, wing-patehes, and belly white; scapulars and primaries black; bill long, black, and curved upward; feet and legs grayish blue.

Adults in Winter: Head, neck, and chest grayish white; otherwise as in summer.

Downy Young: Upper parts grayish, mottled with darker; under parts iighter, nearly white on throat and chest; dark, almost black, splatches on the rump and shoulders. 
Geographical Distribution: Westeru United States in general from latitude $30^{\circ}$ to the Canadian border; sonth in winter to Cuatemala and West Indies.

Breeding Range: The plains of the Dakotas, Montana, Wyoming, Colorado, Utah, and interior of California.

Breeding Season: June to July 15.

Vist: Of grass stems matted together; placed in tall grass near water. Eygs : 2 or 3 ; light olive, spotted with brown. Size $1.90 \times 1.35$.

THE American Avocet is a conspicuous bird nnder any circumstances, for its long, curve(l-up bill, intensely black and white plumage, and long blue legs are sure to attract attention. In some localities its blue legs have given it the nickname of "blue-stocking." In writing of these birds, Mr. Frank Chapman says: "They frequent shores and shallow pools, and in searching for shells, crustaceans, etc., their peculiar recurved bill is used in a most interesting manner. Dropping it beneath the surface of the water mutil its convexity touches the bottom, they move rapidly forward, and with every step swing their bill from sicle to side as a mower does his seythe. In this way they secure food which the muddy water would prevent them from seeing:"

They may occasionally be found swimming in small companies, but never in exposed or very open water, and usually as near shore as possible. The nest is made in a wet meadow, and is not molike that of a king rail, exeept for size. The young, like the young raik, are taken to the edge of a meadow, and, until they are two or three days old, do not go into the water. 'They pick up bugs for themselves from the damp ground and run to cover at the call of the mother, after the mammer of killdeer. Their note is seldom heard until nighthall 
when, during nesting season, it adds much to the weirdness of the marsh music. The alarm call is something between a croak and a whistle, but usually the retreat is made with no sound but the soft flutter of wings as the birds take refuge in the tall marsh grass.

226. BLACK-NECKED STILT. - Himantopus mexicamus.

Family: The Avocets and Stilts.

Length: 14.50-15.00.

Adult Male: Back of head and neck, upper back, and wings iridescent greenish black; tail grayish ; forehead, throat, and under parts white ; white spots above and below each eye; bill black; feet and legs flesh-color.

Adult Female: Similar to male, exeept back, which is grayish brown.

Downy Young: Upper parts light grayish, mottled with dark; large

black patch on back and rump; crown light grayish, with median line of black; under parts white.

Gcographical Distribution : United States, chiefly west of the Great Lakes ; south in winter to Brazil.

Breeding Range: From Southern States to Oregon. In Califoruia, breeds in Los Angeles County and in various localities in interior of State north to Sutter County, west of the Sierra Nevada; east of the Sierra Nevada it breeds as far north as Rhett Lake.

Breeding Season: May 1 to June 16.

Nest: A shallow depression in ground ; lined with grass and occasionally rimmed with rootlets; usually in grass on edge of lake.

Eggs: 3 to 4; light olive-brown, thickly and irregularly marked with purplish brown. Size $1.72 \times 1.20$.

This bird with the extraordinarily long legs is rare east of the Mississippi River, but throughout the West it is abundant. It is a common summer visitant in California, where it breeds in colonies. Formerly it was found in numbers in Los Angeles County, but of late years it seems to prefer more northern nesting grounds, although a few pairs still breed there every year. It is 
a picturesque graceful bird, well proportioned in spite of the stilt-like legs which give it its name. In flight it is not unlike the cranes, but when alighting it drops its feet and raises its wings, poising a moment, as do the gulls. It feeds upon small fresh-water crustaceans, mollusks, and larve of insects, not scorning earthworms, and picks its way daintily through the marsh grass in search of favorite tidbits, with a charming air of quict grace. Surprised, it springs into flight, trailing its long legs behind it. During the breeding season it is quite noisy, uttering its hoarse croaks continually, until the whereabouts of its nesting place may be known by any who will investigate. A large part of this noise oceurs when the food is brought to the mate on the nest, where it receives a joyous, if unmusical, welcome. The nestlings look like balls of down perched upon tootlpicks, but neither their legs nor their bills are developed at all in proportion to those of the adults. They are spry, like the young of most ground birds, and in at marvellously short time become self-supporting.

\section{L(ONG-BILLED) DOWITCHER. - Macrorhamphus griseus scolopaceus.}

Finuly : The Snipes and Sandpipers.

Length: 11.00-12.50.

Adults in Sicmmer: Upper parts black, mottled with buff and light redbrown; rump mottled black and white, and tail barred hlack and white; a light line over 'ye, and a dark one from eye to bill; mnder parts mottled on throat, breast, and belly with red-hrown and blackish; sides and lower tail-coverts barreel with same colors.

Adults in Winter: Plumage uniform dusky gray; line over eye and the lower belly white. 
Young: Similar, but belly and chest tinged with uniform light red. brown.

Geographical Distribution: Mississippi valley and Western North America from Mexico to Alaska. In California it is found as a common winter visitant in the interior valleys.

Breeding Range: The Yukon valley and aretic regions.

Breeding Season: May 28 to July 1.

Nest : A shallow depression in Alaskan moss; placed on dry hill-tops.

Eggs: 3 or 4; dirty grayish buff, marked with blackish brown. Size $1.80 \times 1.20$.

Is California, the Long-billed Dowitchers occur only in the winter, when cold drives them southward from their chosen haunts among the frozen regions of Alaska. They come in October, Hying in little companies along the coast region or through the interior valleys, feeding wherever there is a suitable marshy place. About San Francisco Bay and Alviso they may occasionally be seen on migration, but as soon as possible they find winter quarters in the more sheltered valleys. Their flight is strong and swift, though rather low. When resting, the Dowitchers huddle together in the tall grass, and are either so confiding or so stupid that they are easy victims to the hunter. To know them one must watch them in their nesting grounds in the Yukon valley. Here, according to Mr. Selson, their noisy wooing can be heard morning and evening, the love song being a clear "peeter-wee-too ; wee-too! pee-tel-wee-too ; wee-too," sung as the pair hover in midair, twenty yards above the earth.

The unlined nest is usually in a clump of Alaskan moss or dry grass, and not very near the water. The young are covered with brownish gray down, so protective in coloring as to render their discovery difficult. 
If disturbed, the mother flies a short distance with a shrill cry and, hiding behind a tussock, watches the intruder but makes no attempt to defend.

By September 1 the adults are in winter plumage and ready for their trip south.

\section{LEAST SANDPIPER, OR MEADOW OXEYE.}

\section{Pisobia minutilla.}

Fanily: The Snipes and Sandpipers.

Length. 5.00-7.00.

Adults in Summer: Upper parts Insky, nearly blick; feathers edged with light red-brown; midhlle tail-feathers black, onter ones gray ; mpuer throat, belly, and sides white; neck and breast yellowish white, streaked with dusky.

Allults in Winter: Upper parts lighter than in summer, and elouded with dnsky; under parts light gray, finely streaked with darker.

Ioung: Similar, but with heavy black streak through crown and midlle of back.

Geographical Distribution: North America, wintering from the Gulf Stites southward.

Brealing Range: From Canala to aretic regions.

Brecding Season: May 15 to June 15.

Nest: A slight depression in the dry ground near water; usually lined with leares and grasses.

Eyys : 3 or 4 ; light gray, speckled with cimmamon and lavender. Size $1.15 \times 0.85$.

These tiny little Sampipers are commonly found in flocks, alone or in eompany with the semipalmated sandpipers, along the shores of the bays and lakes of California during the fall, winter, and spring. They trip lightly along the beaches, just at the erlge of the water, with a dainty bobbing walk, scurrying ont of the reach of a wave, picking up bugs and water insects, and so absorbed in the fun that they forget to be afraid. Mr. 
Bailey describes them as quick to take alarm, but I have had them pick up food almost under my feet. Their habit of frequenting the meadows in the vicinity of water and hiding in the long grass has given them the name of "Neadow Oxeye." On account of their small size, they escape the covetous eye of sportsmen and plume-hunters, and are in little danger of being decimated by the gun. When newly hatched, the young are not larger than a man's thumb, and they begin immediately to run about on their spry little legs.

243 a. RED-BACKED SANDPIPER, OR OX BIRD. Pelidna alpina sakhalina.

(Common names: American Dunlin; Lead Back; Black Breast.)

Family: The Snipes and Sandpipers.

Length: 7.50-8.00.

Adults in Summer: Upper parts bright reddish-brown, more or less mottled and streaked with black; breast whitish, streaked with dark gray; centre of belly black; sides and lower belly white.

Adults in Winter: Upper parts brownish gray, streaked with dark gray; breast ashy, streaked indistinctly with darker; rump, throat, and belly white.

Young: Similar to winter adults, but with upper parts streaked with black and buffy.

Geographical Distribution: North America; south in winter to South America.

Breeding Range: Arctic regions.

Nest: A slight hollow; lined with grass.

Eggs: 3 or 4 ; grayish buffy or greenish white, dotted with shades of brown. Size $1.43 \times 1.01$.

THIs species may be known in any plumage by its curved bill. It is common along the coast of California 
in the winter, and is found in the interior in spring and fall. Early in May it leaves for its breeding grounds in the arctic regions, returning in October. 'It is seen usually in large flocks, and, being less active than most shore birds, is oftener a victim to the surf of the winter storms. Walking along the beach after a blustering night or day, one occasionally may find the lifeless bodies of these little birds half buried in the sand, not in the same numbers as the more venturesome waders, but enough to sadden a morning tramp.

\section{WESTERN SANDPIPER. - Ereunetes mauri.}

Fanily: The Snipes and Sandpipers.

Length $: 7.00$ or 8.00 .

Adults in Summer: Upper parts black or dusky, conspicuously mottled with buffy and red-brown; breast and silles streaked with blackish ; rest of under parts white.

Adults in Winter: Upper parts dull brownish gray, indistinctly streaked with dusky ; under parts white, with faint dusky spots on breast and sides.

Dormy Ioung: Upper parts bright rusty buff, spotted with black; a black line through crown and midille of back; laair-like feathers among the down, tipped with yellow; under parts cream-white.

Geagraphical Distribution: Western North America; south in winter to Central America.

Breelling Range: Alaska and British America.

Breeding Season: June 1 to July 1.

Nest : $A$ hollow in the ground, with scanty lining of grasses.

Eygs: 4 ; elay-colored, thickly speckled with reeldish brown. Size $1.20 \times 0.87$.

Tue Western Sandpiper is abundant on the Pacific coast during the spring and fall migrations. In its nesting grounds it is said by Mr. Nelson to be fearless, and conspicuously devoted to its young. He gives an 
instance in which a bird returned to her eggs across a man's outstretched arms. During migrations the Western Sandpiper rests occasionally for two or three days in one locality. It is less timid than most of its family.

\section{SANDERLING. - Calidris leucophaea.}

(Common names: Surf Snipe; Ruddy Plover; Beach Bird.)

Fayily : The Snipes and Sandpipers.

Length: 7.00-9.00.

Adults in Summer: Upper parts mottled white, gray, and black ; darker through erown and middle of back; wing-bar and entire under parts white.

Adults in Winter: Upper parts ashy gray; bend of wing blackish ; under parts uniform clear white.

Young: Upper parts pale gray, spotted with black and white; under parts white.

Geographical Distribution: "Nearly cosmopolitan." In America a few winter in Texas and California, and from there southward to Patagonia.

Brecding Range: Aretic and subaretic regions.

Breeding Season: June 15 to July 15.

Nest : A slight depression in gromnd; lined with grasses.

Figgs: 3 or 4 ; greenish buffy, speckled with brown. Size $1.41 \times 0.91$.

THe Sanderling inhabits the entire American continent, and may be found during spring and fall migrations picking up its food on nearly every salt-water beach. It follows closely in the wake of cach receding wave, scampering out of the way of the returning water with swiftness and dainty grace. This game of tag with the ocean would seem to be as much for fun as for food. for I have often watched them as they ran back and forth after the waves for several minutes without pick- 
ing up anything. In California the Sanderling frequently remains all winter and adds to the delights

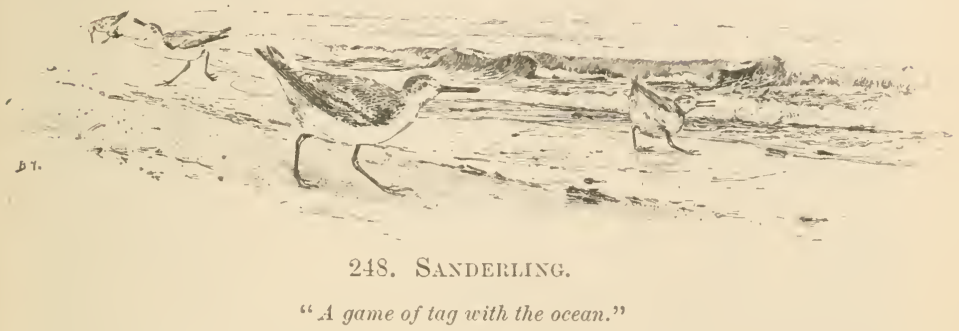

of a stroll along the beach. Not especially shy, it will permit one to come within twenty feet of it, and it palys no attention to any observer seated on the sand.

\section{GREATER YELLOW-LEGS. - Totanus melanoleucus.}

Fanily: The Snipes and Sandpipers.

Length: 12.00-15.00.

Aclults in Summer: Lpper parts black, streaked and spottecl with white and gray; tail and upper tail-eoverts white, barreel with black; midlle of belly white; rest of under parts white, spotted or barred with black; throat streaked light and dark gray.

Aclults in Winter: similar, but upper parts dark gray, mottled with white; under parts white, finely speekled with gray on throat and upuer breast.

Young: Similar to winter adults, but white of plumage tingerl with bulfy.

Geographical Distribution: North America; sonth in winter to South America.

Brecling lange: From latitude $40^{\circ}$ northward.

Nest: A shallow, grass-lined hepression in the groumet.

Eygs: 3 or 4 ; mullily buff, markel with dark lnown. Nize $1.13 \times 1.20$.

'Tнв Greater Yellow-legs is an abundant migrant throughout California, some remaining in the sonthern 
portion near the coast throughout the winter, and, doubtless, a few breed in the more northern Sierra Nevada district, though I am unable to find any anthoritative breeding record. My own record shows that none were seen by me after May 9, although a search and lookout were maintained. They are conspicuous birds, and not easily mistaken for others of their family. The white tail and rump are distinguishing marks, particularly in flight. This bird is the sentinel of the gamc-birds, giving warning of the approach of the hunter in loud, whistling notes repeated rapidly; hence its names "Telltale" and "Long-legged Tattler." Mr. Chapman writes of it delightfully as follows:

"Few birds are flying; lulled loy the lap, lap of the water, I have almost fallen aslecp, when from far up in the gray sky comes a soft wheu, wheu, wheu. I respond quickly, and lying on my back, look eagerly upward. Not a bird can be seen, but the questioning call grows stronger, and is repeated more frequently. Finally I distinguish five or six black points sailing in narrow circles so high that I can scarcely believe they are the birds I hear. But no bar or shoal breaks the sound-waves. The birds grow larger, and widening circles sweep earthward. Their soft whistle has a plaintive tone; their long bills turn inquiringly from side to side. The stolid decoys give no response, they repel rather than encourage; but the whistling continues, and with murmured notes of interrogation, the deluded birds wheel over them, to find too late that they have blundered." 
259. WANDERING TATTLER. - Heteractitis incana.

Fanily: The Snipes and Sandpipers.

Length: 10.50-11.50.

Adults in Summer: Upper parts uniform slate-color ; under parts barred with dark gray and white; throat white, spotted with dusky ; lower belly white.

Adults in Winter: Upper parts, siles, and breast gray ; middle of belly and throat white.

Young: Similar to winter adults, but feathers of wings and back narked with pure white.

Geographical Distribution: Pacific coast of North America from Alaska to Lower California, west to Hawaiian Islands and Kamtehatka.

Breeding Range: From Vanconver Island northward to valley of Yukon River.

"Nest and Eygs apparently not recorded: but young birds taken by Macoun on west coast of Yancouver Island " (F. M. Bailey).

THE Wandering Tattler is well named, for it remains in one locality only during the nesting season, which is from May 20 to . July 1 in Mlaska. Its food consists of mollusks and crustaceans, and for that reason it is seldom found at any great distance from the shore. Its note is a clear, flute-like whistle, not unlike that of the greater yellow-legs, and is translated by one observer as "tu-tu-tu-tu." Like its larger relative, it is a stately little bird, wraceful whether on land or in the air. It is said to grive warning of the approach of danger by a shriller whistle than its customary sweet call, and comsequently is berated by sportsmen. 


\section{SPOTTED SANDPIPER. - Actitis macularia.}

\section{(Common names: Teeter; Tip-up; Sandlark.)}

Family : The Snipes and Sandpipers.

Length: 7.00-8.00.

Adults in Summer: Upper parts gray, with an olive or greenish bronze sheen; head and neck faintly streaked with black; back barred with black; under parts white, spotted with black ; a white wing-bar conspicuons in flight.

Adults in Winter: Under parts uniform white, withont spots or markings.

Downy Young: Upper parts buffy gray, with black line from bill through and down back, crossed transversely at shoulders by two short black lines in form of Greek cross; under parts white.

Young: Similar to winter adults, but finely mottled or barred with buff on back.

Geographical Distribution: North America to Hudson Bay; in winter to South America.

Breeding Range: Breeds locally wherever found. In California breeds ou shores of lakes in the Sierra Nevada.

Breerling Season: June.

Nest: A depression in the sand a little way back on a beach, usually under a tuft of grass; unlined, or scantily lined with dry grass.

Eggs : 4 ; light lutf, thickly spotted with lilac, light brown, and umber. Size $1.34 \times 0.92$.

Found along almost every beach and river and lake of California, this small Sandpiper is the most abundant and most commonly observed of all our shore birds. Its dainty, dipping motion while standing by the shore las given it the nickname of "Teeter," and that name alone would help to identify it. It is the only one of its fumily that nests commonly in California, and is a member well worth studying. It may be found in the same locality day after day, picking up its food at the edge of the water, or venturing out on the lily pads in search of some particularly tempting morsel. The young leave 
the nest as soon as the down is dry, but so protective is their coloring that they might erouch unnoticed at your feet. I have found them sleeping huddled together at night in a hole made by a cow's foot in the grassy meadow bordering a lake, and though they were so openly exposed, I should never have discovered them but for the anxiety of the parent birds. They are about the size of a. walnut, quaint little balls of down, perched on toothpick-like legs, and have the same odd habit of bobbing as the adults. Instead of opening their mouths to be ferl, after the manner of most young birds, they will pick up the food found for them by the parents, and in a day's time they have learned to hunt it along the shore. They are independent youngsters, wise in tricks of hiding motionless on the sand or in the grass, and in kecping together. Their low, sweet, pecping notes are like those of young chickens, and they seem to care more for each other than for the brooding of the parent birds. The call note of the adults is a sharp "peet-weet" uttered on the wing.

\section{LONG-BILLED CURLEW, OR SICKLE-BILLED}

\section{CURLEW. - Numenius americanus.}

Fanily: The Snipes and Sandpipers.

Length : $20.00-26.00$.

Adults: Heal, neck, anl upper parts streaked and mottled grayish buff and black; umler parts brownish bufr, more or less streaked and barred with black; bill very long, slender, and eurved.

Douny Young: Upper parts deep butf, mottled with black; under parts sulphur-yellow; bill straight.

Geogruphical Distribution: Entire temperate North America; south in winter to West Indies. 
Breeding Range: North of latitude $35^{\circ}$ to latitude $50^{\circ}$. In California breeds in northwestern portion of the State, in the Pitt River valley. Breeding Season: May and June.

Nest: A shallow depression in the ground; lined with dry grasses; placed near water.

Eggs: 3 or 4 ; buffy, spotted with purple and umber. Size $2.52 \times 1.85$.

The Sickle-billed Curlew is a conspicuous bird wherever it occurs on the beaches. In California it is common on the coast and valleys west of the Sicrra Nevada during the winter months, appearing early in October and remaining until the last of April or the middle of May. These Curiews fly in wedge-shaped flocks of from fifty to a hundred, the morement of migration being continuous when started, and mostly by daylight; they rest and feed late in the afternoon. A flock of them alighting is suggestive of a multitude of gigantic butterflies, as they touch the earth with feet down and wings raised over their backs.

Their long bills are used to probe in the earth for their food, which consists of worms, small snails, crabs, crayfish, the larve of beetles, and adult insects of all kinds. Their note is a prolonged whistle as heard from high in the air, or a clear rich call as you flush them from the ground. If disturbed in their breeding ground, they unite, as do the jays, to drive the intruder away with harsh cries and a succession of shrill notes.that one observer calls laughter. Failing in this, they circle about as near as they dare, and occasionally one, more daring than the rest, comes too near for comfort. The mother, finding defence useless, tries the old feint of a broken wing, while the others watch her with anxious cries. 
The young bird has a well-developed but straight bill more than an inch long when hatehed; he runs about on strong legs within an hour of his emancipation from the shell.

\section{HUDSONIAN CURLEW, OR JACK CURLEW} Numenius hudsonicus.

Family : The Snipes and Sandpipers.

Length : 16.50-18.00.

Adults: Upper parts mottled and barred with pale cinnamon-brown and blackish; line through the crown buffy, bordered with two brown stripes; under parts bufl, narrowly streaked with blackish.

Douny Young: Buffy brown above, merging to lemonyellow below; "uper parts indistinctly mottled with dusky.

Geogruphical Distribution: Nearly the whole of North and South America; south in winter.

Breeding Range: Aretic regions.

Breeding Serusom : June 15 to July 15.

Nest A slight hollow, scantily lined with grasses.

Eggs: 4 ; pear-shaped, grayish yellow, coarsely scrawled with chocolate and brown. Size $2.27 \times 1.57$.

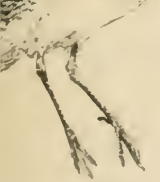

The Ifudsonian Curlew oceurs

265. He:1)soxidx Culilew.

" Hhen alighting." throughout North America, breeding at the ponds and lakes of tine aretic regions and in all parts of Mlaska. In ('alifornia it is abundant as a spring and fall migrant, and is found on the eoast in empany with the longbilled curlew and the jack-snipe. Like the others, it is a conspicuous bird on the beach or flying in triangular flocks orer the edge of the water; like the long-billed curlew, it drops its feet and raises 
its wings in a peculiar butterfly fashion when alighting. It is not so commonly found in the interior as other members of its fanily, and probes in the sand of the beach for its food rather than in the salt mcadows; its favorite food is small snails, water-spiders, and crayfish.

\section{BLACK-BELLIED PLOVER. - Squatarola}

\section{squatarola.}

(Common names: Beetle-head; Oxeye; Whistling Field Plover; Bull-head Plover; Swiss Plover.)

$$
\text { Fanily : The Plovers. }
$$

Length: 11.00 .

Adults in Summer: Sides of head and neck and under parts black; lower

belly and under tail-coverts white; upler parts mottled black and white; tail white, barred with black.

Adults in Winter: Tpper parts brownish gray, mottled with lighter, and under parts white, streaked with gray.

Young: Similar to winter adults, but spotted on upper parts with buff. Geographical Distribution: Nearly cosmopolitan.

Breeding Range: Arctic regions.

-Breeding Season: July.

Nest: A mere depression in the soil, lined with dry grass.

Eggs: 4 ; light butfy olive, heavily marked with lirown or black. Size $2.04 \times 1.43$.

The Black-bellied, or Beetle-head Plover is a common migrant on the California coast. Each spring and fall flocks may be seen flying in lines or wedgeshaped ranks after the manner of geese, and their mellow three-noted whistle sounds clearly above the roar of the surf. These birds run along the beach at the edge of the water, snatching up the sea food left by the receding tide, and when the tum sets in they retreat to the higher sand banks to be out of the way of a wetting. The 
species is nearly cosmopolitan, being found in Asia, Ifriea, Australia, the West Indies, North America, Central America, and South America on migrations; in the breeding season it is found in Russia, Siberia, Alaska, Franklin Bay, and the Barren Lands. In each locality it has a different common name.

\section{KILLDEER. - Oryechus vociferus.}

Family: The Plovers.

Length: 10.50 .

Aclults: Forehead, throat, collar, and under parts white; front of the crown, lores, ring aroumd the neck, band on the breast, black; back olive-brown ; rump and sides of the tail dark butly.

Douny Foung: Upler parts olive-brown; under parts white; collar and bands across the chest, and across lores black, like adults.

Geographical Distribution: North America ; south in winter from latitude $30^{\circ}$ to South America.

Breeding liange: Breeds locally wherever found. In California breeds throughout the State, but in Jarge numbers at Lake Tahoe.

Breeding Season: May and June.

Nest: A slight depression in the earth; unlined.

Eggs: 3 or 4; butfy, marked with dark brown and blackish. Size $1.50 \times 1.10$.

Wherever seen, this pretty plover amounces its name in plaintive eries of "kildee, kildee." Often in the night, as if troubled by bad dreams, it somds this anxious cry. It is abundant everrwhere, and is known to every country boy. Its nest is on the bare ground in the edgre of an myland meadow; but the eggs are so protectively colored that you might pass it without notice, did not the old bird by her great anxiety proclaim the hiding place. In hour later you may find every shell broken and the little ones gone, for they run about in the grass as soon as free. No other bird will 
make more frantic efforts than the Killdeer to lead you away in order that the young may escape: she feigns broken wings, falls over and over on the ground, moaning as if with pain, and begging you to capture her. But the whole performance is only a feint, for when you come up to her, she will fly away on swift, strong wings. The favorite nesting ground is more or less stony, and the little Killdeers, crouching motionless to hide, so resemble the stones as to render discovery difficult. They are very like the adults in form and markings, the characteristic black bands across the upper breast proclaiming the kinship were other sign wanting.

\section{SNOWY PLOVER. - Egialitis nivosa.}

\section{Family: The Plovers.}

Length: $6.00-7.00$.

Adults in Summer: Upper parts pale buff-gray ; forehead, cheeks, and under parts white; har across forehead, patch at back of cheeks, and patch at the side of chest black.

Adults in Winter: Black, replaced by grayish.

Young: Like winter adults, but feathers of the upper parts distinctly tipped with white.

Downy Young: Upper parts pale grayish buff, mottled with black; white collar across neck; under parts white.

Geographical Distribution: Westem United States; south in winter to Chili.

Breeding Range: Breeds wherever found in the United States; throughout California as far north as Pescadero.

Breeding Season: April and May.

Nest: A slight hollow in the sand; unlined.

Eggs: 3 ; pale grayish buff, spotted with umber and black. Size $1.20 \times 0.90$.

THE Snowy Plover is resident all the year round in the southern part of California near the coast, and occurs 
as far north as Cape Mendocino. It is abundant at Long Beach, San Pedro, and all along the sandy coast near Los Angeles. These Plovers are pretty, plump little birds, and trip unconcernedly at the water's edge, picking up the food left by the retreating waves. If one is disturbed, it crouches flat on the sand, in a hollow if possible, trusting to protective coloring to escape notice. A nest found near San Diego in April, contained, when discovered, three clay-covered eggrs. When it was visited three hours later, two little ones had broken the shell and were crouched down like small gray stones. The third egg was sterile. The young were abont the size of large walnuts and were the prettiest creatures imaginable. The next morning the nest was deserted, only the particles of eggishells seattered about told where it had been; but the mother bird was discovered with both chicks hiding behind a tuft of grass. No other nest was found nearer than two hundred feet, and it is doubtful whether the one found at that distance was really the nest of a Snowy Plover.

This species has none of the dipping motions of the sandpiper, and is much plumper-looking, though not less trim than the sandpipers. Its call is a whistled "pleep, pleep," somewhat between the note of a spotted sandpiper and that of a golden plover. 
284. BLACK TURNSTONE. - Arenaria melanocephala.

FAniLY : The Surf Birds and Turnstones.

Length: 9.00 .

Adults in Summer: Forehead, sides of hearl, neck, throat, and chest

black, more or less spotted with white, a snuall white patch in front

of the eye; crown and back iridescent greenish black; belly and sides white.

Adults in Winter: Similar, but withont white spots on head and neck. Young: Plumage like winter plumage of adults, but black is replaced by grayish, and feathers of the upper parts are tipped with white or buff. Geographical Distribution: Pacific coast of North America, from Point

Barrow to Lower California.

Breeding Range: From British Columbia northward.

Breeding Season: June and July.

Nest: A slight depression in the ground, near beach.

Egys : 4 ; grayish green, thickly spotted with brown. Size $1.62 \times 1.12$.

The Black Turnstone is common along the coast district of California throughout all the year. Mr. Grinnell says that although a few individuals remain all summer, they are not known to breed within the confines of the State. They are seen most frequently along the exposed ocean beaches, where their curious habit of poking under small stones for food has given them their name. They may be known by their short, sharp, tip-tilted bill, black head, and white rump. There are but four species in the family, three of which oceur in the United States. Of these the Black Turnstone is the only one met with frequently in California, although the Ruddy Turnstone occurs as a migrant throughout the coast district. All the species are strictly maritime birds, living on the outer beaches and shunning the interior. 


\section{BLACK OYSTER-CATCHER. - Hamatopus bachmani.}

Family: The Oyster-catchers.

Length: 17.00 .

Adults: Hea:t and neck bluish black, rest of plumage rusty black; bill chisel-shaped and rest; feet and legs red.

Young: General color more brownish.

Douny Foung: Head, neck, and upper parts sooty brown; the down tipped with rusty; under parts black.

Geographical Distribution: Pacific coast of North America from Lower California to the Aleutian Islands.

Breeding Range: Breeds nearly throughont its habitat.

Breeding Serson: June.

Nest: The bare ground of the beach or the sliale.

Eggs: 1 to 3 : olive, spotted with umber and purplish gray. Size $2.20 \times 1.52$.

Tue Oyster-eatcher family inclucles ten species, mostly found in the tropies; but three species are found in North America, and two occur in California. While found all along the coast of California, they are especially partial to rocky portions and islands, and are not usually seen on the sand beaches. Their feeding grounds are the outer bars, beaches, and rocks, where they search for clims, muscles, and oysters exposerl by the fill of the tide. The strong shells of these mollusks the birks pry open with their bills. Oystrer-catchers are abmulant along the rocky coast at Ia . Jolla, but I have never fommd any breceling there. Mr. Anthomy foumd them breeding on the rocky islands close to the coast, the egress having been laide on the bare rocks, usually but a few feet above high water, and close to the eige. All about them were empty shells of limpets brought there 
by the mate of the nesting bird. In no case was there any attempt at nest-building.

When watehing this bird stride over the rocks with a queer stilted motion, one is impressed with the idea that its odd gait is the effeet of self-consciousness. So shy is it that it keeps up a constant nervous turning of its head in search of danger, and takes alarm at the least unusual sight in the distance. The eall note is a low, rather musical whistle.

\section{BIRDS FOUND IN BAYOUS AND MARSHES}

1. WESTERN GREBE. - Rchmophorus occidentalis.

Fayily: The Grebes.

Length: 27.50 .

Adult Plumage: Top of head and stripe down back of neck black ; rest of upper parts brownish gray; lower parts, including sides of head and all of neck except stripe down back, glossy white; bill long and yellowish white, with black stripe down upper mandible from base to tip.

Douny Young: Above uniform light brownish gray; under parts white. Geographical Distribution: Western North America from Lower California to British Columbia ; east to Manitoba.

Breeding Range: Breeds locally nearly throughout its habitat.

Breeding Season: Approximately, May 15 to July 1.

Vest : A mass of floating vegetation on the surface of the water in a slough or marsh, and usually fastened to surrounding rushes.

Eggs: 2 to 5 ; soiled bluish green. Size $2.50 \times 1.40$.

Achmophorus occidentalis is the largest of all the North American grebes, but not the most common. It is found in the marshy portions of the inland lakes on the Pacific coast and throughout the Western States. Gre- 
garious, like all the grebes, it nests in colonies sometimes numbering a hundred. I marshy place where there is water from two to four feet deep is chosen, so that safety from storm may be secured for the nest anong the strong rushes, and escape from pursuit may be found for parent and young by diving directly from the nest into the water. Knowing their helplessness on land, the wise grebes avoid all travel on it for themselves and their broorls. The nest platform of rushes is made by pulling the reeds down one by one until they lie eriss-cross on the surface of the water. Upon this foundation is placed decaring regetation of all sorts, picked out of the water, - apparently the wetter the better. The eggs when first laid are a pale blue-green, but soon become a dirty brownish color from contact with the slime of the nest.

Naturalists assert that all grebes cover their eggs during absence both for purposes of eoncealment and to assist incubation. I believe, however, that this is less the practice of Western Grebes than of any other variety, for out of many nests I visited only one was covered, while I have never fouml the nest of either a pied-billed grebe or an American eared grebe where there han not been at least an attempt at corering. The engres of the Wrestern ripecies also are invariably less stained than those of either of the others, a liact which may support the theory that they are not so fully covered.

Egrgs of the American eared grebe are often found in the nest of a Western Girebe, but never, to my knowledge, rice rerse. I believe this is to be accounted for 
by the more exposed position and looser construction of the nests of the American eared grebe, which results in their destruetion by storm. When this occurs, the homeless bird nearly always invades another nest, and usually the better made one of his larger neighbor. Frequently, this results in a battle to the death for the possession of the nest, but never, so far as I have observed, in a victory for the smaller bird.

\section{AMERICAN EARED GREBE. - Colymbus nigricollis californicus.}

\section{Fayily: The Grebes.}

Length: 13.00 .

Adults in Nuptiol Plumage: Hearl, neck, and chest black; sides of head behind eyes with tuft-like patches of small buffy brown feathers; under parts silky white, washed with dusky on sides; inner quills dusky; eyes searlet; eyelids orange.

Douny Young: Top of head dusky; with white markings; upper parts light brownish gray ; under parts white.

Geographical Distribution: Western North America from Guatemala to Great Slave Lake. East to Mississippi valley.

Breeding Range: Locally throughout above territory.

Breeding Season: Aplroximately, Nay 15 to August 1.

Nest : A mass of floating vegetation more or less matted together and woven to surrounling rushes; in more open situations than that of the western grebe.

Eggs: 3 to 7 ; elliptical in shape; bluish white, more or less soiled by dampuess of nest. Size $1.75 \times 1.19$.

This little Grebe breeds commonly in the inland lakes, grassy ponds, and sloughs of California, Washington, Oregon, and Lower Canada. I)r. Jeffries tells me that it also breeds somewhat sparingly in the slough across the isthmus at Santa Catalina Islands, and I found several individuals there, in nuptial plumage, in 
These habits in the care of the young characterize all species of grebes, for in no birds are the family traits more prominent than amoug these queer divers. To the shame of all plumage-hunters be it said, the love of the grebes for their young is one cause of the rapid diminution of their number, for so expert are the grebes in diving at the flash of the gun that, but for the mother love which impels them to protect their helpless little ones, they could easily escape. But they are mercilessly shot while defending their nests, and the young are left to starve, while the silvery breast of the mother bird adorns the hat of a thoughtless woman.

\section{PIED-BILLED GREBE. - Podilymbus podiceps.}

(Common names: Hell Diver; Water Witch; Dabchick.) Fanily: The Grebes.

Length: 13.50 .

Adults in Summer: Upper parts glossy blackish brown; sides of head and entire neck soft gray-brown; throat black; upper breast and sides of belly light gray-brown, indistinctly mottled with dusky; belly and lower breast glossy white; bill light, crossed by black band.

Vinter Plumage: Throat changed from black to dull white; head hrowner; lower parts whiter, with no dusky spots; white bill replaced by lrown withont blaek band.

Yonng: Similar to winter adults, but sides of head striped with brown. Douny Youny: Hearl and neck black and white with rufous spot on crown; upler parts blackish, with stripes of white.

Gcographicul Distribution: The whole of North America from Mexico to Hulson Bay.

Breeding Range: Breeds locally throughout its habitat.

Breeding Season: Approximately, May 15 to July 1.

Nest: A more or less solid structure of mud, marsh grass, and wet weeds ; fastened to growing plants. Sometimes built entirely up from the bottom of the slongh, and sometimes laid on the rushes pulled over 


\section{BIRDS FOUND IN BAYOUS AND MARSHES 87}

to support it. It is fastened securely, and usually rises several inches above the surface of the water.

Eggs: 5 to 10 ; soiled greenish white. Size $1.70 \times 1.18$.

THIs, the most abundant of the grebes, is the one usually shot for its plumage. It breeds commonly in Los Angeles County, California, and about San Francisco Bay. Its common names express well its marvellous powers of diving and remaining for a long time under water, where it swims easily and rapidly with just the tip of its bill exposed. On land it is, like all grebes, awkward and helpless, and, as one author says, looks more like a tiny kangaroo than a bird. Possibly on account of its helplessness when on the nest, it has formed the habit of covering the egors with decaying vegetation during the daytime and leaving them to be cherished by the artificial heat, and of returning to brood them during the night. Certainly these little Grebes are never found on their nests during sumny days, and in California June days are always sumny. In Oregon, on dark cold days, they are close sitters, and it is an ocld sight to see them jump into the water at any distance and disappear with scarcely a ripple. They breed abundantly throughout California in the more sheltered ponds and inland lakes, requiring only that there shall be tule, rushes, or flags to form a platform for the slimy structure called a nest. The young Grebes attempt to dive as soon as hatched, but rarely suceeed in submerging their entire bodies at the first trial ; and their plumage, like that of the adults, seems to be waterproof, for never a wet feather do they show on emerging. The Piedbilled Grebe is a much shyer bird than either the West- 
ern or the eared grebe, and is less noisy, its call being only a plaintive note quite in contrast to the hoarse croaking cries of the larger species. It is also less gregarious ; a pair may sometimes be found nesting in a marsh unfrequented by any other of their species.

187. WHITE-FACED GLOSSY IBIS. - Plegadis guarauna. FAMILY: The Ibises.

Length: 22.50 .

Adults: Head, neck, and lower parts reddish brown; feathers around base of bill white; lores pink; upper parts iridescent green and purple.

Young: Upper parts as in adults, except head and neck streaked with white and dark ashy gray; under parts plain gray-brown.

Downy Young: Entirely black.

Geographical Distribution: Tropical America, south to Argentine Republic and Chili; north from Texas and Lower California to Oregon. Brecding Range: Texas and the Gulf States, and, to a limited degree, in the Ballona marshes, as well as various San Diegan points.

Breeding Season: April, May, and June.

Nest : Of reeds woven in among the rushes; shaped similar to the red-

winged blackbird's nest, but much larger.

Eygs : 3 to 5; deep bluish green. Size $1.95 \times 1.35$.

In the wet meadows and marshes of California there are frequently seen queer black birds which might be taken for large crows but for their long legs and long, curved, curlew-like bills. They wade about probing in the mud for crayfish or snails, or stand motionless on one leg in heronesque attitudes, watching for mimnows in the shallow water. In habits they seem to resemble the bitterns, nesting in the rushes and feeding upon frogs, fresh-water crustaceans, or small snakes, trusting to protective coloring for safety except when forcerl to 
take flight. At dusk and at dawn, large companics of them may sometimes be secu circling slowly over a marsh as if to find a suitable feeding ground, or flying in long lines as after the nesting become more sulless frequently wing.
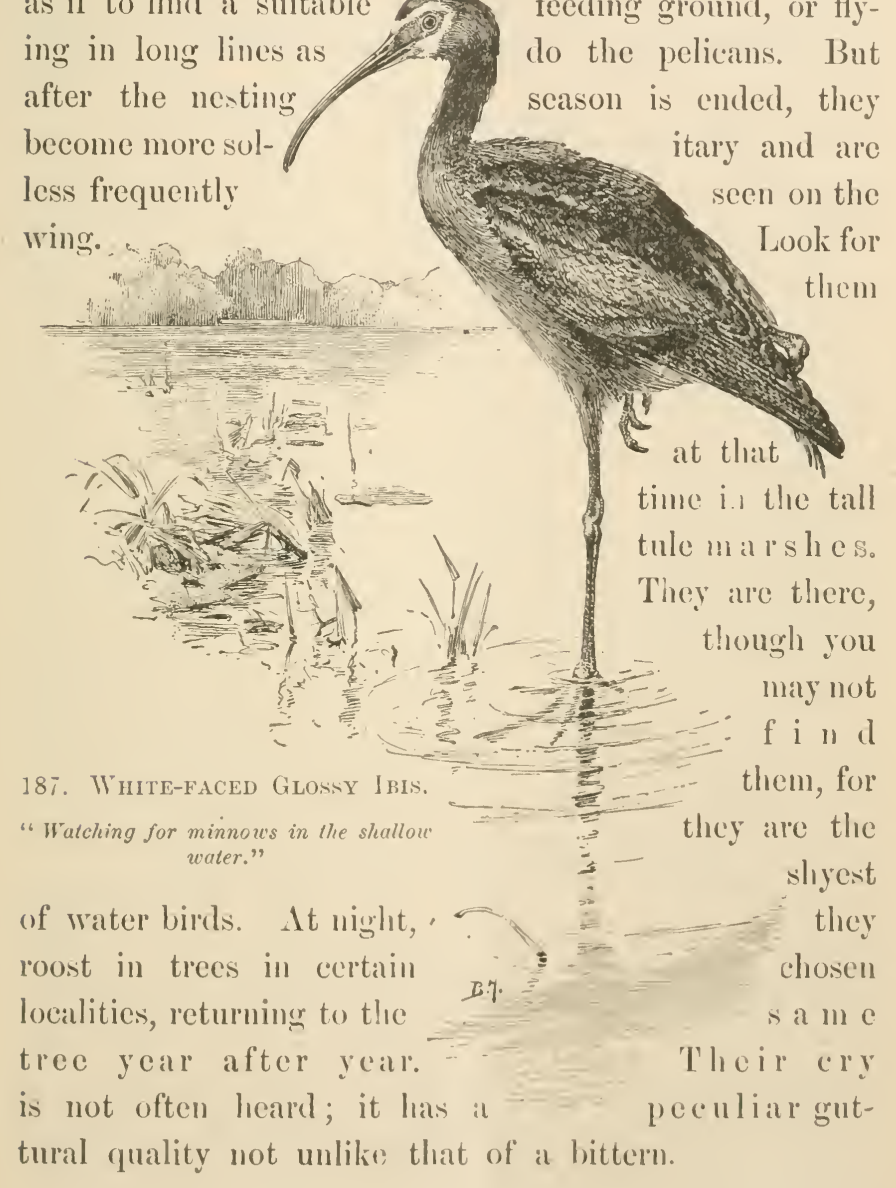
190. AMERICAN BITTERN. - Botaurus lentiginosus.

(Common names: Marsh Hen; Stake-driver; Thunder Pump.)

Family: The Herons, Egrets, and Bitterns.

Length: 29.00 .

Adults: Crown and nape slate-color, more or less tinged with light brown ;

a black stripe on either side of the neck; back irregularly mottled chestnut, blackish, and light brown; quills and coverts gray, tipped with chestnut; under parts light brown to pale buffy-white on throat, striped with darker.

Youny: Similar to adults.

Geographical Distribution: Temperate North America, south to Guatemala.

Breeding Runge: From the Middle States northward. In California in limited numbers.

Brecding Season: May and June.

Nest : A loose mat of marsh vegetation or grasses; on the ground in swampy places.

Eggs: 3 to 5 ; light olive. Size $1.90 \times 1.50$.

THIs much-scorned bird, for whom neither sportsman nor ornithologist has much regard, is common in nearly every marsh and slough throughout the United States at some season of the year. It is called "Fly up the creek," "Stake-driver," "Bog-bull," and other names too unpleasant to mention. Most of them bear some reference to its peculiar love song, called commonly "pumping." The sound is somewhat like the noise of a distant piledriver, and is at once recognized as soon as heard. The birds may be both heard and seen in the marshes at Alviso and in Los Angeles County, California. Only two things are required by the observer, - patience and leisure. Twilight and dawn are the hours at which they 
may be most frequently heard. They are solitary birds, each pair nesting alone. Their food consists largely of frogs and small fish, which they obtain by still fishing, standing motionless for almost any length of time in shallow water anong rushes.

The newly hatched Bitterns are particularly homely nestlings, with their disproportionately long neeks and bills. They are fed by regurgitation for at least fortyeight hours after hatching. The Bittern's attempts at love-making and brooding are rendered pitifully grotesque by the ungainly body of the birl and his queer contortions. Even in flight he is slovenly and loose-jointed, as if his legs were likely to be shaken off from the efforts his wings are making. In fishing he sits motionless for hours with head drawn back to the shoulders, the very picture of discomfort. In fact, under no circumstances does he seem joyous or even moderately happy.

191. LEAST BITTERN. - Ixobrychus exilis.

Fanul: The Herons, Egrets, and Bitterns.

Length: 13.00 .

Adult Mule: Top of head, back, rump, and tail glossy blark; sides of head and neck light buff, deepening to chestnut on nape ; throat and fore-neck white, striped with pale straw-color. Under parts pale buff; a lark patch on either side of the breist.

Arlull Frourele: Similar, with brown in plane of black on wpler parts. Foung: Similar to aulult female, but coloring more buffy on upper parts.

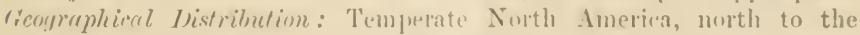

British provinces, south to the Wrest Indies and Brazil ; less common wrst of the liorky Mountains. (1n the Pacilic coast north to Oregon. Biereding Rerenge: lireeds locally whererer found.

Brefoling Seasun: Ma. to August. 
Nest : A platform of marsh grass or rushes; placed on a floating bog or slongh.

Eygs : 3 to 5 ; light olive. Size $1.23 \times 0.93$.

The Least Bittern, or Little Green Heron, as it is sometimes called, is a smaller and much shyer bird than the American bittern. It is found nesting in small colonies in the edge of swamps; its nest is a mere crushed-down platform of rushes, and itself so exact an imitation of its surroundings as to be practically invisible to the naked eye. On the approach of danger it becomes rigid, with head and bill extended straight up, in mimicry of a reed, thus rendering its discovery much more difficult. If discovered and flushed from the water-side, it straddles off through the weeds by grasping them on either side with its feet, producing a comical effect of walking on stilts. It looks back often to see whether it is being pursued. If approached from the land side, it takes wing with lond squawks of terror, and flies low but swiftly through the open channels of the marsh to a tree if there be one near. It is frequently found roosting in trees in the early morning or evening, in groups of six or more, after the breeding season is over. During the breeding season its call is a soit dove-like note, repeated over and over in a sort of undertone, as if it were intended for the ear of its mate alone. 


\section{4 (part). TREGANZA BLUE HERON, OR BLUE CRANE. - Ardea herodias treganzai.}

Fanily: The Herons, Egrets, and Bitterns.

Length: 45.50 .

Adults: Crown and throat white; sides and back of head white; feathers lengthened to form a crest; upper parts bluish gray ; under parts broadly striped black and white; legs and feet black.

Young: 'Top of head sooty slate; throat white; neck ashy, washed with light brown; under parts streaked buff, slate, and white, with some black.

Geographical Distribution: Western United States, sonth to western Ilexico.

Brcelling Range: Breeds locally in colonies wherever found.

Breeding Seeson: April and May.

Nest : A platform of coarse sticks ; placel high up in the tree; always in colonies.

Eggs: 3 to 4 ; pale bluish gray. Size $2.50 \times 1.50$.

Thr: Great Blue Heron is a common species throughout California, and nests in almost every locality where it is found. It Murr Station, California, there is a large heromry in sycamore trees on the property of Mr. John Muir, and the noise of the young birds at feeding time can be heard half' a mile away. 'The birds return to their heronly in February, and the young ane liatched in April, though fresh ergers have been found as late as . func 1. 'ìhe young are feal by regurgitation, which in this case is a more than usually ludierous performance. So violent is the shaking which each young heron undereges in the proess of receiving his food that he secms in imminent danger of being jerked out of the nest and hurled to the ground fifty feet below:

These herons fly miles to obtain fish for food, and one or the other parent is en ronte during all the daylight 
hours. After having been fed, the young heron draws back his head until it lies upon his shoulders, and sits there a sleepy, solemn-looking hunchback until next feeding-time.

\section{AMERICAN EGRET.-Casmerodius egretta.}

Family : The Herons, Egrets, and Bitterns.

Lenyth: 39.00 .

Allults in Nuptial Plumage: Snowy white; the interscapular plumes straight, filamentous, very long, reaching below the end of the tail ; head without crest; bill yellow; lores orange.

Youny, and Adults after Breeding Season: Same, but lacking the interscapular plumagre.

Geographical Distribution: Tenprerate and tropical America, on the Pacific coast from Oregon to Patagonia.

Breeding Runge: As far north as Oregon on the Pacific coast.

Breeding Seuson: April, May, and June.

Nest: A loose platform of coarse twigs; in colonies in trees near water. Eggs: 2 to 4 ; light hluish. Size $2.35 \times 1.65$.

The story of the American Egret is one more tragedy in the annals of ornithology, and is "a startling evidence of man's power in the animal world. At his word a species is almost immediately wiped out of existence." These beautiful birds are exterminated in Florida, and the devastation has begun on the Western coast ; already they are listed as "rare" where they once bred in abundance. The "nuptial plumage" only is salable, since it alone contains the pretty "aigrette" plumes; and so, at a time when the true sportsman is bound by an unwritten law to protect the nesting birds, the plumehunter shoots them mercilessly for commercial purposes. 


\section{SNOWY HFRON. - Egretta candidissima.}

Fanus: The Herons, Fgrets, ana Bitterns.

Lenyth: 23.50 .

Adults: Plumage always pure white.

Nuptial Plumrge: Pure white: "aigrette" plumes hang like a whire fringe from interscapular resion to beyond the end of the tail ; similar plumes on lower neck and forming an oecipital crest; hill black, yellow at base; legs black ; feet yellow.

Young: Like adults after breeding season ; that is, white, with no interseapular plumes.

Geographical Distribution: Temperate and tropical America; on the Pacific coast from Oregon to Rinenos Ayres.

Brreding Range: As far north as Oregon.

Breeding Season: A pril 15 to June 15.

Nest: A loosely built platform of sticks; placed in trees or bushes near swamps.

Eggs : 2 to 5 ; light bluish. Size $1.80 \times 1.20$.

BEAUTY has proved a fatal dower to this exquisite bird, which has become nearly extinet through the ravages of the plume-hunters. "The delicate aigrettes which it donned as a nuptial dress were its death warrant. Woman demanded from the bird its wedeling plumes, and man has smpplied the demand." The saddest part of the whole sad story is the fact, not sentiment, that the killing must be done during the nesting season: conseguently the young, bereft of both parents, starve in the nest. For every dainty aigrette in hair or bomnet. a brood of baby heroms has suffered excruciating, longcontinued torture, and death. In Califormia this heron is a summer visitant to the interior valleys, but is by no means eommon at any season of the year. 
201 b. ANTHONY GREEN HERON. - Butorides virescens anthonyi.

Fanily : The Herons, Figrets, and Bitterns.

Length: 15.00-22.00.

Adults: Crown, erest, tail, and wings green; sides of neck yellowbrown; belly light grayish brown.

Geographical Distribution: Sonthwestern Unitel States; south in winter.

Breeding Range: Preeds locally wherever found, along the rivers of the interior.

Breeding Scason: April.

Nest: On branches of trees and bushes; a loose platform of sticks; lined with leaves.

Eggs : 3 to 5 ; light greenish buff or olive.

THIs is a subspecies of the Green Heron, and is found resident only in the southern part of California. Mr. Grinnell lists it as a common migrant, and says it breeds along the larger streams of the interior valleys. It is largely nocturnal in habit, and not unlike the American bittern in its guttural alarm note.

This species is found less often in the marshes, and more often along the banks of shallow streams and small lakes, where it sits for hours motionless in a dead tree or concealed stump, seeming to doze through the daylight hours. Early in the morning or late in the evening, however, the heromry awakes to great activity; for the hungry young clamor harshly for food, and the adults hurry to and fro in pursuit of it. This noise continues far into the night and begins anew with daylight. Frogs, small snakes, fish, and lizards are the prey this Heron seeks, but it occasionally contents itself with insects and field mice. 


\section{BIRDS FOLND IN BAYOLS AND MARSHES 97}

202. BLACK-CROWNED NIGHT HFRON. Nycticorax nycticorax nerius.

FamiLY: The Herons, kgrets, and Bitterns.

Length: 24.50 .

Adults: Crown, scapulars, and back iridescent black, with greenish reflections ; forehead, silles of heal, throat, and umler parts crean white; sides ashy; sides and back of neck light brownish gray; wings, rump, and tail dusky brownish gray; heal ornamented with a few very long, narrow, white oceipital feathers.

Young: Cpper parts grayish brown, each feather marked with a wedgeshaped streak of white; the quills with white at tips; tail brownish gray ; under parts striped dark ash-brown and white.

Geographical Distribution: Nearly all America, except the aretic regions. Breeding Range: From Manitoba to South America.

Breeding Season: April and Nay.

Nest: A platform of sticks, bulky; placed in high trees; in colonies of

2 to 5 in a single tree, and thousands in the close vicinity.

Eggs : 4 to 6 ; pale greenish. Size $2.15 \times 1.55$.

THE Black-crowned Night Heron is an abundant resident in all parts of California, breeding in suitable localities. Although these herons prefer a nest in a tree, they frequently build in tule swamps, following the habits of the bitterns. They are gregarious at all times, nesting in large colonies. Except when there are young in the nest, these birds are nocturnal feeders, begimning at dusk. Their food consists largely of frogs. During incubation, one bird remains on the nest constantly, and is fed by the other, who also shares in the sitting. Is soon as the young are hatehed the fact is male known by the constant foraging for food during the day and carrying it to the nest. It is, however, partly digested and fed to them by regurgitation until they are a week or ten days old. I have never seen anything but frogs, 
minnows, and small suakes brought to the nest, and these are carefully killed before being given to the young. The cry of the Black-crowned Night Heron is a harsh guttural squawk or croak, and the noise made when the rookery is full of young birds screaming for food is indescribable. Each brood discern their own parent flying toward the nest, and, although the nestlings have sat in unbroken silence until then, at sight of him the hungry cries begin.

\section{SANDHILL CRANE. - Grus mexicana.}

Favily: The Cranes.

Length: 44.00 .

Adults: Bluish gray, varying to brownish gray; paler on throat and sides of head, darker on primaries; crown nearly bare, covered with reddish membrane and a seant growth of black hairs.

Young: Crow feathered; plumage rusty brown.

Geographical Distribution: United States from the Mississippi valley west to Pacific coast, south to Mexico, east along the Gulf coast to Florida.

Breeding liange: In mild localities thronghout its habitat.

Breeding Season: February, Mareh, and April.

Nest: A platform of weeds and grass, on the water line, in a marshy lagoon.

Eggs: 2; grayish yellow, spotted with cinnamon and gray. Size $3.98 \times 2.44$.

The habits of the Sandhill Crane and those of the whooping crane are very similar. "During courtship and the early breeding season their actions and antics at times are ludicrous in the extreme, bowing aud leaping high in the air, hopping, skipping, and circling about, with drooping wings and croaking whoop, - an almost indescribable dance and din, in which the females join, 
all working themselves up into a ferer of excitement equalled only by an Indian war dance; and, like the same, it stops only when the last one is exhausted." 1

The alarm call of this species is a long clear note like a bugle blast; it may be heard nearly a mile away. It is repeated over and over, as the birds fly in flocks, like the honk of wild geese.

210. CALIFORNIA CLAPPER RAIL. - Rallus obsoletus.

Fanily: The Rails, Gallinules, and Coots.

Length: 17.50 .

Adults: Upper parts greenish gray, indistinctly but broadly streaked with hlackish brown; under parts red-brown, washed with gray on neck and siles.

Douny Young: Uniform black.

Gcographical Distribution: Salt-water marshes of the Pacific coast from Lower Califoruia to Oregon.

Brecding Range: In sloughs and salt-irater marshes, throughout California and Oregon.

Breeding Season: April, May, and June.

Nest: A loose mat of dry grass ; placed among rushes in marsh.

Eygs: 8; buff, marked with cinnamon and lilac. Size $1.71 \times 1.21$.

Tris species is abundant on the salt-water marshes in the vicinity of San Francisco and Oakland, and particularly in the sonth end of the bay near Mlviso. They are either tame or exceedingly stupid birds - I believe the latter, for they may be captured alive during the early spring and late fall, as they trust to protective coloring and do not try to escape until too late. During the breeding season they are somewhat more shy, but eren then it is nearly impossible to flush them beeause they

\section{Goss.}


skulk or dive rather than fly, and refuse to desert the nest. About the middle of April they commence to make a nest of marsh grass on a tussock, and from that time on are devoted to it. Eight or nine eggs are laid, and incubation lasts nineteen to twenty-three days. The young Rails rmu about within an hour after hatching, and look much like tiny black chickens with overgrown legs and bills. If discovered on a mud flat, they crouch motionless like so many small black lımps of dirt or stones, and though one may know where to search, it is liard to find them. The immature rails are as stupid as the adults, and will often allow themselves to be picked up without trying to get away. Their food consists largely of the larvie of marsh insects which they pick up in the shallow water and along shore, and mature insects of all sorts, as well as small crustaceans. As is well known, certain varieties of marsh birds build several nests, using but one. The "dummy" sometimes serves as a shelter for the adult male; sometimes the making of it seems to have been a mere pastime; and, occasionally, as in the case of the clapper rail, it forms a convenient platform or nursery on which the young can scramble for a sun-bath when weary with their first swimming lessons. These unused nests are commonly placed close to the one oceupied by the brood and closely resemble it. My own observations in this matter, made at Alviso, tally with those of Mr. Adams at San Francisco Bay and Mr. Shields at Los Angeles. 


\section{BIRDS FOUND IN BAYOUS AND MARSHES \\ 212. VIRGINIA RAIL. - Rallus virginianus. FAnily: 'The Rails, Gallinules, and Coots.}

Length: 9.30 .

Adults: Upper parts brownish olive, striped with sooty ; breast and wing-coverts light chestunt; wings and tail dark olivebrown; cheeks gray ; throat white; under parts light chestnut; sides barred with white.

Downy Young: [niform black.

Geogrephical Distribution: North America, from the British provinees south to Guatemala. Breeding Range: Wherever resident. Breeding Season: April, May, and June. Nest : A mat of grasses; placed on a hummock in a marsh. Eggs : 7 to 12 ; buffy, marked with chestnut. Size $1.24 \times 0.94$.

The Virginia Rail, although more common east of the Rockies, is by no means rare throughout California. He is an odd-looking bird with voice and mammers in keeping with his appearance. In the early morning and at twilight his call is a curious combination of grunt and squeal. The love sollg, however, is quite lifferent; it is llescriberl as "a guttural cut, cuttu-ruttu-c*uttu oft repeated for hours in succession." You have only to visit a marsh lake in the afternoon or early in

the morning and listen, "Pisking his uray contiously between the tules."
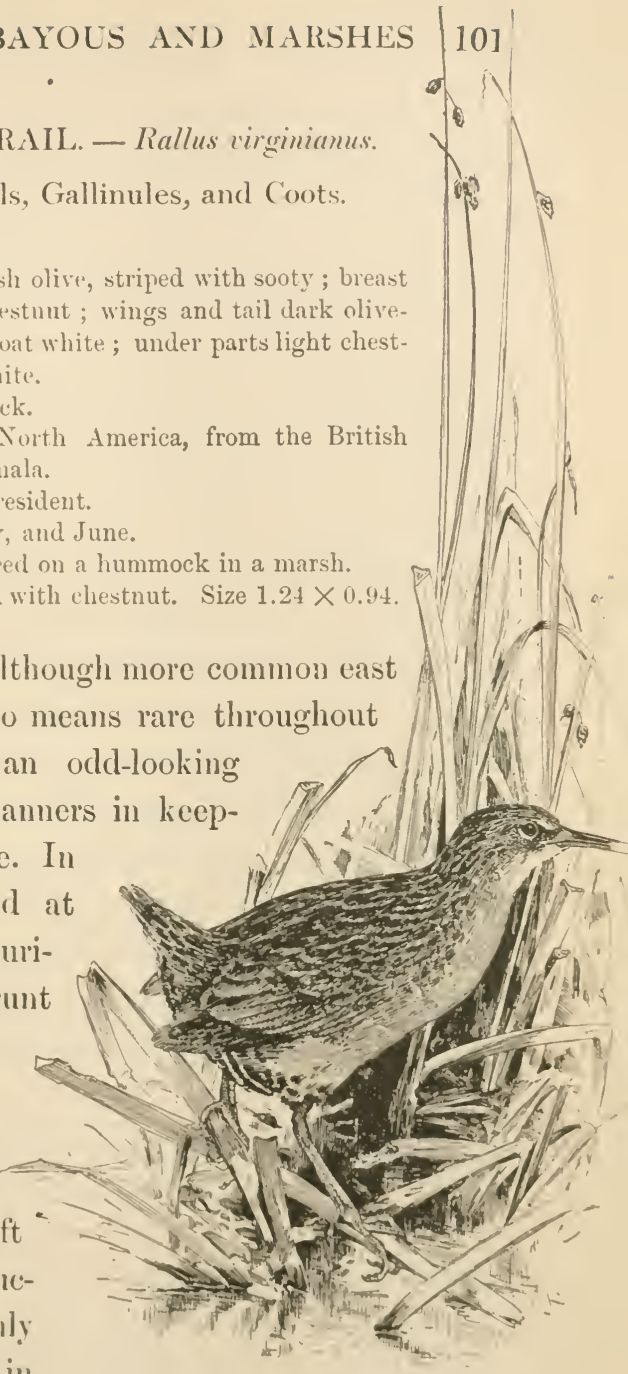

212. VIBgisia RaIL. 
to discover whether or not he is nesting there. But the marsh birds are shy and very wary, and the long marsh grass guards them well. It is far easier to hear them than to see them. If your patience endures long enough, you may catch a glimpse of a Rail picking his way cautiously between the tules, with a curious bobbing motion. If you are so fortunate as to find a mother bird on her eggs, she will become rigid with terror, her red eye dilating and her long neck stretehed up not unlike a water snake. In this position you may easily mistake her for a stick or a dry rush. If flushed, her small powers of flight suffice to carry her only a short distance, when she will disappear in the rushes and no patient waiting will give you another glimpse of her. My own experience goes to prove that the nest is always deserted by her after the first forced flight from it.

Mr. Brewster says: "The female, when anxious about her eggs or young, calls ki-ki-lik-ki in low tones, and kiu much like a flicker. The young of both sexes in antumn give, when startled, a short explosive kep or kik, closely similar to that of the Carolina rail."

214. SORA, OR CAROLINA RAIL. - Porzana carolina.

Fanıly: The Rails, Gallinules, and Coots.

Length: 8.60 .

Adults: Feathers about base of bill black; a broad black line through crown and extending down the back of the neck; throat, breast, and cheeks gray; upper parts grayish brown, streaked with black and white; belly white; flanks barred with blackish slate-color.

Young: Similar, but no black at base of bill ; upper parts larker.

Downy Young: Uniform black; a tuft of orange-colored, hair-like feathers on throat. 
Geographical Distribution: North America ; south in winter to northern parts of Sonth America.

Breeding liange: Northern United States, northward, including California and Oregon.

Breeding Season: May and June.

Nest: Of grass; on the ground, in a marshy place.

Eggs: 7 to 14; cream-color, marked with cinnamon and lilac. Size $1.26 \times 0.90$.

THe Sora Rail breeds commonly in California in swamps about Los Angeles and other suitable localities. Unlike the elapper rail, it prefers fresh-water sloughs, where it hides among the tall rushes. The baby Rails are fluffy little black chicks with absurdly large feet, and neeks too long for their fat little bodies. Almost as soon as hatched they rum about among the grass of the drier parts, sometimes being taken away from the water to an adjacent meadow, where they soon learn to snap up bugs and small grasshoppers. Like all the rail family, the Soras are most musical at dawn and dusk, when their queer weird notes make the marshland seem an uncanny spot. In the South this species is sold as a game bird under the name of ortolan, and is much liked by epicures, though its thin little body has, not without reason, given rise to the saying "As thin as a rail." It is abundant on migrations, flying at night and resting wherever it happens to be during the day, even in the noisy streets of Chieago. In these circumstances it seems stupid and confused. I have captured it without difficulty while it was resting, as it squats on the ground, making absolutely no effort to cseape.

Mr. Frank Chapman writes of this species: "The Sora's summer home is in fresh-water marshes, where, 
if it were not for their notes, the reeds and grasses would long keep the secret of their presence. . . . They will greet you late in the afternoon with a clear whistled keewee which soon comes from dozens of invisible birds about you, and long after night has fallen it continues like a spring-time chorus of piping hylas. Now and again it is interrupted by a high-roiced rolling whinny which, like a call of alarm, is taken up and repeated by different birds all over the marsh. They seem so absorbed in their musical devotions even when calling continuously, it requires endless patience and keen eyes to see the dull-colored, motionless forms in places where one would not suppose there was sufficient growth to conceal them."

\subsection{CALIFO RNIA BLACK RAIL. - Creciscus} jamaicensis coturniculus.

Family: The Rails, Gallinules, and Coots.

Length: $5.00-6.00$.

Adults: Crown blackisl slate; upper parts dark red-brown, speckled with white; under parts, neck, and sides of head slate-color; belly sooty brown.

Douny Young: Uniform black.

Geographical Distribution: Coast region of California ; probably south to Lower California.

Breeding Range: For the Pacific slope, Oregon and California; east of the Rockies, through the United States.

Breeding Season: June.

Nest: Of grasses; on ground; in wet meadows or marshes.

Eggs: 7 to 10 ; white, thinly spotted with cinnamon. Size $1.05 \times 0.80$.

MosT of us are quite willing to agree with the man who said that this bird is "about as difficult to observe as a field mouse." It is its shyness and small size that render it so little known to local ornithologists, who content themselves with pronouncing it rare. Its nest is a 
cup-shaped depression lined with fine grasses, usually in a wet meadow; it may be mistaken for that of a meadow lark, but is nearly an inch less in diameter and never arched over. The Black Rail nests in the marshes at Alviso, California, and, I have no doubt, elsewhere throughout the State. The young are tiny black balls of down, apparently less than one inch in dimeter; they leave the nest the moment the down is dry, and run about with the agility of sandpipers. Although so tiny, they have the instinct of self-preservation to a marked degree; whenever danger threatens they stiffen into unwinking puff-balls, with only their beady black eyes to betray life.

\section{FLORIDA GALLINLLF, OR REI)-BILLED MUD-HEN. - Gallimula galeata.}

Famil: : The Rails, Gallinules, and Coots.

Length: 13.25 .

Adults: Dark slate-color, sometimes tinged with brown on back and whitish on belly; erge of wing and a patch on flank white ; bill ausl frontal shiell refl, tipped with greenish; legs and feet greenish.

Downy Young: Uniform black, a few white hairs anong the down un throat anil cheeks.

Geographical Distribution: Tropical and temperate North Amerien, north to British provinces.

Breeding Range: For the P'acific slope, from Oregon southwarl.

Breeding Secuson: April, May, and June.

Nest: A mat of rushes bent over and more or less woven together, over water.

Eggs: 8 to 10 ; cream-buff, finely marked with reddish brown and chocolate. Size $1.87 \times 1.25$.

Is form so like a sleek bantam hen, in habits so like a coot, the Florida Gallinule is a most interesting study. 
It has a large vocabulary of calls ranging from harsh squawks to pathetic complaining cries not unlike the skirl of a bagpipe. It is a common resident on the freshwater marshes of California, where it can be heard much oftener than seen; for it is exceedingly shy, and its dusky plumage renders it inconspicuous among the rushes. In swimming it has a rather awkward way of sitting up very straight and bobbing its head with every stroke of its feet. Feeding on the mud-flats, it dips daintily, as it picks its way through the tangled reeds after the manner of the king rail. Its nest is of dried tule or marsh grass, lined with softer grass of the neadow, the latter being brought there from a distance. All about the rim of the structure the rushes are broken to form a guard for the eggs, for although usually about three inches deep the nests are sometimes only a shallow platform. The young run about like tiny black chicks, and pick up a living from the water, almost as soon as they are hatched. It would be impossible to distinguish them from young clapper rails except for the sprinkling of white hairs among the black down. They are quite unlike little chickens in one thing: at the warning call of the parent they disappear noiselessly, as if by magic, or are metamorphosed into dark stones; feathered barnyard babies, on the other hand, run to the mother with cries of fear. 


\section{AMERICAN COOT. - Fulica americana.}

(Common names: Mud-hen; Blue Peter.)

Family: The Rails, Gallinules, and Coots.

Length: 15.25 .

Adults: Dark bluish slate, nearly biack on head and neck; under parts paler; edge of wing white; bill white; frontal plate, and spots on bill near end, brown; legs and feet greenish; toes with scalloped flaps. Downy Young: Upper parts rusty black; under parts white; head and neck with orange-colored hair-like feathers, and upper parts with pale ycllow hair-like feathers among the down; bill red, tipped with black. Geographical Distribution: North America.

Breeding Range: Breeds locally through the United States, British Columbia, ancl Canada.

Breeding Season: April, May, and June.

Nest: Of grass and reeds; among the flags or tall marsh grass.

Eygs: 8 to 16; cream-colored, speckled with dark chocolate. Size $1.89 \times 1.42$.

Althocgh so closely resembling the Florida gallinule in appearance, the Coots may be easily distinguished from them by their white bills. They are much more social and are better swimmers than the gallinules, gathering in companies morning and evening in the shallow water at the edge of a marsh, to feed upon the larve of water insects and small crustaceans, which they obtain by diving. 'They like best, however, to pick up) their food from the slime at the border of a mud flat or low marshy place, and here they take their newly hatched bantlings. The young are covered with down of a rusty black color above and white bencath, with pale yellow hair-like feathers sprinkled through it. 'Their' bills, unlike those of the parents, are red. They sometimes stray near a farmyard and may be picked шр easily, as they seem stupefied with lear. 
The adult Coots are very noisy birds, constantly calling, screaming, or complaining. Just after nightfall and before dawn, most California marshes are vocal with their varied cries. But, like the gallinules, they are more easily heard than seen, for they are exceedingly shy. If surprised and forced to flight, they rise with much splattering, fly rapidly a short distance, and fall back into the marsh. They are worthless as game birds, as their flesh is tough and rank in taste; for this reason the real sportsman shuns them. 


\section{Part II \\ LAND BIRDS}





\section{PART II \\ LAND BIRDS}

\section{I. - UPI, NI) GAWE BIRDS}

230. WILSON SNIPE.--Gallinago delicata.

(Common names: Jack Snipe; Fnglish Snipe.)

Famil: 'The Snipes and Sandpipers.

Length: 10.85 .

Adults: Crown buff ; upper parts black, bordered ant mottled with buff ; neck and breast inottled and streaked buffy and blackish brown ; sides barred black and white; belly white.

Douny Young: Upper parts dusky, more or less mottled with light brown ; under parts whitish.

Geographical Distribution: North America ; south in winter to Brazil.

Breeding liunge: From latitude $45^{\circ}$ to the aretic circle. In California, the valleys of the northem Sierra Nevada.

Breeding Seceson: In California, June 15 to July 15.

Nest: A slight depression on open, marsly ground; sometimes lined with grass, usually unlined.

Eyys: 3 or 4 ; olive, streaked with black and elocolate. Size $1.55 \times$ 1.07 .

THe species known as Jack Snipe, or English Snipe, is a prime favorite with sportsmen and epicures. Breeding so far north, they are commomly hunted as migrants, and so are more or less protected during their nesting 
season. They usually migrate in small companies. During the breeding season solitary birds are frequently seen, which spring from the marsh grass with a harsh cry and zigzag swiftly out of sight in a way most tantalizing to the sportsman. Only an expert can hope to bag them. The Jack Snipe frequents low wet places, obtaining food after the manner of a woodcock, by probing with its long slender bill, which, although not prehensile to the extent of a woodcock's, is yet very sensitive at the tip, and readily detects the choice morsels of food down in the damp earth.

Their capricious selection of feeding ground seems to be governed by some occult knowledge as to the conditions of the soil, for they are here to-day, gone tomorrow, and often the only places which seem most likely to be their haunt will not be visited by them at all.

Mr. Bailey writes of the Jack Snipe: "He is a common bird wherever there are marshes to his taste. . . . On warm summer evenings or cloudy days before a storm, he mounts high in the air and with rapidly vibrating wings produces a prolonged whirr that increases to a diminutive roar, and repeats it every two or three minutes for sometimes half an hour. At other times he flies low over the grass uttering a guttural chuck-chuckchuck-chuck-chuck, and then drops out of sight. His common all-round-the-year note is a nasal squawk." 
281. MOLNTAIN PLOVER. - Podasocys montanus.

Fanily: The Plovers.

Length: 8.00-9.00.

Adults in Summer: Upper parts grayish brown; under parts buffy; a white baud across forehead and over the eye; front of crown and lores black.

Adults in Wrinter: Without distinct black or white on head.

Young: Similar to winter adults, but general tone light yellowish brown or buffy.

Geographical Distribution: United States bordering the Pacific; in winter as far south as Santa Ana.

Brecding Range: Interior of the United states from Texas to Montana. Breeding Season: June and July.

Nest: Anywhere on the open prairie; a depression in the ground, thinly lined with grass.

Eggs: 3 ; light buffy olive, thickly speckled with lavender, brown, and black. Size $1.45 \times 1.11$.

Throughout the interior plains of Califormia west of the Sierra Nevada the Mountain Plover is a common winter resident. It can be easily recognized by its large size, and by the absence of rings on throat and breast. Mountain Plover is one of the many misnomers, for although called by this name, the bird loves the prairies and treeless plains, and is never found at great altitudes. Unlike most plovers, it seems to shun the water; even in California it is not found along the beaches where its relatives feed, but hunts grasshoppers and terrestrial insects in the drier inland meadows. Its nest comsists of a few grasses scratched togrether in a spot exposed to wind and weather; and here the female broods for nineteen days. As soon as the down is dry on the ehicks, they scramble off at their mother's heels, and in twentyfour hours are catching bugs for themselves. 


\section{MOUNTAIN PARTRIDGE. - Oreorty.x pictus.}

Family : The Grouse, Partridges, Quails, etc.

Length: 10.00-11.12.

Adult Male: Crest black; back and upper parts olive-brown, striped on sides of back with light brown; top of head and entire breast slate-culor; throat and sides dark red-brown; sides barred with black and white.

Adult Femole: Crest shorter, otherwise like male.

Young: Upper parts grayish brown, speckled with white; breast gray, with wedge-shaped white spots; a whitish line over the ear; belly white; sides washed with chestnut.

Gcographical Distribution: Humid transition zone of Pacific coast region, from about latitude $35^{\circ}$ to Southern Washington.

Breeding Range: Nearly coincident with its habitat.

Breeding Season: April and May.

Nest: A slight depression in the gronnd, lined sparingly with dry leares ; placed beside or under a fallen tree or a bush. Eygs : 8 to 13 ; plain light buff. Size $1.36 \times 1.02$.

The Mountain Partridge of the coast belt is so nearly like the plumed partridge of the Sierra Nevada in habits and coloring as scarcely to need a separate description. Both are designated as "mountain quail" in the common parlance, and it is about as difficult to obtain a satisfactory riew of one as of the other. The plumed partridge is said to measure a trifle less than this species, but in the field the only distinguishing marks are the grayer tone of the back and the bluish nape, all of which makes it difficult to differentiate the species. The Range is possibly the best guide for an amateur in identifying the species.

\section{(For habits see "Plumed Quail.")}




\section{2 a. PLUMED PARTRIDGE. - Oreortyx pictus plumiferus.}

Fanul : The Grouse, Partridges, Quails, etc.

Length: $10.50-11.50$.

Adult Male: Crest black; forehead whitish ; upper parts grayish olive, striped on sides of back with light brown; top of head, hind-neck, and breast bluish slate-color ; throat and sides dark red-brown; sides barred with black and white.

Adult Female: Crest shorter; otherwise plumage the same.

Young: Upper parts grayish brown, speckled with white; breast gray with triangular white spots; a whitish line over the ear; belly white; silles washed with chestnut.

Douny Youny: Head and neck buffy; broad chestnut stripe down the mildle of back and rump, bordered along each side by dlusky ; breast and belly dull whitish.

Geographical Distribution: Arid transition zone of Pacific coast distriet, from Lower California northward through Oregon.

Breeding liange: Along both sides of the Sierra Nevada and the southern ranges.

Breeding Secason: April and May.

Nest : On the gronnd; on bed of lead leaves; concealed under a bush, or weeds, or $\log$.

Eggs: Usually 8 to 14 ; uniform buft. Size $1.36 \times 1.02$.

Food: Insects, berries, and bugs.

Oxe bright morning in early June, on the way from Fyffe to Slippery Ford on the Lake Tahoe stage route, we flushed a Plumed Partridge from the roalside, and my companion remarked that lie had flushed a partridge from that place two days before. I seareh for a nest began among the manzanita bushes and "mountain misery," which latter was thick, nearly ten inches high. After a short hunt we discovered the treasure hidden well at the batse of a tall cedar and guadrded by the pretty white blosisoms and green leaves of Chamabatia. 
It was made of leaves and stems of this plant and lined with feathers, and in it lay ten eggs of the Plumed Partridge. They were nearly ready to hatch, - how ready I did not guess, - and with a hope that no one would molest them in the meantime, we departed, resolving to come back the next day. But I reckoned without my host, for having eaten luncheon and rested, I stole back alone for a last peep at them, and two had pipped the shells while a third was cuddled down in the split halves of his erstwhile covering. The distress of the mother was pitiful, and I had not the heart to torture the bearitiful creature needlessly; so going off a little way, I lay down flat along the "misery," regardless of the discomfort, and awaited developments. Before I could focus my glasses she was on the nest, her anxious little eyes still regarding me suspiciously. In less time than it takes to tell it, the two were out and the mother cuddled them in her fluffed-out feathers. This, was too interesting to be left. Even at the risk of being too late to reach my destination, I must see the outcome. Two hours later every egg had hatched and a row of tiny heads poked out from beneath the mother's breast. I started toward her and she flew almost into my face, so closely did she pass me. Then by many wiles she tried in vain to coax me to go another way. I was curious and therefore merciless. Moreover, I had come all the way from the East for just such hours as this. But once more a surprise awaited me. There was the nest, there were the broken shells; but where were the young partridges? Only one of all that ten could I find. For so closely did 
they blend in coloring with the shadows on the pine needles under the leaves of the "misery" that although I knew they were there, and dared not step for fear of crushing them, I was not sharp cnough to discover them. No doubt a thorough seareh woukl have been suecessful, but this a dread of injuring them forbade me to make.

So pieking up the one which had erouched motionless beside a leaf and which was really not much larger than my thumb, I contented myself with trying to solve the mystery of how so much bird ever grew in that small shell, half of which would scalrecly cover his head. Once fairly in my hand, he cuddled down perfectly eontented to let me fit the empty shell to his fat little body, as if he knew he was ont of that for good. He was a fumny little ball of fluffy down, with a dark stripe down his back and a lesser one on each sicle of that. Mleanwhile the adult bird had disappeared, and there was no choice but to put the youngster back in the nest and go on my way. But I had learned two things, - that affairs move rapidly in the partridge household, and that human eyes are seldom a mateh for a bird's instinct.

Most interesting of the many characteristies of the Plumed Partridge is the habit of migration into the valleys by the first of September each year, and back to the elevations in the early spring. Sicarrety of food does not drive them to more fortile foraging grounds, for in the spring they return while yet there is snow. Unlike their relatives, these birds do not band tougether in larege flocks, and seldom more than two brookls are to be foumd in the same cover. Mr. Edwyn Samlys says: "The call 
of the male is suggestive of the crowing of a young bantam, while the rallying cry of seattered birds is not unlike the yelping of young wild turkeys."

\section{CALIFORNIA PARTRIDGE. - Lophorly $x$ californicus.}

FAMILY : The Grouse, Partridges, Quails, etc.

Length: 9.50 .

Adult Male: Crest black; nape dusky brown, bordered by black and white lines; upper parts dusky brown, striped with chestnut along the sides of the back; throat hlack, bordered by white; breast slatecolor; belly, except chestnut patch, scaled; sides dusky brown, streaked with white.

Adult Femole: Head plain, with no black and white; plumage uniform dusky brown; belly scaled; no chestuut on under parts; sides streaked with white.

Young: Upper parts gray-brown; featkers of back and wing-coverts edged with dark gray and white; under parts white and gray.

Geographical Distribution: Pacific eoast region from 11 onterey to Oregon. Breeding Range: Nearly coincident with the Geographical Distribution. Breeding Season: April and May.

Nest: A hollow near a rock or at foot of a tree trunk; scantily lined with grass; sometimes under hedge, bush, or brush-heap.

Eggs: 8 to 10 ; buffy, thickly spotted with shades of brown. Size $1.33 \times 0.97$.

The crest of the California Partridge is a little longer than that of the valley partridge, and tips forward in the same way.

This handsome little partridge is unfortunately a favorite game bird, and, as such, has become not only somewhat scarce but exceedingly shy. It haunts the cañons and slopes covered with underbrush, as well as the sagebrush and stubble, and has learned to run to cover rather than to flush when pursued. In this way 
it offers a difficult mark for the true sportsman, and is less in danger from him than from the pitiless trapper.

It differs from the valley partridge in being darkercolored and of a more northern range, but is often mistaken for it, as the habits and call are exactly alike. It is quite unlike the mountain partridge, - an inch smaller, and with more of a blue tinge to the slate-color of the plumage. Noreover the crest is shorter and tips

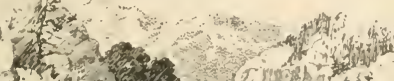

forward like a pompon,

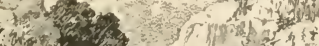

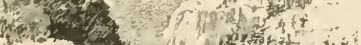
while the mountain

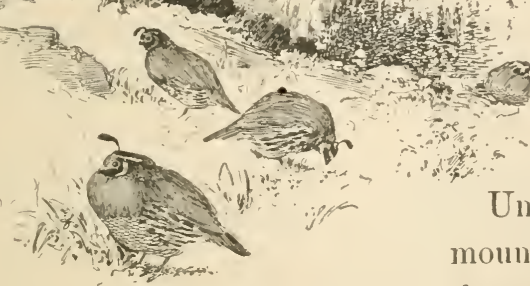

294. Califoryia Partringe.

"It haunts the cañons and slopes." partridge usually car. ries his long erest floating backward.

Unlike the nest of the mountain partridge, too, the nest of californicus is rarely concealed, the eggs being laid on a mat of leaves or grass on the open ground beside a stump or under a bush, and they are sometimes found in the nest of the Oregon towhee. Doubtless the protective coloring helps to prevent their discovery during the three weeks required for incubation. In this task, unlike our Eastern "Bob White," the male does not assist, but frequently stauds guard at a short distance and warns of danger by a sharp short call. The chicks are out of the nest almost as soon as out of the shell. and are as skilful as their parents at rmming to cover. When a day or two old they learn to find their own food, picking up the bugs and even jumping for them when 
they themselves are not much larger than a good-sized beetle. Although so capable and independent, they are constantly attended by both parents until the down has merged into fully developed feathers. Then the gregarious habits of the grouse blood assert themselves, and by September 1 all the broods of that district band together to the number of several hundred individuals, and remain so throughout the fall and winter. This is the harvest time of the hunters and the season of unrest for the birds. In the early autumn mornings in the stubble of the field and the underbrush of the cañons, you may hear their plaintive whistle, "who-are-you," questioning whether friend or foe is astir.

\section{4 a. VALLEY PARTRIDGE. - Lophortyx californicus} vallicola.

Fanicy: The Grouse, Partridges, Quails, etc.

Length: 9.50 .

Adults: Similar to the California partridge ; upper parts grayish; sides olive; crest short and tipped forward.

Young: Breast gray, marked with wedge-shaped black spots; belly faintly barred dark and light gray; upper parts striped brown and white.

Downy Young: Upper parts white, washed with rusty and mottled with dark brown; under parts plain dull whitish.

Geographical Distiibution: Pacific coast region from Southern Californiil to Oregon ; through upper and lower Sonoran zones.

Breeding liange: The interior valleys between the humid coast belt and the Sierra Nevada.

Breeding Season: April and May.

Nest: A slight depression in ground, under hedge, bush, or brush-heap. Eggs: Generally 10 to 12 ; buffy, thickly spotted with sharles of browu. Size $1.23 \times 0.94$.

So closely allied are the California partridge and the Valley Partridge that only by direct comparison of the 
two species may the lighter eoloring of the latter be distinguished. In habits they are alike, but in range they differ, the former being a coast bird and found from Monterey northward, while the latter oceurs in the interior and southem valleys. In spite of being dubberl the Valley Partridge, it is found on the mountains of Lower California sometimes at an elevation of eight thousand feet.

It breeds throughout suitable localities in Sonthern California, and is hunted wherever resident, though not so extensively as formerly, when it was the favorite game bird of that region.

The eggrs are laid on a mat of leaves or grass, or on the bare ground either in mulerbrush or in the farmer's door-yard. Incubation requires three weeks, and usnally the hen alone broods the eggrs. After the young are hatehed they are kept in the underbrush or heary stubble and can rarely be discovered, so expert at hiding are they. Like the California partridge they run to eover rather than fly, and they are so swift-footed that it is almost impossible to flush them. When the young are feeding, the arlult males constantly call them, either to keep the corey together or to give warning of danger, and they answer each call with a faint piping note. This is not unlike the seatter call of the Gastern Bob White, but eonsists of two syllables in one tone, or one longer note. It is not monsual to eome upon a covery of these when driving through the foothills and valleys of Sonthern California, but the sensation is simply of something scamperiug into the brush rather than a definite sight 
of any bird, unless the cock comes out into view for a moment to sound his warning and draw your attention from the brood to his handsome self.

\section{GAMBEL, PARTRIDGE. - Lophortyx gambeli.}

Family: The Grouse, Partridges, Quails, etc.

Length: 9.00-10.00.

Adult Male: Crest black ; forelread and throat black, elged with white ; crown chestnut; upper parts slate-color; breast gray ; belly buff, with black patches; sides bright chestnut, streaked with white lines. Adult Female: Similar to male, but plainer; belly without black patches, and sides without white stripes.

Foung: Upper parts brownish gray, finely mottled black and white; belly uniform white; breast gray, striped with white.

Geographical Distribution: Lower Sonoran zone from Western Texas to

Southenstern California, and from Southern Utah to Mexico.

Breeding liange: The desert region of California southeast of the Sierra

Nevada.

Breeding Season: April 15 to July 1.

Nest: A slight depression in the ground, under a bunch of tall grass; usually without lining.

Eggs: 10 to 12 ; buffy, marked with brown and blotched with light purple. Size $1.27 \times 0.98$.

EARLY in the morning during the months of March and April, the love note of the Gambel Partridge may be heard from the underbrush of the valleys and foothills of Southeastern California. So handsome, so confident in his wooing is he that he sounds it over and over, alike in the warm spring sumshine and the soft spring rain. And it is always answered by a demure little hen that comes stealing noiselessly through the mesquite to peep coyly at her lordly wooer. She admires him. Who would not, as he swells and struts before her, lowering his pretty crest, assuming such loverlike airs? And the 
protection he seems to offer is not all a mockery, for, although he scorns to take part in the feminine task of brooding those buffy eggs, he will stand on guard ready to warn, and will expose his trim body to the hunter for the sake of his mate and young. The brooding time is twenty-eight days, but the little brown mother has endless patience and camnot be induced to desert. If meddled with, she will in some way remove the eggs to another hollow in the ground, and brood as before. This has been done in four instances that I have recorded, and however much it may be disputed, is true. Most of the nests are hard to find, being usually well concealed in a hollow under a log, or mesquite clump, or eacti. The nestlings resemble those of the Bob White in appearance as well as habit, only they are grayer and with less white down on under parts. They run about the moment the.cracking of the shell sets them free, and right spry little balls of down they are, hiding instantly at their father's warning "quit," cuddling under their mother each night, and snapping up bugs for their own breakfasts each day. Fortunately for them, aceording to Mr. Sandys, although so "beautiful, hardy, and prolific." they have some habits which lead a sportsman a hard, wild chase if he gets them at all. They rum rather than fly, keeping under the thickest, thorniest eover; they fly down into cañons only to climb up the other side among the stiffest underbrush; they lie low when the foe is searching close beside them, and they "scoot" when least expected. "Only a Christian of the sternest stripe is fit to be trusted on the trail of this nimble-footed little rascal." 


\section{7 c. SIERRA SOOTY GROUSE. - Dendragapus obscurus sierrae.}

Family : The Grouse, Partridges, Quails, etc.

Length: Adult male 20.00-23.00; adult female 16.00-19.00.

Adult Male: Upper parts blackish slate-color, finely mottled with gray and brown; tail black, with or without gray border on end; under parts very dark slate-color.

Adult Female: Similar to male, but much smaller ; upper jarts washed with dark rusty, and indistinctly barred with sooty brown.

Young: Ulper parts rusty brown, mottled with sooty and buff ; under parts gray, more or less spotted with black.

Douny Youny: Above, brown, white, and black mixed, forming irregu-

lar stripes on the back and head; under parts grayish white or light buffy gray.

Geographical Distribution: California in the timbered Transition and Boreal zoue, north to southern Oregon.

Breeding liange: Nearly coincident with Geographical Distribution. Breeding Season: May and June.

Nest : A hollow under the side of a log or bush, scantily lined with grass. Eggs: 7 to 10; cream, thickly spotted with shades of brown. Size $1.78 \times 1.33$.

The Sooty Grouse is one of the largest and handsomest of its family. It haunts the coniferous forests of the Sierra Nevada, and rears its brood in security in timber too dense for the hunter. Well it knows that in silence and statuesque rigidity lies its safety, and when pursued it takes to a tree, where its sooty plumage makes it seem like a bump on a branch, rather than a bird. Let it guess, however, that its presence is discovered and like a flash it is gone, cackling like a frightened hen and "whirring" like a small cyclone, down into the cover of the underbrush.

"The love-making of the nale is marked by all the 
pomp and vanity of the strutting gobbler ; indeed, in his actions he miglit pass for a turkey bantam, but he has one marked peculiarity. It is his habit to pereh in some thick-growing tree, and by filling the sacs upon his neck with air and abruptly expelling it to produce a low booming whistle, which has an extraordinary carrying and ventriloquial power. This booming, or 'booing' as some. Westerners term it, seldom fails to puzzle sorely a tenderfoot, the baffling feature of it being that it does not appear to gain volume or distinctness when the bird is closely approached." I

In May or June, according to location, the wooing begins, and soon the mother is brooding on her eight buffy eggs in the shade of a fern tangle, near a $\log$, or in a clump of manzanita. No part does the father take in the three weeks of patient incubation, but the mother can seldom be surprised away from the nest. It would be far easier to discover the eggs were she not covering them, for so protective is her coloring that you may be looking directly at her and never suspeet it, although at that very moment you are searching for a nest. Her food is all about her, - buds, berries, and insects. If she leaves the eggs, it is only to stretch her tired little legs and pick up a few dainties close by. But once the little mottled puff-balls are out of the shell and dry, away she goes, proud as a peacock, with them at her heels. And now the father is introduced to family eares, and he scratehes for bugs, calling the young with imperative little chucks to eome. IIe is the drill-master of the

1 Upland Game Birds. 
little flock, teaching them with infinite patience all that they need to know of wood lore. He stands on guard at every suspicious noise, and whistles his warning when danger threatens. When their wing-feathers have developed and they can flutter up to a low branch ii the bush, they roost there instead of cuddling under the mother's broad wings at night. But they remain with the parents and evidently under diseipline throughout the first six or eight months of their existence. In the wintry weather, when their mountain homes are covered deep with snow, they often sleep huddled together deep in a drift, waking to feed upon the buds of the coniferous trees, but seldom seeking a lower level. They are the hardy mountaineers, the children of the forest ranges.

\section{0 c. OREGON RUFFED GROUSE. - Bonasa} umbellus sabini.

Fanily: The Grouse, Partridges, Quails, etc;

Length : 15.00-19.00.

Adult Male: Pough iridescent black, upper parts nottled lark brown and black, tail rusty dark brown; muler parts heavily barred with black and brown.

Adult Female: Similar to male, and with neck tufts less developed.

Young: Similar to adult female, but browner, and neck tufts entirely wanting.

Downy Young: Upper parts chestnut-brown ; deeper on under wings and rump; under parts butf; a conspicuons black line from corner of eye through ear tufts.

Geographical Distribution: Humid transition and boreal zones and the coast ranges from Humboldt County, Califoruia, to the northern limits of Washington.

California Breeding Range: The humid coast boreal from Cape Mendocino northward. 
Nest: On ground in the woods, usually under fallen trees.

Eggs : 6 to 12 ; buffy, sometimes slightly stained or speckled with brown. - Size $1.56 \times 1.16$.

This is a fairly common resident in the coast district of Northern California. Its habits of "drumning," ete. are like those of the Eastern grouse. The cocks leave their mates as soon as sitting begins, and do not usually return until fall, when the broods get together for the winter. The young are to be found with the mother in the vicinity of the nesting place for ten days or two weeks, and then are taken to a thicket-bordered stream. Their food consists of grasshoppers, insects, young leaves of plants, berries, and a few varieties of seed, such as the wild sunflower.

\section{SAGE GROUSE. - Centrocercus urophasiamus.}

Family : The Grouse, Partridges, Quails, etc.

Length: Male 26.00-30.00; female 21.00-23.00.

Adult Male: Upper parts mottled and barrerl gray, luff, and black; cheeks, chin, and throat sprotted black and white; a white crescent on each side of throat reaching to eye ; fore-neck black, merging to dull gray on the chest; the feather's with rery stiff black shafts; belly uniform black; ehest white after breeding season. In breeding season, tufts of wiry black feathers mixel with white down on the shoulders; air sacs on sides of throat yellow.

Aclult Female: Chin and throat white ; fore-neek speekled gray in ruffs; air sacs or shoulder plumes.

Foung: Similar to female, lut hrowner ; makings of lower parts indistinct.

Downy Foung: Upper parts brownish gray mottled with blackish.

Grographiral. Distribution: Sagebrush plains of the Rocky Mountain plateau, southwest to California, uorth to British Columbia.

Breeding Range: In California the arinl Great Basin region, east of the Sierra Nevala.

Breeding Sectson: April and May. 
Nest : A slight depression in the ground; usually unlined, and under a sagebush.

Eggs : 8 to 12 ; olive-yellow, spotted with dark brown. Size $2.16 \times 1.50$.

As its name implies, the Sage Grouse loves the barren alkali plains, "sun-parched in summer and swept by icy blasts and wolf-roiced blizzards during the winter," where no green thing can grow save the sagebrush and the cacti. Here, of necessity, his chief lict is sage leaves, insect;, and the pulp of the cactus fruit; his drink the strong alkali water of the desert. The storms of winter drive him through the timber belt to the stunted regetation under the snow, and he lives for weeks at a time in the warm shelter of a deep drift, eating the young green shoots that he scratches from their wintry cover, five or six feet below the level. With the spring comes a revival of life to the big Grouse. A restless hunting for something takes possession of him, and he wander's through the brush, fighting every male grouse that he meets. In March he encounters his fate in the form of a tiny gray hen, before whom he struts and salaams, sliding along on his breast until he wears a bare place among his fine feathers. What greater proof of his infatuation could he give than this? "Then the big air sacs are filled to their fullest capacity, the spiny feather's about them bristle out like thorns, the long tail is spread and the wings trailed. One familiar with the noise of other grouse naturally would expect from this great fellow a thunderous booming, but the fact is the sounds produced amount to nothing more than a broken, indistinct croaking." It is all done with an air of desperate earnestness, 
comical to a disinterested observer, but very pleasing to madam, who, feigning indifference, is not too easily won. Finally, when his much salaming has scoured his breast nearly bare, you may, if you are sharp enough, discover a nest with gireenish-buff eggs in it, hidden smugly under a sagebush. When the mother is brooding, - and during the twenty-two days required for incubation she is rarely away from the nest, - you will find the search difficult if not futile. So protective is her coloring, and so perfectly does she blend with the alkali dust and the shadows of the sage, that it is impossible to distinguish her so long as she remains motionless. She will sit in unwinking stillness until you are about to step on her, and then, with a blinding "whirr" she scoots through the brush, eackling angrily, to return before you are fifty yards away.

When sitting begins, the erstwhile ardent wooer deserts his mate, and the entire eare of the little ones falls upon her. Jike all grouse nestlings, they run about as soon as the down is dry, which is about fifteen mimutes after the shell breaks. They pick up food at her scratching all day, and at night they nestle on the gromnd under her wings, only a row of little heads being visible. Is soon as their own feathers are dereloped, they sleep every night in a circle about her, each one with head pointed to the outside as before, and always on the gromnd; for the Sage-Grouse never trees. It is not diflicult to come upon. a brood sleeping this way on a moonlight night; but the only satisfation will be to hear the sharp alarm of the mother, a whirr as she rums hy you, amd a knowledge that though the young are hiding on the dust at 
your feet, you could not find then were your eyes tenfold sharper. I have groped carefully on hands and knees among them, and actually touched one before I saw it at all. For the desert hides its secrets well, and the little grouse have learned to trust to it for safety.

These broods unite with others in the same locality, forming coveys of a hundred or more individuals, and as cold weather advances, they retreat to their snow shelters at the timber edge. This is the time the hunters go forth to seek them, for the flesh of the young is not yet tainted with the bitterness of sage diet, and in that barren region game is scarce.

\section{BAND-TAILED PIGEON. - Columba fasciata.}

Fanily : The Pigeons, or Doves.

Length: 15.00-16.00.

Adult Male: Upper parts grayish brown, browner on the back, bluer on the rump, high neck bronzy green, crossed by narrow collar of white ; head and under parts metallic purplish, becoming pink on belly and gray on the sides; belly whitish ; end of tail crossed by broad band of pearl-gray, bordered by black on the upper edge; wing-coverts narrowly edged with white.

Adult Femule: Similar to male, but duller and grayer.

Young: Without white on nape ; upper parts paler; under parts gray, washed with brown.

Geographicul Distribution: Western United States from Pocky Mountains to the Pacific, south through Mexico to Guatemala, through the Transition zone.

California Breeding Range: Mountains of Southern California.

Breeding Season: May, June, July, and August.

Nest: A thin platform of sticks, in trees or bushes near water; sometimes on the ground.

Eggs: 2 ; white. Size $1.50 \times 1.20$.

The Band-tailed, or White-collared, Pigeon is irregularly distributed from the Rocky Mountains to the 
Pacific. It breeds in small numbers at several points in the Coast Range between Santa Cruz and San Diego, laying its two white eggrs on the ground near the bank of a pond or river in some localities. In other places it prefers to construct a shallow platform of twigs in a tree or bush. Incubation lasts fiom fourteen to sixteen days. In shape the newly hatched young are like miniature geese, and their yellow skin is covered with the sparse, cottony, white down. They are fed on a thin milky fluid, by regurgitation, for twenty days. The adult deserts its nest, eggs, or young on the slightest provocation ; it is cxceedingly timid, so that any attempt to study its nesting habits, should one be so fortunate as to discover a nest, would prove disastrous to the brood, unless very cautiously done. They are said to have no breeding season in California, but to raise their young during any month except Decomber. From April to September is their usual time. Deep in the recesses of a cañon you may come upon a company of these gregarious birds in the tree-tops. Unless you see the bird, you will fancy you have discovered a new owl, so hootlike is their "coo." It has been described as "a short, hard hoot and a long coo." In the large aviary on the grounds of Mrs. Sefton at Sin Diego, a pair of these pigeons taken at Bear Valley lare been kept some time; their note has become modified, I presume by continement with other birds, for it is much less expulsive and more purring in quality than when heard in the mountains. They breed in the aviary, laying their egrgs on the ground behind a bush in one corner and also in eom- 
partments for the purpose, like domestic pigeons. The eggs are glistering white, equally round at both ends and very beautiful to look at. The birds themselves are remarkably handsome, and seen coming like rockets through the air down the side of the mountain, are startling to the ear as well as to the eye. The noise is produced by the rapid vibration of the wings, and resembles the roar of escaping steam. In flying upward or on a level, the sound is less loud but quite as characteristic, and, when a large flock are startled into flight, the vibratory effect is not unlike that of a small cyclone.

\section{MOURNING DOVE. - Zenaidura macroura carolinensis.}

Family: The Pigeons, or Doves.

Length: 11.00-13.00.

Adult Lale: U Uper parts soft brownish ; head and neck iridescent grayish pink; a black spot on sides of the lieal ; sides of neck, ehest, and breast changeable metallic purple-pink, changing to buff on the belly.

Adult Female: Similar to male, but paler, and metallie gloss less distinct.

Young: Duller than female, and withont black spot on the head.

Geographical Distribution: Temperate North America, north to Canada, south to Panama.

Brceding Range: Breeds throughout its habitat.

Breeding Season: March to October.

Nest: A platform of sticks, in a bush or tree.

Eggs: 2 ; white. Size $1.12 \times 0.82$.

For a land bird, the Mourning Dove is strikingly fond of the water and usually tries to build within sight of it. At intervals all day, the parent birds fly back and forth between it and their nest, if brooding, and I have reason to believe that the male brings the female water as well 
as food in his own throat. Both adults feed their young by regurgitation for twenty days, and undoubtedly give them water in the same way until they learn to drink, in true pigeon fashion, by suction. The newly hatched Mourning Doves are unique among young birds, for they are daintily formed miniature goslings with goose bill and all. This bill ends in a pearly tip, and the young doves are covered with short, cottony, white down, through which the yellow skin is apparent. The mother birds are both shy and stupid, for they will invariably betray their nest by flying off' when, if they remained quiet, it might not be noticed. I know of no birds who desert their eggs and young so readily. The mother bird is also a slack homselieeper, and so loosely is the nest built that the egges may nearly always be seen from below. In two instances Mr. I?. W. Smith, of Greenville, Illinois, found these hirds ocenpying old robins' nests, and once he discovered two of their egrgs in the home of a thrasher, which also contained one thasher egrog.

In spite of these well-authenticated instances, and the fact that I have found Mourning Doves brooling their young in a kinghbid's old nest thiclily lined with sheep's 
wool, I believe such cases are uncommon; the bird usually builds her own home, and returns to it two years in succession, if not molested.

\section{II.-BIRDS OF PREY}

324. CALIFORNiA VULTURE, OR CONDOR. Gymnogyps californianus.

Fanily : The Vultures.

Length: 44.00-55.00; extent $8 \frac{1}{2}$ feet to nearly 11 feet.

Adults: Head and neck covered with a warty orange skin; bill pale yellow; plumage black; wing-coverts tipped with white; under wing-eoverts pure white.

Young: Like arlults, but naked skin and bill black; more or less covered with sooty gray down.

Douny Young: Covered with white cottony down; bill yellow.

Geographical Distribution: Coast ranges of Sonthern California from

Monterey County to Mexico.

Breeding Range: Breeds in the mountainous districts throughout its habitat.

Breeding Season: Eggs have been taken in April and May.

Nest: The bare floor of a cave or recess among the rocks, or in a hollow stump.

Eggs: 1 or 2; plain grayish green or dull greenish white. Size $4.46 \times 2.48$.

The California Condor is, so far as known, the largest bird that flies, except its cousin the Condor of the Andes, and was formerly abundant throughout the coast ranges of Southeru California. It has become comparatively rare through various causes, chief among them the feeding upon poisoned fiesh put ont by stockmen to kill wild animals. For a long time the.species was on the verge of extermination, but through the efforts of the Cooper 


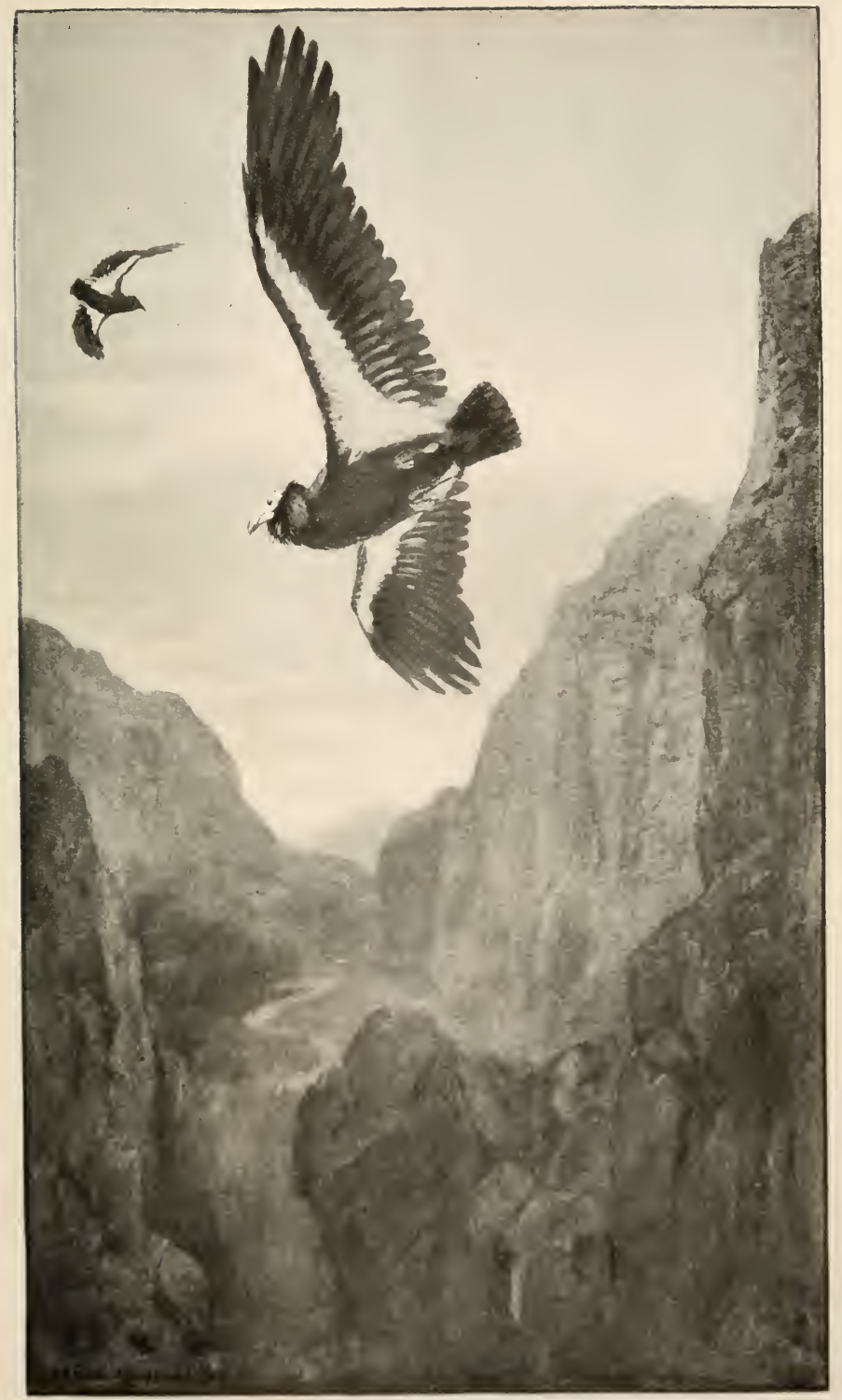

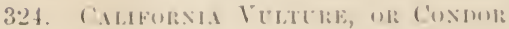



Club it has been protected, and according to latest reports it is increasing in numbers.

On his first trip to California, the Eastern bird-lover expects to see these birds souring majestically over every mountain, and is disappointed when he has remained a year, or two, or three, with never a grimpse of one, although right in the Condor range. The truth is the Condors keep well back in the hidden and inaceessible parts of the mountains, and if you would see one, you must go where they are and see the sun rise, - as they do; for the Condor secks his prey as soon as the sunlight has reached the valleys and before the world is fairly astir. Then you maty sec him on glorious wings, circling, circling, with scareely a movement save of his head, which, streteherl ont before him, turns this way and that. He is magnificent to look at, - nearly eleven feet from tip of wing to tip of wing, - but in some ways he is very stupid. All vultures are stupid. Mlthough so keen of vision that you can never hope to conceal your presence from him, yet he will betray his nest and make no effort to lead you from it by the wise feints of smaller birds. Thus in the animal world nature compensates for great strengtl and ferocity by giving the quicker instincts to the hunted, not to the hunters. The Condor's senses are keen to show him where to obtain food, and his wings are stromer but, in danger from no creature, lie hats not been trained to protect himself. He gorges, is satisfied, and sleeps with no need of precantion for self or young, because, muless his food be poisomed, what has he to fear? The young Condor reared by Mr. 
Holmes of Berryessa developed some remarkable habits, but I believe these were due to artificial conditions.

Solomon puzzled over "the way of an eagle in the air" and left the mystery unsolved, and bird-lovers have been studying it ever since. When I have been able to watch the nesting habits of the Condor, as I have done those of some more accessible birds, I may recall the epithet "stupill, for in the training of their young some otherwise dull birds show wonderful sagacity. Whether sagacious or stupid, the Condor is one of the glories of a glorious State, and deserves the protection of all loyal citizens.

325. TURKEY VULTLRE. - Cathartes anra septentrionalis. FAuILY : The Vultures.

Length : 26.00-32.00.

Adults: Head covered with hare, red, warty skin; bill white; npper prarts iridescent black; under parts dull black, shafts of quills and tail-feathers dirty white.

Young: Similar to adults, lut bill blackish and naked skin of head and neck livid dusky.

Douny Young: Covered with a white cottony down, naked head covered with a sallow skin.

Geographical Distribution: Temperate North America.

Breeding Range: North to latitude $40^{\circ}$.

Breeding Season: April 1 to June 15.

Nest: Frequently built in a tree, or a slight depression under a ledge or a cliff.

Eggs: 2; greenish buffy or white, more or less spotted with brown and light purple. Size 2.73 $\times 1.87$.

Food: Carrion.

The Turkey Vulture, or Turkey Buzzard, is a common bird East and West, an industrious seavenger, and a self-appointed "Board of Health." In the warmer 
portions of the United States its offices are necessary and are valued greatly by the farmers and ranchmen. Long before the owner has missed the sheep or known that it is dead, the quick eye of the Vulture has discorered the carrion and he has called his family to the feast. Unlike most birds of prey, the Tulture feeds upon the ground where the carciss is found, and for this reason his foot has become modified for walking rather than for grasping. He is usually silent, except for hisses and guttural growls, uttered when feeding, which remind one of a hyena. Recent successful attempts have been made to prove that he discovers his food by the sense of smell as well as by keen sight. Carrion has been hidden under a dense growth of brush where it conld not be seen, and the Vultures have found it quite as readily as when exposed to view.

The nesting season of this Vulture in California begins about April 15, the egros being laid in a depression in the ground under a ledge, or on a steep hillside, or in the cavity of a tall stump, or in a tree. The roung are fed by regurgitation, and remain in the nest nine weeks. Except at nesting scason, this Vulture is gregarious, flying and feeding in company and roosting in great numbers in farorite groves. On the wing it is graceful and impressive, moving in great circles apparently without effort and without fatignc. One can scarcely look up to the hills without seeing it, and it comes to be as much a part of California seenery as the mountains or the sea. 
328. WHITE-TAILED KITE. - Elanus leucurus.

Fanily : The Falcons, Hawks, Eagles, etc.

Length: $15.50-17.00$.

Adults: Upper parts slate-color; top of head and tail white; a patch of

black on each shoulder and around each eye ; under parts uniform pure white.

Young: Similar to adults, but tinged with rusty, and more or less streaked with dark gray; wing-feathers tipped with white; under parts streaked with yellow-brown ; tail with a dusky band.

Geographical Distribution: Tropical America north to San Francisco on the Pacific coast; on the Atlantic coast to latitude $37^{\circ}$.

Breeding Range: The central portions of California, west of the Sierra Nevada.

Breeding Serson: April 1 to June 1.

Nest: Placed high in a tree; a platform of sticks, lined with straw and grasses.

Eggs: 3 to 5 ; dull huffy white, spotted and tinged with chestnut over the entire surface. Size $1.72 \times 1.30$.

The White-tailed Kite is a fairly common resident of the interior valleys of California west of the Sierra Nevada, north to Red Bluff and south as far as Los Angeles. Its nest is always placed just as far from the ground as possible, in a sycamore or oak or maple tree, and is a loosely constructed platform of sticks, occasionally lined with straw. In Sinta ('lara valley the birds are not at all uncommon; they nest in the oak groves from April 1 to May 1. They remain paired all the year, and may be seen hunting together over the fresh and salt water marshes. Mr. W. K. Fisher records them as preying upon the field mice in the vicinity of San Francisco Bay. They are common at Alviso in the early morning, hovering over the marshes, as kingfishers do over water, before plunging downward for a strike. Graceful and easy 
on the wing, they have a steadiness of flight unlike the bullet-like dash of some of the hawks, and more closely resembling the flight of the gulls. Their call is a high-keyed whistle, which fills three tones in a plaintive minor key. Besides this, they utter a sharp, short squeak when darting down to seize their prey. Iside from the fact of his beauty and grace, the food of the White-tail is such as to render him beneficial to farmers, and he should be protected by law fully as much as the grame and song birds. Lizards, frogs, snakes, grasshoppers, and beetles are his bill of fare, and

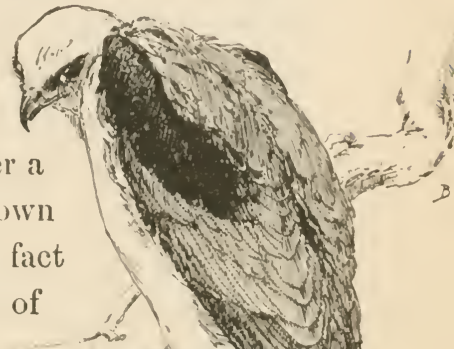
these he eonsumes in great numbers. Small birds do not fear him as they do the birl-eating

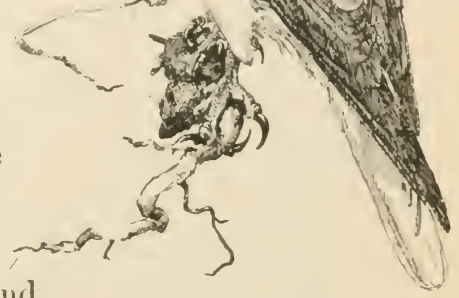
species, and this alone is proof that he does not molest them.

\section{MARSH HAWK. - Circus hudsomius.}

Famisy: The Falcons, Hawks, liagles, ete.

Length: 19.50-24.00.

Selult Mule: Slate-color strestiel with white; umler parts and rump pure white; breast and shlus lightly speckled with redilish brown; tail with alternate hamls of hrown and black, six or seven in number ;

tipss of wings blatek.

dilull Female, and Foung. Pinsty, more or lress streraked with black. Don'n! Founy: Rusty hutf aluve, more or less washed witl gray, and merging to whitish on lower parts. 
Geographical Distribution: North America from southern border of Alaska, south in winter from latitude $40^{\circ}$ to Cuba.

Breeding Range: In California breeds on the interior marshes as far south as San Diego and north to Oregon.

Breeding Season: April, May, and June.

Nest: On the ground, among the inarsh grass; made of grass and sticks, and lined with feathers.

Eygs: 4 to 6 ; dull bluish white, sometimes spotted with light and dark brown. Size $1.80 \times 1.38$.

To most bird-lovers the sight of an old gray Marsh Hawk soaring gracefully over the broad stretch of wet meadows in the early spring suggests but one thing, an immediate tramp in his direction. All sorts of fascinating things are hiding in that grass, and who knows it so well its he? A sudden swoop downward, a slow, cirching rise, with a small dark object in those strong claws, and an alighting on the nearest tree to dine. What is the menu? Perhaps a pretty field monse that, unconscious of the sharp eyes overhead, ran through his burrow ; or a gopher, or possibly a lizard. He has little choice between these and frogs, snakes, young groundsquirrels, and insects. In that he never molests the chicken yard but rids the meadow of insects and small animals, he is the protégé of the intelligent farmer. A few there are to whom a hawk is simply a hawk, to be destroyed without merey or discrimination, but such persons become fewer every year as the economic value of certain varieties of these birds becomes better known.

In a clump of stiff marsh grass or a bunch of weeds, you may find the nest of this "soft-winged still-hunter." It is simply a thick mat of coarse sticks and straw, lined slightly with feathers, and usually measuring about thir- 
teen to fifteen inches at its largest diameter. In it are laid four or five dull light-green eggs, either plain or sparsely spotted with brown. Here the adults brood by turns, the free one bringing food in its claws and dropping it from the air to its mate on the nest below, as if by accident; for these handsome Hawks are wise and very, very wary. I have seen them bring sticks for nesting materials and drop them in the same way to the other bird in the grass. You will rarely discover the nest by seeing them alight near it. When the time for a change of labor has come, one of the birds circles over and over, without dropping food, and finally alights in a tree, if there be one there. Before you know it another Hawk, his counterpart except for size, is circling in his place while he still sits in the tree. By and by he is gone from the tree, but in most instances you have not seen him go, you have been so intently watching the gyrations of his mate in the air.

In eighteen to twenty days the young Hawks break their hard shells, one ench deng, and cuddle down among the feathers and straw of the crude nest. From the day the first little ball of down appears, one or the other of the adults may be seen constantly on the wing orer that meadow. The same tactics are pursued ats before, for' the food is dropped to the parent on the nest, who, after the first few days, holds it fist in her beak while the nestlings tear off bits from it for themselves. In this way the muscles of bill and neck are developed. Later on the food is simply dropped to them, both parents being off on the hunt, and the little fellows grasp it in 
their sharp claws and tear from it with a right good-will. It is comparatively easy, with a large amount of patience, a good blind, and a field glass, to watch the brood develop day by day; for although so wild, the Marsh Hawks will not desert their nestlings, and if you can so arrange as to be inconspicuous they have little fear of you.

\section{2 (part). WESTERN SHARP-SHINNED HAWK.} Accipiter velox pacificus.

Family : The Falcons, Hawks, Eagles, etc.

Length: Male 10.00-11.50; female 12.50-14.00.

Adult Male: Upper parts slate-color; under parts white, heavily barred and spotted with chestnut; tail with three or four narrow black bands and a white tip.

Adult Female: Similar, but with markings less pronounced.

Yonng: Dusky brown above, buffy below, striped with brown or dusky. Geographical Distribution: Western United States, south in winter to southern Mexico.

Breeding Season: April, May, and June.

Breeding Range: Throughout the United States and north to Alaska. Nest: Of small sticks, Jined with fibre of leaves, placed from 10 feet to 60 feet high in a tree.

Eggs: 4 or 5; dull greenish white or grayish green, irregularly marked with brown. Size $1.46 \times 1.20$.

Equally at home in the dense shadows of the forest, on the treeless plains, or on the pine-covered mountain tops, the little Sharp-shinned Hawk requires but two things, - plenty of food and good water. Alas, that the food should preferably be small song birds! He is a dainty eater, also, stripping all feathers from his victim and refusing to swallow a bit of fur or a bone. This is the only good thing which can be said of him, for a bird more baleful to other feathered creatures, large and small, can nowhere be found. All laws protecting native 
birds should offer a bounty on his head and that of his relatives, the big Cooper liawk and the goshawk. Fortunately the last two are not numerous in the Land of Sunshine.

The Sharp-shinned is a fierce defender of his home in the top of a pine or spruce. And this nest he has very likely seized by force from its owner's, the magpies or squirrels or crows; for might is always right in the forest world, and whatever this brigand wants he takes. His nestlings receive such constant care and strong food that, by the time they are feathered and ready to leave the nest, they are noticeably larger than the parents. It is worth while to note, also, that the female is larger and fiercer than the male, consequently more rapacious. The note of the Sharp-shinned is in accord with his nature, a high-keyed shrill whistle or shriek, and is uttered when in triumph he dashes into a terrorized flock of small birds or down into a barnyard full of poultry. For he is no coward, and will attack a hen many times his own weight even though she be surrounded by her kin. As one writer says of him, "He is the boldest fellow for his inches that wears feathers." Certainly he is the most destructive desperado, without fear and without merey.

\section{COOPER HAWK. - Iccipiter cooperi.}

Fanuly: The Falcons, Hawks, Eagles, etc.

Length: Male 14.00-17.00 ; female 15.0(1-20.00.

Adult Male: Upper parts slate-('olor, top of heal black; under parts white, heavily barred with chestunt : tail rounded at end, harred with black, and tipled with white.

Adult Female: 'Tper parts cluller, top of head rusty black. 
Young: Upper parts dark brown; under parts streaked, not barred.

Downy Young: Uniform pure white.

Geographical Distribution: The entire United States and southern British

Provinces, south in winter to Mexico.

Breeding Range: Throughout California.

Breeding Season: April and May.

Nest: Usnally in high trees ; often a remodelled crow's nest.

- Eggs : 4 or 5; pale greenish white, plain or dimly marked with light

brown. Size $1.97 \times 1.42$.

Like the sharp-shinned, the Cooper Hawk is the bane alike of the farmer and the bird-lover. He is known throughout the United States by the name of Chicken Hawk, and so daring is he that he will come down into the farmyard for poultry in the face of the farmer. There are several records of weasels that have been seized by this hawk, sucking its blood at the throat and causing its death. One skeleton specimen was found with the teeth of the weasel so locked in the bone of the hawk that it could not be removed. But unfortunately, although chickens, weasels, suakes, lizards, and small quadrupeds are doubtless upon his bill of fare, song birds are too often his victims, and the ornithologist who is patiently studying the development of some rare brood has good cause to dislike him.

The nest of the Cooper Hawk is placed in tall trees, and being added to and oecrupied year after year, it becomes an exceedingly bulky structure. April to May is the usual date, in California, at which nesting begins, and ineubation lasts thirty-one days. The young remain in the nest six to eight weeks, and are fed upon the small live mammals, never upon dead flesh. Small wonder they learn to pounce upon and tear anything that moves in the grass or among the trees. 


\section{PRAIRIE FALCON. - Falco mexicanus.}

Family: The Falcons, Hawks, Lagles, etc.

Length: IIale 17.00-18.00; female 18.50-20.00.

Adult Male: Upper parts light yellow-brown; indistinetly barred with buffy on the heal and neck, and with slate-color on lower back and tail; sides of the head with dark patches; under parts and nuchal collar white; belly lightly streaked or spotted with dusky, and flanks heavily spotted with same.

Adult Female: [uler parts same as male, but duller; palest toward the tail ; tail tipped with white on the onter edges of the feathers.

Foung: Upler prats grayish lrown; under parts grayish buff with broad dusky streaks.

Geograplical Distribution: Western Uniterl States from the plains to the Pacific.

Breeding Range: Throughout the United States.

Breeding Season: May.

Nest: Of sticks, with a lining of grasses; usually ou cliffs, sometimes in carities in trees, always in inaccessible places.

Eygs: 2 to 5; deep cream-buff, corere l with fine specks of cinnamon, rufous, and light chestnut. size $2.10 \times 1.64$.

Althovgh not a large hawk and apparently built for swift flight rather than for strength, the trim Prairie Filcon has the courage of an eagle and does not hesitate to attack prey of twice its own weight. Poultry it seizes only when other food is scarce, but a good-sized jackrabbit is often a victim, and is carried to the nearest low perch to be deroured; - this by a bird the size of the American crow, but with sinews of steel and a heart that absolutely knows no fear. With an audacity worthy of a better cause it pursues marsh hawks, compelling them to relinquish the fish they have caught: and not even the bald eagle can strike such terror to a flock of grouse. Their eyrie is a crevice or ledge on the perpendicular face of a cliff where none but the most daring can 
climb. Of one such exploit Mir. ard writes in "The Con1902, as follows:

"April 18, I secured dred feet of inch-andrope, and we again way to the cliff. On top of the ridge we way down to the edge where a bunch of oak growing. We tied the and I slid down it thirty projection. I was then the nesting cavity hung considerably. side was a crevice in rope over a point down it, which I nest. It was I made my way I held the rope points of rock using my feet my handenough to and somethe cavity four feet the solid a few $/ b^{4}$ tis

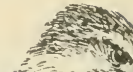

O. W. Howdor," Nay, one huna-quarter made our reaching the made our of the cliff trees were rope to vaks, 2 l, 10 fect to a shelf-like standing just above where the eliff overAbout four feet to one the rock, and by jerking the above me I could let myself did to a point opposite the rather a risky undertaking as along the face of the cliff, and in one hand and the sharp in the other, at the same time to steady myself. By keeping hold I could lean over just far see that the nest contained eggs, how managed to squeeze into head first. The nest was about from the entrance in a depression in rock, with no nesting material except feathers of the old bird and small

355. Prairie Falcon. 
bones and hair of the smaller quadrupeds; also a number of pellets ejected by the old birds. I an certain that both birds occupy the nesting cavity at night, for there was a depression in the end of the cavity which showed signs of being occupied by one of the birds.

"The nest contained five eggs, rather light in color for this species. They have a yellowish brown appearance, the color being almost solid but darker about the larger ends."

It is a matter of regret that Mr. Howard gives us no record of how the adults conducted themselves during the time they were being robbed; also, that he did not make a study of the feeding and nesting habits of the birds with regard to incubation and eare of the young, as this is a field open for just such daring observers and one where good work is needed.

\section{7 b. WESTERN RED-TAILED HAWk. - Buteo} borealis calurus.

Family: The Falcons, Hawks, Fagles, etc.

Length: Male 19.00-22.50; female 23.00-25.00.

Adults: Varying from light grayish brown to uniform lark sooty brown ; under parts white or buffy, with broad brown streaks on throat, belly, and silles; tail bright redilish brown in any phase, crossed by one or more black bars. In the dark extreme the entire plumage exeept the red tail is a dark sooty brown.

Young: Darker throughout, ant more heavily spotted; tail grayish brown, barred with black lauds.

Geographical Jistribution: Wistern North America, east to Rocky Mountains, south to Mexico.

Breding Range: Almost throughout the State of California. Ereeding Season: March, April, and May. 
Nest: Of sticks; lined with roots or fibre, placed in trees or ledges of cliffs from 25 to 50 feet high.

Eggs: 2 or 3 ; dull whitish, plain or marked with shades of brown. Size $2.36 \times 1.80$.

The Western Red-tail is common, though not very abundant, throughout the wooded mountainous districts of the central portion of the State. On the road from Tallac to Lake Valley several were seen, and one nest was found in a coniferous tree thirty feet from the ground. The climber sent up to investigate slouted back that there were four young nearly ready to fly. Being told to bring one down, he picked one out of the nest, but it bit his finger, and angrily he hurled it out into the air. Fluttering, turning over and over, down it came; but the fall did not hurt it much, and as soon as it could catch its breath it fought like a little fury. It was a handsome bird, nearly feathered, and in a week more would have flown of its own accord. It fluttered about on the grass, and after resting a time managed to scramble into a low bush, where it felt more secure though it was really much more exposed. In the meantime the adults had circled wildly about with discordant screams, and the mother still remained near. Curious to see how she would manage to get that unlucky youngster back into his nest, we moved off fifty yards and watched through the glasses. Both parents swooped down and looked at him, from on the wing, again and again, screaming when away, but silent whenever near him or the nest. It length a more sudden swoop and a momentary flutter, as a butterfly flutters over a flower. Then she rose carefully and slowly, with the young in 
her claws, and carried him to the nest. It was impossible to see whether she was holding him between them or grasping him by them. Five days later the nest was deserted and the young hawks were nowhere to be found. The adults still appeared in the vicinity, but the young were safely hidden from prying eyes in the heary foliage.

339 b. RFD-BELLIED HAWK. - Buteo lineatus elegans.

Fanily : The Falcons, Hawks, Eagles, etc.

Length: Male 17.00-19.00; female 15.50-21.00.

Adults: Upper parts dark brown, streakel with buffy or white; shoulders

bright rel-brown; under parts chestnut, barred with white on belly and sides; wings and tail barred with white.

Foung: Under parts dusky; wing-quills spotted with buffy.

Downy Young: Dull grayish white.

Geographical Distribution: Pacific coast of the United States, south to

Mexico, east to Texas.

Breeding Range: In California, chiefly in the interior valleys from latitude $33^{\circ}$ to $41^{\circ}$.

Nest: Of twigs; lined with vegetable fibre, feathers, and leares; on limbs of trees, usually in the neighborhood of water.

Eygs: 2 to 5; grayish white, marked with brown and lilac. Size $2.40 \times 1.7 \%$.

Turs is the Western race of the red-shouldered hawk. It is one that should receive all protection from the law. Mr. Iyman Beldings records a pair that for three seasons nested near a poultry yard, and whose post mortem proved their food to have been exclusively lizards, treefrogs, and insects. Mrs. Bailey says that their food is "sometimes small birls," but this is doubtless in treeless regions, where their farorite food is less casily obtained. In most parts of California where they breed, the records 
show them to have eschewed everything with feathers, and to have dined upon small snakes, lizards, frogs, insects, and crawfish. Fur and feathers are caught only as a last resort, when there are hungry young in the nest.

The Red-bellied Hawk is exceptionally fond of bathing, and in California it usually builds within a hundred yards of water. Both adults indulge in a daily bath, returning to the same place at about the same hour for it. The nest is placed in a tree or giant cactus; it is composed of twigs with leaves and usually lined with leaves and feathers. This hawk utters a shrill, high scream when molested, but does not offer to fight unless the intruder be a bird or snake. Incubation lasts thirtyone days.

\section{SWAINSON HAWK. - Buteo swainsoni.}

Family : The Falcons, Hawks, Eagles, etc.

Length: Male 12.50-20.00; female 21.00-22.00.

Adult Male: Upper parts dark grayish brown; forehead, chin, throat, and under parts white, except a sharply defined reddish brown chest band; belly often barred or spotted with brownish; tail a brownish gray, crossed by 9 or 10 narrow dusky bands.

Adult Female: Similar to male, but chest band grayish brown instead of reddish brown.

Melanistic Phase: Both sexes uniform rusty black; many gradations are found between this black phase and the normal plumage.

Young: Tail as in adult; upper parts sooty brown, varied with yellowbrown; under parts and head streaked brown and black.

Geographical Distribution: From the aretic regions to South America, from the Pacific to the Eastern States.

California Breeding Range: San Joaquiu and Sacramento valleys, and the San Diegan district.

Breeding Season: May. 
Nest: Made of sticks, sagebrush, and leaves; lined with green leaves and plant fibre; from 20 to 50 feet high in trees, sometimes in bushes, sometimes on the ground, sometimes on ledges of rocky cliffs.

Eggs: 1 to 4 ; pale greenish buffy, lightly spotted with shades of brown. Size $2.21 \times 1.70$.

Throughout the interior valleys of California, Swainson's Ilawk is a common spring and summer visitant, and one whose full value is not ret so well known as it should be. Pocket gophers, ground squirrels, insects, hoppers are its sule diet in trict, and no one can compute the benefit that acerues to the farmer from the breeding of these hawks on or near their land. Particularly is this true of a sindy barren soil where gopher burrows are numerous. Dozens of the
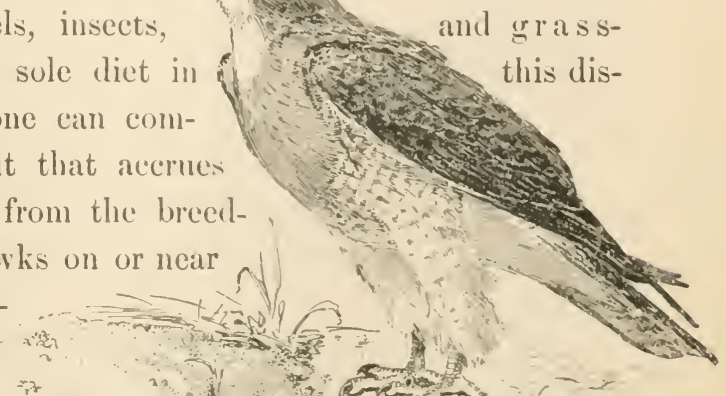

lıaks fly down to the gropher colony, just at dusk, and take up their stamel at the entrances of the bur-

342. Nwalssos HAWk. "Wit silently until the prey appears." rows, where they wait patiently and silently until the prey appears. It never escapes them. If there are young hawks in the nest, the victim will be carried to them; if not, it will usually be eaten at the pereh nearest to the hunting ground. In either case, back (e)mes the hiowk for a 
second and a third course in surprisingly few minutes. Anyone who cares to watch will probably find that sixty gophers to each dozen hawks each day, besides countless insects and grasshoppers, is a fair estinate. Small birds they do not harm. If any proof of this were needed, the song birds themselves furnish it every season by building their nests fearlessly in the same tree, and not seldom within ten inches of that of the hawk. Arkansas kingbirds, shrikes, and bullock orioles have all been found, by Captain Bendire, rearing their young close to the young hawks, and a veritably hapuy family they are.

The hawk's nest is large and slovenly, a mere platform of sticks, placed indiscriminately in a low bush or a tall tree, and lined with green leaves and corn luusks. Equally indifferent is he as to the location; for he is content on a grassy prairic where there are few trees, or in the timbered districts. The only requirements for his home seem to be food and water, - the last for bathing as well as drinking, for, like all birds of prey, Swainson's Hawk is an enthusiastic splasher. Early every morning he flies down to his farorits pond or stream, and sends a shower of sparkling drops in every direction. It is a very wet, bedraggled-looking bird that, a few moments later, files up to a sumy perch to shake himself and preen his feathers.

His hunting is mostly done on the ground; after his young are fledged, you may see them jumping with raised wings through the grass in brisk pursuit of crickets and grasshoppers. This they learn to do by imitating the parent, and it is probably their first lesson in pursuing prey. 
In the nest, they are fed upon small mammals and, even before their down has elsanged to feathers, they will tear their food with all the ferocity of a young puppy.

The adults arrive from the Sonth abont the middle of

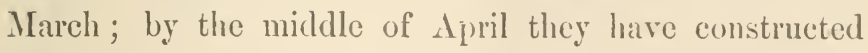
their nest and are brooding their two or three eggrs. Ineubation requires twenty to twenty-two days, and the young remain in the nest from four to five weeks. One anthority says eight, but this is a longer time than any of my own records show, and is, I believe, unusual.

In flight, swuinsoni seems a trifle chumsy as he rises from the ground with a good-sized gopher in his claws; but, as he swings into full headway, you realize that, like all his family, he is both swift and graceful on the wing.

\section{FERRLGINOUS ROL'GH-I.EG. - Archibuten ferrugineus.}

Family : The Falcons, Hawks, Eagles, etc.

Length: Male 22.50 ; female 24.00.

Adults, Normal Phase: Upper parts and flanks bright rufous: und.r parts white, lightly streaked with brown; tail white, tinged with rufons and sometimes banderl with dark.

Adult, Melinistie Phose: Upper parts dark brown marked with rusty; under parts dull rufous.

Young: Upper parts grayish brown, feathers elged with rusty; tail white at upper third ; rest brownish, banded with clark.

Geographical Distribution: From Dakota and Texas to P'arifice.

Breeting liange: In (alifornia, the interior, west of the Sierra Nevada from Silcramento to Sin Diern.

Breeling Seuson: April and May.

Nest: Of sticks; lined with leaves, grass, and rootlets.

Eiggs: 2 to 5; greenish befly, marked with shades of brown and purple.

Size $2.43 \times 1.91$.

T'Hes species is variously known as "Rough-legrged Buzard," "California Squirrel-Hawk," or "Prairie 
Eagle." It frequents the prairies and desert plains, and, unlike others of its family, cares little to be near water. Its food is small mammals and reptiles, seldom birds, and it is one of the few species that the law should protect. In hunting, it flies low over the fields, carrying its food to a low perch to devour at its leisure. Late in the afternoon it may be seen circling gracefully high in the air; at such times it appears not unlike the golden eagle, which doubtless accounts for its nickname, Prairie Eagle. It makes no attempt to defend its nest when molested by men, but flies away with scarcely a protest.

Incubation is complete in twenty-eight days, the young remaining in the nest six to eight weeks. This difference in time is the difference between a cold and a warm climate, the young of the former maturing less rapidly.

\section{GOLDEN FAGLE. - Aquila chrysaëtos.}

Family: The Falcons, Hawks, Eagles, etc.

Length: Male 30.00-35.00; female 35.00-40.00.

Adults: Entire plumage dark brown; the lanceolate feathers of high

neck and the feathers of tarsus golden brown; tail blackish, irregularly barred with dark gray.

Young: Similar to adult, but upper half of the tail plain white.

Douny Young: Grayish white, grayer beneath.

Geographical Distibution: Northern portions of the northern hemisphere, ehiefly in mountainous regions.

Breeding Range: Throughout its habitat, the mountainous regions of California.

Breeding Season: Febiuary, March, and April.

Nest: Bulky, sometimes 4 feet deep and 5 feet in diameter ; of sticks,

lined with straw, leaves, hair, or feathers; usually placed in trees on a steep mountain side. 
Eggs: 2 or 3 : whitish, marked with heavy blotches, spots, and specks of brown, lilac, and gray, most abuudant at the longer end. Size $2.96 \times 2.27$.

THe Golden Eagle is by no means a rare bird in California. He breeds in the mountains of Santa Cruz County and at many other localities throughout the State. Fortumately, the nest is usually placed in such an inaccessible location as seldom to fall a victim to collectors. It is a large structure, nearly five feet in diameter and several feet deep, lined with stubble, grass, and leafy twigs, and placed in the top of a syeamore, pine, or oak, overhanging a rocky cañon. The two eggs vary from ummarked white to heavily marked with red, brown, and purple. Three and a half weeks are required for incubation, and the young remain in the nest nearly six weeks after they are hatched, so that, although the eggs may be laid in March, the first of June often finds young in the nest. A pair whose record I lave, began sitting March 26, and the young were newly hatehed April 2.2. On June 14 they were still in the nest, but June 16 both laad left. This nest was in a live-oak on the crest of a ridge in Santa Clara County, and had been built new that year. Riabbits, grouse, and many small quadrupeds were carried to the nest, as well as sereral good-sized snakes. I siw no lambs, fawns, or fish, but several times the male brought what looked to be young foxes or eoyotes. Meal-time came twice or three times a day, never oftener. 'This pair hunted together, leaving the young unguarded hour after hour, but I believe they were always kept in range of the mother's keen eye, however far away she seemed to be. Early in the moru- 
ing both plunged into the brook for a bath, and emerged with every feather limp and dripping, to shake violently and preen for half an hour. Then the plumage shone with a tinge of tawny-gold in the sunlight, and the glorious bird seemed worthy his name.

\section{BALD EAGLE. - Haliaetus lencocephalus.}

Fınily : The Falcons, Hawks, Eagles, etc.

Length: Male 30.00-35.00; female 34.00-43.00; extent 7 feet.

Adults: Head, neck, rump, and tail white; rest of plumage sooty brown.

Young: First year, black; second and third years, mixed black and white, sray and brown; liead and neck black.

Douny Founy: Uniform sooty gray.

Geographical Distribution: United States and Mexico.

California Brecding Range: Among the Santa Barbara Islands and locally aloug the coast.

Brceding Scason: December to April.

Nest: Very bulky; made of sticks and lined with rootlets, or rock moss ; in trees from 20 to 90 feet up, or on clifl's. Same nest is occupied year after year.

Eggs : 2 ; ivory white, unmarked except by nest stain. Size $2.51 \times 1.94$.

" 'Here he is again. Here's Old White-head robbing the fish hawk.' I started from the fire and ran out to look. The hawk had risen from the lake with a big fish, and was doing his best to get away to his nest, where his young ones were clamoring. Orer him soared the eagle, still as fate, and as sure, now dropping to flap a wing in his face or touch him gently with his great talons, as if to say, "Do you feel that? If I grip once, it will be the end of you and your fish together. Better drop him peacefully; you can catch another. 
Drop him, I say!' Up to that moment the eagle had merely bothered the big lawk's flight with a gentle reminder that he wanted the fish, which he could not catch himself. Now there was a change, a flash of the kingly temper. Irith a roar of wings he whirled round the hawk like a tempest. But the hawk knew when to stop. With a ery of rage he dropped his fish. On the instant the eagle whirled and bent his head sharply. I had seen him fold wings and drop before, and had held my breath at the speed. But dropping was of no use now, for the fish fell faster. Instead, he swooped downward, adding to the weight of his fall the push of his strong wings, and glancing down like a bolt to catch the fish ere it struck the water, then rising again in a great curve - up and away, steadily, evenly, as the king should fly, to his own little ones far away on the momtain. . . One day, when I came to the little thicket on the eliff where I used to lie and wateh the nest through my glass, I found that one of the young eaglets was gone. The other stood on the edge of the nest, looking down fearfully into the abrss whither, no doubt, his bolder nest-mate had flown, and calling diseonsolately from time to time. His whole attitude showed plainly that he was hungry, cross, and lonesome. Presently the mother eagle came swiftly up from the valley, and there wats food in her talons. She came to the edgre of the nest, hovered over it a moment, so as to give the humgry anglet a sight and smell of food, then went slowly down to the valley taking the foos with her, telling the little one in her own way to come and he should have it. IIe 
called after her loudly and spread his wings a dozen times to follow. But the plunge was too awful; he settled back in the nest, pulled his head down into his shoulders, shut his eyes, and tried to forget he was hungry. The meaning was plain enough. She was trying to teach him to fly, but he was afraid." 1

\section{DUCK HAWK. - Falco peregrinus anatum.}

Family : The Falcons, Hawks, Fagles, etc.

Length: Male 15.50-18.00 ; female 18.00-20.00.

Adults: Top of head sooty black, sides of head and neck blackish, in sharly contrast to white throat; rest of upper parts slate-color ; lighter on the rump, dimly barred with blackish; under parts excejt throat and hreast deep buff, spotted or barred with blackish; tail black, barred with light gray and tipped with white.

Young: Upper parts blackish, feather's edged with rusty; under parts chestnut, heavily streakel with dark.

Geographical Distribution: America, south to Chili. In California, occurs coastwise.

California Breeding Range: Breeds locally in the mountainous regions as far south as latitude $36^{\circ}$.

Breeding Season: Mareh and April.

Nest: On a narrow edge of a cliff; a few sticks to keep the eggs from rolling off.

Eggs : 3 or 4 ; creamy, tinged with brown, spotted and blotched with shades of brown. Size $2.10 \times 1.68$.

"This species," says Mr. F. M. Chapman, "is the noble peregrine of falconry. It would be difficult to imagine a bird more highly endowed with the qualities which make the ideal bird of prey. Its strength of wing and talon is equalled by its courage. No bird flies more swiftly than the Duck Hawk. Even teal, those winged bullets, cannot escape it. No bird is more daring. I

1 W. J. Long in "School of the Woods." 
have had Duck Hawks dart down to rob me of wounded snipe lying almost at my feet, nor did my ineffectual shots prevent them from returning."

There is little to be said in favor of this relentless persecutor of water-fowl, shore birds, and song birds. Solitary in habit except at the breeling season, it fears no bird of its kind except the marsh hawk and the prairie falcon. These two wage unceasing warfare on it when it becomes conspicuous abont their hunting grounds, which it never does willingly. Its nest is marle on an inaccessible cliff, or in a high tree away from all its kind. From the hour they emerge from the shell, the young are taught to devour anything in feathers bronght to them ; and when they hunt for themselves, feathered gane is the only food they know. When the first wave of migration starts southward in the fall, the Duck Hawks are close behind, easily overtaking any stragglers or weak ones, and, if necessary, pursuing the swift, strong flicers of twice their size and weight. So every flock of coastwise migrating birds, particularly those classed as water-fowl, has one or more of these fieree birds of prey in its wake, and its numbers are constantly decimated to furnish food for its pursuers.

\section{PIGEON HAWK. - Falco columbarius.}

F.nily: The Falcons, Hawks, Eagles, etc.

Length: Male 10.00-11.00 ; female 12.50-13.25.

Adult Iyale: Uprer parts slate-color; streakud with black; wing-quills black, iuner web spotterl; under parts and hiud-neck bully, nearly white on throat; streaked on breast, sides, and belly with dark; middle tail-feathers barred with blawkish and light gray. 
Adult Female: Top and sides of the head streaked black and brown; back, wing, and tail brownish; under parts whitish or buffy.

Young: Like female, but darker; tail brown, with three or four white bands.

Geographical Distribution: Whole of North America, chiefly north of the

United States; south in winter to Norther'u South Ainerica.

Breeding liange: From Mackenzie River region down to Washington and Oregon.

Breeding Season: May.

Nest: On ledges of cliffs or in hollow trees; made of sticks or grass, and lined with feathers.

Eggs: 4 or 5; ground color cinnamon, covered with large indistinct rust-colorel blotches. Size $1.59 \times 1.24$.

The Pigeon Hawk is one of the trimmest and handsomest of its family, and is tolerated in spite of its birdeating habits. It is not at all shy, and may be seen feeding in the open country or on the edge of timber land or along the shores. Its food consists of small birds, pigeons, flickers, blackbirds, orioles, mice, and gophers. Like the duck hawk, it follows birds in migration to eat stragglers. Its favorite victims are gallinaceous birds, but it also devours many of our familiar friends among the song birds. This may be one cause for the habit of migrating at night.

It nests largely north of latitude $40^{\circ}$, and in Northern California it begins to build early in April. The nest is only a rude platform of sticks, scantily lined with feathers, and placed in the crevices of a cliff, or in a hollow tree, or high among branches of trees; one observer has found it oecupying a space between the rafters of a deserted miner's cabin. It is most common throughout California in the winter months, when it comes into the interior valleys from the colder districts and remains until the early spring. 
360 a. DESERT SPARROW HAWK. - Cerchneis sparveria phalana.

Fanily: The Falcons, Hawks, Eagles, etc.

Length: Male 9.00-11.00 ; fenale 10.00-12.50.

Adults: Top of head pale grayish brown, usually with rufous crownpateh; back light redrlish brown, with or without black spots ; wings all grayish brown; tail reddish brown, with dark band; under parts whitish to butf, with or without brownish spots.

Young: Similar to adults, but colors more blended.

Geographical Distribution: Western United states and British Columbia, south to Guatemala.

Brecding Range: Wherever resident throughout the State of California. Breeding Season: April.

Nest: In holes, usually in dead trees.

Eggs : 2 to 5 ; white, marked with shades of brown. Size $1.36 \times 1.12$.

Next to the marsh hawk, the handsome little Sparrow Hawk is the one oftenest met with in California. From his lookout on a dead tree at the edge of the meadow, he watches for his prey. I slight morement in the grass, and ont he flies, poises over the spot like a kingfisher over the water or a humming-bird at a flower tube, then swiftly he drops with feet extended, strikes the moving object, and rises with it in his taluns. If he has neither mate nor young in the nest, he carries the tidbit to his dead-tree pereh and eats it himself. But when his home, in an old stump near by, is filled with hungry nestlings, he flies directly to it with every morsel he picks up. Sometimes it is a fick mouse, sometimes grasshoppers, lizards, or froers, and sometimes, alas! small bircls.

Although so small, he has the courage of his race, and often captures prey at least twice his own weight, man- 
aging in some way to convey it to a perch before eating. Of man he has little fear, building his nest in a tree near to human habitation, and paying little attention to anything but his own limnting.

His call is a sharp, highl "killy-killy-killy," nttered as he flies over his prey, and has given him the nickname of "Killy Hawk." He is also called "Mouse Hawk" in some sections, from his habit of preying upon field mice.

Early in April the Sparrow Hawk looks about for a place in which to set mp housekecping. Sometimes it is an old magpie's nest that pleases him best, sometimes a kingfisher's hole in the bink of a river, sometimes a smug crevice in a wall of rock, but usually he chooses the deserted excavation of a woodpecker, or a natural eavity in a sycamore tree. No nest is made, but on the unlined surface of the cavity the four or five speckled egrgs are laid. Incubation lasts twenty-three to twentysix days, and the young remain six weeks in the nest.

For the first week the nestlings are fed exclusively on insects; after that, insects predominate in the nursery menu, although mice are brought several times a day. After leaving the nest they are fed in the tree, for a week or so, before they try to hunt for themselres. The first lesson is very interesting to wateh. One of the adults brings a bit of food to the youngster, who is sitting on the perch where for several days he has been fed, and instead of giving it to him, lets it fall in full view, at the same time calling "killy-killy-killy." In nearly every case the young hawk springs after it without hesitation the first time this is tried, and he often 
gets it. The motlier is beside, orer, and under him as he drops for it, encouraging him with her calls, and he soon responds with a little ery of unmistakable triumph. But he is not allowed to eat it on the ground, as he would like to do. In imperative call from the adult makes the young hunter exert his strength and follow to the nearest low perch before he tastes it. You watch and wonder at the instinct that prompts such skilful training, and the longer you wateh the more there is to see.

364. FISH HAWK, OR AMERICAN OSPREY. - Pandion haliaëtus carolinensis.

Family : The Falcons, Hawks, Eagles, etc.

Length: $20.75-25.00$.

Adult Male: Heal, neck, and under parts white; a broal black line from bill throngh eye ; top of head, and nape sometimes streaked with blackish ; a few light brown spots on the breast; back of wings and tail dark gray-brown, the latter banded with black and tipped with white.

Adult Female: Similar, but upper breast distinctly spotted with brown. Young: Ulyer parts dusky brown, each feather tipjed with white or buffy ; rest of plumage like that of arlults.

Douny Foung: Dull sooty grayish above, with broad white stripe down the middle of the back, and a dark stripe on the sicles of the heal; erown striped white and dark; muler parts whitish, washed with brown on the ehest.

Geographical Distribution: Temperate and tropical America, north to Hurlson Bay and Alaska.

Breeding liange : Santa Parbara Islands, and locally along the entire seacoast and on some of the inlanit likes.

Breeding Season: A pril anrl May.

Nest: Bulky ; of sticks; on treps near water.

Eiggs: 2 to 4 ; buffy white or deep buff, sprotted with shades of brown and purplish gray. Size $2.4 t \times 1.81$.

Wherever there are fish there are pretty sure to be fishermen and Fish Hawks. Right good comrades are 
these two, neither one grudging the other his fine catch, and the more skilful the fishing the greater the admiration for the fisher, be he man or bird. On bold, free wings the Osprey comes swinging over the lake in the cool of the morning, and his clear whistle gives you "Good hunting" before he fairly comes into sight. Down he dives with wings folded. There is a splash of silver spray and he rises triumphant, with a fish held lengthwise in his talons, and flies swiftly back to his nest. It is quite likely to be in that tall tree across the lake that has been his home for years. It is said that each fall, before leaving it, he carefully repairs it with fresh sticks, so that spring finds it ready for him. To make it in the first place was an arduous task, for it is a bulky platform of strong sticks, sumounted and interwoven with smaller ones and carefully lined with leaves, moss, or soft vegetable fibre. Now the Osprey never alights on the ground when it is possible to avoid doing so; his method of obtaining these sticks is similar, though on a larger scale, to that by which the little chimneyswift gets his, - that is, by breaking them from the tree. But the Osprey does this with his feet, while the swift uses his bill. The former swoops down upon a dead twig with such force as to smap it off, sometimes with a loud crack, and flies with it to the chosen nesting-site. Some of these twigs are four feet long, and several efforts are necessary to break them. If he has the misfortune to drop one en route, he will not pick it up again, but with renewed energy will break off another. Hundreds of these twigs must be brought to fashion his strong nest, 
and it is small wonder he uses it year after year. As in the building of a home, so in the choice of a mate, the Osprey acts once for all; the pair remain together throughout the years, together making the long trip sonth, as do the loons. When the leares on the trees are the size of a mouse's ear, the Fish Hawk lays her three characteristic egrgs and begins to brood. In a little more than two weeks downy nestlings stretch up their pretty heads for food, and both parents are kept busy supplying the demand. Small fish are carried constantly to the nest, the heads, bones, and fins being thrown to the ground and the soft parts given to the young. As the young emerge from the downy state to the dignity of feathers, they begin to sit up cantiously on the edge of the nest and call with short, sharp, impatient whistles for their fool. This the parent answers with a clear, cheery whistle, as he rises from the water, and when he nears the nest the calls of both grow very quick and excited. It is a charming bit of home life, well worth some discomfort to watch.

When the young are fully feathered and strong, - at about four weeks old, - their training in fishing begins. 'They are taken to the water and, by repeaterl triak, learn to dive and strike their fish. Sometimes it is learned the first day, and sometimes several lessons must be given, but the end is the same, - the nestling is foreed to catch his own dimer, or go lumery.

Among the twigs of the large nest small bircls frequently make their home ummolested. I hate known wrens to do this, and there are other well-authenticated 
records of purple grackle, jays, and tree swallows nesting beneath the bulky platform, thus attesting their faith in the friendly attitude of their carnivorous neighbor.

\section{AMERICAN BARN OWL. - Aluco pratincola}

FAMiLY: The Barn Owls.

Length: 18.00 .

Adults: Upper parts mottled gray and tawny, finely streaked with black and white; face white to light brown; under parts white to tawny, with triangular spots of black or dark brown ; wings and tail tawny, barred with black.

Geographical Distritution: United States generally, south to Mexico. California Breeding Prenge: Snitable localities in the latitude of the State of Sonora, in the northwest of Mexico.

Breeding Season: April 1 to June 30.

Nest: In holes in the ground, holes in river banks, hollow trees, old

crow's nests, barns, belfry towers, etc. The nests are scantily made, with a few sticks, straw, bones, and other refuse.

Eggs : 5 to 8 ; plain, dead white. Size $1.72 \times 1.35$.

WHex the sun sinks behind the oak trees and the shadows creep over the valleys, the Barn Owl hurries to the nearest meadow or marsh land on a hunting trip. If it has young at home in the nest, its flight will be swift and noiseless, as it crosses the intervening fields at short intervals, carrying mice, gophers, and ground squirrels. Nine mice form a meal for the brood, and sixteen mice have been carried to the nest in twenty-five minutes, besides three gophers, a squirrel, and a good-sized rat.

Early in April the Barn Owl begins its nesting, laying one white egg every other day until there are from five to ten or eleven hidden in an old crow's nest, or in a hollow tree, or even in a hole in a bank. The cares of incubation are shared by both birds, and last from three 
to three and a half weeks. Mr. Bendire says it is not unusual for the last eggs to hatch two weeks after the first. The young owls are corered with a whitish gray or brown cottony down, and have the hooked bill and talons of the adults. They stiy in the nest until seren weeks old. At four weeks old, a young Barn Owl will tear a gopher as fiercely as an adult, swallowing it fur and all. The noise of a family of these hungry young birds in a tree can be compared to nothing, for it is like nothing else. As soon as they discover, by some oceult sense, that the adult is on the way home with supper, the hissing and shrieking begin, and are kept up all night long.

When the nestlings are seven or eight weeks old, the first lesson in hunting is given early in the evening, and the young owls flit about with the adults on noiseless wings like roly-poly bats.

They soon learn to imitate the ludicrous attitude of the parent as, bolt upright, with half-closed eyelids, it blinks at the daylight, looking ats wise as a sage and ats comical as a monkey.

Except in the breeding season these owls are gregarious, and an old belfiry is often the home of from ten to twenty inhabitants. Besides its sereceh, the Barn Owl hats a masal snore. 


\section{AMERICAN LONG-EARED OWL. - Asio wilsonianus.}

Family : The Horned Owls and Hoot Owls.

Length: 14.80 .

Adults: Conspicuous brown ear-tufts an inch or more in length; face tawny; upper parts mottled tawny, black, and ashy; wings and tail barred; under parts mottled buffy and white, the breast broadly streaked, the sides and belly irregularly barred with brown; flanks tawny unspotted.

Geographical Listribution: Temperate North America.

California Breeding Range: Suitable localities in the interior valleys.

Breeding Season: In Califoruia, from February 15 to May 15.

Nest: Occasionally an old magpie's nest; sometimes in hollow trees, cavities in rocks, old erow's or hawk's nests.

Eggs: 3 to 6 ; white. Size $1.62 \times 1.32$.

The American Long-eared Owl breeds in the interior valleys and foot-hills, haunting the lower range of coniferous timber. Unlike the short-eared owl, it never hunts in the daytime; it is rarely found in the open, but hides through the sunny hours in the sharle of the thick woods.

It is not shy, and trusts to protective coloring rather than to flight. When discovered, "it sits upright, draws the feathers close to the body, and erects the ear-tufts, resembling in appearance a piece of weather-beaten bark more than a bird." In flight it is swift and noiseless, and flits about on moonlight nights like a huge black shadow. It has a habit of always flying to the same tree to devour its food, of taking a nap afterwards, and on awakening, of ejecting the undigested portions of food in little wads, which may be found in heaps under the tree. This is a curious performance; the bird yawns once or 
twice, and then shakes its head violently sidewise till the pellet is dislodged from its throat.

During the nesting season the male bird is exceedingly devoted to his mate, frequently occupying the nest with her or sitting on a branch of the same tree in close proxinity. The incubation requires three weeks ; the young stay in the nest about five weeks and afterwards hide in the trees, not catching their own food until eight or nine weeks old.

Major Bendire describes the nest of a pair of these owls less than two feet above an excavation occupied by a family of flickers. The owls were late in nesting, it being a second or third brood, and the families were reared at the same time, neither apparently paying any attention to the other. As the young of these owls keep up a constant calling for food all night long, this brood doubtless disturbed the slumbers of the young flickers. Their note is a low, not unmusical, whistling call, but during the breeding season they hoot like screech owls.

\section{SHORT-EARED OWL. - Asio flammeus.}

Fanily: The Horned (Owls and Hoot Owls.

Length: 15.50 .

Adults: Ear-tufts conspicuous; a blackening around the eye, and conspricuous white eyebrow: jlumage tawny to buff, heavily streaked with dark brown; wings and tail broally and irregularly birred with dark brown aud tawny.

Young: Above dark hown : moler parts grayish bufly ; face brownish black.

Geographical Jistributim: Westurn lemispluere; common winter visitant in California, somm remaining through the summer.

Breding Range: In ('aliforniat, breeds spraringly on certain coast marshes. 
Breeding Season: March 15 to May 15.

Nest: A few sticks; lined with grasses and feathers; placed on the gromd in the long grass of the meadow, or at the foot of a bush, or beside a $\log$, or in a rabbit burrow.

Eggs: 4 to 6 ; white. Size $1.56 \times 1.19$.

THe habits of the Short-eared Owl differ so greatly from those of the rest of its family that it is sometimes called the Marsh Owl. It is rarely seen in a tree, and never in the dense woods. On bright days it sits concealed in the long grass of a marsh; but at dusk or in cloudy weather it can be found hunting its food over the low, wet meadows. In California it breerls on the coast marshes and islands, making its nest on the ground and lining it with feathers from its own body. Incubation lasts ncarly four weeks.

The young are more fully feathered when hatched than most young owls. They soon flutter about in the grass with their parents, sitting patiently beside a marsh rat's run, or chasing grasshoppers with awkward fluttering hops. The adult, although it usually flies low over the marshes, may be seen during the breeding season flying quite high in the air and uttering a shrill, high, yelping call.

The food of these owls consists mostly of mice and quadrupeds, but they are very fond of terns, which they jursue through the open, and which, being the better fliers, usually make good their escape. They are eminently gregarious, remaining in flocks and colonies of several hundred. 


\section{3 c. CALIFORNIA SCREECH OWL. - Otus asio bendirei.}

Fanily : The Horned Owls and Hoot Owls.

Length: 10.00 .

Adults: Ear-tufts conspicuous, about an inch in length; upper parts brownish gray, heavily streaked with black or dusky; under parts grayish, with heavy streaks and indistinct cross lines of black.

Young: Plumage barred grayish and whitish.

Downy Young: Covered with a pure white cottony down.

Geographical Distribution: Throughont California.

Breeding liange: In wooled districts throughout the State.

Breediny Season: March to June.

Nest: A cavity in a tree, usually oak or cottonwood.

Egys : 3 or 4 ; white. Size $1.40 \times 1.17$.

This bird may be known by its small size and conspicuous car-tufts. It breeds commonly throughout California. On .June 15 one was seen groing into a red-shafted flicker excavation, eighteen feet from the ground, in an old stump near Santa Cruz. An investigation showed five eggs, three of which were the flicker's. The Owl had evidently driven off the flicker and taken possession of the nest, and was brooding a!l the eggs indiscriminately. Curious to know low it would come out, I hired a boy to wateh it. ()n .June 17 the flicker eggs evidently had hatehed, for every trace of their eontents had risappeared, but the Owl's orgess were still there. Seven days later they latehed, and two fumny ()wlets thickly covered with white down were the result. In order to look at them it was necessiry to drive the mother from the eavity hy rapping on the tree with a heary rod, and even then she would not realily gor. All 
the feeding of the young was done at night, and each morning witnessed a fresh heap of debris under the nesthole, as well as in the nest itself. This habit of leaving all the remains of undigested food heaped just outside the burrow seems to me particularly stupid, but I have found it the case with burrowing owls also. Most birds are careful to remove all trace from the vicinity, in order not to betray the nesting place, as well as for cleanliness.

The parent Owls were remarkably silent when at the nest tree, uttering no sound beyond an occasional odd chuck when one arrived with food for the young before the other had left it. After careful observation, we decided that the young were fed upon insects at first, and afterwards upon mice. The adults came and went every half-hour during the evening, and our presence so near did not seem to bother them in the least. One of them usually sat on the stump, pending the absence of the other, but not infrequently both left at the same time. The young Owls remained in the nest tree eight weeks, and then, one day, were seen sitting side by side among the thick foliage of a neighboring oak.

This species is strictly nocturnal in habits, and is one of the most important aids to the farmer in ridding him of mice and insects, though song birds and sparrows are also among its victims. Like most birds of prey, it is fond of bathing, and may be found just at dusk or dawn in a quiet corner of a small brook or pond, splashing and ducking energetically with evident enjoyment. I have watched one shake himself after such a bath until his mandibles rattled like castanets, and a funnier sight I 
never saw. Then every feather was carefully eombed out with the point of the bill until it felt comfortable and lay well in its place. For birds so untidy in the eare of their nest, these Owls are surprisingly particular about their own toilet.

\section{5 d. PACIFIC HORNED OWL. - Bubo virginianus pacificus.}

FamiLy: The Horned Owls and Hoot Owls.

Length: About 16.00 to 18.00 .

Adults: U1per parts grayish, mottled with buff and darker; under parts heavily mottled light and dark grayish.

Geographical Distribution: The wood regions east and south of the humid coast belt, almost throughout the State. Breeding Range: Same as Geographical Distribution. Breeding Season: February, March, anl A pril.

Nest: In hollow trees ; 30 to 50 feet from the ground. Eggs: 3 ; white.

AMovg the tall redwood timber about Rowardennan, the hooting of a chorus of Horned Owls at dusk is a weird, ghostly sound. The theory has been advanced that the call of the owl is a means of terrifying the small animals, which, by their excitement, would reveal their presence to the keen ears of the soft-winged hunter. But this is not always the case, for those six or eight Horned Owls which congregated each night in the trees elose together, and made the moonlight hours voeal with their uncimny notes, evidently did so from the mere joy of too-hooing. The effect in itself was bald enough, but when one thonght of the timid little wood creatures trembling in their nests from terror at the sound, one 
longed to wring the necks of the ghostly choir and end their music forever. Yet, when a friend offered the same result with a gun, the relief was declined. The next day when we found many despoiled nests and I was told that these same Owls were the ravagers, I regretted my clemency.

This species breeds more or less abundantly throughout the redwood distriet and in most of the mountainous regions of the State. So early in the year do they commence their cares that January sometimes finds young in the nest. The only pair with whose domestic arrangements I ever attempted to interfere had domiciled themselves in a hollow tree, where, although at a distance of thirty or more feet from the ground, it was accessible from a ledge near by. All dreams of watching the young develop were rudely dispelled the first time an attempt was made to pry into the nest hole. The prier eseaped with one finger badly damaged and nerves somewhat shaken, never again to meddle with that Bubo household.

The incubation lasted four weeks, and then we knew by the squeaking cries and hisses that issued from the nest, as well as by seeing the adults carry food, that the young were hatched. From that time on for nearly eleven weeks the devoted parents foraged for the brood, bringing food constantly, and never once did those small Owls venture to peep out of the hole in the daytime. Just at dusk we could hear them serambling about and practising little "too-hoos," and fancied that we could see a head or two in the doorway. The adults roosted 
outside during the day, bringing food by sunshine or moonlight as it happened.

In Santa Cruz County the food of this species consists, I am sorry to say, oftener of poultry and song birds than of mammals, though squirrels, chipmunks, and lizards are among its victims. In other parts of the State, under different conditions, it is said to prefer rodents and to be of value to the farmers.

\section{BURROWING OWL. - Speotyto cunicularia hypogeea.}

FAuILY: The Horned Owls and Hoot Owls.

Length: $9.00-11.00$.

Adults: Upper parts brownish, mottled with white and tawny; under parts tawny to buff, barred with brown.

Young: Upper parts uniform brown, except darker bars on wing and tail; under parts plain tawuy.

Geographical Distribution: From the Pacific, east to Dakota and Texas. Breeding Runge: Same as Geographical Distribution.

Breeding Season: In California, April to June.

Vest: In a burrow of prairie dog, or rabbit, or badger, or gopher.

Eggs: 6 to 11 ; glossy white. Size $1.24 \times 1.03$.

OxE of the commonest sights throughout California is a pair of these little Owls sitting side by side at the entrance to their burrow, sumning themselves, or perched on a fence post or low stmmp, blinking wisely at the passer-by. They are numerons on the drive firom san Diegro to Tia Juana, and are scincely less interesting to the Easterner than is the far-famed roat-rmoner. In vicinities where the pratio dog aboumds, many fairy stories are told of how he shares his home with the owls and with the rattlesnakes, but I believe there is no grain 
of truth in them. The owls hunt among the burrows for young mammals, and the offspring of the "dogs" are doubtless a choice tidbit; the snakes crawl from hole to hole for the same purpose, but include owl eggs and nestlings in their menu. So far as I have been able to observe, the "dogs" are in terror from both, but the

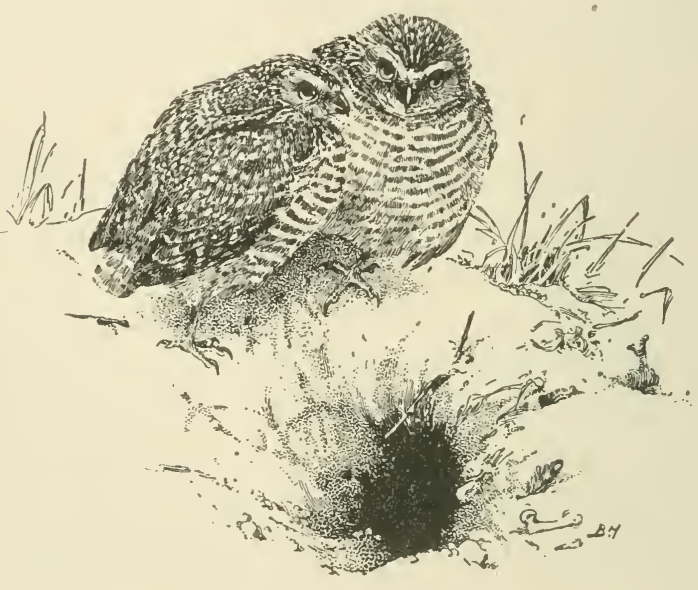

378. BurrowiNg Owl.

"They converse in soft love notes."

sudden advent of a human intruder causes the three enemies to pop suddenly down the same hole with surprising unanimity.

Usually one may find the Owls sitting at the doorway of their own nest-burrow, which may be the excavation of some badger or prairie dog whose claim they have "jumped." If the young (Owls are old enough, they will be there also in the family circle, but at sight of a 
human visitor they will scramble into the hole and hide, leaving the adults to fool him by flying away. If, however, only the adult birds are outside and there are eggs or young in the nest, the result is quite different. Their antics as they watch a person approaching from a distance of, say, fifty yards, are comical enough. They straighten up and duck excitedly, exactly as a tiny chicken makes a show of his fighting powers, bending so low that the head nearly touches the ground. Then straightening up again, they turn their wise-looking heads slowly from side to side, as if to see the effect, and duck again. Finally one, presumably the male, decides to fly and the other pops into the burrow. It is of no use to try to coax or krive the mother out. She will seize and bite a stick thrust into the nest, but out she will not come, and the only way to see her is to dig for her. All about the door are heaps of cow or horse dumg and wads of hair and bones, and I believe the same usually continues to the end of the burrow. It did in the only one I ever exearated.

Incubation begins any time in March, April, or May, and lasts three weeks. Both parents assist, and frequently both brood at the same time at the end of the burrow, which is from four to ten feet long. Usually, however, one acts as sentinel at the loor.

While the courtship of these quecr birds lacks the grotesqueness of that of the sage grouse, it has some features no less amusing; after watching a pair, you will conclude, as I did, that the sofa-pillow caricatures are not far from the truth. Sitting as close together as 
possible on top of their chosen burrow, they converse in soft love notes not unlike a far-away "kow-kow-kow" of a cuckoo; at the same time caressing with head rubbings and billings.

Although the Burrowing Owl is more or less shy, it is not at all difficult to study its habits, and none of the owls are better worth while. Only one thing is needful, patience, - patience to lie flat on your face in the broiling sun with field glass glued to your eyes, hour after hour, and, if you are a woman, thoughts of possible lizards or rattlers tormenting your inner consciousness. But the game is worth the candle, as always in nature study. On the Tulare plains you may watch them at any hour of the day hunting grasshoppers, crickets, mice, gophers, squirrels, lizards, and shore larks. You may even see them kill bull snakes that are crawling too near their nest. This war they wage on bull snakes has doubtless given them the reputation of killing rattlers, but I know they are afraid of the latter and scramble away with queer sidewise hops, breaking into flight at the near approach of one.

\section{PYGMY OWL. - Glaucidium gnoma.}

\section{FAMILY: The Owls.}

Length: $6.50-7.50$.

Adults: Upper parts grayish brown or reddish brown or drab; top of head speckled with white; under parts white, thickly streaked with dark brown; tail barred with white and blackish; face encircled by a dusky border.

Young: Similar, with head not speckled.

Downy Young: Gray, merging to white. 
Geographical Distribution: Western North America through the timbered regions, from British Columbia to Mexico; not in the humid coast district.

Breeding Range: Thronghout its habitat.

Breeding Season: April 20 to June 15.

Nest : In deserted woodpeckers' holes.

Eggs: 4 ; white.

The Pygmy Owl is a tenant of old woodpeckers' holes all through the San Bernardino Mountains. Early in May it may be seen sitting close beside its mate near the trunk of a pine tree, looking somewhat like a luge pine cone wrong end up. It is a very love-sick wooer, and the indifference of petite Madame $\mathrm{Ow}_{\mathrm{w}}$ is, we are all convinced, only feigned. All the soft, purring love notes may come from the throat of the male, but after lying concealed and listening for hours at different times, I felt certain that it was a conversation in which both took part. The home of this pair was in a charred tree-trunk next to the pine in which they used to sit morning and evening. They were so chubby that it seemed to me the doorway must be too small; but evidently it suited, for on May 20 there were four white eggs in it, and from that time on Madame Owl was a devoted mother. I watched closely but never saw the male go to the nest between 7 A. M. and 5 P.M. As soon as the sum's brightest rays were grone, he would call softly from the pine, and soon a small brown head appeared in the round doorway. After a moment of sleepy winking and blinking at the great sun sinking behind the trees, the head would come farther out of the nest hole, followed by the plump brown body, and the next instant there were two in that old pine tree. It was comical to wateh 
her stretch each little leg in its pantalette of feathers and give a few preliminary wing flaps, as if so relieved to be out of that dark hole and into the free air once more. But she is hungry, and soon flits down through the low shrubs to hunt grasshoppers or small lizards, while her mate goes into the nest to brood. He does not always do this, I am told, but in the case of one brood I watched the male took his turn on the eggs each night and morning. I judged him to be a male bird from his trimmer appearance and long absence from home during the daylight hours, which he spent largely in eating. Often he would pereh on the top of the nest shrub and fluff out all his feathers in a sun-bath, until he looked like a miniature porcupine. This was his favorite place to breakfast also, but I never saw him eat there during the brightest hours of the day. These he spent in the shady depths of the old pine tree.

When the young were hatched, - eighteen day's after the first eggs were laid, - they were covered with a cottony down of a soft mouse-color, merging to whitish on under parts, the funniest little puff-ball nestlings imaginable, in size not larger than a walnut. Grasshoppers and various kinds of insects were carried to them by both parents throughout the day. At night the mother remained in the nest while the male hid in the thick foliage of the pine, but with the sun's first ray both were astir hunting breakfast for the hungry babies. 



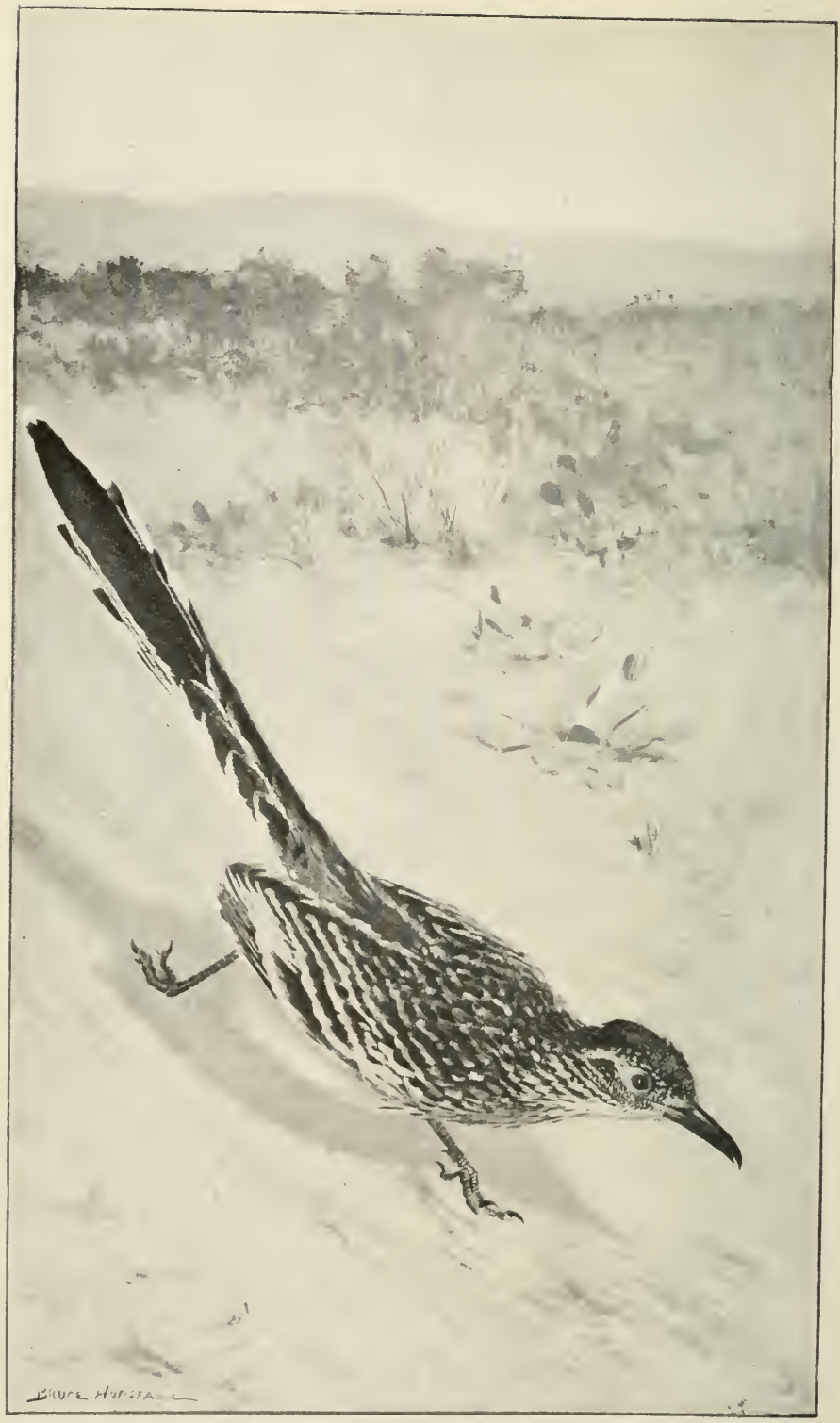

385. ROAD-RUNxeR

Geococcyx californianus 


\section{III. - COWMON LAND BIRLS IN COLOR GROLPS}

WITH BROWN PREDOMINATING IN PLUMAGE

385. ROAD-RUNNER. - Geococcyx californianus.

(Common names: Chaparral Cock; Ground Cuckoo; Lizard Bird.)

Fanily: The Road-runners, Anis, and Cuckoos.

Length: $20.00-24.00$.

Adults: Tpper prarts iridescent blue-black on head, neck, and shoulders ; metallic greenish brown on lower back, tail, and wings; feathers broadly edged with white; tail-feathers blue-black, broadly tipped with white; under parts whitish, and throat streaked dull buff and blackish; naked skin in front of the eye, blue and orange; feathers of the head and neck stiff and bristly : tail long and graduated ; four white thumb marks on the under tail-feathers.

Geographical Distribution: Texis, New Mexico, Southern California, west through California, south into Mexico.

Brealing Range: Throughout its habitat.

Breeding Secason: March 15 to July 1.

Nest: A platform of twigs; lined with cowhair, leaves, or feathers, or nearly unlined; variously placed in bushes or trees, from 3 to 8 feet from the ground.

Eygs : 2 to 12 ; butfy white., Size $1.515 \times 1.23$.

The "Roal-l'mumer" is well named. No matter how long one has lived in California or how familiar one may be with Westem birds, the novelty of seeing one of these birds dart out of the chatparral and race ilown the road ahead of onc never loses its charm. "It takes a right smart horse to ke(e) up with him." Do not expect to overtake him or to win the race. I lrisk trot merely keeps you the sime distance behind him, and a fister gait only sends him scudiling along more rapidly. When 
tired, or if he sees that you are gaining on him, he dodges into the roadside thicket, stopping so suddenly as to go heels (or rather tail) over head. It is a unique performance, and one never becomes quite used to it.

Few birds are more interesting to sturly, or better repay observation. The Road-rumners are common residents of the valleys and desert regions of California, from the Mexican border north to Sacramento valley. In the southern part of the State and in Mexico they are occasionally found at an altitude of five thousand feet, but they prefer the lower range of the cactuscovered plains and foot-hills.

Their food consists of insects, land crustacea, small reptiles of all varieties, young birds, and field-mice. They are popularly believed to destroy rattlesnakes, but Mr. Bendire denies this. At the same time he reports having found a garter-snake twenty inches long in the crop of one of them. A Road-rumner killed by Mr. Anthony had just swallowed a large lizard. Undoubtedly its fondness for lizard diet has giren it one of its many nicknames.

In habits, the Road-runners are shy, suspicious, and unsocial. Except during the breeding season, I liave rarely seen more than one in a neighborhood. Just before rearing their broor, and for some time after, they feed and roost in pairs. In the choice of nesting site and material they are capricious. Of several nests examined, no two were alike. One found in May was in a manzanita bush about four feet from the ground, was lined with rootlets and a few feathers, and contained 
five eggs. Another in an oak, eight feet from the ground, looked as if it might have been built originally by a jay and relined with a few dried leaves. Sereral were in clumps of cactus; and one was within a foot of the ground, on a broken part of a log, well sheltered by bushes, - the bird perhaps having fancied that the log was part of the bush. This nest was quite elaborately constructed of twigs and lined with cow-hair, snakeskin, and feathers interwoven with rootlets. It contained, June 3, five young birds, corered with quills. Twenty-four hours later, every feather on three of them had burst its sheath, and they were apparently ready for their début; but they clung desperately to the nest with their strong feet when an attempt was made to lift them from it. The noise made by the young resembled the elick of two pieces of wood - not metal - striking sharply together, and did not firil to bring both parents to the seene. They were very angry, and presented a ludierous though more or less formidable defenee, with bills snapping sharply, wings and head bristling, and long tail wagging. But they preferred discretion to valor, and on being pursued slunk away swiftly after the manner of enckoos.

In Southern California the Road-rumers begin nesting in March, and eggs are found late in Jume; hence we may infer that in some instances eren three broods are raised in a single season. I believe, however, that this is true only when an alceident destroys the exgrs or young of the earlier broods. The Mexicans insist that the pairs remain united throughont the entire year; but 1 
doubt if there is good scientific authority for such a statement, and, like the rattlesnake story, it should be taken with a grain of allowance.

Although so shy, these birds are very inquisitive, often coming close to human habitations for apparently no other reason than to satisfy their curiosity. A ranchman told me about a Road-runner that carried off a bright red ribbon half a yard long, which he had picked up in the road, running as fast as his swift legs could carry him with the ribbon fluttering behind him like a flag. Nor do I doubt this, after having seen a very amusing comedy played by one of these birds. The sole actor was a handsome cock, who was jumping backward and forward over a clump of sagebrush at least eight times in succession, each time leaping higher than before. It first I thought it was some sort of lovedance; but no female was in sight. Then I fancied he might be killing some enemy, he seemed so excited. But the passage of a horseman startled him, and away he ran on a merry race, with nothing in his beak. There was no trace of anything on the ground by the time I could cross the thirty yards' distance to investigate.

The usual note of the Road-runner is a modification of the "kow-kow-kow" of the yellow-billed cuckoo into a softer "coo-coo-coo," which some one has likened to the "coo" of a mourning dove; but this is varied by the chuckling notes I have heard a crow utter when talking to himself, and it occasionally degenerates into a cackle. 


\title{
387 a. CALIFORNIA CLCKOO. - Coccyzus americanus
}

\author{
occidentalis.
}

FAully : The Road-runners and Cuckoos.

Length: 13.00 .

Adults: Upper parts grayish brown, slightly glossed with greenish; under parts white, tinged with gray on chest; lower mandible yellow ; tail with broad white thumb-marks on the tips; middle tail-feathers brown, tipped with black; remainder iridescent blue-black.

Young: Similar to adnlts, but duller.

Geographical Distribution: Western United States and Lower California. Breeding liange: In California the breeding range seems to be confined to the willow bottoms.

Breediny Scason: May, June, July, and August.

Nest : A loose platform of sticks; sometimes lined with leaves and catkins.

Eggs: 3 or 4 ; glossy light bluish green; paler in the incubated than in the fresh laid. Size $1.27 \times 0.89$.

The California Cuckoo, or Western Yellow-billed Cuckoo, breeds extensively along the willow bottoms of the interior valleys of the State. Mrs. Echstron says: "Is a nest-builder the euckoo is no genius; or, if a genius, he belo:igs to the impressionist school. The nest is but a raft of sticks flung into the fork of a bongh." Indeed so fiail and so loosely put together is it that one may see the egrgs from underneath. Oceasionally an individual will be found who aims at better things and has made some slight attempt to line her cradle with grass. Most of these twig platforms are so shallow that an effort to peep into them will result in spilling the contents, and a windstorm often scatters the egrgs over the ground in spite of the mother's care. When this happens, or when the eggs have been stolen, 
a second set is laid in another nest, and for this the unfortunate bird sometimes occupies the abandoned nests of other birls. There is no authentic record of her having left her own eggs to be brooded by another, however, and the accusation of parasitic parenthood is, in her case, unjust. It belongs rather to the European species.

Always shy haunters of the willow thickets, cuckoos are most apt to be heard during the mating season, which varies from May, in San Bernardino County, where they are more or less scarce, to the last of August in Sacramento valley, although a brood of the latter date, as noted by Major Bendire, undoubtedly was a belated one.

The only brood of the Western Yellow-billed Cuckoo that I have watched develop was housed in a willow clump in Santa Clara valley. The last of three pale green eggs was laid May 30, and ineubation began the next day. For eighteen days the slim brown mother brooded; and when, at the end of that time, three wriggling, naked birdlings filled the nest, her watchful care was doubled. Noiselessly as a shadow she would slip through the low bushes with a ericket in her bill, and during the early hours of the morning one or the other of the parents was en route continually with food for the hungry but silent nestlings. These were fed by regurgitation at first, and they grew surprisingly as the days went by. At the end of twenty days they were eovered with pinfeathers and looked like tiny poreupines. Suddenly, on the twenty-first day, these sheaths burst, and 
the young Cuckoos were arrayed in all the glory of real plumage. The next day the three left the nest and I was unable to find them again.

During this period of brooding and caring for the youmg the adult Cuckoos, though at first suspicions, became somewhat reconciled to my visits; at any rate, they neither moved the eggs - as cuckoos have been thought to do when disturbednor deserted them. At my approach the mother would ruflle her feathers until the usually sleek, slender bird seemed to be bristling with rage, her head extended on a level with her body and her long tail slightly elevated. But ff though her eye followed me with unwinking intensity, she would not desert her post, nor dirl I ever force her to do so.

The clear" "kow-kow-kow" of

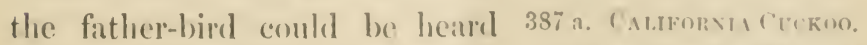

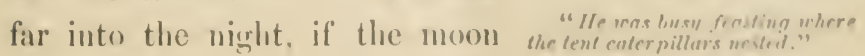
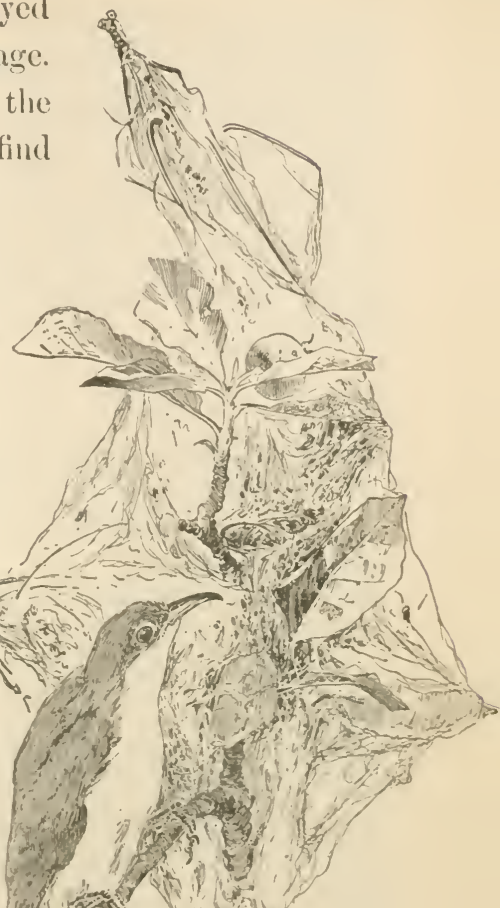
lighted the lowlands, and during the day it floated through the wood like a wandering voice. It was difficult to tell by the sound just how far away he was, but I knew that he was busy feasting where the tent caterpillars nested. In my heart I blessed him for his choice of food, for he is the only bird that will touch these pests, and even he clips off the hairs before he swallows the morsel.

413. RED-SHAFTED FLICKER. - Colaptes cafer collaris.

Family: The Woodpeckers.

Length : 12.75-14.00.

Adult Irale: General color of borly and head brownish, becorning noticeably grayer on back of neck; rump white; back narrowly barred with black; tail black; nuchal band and mustache red; a black crescent on chest; under side of wings and tail red; under parts thickly spotted with round black dots.

Adult Female: Like male, but malar stripe usually buffy.

Young: Like adults, but with no mustache.

Geogruphical Distribution: Western United States from Rocky Mountains to the Pacific coast; north to Sitka, sonth to Mexico.

California Breeding Range: In suitable localities thronghout the State. Breeding Season: May and June.

Nest : In trees or stumps, from 2 to 70 feet from the ground; and also in sides of banks.

Eggs: 5 to 10 ; white. Size $1.12 \times 0.86$.

The Eastern flicker, known as "yellow-hammer," "high-holer," or " golden-shafted woodpecker," is represented in California by the Red-shafted Flicker, a bird similar in everything except his red malar stripe and the under surface of the wing-quills and tail-feathers, which in his case are rose-color or soft scarlet instead of yellow. In call-notes, nesting liabits, and food the Western is 
identical with the Eastern species. The nest is a hole eighteen or twenty inches deep and four inches wide at the bottom, with an entrance two inches in diameter at the top. It is made in old stumps or dead trees, gateposts, nooks and cramnies in deserted buildings, and sometimes in banks of earth. Both male and female birds share in the excavation, working in turns of about twenty minutes each. The site having been chosen, the male clings to the surface and marks with his bill a more or less regular circle in a scries of dots, then begins excavating inside this area, using his bill, not with a sidewise twist, as do many of the woodpecker family, but striking downwards and prying off the chips as with a pickaxe. When his mate has rested and wishes to share in the labor, she calls from a near-by tree and he instantly quits his task. In a few moments, before one has realized how or whence she eame, the female has taken his place and the chips are flying merrily. As a rule, the birds work only early in the morning and late in the afternoon, taking from ten to fourteen days to finish the excavation. By the middle of May there have been laid seven or eight beautiful, glossy-white eggs, having a pearly lustre, and so transparent that when fresh the yolks show through the shell. As incubation advances, the shells become more opaque, until, when ready to hatch, they have a limy ring around the middle, showing where the shell will part. In fifteen days appear the most grrotesque of all bird babies, unless it be those of the pileated woodpecker or of the cormorant. Their bodies are the shape, size, and color of a pink rub- 
ber ball, such as ehildren use for playing "jacks." Two worm-like appendages, for embryo wings, dangle helplessly, and two long, sprawly, weak legs are set far back on the ball-like body. An extremely long neck waves aimlessly, ending in a camel-like head, the lower mandible of the wide mouth projecting beyond the upper; there are black, skinny knobs for eyes and curious, large ear-holes. If placed on a level surface, these animated balls roll about helplessly, the only way of steadying themselves apparently being by bracing and pushing with their heads. As they are fed by regurgitation they will swallow two inches of one's finger and hold on so tightly that they may be lifted up by it. Having been unable to complete my observations at Lake Tahoe, I once took two of these ungainly but interesting pets, when three days old, from California to Chicago, on the "Overland," feeding them with hard-boiled yolk of egg mixed with water, potato, and grated carrot. They were remarkably well behaved, and excepting an occasional clattering noise, somewhat between a mowing-machine and a nestful of bees, they were silent and throve well. In feeding, I first gave them the food and then allowed them to suck a finger, shaking them by moving it, as I had seen the parents do, as otherwise they would have been unable to swallow. As they grew older they were given mocking-bird food, composed largely of ants' eggs and resembling their natural diet.

When left to the parent, however, they are brought up in a much more hygienic fashion. For nearly three weeks they are fed by regurgitation, and after that time the in- 
sects brought are masticated by the parents. The adult, coming with food, lights on the tree at one side of the nest-hole, and instantly the small doorway blossoms with two or three grotesque heads, mouths wide open and ready. Meanwhile all the infants are joining in the buzzing chorus that announces their hunger in language plainer than speech. The parent inserts his bill into the throat of each one in turn, shaking the nestling back and forth vigorously. When all have been fed, he retires behind the tree trunk out of sight, to wait until the hubbub subsides and to determine whether any of the youngsters are still hungry or are only crying from habit.

After they are old enough to leave the nursery, they follow their parents about for nearly two weeks, begging to be fed and gradually learning to hunt for themselves. This lesson is wiscly taught by the parents, who place the food under a crevice in the bark, in full sight of the young, who must pick it out or go hungry. The baby cocks his head wiscly, looks at it, and proceeds to pull it out and dine.

Flickers are essentially ant-eating woodpeckers, and consequently are seen upon the ground oftener than any other variety. They run their long bills down into the ant-hills, and, extending their spiny, sticky tongues still farther, withdraw them covered with eggrs and larve. Their call-note is a shrill "wicker-wicker-wick-wickwick," and sometimes, when angry, a high, screaming "hii-k-ha." The wooing of a pair of these birds is the most ludierous performance that can be imargined, and well worth watching. 
418 b. DUSKY POORWILL, OR CALIFORNIA POORWILL. - Phalanoptilus nuttalli californicus.

Family: The Goatsuckers.

Length: 7.00-8.00.

Adult Male: Upper parts blackish or dark brown, with a velvety motll-

like surface, barred with tinely mottled grayish brown and distinet black arrow-shaped markings; middle of crown black ; tail-feather's, except the middle ones, tipped with white; siles of head and chin black; white throat-patch bordered with black; under-tail coverts buffy; rest of under parts barred.

Adult Female: Like male, but tail-feathers tipped with a narrower band of white.

Young: Upper parts grayish, finely mixel with brown; markings less distinct.

Geographical Distribution: From the foot-hill regions west of the Sierra

Nevada to the coast and south to Lower California.

California Breeding Range: Latitude of Upper Sonora, west of the Sierra Nevada.

Breeding Season: May.

Nest: No nest, eggs being laid on the ground.

Eggs: 2 ; glossy white, with a faint pinkish tint. Size $1.00 \times 0.76$.

Throughoct the coast region of California I believe the Dusky Poorwill is a rather common summer visitant, if not a summer resident. It is a haunter of cañons and deep woody places, never of the open. I found the eggs of a bird of this species on the bare ground at the foot of a tree in Marin County. The mother was brooding; she flushed from literally under my feet, brushing me as she took flight and hid in the deep wood, and I found the eggs scarcely a foot from where I was standing. Marking the tree and leaving for several hours, I returned to find her on the eggrs again, and this time watched her through my glass, not going nearer than fifteen feet. So far as I could judge in that way, she 
corresponded perfectly to the mounted specimen of the Dusky Poorwill which I had seen, but it was my first experience with the live bird. Three days later, when I went to the spot, there were two downy young ones in the nest, looking so much like the shadows on the pine needles that at first I could not see them and, but for the mother's antics, would have given up the search. She flopped about on the ground, feigning a broken wing, wallowing among the leaves, and whining like a young puppy. I picked up one of the fuzzy babies, looked it over carefully, and replacing it, withdrew to hide and watch. For two hours she did nothing but brood them, but thereafter I was rewarded by seeing her lugr one off to a distance of half a rod and drop down with it in a fern tangle. In a moment she came back for the other and repeated the performance.

During the early evening hours of my watching she left the nest and eame again, but apparently brought nothing in her bill, and if she fed them then it was by regurgitation. In all this time I saw nothing of the other parent either in the wood or near the nest, and do not think he paid any attention to the cares of the family.

The Poorwils are nocturnal and crepuscular in habits, feeding upon night-moths, beetles, griashoppers, and gnats, and ejecting the indigestible parts in the same mamer as do the owls. Like owls also, they are absolutely noiseless and bat-like in flight. Their note is the well-known soft, two-syllabled call, so imperfectly represented by letters, and rapilly repeated with scarcely a pause for breath throughout the evening hours. 
Although it may never have been heard before by the watcher, it may be instantly and instinctively recognized as it floats out of the deep ravine or from the darkness of the woods.

\section{0 d. CALIFORNIA NIGHTHAWK. - Chordeiles virginiamus hesperis.}

(Common names: Bull Bat; Mosquito Hawk; Will-o'the-Wisp.)

Family : The Goatsuckers.

Length: About 9.00.

Adult Male: Upper parts black, mottled with gray and buffy; a white or buffy patch on the wing; tail, except the middle feathers, banded with white near the tip; throat white; chest black; belly barred black and white.

Adult Female: No white on tail ; otherwise like male.

Downy Youny: Covered with thin yellowish brown down mottled with darker.

Young: Markings less distinct than on adults.

Geographical Distribution: In California, the Transition and Boreal zones of the northern end of the State, and south through the Sierra Nevada; recorded during migration through the western valleys; south in winter to the tropies.

California Breeding Range: Wooded districts of northern part of the State.

Breeding Season: May 15 to June 15.

Nest: None; eggs laid on the bare ground.

Eggs: 2 ; vary from pale olive-buff to buffy and grayish white; thickly mottled and dashed with varied tints of darker gray, olive, or even blackish, marbled, and clouded with lavender. Size 1.25 × 0.85 .

WiтH the exception of the Texan nighthawk the subspecies of nighthawks occurring in California resemble each other so closely that it is impossible to distinguish them without shooting, and their ranges overlap in such a way as to make locality an uncertain guide. Therefore only one form, Chordeiles virginimus hesperis, without 
the other subspecies, will be here recorded. The characteristics of this race may be regarded as belonging to all.

Although called "Nighthawk," it really hunts almost as much by day, and may be seen late in the afternoon or early in the morning, skimming over the water or low wet ground with graceful swallow-like flight. Its food consists of the insects found in the air and near the water, swarms of small gnats, small night-moths and flies. These it eatches in its capacious mouth in the same manner that a fisherman uses a scoop net, the "whiskers" helping to trap the prey. It may easily be distinguished from the poorwill, which it closely resembles, by the conspicuous white patches on its wings, which, when seen from bencath in flight, look like holes. It is known also by its diurnal habits, as it seldom flies after the sun has set. The poorwill, on the contrary, unless flushed, never flies by daylight, but hides through the sunny hours in the shadows of the deep wood, usually erouching on the ground or on a well-shaded log. Nighthawks spend the middle of the day squatting lengthwise on a limb, their feet, like those of the poorwills, being too weak to perch. Here they sleep, trusting for safety to protective coloring, and refuse to move unless startled into flight.

They make no nest, but lay their two speckled eggrs on the bare gromel usually in plain riew of the passer-by, and not infreguently on the flat gravel roofs of buildings. Always a well-dlained, rather sunny place is selected, and the eggrs are less frequently found than one would 
suppose, because their color usually blends so well with that of their surroundings.

Ineubation lasts sixteen days, and it is a question how far the male shares in it. In some cases he does; but as a rule he prefers to watch from a limb overhead so long as there are eggs only. So soon as these become animated bits of bird life, his interest is aroused, and he is quite as ready to guard them as is the mother. The newly hatched young are little balls of rusty down, mottled slightly with dusky, and have the characteristic

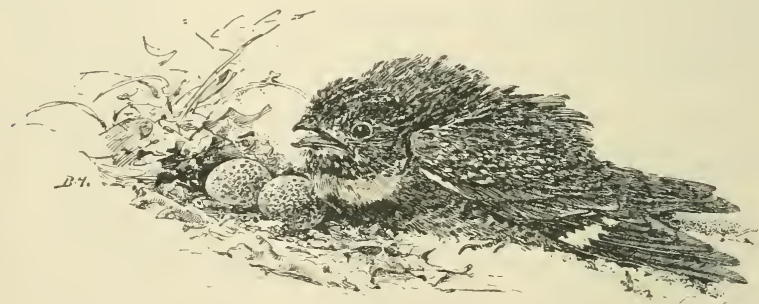

420. NighthaWk.

"Crept back as often as she was driven away."

large head, wide mouth, and short thick neck of the adults, so that you know at once to what family they belong. They are carefully guarded by one of the parents continually, and if molested they will likely be removed to another hiding-place; but the nighthawks remove their young less frequently than the poorwills.

The feeding of the nestlings is accomplished by a modified regurgitation, the small insects being brought in the gular pouch or cheeks of the parent. A female that we found on the nest would not leave the young 
until flushed, and then she crept back as often as she was driven away, all the time spitting like a cat and ruffling her feathers like an angry owl. I believe this was due to her courage in defending her young and not to any stupidity. The next day she had removed them, and we did not find them again. Other cases of as great courage on the part of both adults of this species I have noticed, and am sure that the Nighthawks are more devoted to their nests and young than any other birds I have studied.

On the wing, Nighthawks are very sociable, circling in flocks and twittering after the manner of chimmeyswilts, to which they are closely related, and uttering their characteristic "boom" which has given them the name of " night jar." They seem always to be having a good time together, - a jolly good fellowship, as it were, - that fits in well with the joy of morning or the glory of evening.

\section{TEX IN NIGHTHAWK.-Chordeiles acutipennis} texensis.

Finuly: The Goatsuckers.

Length: $8.00-9.00$.

Allull Wule: Upler parts dull mottled gray, streaked with rusty black; chest and muder parts barred black and light brown: throat white; a white bamd-like gatch (rossing wing: wing-eoverts spotted and mottled with brown.

Adult Female: Similar, but wingr-pateh buffy.

Young: Finely mottled above; under parts washed with pale red-brown. Geographical Distribution: Southorn border of United States from Texas to Southern Californiil, north to Utah, south to Cape St. Lucas. Breerling Reruge: In California, the southeastern portion of the State. 
Breeding Season: April and May.

Nest: None ; eggs laid on the bare ground.

Eggs: 2; clay-colored, dotted, mottled, or marbled with brown and obscure lilac. Size $1.07 \times 0.77$.

Mr. Grixselu says the Texan Nighthawk is a common summer visitant throughout the Lower Sonoran zone, and occurs as far north as Stanislaus and San Benito counties. Mr. Bendire records it at San Joaquin County, and Mr. Merriam found it breeding in Inyo County.

It is the smallest of all the nighthawks found in the United States. Like the other varieties, it is gregarious while feeding; it skims over the water like a swallow, and scoops the tiny gnats in its wide mouth. It is said not to make the peculiar booming of the Eastern nighthawk, but to utter a peculiar humming sound while on the wing.

Dr. Merrill writes of it: "The eggs are usually deposited in exposed situations, among sparse chaparral, on ground baked almost as hard as brick by the intense heat of the sun. One set of eggs was placed on a small piece of tin within a foot or two of a frequented path. The female sits close, and when flushed flies a few feet and speedily returns to its eggs. They make no attempt to drive an intruder away. I have ridden up to within five feet of a female on her eggs, dismounted, tied my horse and put my hand on the bird before she would move... The notes are a mewing call and a very curious call that is with difficulty described. It is somewhat like the distant and rery rapid tapping of a large woodpecker, accompanied by a humming sound, and it is 
almost impossible to tell in what direction or what distance the bird is that makes the noise. Both these notes are uttered on the wing or on the ground, and by both sexes.

\section{SAY PH(EBE. - Sayornis sayus. \\ FaniLy: The Flycatchers.}

Length: $7.50-8.05$.

Adult: Upper parts dark brownish gray ; tail black; belly light cinnamon, nerging to light brownish gray on breast.

Young: Similar to adults, but wing-coverts tipped with brown.

Geographical Distribution: Western United States, north to aretic circle, south to Mexico.

Californio Breediny Liangr: East of the Sierra Nevalla to Lower California.

Breeding Serssun: Marreh 10 to Jume 20.

Nest : Of weed stems, Iry grasses, moss, plant fibre, wool, spider webs, hair, and sometimes of mul; the lining generally conposed of wool or hair ; placed on [rojecting ledges, protected by overlanging walls, in old tunnels, about barrs, or muler hridges.

Eggs : 3 to 6 ; white. Size $0.75 \times 0.61$.

Somewhat larger than the Eastern phœbe is the Western representative of the family. It has a wide greographical distribution, breeding from the aretic circle to the southern limit of the United States. In habits and general characteristics it resembles the Eastern phobe, returning among the carliest springr migrants to its old home, whether that be just inside the border's of Sonthem ('alifornia or in frosty Alaska. For in whatever spot the say Phobe hats reared its first brood it will continue to nest year after year.

This species is fouml in greatest numbers in the open country, seldom or never frequenting the deep forests. 
Originally, all phœbes built on sheltered ledges of cliffs, or shelves in caves, or on any jutting bit of rock secured from storm by an overhanging roof. But all this is changed, now that men have conquered the wilderness and caused it to blossom like the rose. These birds were among the first to recognize the advantage of human friendship and to seek its protection. Without a question they preëmpted the beams of barns together with the swallows, encroaching more and more upon the new-found territory, until now they build their nests as close to human dwellings as the owners will permit. Beams of piazzas, window-ledges behind blinds, and summer book-shelves nailed to the wall of the veranda are among their chosen sites. Unlike her Eastern representative, Sayornis saya rarely uses mud in the construction of her home, making quite a flat structure of weed stems, dry grasses, moss, wool, hair, spider webs, and silky material from cocoons or plant down. Usually it is smoothly lined with this silky fibre or wool, or sometimes hair. Four or five pearly eggs are laid, one each day, and the day after the set is completed the mother begins her cares. Incubation lasts two weeks, and although the male does not brood he sits all day long on a lookout near by. The newly hatched young are naked except for a slight gray fuzz on their saffron skin. Until six days old their eyes are closed by a skinny membrane, and during this time they are fed by regurgitation. They mature very rapidly, and in two weeks have their feathers well in order for their first attempts to fly. Up to this time the father bird has diligently 
fed and guarded both them and the mother, coming to the nest every two or three minutes with butterflies in his bill. But as soon as they are ready to try their wings, he assumes full charge, teaching them to fly and to catch insects on the wing in true flyeateher fashion.

Two, and oceasionally three, broods are raised in a season. No sooner has the father fairly launched the young on the world than the industrious little mother repairs the nest, and in it lays a second set of pretty white eggs. Again she broods for fourteen days, now seldom or never fed by her mate; but, since the days grow warmer, leaving oftener and for longer intervals to forage for herself. Whe if the second fanily is ready to fly, she "The nest." takes charge of it unless the necessity of rearing a third brood should compel her to desert them; and then, from somewhere, the hitherto unnoticed male appears, to assume care of them. It is a mooted question whether any bird rears three broods in one year, and this is the only species for which I make the elaim. While the same pairs usually return each year to the same locality to nest, some instances 
of very unusual choice of sites have been recorded: "in an old robin's nest placed in a bush four feet from the ground"; in old tunnels and mining shafts, in prospect holes, in an old embankment, in burrows of the bank swallows, etc. But always the nests are lined with some soft warm material, such as wool or short hair.

The ordinary call-note of the Say Phøbe is a plaintive "phee-er," always accompanied by a twitch of the tail and the raising and lowering of the crest. Besides this note, during the mating season it utters a short low warble.

462. WESTERN WOOD PEWEE. Horisopus richardsoni. Family : The Flycatchers.

Lenyth: 6.20-6.75.

Adults: Upper parts dark grayish brown; under parts washed with dark gray ; belly and under tail-coverts whitish or tinged with yellow.

Young: Similar to adults with brownish wing-bars.

Geographical Distribution: Westem North America, north to British

Colunbia, east to Great Plains, south in winter to Mexico and South

America.

Californic Breediny Range: In Transition zone thronghout the State.

Breeding Season: June and July.

Nest: Of plant fibre, rootlets, down, sage, and grass tops ; sometimes

covered with lichens or spider webs; in trees, from 5 to 40 feet from the ground.

Eggs: 2 to 4; irregularly spotted with brown and purple at the larger end.

Is general characteristics the Western Wood Pewee does not differ much from the common wood pewee of the East. Its call-note is, however, harsher and more emphatic, lacking the plaintive quality of the "peeahwee" heard morning and evening in the Eastern woods. It is variously described as " pee-ee," "pee-eer," "pee-ah," 
"tweer," or "deer." It ranges from the valleys to the higher Sierra Nevada, building its nest indiseriminately in pine, cottonwood, aspen, oak, ash, or fruit trees, but always near water. In habits it is essentially a flycatcher, darting out from a favorite perch to seize its prey in the air. Mr. Lawrence advances the theory that it feeds high among the tree-tops during the early moming and late evening, because the sunlight sets the inseets stirring there before it does those of the undergrowth.

The nests of this species are deeper and more solid than those of the Eastern pewee, in whose shallow structures the bare foundation branch sometimes shows through the scanty lining. Fine dry grasses, vegetable fibre, shredded inner bark and plant down, woven well together and bound with web from spider or cocoon, form the walls. A lining of softer material, with oceasionally a few feathers, completes the cradle which, about the middle of June, will contain two or three small eggs. Both parents share in the building of the home, though the male usually prefers to bring the material and the female to weave the walls to her own liking. She alone broods on the nest, but her little lover sits on a twig near by, calling her "dear" in sweetest tones, and if he makes two syllables of it, the meaning is just as elear. It the end of two weeks his eocky airs tell you there are babies in the wee nest, and that upon him falls the tremendous responsibility of guarding and feeding them. Small butterflies, gnats, all sorts of small winged inseets are the orthodox food for infant flycatchers, and are swallowed at the rate of one every two minutes. Nor 
does the supply ever quite equal the demand, for every visit of the devoted father is welcomed with wide-open mouths and quivering wings. At first all this feeding must be by regurgitation, the adult swallowing the insect first and partially digesting it in some cases, and in other's merely moistening it with the saliva. After four or five days most of the food is given to the young in a fresh state.

\section{4 a. PALLID HORNED LARK, OR DESERT HORNED LARK. - Otocoris alpestris leucolama. Favily: The Larks.}

Length: Male 7.50-8.00.

Adult Wale in Breeding Plumage: Fore part of crown, cheeks, horn-like tufts, and patch on the breast black; white stripe across forehead, extending back over the eyes; throat and siles of neck white, sometimes washed with yellow; sides of breast, nape, and upper parts pale cinnamon ; the back more or less distinctly streaked with darker ; belly white.

Adult Wale in Fall and Winter: Plumage generally softer and colors more blended; black markings more or less obscured; chest often streaked or washecl with gray.

Adult Female: Similar to male, but decidedly smaller; black on the head replaced by brownish or buffy; the back reddish, and the plumage streaked.

Young: Upper parts brownish, white parts washed with buffy; throat and sides of the head spotted.

Geographical Distribution: Great Plains and Great Basin of the United

States; migrating in winter to Mexico.

California Breeding Range: In deserts of southeastern region.

Breeding Season: May 16 to July 21.

Nest: On the ground; well built of grass, roots, and bark; lined with hair and old cocoons.

Eggs : 3 to 4 ; grayish, irregularly marked with brown. Size 0.86 $\times 0.60$.

Is every suitable locality throughout the great State of California some form of the Horned Lark is found. 
From the Sierra Nevada to the coast, and from San Diego north to the ricinity of San Francisco, it is called the "Mexiean Horned Lark"; in the upper Sacramento valley we find the "Ruddy" and south through the interior to San José and Santa Barbara the "Streaked." In the northeastern corner, east of the Sierra Nevada, the species is known as the "Dusky," and that found on Santa Barbara Island is designated as the "Island Horned Lark." The distinction between these forms is one of size and color of plumage rather than structure or habits; and while all are listed for purposes of identification, the description here given of the habits of the "Pallid" or "Desert" IIorned Lark is true of all.

This is an abundant resident in the deserts of Southeastern California, east of the Sierra Nevada and through the Great Plains and Great Basin of the United States. It is characteristically terrestrial in all its ways, nesting and feeding on the ground, and is never found in heavily wooded districts. As its name implies, the arid, sandy regions where only stunted growth is found are the favorite haunts of this species. The others of its family, while equally terrestrial, prefer fallow fields, prairies, meadows, or edges of wet lowlands. The name of Homed Lark has been given them on account of the erectile tufts of black feathers on either side of the head, which, in anger, surprise, or the ardor of wooing, stand erect like tiny black lorms. By this you may know them at first sight and love them ever after. Except during the breeding season, these birds are found in flocks; but as soon as the spring rains are orer they 
separate, each pair preëmpting a quarter section of land and setting up a homestead claim. Anywhere in the open, sometimes close to a clump of sage, sometimes almost in the travelled wagon road, the little nests are made in a saucer-like hollow in the ground. The only material used is dry buffalo grass or fine vegetation, a small quantity of which usually lines the nest for the earliest brood. In the second brood, however, whether because of the warmer season or the carelessness of custom, the eggs are often laid on the bare ground, with no attempt at nest-building.

While the mother prepares the cradle, the father indulges in aerial concerts. You may hear the sweet, tinkling music while yet he is a mere speck in the blue, tumbling and turning with the rapture of his song. He calls to his mate; she hears, you may be sure, and in a moment she too is frolicking through the sunny air as if life held no such word as care. But when the snug little nest holds eggs, she foregoes the fun of a chase over the fields and sits patiently for nine days, in heat so intense that she gasps with open bill. It has seemed to me the eggs would be cooked if left too long exposed to the hot desert sun, and that her brooding was fully as much to shield them from his fiery rays as to preserve them from the cool night air with her body. If surprised on her eggs, the mother runs a few yards and begins feeding as unconcernedly as possible; but if there are young in the nest, both parents exhibit great distress. Back and forth over the field they fly, erying "tseet, tseet!" in pitifully appealing tones, and trying 
to muster courage sufficient to come down and defend their little ones.

The young larks leave the nest usually on the ninth day after hatehing, although one brood certainly were gone on the fourth day, and one remained until the tenth. They are beautiful babies, of soft mottled light and dark brown and cream buffy ; they are fed by both parents until fairly well grown, when the male takes entire charge, and the female seratches out another nest in the stubbly grass or sand. The education of the family thus depends entirely on the father bird, who may be found any sumny afternoon, initiating them into the mysteries of a dust bath, or standing beside them under a sagebush, panting in the terrible leat that beats down from the cloudless sky and up from the blistering sand. In the early morning you can wateh them feeding on the insects and seeds on the ground. A little later in the season, if you are an early riser, you may witness their first singing lesson. With wide-eyed amazement and dawning enry they have watched their father rise twittering through the elear air ; and, one by one, they learn to do it too. The first I ever saw start gave a little bound, uttered a weak "tweet, tweet," and fluttered up about ten feet only to sink back again. But he was full of triumph and, unable to contain himself any longer, soon attempted a second flight. The method is very like that of the bobolink, though the result is far less brilliant. Yet so full of irrepressible joy in living is the Ilomed Lark that as you listen you are glad, like him, just to be alive. 


\title{
474 e. CALIFORNIA HORNED LARK. - Otocoris
}

\author{
alpestris actia.
}

\author{
FAMily : The Larks.
}

Length: Male 6.75-7.25; female 6.50-7.00.

Adults: Upper parts redilish, more brownish in female, nape, shoulders, and rump light reddish brown, in contrast to back ; breast pure white in both sexes.

Geographieal Distribution: Coast district of California and sonth to Lower California.

Breeding Range: West of Sierra Nevada from San Diego to Marin County.

Breeding Season: April 15 to June 15.

$N^{\top}$ est : On the ground; of dried grasses; similar to that of pallid horned lark.

Eggs : 2 to 4 ; resemble those of the pallid horned lark. Size $0.82 \times 0.60$.

\section{4 $\mathrm{f}$. RUDDY HORNED LARK. - Otocoris alpestris rubea.}

\section{Fanily: The Larks.}

Length: Male 6.50-7.00; female 6.00-6.50.

Adults: Similar to the Mexican horned lark, but smaller and brighter colored ; hind neck, shoulders, and rump tawny cinnamon ; forehead, superciliary, and throat yellowish; sides marked with reddish brown. Geographical Distribution: California, in Sacramento and San Joaquin valleys.

California Brecding Range: Upper Sacrameuto valley.

Breeding Season: May to June 10.

Nest : Usually placed in a depression on the ground under a small bush, a tuft of grass, vines by the side of a clod of earth, or a small rock; sometimes in a cultivated field; composed of fine straw and grasses ; lined with horsehair.

Eggs: 2 to 4 ; pale olive buff, finely sprinkled with rusty gray. Size $0.82 \times 0.54$. 


\title{
474 g. STREAKED HORNED LARK. - Otocoris alpestris strigata.
}

\section{Family: The Larks.}

Length: Male 6.75-7.25; female 6.25-6.50.

Adult Male: Upper parts dull olive-brown; back broadly and couspicuously streaked with black; nape and rump ruddy; under parts generally pale yellow.

Adult Female: Similar, but upper parts more olivaceous and more distinctly streaked.

Geographical Distribution; Coast districts of Oregon, Washington, and British Columbia, west of the Cascade Mountains, south in winter to Southern California.

Breeding Range: Coast region of British Columbia, Washington, Oregon, and possibly the northwestern corner of California. Breeding Scason: Mlay.

Nest: On the ground, in a depression; of grass stems, and lined with cattle hair.

Eggs: 3 or 4 ; grayish or pale greenish tint. Size $0.83 \times 0.56$.

\section{GRAY-CROWNED LELCOSTICTE. - Leucosticte tephrocotis.}

\author{
Fanily: The Finches, Sparrows, etc.
}

Length: $5.75-6.85$.

Adult Male: Gerieral plumage deep cinnamon-brown ; forehead and fore part of crown black; rest of head gray, but not spreading down over ear-coverts; bill black; back, rump, and belly streaked with blackish; upper tail-coverts, wings, and tail more or less tinged with pink; winter plumage edged with whitish ; black crown smaller; bill yellow, tipped with black.

Adult Femrile: Similar to male, but colors paler and duller; same change in winter.

Young: Feneral plumage brownish, without the eharacteristic markings of the male.

Geographical Distribution: Along the crests of the Rocky Mountains and the Sierra Nevala and the highest peaks of the Caseades, from British America south to Mexico. 
California Breeding Range: Locally in the upper Boreal along the Sierra Nevada from Mt. Shasta south to Mt. Whitney. Breeding Season: June.

Nest: Carelessly arranged on a ledge of a bluff, or in a small crevice; composed of wild parsnip stalks, coarse grass stems, and lined with finer grasses.

Eggs : 4 or 5; white. Size $0.97 \times 0.67$.

Where the range of the Pipilo ends that of the Leucosticte begins. Far above the timber line, amid a wilder-

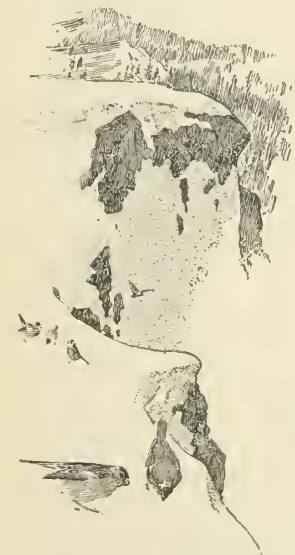
ness of snow-clad peaks these Alpine dwellers have their home. Only the severest storms of winter are able to drive them to the shelter of the forest. Flying high over the topmost peak of the range, searching in the snow for beetles and bugs that a kind Providence sends there for their special nourishment, they lead charmed lives. Even bumblebees and butterflies are on their menu, coming as mysteriously as do the birds themselves. When storms swirl over the

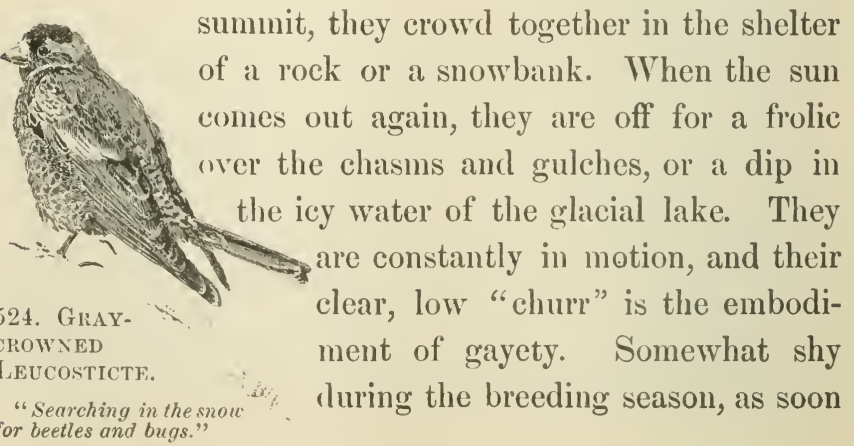


as the family cares are over they become as friendly as possible with the few who invade their haunts.

The nest is snugly hidden in a cleft in the rock underneath a crag, where the fury of the storm will pass it by. It is not an elaborate affair, but composed of weed stalks, and lined with deer moss and oceasionally a few feathers. Late in June incubation begins, and it continues fourteen days. The newly hatehed young are only thinly sprinkled with hair-like gray down and look not unlike baby juncos. They remain in the nest fully three weeks, and by the middle of August are able to fly nearly as well as the adults. In September the broods of the vicinity unite in bands of one or two families, frolicking and chattering about the summit as if it were miclsummer, and braving the snowstorms until the cold dark November days drive them to the firs for shelter at night. Even then the adults fly back to the crests during the sumny hours, as if homesick for the bare, bleak crags and the broaid vista of snowy peaks. By December they are well within the forest, whirling from place to place in masses like juncos, and sleeping huddled together in the heavy firs, sometimes almost buried in the snow but always sure of a joyous resurrection in the morning.

533. PINE SISKIN, OR PINE FINCH. — Spinus pinus.

Famu: :The finches, Sparrows, ete.

Length: $4.50-5.25$.

Adults: Upper parts gravish or brownish; under parts whitish; whole body fincly streaked with brown; sulphur-yellow patehes on wings aud tail. 
Young: Upper parts bright greenish yellow, tinged with brownish yellow ; feathers streaked, except on belly; wing-bands and patches brown.

Geographical Distribution: Northern North America, west to the Pacific, south in winter to Gulf States and Mexico.

California Breeding Range: In Boreal and Transition zones, along the Sierra Nevada forests, south through the San Bernardino mountains; also in Santa Cruz mountains.

Breeding Season: May and June.

Nest : Usually a rather flat compact structure of fine twigs, pine needles, grasses, rootlets, and plant fibres; lined with fine rootlets and hair; placed generally in pine or cedar trees, from 20 to 35 feet from the ground.

Eggs: 3 or 4 ; pale greenish blue, spotted with various shades of brown, especially at the larger end. Size $0.67 \times 0.44$.

HigH up in the mountains the tramper will find these fascinating little birds flitting through the pines, flashing a glint of yellow from wings and tails as they dash from tree to tree.

Wherever a pine cone offers its seeds, or a clump of weeds hangs full of brown pods, a banquet is spread for the Siskins. With a merry note, strikingly like the "per-chic-o-ree" of the goldfinches, they settle down to the feast, only to rise and fly farther on as the whim seizes them. The flight also is of the graceful, undulating character, as the flight of the goldfinch, as if the birds were playing with the air rather than trying to go somewhere. Yet they can fly with speed and strength, and in the breeding season they indulge in dizzy aerial gymnasties, accompanied by their own merry music. Their song is a wheezy little tune in the ascending scale, - a kind of crescendo, - which sounds as if it were produced by inhalation rather than by exhalation, but so bubbling over with gladness as to be enchanting. 
The nest of these charming feathered romps is high in a pine tree on the steep side of a cañon, so inaccessible that never have I looked into one. After the broods are reared and able to look out for themselves, the Pine Siskins band together in small flocks. So long as every bit of food is not covered with snow too deep for shaking off, they feast and frolic among the scrubby pines of the mountains until storms drive them to the foot-hills.

\section{0 a. WESTERN VESPER SPARROW. - Poøetes gramineus confinis.}

Family : The Finches, Sparrows, etc.

Length: $6.00-6.75$.

Adults: Upper parts brownish gray, everywhere streaked with dusky; bend of wing reddish brown; outer tail-feathers mostly white; under parts pale buffy white; streaked along sides of throat and across chest with dark grayish brown.

Young: Similar to adult, but markings less distinct.

Geographical Distribution: Western North America, north to British America, east to Manitoba, south to Lower California and Mexico. California Breeding liange: In the valleys east of the Sierra Nevada. Breeding Serason: May and June.

Nest: On the ground; of dried grass.

Eggs : 3 to 6 ; pale buffy, or dull whitish, often blotched and streaked with reddish brown and lavender. Size $0.80 \times 0.60$.

TuE hall marks of this dull-colored haunter of grassy upland mearlows and roadside thickets are its pale redbrown shoulders and white outer tail-feathers, shown as it flies low over the ground ahead of you. Rarely does it venture higher than the top of a fence post, or the low branch of a scrub pine, to sing its quaint melodious vesper hymı. Is the sun sinks behind the dark trees it 
begins its chant, to end only when all the world is asleep, and when its music alone breaks the silence of the forest.

Hidden deep in the grass of the meadow is its nest, woven of grass and rootlets, and roofed with leaning green spears. Here, rendered doubly safe by her protective coloring, the pretty brown mother broods for twelve days, and though you may locate the spot you will find her difficult to diseover. I have actually put my hand down within a few inches of the nest without noticing it, even when I was looking for it. The young are born without feathers and are blind, like most young birds; but they soon don coats of soft brown, indistinctly streaked with darker, and, did not their open mouths stretched up for food betray them, they would, I am sure, never be discovered. The feeding is by regurgitation for the first four days. In eight to ten days they are feathered, and leave the nest, though unable to fly. Like the meadowlarks, they remain hidden in the long grass, fed by both parents, and gradually becoming expert in picking up bugs for themselves.

In the fall the broods flock together in small companies, and leaving the high altitude of the breeding grounds, gradually work down to the brush-covered foot-hills for winter food and shelter. 
542 b. WESTERN SAVANNA SPARROW. - I'asserculus sandwichensis alaudinus.

Family: The Finches, Sparrows, etc.

Length: $4.75-5.90$.

Adults: Upper parts brownish gray, streaked with black; the streaks in sharp contrast to feather-edgings of whitish, grayish, or buffy ; crown stripe and superciliary usually yellow, sometimes white.

Young: Similar to adults, but light markings more buffy ; under parts less distinetly marked; superciliary stripe usually withont yellow, and finely streaked.

Geographical Iistribution: Western North America, from Alaska south in winter to Guatemala.

California Breeding Range: In valleys east of the Sierra Nevada recorded from Owens Lake.

Breeding Season: May and June.

Nest: On the ground, in meadlows or other grassy places.

Eggs : 3 to 6 ; pale brownish, varying to dull whitish or greenish white, spotted with brown. Size $0.75 \times 0.55$.

Whes on a tramp through salt marsh or upland meadow you flush a sparrow-like bird, with more white in its plumage than most sparrows, and with yellow about the eye and on the band of the wing, you may write it down tentatively as a Western Savanua Sparrow. If, a little later, you find it swinging on a grass stem, uttering its "weak little insect-like trill," you may be sure of its identity. He is one of the hardest of all the sparrow tribe to observe, and the one least apt to be discovered by the bird-lover, because the moment he becomes aware of your presence lie drops into the grass and refuses to eome into view. Even when flushed, his flight is merely a short zigzag to the nearest cover. Yet although you find so few, there are doubtless a large 
number hidden in the weed patches and nesting in the wiry marsh grass. His song at best is so weak and low as to seem like the note of an insect, to one who has never leard it, and is not likely to attract attention unless the listener is very near.

In nesting habits the Savanna resembles the field sparrow described elsewhere.

\section{2 c. BRYANT MARSH SPARROW. - Passerculus sandwichensis bryanti.}

Family : The Finches, Sparrows, etc.

Length: 4.78-5.30.

Adults: Similar to the Western savanna sparrow, but darker and browner, with sides and breast usually more heavily streaked; the whole head often tinged with yellow.

Geographical Distribution: Salt marshes about San Francisco Bay, south in winter along the coast to the San Diegan district.

California Breeding Range: On marshes of San Francisco and Monterey Bays.

Breeding Season: May.

Nest: Placed on the ground, usually in a slight depression.

Eggs: 4 or 5 ; grayish white, irregularly blotehed with shades of brown and marked with light purple. Size $0.73 \times 0.57$.

Amoxg the thick rushes of the San Francisco Bay marshes the Bryant Marsh Sparrow makes its home. There you may find it swinging on a tule or warbling a short sweet song, as it flies out over the tangled sedges. Its nest is made on the ground among the coarse meadow grass at a safe distance from the edge of the marsh, to escape high tides. Here in the thickest tussock, or perhaps in a hollow in the soil, a thin mat of 
grass is scratehed together and serves as a nursery. It is always more or less damp, but this does not to any marked degree interfere with the hatching. When near their nests these birds skulk through the rushes in the same manner as a rail, straddling along with one foot on one tule and the other on a second. In the shadow of the rushes one might easily mistake them for little black rails. After the four weeks of this constant brushing through the rushes to and from the nest, both parents present a decidedly threadbare appearance, and their tails are often almost as stringy as a rat's. Incubation lasts thirteen days, and the young remain in the nest ten days longer. They are fed mostly upon insects picked up in the damp grass or at the edge of the water.

\section{BELDING MARSH SPARROW.-Passerculus beldingi.}

Family: The Finches, Sparrows, etc.

Length: 5.00-5.25.

Adults: Upper parts olive-brown, with broad black streaks on back; superciliary and median crown-stripe very indistinct or wanting; forepart of superciliary stripe greenish yellow; siles of head and neck darker; under parts more thickly and heavily marked with black; under tail-coverts with concealed streaks.

Young: Similar to adults, but upper parts more buffy; superciliary tinely streaked and usually without yellow; under parts less distinctly streaked.

Geographical Distributione : Salt marshes of Southern California south to Lower California and Todos Sintos Island.

California Brerding Runge: On southeru coast marshes from Port Harford to National City.

Breceling Seceson: May. 
Nest: Placed in salt marsh mud, raised about 6 inches from the ground; made of weed stalks, grass, horsehair, or feathers.

Eggs: 3 ; light blue, marked with lavender specks; reddish brown blotches principally at the larger end. Size $0.78 \times 0.58$.

The Belding Marsh Sparrow is abundant on the salt marshes near the coast of Southern California from Santa Barbara south to Lower California. It replaces the Bryant marsh sparrow of the San Francisco Bay region. Like the latter, its nest is a thin mat of grass on the ground as near the elge of the marsh as the tide will allow. In the vicinity of National City, San Diego County, the nests outnumber those of any other sparrow. Many of them are placed on tussocks of grass, which raise them several inches above the ground. Even then they are usually quite damp, and we might expect to find the eggs addled, which they doubtless would be were not the water salt. In May, or early June, the newly hatched, naked, pinky grayish nestlings are to be found wriggling their wrinkled necks and opening their tiny mouths for food. This consists of the insects picked up from the wet vegetation, and the seeds of marsh plants given at first by regurgitation. By June 20 the young sparrows are looking out for themselves, secure in their protective coloring in the long grass.

\section{LARGE-BILLED SPARROW. - Passerculus}

\section{rostratus.}

Family : The Finches, Sparrows, etc.

\section{Length : 5.30 .}

Adults: Upper parts light grayish brown, indistinctly streaked with darker: under parts streaked with rusty brown: bill long and swollen and regularly curved from the base. 
Geographical Distribution: Coast of Sonthern and Lower California; south in winter to Cape St. Lucas and Nexico.

California Breeding Ranye: Along the salt marshes of the coast from the San Diegan district north to Santa Barbara. Nest and Eggs: Similar to those of the Belding marsh sparrow.

The Large-billed Sparrow is found in the winter along the seacoast of Southern California from Santa Barbara to San Diego, usually close to the water; at San Pedro it might be called the Harbor Sparrow, as, according to Mr. Grimmell, it frequents the decks of vessels and haunts the wharves and breakwaters. Its breeding habits are so similar to those of the Belding marsh sparrow that no separate description is necessally. It may be known from all its kinsfolk by its large bill and the uniform pale brown of its upper parts.

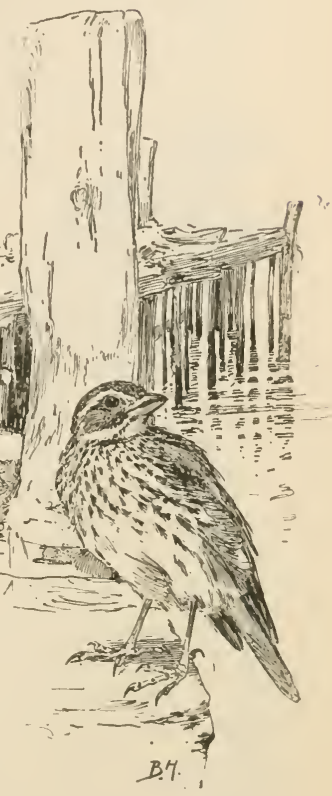

544. LARGE-BILLEU SparRow.

"It haunts the uhurves and breakwuter.."

546 a. WESTERN GRASGHOPPER SPARROW. - Immodramus savannarum bimaculatus.

Finus: The linches, Sparrows, etce.

Length: $5.00-5.50$.

Adults: Tprer parts reddish lorow, hlack, gray, and bufly ; teathers of back spotted with black and brown; metian crown-stripe buffy, bordered on each sile with blackish stripes; nuchal jutch dull gray, 
marked with reddish brown; edge of wings yellow; under parts plain buffy on throat and sides; belly white.

Young: Similar to adults, but with little or no reddish brown on upper parts, feathers being more conspicuously bordered with pale buffy and whitish ; median erown-stripe more ashy ; under parts dull buffywhitish; chest distinctly streaked with dusky.

Geographical Distribution: Western United States east to Great Plains, from British Columbia to Southern California and Arizona.

California Breeding Range: West of the Sierra Nevada, in valleys north to Sacramento, south to San Diego.

Breeding Season: April, May, and June.

Nest: On ground; rather bulky and deep; sometimes partially arched over ; made of dried grasses.

Eggs: 3 to 5; white, spotted with reddish brown, mixed with a few markings of black and lilac, mostly at the larger end. Size $0.75 \times$ 0.57 .

As its name implies, this tiny brown bird hides away in the grass and low shrubbery, like a wee brown mouse or a big brown grasshopper. Its weak, shrill "zeeee-ee," so like the song of an insect, is readily passed by as belonging to such in the medley of meadow music, unless the listener is close to the little musician. It is even better known as the "Yellow-winged Sparrow" on account of the bright lemon-color at the bend of the wing. It is so shy that one seldom catches a glimpse of it, and "none but the grazing cattle know how many nests and birds are hiclden in their pastures." Instead of flying up when alarmed, it runs deeper into the grass, and is seldom flushed. If driven to desperation by close quarters it may dart out in a short zigzag flight of a few yards and seek the first concealment that offers. Unlike most sparrows, it feeds mostly upon insects, and is of incalculable benefit to the farmer. Its nest is hidden in the meadow grass, and differs from that of most other ground birds in being deep and arched over. 


\section{2 a. WESTERN LARK SPARROW.-Chondestes grammacus strigatus.}

Famly: The Finches, Sparrows, etc.

Length: $6.50-7.25$.

Adults: Upper parts brownish or brownish gray, the

back streaked with blackish; crown and ear-coverts chestnut with nedian stripe white or buffy; black and white streaks on side of head, bordering the chestnut patch, also a black streak along each side of throat; a small black spot on middle of chest; tail dark brown, all but middle feathers tipped with white; under parts white, with a small black spot on breast.

Young: Ulper parts buffy; head without chestnut crown or patches or black and white streaks; chest streaked with dusky.

Geographical Distribution: Western U'nited States east to Great Plains and Middle Texas, south to Mexico, north to British Columbia.

Californin Brealing Range: Upper Sonoran zone, chiefly in interior valley's west of the Sicrra Nerada.

Breeding Sectson: M ay aul June.

Nest: Of dried grasses, plant stems, and fibres; placed on the ground, or in bushes and trees.

Eyys: 3 to 6 ; white or pale bluish or brownish, speckled and lined, chicfly on the larger end, with black and brown. Size $0.50 \times 0.60$.

Tre Lark Sparrow is one of the sweetest singers, as well ats one of the most abunlant of the Western sparrows. Walking along the country roadsile at any hour of the day during April, May, or June, one is likely to hear "a gush of silvery notes accompanied by a metallic tremolo," and find the singer swinging on a weed 
stalk or on a low bush, ruffling his little throat with a continuous flow of music. Or he may be caught dancing before his demure brown sweetheart, ecstatically pouring out melody. It is difficult to go anywhere in the interior valleys of California and not see him. His striped head and white-bordered tail and sweet song are the characteristics by which you may identify him.

His nest is usually well hidden, either on the ground or in low bushes, and in going to it he skulks through the intervening foliage in a secretive fashion hard to follow. The young are like those of his kind, naked, except for thin down, and blind for the first few days, during which they are fed by regurgitation. They are well feathered on the tenth day, and at this stage scramble out of the nest at the approach of danger. Like young meadowlarks they spend their babyhood days in the concealment afforded by the grass and thickets, and not until able to fly do they follow the adults to the more conspicuous feeding grounds.

\section{WHITE-CROWNED SPARROW. - Zonotrichia leucophrys.}

Family : The Finches, Sparrows, etc.

Length: $6.50-7.50$.

Adults: Upper larts grayish brown, back streaked with brown or black; crown with median white stripe, having lateral deep black stripe; a broad white superciliary stripe, below which is a narrower black stripe behind the eye; edge of wing white; under parts plain gray.

Young: Similar to adults, but head striped brown and buffy instead of

black and white; under parts very light hrown; breast, sides of throat, and sides of belly streaked.

Geographical Distribution: United States and Canada, north to Lab- 
rador; in winter migrates stragglingly over the whole of the United States and south into Mexico.

California Breeding liange: In the higher Sierra Nevalla as far south as Mt. Whitney.

Breeding Season: June and July.

Nest : Composed of fine twigs, weed stalks, and coarse material ; lined with fine grasses and hair; placed on the ground or in low bushes.

Eggs: 3 to 5; pale greenish blue, specklerl with light reddish brown, more thickly at the large end. Size $0.89 \times 0.63$.

As the snow disappears from the sides of the Sierra Nevada, the White-crowned Sparrow follows in its wake, higher and higher, until it reaches the extreme limit of the willows. Among the dense thickets that border the upper edge of the timber line it is most abundant, and during June, July, and August its song rings constantly, fine and clear. During the breeding season it haunts the willows along the mountain meadows, placing its nest on the ground, or, more conmonly, in the lower branches. Its nest and young can with difficulty be told from those of the song sparrow; and as it scratches among the dry leaves of the underbrush for insects with which to feed the nestlings, its manner distinctly suggests the latter. But here the resemblance ends; the White-crowned sparrow is distinguished by its white crown and plain gray breast, as well as by its large handsome form.

When there are egrgss or young in the nest, the male sings early and late, often piping his clear whistle when all the world is silent. I have heard him at intervals until long past midnight, as if the joy of parenthood forced him to waken and grive to his sleepy mate and little brood below the assurance that " All 's well." Evidently the singer needs little rest, for with the earliest 
dawn the whole thicket rings with his melody, rousing the more drowsy willow-dwellers to rejoice with him. "The ballad singer of the mountains," some one has called him.

His is a vertical as well as longitudinal migration, for when the September snow-flurries threaten, the various broods form a straggling flock that retreat slowly before the cold, until in October they have reached the valleys of Southern California, and pass on farther south.

\section{4 a. GAMBEL SPARROW, OR INTERMEDIATE SPARROW. - Zonotrichia leucophrys gambeli.}

Family : The Finches, Sparrows, etc.

Length: $5.75-6.75$.

Adults: Similar to the white-crowned sparrow, but edge of wing pale yellow instead of white, and lores white or bufiy instead of black, and white superciliary stripe extending to bill.

Geographical Distribution: Coast ranges of California and north to British Columbia, straggling east as far as Iowa, and south to Mexico.

Breeding Range: From Alaska and Montana to Eastern Oregon.

Breeding Secuson: June 15 to July 15.

Nest: Similar to that of the white-crowned sparrow, but placed in bushes, trees, and thick clumps of weeds.

Eggs: Similar to those of the white-crowned sparrow, but tinged with rusty brown.

Is form, coloring, and habits the Gambel Sparrow, or Intermediate Sparrow, elosely resembles the whitecrowned, of which it is a subspecies. It breeds in the far north, returning to California in October, and is an abundant winter visitant throughout the State. For nesting habits, see "White-crowned Sparrow." 


\title{
554 b. NUTTALL SPARROW. - Zonotrichia leucophrys
}

\author{
nuttalli.
}

Fanily: The Finches, Sparrows, etc.

Length: $6.00-7.00$.

Adults: Like the white-crowned sprarow, but white superciliary stripe extending to bill; lores white, and general coloration brown.

Geographical Distribution: British Columbia to Sunthern California, south in winter to Lower California.

California Breating liange: Humid coast belt from Oregon south to Point Sur.

Breeding Season: March 15 to May 1.

Nest: Bulky ; of weed stems, and linet with grasses; placed in thick clumps of weeds or low trees or bushes.

Eygs : 3 to 5 ; pale greenish blue, spotted with pale rusty. Size $0.87 \times$ 0.64 .

Like the intermediate sparrow, the Nuttall Sparrow is also a subspecies of the white-crowned, and similar in habits. It is a resident of the coast belt in the vicinity of Santa Cruz, and straggles as far south as Los Angeles in winter.

\section{GOLDEN-CROWNED SPARROW. - \%onotrichia coronata.}

Famus: The Finches, Sparrows, ete.

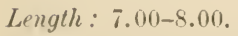

Adults: Ulyer parts olive-brown, streakel on the back with rusty llack; two white wing-bars; midelle of arown yellow, between two black lines, the yellow merging to gray for the last thirel ; under parts gray, tinged with hrown on sicles.

Young: Similar, with forehead suflused with yellow, and hlack crown. stripes streaked with brown : under parts soiled white.

Geographiral Inistribution : Pacifie Const, Sonthern California to Alaska, straggling to the Rocky Mountains and Wiscousin.

Breeding liange: Alaska.

lierenling Sienson: June. 
Nest: Of weed stems; lined with grasses; placed in alder bushes. Eggs: 4 to 5; pale greenish blue, heavily spotted with pale reddish brown. Size $0.90 \times 0.66$.

Like the Gambel sparrow, the Golden-crowned Sparrow is found in California during the winter months only. He occurs at this season throughout the length of the State west of the Sierra Nevada, and is oftenest found near the haunts of men. City parks and dooryards are not infre-
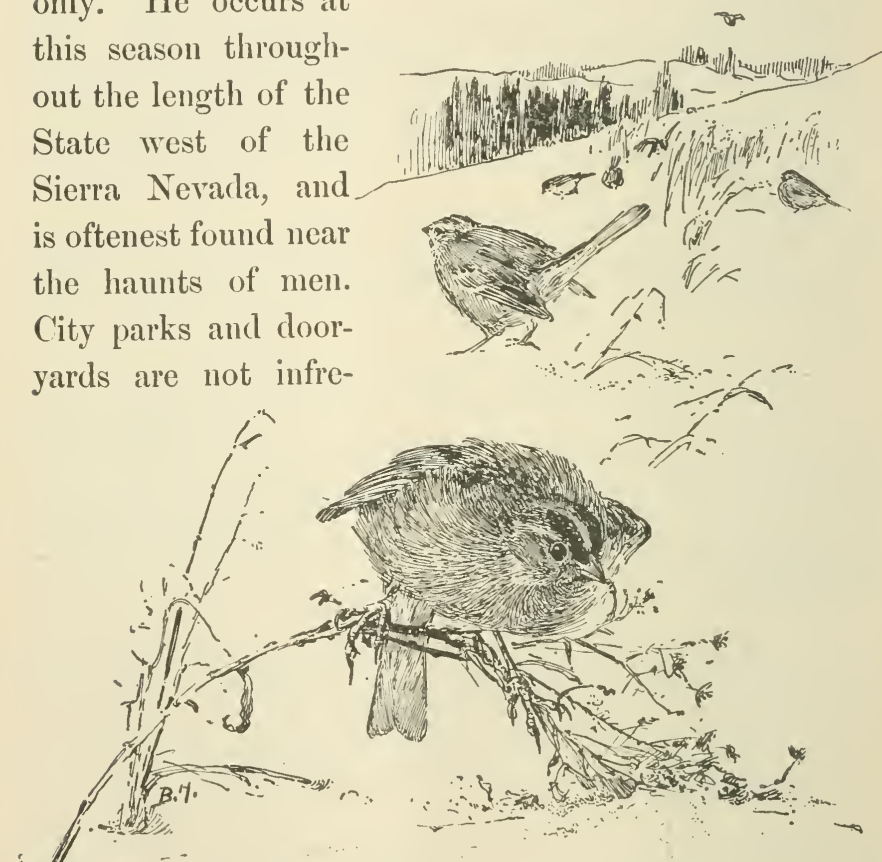

557. Golnex-crowned Sparrow.

"Their food is chiefly weed seeds and winter berries."

quently his banquet hall, and he regards human friends almost as trustfully as do his less welcome English cousins in the East. Along the foot-hills the Golden-crowned fre- 
quents the thickets, keeping on rather than in the bushes. Other varieties, especially white crowned and grambeli, are often found in a flock of the Goldens, and are evidently received into the freemasonry of good-fellowship. Their food is chiefly weed seeds and winter berries, but insects are also eaten, and oceasionally caterpillars.

\section{sऽo a. WESTERN CHIPPING SPARROW. - Spizella} passerina arizona.

Family: The Finches, Sparrows, etc.

Length : $5.00-6.00$.

Aclults: Back light hrown, narrowly streaked with black; rump and tail gray; top of head reddish brown, sometime's streaked with ashy and dark; forehead black, with short white median line; superciliary line white; narrow line through the eye black; sides of head gray ; under parts gray, whiter on chest, and throat unstreaked ; bill black.

Young : Top of head streaked brown and black; breast streaked.

Geographical Distribution: Western North America, (ast to Rocky Mountains, north to beyoul latitude $60^{\circ}$ in summer; south in winter to Southern Mexico.

California Brceding liange: Upper Sonoran to Boreal zone, nearly throughout the State.

Breeding Scason: May and June.

Nest: Of fine grasses ; lined smoothly with horsehair ; placed in bushes or small trees.

Eggs : 3 to 5 ; light greenish blue, speekled around the larger end with black and brown.

The Chipping Sparrow, or Hair Bird, is the universal favorite of the sparrow family. No other is so confiding, so trustful, building his nest in the fruit tree near the dooryard, or in the evergreen on the lawn, or even in a large rosebush. I have found him weaving his dainty hair-lined cradle in the same bush in which a thrasher was rearing his brood. The wee sparrow mother had 
danntless courage, and allowed me to touch her before she could be induced to leave her nest, when the speckled eggs were laicl. She was a fluffy, fascinating bit of soft grayish brown and buffy, with sparkling eyes that flashed indignant protest at my intrusion. After ten days, when those small eggs had hatched into nestlings, the life of both parents was full of care. The nestlings were fed by regurgitation for the first few days. After that insects of many sorts, and seed, were brought to the nest at surprisingly short intervals, yet those young Chippies were never satisfied; and long after they were well feathered and out of the nest they followed the parents about, begging constantly for food. They were exquisitely proportioned little creatures, from the time the thin fuzz began to show on their bald heads until they were clothed in soft brown feathers, like the adults.

The call note of this bird is a thin, shrill "chip, chip," which has given it its name. The fact that, wherever placed, the nest is always beautifully lined with horsehair, has won for it the nickname of "Hair Bird" in the East, and this name is equally applicable to the Western variety, though less frequently applied to it.

\section{BREWER SPARROW. - Spizella breweri.}

Family: The Finches, Sparrows, etc.

Length: 5.00-5.60.

Adults: Entire upper parts grayish brown, streaked with blackish, less distinct on head and ear-coverts ; under parts soiled grayish; winter plumage more buffy.

Young: Similar to adult, but chest and sides streaked with dusky; upper parts less distinctly streaked; wings with two distinct bands. 
Geographical Distribution: Western United States east to Rocky Mountains, south to Mexico, north to British Columbia.

California Brecding Range: Arid fout-hill regions of the interior, chiefly along the southern Sierra Nevada.

Breeding Season: May and June.

Vest: Of dry grasses and rootlets; lined with hair; placed generally in sagebushes a few feet from the ground.

Eggs: Usually 4; light greenish blue, with reddish brown markings, chiefly at the larger end. Size $0.69 \times 0.53$.

Wherever in California there is sagebrush there are Brewer Sparrows, be it in the arid deserts of the southeru district, or among the foot-hills, or on the mountains. As Mrs. Bailey says, 8,400 feet high on the snowy crests of the sierras, "morning and evening the curious little tinkling song comes up from all over the brush, and it seems as if we had come upon a marsh full of singing though subdued, marsh wrens."

In appearance this sparrow is much like the elaycolored sparrow, but is paler and duller, being almost ashy on the under parts, and harmonizing well with the tones of its arid nesting ground. The nests are usually in sagebushes a foot or two from the gromnd, and, unlike those of most sparrows, are lined with hair. In this and in other habits it resembles the chipping sparrow, and the eggs are so like those of the latter as to be distinguishable from them with difficulty. It is sometimes ealled the "Sagebrush Chippie." The newly hatched young eomplete the family resemblance, being the same daintily proportioned little creatures that we find in the nests of the Fastern chipping sparrow or hair bire. Is soon as they are able to fly, they care for themselves, and the parents turn their attention to another broml. In 
the winter these birds wander to the coast and the San Diegan district and south through the table-lands of Mexico.

\section{BLACK-CHINNED SPARROW. - Spizella atrogularis.}

Family : The Finches, Sparrows, etc.

Length: $5.50-5.75$.

Adults: Upper parts rusty brownish, narrowly streaked with black; head, neck, and under parts gray, becoming white on belly and under tail-coverts; chin and upper throat black; bill pinkish.

Young: Similar to adults, but chin and throat gray instead of black; chest indistinctly streaked.

Gcographical Distribution: Arizona south to the southern border of the United States and Lower California.

California Breeding Range: Arid foot-hill regions of the southern Sierra Nevada and desert ranges.

Breeding Season: April and May.

Nest: Of grasses, on a foundation of leaves; lined with hair; usually placed in low bushes.

Eggs: 3 to 5 ; light greenish blue. Size $0.68 \times 0.50$.

THE Black-chinned is a common summer visitant in the foot-hills of Southern California, and oceasionally wanders as far as Alameda and Monterey counties. It haunts the grassy fields and low thickets on the edges of meadows, where the clear, low trill is heard through sunny hours. The nest is very like that of the Eastern field sparrow in construction, but is placed in bushes rather than on the ground.

Incubation lasts twelve days, and the young remain in the nest ten days longer, being fed by one parent while the other anxiously tries to attract the attention of the intruder to himself. Rather than betray the hiding place 
of the little brood, the adult will flit restlessly about for an hour with a bug in his bill, which he himself absolutely refuses to eat. Finally he compromises by alighting in the grass at some distance from the nest, and running under cover to the bush where it is located.

This species has the red bill of the field sparrow and is said to resemble it in song.

\section{7 c. THURBER JUNCO, OR SIERRA JUNCO.}

Junco oreganus thurberi.

Fanily : The Finches, Sparrows, etc.

Length : 5.60-6.20.

Adults: Similar to the Oregon junco, but wings and tail longer; head, throat, and breast black, sharply defined against light brown of back and white of under parts; sicles buffy.

Foung: Similar to the young of the Oregon junco, only upper parts lighter.

Geographieal Distribution: Sierra Nevala, the desert, and the southern coast ranges of California from Oregon to latitude $32^{\circ}$.

California Breeding Range: Transition and Boreal zones along the whole length of the Sierra Nevada.

Breeding Season: April to July 23.

Nest: Of dry grasses and bits of moss; lined with finer materials of the same; placed on the ground, usually under a bush.

Eggs: 4 or 5; bluish white, spotted with chestnut, red, and lavender, forming a ring around the larger end; a few spots seattered over the smaller end. Size $0.71 \times 0.58$.

BeFone the snows had left the sides of Mt. Tallac, I found a nest of the Thurber Junco among the pines at its foot. Hidden snugly under the edge of a log and close by a clump of scarlet snowflower, it might liave been secure from all detection had not the ealls of the parents attracted my eager prying eyes. When I peeped in, the four nestlings were cuddled down on a bed of red-brown pine needles, so exactly matching their own 
striped plumage that at first I saw nothing. They were too old to be fooled into opening their bills for food, but crouched flat in fear, only their beady eyes telling me they were alive. As I put down my hand to take one, the four popped out of the nest with one accord so swiftly that I could not see what happened. Then ensued a search, long and painstaking, before I

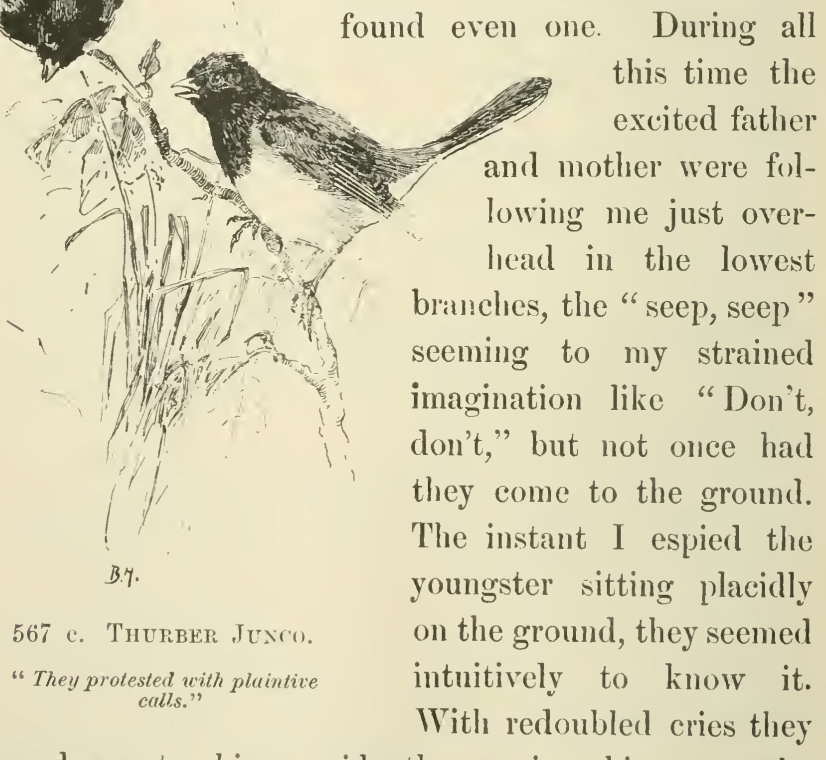
flew down to him, evidently coaxing him to make some effort to escape. And he did try, but I had never photographed a Junco baby and this chance was too good to lose, so I caught him. Soon after I found two of the others. Once caught, they seemed to lose 
fear and ate readily while sitting contentedly on my hand. There was no difficulty in indueing them to sit for their pictures, nor did the parents interfere. From a near perch they protested with plaintive calls, but ceased to fly down as they had done when the little ones were first discorered.

On the same day that this brood were found, I flushed a mother from her nest on the lawn of the Hotel Tallac, not a hundred feet from the main entrance. In this case the nest was a little hollow in the ground, lined with dried grasses and entirely concealed by the green grass of the lawn. It was not near any tree or other protection, and, when built, must have been quite exposed to view before the grass had grown tall enough to cover it. Four eggs nearly ready to hatch were its precious contents, which I left as speedily as possible, trusting that no careless foot or knife of the mower would ruin the pretty home. Before I was twenty feet away the mother had returned to them and the father had ceased his anxious cries.

In this and subsequent broods in the same locality I noticed the same fondness for bathing as in the case of the Point Pinos juncos at Monterey. No water was too icy for their plunge, but they usually chose an hour soon after noon when the sun was high, and sat in his rays to preen their little brown coats.

Their food was whatever could be picked up, whether crumbs seattered for them or weed seeds or fruit, and quite as'often insects eanght by hopping up from the grass or gathered from the trees. The green worms 
found on evergreen trees they ate with impunity, though I feel certain the same variety has killed other birds in the East.

567 d. POINT PINOS JUNCO. - Junco oreganus pinosus.

Family : The Finches, Sparrows, etc.

Length: 5.25-5.75.

Adults: Similar to the Thurber Junco, but the black on sides of head and throat replaced by slaty.

Young: Similar to the young of the Thurber Junco, but under parts more strongly tinged with buff.

Geographical Distribution: Vicinity of Monterey, California, north through San Mateo County, east through Santa Clara County, south. to Point Sur.

California Breeding Range: Santa Cruz district sonth to Point Sur, north as far as King Mountain.

Breeding Season: May to August.

Nest: Of leaves; lined with dead grasses and hair; placed in a hollow at a clump of grass.

Whether seen in the beautiful grounds of Del Monte or in the pine forests of the Sierra Nevada, the Juncos are the same friendly little birds that we have known and loved as the "snow-birds" of the East. Some one has called them gray-robed monks and nums, and the description fits them well. During the fall, winter, and early spring they are found in flocks of from ten to twenty, feeding on the ground, flying up at the approach of an intruder, only to alight again farther on. If you sit quietly they will hop quite near you, particularly the Point Pinos Juncos found at Monterey, who are accustomed to the presence of strangers in their haunts and have become as fearless as the English sparrows of the 
East, hopping close to the benches and picking up food at your feet. They have a not unmusieal call-note and a soft, sweet, twittering song. When the birds are about to begin housckeeping in the spring, this musical effort is heard at intervals all day long and is very pleasing. Both sexes coöperate at the preparation of the nest, which they build in a hollow under the roots of a tree, or, at Del Monte, under the heavy evergreens and lowgrowing shrubbery. It is a simple affair of pine needles or fine grass, and so nearly matehes the bird in coloring as to render her practically invisible when sitting. The little Juncos, although born naked, soon don a pretty habit of striped light and dark brown, and are eren more invisible than the adults among the reddish pine needles. They remain in the nest about ten days, when they are fully feathered and able to fly. They are fed by regurgitation for several days, and then with raw insects brought by both parents. For some time after making their début from the nest, the hungry youngsters follow the adults about, begging with quivering wings for fool.

They are fond of bathing, and run into the spray of the lawn hose or splatter in the puddles made by it with utter disregard of the presenee of gardener or guest. I have seen them pick up crumbs seattered for them by a Chinese helper within two feet of where he lay under a tree eating his own dimner. Evidently the most perfect camaraderie existed between the man and the birds, for when the feast was spreal he called them by a peeuliar squeaking noise and was instantly surrounded by several pairs. This was late in May, and they were 
housekecpmin; but both male and female responded to the call, leaving the nest unguarded.

All these Juncos found at Del Monte or Monterey and vicinity are of the variety known as Point Pinos, a subspecies of the gray-headed or common junco of the Eastem States. In habits and song the species are closely identified.

\section{BELL SPARROW.-Amphispiza belli.}

Family : The Finches, Sparrows, etc.

Length: $5.50-5.75$.

Adults: Upper parts brownish gray, grayer on head and neck; the back generally without distinct streaks; orbital ring, spot over the eye, broad nıalar stripe, chin, throat, and under parts white; black spot on middle of chest; throat marked on sides with a contimuous stripe of blackish ; wing-coverts edged with buffy ; edge of wing yellowish ; tail-feathers black, indistinctly marked with lighter.

Young: Upper parts light grayish brown, streaked with dusky ; under parts buffy; chest distinctly streaked with dark gray; wings with two rather distinct pale buff bands.

Geographical Distribution: West of the Sierra Nevada and San Bernardino mountains from Marin County to Lower California.

California Breeding Range: In upper Sonoran zone locally, west of the

Sierra Nevada from latitude $38^{\circ}$ southward.

Breeding Season: May and June.

Nest: Of grass stems and vegetable fibre; lined with hair; placed in low bushes.

Egys : 3 or 4 ; pale greenish blue, finely dotted and speckled with dark reddish brown. Size $0.74 \times 0.60$.

The Bell Sparrow is abundant on the bush-covered plains of Southern California as well as in the foot-hills. It is a thicket-dweller, darting from the cover of one clump to another with rapid flight as if uneasy in the open. Its nest is in the thickest of the bushes, but the anxious chirp of the male sparrow is sure to reveal 
his secret to the intruder. His song is a clear, monotonous twitter, not unmusical and full of enthusiasm. Only early in the breeding season does he attempt as much as this, usually preferring to flit silently through the thick foliage. His food consists of both insects and seeds, the latter predominating.

\subsection{SAGE SPARROW. - Amphispiza nevadensis.}

Fanily : The Finches, Sparrows, etc.

Length: $6.00-7.00$.

Adults: Upper parts light ashy brown, tinged with ash-gray, the back usually distinctly streaker with dusky; siles of throat marked with a series of narrow blackish streaks; under parts whitish, with black spot on chest; sides and flanks faintly tinged with light brown; outer web of lateral tail-feather white.

Young: Similar to adults, but upper parts and chest streaked; wings with two buffy hands.

Geographical Distribution: Sagebrush region of Western United States, north to Sonthern Idaho and Montana, east to Colorado and New Mexico, south to interior of Southern California and Western Mexico, west to Los Angeles.

California Breeding Range: In arid upper Sonoran and Transition zones, east of the Sierra Nevala. Arid desert region of Southeastern California.

Breeding Season: April and May.

Nest : of shredded sagebru. $h_{1}$ hark, dry grasses, etc.; in a hollow in the - ground, or lower branches of the sage or other bushes.

Eggs: 3 or 4 ; light greenish or dull grayish white, speckled all over with reddish brown and a few blotehes of darker brown at the larger end. Size $0.80 \times 0.60$.

Trusy well named is the little gray bird called the Sagre Sparrow. Everywhere in the sagebrush distriet his metallic call may be heard; and during the sumny spring days when the enthusiasm of nesting time inspires him to music, his sweet, riuging song is a delight to the ear. Jittle cares he for that. Swinging care- 
lessly on the highest twig of the nest bush, he sings to his mate, not to you; and, the song finished, he disappears earthward in the gray-green foliage.

His nest is either hidden in a low crotch of a bush or on the ground underneath it, and so formed of sagebark and leaves and dried grasses as to seem a part of its surround-
ings. Unless the nestlings a re
hungry and stretch
fp wide-open bills
for food, you will

The buds of the sage-

574 a. SAGE Sparrow.

"He sings to his mate, not to you." brush form at least a part of their diet, but I am inclined to believe that insects form the larger half.

Mrs. Bailey says: "The absence of a continuous stripe on the side of the throat is enough to distinguish the Sage Sparrow from the Bell," and "his long black tail and its gently tilting motion are good long-range recognition marks." 


\section{RUFOLS-CROWNED SPARROW. - Aimophila ruficeps.}

Finuly: The Finches, Sparrows, etc.

Length: $5.50-5.75$.

Adults: Upper parts grayish or grayish brown; back broally streaked with reddish brown; erown reddish brown; under parts light brown, palest on throat and belly; a distinct black stripe on each side of throat; a rusty streak extending back from eye; edge of wing dull white or grayish.

Young: Similar to adults, but upper parts dull brownish; streaked with deeper; under parts dull buffy, chest and silles streaked with dusky.

Geographical Distribution: California coast from about latitude $40^{\circ}$, south to Cape St. Lucas.

California Breeding Range: In upper Sonoran zone west of the Sierra Nevada from Sam Diego to Marin County.

Breeding Season : April to August.

Nest: Of coarse grass and weed stalks; lined with a few hairs; placed on the ground in a hollow.

Eyys: 3 to 5 ; plain white or bluish white. Size $0.39 \times 0.65$.

Brosh-Coverev hillsides are the favorite haunts of the Rufous-crowned Sparrow. Here, on the ground under thick low bushes, its nest is hidden so securely that only accidental discovery is possible.

The only way possible to observe these birds is to sit motionless among the sparse growth of bushes on the side of a hill and wait their eoming with endless patience. Their bright chestmut upper parts will serve to identify them. A short, rather swect song is sung morning and evening during the nesting season, and oceasionally in their winter haunts in the interior valleys. Their food is mainly secels and flesliy secel-pods, such as haws. 
581 a. DESERT SONG SPARROW. - Melospiza melodia fallar.

Family : The Finches, Sparrows, etc.

Length: 6.10-6.50.

Adults: Upper parts light gray; back streaked with rusty, usually without blackish shaft-line; uncler parts brownish buffy; chest streaked with chestnut.

Foung: Upper parts dull brown; back streaked with brown; under parts butly white; chest streaked.

Geographical Distribution: New Mexico, Arizona, Southern Nevada, Utah, Southern and Lower California.

California Breeding Range: In extreme sontheastern portion, along the lower Colorado River.

Breeding Secuson : April and May.

Nest: Of grasses, weeds, and leaves ; lined with fine grass stems, roots, and sometimes hair ; placed in low bushes, or in tufts of grass on the ground.

Eggs: 4; light greenish or bluish white, more or less spotted with brown. Size $0.75 \times 0.55$.

The Song Sparrow is a bird with a name that fits. Every day in the month, every month in the year, you may hear his eestatic song. In rain or shine, in heat or cold, whether in Maine or California, he is the same jolly fellow, singing his glad little roundelay, a "plain, every-day home song with the heart left in." And he may be found everywhere. No State in the Union lacks the cheer of his sunny presence. To be sure, he has various prefixes to his name, - as in California he is dubbed "Desert Song Sparrow," "Mountain Song Sparrow," "Heerman Song Sparrow," "Samuels," "Rusty," "Santa Barbara," "San Clementa," and "Nerrill" Song Sparrow, - each name indieating some variation of plumage due to environment. In the extreme northern por- 
tions he wears dark brown, while on the sands of the extreme south border he is almost clay-color. But the habits and song remain unchanged. Thoreau declares the Massachusetts maidens hear him say, "Maids, maids, maids, hang on your tea-kettle, tea-kettle, ettle-ettle," and this is exactly the advice he gives to campers in the sierras when the first rays of the sun strike the tops of the pine trees. Day has begrun for bird and birdlover. Then if you rise quickly and steal down to the elge of a mountain brook you may catch him at his batl. IVhatever the locality or tiie subspecies, do not expect to see him at any great distance from water, for he is an inveterate splasher. I have seen him dip into a purldle whose edges were crusted with ice and apparently enjoy it as well as a bath in the heat of a July day.

When alarmed, his first impulse is to dart downward into the friendly shelter of bushes, pumping his expressive tail vigorously as he flies. But in rising from the 
ground he hops from twig to twig and seldom, if ever, flies in any direction but downward or straight ahead.

Unlike some of the sparrow family, these birds do not travel in compact flocks. If several individuals are together, they are usually part of a scattered band that is working its way to or from the nesting ground.

The nests and nesting habits of all the various subspecies are so alike that one description will apply to all. The structure is usually near the ground, and often on it, with very little effort at concealment. Ineubation lasts twelve days, and is shared by the male to a limited extent; but as soon as the little ones emerge from the shell the greater part of the labor of caring for them falls upon him. In ten dars they are fully feathered and ready to leave the home shelter and follow him. As soon as this family are launched into the green forest, the busy mother prepares a new nest for a second brood. The male soon leaves the first to shift for themselves, and returns valiantly to lis post of duty, guarding and feeding the next instalment with the same zealous eare he had given the first.

\section{1 b. MOUNTAIN SONG SPARROW. - Melospiza melodia montana.}

Finily: The Finches, Sparrows, etc.

Length: $6.25-7.00$.

Adults: Upper parts grayish, with narrow streaks of black and brown; wings and tail brown; under parts white; chest and sides streaked with brown.

Young : Similar to adults, but upper parts paler and less tawny; under parts whitish and streaks narrower. 
Geographical Distribution: Rocky Mountain district, west to Nevada, Oregon, and Washington, and extending to Westem Texas.

California Breeding Range: Eastern slope of the Sierra Nevada from

IIt. Shasta to Mono Lake.

Breeding Sereson: Nay and June.

Nest and Eggs: Similar to those of the desert song sparrow.

\section{1 c. HEERMAN SONG SPARROW. - Melospiza}

\section{melodia heermanni.}

Famly: The Finches, Sparrows, etc.

Length: $0.25-6.50$.

Adults: Plumage brown or olive; upper and under prarts streaked; flanks light grayish brown; spots on chest separate and listinct from one another.

Young: Similar to adults, hut under parts tinged with brownish buff, having broad streaks.

Geographical Distribution: Interior districts of California, including eastern side of Sierra Nevada.

California Bresding liange: Along streams of the San Joaquin-Sacramento basin.

Breeding Sertson: March, April, and May.

Nest: ()f grasses, weeds, and leaves; lined with finer grasses and sometimes hair; placed in bushes from 2 to 6 feet from the gromel.

Egys: Usnally 4; hlnish gray, spotted and blotched over most of the surface, with ilark brown, the spots becoming more confluent at the larger end. Size $0.87 \times 0.64$.

\section{1 d. SAMULLS SONG SPARROW. - Melospiza melodia samuelis.}

Fanuy: The Finches, Sparrows, ete.

Length: $4.70-5.75$.

Adults: Very similar to the Heerman song sparrow, only smaller.

Geographical Distribution: Coast of California.

C'alifornic liresling liange: Along the coast belt from Santa Cruz north to latitucle $40^{\circ}$.

Breeding Season: March to June.

Nest: Of course dry grasses and weed sterns; lined with finer kinds of 
the same; placed on the ground beneath tufts of grass, in salt weeds, or low shrubs on the sand drifts.

Eggs: 3 or 4 ; blnish gray, spotted and blotched over the entire surface

with reddish brown. Size $0.75 \times 0.59$.

\section{1 e. RUSTY SONG SPARROW. - Melospiza melodia morphna.}

Fimily: The Finches, Sparrows, etc.

Length : $6.00-7.00$.

Adults: Upper parts rusty brown, almost obscuring the black streaks; chest with heavy dark brown markings; flanks greenish olive.

Young: Upper parts dark brown, back streaked with blackish; under parts buffy grayish; chest and sides light brown, streaked with darker brown.

Geographical Distribution: Pacific coast district, Washington, Oregon, and Alaska; south in winter to Southern California.

Breeding Range: Pacific coast region, from Northern California northward through Washington and Oregon.

Breeding Season: May and June.

Nest and Eggs: Very similar to those of the desert sparrow.

\section{LINCOLN SPARROW. - Melospiza lincolni.}

Famil: The Finches, Sparrows, etc.

Length: 5.25-6.00.

Adults: Upper parts dark brown and olive, sharply streaked with black; crown sharply streaked with black and divided by a median grayish line; malar stripe, ehest, and sides buffy ; sides and chest narrowly streaked with black.

Young: Similar to adnlts, but colors and streaks less sharply defined. Geographical Distribution: Whole of North America south of Hudson

Bay region.

California Breeding Range: Breeds sparingly along the high Sierra Nevarla from Mt. Shasta south to near MIt. Whitney.

Breeding Season: June and July.

Nest: Of grasses ; placed on the ground.

Eggs: 3 ; light greenish white, heavily marked with chestnut and lavender gray, chiefly at the larger end. Size $0.79 \times 0.58$.

A sHy bird, skulking through the tangle of grass and bushes in the swampy borders of a marsh, is the Lin- 
coln Sparrow. About the edges of a mountain meadow as well as in the wet lowlands, he flits in and out of the willows, giving the observer as little opportunity to see him as he ean, and never so absorbed in his insecthunting as to forget the presence of a stranger. His song is rarely heard, yet he has a happy little lay not unlike that of a song sparrow but inferior in quality.

His nest is deftly concealed on the ground, and he approaches it by a circuitous route, dodging through the grass and never by any chance revealing its whereabouts. Only by catching a glimpse of him with food in his bill one may be able to guess at its location, and that there are young to be fed.

\section{5 a. TOWNSEND SPARR()W. - I'asserella iliace ton'nsendi.}

Famw: The Finches, Sparrows, etc.

Length: $7.00-7.50$.

Adults: Upper parts bright chestnut, mixed with gray; wings, upper tail-coverts, and tail rusty brownish; under parts white, with dark brown markings on clest.

Foung: Similar to adults.

Geographical Distributim: Pacific coast region from Alaska south in winter to California.

Brecting Rirnge: From British C'olumbia north through Alaska.

Breeding Sertson: May and Jume.

Nest: Of grasses, moss, and vegretalule tibres, elosely woven together; placed near the gromud, in dense thickets.

Eygs: 3 to 5 ; pale bluish green, spotted and blotehed with reddish brown aud lilac. Size $0.90 \times 1)$.(it).

The Townsend sparrow is one of the largest and reddest of all our fox sparrows, and in his musical efforts is 
surpassed by few of that family. In the quiet woodlands of his summer home, he sits on the topmost bough of the dusky thicket and pours out his joy in a song of exquisite melody, clear and pure as that of a thrush, yet lacking the spiritual quality of the latter. The song has a wonderful carrying power withal, that renders it peculiarly attractive.

But it is as a scratcher that he excels all his kind. Among the dead leaves under a thicket, he may be

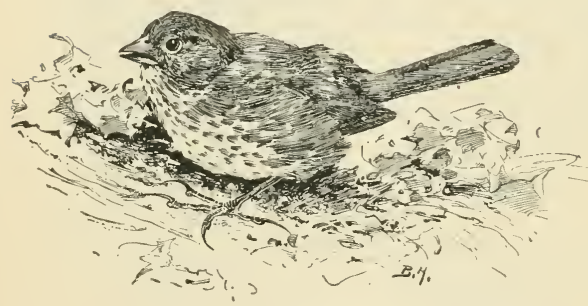

585 a. Tow

"The way he digs for his supper."

heard rivalling a towhee in the vigor with which he makes the dirt fly. A few steps forward, and a sudden kick out with both feet, then a thorough searching of the ground laid bare, is the way he digs for his supper. With the same energy that characterizes his scratching, he wooes his chestnut mate by alternate scoldings and songs, treating her with the lordly airs of a successful suitor, and fairly compelling her to accept him. To his credit be it said that he does his share of the nest building, such as it is, and though a tyrant, he is a brave guardian of his brood. When, after twelve days of patient brooding, the eggs are transformed into naked nestlings, he is ready to scratch enthusiastically all day for their sustenance. And this is really just what he is compelled to do so long as they remain in the nest and 
for at least two weeks afterwards. Then his fine song is hushed and only the metallic "tseep " of his call note is heard. Until the nestlings are three or four days old they are fed by regurgitation, and after that upon insect food.

Usually the Townsend Sparrows fly and feed in small flocks, often along the roadside thickets, and occasionally they stray into the city parks in the winter season. In the great State of California, with its varier climate, which produces variations of form and coloring, the fox sparrows have been divided into several subspecies. These are all so much alike in habits that the description of one applies to all, with a few modifications to be noted in the different subspecies.

585 b. THICK-BILLED SPARROW. - Passerella iliaca megarhyncha.

Fasily: The Finches, Sparrows, etc.

Length: 7.00-7.75.

Adults: Bill thick; upper parts plain brownish gray, becoming rusty brownish on wings, ulper tail-coverts, and tail; under parts white, with small dark brown spots on chest.

Young: Similar to adults.

Geographical Distribution: Mountains of California, including eastern

slope of the Sierra Nevada. South in winter to Los Angeles County. California Breeding liange: From IIt. Shasta south to Mt. Whitney, in Boreal and Transition zones.

Breeding Season: June.

Nest: Of plant fibre and willow bark; lined with grasses and horsehair ; placed on or near the ground, in thickets.

Eygs: 3 or 4 ; pale bluish green, spotted with dark brown. Size $0.86 \times 0.64$.

THE Thick-billed Sparrow inhabits the forests of the Transition and Borcal zones, breeding among the ever- 
greens. His big bill serves to identify him, and during the warm June days his loud clear song rings out from all the thickets early and late. In the winter this subspecies migrates southward to the San Diegan district.

\section{5 d. STEPHENS SPARROW. - Passerella iliaca stephensi.}

Family: The Finches, Sparrows, etc.

Length: $7.10-7.90$.

Adults: Similar to thick-billed sparrow, but averaging somewhat larger, with much larger bill.

Geographical Distribution: Mountains of California.

California Breeding Range: In Boreal zone on sonthern Sierra Nevada. Breeding Season: April and May.

Nest and Eggs: Similar to those of the thick-billed sparrow.

\section{1 b. CALIFORNIAN TOWHEE. - Hortulamus fuscus} crissalis.

Family: The Finches, Sparrows, etc.

Length: 8.50-9.00.

Adults: Upper parts uniform grayish brown, darker on head; throat pale rusty, marked with dusky; belly whitish, washed on sides with grayish brown.

Young: Sinilar to adnlts, but browner ; under parts buffy white ; throat and belly rusty; throat streaked with darker.

Geographical Distribution: California, west of the Sierra Nevada from Shasta County, sonth to Santa Barbara County.

California Breeding Range: Upper Sonoran zone, west of the Sierra Nevada, south to latitude $35^{\circ}$, north to Shasta valley.

Breeding Season: April and May.

Nest: In trees or bushes, nsually from 3 to 5 feet from the ground; occasionally in hollow trunks of trees, or in crevices of vine-covered rocks of cañons; made of twigs, bark, and grass ; lined with rootlets. Egys: 4 or 5 ; bluish, marked with various sharles of dark and light purple and black. Size $0.92 \times 0.73$.

The Californian Towhee is the brown chippie, or longtailed chippie, of common parlance throughout most of 
California west of the Sierra Nevarla. Unlike the shy chewink of the Eastern States, it comes to village dooryards not only in winter but often to rear its brood. Mr. Grinnell called my attention to a nest in a bush not twenty feet from the house at Pálo Alto, and remarked that at Pasadena the Towhees usually nested upon the ground, while at Palo Alto they were oftener found in bushes. Mr. Shields records nests of the Californian Towhee in erevices of vine-covered rocks, in hollow trunks of trees, and in thickets five feet from the ground. These Towhees are most deroted parents, resembling the eatbird in their piteons protests against any molesting of their treasures. Early and late they scrateh under the dead leaves or in the rich garden soil for insects, or pick up scattered grain in the barnyard, or erumbs at the door. I have seen bits of muffin fed to the nestlings with impunity, but their orthodox diet is small insects and seeds, tl.e former predominating while the parents feed them. They are fed by regurgitation at first, but in a few days they receive fresh foorl. As soon as able to fly woll, they take to the trees and spend only enough time on the ground to satisfy their hunger.

The characteristic song, like the tinkle of a silver bell, is heard oftenest at this time when, late in the afternoon, the little brood are siffely housed in the sheltering branches of an oak tree, and in the earliest dawn the same clear notes come up from the copse on the edge of the brook. For, unlike most birds, the 'Towhee sings after his family eares are over as joyously as he did in the full tide of his wooing. Mr. Frank Chapman's 
happy description of some characteristics of the Eastern variety is applicable also to that called the Californian. He says:

"There is a vigorousness about the Towhee's notes and actions which suggests both a bursting, energetic disposition and a good constitution. He entirely dominates the thicket or bushy undergrowth in which he makes his home. The dead leaves fly before his attack; his white-tipped tail-feathers flash in the gloom of his haunts. He greets all passer's with a brisk, inquiring chewink, towhee; and, if you pause to reply, with a fluff, fluff of his short, rounded wings he flies to a near-by limb better to inspect you.

"It is only when singing that the Towhee is fully at rest. Then a change comes over him; he is in love, and, mounting a low branch, he gives voice to his passion in song. I have long tried to express the Towhee song in words, but never succeeded as well as Ernest Thompson when he wrote it chuck-burr, pill-a-willa-will-a."

591 c. ANTHONY TOWHEE. - Hortulanus fuscus senicula. Family : The Finches, Sparrows, etc.

Length: 8.20-8.30.

Adults: Similar to Califurnian towhee, hut smaller, darker, and grayer. Geographical Distribution: Southern California.

Californic Breeding Range: Below Transition zone in the San Diegan district.

Breeding Season: March, April, and May.

Nest and Eggs: Similar to those of the Californian towhee.

The Anthony Towhee chooses more sonthern breeding grounds than any of its Californian kinsfolk. This is 
the species commonly met with in the San Diegan district, and from there north to the valleys about Pasadena. Unless you have the two birds in hand, you are likely to mistake it for the Californian towhee, so similar is it in. form and habits.

The song of the Anthony 'Towhee is less liquid and more metallic in quality. It is most effective in the twilight, when one singer after another takes up the short refrain, tossing it from bush to bush like the echo of fairy bells.

\subsection{GREEN-TAILED TOWHEE. - Oreospiza chlorura.}

Family: The Finches, Sparrows, etc.

Length : $6.35-7.20$.

Adults : Crown bright chestnut; upper parts grayish olive, merging to bright olive-green on wings and tail ; throat, malar stripe, and middle of belly white; edge of wing and under wing-coverts yelluw.

Young: Crayish olive above, streaked with dark gray; under parts whitish, streaked with rlark.

Geographical Nistribution: Rocky Mountains to the coast, north to Mt. Shasta, south to Lower Califoruia.

California Brediny Range: II igher Sierra Nevada aul desert ranges from

Mt. Shasta to Sin Beruardiuo monntains.

Breediny Srreson: June.

Nest: On or near the ground, in cactus, sagebrush, or chaparral; of twigs and weed stems; lined with grass.

Eyys : 3 or 4 ; whitish, speckled with chestuut.

Is the higher Sierra Nevada, where the solitaire and leneosticte form the mountain chorns, look for the Greentailed Towhee. Among all the momintain songsters he has few rivals. Whether perehed on top of a chump of ehaparral pouring ont his rich bell-like music in the half-light of evening, or dodging among the dense 
brush, or rumning swiftly across the open spaces from bush to bush on the arid mountain sides, the Greentailed Towhee has a manner distinctly his own. You -zi may know him by his semi-erectile chestuut crown, white throat, and green tail.

His alarm note is a cat-like mew, lacking the harshness of the note of the catbird, and the insistent force of that of the spurred towhee. It is a polite protest against your intrusion. His song has somewhat of a thrushक

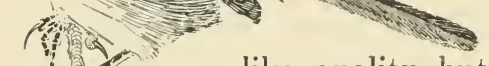

like quality, but is more varied, possessing a vigor and enthusiasm not found in that of the more quiet singer.

His nest is hidden in, or under, one of the stunted bushes with which the rocky ground 5 , J is covered, and, brooding there day after day, his olive mate is safe in her protective coloring. Newly hatched Towhees are the same naked nestlings, whether cuddled in a chaparralB.\%. sheltered nest of the mountains or rocked in a garden rosebush; dark bluish gray in color, with yellow bills, they are covered with a thin whitish down. They feather rapidly, and leave

592.1. GreeNTaIled Towhee.

"A manner distinctly his own."

the nest when from ten to twelve days old, those of the warmer localities maturing somewhat sooner than those born on the edge of the Boreal zone. They follow the adults for several weeks, learning to jump forward and kick out backward, in scratching for their food, just as the 
parents do. But this is only a small part of the hunting, for the Green-tail uses his bill more and his heels less in procuring his food than do others of his kind. Insects and seeds of all sorts are his chief diet.

\section{BLACK-HEADED GROSBEAK. - Zamelodia melanocephala.}

Famil: The Finches, Sparrows, etc.

Length: $7.50-8.90$.

Adult Wale: Upper parts mostly black; rump and collar light chestnut; wings and tail black; two white wing-bars; unler parts buffy cinnamon, changing to lemon-yellow. on helly and under wingcoverts.

Adult Female: U'pler parts blackish brown, streaked with buffy ; collar and under parts buffy; sides streaked; belly pale yellowish; under wing-coverts lemon-yellow.

Foung: Similar to adult female, but without yellow on belly ; and back mottled, not streaked.

Geographicul Distribution: Western United States, east to Great Plains, south to Mexico.

Californiu Breeding liangr: Upper Sonoran and Transition zones throughout the State.

Breading Season: April, May, and June.

Nest : In trees or bushes, usually 5 to 20 feet from the ground; made of twigs, weed stems, grass, and rootlets.

Eygs: 2 or 3 ; blnish white, speckled and bloteled with rusty brown. Size $0.92 \times 0.69$.

Arowg the alders that border small streams in the valley, in the cherry orehards at cherry time, in the potato field when bugs are rife, in the oaks and evergreens of the lower Sierra Nevada, one may hear the metallic "eck, eek," of the Black-headed Grosbeak. But do not judge his vocal powers by this squeaky eall-note, for he is a delightful musician. Unlike most woodland singers, he ehooses the smmy hours of the midday for 
his best efforts. Then from high in an oak or pine he will whistle a rhapsody, so tender, so pure, so full of joy that it seems a floodtide of
love let loose in music. But alas for
sentiment! No sooner is one round fin-
ished than the singer turns his atten-
young buds nearest to him,
sometimes even interrupt-
ing his song to seize an 596. BLACK-HLADED pleasing. He leans forward to reach GrosbeAk.

"His little brown throat swelling with music." a sprig beneath him much as a crossbill feeds on a cone, or he stands erect 
with the sunlight bringing out the strong contrasts in his plumage, and his little brown throat swelling with music ; or, in masculine awkwardness, he tries to corer the eggs while his mate is enjoying a vacation. Nearly half of the dayliglit hours he takes her place, but at night it is the mother who broods. Often when the female has been gone a long time he calls her, coaxingly, querulously, and at last imperatively, but I have never seen him leave until she had returned. This constant care enables the Grosbeaks to defend their brood from the feathered kidnappers; and it is very necessary, for the nests are exposed to view from above. After a rest, when the mother has come to the nest agrain and settled herself comfortably with much turning and fluffing of feathers, she often indulges in a sweet, warbling soliloquy, - a faint imitation of her mate's brilliant song, but so low as to be inaudible at any great distance from the tree.

The little Grosbeaks look like over-sized sparrow babies, covered at first only with a sparse hair-like down on crown and shoulders and afterwards feathering out in soft shades of brown. The bill is wide, rather than swollen, and both it and the tottery legrs are pale straw color.

From watching the adults gather insects for the young, I am confident that so long as they remain in the nest, they are fed upon an animal liet, and for the first few days by recrurgitation. In a little less than two weeks they hop out onto the small branches, and by instinct are soon pecking at every green thing in sight. For some time they seem to keep with the adults, being fed and guarded tenderly by them. 
Notwithstanding the assertion sometimes made that young birds do not sing, I know positively that young Grosbeaks sing when eight weeks old, though, of course, their song is only a low warble as compared with the finished song of the adult.

\section{CLIFF SWALLOW. - Petrochelidon lunifrons.}

FamiLY: The Swallows.

Length: $5.00-6.00$.

Adults: Forehead white or brown; crown, back, and patch on chest glossy blue-black ; rump cinnamon-buff ; throat and collar chestnut ; sides and flanks brown; remainder of under parts white.

Young: Similar to adults, but colors duller and not sharply outlined; chin and throat and often other parts of the head spotted with white; tertials and tail-coverts margined with brown; chestnut of head partly or wholly wanting; upper parts dull blackish.

Geographical Distribution: Whole of North America; migrating in winter to Central and South America.

California Breeding Range: Locally throughout the State.

Brceding Scason: June and July.

Nest: Generally a round or retort-shaped structure, made of pellets of

mud mixed with a few straws; lined with feathers; attached to cliffs or buildings.

Eggs: 3 to 5; white, speekled or spotted with brown and lilac. Size $0.82 \times 0.56$.

Cliff Swallows present a curious example of the adaptation of a species to its environment. Formerly these little masons were all cliff-dwellers, their adobe nests being hung on the side of a cliff; but the advent of man into the wilderness has brought many changes, and now it is not unusual to find a colony snugly ensconced beneath the eares of the farmer's barn.

In 1902 these birds were nesting under the projecting tiles of the roofs corering one side of the quadrangle 
of Leland Stanford University. Students passed constantly just below them, but they showed no fear.

Unlike the retort-shaped nests of most Cliff Swallows, the majority of these nests were open at the top like a wall pocket. The material was sticky elay, and was gathered outside the quadrangle. The Swallows flew down to this in small companies, and there were always one or two on the way going or coming. They seemed to pick up as much as their mouths would hold, but whether they also filled their throats, as some aver, seemed doubtful. The only support I have found for this view is the shape and size of each pellet as seen in an old nest. Also, some of the nests were so much harder than others that it would seem there might have been a difference in the saliva of the builders.

In the case of these nests, the foundations were laid in a semi-circle, and on this were placed the pellets of mud, like bricks on a wall, thus building out and up at the same time. No straw or hair or other material than clay was used in the walls of these nests, but after they were completed a lining of feathers and fine grass was placed in them. We also found these Swallows building in the ruins of the patio of the old mission of San Juan Capistrano. Upon the quaint fresco designs of the chapel, the nests were plastered as abundantly as under the eaves of a barn. "Yesterday a great mission; to-day a nesting place for owls and swallows." Here, as at Palo Alto, in some of the nests housekeeping had begun, and the pretty head of the mother bird peered over the adobe rim when we rapped on the wall. 
The young or Cliff Swallows are fed by regurgitation of small insects. These are caught, scoop-net fashion, by the adults in flying through swarms of the gnats and other small winged insects that hover in the air morning and evening, or that dance in the sunshine of mid-day. Once every ten or fifteen minutes is the usual time for a meal, but the intervals are shorter early in the morning after the night's fast, and late in the afternoon.

\section{ROUGH-WINGED SWALLOW. - Stelgidopteryx serripennis.}

FAmily: The Swallows.

Length: $5.00-5.75$.

Adults : Upper parts dull grayish brown, darker on wings and tail ; tertials usually margined with grayish; under parts plain brownish gray; belly and under tail-coverts white.

Young: Similar to adults, but plumage more or less tinged with brown; wings with broad cinnamon tips and margins.

Geographical Distribution: United States, from Atlantic to Pacific, and adjoining British Provinces; migrates to Guatemala.

California Breeding Range: Below Transition zone, east and south of humil coast belt.

Breeding Season: May and June.

Nest: In crevices of stone walls and bridges, and in holes in banks; made of grasses and straws: lined with a few feathers.

Eggs: 3 to 6 ; white. Size $0.75 \times 0.53$.

Althodgh sometimes confounded with the bank swallow, the Rough-winged is slightly larger, lacks the sooty chest-band and clear white under parts, and has in addition the distinguishing serrated outer web of the outer primary. Both this variety and the bank swallow differ from the other members of their family in their 
lustreless sooty-gray plumage and entire absence of metallic coloring.

In habits the two are very much alike, nesting in banks and congregating in flocks for migration. The Rough-winged are, however, found in small colonies, seldom more than two or three pairs in a bank, - and are more apt to choose a gravelly soil than are the bank swallows. They are somewhat less timid also, and sometimes make their nests about buildings. The one essential seems to be running water, and crevices in the abutments of bridges are often filled with their nests. The hooked edge of the wings, which has given them their name, seems to be slightly less prominent in the present species than in specimens collected fifty years ago, and it is possible that this characteristic will become modified as their environment changes.

\section{CEDAR WAXWING. - Bombycilla cedrorum.}

Fasily: The Waxwings and Phainopeplas.

Length: $6.50-7.50$.

Adults : Crest, head, and under parts soft fawn-color, changing to oliveyellow on flanks; streak through eye velvety black; upper parts plain olive-gray, becoming blackish on wing-quills and tail ; the latter tipped with yellow; both tail and wings sometimes tipped with red wax-like appendages.

Youny: Similar, but colors duller, and under parts strongly, upper parts lightly, streaked.

Geographical Distribution: Whole temperate North America, from Atlantic to Pacific; sonth in winter to Guatemala and West Indies.

Pucific Coast Breeding Range: In the humid Transition zone of Oregon, Washington, and British Columbia. No breeding record for California (Grinnell).

Ereeding Serson: June, July, and August. 
Nest: Rather bulky ; composed of bark, leaves, roots, twigs, weeds, paper, etc.; lined with finer grasses, hair, and wool ; placed usually in cedar bushes or orchard trees, from 4 to 18 feet from the ground.

Eggs: 3 to 5; bluish or light slate-color, tinged with olive, spotted with brown and dark purple. Size $0.84 \times 0.61$

The Cedar Waxwing has kept his individuality so unchanged in the transit from east to west that the California ornithologists have not been able to make a Western subspecies of him. In the coniferous forests of the Sierra Nevada they are the same handsome, gentle birds that we have known and loved in other parts of the United States. When other birds are absorbed with the cares of nest building, the Waxwings are leisurely flying in small companies low over the level tree-tops, or sunning themselves on the highest twig of the pines. After most of the forest nestlings are out of their cradles and foraging for themselves, the quiet Waxwings look about for a nesting site and commence building. Only the goldfinches are late enough to keep them company. Both male and female Waxwings bring material and fashion the nest, though the former does most of the work. It is a coarse affair to be the home of such dainty, satiny birds, and is often in or near a tree bearing berries or small fruit. Both sexes share in the incubation also, brooding by turns of from thirty to sixty minutes at a time; but it is the mother who sleeps there at night while the father perches in the same tree.

When large enough to leave the nest, the young Waxwings look like their parents, but lack the red waxy tips on the wing-feathers. They are very confiding little creatures, and I have repeatedly called them to me in 
the wood, when they would answer every call, coning nearer and nearer until they lit on a branch of hawthorn berries I was carrying and began to eat as I walked along. I know of no other birds who will endure so much meddling with their domestic affairs with no show of resentment or deserting the nest. They will suffer all sorts of indignities and disturbance of nesting site and environment without seeming to be disconcerted. This is due to the remarkable derotion of the adults to their brood, which induces them to care for the young at whatever cost to themselves. Most of the feeding is done by regurgitation, and often the gular pouches of the adult will be noticeably swollen as he comes to the nest with it full of food, which he transfers to the throats of his brood. It is less casy to tell what that food is by looking at the crops of young birds fed by regurgitation than of those fed with the raw food, yet it is often quite possible to do so with unfeathered nestlings. In the case of the young Waxwings the remains of insects were plainly visible through the semi-transparent skin; and about as soon as the feathers appeared the regurgitation was supplanted by feeding at first hand with large insects. The food of the adults consists of insects, secds, berries of trees, and any small fruits except strawberrics.

The Cedar Waxwings have no varied song, but they have a soft, conversational, whistling chirp and a plaintive call-note like "pee-eet, pee-eet" which they keep up most of the time.

They oceur in California during the fall, winter, and spring, departing in June for their northern breeding grounds. 


\section{AMERICAN PIPIT. - Anthus rubescens.}

Fanily : The Wagtails.

Length: $6.00-7.00$.

Adults in Summer: Upper parts brownish gray, more or less indistinctly streaked; wings dnsky, with two buffy wing-bars and light edgings; tail dusky; inner web of outside feathers white, second feather buffy; chin light cream-buff; under parts buff, streaked with dusky on chest.

Adultsin Winter: Upper parts decidedly browner; under parts lighter, streaks on breast usually broader.

Young: Upper parts dull brownish gray; under parts dull brownish white; chest spotted or broadly streaked with blackish.

Geographical Distribution: Whole of North America; migrates in winter to Gulf States and California.

Breeding Range: From about the timber line in the Colorado mountains, north to the Arctic coast.

Nest : Bulky and rather compact; composed of dried mosses, grasses, etc.; lined with hair, feathers, etc. ; placed on the ground.

Eggs: 4 to 6 ; dark chocolate-color, surface nearly covered with grayish brown specks and streaks. Size $0.76 \times 0.56$.

During migration and in the winter the American Pipit occurs in flocks on the large open stretches of country along the coast and interior valleys of California. Wherever fire has swept over the grass, or the ploughman has turned the sod, these dull-colored little birds alight in numbers and walk about picking up food with dainty teetering of head and tail. If alarmed, they rise with one accord high into the air, but, instead of flying away to another meadow, they usually come back to finish their feast as if it were only a foolish fright after all. Their plaintive note is a softer edition of the loud "kill-dee" of the plover, and is uttered constantly as the birds circle over their feeding ground or fly from one locality to another. 
Early in the spring the Pipits start on their journey to the Boreal zone, either in the far north or above the timber line in the mountains.

Up to the very highest peaks they wander, where snow reigns forever and the ficrce heat of the lowlands never comes, there to build "half-way houses on the road to heaven." And although unmusical in the lowlands, as soon as he reaches the solitude of the silent mountains the Pipit rises on graceful wings, a hundred feet in the air, and breaks into song with a melodious crescendo, ending the flight and the song in a precipitous drop back to eartl.

In form, color, and tail-wagging, the Pipit is so like the water thrush as to be readily confused with it but for one thing, - the thrush is found alone, or in pairs, and dodges about among the alders low over the surface of a brook; while the Pipit flies high in the air, in flocks, for a
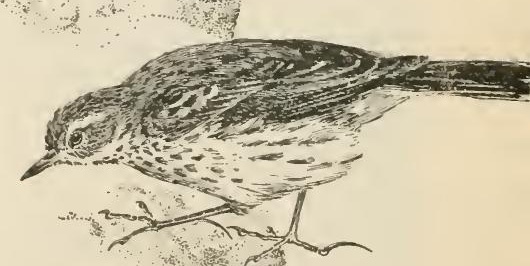
short distanee, wheeling like the killdeer and alighting near the starting point. This species is a common winter visitant and migrant thronghout Sonthern California, while the water thrush is listed by Mr. Grimnell as rare. 


\section{WATER OUZEL, OR AMERICAN DIPPER. Cinclus mexicanus unicolor.}

Family : The Wrens, Thrashers, etc.

Length: 7.00-8.50.

Adults in Summer: Entire plumage uniform slate-gray, more brownish on head and neck; bill black.

Adults in Winter: Similar, with feathers of wings and under parts tipped with white.

Young: Plumage similar to that of adults in winter, but under parts more or less mixed with white and tinged with rusty.

Geographical Distribution: Mountainous districts of Western North America, north to Alaska.

California Breeding Range: Along mountain streams throughout the State.

Breeding Season: May to June 15.

Nest : A very bulky, oven-shaped structure ; composed of green mosses;

the entrance on one side; lined with fine rootlets; placed among rocks, close to running water or behind a waterfall.

Eggs: 3 to 5 ; white. Size $1.01 \times 0.70$.

"Among all the countless waterfalls in the Sierra Nevada, whether of the icy peaks or warm foot-hills, or in the profound Yosemitic cañons of the middle region, not one was found without its Ouzel. No cañon is too cold for this little bird, none too lonely, provided it be rich in falling water.

"During the golden days of Indian summer, after most of the snow has been melted, and the mountain streams have become feeble, - then the song of the Ouzel is at its lowest ebb. But as soon as the winter clouds have bloomed and the mountain treasuries are once more replenished with snow, the voices of the streams and of the Ouzels increase in strength and 


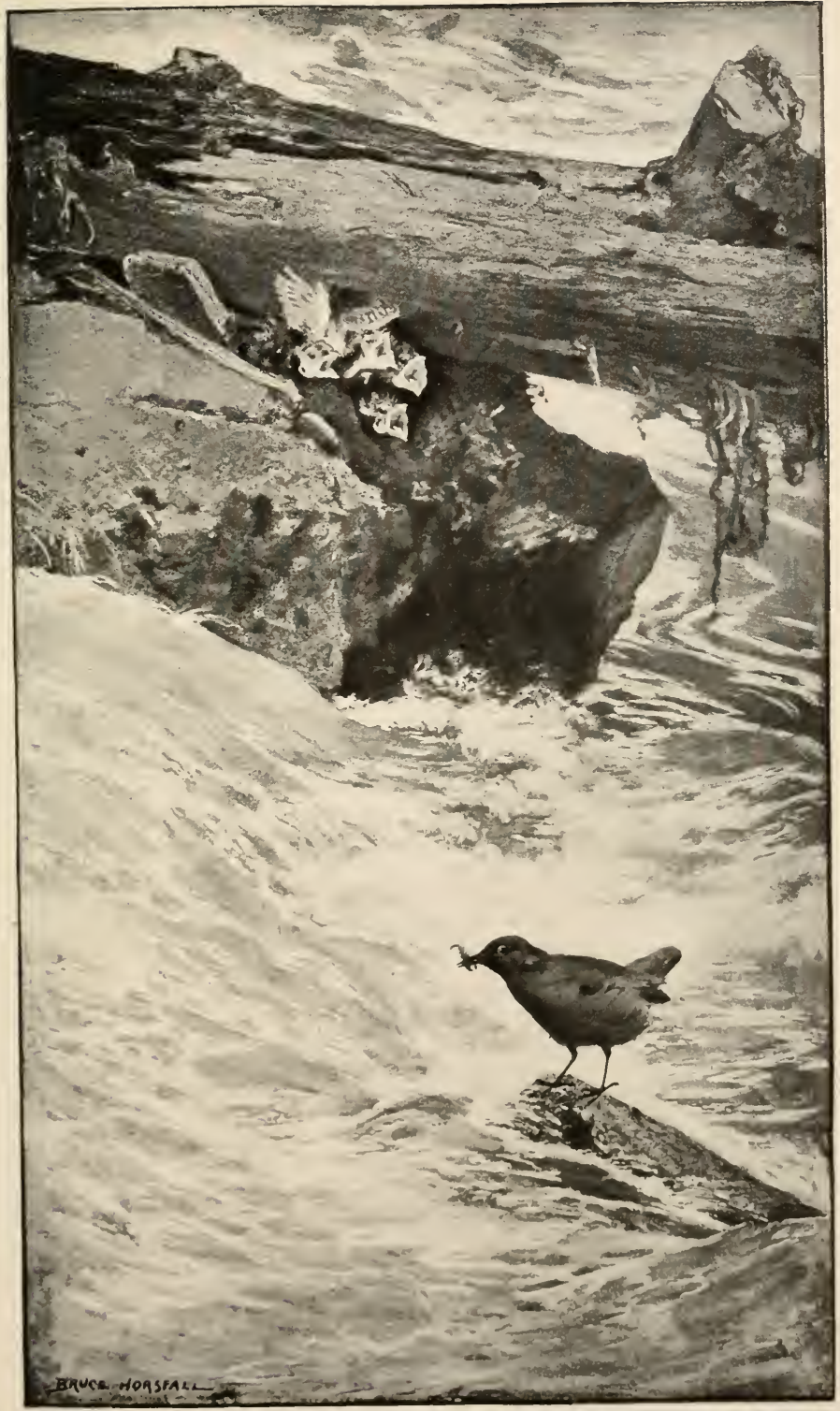

701. WatkR OUYKL, OI AMERICAN DIPPKK 

richness until the flood season of the early summer. Then the torrents chant their noblest anthems, and then is the flood-tide of our songster's melody. As for weather, dark days and sun days are alike to him. No need of spring sunshine to thaw his song, for it never freezes. Never shall you hear anything wintry from his warm breast, no pinched cheeping, no wavering notes between sorrow and joy; his mellow fluty voice is ever tuned to downright gladness, as free from dejection as cockcrowing. . . . The more striking strains are perfect arabesques of melody, composed of a few full, round, mellow notes, embroidered with delicate trills which fade and melt in long slender cadences. In a general way his music is that of the streams refined and spiritualized. The deep booming notes of the falls are in it, the trills of rapids, the gurgling of margin eddies, the low whispering of level reaches and the sweet tinkle of separate drops oozing from the ends of mosses and falling into tranquil pools." 1

After this exquisite description gleaned from Mr. Muir's essay on the Water Ouzel, one scarcely dares attempt anything original on the subject. And yet the thrill of discovering my first Onzel's nest will never be forgotten. Often had I watehed the bird fly through the waterfalls, dart in to the swirling rapids, or courtesy daintily on a rock that rose in the middle of a white torrent; often heard his clear song rising above the wild tumult of the water; often seen the ball of moss on a slender shelf of rock wet by the spray, and been told that it was the nest

I John Muir, in "The Mountains of California." 
of a Water Ouzel. But to find one in the middle of a pine-fringed mountain stream, where it seemed to belong just to the bird and me, - ah, that was a different matter.

It was located on a smooth granite boulder that rose from the white foam of the American River in the Sierra Nevada. Resting half on the rock and half in the stream was a fallen tree trunk, and under the shelter of this on the slippery rock the Ouzel had woven his little moss nest, kept fresh and green by the spray that dashed over it. As the mother approached the nest, she paused just a breath on a projecting point of the old trunk, and I distinctly saw that she carried the larva of some water insect in her beak. The babies in the nest knew it also, and the small doorway, where a dainty fern nodded its green plumes, instantly blossomed with four little heads. Four hungry mouths opened wide to receive the morsel. How would she apportion it among so many? After a moment of indecision, she tucked it deftly into one of the four gaping yellow bills; then, as if afraid of a wail of protest from those still unfilled, she darted hastily into the water and was lost to view. In exactly three minutes she appeared on the tree trunk again with another of the queer-looking larvæ, and again the four nestlings stretched hungry little beaks to be filled. This time she was joined by the male, who, though he came last, managed to deliver his load first, and perching on a smaller stone near by, where the spray dashed over him as he sang, he poured out his joy in sweetest music. How I longed to have the river keep 
silence for one moment that I might hear the wonderful song! The twitter of the young was clearly audible from where I sat, twenty feet away, and the melody of the father bird's rhapsody rang clearly over the noise of the rapids, but there must have been half tones lost in the tumult that were even sweeter than the notes that reached my ears. His song ended, into the water he plunged where the current was swiftest and where a strong man could not venture and live. Yet the bird flew upstream against it as easily as if in the air alone.

In feeding the young, both adults hovered just below the entrance to the nest, as a humming-bird beneath a flower, darting up with a little bound to deliver the food. The queer-looking larve were evidently picked up on the bottom of the river, but did not, I am sure, belong to any species of mosquito, for each was an inch and a half long and seemed to have many legs, like a scorpion. These constituted fully half of the food brought, and the rest was too small to be aceurately identified. One or the other of the adults came to the nest as often as every ten minutes during the week that I watehed them, and at times the intervals were much shorter. They invariably approached the nest in the same way, alighting first on a smaller rock whose top just broke the surface into foam, dipping and winking awhile on it, and hopping to the projecting splinter on the trunk, whence, after more dipping and winking, they fluttered over to the nest. The little Ouzels never appeared in the doorway until the parent had come to the 
tree trunk, and I think some signal note was uttered by the latter which told the nestlings that dinner was ready. Later on, in another locality, I witnessed the début of one of these interesting water-babies. He was a comical counterpart of the adults, wink and all, except for the touch of white on his feathers and his absurdly short tail, rendered more absurd by his continual bobbing dip. This dipping on the part of young and old Water Ouzels is a distressingly undecided performance, as if the bird could not quite make up his mind whether or not to sit down, and stood continually in the valley of indecision. This young Ouzel remained all day on a ledge at the foot of the wall of rock which held his former nursery, and was fed by the male as devotedly as though still in the nest. So long as it was light enough to see, he was there, and at my last glimpse of him he stood winking and dipping in the same fumn way. The other nestlings were still in the oven-like ball of green moss wherein they had been hatched, and their heads filled the doorway in eager petitioning for food. It never came often enough or in sufficient quantities to satisfy them, and one could only wonder when the overworked parents found time to supply their own needs.

702. SAGE THRASHER - Oroscoptes montanus.

Family: The Wrens, Thrashers, etc.

Length : 8.00-9.00.

Adults : Upper parts brownish gray, indistinctly streaked; two narrow white wing-bars ; inner webs of two to four outer tail-feathers broadly tipped with white; under parts whitish, tinged with buffy on flanks 
and under tail-coverts; the chest, breast, and silles thickly marked with wedge-shaped longitudinal spots and streaks of dusky.

Young: Similar to adult, but upper parts indistinctly streaked with darker, and streaks on under parts less sharply defined.

Geographical Distribution: Sagebrush plains of Western United States, from Montana south in winter to Mexico.

California Breeding Range: In upper Sonoran zone southeast of the Sierra Nevada.

Breeding Season: March to July.

Nest: A loose, bulky structure; made of bark strips, small twigs, dry sage shreds ; lined with fine stems and rootlets, and sometimes hair; placed generally in sagebrush from 10 inches to 3 feet from the ground. Eggs: 3 to 5 ; rich greenish blue, spotted with bright reddish brown. Size $0.95 \times 0.70$.

Evex amid the sands and barrenness of the sagebrush district, you may hear the full, sweet song of the Thrasher and dream that you are in a shady nook of New England with a babbling brook at your feet and the thick green canopy of vines overhead, - that is, if you close your eyes and forget the glare of the desert sunshine. What a medley of music he pours from that full throat! It is a sort of "rag-time," and unconsciously you interpret it in words as mixed as the tune. Who else can do it but the brown thrasher of the East? It is somewhat of a shock to open your eyes and see the grayish bird singing in the top of the low sagebush with, maybe, not a tree in sight. But his drooping tail and raised bill proclaim lim a true thrasher for all his queer environment. Somewhere in the sagebrush his mate is patiently brooding on the four or five blue egres. For fourteen days she keeps to her appointed task, and then her busy life begins anew. There are naked nestlings to be fed, and all the food must be swallowed by the adult before the delieate baby throats 
can receive it. At first the young Thrashers seem to be all legs and bills, but on the second day the down grows more perceptible on head and back. On the fifth day the eyes are open, the feathers show well, and the food is given to them in a fresh state. Worms and insects of all sorts form the Thrasher's menu, and these he obtains mostly on the ground under the bushes, working hard early and late to supply the hungry brood with food. It is not an easy task to raise nestlings in such surroundings. In some localities lizards and suakes rifle the nests of eggs and young, while in others hungry owls make havoe. My observations go to prove that the destruction from various causes outside of human agency is greater among Thrashers than among almost any other wild birds.

\section{CALIFORNIAN THRASHER. - Toxostoma} redivivum.

Family : The Wrens, Thráshers, etc.

Length: $11.50-13.00$.

Adults: Upper parts deep grayish brown, the tail darker and browner ; under parts dull buffy, darker on chest; under tail-coverts tawny; ear-coverts dusky, with distinct whitish shaft-streaks.

Geographical Distribution: Coast district of California, south to Lower California (F. M. Bailey).

California Breeding Range: Coast region of California north of latitude $35^{\circ}$.

Breeding Season: March to August.

Nest : A coarse, rudely constructed platform of sticky, coarse grass and mosses ; placed in bushes.

Eggs: 3 or 4 ; light greenish blue, spotted with chestnut. Size $1.18 \times$ 0.85 .

To the bird-loving tourist or new-comer, accustomed to the one brown thrasher of the East, the five or six 
species of thrasher found in California are a little puzzling. Of them all, the Californian Thrasher is the most widely distributed and best known. In form, habit, and song he is very like the Eastern bird, exeept that his tones have a metallic quality entirely lacking in that of the brown thrasher.

The young Thrashers leave the nest when twelve to fourteen days old, but are fed by the adults for some time after. I liave found the male caring for a fully fledged brood, while his mate was sitting on a nestful of eggs; and after this second series were hatehed, he at once began to feed them as faithfully as he had fed the first. Even with all this, he one day managed to sing a very short, low monologue which had in it the suggrestion of all his old-time ardor.

Both sexes assist in the construction of the bulky nest, and both brood on the eggs. In fourteen days the naked pink young emerge from the shells and are fed by regurgitation for four days, or until their eyes open. By regurgitation, in such eases, I mean that the food is swallowed by the adults first, though it may or may not be partially digested by them. I believe it is not digested, but is swallowed for the purpose of softening and moistening it. Ifter the fourth or tifth day, however, large insects are griven to the young, having been first carefully denuded of wings, legs, ete. Young Thrashers, while less voracious than young robins, yet require their meals at short intervals, and long after they are ont of the nest the overgrown fledglings follow the adults about begring for food. But they soon learn to 
swing their long bills sickle-fashion through the dead leaves, and to pick up the insects uncovered by it or to probe in the soft mould for worms.

In describing the song of the Californian Thrasher Mr. Williams says that mingled with its own peculiar notes are various imitative sounds, as the "quare, quare, quare" of the jay, the "kwee-kwee-kuk" of the Western robin, the piping call of the valley quail, and the harsh cackle of the flicker.

710 a. PASADENA THRASHER. - Toxostoma redivivum pasadenense.

FAMiLY : The Wrens, Thrashers, etc.

Length: About 12.00 .

Adults : Similar to the Californian thrasher, but colors duller, chest-band darker ; throat white.

Geographical Distribution: Interior of Southern California.

California Breeding Range: Below Transition zone in the San Diegan district.

Breeding Season: December to May.

The Pasadena Thrasher is a local subspecies of the Californian thrasher. There is one authentic record of eggs laid by this bird on December 16, and from this a very pretty story, entitled "A California Christmas Carol," has been woven in "The Sunset," January, 1903, which describes the affair as if it were the ordinary habit of this bird to rear his brood at Christmas tide. The usual nesting season begins late in January and extends to the middle of May, though nests have occasionally been found later. 
The song of the Pasadena Thrasher is at its best during the late winter, and is a jolly rollicking roundelay, as full of fun and mimicry as that of the Califorman. The nesting habits are very similar, modified only by its more southern range.

\section{LECONTE THRASHER. - Torostoma lecontei.}

FAniLY : The Wrens, Thrashers, etc.

Length: 10.50-11.00.

Adults: Upper parts light grayish brown; tail dusky and tipped with lighter ; under parts dove-color, becoming white on throat and belly ; the under tail-coverts bright tawny buff, in marked contrast; earcoverts light brownish gray; a distinct malar stripe of whitish, narrowly barred with dusky; a distinct dusky streak along each side of throat.

Young: Similar to adults, but upper tail-coverts more rusty, and under tail-coverts paler.

Geographical Distribution: Lower Sonoran zone in the desert region from Southwestern Utah to Southern California and south to Mexico. California Breeding liange: Desert region of Southeastern California. Breeding Season: February to May.

Nest: Large and bulky; made of twigs, grasses, and weeds; lined with feathers; placed in cactus bushes or mesquite trees from 1 to 7 feet from the ground.

Eggs : 3 or 4 ; pale bluish green, faintly speckled, chiefly at the larger end, with yèllowish brown and lavender. Size $1.07 \times 0.76$.

THE Leconte Thrasher loves the barren desert as a petrel loves the sea; and so many generations have its hot suns beaten down upon his race that the characteristic light brown of the family has fuded to dull grayish tinged with brown, and his breast has taken on the ashy hues of the alkali dust. Wastes of sand with sparse patches of sagebrush, cactus, and perhaps mesquite are 
his favorite haunts, and from the top of this stunted,

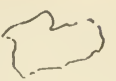
grayish green vegetation, he peals out the earliest a $\rightarrow a^{2}$ greeting to the day. So loud and so enthusi-
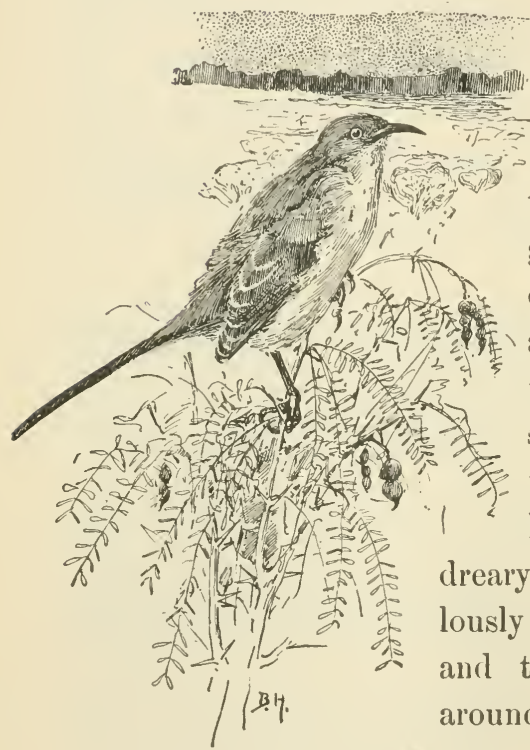

711. Leconte Thrasher.

"He loves the barrenness of the desert." est music ever heard by mortal ears.

astic is his song that it can be heard nearly half a mile away. As the sun rises and the air grows hotter his music ceases, and he skulks anong the sagebrush until evening, when he sings again, sometimes far into the night. If you have camped in this dreary waste with the marvellously bright stars overhead and the silence of the desert around you like a tomb, the song of the Leconte Thrasher, breaking the mysterious stillness, has seemed the sweet-

712. CRISSAL THRASHER. - Toxostoma crissale.

Fanily: The Wrens, Thrashers, etc.

Length: 11.40-12.60.

Adults: Bill long, sharply curved; upper parts plain grayish brown, the tail darker and faintly tipıed with rufous; under parts dark fawn or grayish; the chin and throat nearly white; under tail-coverts 
chestnut; malar stripe white, with dusky streak under same on each side of throat.

Young: Similar to adults, but more rusty on upper parts, especially on rump and tips of tail-feathers; lower parts more fulvous.

Geographical Distribution: Southern California and Northern Lower California, New Mexico, Arizona, and Utah, east to Western Texas. California Breeding Runge: Locally in desert regions along lower Colorado River, fronı Fort Yuma, northwest to Palm Springs. Breeling Season: February to July.

Nest: Large and conspicuous; made of coarse twigs ; lined with strips of plant bark ; placed in bushes.

Eggs: 3 or 4 ; pale greenish blue. Size $1.08 \times 0.75$.

Look for the Crissal Thrasher in the low, bushy underbrush of the valleys where a clear brook winds its way or a pond hides in a fringe of alders. Rarely will you find him nesting at any great distance from water, and one of the first lessons he gives his brood is to take a morning splash. It is well worth while rising at four A. x. to see him plunge so eagerly into the cold water and splash it in a shower of sparkling drops. The bath over, he flies up to the top of a tall bush to preen his wet feathers and fill the air with melody. His song is unlike that of any other thrasher in its smoothness of execution and richness of tone. Every note is sweet, true, and perfect, but the whole lacks the spasmodic brilliancy we are accustomed to expect in his family. It has a more spiritual quality but less dash. From February until late in April this 'Thrasher sings his sweetest, for then is his springtime of love and joy. From that time on through .July, when the second brood is fledged, he sings less enthusiastically, and soon he ceases altogether. Late in the autumn he sometimes is heard again in the valleys, but the full sweetness is withheld until the mating season comes again, in February. 
After the breeding season, and often for his second brood, the Crissal Thrasher ranges high up into the oakcovered foot-hills, returning to the valleys with the first fall days.

The young Thrashers hatch in fourteen days. They are naked, except for the faintest suggestion of down on head and back, and are fed by regurgitation until four days old. On the ninth day the young are feathered all but the wings and tail, which still wear their sheaths, and the featherless tracts which are on all young birds. The iris of the eye is white at this time, but gradually becomes straw-color like that of the alult.

Unless startled into an earlier exit, the Thrasher nestlings do not leave the cradle until eleven or twelve days old, and even then they hide in the bushes for many ensuing days, helplessly waiting to be fed by the adult.

Mr. Mearns tells in "The Auk" of shooting a female Crissal Thrasher and, on going back the next day after the nest, he found the male patiently brooding on the two eggs. Surely such devotion in a bird deserves a better end than the collector's basket.

\section{CACTLS WREN. - Heleodytes brunneicapillus couesi.}

Family: The Wrens, Thrashers, etc.

Length: 8.00-8.75.

Adults: Upper parts brown, back streaked with white and black; wings spotted with pale grayish brown and whitish on a dusky ground ; tail black, except for brownish gray middle feathers, which are spotted with black, and the outside feathers barred with white; conspicuous white superciliary stripe, bordered beneath by a dusky line; throat and chest white, heavily spotted with black, in contrast to buffy brown belly, which is sparsely marked with brown. 
Young: Similar to adults, but streaks on hack less distinct, spots on under parts smaller, and colors more suffused.

Geographical Distribution: Southwestern border of United States from Southern Texas to coast of Southern California, south into Mexico, north to Utah.

California Breeding Range: Lower Sonoran zone in Southern California, on both sides of the Sierra Nevala.

Breeding Season: April 15 to August 1.

Nest: Placed in cactus or thorny bushes; flask-shaped, with an entrance at one end ; made of little twigs and grasses ; lined with feathers.

Eggs: 4 to 7 ; white or creamy white, thickly covered with reddish brown spots. Size $0.97 \times 0.65$.

Unless you have heard the Cactus Wren sing, you will wonder at the science that classes him with the wrens. But when you listen to the rich, ringing, wrenlike song, and come upon the singer sitting on a thorny twig in the exact attitude of the thrashers, with lifted bill and tail curved downward, you are satisfied to leave his name among the wren family. He sings constantly as well as sweetly. His elear notes are the first to waken the weary camper in the morning, and oftentimes they alone break the death-like hush of evening. The Leconte thrasher runs him a close race in this, but, I believe, is always a little short of winning. A spirit brave enough to sing in all the dreary waste and scorching heat wins your honest admiration, and you try to imagine what the parched and silent desert would be without these two birds.

In places it seems as if every other cactus contained a nest of this species, so common is it. A long, purseshaped affair, it is laid flat in the fork of a eactus and having a doorway at the small end whereby the busy brown mother may enter. Another wren-like trait of this 
bird is the building of dummy nests. I can find no authority for this statement other than my own observation. but am positive investigation will prove it to be true. The male sometimes, if not invariably, sleeps in one of these "dummies."

By cutting a slit in the roof of a nest containing young, it was possible to watch the brood develop.

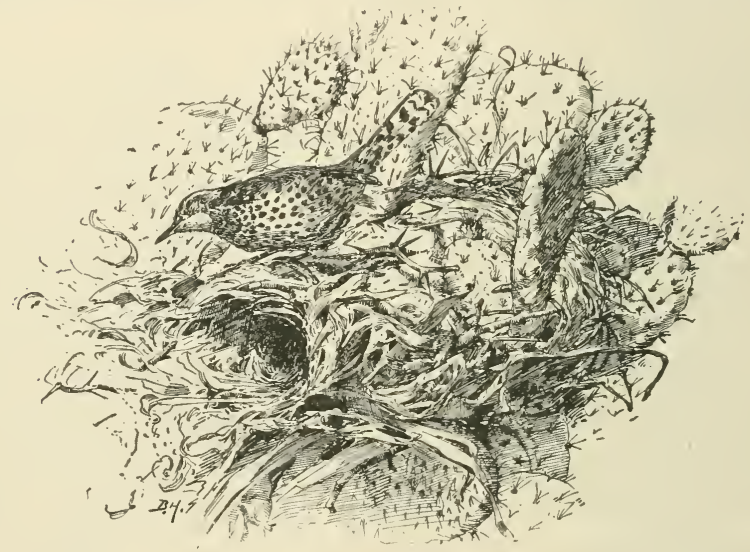

712. Cactus Wren.

"A long, purse-shaped affair."

This slit was closed and fastened after each examination. At first they were the usual naked, pinkish nestlings, with a sparse sprinkling of whitish down on crown and back, but they soon took on the soft brown and white plumage of young wrens, and were remarkably enterprising. While very young they were fed by regurgitation, but on the fifth day, when their eyes had opened, the parents carried insects in their beaks when they entered 
the nest, and then the crops of the young plainly indicated a stronger diet. By regurgitation in a case like this, I mean that the adults masticated the food and carried it in their own gular pouch, or crop, to the young. During the last few days that the young Wrens spent in the nest the doorway was full of little brown heads most of the time, and the mother no longer went inside to feed them. She still slept in the nest with them, however, and each night there was a struggle for supremacy between the nestlings who wished to look out and the mother who tried to get in. Finally, one morning when she emerged, it seemed as if the cork had popped from a bottle allowing the contents to escape, for two of the youngsters darted out close behind her, and two more peeped from the doorway. Except for smaller, plumper form and softer coloring, they were exact counterparts of the adults, and they possessed the nervous activity of their family.

\section{ROCK WREN. - Salpinctes obsoletus.}

Fanily : The Wrens. Thrashers, etc.

Lenglh: : 5.12-6.35.

Aclults: Upper parts grayish brown, more or less speckled with dusky and white dots; rump light brown; tail tipped with bufly brown and with subterminal band of black; midille dnsky; under parts dull whitish; flank tinged with pale cimmamon; chest usually finely spreckled; under titil-roverts barred with blackish.

Young: Upler parts plain rusty-griay ; under parts whitish on throat and breast, brownish on flanks and mnder tail-eoverts.

Geographical Distribution: Arid recrons of Western Vuited States, east to the Great Plains, south to Mexicu, north to British ('olumbia.

California Breeding Range: locally throughout the State, chiefly east of the humid coast belt. Recorded from the Farallones. 
Breeding Season: March and April.

Nest: Usually placed in a rift of rocks or on the ground under a project-

ing rock, sometimes in hollow stumps or about buildings; composed of sticks, bark strips, weeds, grasses, moss, etc.

Eggs: 7 to 9 ; pure glossy white, finely speckled with a few reddish brown spots, chiefly at the larger end. Size $0.72 \times 0.54$.

After finding this Wren, the only land bird among the thousands of sea fowl on the Farallone Islands, one is inclined to believe that he is well named, since all he asks for in a home are bare bleak rocks in which to hide.

In the deserted rocky cañons, where even sparse vegetation refuses to grow, he may be seen busily hunting insects in the crevices of the rocks, dodging in and out among the boulders, picking up spiders and worms, and uttering his crisp, loud note. If you startle him he will fly a few feet to the top of a small rock and, facing you, sway from side to side, scolding and bobbing in comical excitement. It may be that his nest is close by in one of the dark crannies, but, as a rule, only the master and mistress of the household can pass through the narrow doorway. About the entrance is a curious conglomeration of treasures, evidently carried there by the bird. Bits of glass, pebbles, shells, and anything else that strikes his fancy, are carefully collected in his dooryard. On the Farallones, mussel shells, small bones, and small pieces of coal form the usual collection. The nest itself is lined with feathers and hair or wool, or any available soft substance. While you are searching for it, the gay little Rock Wren is doing his best to lead you astray. As Mr. Keyser so aptly says, "He will leap upon a rock 
and send forth his bell-like peal as if he were saying ' Right here, right here, here is our nest,' but when you go to the spot he flits off to another rock and sounds the same challenge." If perchance you find the treasure, the anxiety of the tiny brown householder manifests itself in ludicrous tail-waggings and excited bobbings, together with energetic scolding protests. The half-fledged nestlings are soft brown balls of feathers with only a promise of the perky little tail of the adults. Apparently they have all the nervous activity their race, for even in the nest they wriggle and fuss.

The Rock Wren's song, which Mrs. Bailey calls the " most unbird-like of machine-made tinklings," is peculiar to himself, and once heard will be recognized instantly ever afterwards.

717 a. CAÑON WREN. - Catherpes mexicanus conspersus.

Fanıl: The Wrens, Thrashers, etc.

Length: $5.50-5.75$.

Adults: Plumage conspicuously brown, except for white throat and breast; upper parts varying from dull brown to cinnamon-grayish and speckled with white and blackish; the wings cinnamon-rusty and barred with dusky tail light reddish brown with narrow black bars; belly dull reddish brown.

Young: Similar to adults, but without white spots on upper and posterior under frarts, which are instead mottled more or less with dusky.

Geographical Distribution: Sonthwestern United States, north to Wyoming, east to Texas and Rocky Mlountains, south to Lower California and Mexico.

California Breerling Range: Desert ranges southeast of the Sierra Nevada.

Breeding Season : April, May, aud June.

Nest: Generally placed in some deserted tunnel or cave, or in holes in 
bluffs or about buildings; made of twigs, stalks, bits of leaves; covered with moss, and lined with down and feathers.

Eggs : 3 to 5 ; speckled chiefly at the larger end with reddish brown and lavender gray. Size $0.72 \times 0.53$.

The Cañon Wren is found in the southeastern portion of California among the mountains of the desert range. In habits he is like the dotted cañon wren, though much less often seen than the latter, because less common. Wherever he occurs in California he is a resident, remaining practically in the same portion of the same cañon all his life.

\section{$717 \mathrm{~b}$. DOTTED CAÑON WREN. - Catherpes mexicanus punctulatus.}

Fayily : The Wrens, Thrashers, etc.

Similar to cañon wren (C.m. conspersus), but smaller, bill shorter, and spots on back more numerous and more conspicuous.

Geographical Distribution: Oregon and California west of the Cascades and Sierra Nevada, as far south as Lower California.

California Breeding Range: Local in Transition zone on west slope of

the Sierra Nevada. Rarely in Coast Range north to Mt. St. Helen's. Breeding Season : April.

N'est: In crevices of rocks or on ledges of eliffs; made of green moss. Eggs : 3 to 5 ; white, speckled with rusty-brown and purple.

The Dotted Cañon Wren is a fairly common resident in certain parts of the Sierra Nevada, chiefly along the west slope. He may be seen darting in and out on the steep sides of rocky cañons, and, but for his white throat, looking much like a big brown bug. A nearer view with field glasses reveals the tiny black and white polkadots of his brown coat. He is a handsome little fellow and a fine singer, making the cool depths of the cañon 
ring with his jubilant song. "The Bugler" some one has ealled him, and one thinks of the name whenever listening to the song. He is a rather shy bird, creeping in and out among the rocks, pausing a moment to eye the intruder curiously, tilt his tail, and scurry off again. The busy search in every erack of the hard stone for possible insects so absorbs him that he has no time to speculate on what business the intruder may have there. Enough for him if he can place a boulder between himself and observing eyes while he gathers food for his mate or his brood. His long bill probes every mosscovered crevice and tiny hole, and often you may see him jerk a worm out of its hiding place and scramble up the eañon wall to his nest with it. I tiny hole is the entrance to his nesting site, sometimes under a boulder, sometimes far up the face of a cliff. He will fly down from it, or rather drop down with elosed wings like a stone, but I have never seen him fly all the way up to it. Sometimes he ascends by a series of short flights, but oftener by hops and fluttering scrambles. He loves those bare bleak rocks and sits upon them to sing, rather than upon any regetation there may be, hiding behind them or on them, much as the lizards do.

The only nest of this variety I have ever seen resembled that of a pewee in material and construction, but was much larger and more loosely put together. The moss of the outside was fresh and green, in exquisite contrast with the lining of silver plant-down and with the gray stone cliff. In it were fire diminutive Wrens, the brightest, perkiest birl-babies imaginable. 
The effect was irresistibly funny when one ventured out to the edge of the nest and tilter its comically small tail in exact imitation of its elders. Unfortunately, as soon as our presence was discovered, fear spoiled the picture, for the nestling crouched a moment and then scampered back into the dark nesting place. As the nest was discovered on a one day's trip, I do not know how old the nestlings were nor how much longer they remained in the nest. At this stage they were fully feathered, but the dots were much less distinct, shading into the general coloring. Otherwise they were like the adults. The coloring was so exactly in harmony with the rocks in which the nest was placed that the young birds were practically invisible at a distance of ten feet.

719 a. VIGORS WREN. - Thryomanes benichi spilurus.

Fanily: The Wrens, Thrashers, etc.

Length: $5.00-5.50$.

Adults: Upper parts dark brown, with a conspicuons white superciliary stripe; middle tail-feathers more grayish brown and barred; outer feathers blackish, spotted and barred; under parts gray, flanks brownish.

Young: Similar to adults.

Gcographical Distribution: California west of the Sierra Nevada to the coast.

California Breeding Range: Humid coast belt from Monterey to Mendocino County, including San Francisco Bay region.

Breeding Season: May.

Nest: Placed in boxes, holes, fence posts, brush heaps, stumps, etc. ; made largely of sticks and grasses; lined with feathers.

Eggs: 5 to 7 ; white, finely speckled with reddish brown and lilac. Size $0.64 \times 0.50$.

The Vigors Wren is a subspecies of the Bewick wren of the Central United States, and combines the characteris- 
tics of this species with those of the Pacific house wren. In the neighborhood of towns this bird prefer's to nest about houses, choosing all sorts of queer places in which to rear its brood; but throughout Western California, in open districts as far south as Pasadena (although there Mr. Grinnell calls it the San Joaquin Wren), it is found building among brush heaps and in hollow trees. For breeding habits see Parkman Wren, also called Pacific House Wren.

\section{1 a. PARKMAN WREN, OR PACIFIC HOUSE}

WREN. - Troglodytes aedon parkmani.

Fanily: The Wrens, Thrashers, etc.

Length: $4.25-5.20$.

Upper parts grayish brown barred with blackish, except head; tail barred with black and pale ashy; under parts indistinetly barred with ashy and brownish.

Geographical Distribution: Pacific Coast from British Columbia south to California.

California Breeding Range: West of the Sierra Nevada nearly throughout the State.

Breeding Seuson: May.

Nest: In cavities in trees, or about buildings; of twigs ; lined with mass of feathers.

Éggs: 5 to 7 ; flesh-eolor, thickly speckled with pale brownish purple and rusty.

The Parkman Wren is the house wren of the Pacific Coast and is a common summer visitant west of the Sierra Nevada. IIs gay canary-like song rings from barn, house, or cabin, wherever there is a crevice for him to nest in. From morning until night the bubbling notes "tumble over each other, they are poured out so fast," and you wonder when he takes any breath, yet he is as 
full of enthusiasm at the day's close as he was at its beginning. He is very friendly and sociable, allowing you to watch him, and watching you with equal interest.

When nest-building commences it absorbs the attention of both sexes, though the master of the household still sings between loads. Such a mass of material they manage to gather! Shreds of bark, twigs, feathers galore, straw, and often bits of plant-down, such as cotton. The cavity is stuffed to its fullest capacity, and in the top of the mass madam shapes a shallow cup to hold the eggs. But these Wrens are capricious folk, and after the nest is all ready they will often take a vacation and pay no further attention to it for several days, or even a week. Then, one day, you may see the female slipping slyly into the nest hole while her mate sings louder than ever near by, and you conclude rightly that the first egg has been laid. She may lay another the next day or she may wait a day or two, but as soon as there are five or six, she will commence to brood. Fourteen days are necessary for the incubation of those small eggs, and, at the end of that time, a peep into the nest will reveal tiny, naked nestlings, a trifle less than one inch long, with knobs for eyes and little more than mere slits for beaks. Their wingbones are about one-sixth of an inch in length, and their legs are not much longer. But they double their weight every twenty-four hours, and at the end of four days they have down on heads and along the feather tracts, and look much more like birds. The beak also has taken shape and is more or less firmly cartilaginous. On the fifth day the eyes open. Up to this time they have been fed 
by regurgitation (see Foreword) at intervals averaging every half-hour throughout the day, the periods being longer from 8 to $10 \mathrm{~A} . \mathrm{M}$. and 12 to $3 \mathrm{P} . \mathrm{M}$., but now fresh food is given them. The young Wrens feather more slowly than some young birds, and usually remain in the nest until sixteen days old; one brood could neither be coaxed nor starved into flying until the twenty-first day. The location of the nest seems to affect the time of their departure, and, in cases where it is high up, with no near perch, the little ones seem to be afraid to venture. For some time after leaving home they are fed by both adults, and sometimes return to the nest at night either alone or with the mother bird.

\section{2 a. WESTERN WINTER WREN. - Nammus}

\section{hiemalis pacificus.}

Family: The Wrens, Thrashers, etc.

Length: $3.60-4.25$.

Adults: Tail very short; upner parts dark cinnamon-brown, brightest on rump; wings, tail, and sometimes hack fincly barred with black: line over eye, throat, and heast rust color ; rest of under parts larker and barred with dark.

Geoyraphical Distribution : P'acific coast from Alaska to Southern California ; south in winter to Mexico.

C'alifornin Breeding liange: In the humid coast belt (T'ralsition), south to Point Șur.

Brereling Serrson: April and May.

Nest: In erevices of stumps or logs ; a mass of moss, with hollow lined with feather's.

Eygs: 5 to 7 ; cream-white, thinly speckled with rusty. Size $0.10 \times$ 0.48 .

J. N. Bowles says of this bird: "The stillness was suddenly broken by the heautiful bell-like warble of the 
Western Winter Wren, and I knew that within half a mile must be his nest. I walked to the edge of the brook, and after travelling a short distance along it, the way was blocked by a giant fir that, in falling years before, had split in the middle. From deep in this split appeared suspicious looking twigs, but past experience had taught me not to expect the real nest within a hundred yards of a singing Winter Wren. Nor was I mistaken, for it proved to be nothing more than a well-built decoy, about which the bird had made a very natural 'bluff' of anxiety. . . . I continued up the brook, finding two more decoy nests of the Wrens in the roots of fallen trees. . . A half-uprooted fir tree, some two hundred yards from where the Wren was heard singing, gave me a thrill of interest. The opening under the roots extended in about ten feet, and was only three feet high at the entrance, so there was nothing for it but to imitate the serpent. The Wren had left me long since, and nothing stirred when I shook the roots, therefore my hopes were high, as these Wrens are never seen near their eggs. After crawling in as far as possible, I turned over on my back and waited for my eyes to become accustomed to the darkness. As things gradually took shape, almost the first thing I saw was the much-hoped-for nest, all of twigs and green moss, directly over my head. It was wedged in among the earth and roots, and a feather protruding from the entrance told me that my search had rerealed a satisfactory end - the decoy nests are never lined. The set consisted of six partially incubated eggs, and only one 


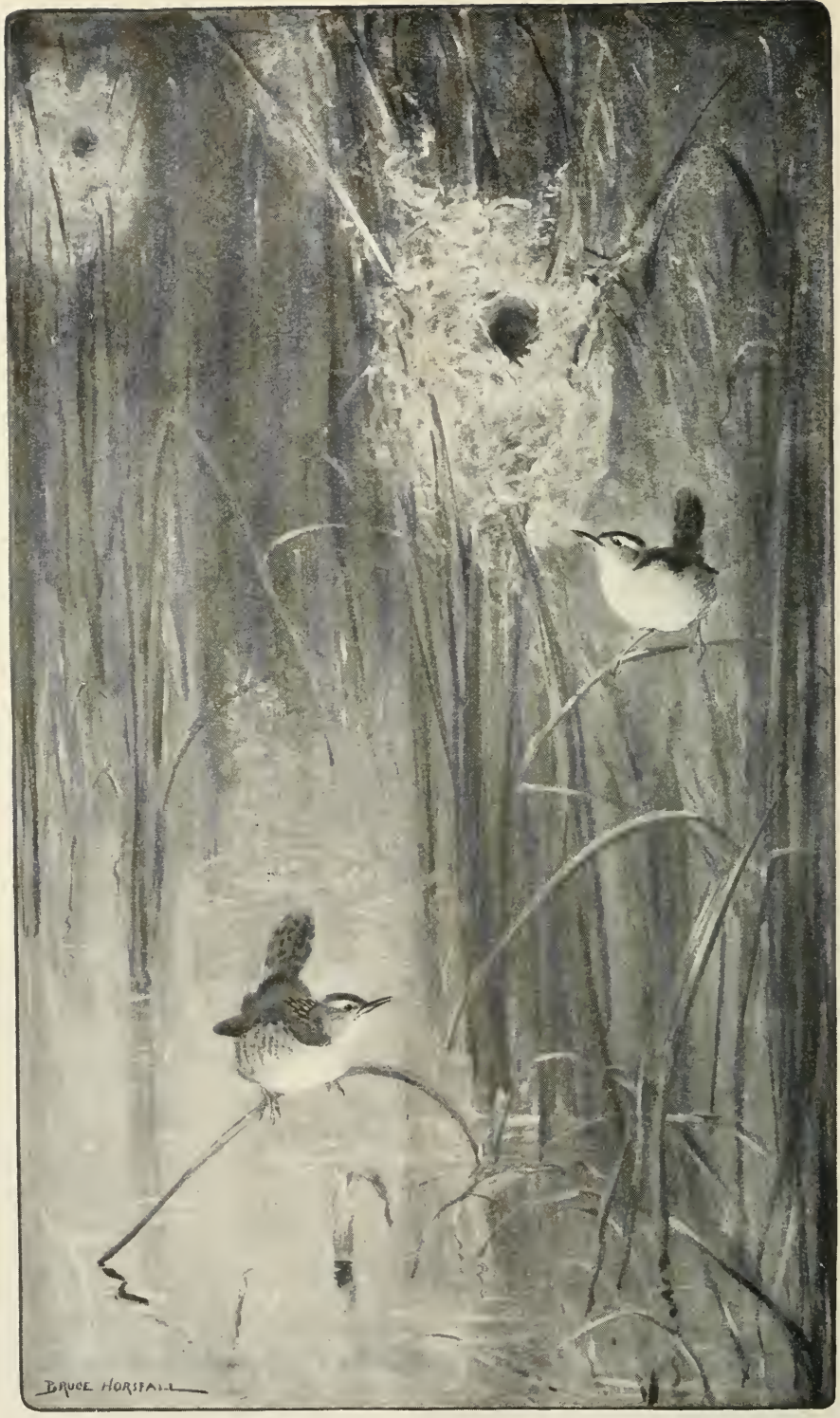

725a. TULE WreN 
more decoy was found a short distance further on in a long-deserted placer mine."

Unfortunately Mr. Bowles's excellent description - a part of which I have quoted here from "The Condor," Vol. III. No. 1-does not record the rearing of the brood or the mammer of feeding the young, and these J supply from my own notebook.

One particular pair which my notes record nested in the crevice of an old stump, which, when the young were five days old, I broke open slightly to obtain a better view. This did not in the least deter the dauntless parents from caring for the nestlings, though it doubtless eaused them much anxiety. The young of this Wren resemble the young of tule wrens when first hatched, and are rather slow in feathering. They are fed by regurgitation for several days after hatehing, the menu being chiefly small grubs which the busy little parents pick out of the bark of the coniferous trees. They are fed on insects and worms also. After the sixth day the food is mostly given in the fresh condition. The Wren nestlings leave the nest between the seventeenth and twenty-first days.

725 a. TULE WREN. - Telmatodytes palustris paludicole Family : The Wrens, Thrashers, etc.

Length: $4.50-5.75$.

Top of heal black; erown brown; midlle of back with triangular black patch, streaked with white; rest of upper parts buffy brown; tail-coverts and midhle-tail feathers barred with black; under parts unfly white, browner on silles.

Geographical Distribution: Pacific coast from British Columbia to Mexico. 
Califomia Breeding Range: West of the Sierra Nevada, in suitable localities.

Breeding Season: June and July.

Nest: Large oval ball, attached to tule stems; composed of wet tules, marsh grass, and pond weed matted together ; lined with tule pith and dry algæ. Entrance at one side.

Eggs: 3 to 5 ; pinkish brown, clouded with darker.

To know the Tule Vren you must go to the tall reeds of a lowland marsh and live for hours each day with him. He will protest with all the force of his little throat against your intrusion and will call all his neighbors to the scene. Clinging to the slender tule, with much tailbobbing and attitudinizing, he challenges you angrily and, were he as big as he is brave, you would never venture further. His nests are many, all dummy save one, but you will not be able to guess which that one may be. I have examined thirty in one day and found but one occupied, and that was the oldest, most tumble-down of the lot. With undiminished vigor he sings and works, carrying wet marsh vegetation and weaving it among the rushes into a ball many times the size of his industrious little self. His mate is already brooding in one of those nests which he made last year, but that is no reason, according to his way of thinking, why he should not keep busy making more. So, resting only long enough to satisfy his hunger, he keeps on with his self-appointed task from morning until night, singing as he goes the merriest, maddest medley of banjo-like notes.

Each nest is lined with pith of the tules, which is exactly like cat-tail down of the East, but the one containing the purplish brown eggs is padded very carefully with this material. These nests are conspicuous objects 
among the thin-stemmed tule-rushes, and on this account are much more easily watched than are the nests of the long-billed marsh wrens, which live in heavier marshes. It is steaming hot inside the thick-walled ball, and the eggs feel like little hot pebbles to your fingers. Twelve days are required for incubation, and even during this short period the mother is not a elose sitter. I have known her to leave the nest for two hours in the middle of the day, trusting to the intense heat of the sun to perform her task for her; and but for the thick, moist walls of the cradle, this same sun would have been fatal to the bird life within the shells.

As soon as the eggs hatehed in the nest I was watching, I cut a slit in the top of it to look at the young. They were naked, light pink in color, with tiny heads, mere knobs for eyes and buds for wings; each nestling measured one inch in length. After this examination I tied up the slit, and before I was a yard away the mother entered the nest again. Four days later the eyes of the young Wrens had begun to open, and looked like tiny slits, while a thin buffy down eovered the top of their heads and was scattered sparsely over their bodies. Is in the young of the long-billed marsh wrens, the ear openings were conspicuously large. Bill and legs had changed from pink to light burnt-orange in color. They were fed by regurgitation for the first four days and doubled in weight every twenty-four hours. (See Foreword.) When a week old they were commencing to feather, and in three days more were nearly readly to leave the nest. They were now fed on larva of water insects, 
slugs, and dragonflies, besides other insects, and meals were served four times an hour during most of the day.

When the young Wrens were twelve days old, my attempt to pecp into the nest for the last time resulted in a sudden discharge of all its contents, one by one, into the green rushes, where they sat breathless clinging to the thin stems in desperate efforts to keep right side up. They were entirely feathered and able to pick up food for themselves, but for two weeks more their pretty coaxing chirps induced the adult Wrens to supply them with marsh tidbits even more frequently than before they left the nest.

725 c. INTERIOR TULE WREN, OR WESTERN MARSH WREN. - Telmatodytes palustris plesius.

Family : The Wrens, Thrashers, etc.

Length: About 4.50-5.75.

Top of head and patch dark brown; middle of crown light brown; upper parts buffy brown; tail heavily and sharply barred with dark; under parts pale ashy gray.

Geographical Distribution: From British Columbia south to Mexico, from east side of the Sierra Nevada to Rocky Mountains.

California Breeding Range: East of the Sierra Nevada at various localities. Mr. Grinnell mentions Eagle Lake. Nest and Eggs: Like thase of tule wren (C.p. paludicola).

The Western Marsh Wren is the Western representative of the long-billed marsh wren of the East, and is identical in habits with that bird. (See "Nestlings of Forest and Marsh.") 


\section{6 c. CALIFORNIAN CREEPER. - Certhia familiaris} occidentalis.

\section{Family : The Creepers.}

Length: About 5.00 or 6.00 .

Upper parts bright brown, reddest on rump; line over eye, streaks on head, and back yellowish brown.

Geographical Distribution: Pacific coast of North America from Alaska to Santa Cruz mountains, California.

California Breeding Range: Humid coast of Transition zone, south as far as Santa Cruz mountains.

Breeding Season: May.

Nest: Under loosened bark of redwood or cedar, within 5 feet of ground ; made of finely shredded cedar bark; lined with plant down or feathers.

The Californian Creeper is the Western representative of the brown creeper. It is so like the sierra creeper in form and habits that no separate description is necessary. Its shrill, wiry note is heard in the redwoods of the humid coast district, but the bird itself is so protectively colored as to look like a large brown bug against the redbrown trunks. Only a few nests have been recorded from the Santa Cruz mountains, but the Creeper undoubtedly breeds there quite commonly.

726 d. SIERRA CREEPER. - Certhia familiaris zeloles.

$$
\text { Fanily: The Creepers. }
$$

Length: About 5.00 or 6.00 .

Adults: Upper parts dark grayish brown, becoming tawny brown on rump; line over eye, streaks on shoulders, and spot on wing white; under parts white, washed with brown on sicles.

Geographical Distribution: Cascalle Mountains of Oregon and the Sierra Nevada, west to valleys in winter. 
Breeding Range: Transition and lower Boreal zones along whole length of the Sierra Nevada.

Breeding Season: June.

Nest: Described by Mr. Barlow as under the bark of dead pines, about

20 feet up; made of cedar bark and a few feathers.

Eggs: 5; white, spotted and blotched with reddish brown and pale lavender.

The quaint little bird called the Sierra Creeper is a summer resident of the pine forests, and so perfectly does his striped brown back blend with the bark that he becomes practically invisible the moment he alights on it. His habits are so exactly like those of the brown creeper of the East that Mr. Chapman's delightful description of that bird fits him perfectly. He says:

"The facts in the case will doubtless show that the patient plodding brown creeper is searching for the insects, eggs, and larva which are hidden in crevices in the bark; but after watching him for several minutes one becomes impressed with the thought that he has lost the only thing in the world he cared for, and that his one object in life is to find it. Ignoring you completely, with scarcely a pause, he finds his way in a preoccupied, near-sighted manner up a tree trunk. Having finally reached the top of his spiral staircase, one might suppose he would rest long enough to survey his surroundings, but like a bit of loosened bark he drops off to the base of the nearest tree and resumes his neverending task. He has no time to waste in words, but occasionally, without stopping in his rounds, he utters a few screeping squeaky notes, which are about as likely to attract attention as he is himself. As for song, one would say it was quite out of the question; but in its 
summer home among the northern spruces and firs it has an exquisitely pure, tender song of four notes, dying away in an indescribably plaintive cadence, like the soft sigh of the wind among the pine boughs.'

At all times an unsocial bird, the Creeper is seldom, even at nesting time, seen in company with another of his kind either male or female. Apparently too busy for any lorer's nonsense, he yet does indulge in it upon occasion and, like all drudges, when he wishes to be sentimental he succeeds only in being serio-comic. With utmost gravity he offers his sweetheart a fat grub, cocking his hear sidewise as he sees it disappear down her throat. She puts up her bill for more, which he pretends to give, necessarily at long range on aceount of the slender curve of his beak. Then he goes on with his task of hunting, while she tags close behind teasing for more after the manner of a hungry nestling. This does not last long. The business of house-buildingr begins. His little home is hidden snugly behind the burk of a dead pine tree high up from the ground, but highlier

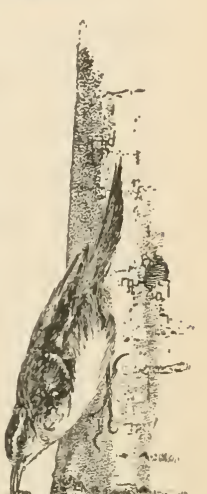
still from the same tree he warbles his queer little love song, when the glorious dawn of a Jume morning moves even his plodding soul to musie. 
Only nine days are required to hatch the snıall eggs, and the naked nestlings squirm and wriggle like so many pink mice in the cosy nest. They are slow in feathering, not being fully covered until fifteen days old, and even then the down shows through the feathers in hair-like patches. According to the best of my observations with a powerful field glass, they are fed by regurgitation until four days old. After that a visible supply of insect food is given them. Their first journey from home is a creeping about on the bark of the nest tree, to which they cling desperately, aided by their sharp little tails. Instinctively they pick at every crevice in the bark, and soon become so business-like about it that they are quite independent of the adults and of each other.

\section{PALLID WREN-TIT. - Chamaa fasciata.}

Family : The Nuthatches and Tits.

Length: About 6.00-6.50.

Adults: Upper parts gray, washed with olive on rump and tail; tail long; under parts fawn-color, indistinctly streaked with dusky.

Geographical Distribution: California, from Shasta County southward to San Diegro.

California Preeding Range: Upper Sonoran zone, west of the Sierra

Nevada, except hunid coast belt, from San Diego northward to lower

McCloud River.

Breeding Season: April and May.

Nest: In thickets or low bushes; compactly made of twigs, bark strips, and grasses ; lined with feathers and cow hair.

Eggs: 2 to 5 ; uniform turquoise blue. Size $0.73 \times 0.56$.

Some California birds, such as the phainopepla, wrentit, and others, are like the California big trees, - sui 
generis. There is nothing like them east of the onehundredth meridian and they are well worth a long journey to study.

The Wren-tit is a unique combination, as his name implies. Exceedingly difficult to watch, he slips along the ground under the chaparral and through fields of dead mustard stalks, eluding observation as well as pursuit by scooting into the thickest patches of weeds, until the patience of the student is exhausted and he drops down to rest in a shady corner. This is really the best thing to do, for if one keeps still long enough the bird is sure to come into view, and often, impelled by curiosity, will approach within a watchable distance. With tail atilt over its back, like a wren, it sidles up the dry stalks, searching diligently for insects, but with one eye on its visitor. A slight movement on your part will send it diving into the thick tangle out of sight again, and only its harsh, scolding notes will betray its whereabouts. Its long tail is the Wren-tit's most expressive feature, for it wags up and lown in excitement or anger, and it shakes when the bird sings, as if it had some part in helping on the music. The song is described as a "clear ringing voice running down the scale slowly, distinctly, 'keep, keep, keep, keep-it, keep-it,' ending in a trill." $\Lambda$ t other times it is a slow, monotonous singing note like "pee-pee-pee-peep," and again a varied succession of whistles. In the early spring the Wren-tits wander in pairs, keeping up a constant call and answer, somewhat like a quick "pitpit, prrrrt." 
Mrs. Bailey aceuses this bird of breaking up the nest of a pair of gnatcatchers and one of lazuli buntings, although both parents were present. It is probably the habit of Wren-tits to steal eggs or nestlings ; for, wherever found, they seem to be a terror to smaller birds, and their approach is attended with as much consternation as that of a shrike.

\section{3 a. CALIFORNIAN BUSH-TIT. - Psaltriparus}

\section{minimus californicus.}

Family: The Nuthatches and Tits.

Length: 4.00-4.50.

Adults: Top of head light brown; upper parts ashy gray ; under parts dull brownish gray.

Geographical Distribution: California, except northern coast district.

Cnlifornia Breeding Range: Oak regions below Boreal zone, west of the Sierra Nevada.

Breeding Seuson: April and May.

Nest: Bulky; pensile; gourd-shaped; entrance a small hole near the

top ; made of moss, fibre, plant down, oak blossoms, and lichens;

lined with feathers.

Eggs: 5 to 9 ; plain white. Size $0.34 \times 0.42$.

Throughout California west of the Sierra Nevada, the tiny gray birds known as Bush-tits are numerous, though so small are they and so protectively colored, one may easily overlook them. At Elysian Park, Los Angeles, they build each year in the circle of evergreens near the pool, and usually there are several nests in the live-oak at the foot of the slope near by. One busy pair were finishing their nest when I discovered them, May 2. They were belated, for in the next tree swung 


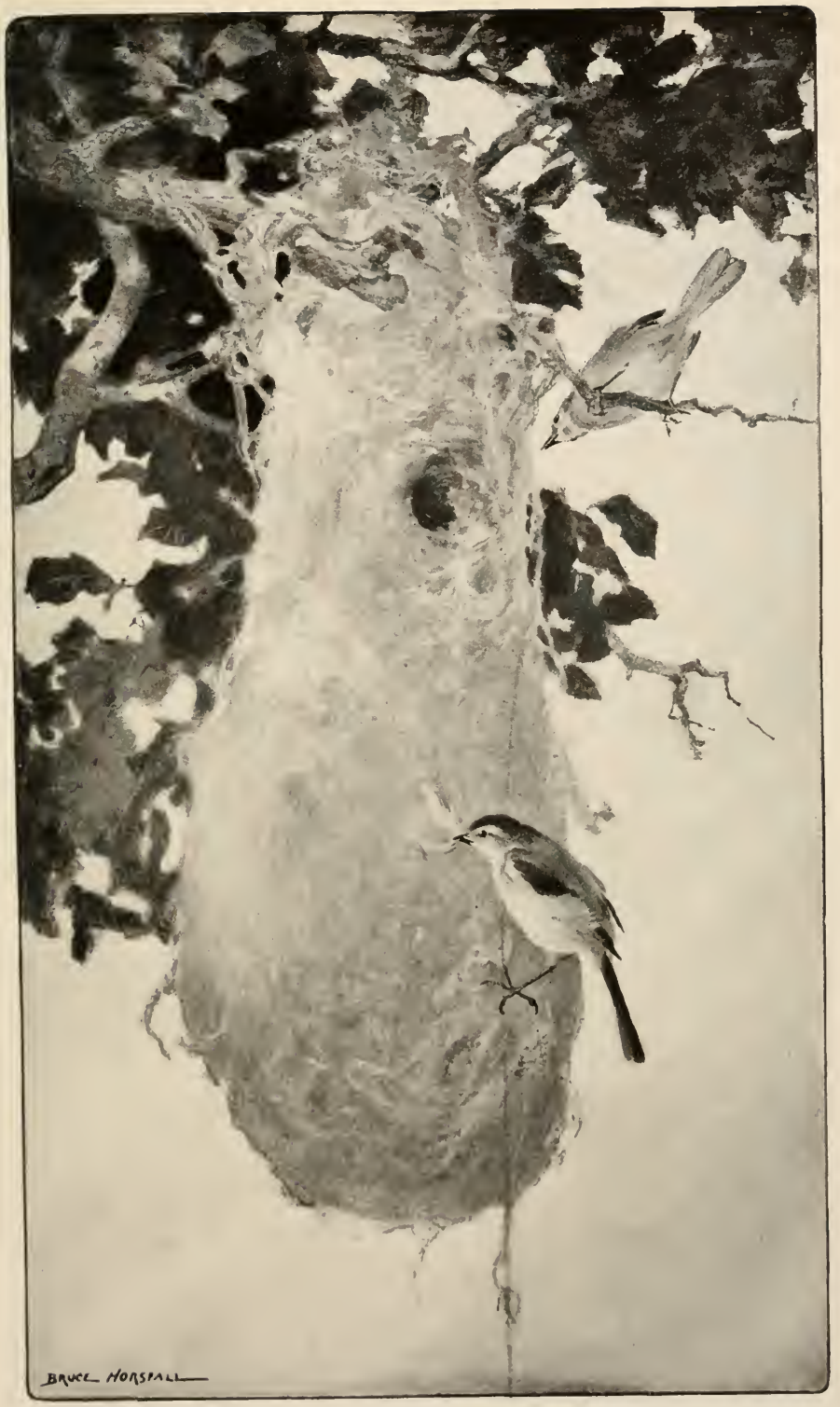

743a. Califorian Bush-tit

Psaltripurus minimus culifornicus 

another gray pocket containing young nearly ready to fly. The pair which were building worked together, bringing moss, tiny leaves, lichens, and bits of paper, which they tucked dexterously into the outer walls. At first one could see through the structure, so loosely was it woven, but little by little the weaving and lining filled the interstices until it was of the proper solidity and thickness. Then began the carrying of feathers to the pretty cradle, and for a whole day one or the other of the wee builders, neither one of which was larger than a man's thumb, brought feathers. Often, with his bill so full of these that the bird was very little larger than his load, the tiny male would dart in through the little round doorway, followed closely by the female with her portion; and both would fly out again almost instantly. Usually, however, only one feather at a time was carried. The nearest chicken yard was at least one hundred yards distant, and from the frequency of the trips to the nest and the distance the feathers were brought, the birds must have been constantly on the wing.

When all was finished to their satisfaction, the female disappeared into the depths of the swinging eradle and was seen by me no more for twelve days. Her mate brought her food at short intervals during the warm hours of the day, always alighting near and calling before he ventured to the nest. He never went inside while I was watehing, but leaned down to her until only the tip of his tail conld be seen in the doorway. On the fourteenth day after incubation had begun, a slit 
was carefully cut in one side of the nest and a cautious peep taken. A wriggling mass of pinkish heads, wings, and legs lay cuddled in the downiest of feather beds. They seemed even smaller than the young hummingbirds, and were certainly less than an inch long. Each little head was triangular in shape, with a mere yellow ridge at the point for a bill, and skin-covered knobs for eyes. The slit in the nest we carefully sewed shut again. Before we had gone three yards the parents were there, and the male had gone inside to the nestlings. A careful watch proved that for the first four days neither of the parents brought visible food in the bill, and it is fair to record them as feeding by regurgitation for that length of time at least. (See Foreword.)

On the sixth day the young Bush-tits were covered with a hairlike grayish white down, and had quadrupled in size. This was the last observation of that family I was able to make. Meanwhile several other broods of Bush-tits had flown and were being cared for in the neighboring shrubbery by the adults, although seeming well able to feed themselves. An old nest that I secured measured ten inches in length, four and a half in diameter at the bottom, and the doorway was just the size of a dime; a nickle was too large to pass through it.

The call-note of the Bush-tit is commonly described as "scritt, scritt," very weak and thin. Aside from this, the male gives voice to a conversational warble, quite in keeping with the diminutive size of the bird. This 
species, like the other Bush-tits found in California, are of untold benefit in destroying eggs, grubs, and adult insects injurious to the trees, especially black scales and caterpillars.

\section{CHFSTNLT-BACKED CHICKADEE. - Penthestes} rufescens.

FaMily: The Nuthatches and Tits.

Length: $4.50-5.00$.

Adults: Throat blackish brown ; crown and nape clear brown; sides of head white; line over eye black; back reddish brown; under parts white; siles chestnut.

Young: Crown, uape, and throat dark brown; back olive-brown. Geographical Distribution: Alaska to California (Mt. Shasta). Culifornia Breeding liange: Notthern humid coast belt in Del Norte, Humboldt, and Mendocino counties.

Breeding Seuson: April.

Nest : 12 to 40 feet from grouud, in dead trees, either in natural cavities or old woodpeckers' holes ; materials cattle hair, fur, wool, feathers, or moss.

Eggs: 5 to 7 ; white, sometimes finely speckled with rusty browu. Size $0.64 \times 0.47$.

Ix the northern humid coast belt along the most northern edge of California the Chestnut-backed Clickadee is a common resident. He keeps to the more open woods along the roadways, and is even more fearless than the common chickadec of the Wastern States. Hanging head downward over a slender twig, searching for bugs under the young leaves, swinging in happygo-lucky fashion from the tip of a branch, seampering in flocks through the tall trees, he is a most fascinating 
little chap. His nestlings are handsome fluffy counterparts of their parents, and present an appealing picture of innocence as they sit on a concealed perch waiting to be fed.

After the breeding season these birds unite in flocks, often in company with the golden-crowned kinglets and Oregon chickadees.

742 a. COAST WREN-TIT. - Chamcea fasciata phoca.

Family : The Nuthatches and Tits.

Length: Wing 2.37, tail 3.41, bill 0.42 .

Upper parts sooty browu, darkest on head; under parts chestuut streaked with dusky. Eye pale yellow.

Geographical Distribution: Humid coast region of Oregon and California. California Breeding Panye: Transition zone of the coast region from Carmel River, Monterey County, northward through the State, east through the San Franciseo Bay region.

Like the pallid wren-tit, this species belongs exclusively to the Pacific slope and is a characteristic bird of California. It is a common resident of the humid coast belt, and its clear ringing song is one of the usual sounds in a quiet tramp along the San Francisco Bay meadows. That it is much more frequently heard than seen is due to the shy dodging and persistent hiding among the low bushes. 


\section{TOWNSEND SOLITAIRE. - Myadestes tonnsendi.}

Family: The Thrushes, Solitaires, Bluebirds, etc.

Length: $7.80-9.50$.

Adults: Upper parts brownish gray, under parts lighter ; two white bars on wing; tail-feathers edged with white on outer web and across end; bill short, flattened at base ; legs weak.

Foung: Plumage, except wings and tail, spotted with buff; wings and tail brownish gray, marked like those of the adults.

Geographical Distribution: From British Columbia to Mexico and from the Black Hills to the Pacific, chiefly along highest altitudes. South in winter to Southern United States.

California Breeding Range: Local in the high Sierra Nevada from Mt. Shasta to San Bernardino mountains.

Breeding Season: June.

Nest: Bulky ; of twigs, pine needles, and grass or moss ; on the ground, under roots of overturned trees, in crevices, in banks, or among rocks near water.

Eggs: 3 to 6 ; pale ashy or whitish, spotted with rusty. Size $0.93 \times$ 0.67 .

Arrove all the forest singers of California, the Townsend Solitaire is without a rival; and were he as casily heard as is the mockingbird or the thrush, he, and not they, would be the theme of the poet's verse. Only in the majestic solitude of rugged mountains, when all the world is silent, will he pour out his soul in music; and to hear him at his best requires hard climbing and long, patient waiting. In the highest Sierra Nevada his song rings clear morning and evening; and on a tall, dead tree, sharply outlined against the sky, you may discover the happy singer. Is you watch, suddenly, without pausing in his burst of melody, he flies outward and upward, higher, higher, singing as he goes, until the silver notes fall like a shower of music which the listening 
earth drinks eagerly. His song ended, he floats down again, alighting with the easy grace of a mocker, and is at rest all but his quivering wings. He seems to squat rather than perch and is happiest when flying.

It was rare good luck that showed me the only Solitaire's nest I ever found. A rolling stone and a misstep landed me flat on my back directly in front of it and within a foot of the water's edge. At first I did not realize my good fortune, because I did not recognize the nest or the young. It was a bulky affair, under a huge boulder which lay in such a position that only two inches intervened between the earth and the overhanging stone ; and in this low-roofed crevice the Solitaire had gathered more than a quart of grass, weed stems, shredded bark, pine needles, rootlets, and dead leaves. These seemed to lie in a thick mat as if driven there by the wind, and, but for the hasty exit of a bird, I should never have looked at them.

Examination revealed a foundation of larger weed stems and a neatly moulded inner nest. In it were five feathered nestlings. They were much browner in tone than the adults and were beautifully mottled on the 
breast with light brown. At first they crouched far back in terror, but when I put in my hand to pick up one the others popped out faster than I could eatch them. This unexpected début startled me and called the adult male, who had evidently lingered in the neighborhood. He was naturally much distressed and, without coming nearer than fifty feet, lit on a conspicuous perch with many restless turnings and flutterings. Finding that this did not win me from my unfortunate proximity to his brood, he slipped out of sight and began calling to the young in a loud, liquid note more imperative than plaintive. I sat immovable as the rock behind me, and in half an hour was rewarded by seeing both Solitaires come near enough to be recognized without a glass and feed a nestling who was erouching in a heap of stones, thirty feet, from the nest site. As the parents were so much alike in form and color, I could not tell which one came to him. The other disappeared behind the stones and probably found the rest of the young to care for. So long as I sat there neither of the adults came into sight again; and, putting back into the nest the young Solitaire I had caucrht, I withdrew to a distance and hicl. More than two hours elapsed before either adult returned to the locality, and then the female was seen slipping silently to the nest. Her mate took up his guard on a high bare tree and after a time tried to sing, but the song lacked the joyous spontaneity of his usual outburst and, eutting it short, he flew down near the old nesting site. In a few moments he reappeared on the bare tree and remained there singing when the shatows of evening 
closed over the scene, but the next morning the entire family of Solitaires had vanished utterly from the vicinity, so far as any trace of them could be found.

\section{RUSSET-BACKED THRUSH. - Hylocichla ustulata.}

Family : The Thrushes, Solitaires, Bluebirds, etc.

Length: $6.70-7.50$.

Adults : Upper parts olive-brown, brownest on tail ; conspicuous light yellow eye-ring; sides of head washed with reddish brown; chest pale buff, with wedge-shaped spots of dark brown; belly white, washed with olive on sides.

Geographical Distribution: Pacific coast from California north through British Columbia ; south in winter to Lower California, Mexico, and Guatemala.

Breeding Range: From Northern California to Alaska, chiefly in Boreal zone.

Breeding Season: May and June.

Nest: Compact and bulky; of plant fibre, shreds of bark, and moss; placed in saplings or bushes.

Eygs: 4 or 5 ; pale turquoise blue. Size $0.94 \times 0.65$.

The Russet-backed Thrush is a common species along the Pacific coast from latitude $37^{\circ}$ northward, remaining through the summer in the foot-hills and lower mountains, and occurring southward during migration. It is a lover of dense thickets, retiring and unsociable, protesting against intrusion with a sharp "chuck, chuck," and dodging into impenetrable tangles when aware that it is discovered. Only at twilight and in the earliest dawn may one hear the rich sweet song of this shy singer. As the first full notes float out from the quiet woodland, the bird-lover knows that a thrush and no other is the songster. The music is less spirituelle in quality than the 
song of the wood thrush, but instantly suggests the latter. A nest of the Russet-backed that was built in a roadside thicket between San José and Alum Rock Ciñon contained, May 20, three young Thrushes evidently about a week old. They were sparsely covered with brownish gray down, and pinfeathers were just showing along the feather tracts. Both parents disappeared, and did not come back so long as we remained in the ricinity. Fearing lest any attempt to study the derelopment of the brood at close range

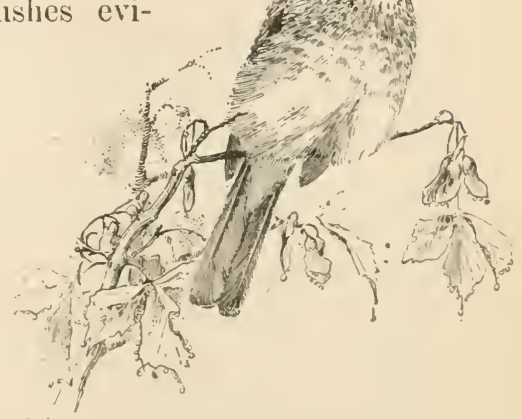
$3 . \%$

758. Russet-backeil Thrush.

"Only ut fuilight and in the enrliest dann may one hear the rich sweet song of this shy singer."

would result in their being deserted by the parents, we allowed the opportunity to pass by and did not visit them again.

759 e. SIERRA HERMIT THRESH. - Hylocichla guttati sequoiensis:

Fanus: The Thrushes, Sulitaires, Bluebirds, etc.

Length: $7.50-8.25$.

Adulls: Lipure jurts light brownish gray; tail rufous; rhest thickly markel with hood, weelge-shapenl spots.

Geographical Instribution: Caseade and sierra Nevada hanges, neeth to the Yukon valley; in migration east to Wyoming and Tiexas, and south into Mexico. 
California Breeding Range: Breeds sparingly and locally in the Boreal zone of the Sierra Nevada, from Mt. Shasta sonth to Owen's Lake.

Breeding Season: May aud June.

Nest: Composed of twigs, straws, rootlets, coarse grass, and moss; placed in bushes.

Eggs: Usually 4 ; greenish blue. Size $0.86 \times 0.64$.

OF the Sierra Hermit Thrush, Mr. Lyman Belding, who first discovered the subspecies and named it, writes: "It is the finest song bird of the Pacific Coast, breeding in many localities in the sierras on both slopes, usually choosing damp, densely wooded localities for a summer home. It begins to sing about the middle of May at 5,000 feet altitude, below which it is seldom found in summer, and sings until about the first of September, when it leaves for warmer regions. Altogether I have found seven nests of this bird; all of them were within a few feet of paths. They were mostly well concealed, but one was the reverse, having been saddled on a fallen, dead, barkless fir sapling, with nothing to hide it except a few dead and leafless twigs. This nest contained four young, which were quite fit to leave the nest about the middle of June. Three of the nests were in yew trees, one was in a hazel bush, and two were in deer brush. The highest was about ten feet from the ground and the lowest about three feet. There was more or less moss used in all, though the materials used in them varied considerably." 
759 c. DWARF HERMIT THRUSH. - Hylocichla guttata nana.

Family : The Thrushes, Solitaires, Bluebirds, etc.

Length: $6.00-7.00$.

Adults: Upper parts rich olive-brown, brownest on crown and rump, dullest on tail ; uniler parts buffy, spotted on chest with wedge-shaped marks of brown.

Gengruphical Distribution: Pacific slope, north to British Columbia, south to California.

Breeding Ringe: Breeds on the Queen Charlotte Islands, British Columbia, and southern Alaska.

Breeding Season: June.

Nest: In a bush, near the ground.

Eygs: Lighter than a robin's, and unmarked. Size $0.83 \times 0.63$. (Young Ornithologist, Vol. I. p. 149.)

THIs is an abundant winter visitant to California, occurring in almost all localities west of the Sierra Nevada, but there is only one record of its nest being found within the State. Mr. C. N. Comstock, of Oakland, took a nest of this species containing two eggs, in June, 1883, at the Calaveras Big 'Trees.

\section{1 a. WHATERN ROBIN. - Planesticus migratorius propinquus.}

Fanily : The Thrushes, Solitaires, Bluebirds, etc.

Length : 10.00-11.00.

Adults: Head, wings, and tail brownish black; back brownish gray; throat streaked black and white ; breast and belly bright red-brown ; under tail-coverts white.

Foung: Under parts yellowish, spotted with brown; upper parts grayish brown, streaked with light.

Geographical Distribution: Western United States from Rocky Mountains to Pacific.

California Brecling liange: Along the higher Sierra Nevala soutb as far as tho San Bernardino mountains. 
Breeding Season: May to August.

Nest: In low trees and bushes, sometimes near or on the ground; made of grasses, moss, and rootlets; plastered with mud, and lined with fine grass.

Eggs: 4 ; turquoise blue.

The Western Robin, although like his Eastern representative in coloring, is quite unlike him in habits. Instead of building his nest near the homes of men, he goes up into the lonely Sierra Nevada forests; there I have found it containing two blue eggs, when snow four feet deep lay a hundred yards away.

All through the spring and summer he remains in the high altitudes of the Sierra Nevada, breeding along the crest of this range as far south as the San Bernardino mountains, but with the cold days of the fall he starts on his vertical migration to the lowlands. In the winter this species occurs nearly throughout the State ; but, as all birds sing best at the mating season, he is almost silent when in the valleys, and seems quite a different bird from the cheery "Robin Redbreast" who picks up crumbs in our dooryards.

The nests also of the Western Robins that I have found have been somewhat different from those of the Eastern bird and very much prettier, being decorated with moss woven in the mud instead of straw, and carefully lined with moss. It is really a beautiful structure, with the mud practically concealed from view. The eggs of the two species are alike, and the newly hatched young are the same naked, wriggling, skinny nestlings in both cases. In both cases, also, I affirm that they are fed by regurgitation for the first four days, the adult 
sivallowing the food before he gives it to the young. By the fifth day earthworms are given the nestlings after being broken into small mouthfuls, and, as the days go by, these worms as well as large insects are given whole. The young Robins are voracious eaters, each one consuming, one authority says, sixty-seven earthworms daily. Certain it is that they double in weight every - twenty-four hours at first, and at the end of sixteen days are nearly as heary as the adults. Usually the eighteenth day witnesses their first flight, but it is a long time after that before they learn to forage for themselves.

All efforts to find a "Robin Roost" in California, such as is common among the Eastern species, have failed and I can obtain no definite information on this subject. It may be this is one of the habits abandoned with their cntrance into the Land of Perpetual Summer.

\section{VARIED THRLSH. - Ixoreus navius.}

Family : The Thrushes, Solitaires, Bluebirds, etc.

Length: $9.00-10.00$.

Adult Wale: Upler parts dark slate-color, feathers edged with light gray; wings banded with dark brown ; side of lead black, bordered above with brown line; under parts light red-brown; breast verging to orang', and divided from throat by a black necklace.

Adult F'cmule: Similar to male, but much duller in coloring.

Foung: like female, but duller and more or less spotted with light brown.

Grographical Distribulime Along Panifio from Alaska to Northern Califurnia, sonth in winter as far as Lower California.

Brecting Range: Recorded at Humboldt, California, during the summer, and inay breed there. Breeds northwaril to Behring Sea.

Breeding Scason: July. 
Nest: Bulky ; in bushes and low trees.

Eggs: 4 ; pale greenish blue, sparsely marked with brown. Size 1.12 $\times 0.80$.

From November to March the Varied Thrush, or Varied Robin, as he is sometimes called, ranges locally throughout the western part of California and is one of the handsomest of our winter visitants. Wherever there are holly berries, manzanita, or mistletoc there are sure to be flocks of these gayly colored birds. Silent and shy, they take alarm at first sight of an intruder and fly up the cañon, lighting here and there, but keeping well ahead of the observer. They are often found, too, along salt-water

763. Varied Thrush. "Silent and shy." beaches, sometimes in company with the Western robin, sometimes alone, but under all circumstances as silent as if they never sang, contenting themselves now and then with a rare chirp that is without the faintest suggestion of their glorious summer music.

When the first sunny spring days come, the Varied Thrush starts on his trip northward, taking it by easy stages, and en route he sometimes breaks into a sweet 
call-note, but is for the most part as silent as in the winter. By short stages he reaches his nesting ground, in the dark spruce forests from the northern limit of California to Alaska, and here only may one hear him sing. Even here he is the shyest of woodland ehoristers, seldom seén, though his weird music floats through the silent forest at twilight and dawn like the voice of a spirit bird. It consists of five or six notes in a minor key, each one uttered with a peculiar erescendo of its own, complete and perfect in itself, yet in perfect harmony - with the others. In July, when his mate is brooding somewhere among the dense spruces, he chants his evening hymm as full of holy transport as that of the hermit thrush of the Adirondacks, or from the top of some tall pine at daybreak he carols a matin. Never does he seem either enthusiastic or hurried. .His spirit is as full of peace as the forest in which he makes his nest.

WITH DUSKY, GRAY, AND SLATE-COLORED PLUMAGE

390. BELTED KINGFISHER. - Ceryle alcyon.

Faмих: The Kingfishers.

Length: 11.00-14.50.

Heal with occipital crest; bill heavy and longer than head; wings longer than tail.

Adult Ifule: Upper parts, crest, and belt across the breast bluish slatecolor'; umler parts and collar white; wing-quills black, marked with white; mildle tail-feathers slate-culor; other tail-feathers black, spotted with white.

Adult female: similar to male, but belly partially banded, and sides washed with rufous.

Geugruphicul Distribution: North America.

Breding liange: United States ant British Columbia. 
Breeding Season: In California, April and May.

Nest: An excavation 6 to 12 feet long, in a bank, usually over water. Eggs : 4 to 8; white. Size $1.35 \times 1.08$.

Along the streams of the interior valleys of California the Belted Kingfisher lives, the only requisite for his happiness being sufficient water to furnish his necessary supply of small fish. No fresh-water pond or brook is complete without him. Unsocial and even quarrelsome, he is usually seen sitting alone on a low perch overhanging the water, waiting in silence for the gleam of a fin. Suddenly out he dashes, hovers above the wares a moment, then plunges down to reappear with a struggling fish in his bill and fly to a different perch to devour it. Should he wait long with no success, he flies to another fishing ground a few yards away, uttering his harsh rattle; for he is angry, and wants the world to know it. This cry of anger rings loud and clear when he sees you watching him, and all the woodfolk take warning at it. A deer will stop drinking instantly on hearing it and break for cover, although you have not moved an eyclash. Even more than the jay, is the Kingfisher the sentinel of the wooded lakes, and woe to the luck of the hunter whom his keen eye detects in a blind.

His nesting place is a steep bank where he can excavate for himself a burrow from six to twelve feet long, rising at a gentle incline and ending in a dome-shaped cavity from eight to ten inches in diameter. It usually takes from one to two weeks of labor to prepare this subterranean home. In digging, the bird uses his heavy 
bill and queer toes with their shovel-shaped nails, two of which have become united half their length through constant service of this sort. His method of starting the hole is similar to that of the bank swallow. Hovering in front of the bank, he strikes again ancl again as a hummingbird drives his bill into a flower tube, until a small break has been made in the clay or sand of the bank. This is enlarged with bill and claws until he gradually disappears in it, only a shower of sand occasionally testifying to his progress. As in the case of the flickers, both male and female work at the excavating, changing about every twenty minutes. The one who

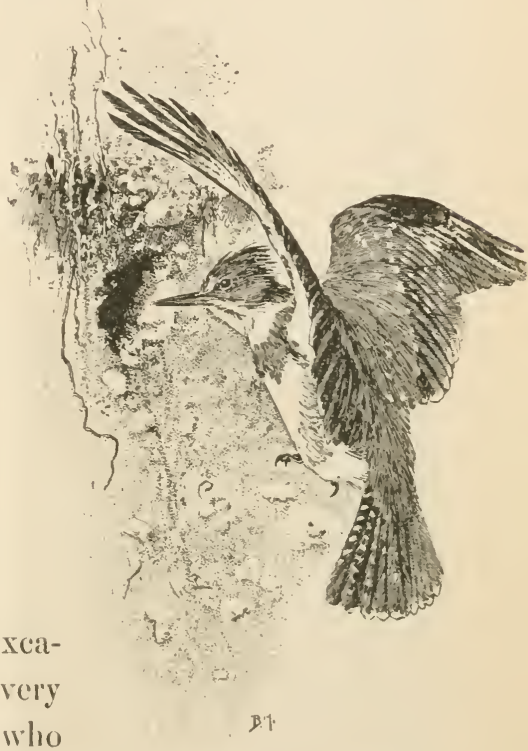
has been resting returns to a 390 . Bitted hisefisher, perch near by, uttering the "He strikes again and again." characteristic ery, - this time not expressing anger, - and almost instantly the mate leaves the hole and flies off to his or her fishing, taking no notice of the relief guard, who promptly enters the burrow and resumes work. When the nest is eompleted and the first one of the six or seven white eggs has been laid, the mother bird broods con- 
stantly by day, leaving only early in the morning and late at night.

If she sees her nest being exanined she returns at once, uttering her hoarse rattling cry in great excitement, and if possible enters it. The male guards the nest and brings food, rarely if ever brooding the eggs. He sometimes prepares a second and shorter burrow as a sleeping place for himself at a little distance from the original nest.

The Kingfisher's habit of commencing incubation as soon as the first egg is laid causes a great discrepancy in the size of the nestlings, which is doubtless increased by the greater attention paid to the stronger ones, who crowd to the front to be fed. The young are absolutely naked when born, and present a ludicrously top-heavy appearance. Nevertheless, to the eyes of their fond parents they are beauties, and are valiantly defended. I have known the mother to allow herself to be pulled entirely out of the burrow by her hold on a stick thrust in, and then turn back into it, showing fight all the way. The male, meanwhile, was administering a series of welldeserved swooping strikes with his bill on the cap of the tormentor.

Unless disturbed, the pair will occupy the same nest year after year; and if a new one must be excavated, it is usually in the same bank. According to the Kingfisher code of ethics, only one pair can fish in a stream or pond, and their rights are usually respected by all the others. 
DUSKY, GRAY, AND SLATE-COLORED 317

424. VAUX SWIFT. - Chatura vauxi.

Family : The Swifts.

Length: $4.15-4.50$.

Alults: Upper parts dusky brown, lighter on rump; under parts gray, merging to whitish on throat; tail spined.

Geographical Distribution: Pacitic coast region, from British ('olumbia to Mexico; east casually to Montana and Arizona. Mligrates to Central America.

California Breeding Range: From the Santa Cruz mountains northward through humid coast belt.

Breeding Seasm : May and June.

Nest: Of small twigs glued together in the shape of a half sancer, and fastened to the inside walls of hollow trees.

Egys: 3 to 5 ; white. Size $0.72 \times 0.50$.

The Vaux Swift, while not very abundant anywhere in California, is found as a migrant in all parts of the State, and breeds in suitable localities from Santa Cruz northward. In a hollow cottonwood tree near the river, and a short distance from the town of Santa Cruz, a colony of several pairs of these small Swifts nest every year. On the fifteenth of Jume three of the nests contained egrgs, and the others were empty but wonld doubtless be used later. Early every morning, four to five o'elock, the adults could be seen skimming over the river quite near the surfice, every now and then darting lown as if to sip, and instantly rising again. One that we found on the gromen, apparently injured, had very large liquid eyes like the chimney swift and was most appealingly confiding. It was either too stumned or too courageous to be afraid, for it rested contentedly in my 
hand, making no effort to escape, not even closing its eyes as do some birds to feign death. The birds nesting in the tree were exceedingly timid, and disappeared as soon as the tree was touched at the base.

\section{ARKANSAS KINGBIRD. - Tyrannus verticalis.}

FAMILY: The Flycatchers.

Length: 8.00-9.50.

Adult Male: Concealed red crown patch; head, neck, breast, and upper parts light ashy gray; throat whitish; belly lemon-yellow ; wings brown; tail black, with inner web of outer feathers white.

Adult Female: Similar, but crown patch smaller.

Young: Like adults, but crown patch wanting, and wing-coverts edged with buff.

Geographical Distribution: Western North America, south in winter to Guatemala.

California Breeding Range: Trausition and lower Sonoran zones. Breeding Seceson: May 1 to June 25.

Nest: In trees, not far from the ground; woven of twigs, weed stems, rootlets, hair, string, paper; lined with wool or hair, and decorated with feathers.

Eggs: 4 ; creamy pinkish, marked with brown and purple irregularly over entire surface. Size $0.94 \times 0.65$.

Look for the Arkansas Kingbird in the open country about the river valleys, rather than in the forests or mountains; wherever water and willows are found throughout the Northwest, you will be sure to find him. A week or so before their mates come in the early spring, you may see a company of these gay bachelors in the tree tops singing with more energy than melody, a queer conglomeration of the notes of blackbird, blue jay, and 
chimney swift, with the ery of a kitten. Far into the night you may hear a soloist, but the chorus is silent after the sun has set. With the earliest peep of dawn they are astir again, down to the water for a bath; and such a splatter! Half a dozen in a place like urchins in a swimming pool, and each one trying to make the greatest splashing! Heads down, tails up! Heads up, tails down! Twisting and wriggling, until every little feather stands for itself and the bare skin is plainly visible between them. A shake, a shower of pearly drops flashing in the sunlight, and a very porcupine-like little bird flies up to a sumy perch to preen and shake and preen again. Before his long performance is finished, a 447 . Arkavis kingbird. lovely golden butterfly flutters by, "Wratching with a great show and, regardless of wet wings, out dishes the hungry little bird after him. Ten to one he grets him, comes back to the perch to breakfast, and flies down to a weed stalk below to hunt for crickets or grasshoppers. After his appetite is appeased he is realy for a scrimmage, and very shortly you may see him tumbling about in midair, the pursued or purster of half a dozen of his kind in mock combat.

As soon as the demure gray dames arrive from the South, a change comes over the spirit of the bachelor, - 
a change of degree rather than kind. He becomes more noisy, and the combat with his former comrades is no longer for mere fun but for a lady's favor. If it must be won by war, he is ready; if not - well, he has already selected a snug spot in an oak tree, protected from wind and weather by a broad trmuk and heavy foliage, - a charming place for a nest. Will Madam look at it? A few days later both are seen bringing twigs, rootlets, paper, rags, - anything in fact that she fancies and can carry and weave into the characteristic structure. Around the top, on the outside, she will, if possible, weave dull-colored but never black feathers in an upright position curving inward over the cradle. Now, it may be that these are intended for ornament; but as they wave rakishly in the wind, they serve the double purpose of somewhat protecting the eggs and young and rendering it almost impossible for an observer to tell from below whether or not the mother is brooding. So whenever there is a chicken yard within a hundred yards of the nest tree, feathers will adorn the nest. Inside it is lined with a felted mat of cow hair, wool, or some warm material or vegetable fibre. In a week it is completed, and an egg is laid each day thereafter until there are four. By this time the gay bachelor has become a model benedict, bringing the little mother moths, dragonflies, ants, caterpillars, big black erickets without number, and bees, - the drones, rarely the workers. When she leaves home for a short outing, he sits near the nest watching with a great show of alertness, but not daring in his masculine awkwardness to brood those precious 
eggs. Even when on guard duty his sex asserts itself, and the sight of a fat moth tempts him to forsake his post long enough to snap it up.

When the mother bird returns, she alights near, preens her feathers carefully, answers his note with a twittering chirp, turns the eggs, and settles herself on the nest with many little fussings to make herself comfortable.

For thirteen days the mother broods while the father bird watches, and then the wonderful bits of bird life in the nest bring another change. Now the male is ever on the wing, eatching and bringing food to those hungry pink mouths. At first they are fed by regurgitation, but after the third day large insects are torn apart and given fresh. Fourteen crickets in ten minutes was the record of one busy forager. The watchful male no longer tucks his head under his wings at night, but sleeps with it drawn back between his shoulders, at his post a few feet from the nest. If danger threatens, not only he and the mother bird will defend the nestlings, but their calls will often bring every Kingbird of the neighborhood to the rescue.

In two weeks the babies have grown so that they overflow the nest, and one balances himself outside. And now his lessons begin. As soon as he has learned to use his wings he is tanght to eatch his foorl in the same way in which he must obtain it all his life. I have seen the parent bring a dragonfly or other insect, alight with it opposite above the young bird, and call his attention to it in a peenliar low twitter. Then, when quite ready, he releases the prey, which half fulls, half flutters, 
downward. Nearly always the nestling is out after it and back with it in his beak before you can realize how it is done. Many times have we watched them, and the lesson is always given in this way, and always repeated until there can be no fear of missing. Then the young are taken to the meadow and taught to dart down after butterflies or grasshoppers. In some way they learn that the worker bees have stings and must not be caught, but that the drones are delicious morsels. So even at the bee-hive they are a benefit to the farmer, while among the fruit trees and meadows their value can scarcely be overestimated; and the stigma of "Bee-bird," so long unjustly borne by them, is fast becoming a word of praise among intelligent people.

\section{CASSIN KINGBIRD. - Tyrannus vociferans.}

Famis: : The Flycatchers.

Length: 8.00-9.00.

Adults: Crown with eoncealed reil patch; upper parts and breast dark gray; belly lemon-color; chin white; tail black, tipped with grayish.

Young: Duller; wing-coverts margined with buffy, and no crown patch. Geographical Distribution: From eastern slope of Rocky Mountains to

Southern Wyoming, Western Texas, New Mexico, and Arizona; from

Oregon to Lower California.

California Breeding Range: Chiefly in upper and lower Sonoran zones throughout the State; south into Lower California.

Breeding Season: May 27 to July 30.

Nest: Similar to that of the Arkansas kingbird.

Eggs: 2 to 5) ; similar in color and markings to the Arkansas kingbird's. Size $0.99 \times 0.76$.

Unuike the Arkansas kingbird, the Cassin loves the mountains and the coast. His nest has been taken at 
an altitude of twelve thousand feet, yet he is by no means rare along the lowlands. Pine, oak, cottonwood, walnut, hickberry, and sycanore trees are his chosen nesting sites, and on the horizontal limbs of these the bulky cradle is constructed. Twigs, rootlets, weed stalks, string, rags, and plant fibre form its walls, grotesquely decorated with feather's, like those of the Arkansas kingbird. These last, waving rakishly in the wind, are quite in keeping with the character of the bird. From two to five eggrs are laid, and incubation lasts fourteen days, the female alone brooding on the nest, although the male is always near to defend. The courage of Cassin Kingbirds cannot be doubted; and though they are far less quarrelsome than the Arkansas, they are not a whit less brave in defence. In some instances their pluckiness exceeds that of their relatives, for while the latter are content to live at peace with hawks and crows, Cassin Kingbirds drive both these from their neighborhood by an onslanght both fierce and speedy. For this they have good cause, for crows are thieves and cannibals, feasting on the eggs and young of smaller birds.

The young Kingbirds, although born naked, soon develop feathers. They stay in the nest about two weeks, and are tanght to fly and hunt in the same manner as are the little Arkansas nestlings, and as also are the young of the Eastern kingbird, ealled the tyrant. Of the many broods of the latter that I have watched, the process has ever been the same. Nor do they differ greatly in any of their labits. The Cassin, sitting on a fence or a weed stalk, flying out after a passing insect, 
chasing a crow, or perched on a dead twig all fluffed out for a sun-bath, shows the same characteristic traits that amuse us in his relatives, and we welcome the sight as of an old friend. His food consists of large insects and caterpillars, with possibly a peck at the farmer's fruit. His call is the shrill note of his family, somewhat modulated.

\section{ASH-THROATED FLYCATCHER.-Myiarchus cinerascens.}

Fayily: The Flycatchers.

Length: $8.00-8.50$.

Adults: Throat and chest light gray, merging to white on the throat;

belly sulphur-yellow; upper parts grayish brown; two white wingbars ; tertials edged with white; onter tail-feathers with outer webs distinctly white.

Young: Sinilar to adults, but tail-feathers rufous.

Geographical Distribution: Western United States from Northern Oregon south to Mexico, east to Colorado, south in winter to Guatemala.

California Breeding Range: Below Transition zone, nearly throughout the State.

Breeding Season: May 5 to June 24.

Nest: In knot-holes of trees or giant cactuses or in woodpeckers' holes, and sometimes behind pieces of bark; lined with hair, snake skin, grass, and rootlets:

Eggs : 3 to 6 ; buffy, covered with longitudinal scrawls of purple. Size $0.88 \times 0.65$.

QUITE different from the noisy kingbirds are these demure, dignified Flycatchers. Even in Southern California they are only summer residents, going south to Guatemala in the winter. They nest indiscriminately in the dense thickets of the river bottoms or in the oak groves of the foot-hills, in the cañons or on the desert plains, where the cactus and the mesquite are the only 
green things. The call may be mistaken for that of the phainopepla, but never were birds more unlike in appearance or habits. This species, more than any other of the flycatcher family, deserves the name of "tyrant" which has been given to its Eastern relative. Not only will it drive all other birds, large or small, away from its nest tree but, it has the reputation of being a "claimjumper." It has been caught nesting in newly formed cavities prepared by both the Texas and Gairdner woodpeckers, and in one case at least I know the woodpeckers were at work on the hole when driven away by usurpers. The battle raged rigorously at intervals for a whole day. No sooner had the Flycatchers settled the affair and begun to line the nest with rabbit fur, than the woodpeckers returned to the fray; during the temporary absence of the bandits they seratehed out every bit of the unwelcome material, and prepared to reoceupy their home themselves. But as always, the fiercer temper of the Flycatchers prevailer over the brave resistance of the woodpeckers, and after repeated defeats they surrendered. Afterwards under the tree was found one broken eggr of the little woodpecker's, probably seratehed out of the nest cavity in their energetic endeavors to get rid of the rabbit fur, and telling more pathetically than any words the story of their ruined hopes.

This family of Ash-throats were wonderful upholsterers, for the cavity was thickly padded on siles and bottom with short hairs and rabbit fur, until there was little space left. In this were laid three small eggrs, and on June 9 incubation began. During the fifteen days 
following I did not once see the male enter the nest or bring food to the female. She seemed a careless mother, leaving the eggs nearly every day for several hours at a time. At least once during these absences she had enjoyed a bath, for her feathers seemed quite wet when she came to the tree. $\Lambda$ fter a short preening she slipped inside. I presume this was a daily occurrence. When the nestlings finally broke the shell, it was not necessary to climb to the nest to discover the fact, for the changed behavior of the male told the secret. He was all fussiness, and instead of dozing in the sun on an exposed perch, he came every fire minutes or so with bugs for those small naked babies. At first he swallowed these and flew almost immediately to feed the young by regurgitation, but as they grew older he carried raw food to the nest. Often he alighted on the tree near the tiny doorway and by pulling off the wings and legs prepared the soft parts of the insect to be eaten by his nestlings. From the amount of food consumed one would imagine nothing smaller than young owls inhabited the nursery. Twenty-two grasshoppers were taken in less than half an hour, making more than seven apiece. The nestlings being so small, this seems an appalling amount to be crammed into those tiny throats ; but it evidently agreed with them, for they grew at a surprising pace, and on the sixteenth day they were well prepared for their début.

The first flight was no farther than a sheltering branch of the same tree, and there the plump little fellows sat all one day looking out over the green forest world with wondering baby eyes. On the fourth day, in a lower 
tree, the mother gave them a lesson in catching insects. She brought a small butterfly and lit a little above and in front of one of the young. She fluttered out toward him holding the inseet in her bill, then she released the latter so that it flew lamely down just in front of the eager baby. He almost lost his balance in his swift darting down after it, and was obliged to alight upon a lower perch to eat it, instead of returning in true flycatcher fashion to the one just left. This did not suit his fastidious drillmaster, whether because of the low perch or lack of obedience to rules is unknown. She fluttered, scolded, and coaxed; but he finished his meal, shut his eyes tightly after the manner of nestlings, and rested where he was. Later on she had persuaded him to come up higher, and the lesson was repeated with variations at intervals all day. Three days after this he was catching flies for himself, although still following the mother about and begging with quivering wings for the larger insects he saw lier seize, and too often getting them.

485. OREGON JAY. - Perisoreus obscurus.

Family : The Crows, Jays, Magpies, ete.

Length: 9.50-11.00.

Adults: Forelı'ad and nasal tufts white; top of head and hack of neek sooty black; back, seapulars, wings, and tail brownish gray; tail slightly tipped with white; feathers with white shaft-streaks; under parts white.

Foung: I Iull snoty-hrown, darkest on head; under parts brownish.

Gengruphicul Distribution : Northern California. Oregon, and Washington to British Columbia. 
California Breeding Range: Higher mountains of Northern California. Breeding Season: Narch 15 to May 15.

Nest: Compactly built of fine twigs, interlaced with dry grass, moss, and plant fibre; lined with fine tree moss; placed usually high up in fir trees.

Eggs : 4 or 5 ; pearl or greenish gray, spotted and flecked quite evenly with lavender and gray. Size $1.04 \times 0.79$.

WE are accustomed to think of jays as mostly blue, or, at least, having some blue in their plumage, but here is a variety that has not a single blue From the tip of his crestless head feather.

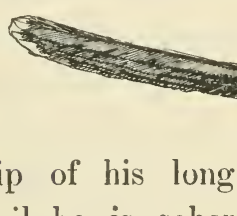
tail he is sober black, white, and brownish gra $\mathrm{r}$. and elegant in are his relatives, fronted, and Calisome one has much more like chickadee.

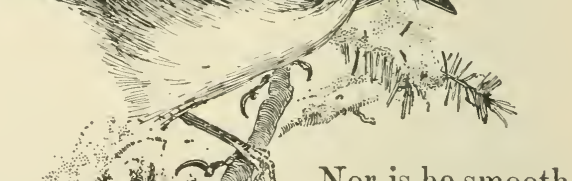
to the

Like the chickadee also, he is easily tamed, coming to house or camp for food and becoming so familiar as to be a source of great amusement. It is only necessary to settle oneself quietly and feed him to be overwhelmed with his attentions. Mr. Anthony tells of a funny experience with these birds. He says: "While dressing deer in the thick timber I have been almost covered with 


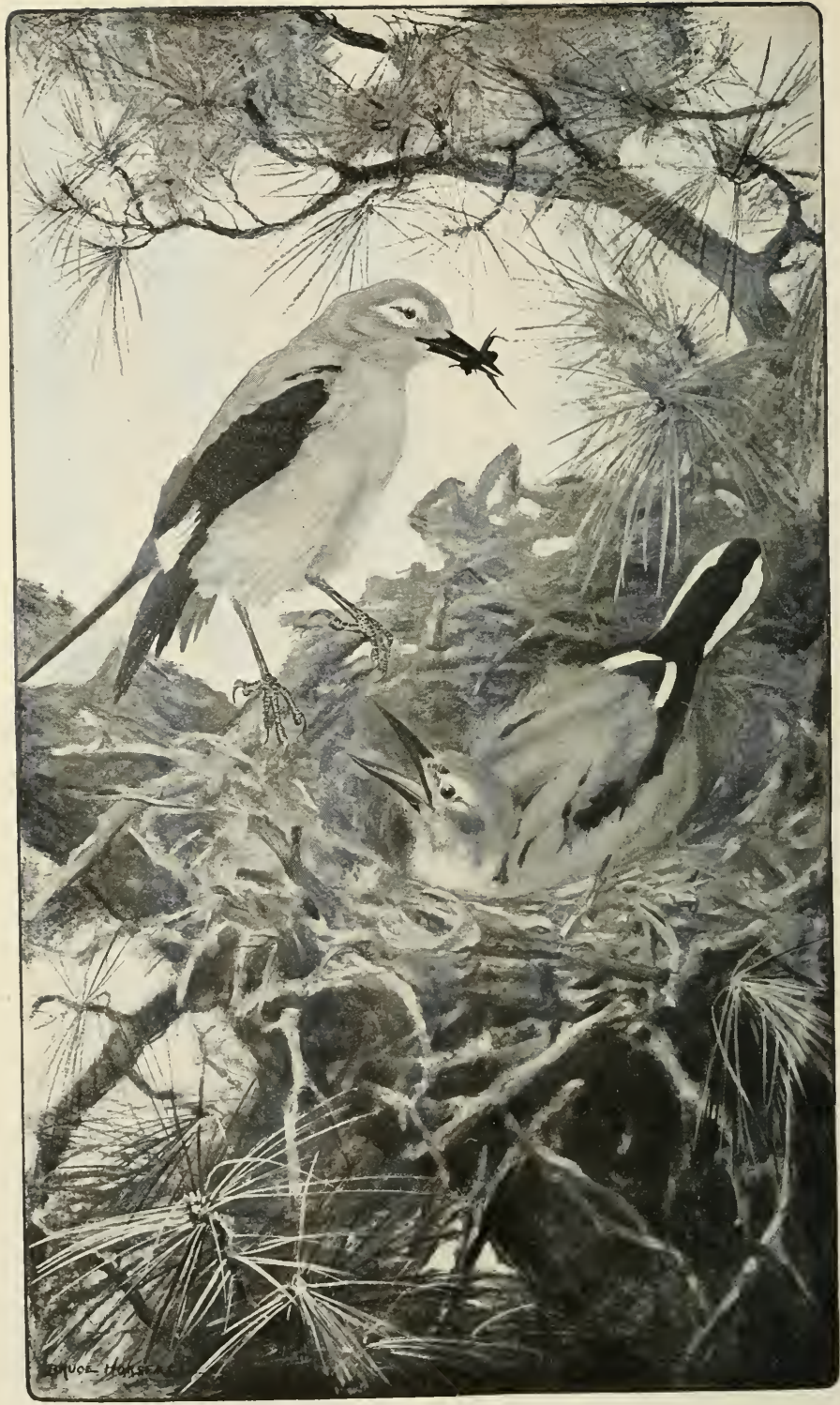

491. Clarke Nutcracker 
Jays flying down from the neighboring trees. They would settle on my back, head, or shoulders, tugging and pulling at each loose shred of my coat, until one would think that their only object was to help me in all ways possible. At such times their note was a low plaintive cry."

The nest-building commences early in March, and a site upon the horizontal branches high up in a fir tree is commonly chosen. Both birds bring material, - twigs and moss from the sides of the trees, and bits of bark, and both work at shaping the nest. At least two weeks are occupied in this work and two more in incubation. On account of the high altitude chosen for residence and the lofty site of the nest itself, the breeding labits of these Jays are less frequently observed than those of the jays of the valleys and foot-hills. In California this species occurs only in the northwestern corner and as far south as Mendocino County.

491. CLARKE NUTCRACKER. - Nucifraga columbiana.

Family: The Crows, Jays, Magpies, etc.

Length: 12.00-13.00.

Alults: Bill cylindrical ; wings long and pointed; uniform light gray, becoming whitish on forehead and chin; wings and middle tailfeathers glossy black; a patch on wings and outer rail-feathers white.

Young: Similar to adult, but upper parts shacted with brown, and under parts more or less barred with brown.

Geographical Jistribution: Higher coniferous forest of Western North America.

Breeding liange: In California the pine regions of the Sierra Nevada from Mt. Shistil to the San Bernardino mountains.

Brceding Season: Marrh 15 to May 15. 
Nest: Bulky; of twigs; lined with shredded bark, grasses, and pine needles; placed in coniferous trees, 8 to 40 feet from the ground.

Eggs: 3 to 5; light green, irregularly marked with brown, gray, and light purple. Size $1.22 \times 0.95$.

"As black as a erow" loses its significance when one looks at the soft gray plumage of the Clarke Crow, or Nutcracker, of the California mountains. In coloring he is much more like our eommon shrikes than like the family with which his strueture classes him. And with the change in plumage we find a change of heart, for the Nutcracker has few of the reprehensible traits of his kin. True, if nuts and insects were scarce and eggs or young birds plentiful, his menu would doubtless include the latter; but his choice is always for vegetable or insect food. Grasshoppers and the big wingless black crickets he devours in untold numbers, and grows fat on the diet. Butterflies he catches on the wing in flycatcher fashion; grubs he pieks from the bark, clinging to the side of the tree trunks and hammering like a woodpecker; like a crossbill, he langs to the under side of a pine cone and probes for seeds; meat or fish he will steal, if he can, from the camper, after the manner of the Oregon jays. He shares with this bird the epithet of " camp robber." His migrations are always vertical and for the purpose of food supplies. Breeding commonly in the spruce belt in September when the piñon nuts are ripening, he comes down the mountains in flocks to feast upon them. Farther north, the deep snows drive him toward the valleys until he finds some snow-bound ranchman's or miner's camp, where seraps of the refuse will provide his daily meals. In the silence and desolation of the winter 
forest, he is hailed as a welcome bit of life and fed until he becomes very tame and very saucy.

It is on the crests of the Sierra Nevada that these birds are found most abundantly. Here they sun themselves on the highest peaks, frolicking noisily in the clear, bracing air. When hungry or thirsty, out they dart from their lofty perches and, with wings folded, hurl themselves down the cañon with the speed of a bullet. Just as you are sure they will be dashed to pieces, their wings open with an explosive noise and the headlong fall is checked in a moment. Sometimes the descent is finished as lightly as the fall of a bit of thistle down; sometimes by another series of swift flights; often by one rocketlike plunge. It the foot a mountain brook furnishes food and drink. Is the shadows creep up the sides of the eanon, the Nutcrackers follow the receding sunlight to the summit again, mounting by very short flights from tree to tree, in the same way that a jay climbs to the top of a tree by hopping from one branch to another.

My own records of the nesting habits of this bird as studied in the San Bernardino mountains differ somewhat from those made by observers in more northern regions. The nests were all rather bulky, composed first of a platform of twigs, each one nearly a foot in length, so interlaced that to pull one was to disarrange the mass. Upon this, and held in place by the twigs at the sides, was the nest proper, - a soft, warm hemisphere of fine strips of bark, matted with grasses and pine needles until it was almost like felt. This is stiffened, bound, and made firmer by coarse strips of bark around the out- 
side, these also binding it to the twigs and helping to hold it on the limb. So firmly is the whole put together and fastened to the branch that no storm can move it from its foundations. None of the nests were higher than twelve feet from the ground, and one was only eight feet up. They were in neighboring trees only about fifty yards apart.

On the tenth of March three nests contained two and three eggs respectively ; incubation had begun, and silence reigned in Nutcracker Camp. Whichever bird happened to be on the nest was fed by the other, and in one instance I am positive that it was the female who brought food to her mate. I judged this because of her more fluffy, worn plumage and heavier build. Incubation lasted eighteen days. The newly hatched young in these nests were naked and very dark bluish gray. I think those recorded by another observer as "pied black and white" must have been taken at a later date. When two weeks old they do look somewhat mottled, though I should describe it as light and dark dusky rather than black and white; or possibly whitish and dark gray would hit it nearer. They were fed on piñon nuts, which were carried to the nest and hulled by the adult while perched just outside on the branch. I could not discover that any other food was brought them. At first this was given by regurgitation, but when the young were a few days old the food was supplied to them direct.

As soon as they were ready to leave the nest they were coaxed by short flights to the nut pines, and readily 
learned to shell the nuts and provide for themselves. Then it would seem a complete change of dict was necessary; for they disappeared from these regions entirely, flocking to a locality where berries, fish, and insects abound. By the middle of June not one was left in the old breeding grounds. We missed their harsh "jar-jaar," the flash of their black and white wings in the summer sunlight, and the woods seemed strangely silent bereft of their gay company.

\section{7 a. OREGON JUNCO. - Junco oreganus.}

Family: The Finches, Sparrows, etc.

Length: 6.00-6.50.

Adult Male: Head, neck, and chest black or dark slate-color ; the chest line being convex instead of straight against the white under parts; middle of back dark brown ; sides deep pinkish brown ; three outer tail-feathers white; outside pair entirely white.

Adult Female: Similar to male, but slate-color in place of black; crown and hind-neck washed with brown, remainder of upper parts brownish ; sides and flank dull pinkish brown.

Young: Upper parts brown and streaked ; under parts buffy.

Geographical Distribution: Pacific coast, Alaska to British Columbia; south in winter to California, east to Eastern Oregon and Nevadi.

Breeding lianye: From British Columbia northward.

Breeding Season: April to July.

N'est : Of dry grasses loosely put together; lined with cow hair; placed generally on or near the ground, in lioles among the roots of bushes and trees, and often under wood piles.

Eyygs: 4 or 5; whitish or greenish white, more or less specked with red-

dish brown. Size $0.77 \times 0.56$. 


\section{BANK SWALLOW. - Riparia riparia.}

FAMiLY : The Swallows.

Length: $4.75-5.50$.

Adults: Upper parts grayish brown or sooty, darker on head and wings, paler on rump and upper tail-coverts; under parts white, with a broad band of sooty across chest and sides; usually a sooty spot on breast.

Young: Similar to adults, but feathers of wings and rump with buffy or whitish edgings.

Geographical Distribution: Northern hemisphere in general; in America migrating south in winter to ('uba and Jamaica, Central and Northern South America.

California Breeding Range: In suitable localities throughout the State. Breeding Season: June and July.

Nest: In horizontal holes or burrows excavated in sand banks and banks of streams; thinly lined with fine twigs, grasses, and feathers. Eggs: 3 to 6 ; white. Size $0.72 \times 0.50$.

Axong the birds that I have watched, few have been more timid and more difficult to study than the dullcolored Bank Swallows. Unless you have seen them, as with wings fluttering they strike the first blow into the hard sand or clay of the nesting site, you will be puzzled as to how it is done. Feet and bill divide the toil, and but for the wings you might suppose a small gray mouse at work. The soil must be stiffer than light sand in order to prevent a "cave in," and not infrequently clay or mixed gravel and sand are chosen. These offer a discouraging resistance to the delicate beak and clayws, but the persistent little miners keep bravely at work in spite of obstacles, so long as human intruders are out of sight. An attempt to investigate their work or study them at close range, if persisted in, usually results in abandonment of the site. 
Like all swallows, these birds are eminently gregarious, nesting in colonies of hundreds. The old birds come back to the same nest year after year, and the young of the colony make homes for themselves near by, until the bank looks as if riddled by cannon balls. The, nests are rudely excavated tunnels about two feet long and a little larger at the inner end. In this the Swallows place a lining of grass and feathers. In such a nest we found in one instance six small white eggs resembling those of a chimney swift, but less transparent. In another, lay the naked, newly hatched young, so small and pink that they looked like tiny new-born mice. In another nest there were, on June 2, four fully fledged young, who popped out at the first disturbance. One flew into my hand and died instantly from fright.

Watch from a distance a colony of these Bank Swallows during the morning or evening feeding-time. Every little doorway is filled with eager heads on the qui vire for the coming meal. As the adult birds alight at their own nest, the nestlings of the neighborhood whose supper is belated stretch their little necks and watch the feeding with mingled euriosity and longing. A step overhead or a sudden shadow, as of a hawk across the sun, and, as if by magic, the yellow bank presents only rows of empty black holes. 
622 a. WHITE-RUMPED SHRIKE. - Lanius ludovicianus excubitorides.

FAmıly: The Shrikes.

Length: 8.00-10.00.

Adult: Upper parts pale bluish gray ; bill, lores, and nasal tufts black; rump whitish, under parts pure white, sometimes very lightly marked. Young: Similar, but colors less strongly contrasted, tinged with brown and narrowly barred; wing-coverts tipped with dull light buffy.

Geographical Distribution: Western North America from eastern border of the plains to Lower California, and from Manitoba to Mexico.

California Breeding Range: East side of the Sierra Nevada from Shasta valley, south to Lower California, chiefly below Transition zone.

Breeding Season: April and May.

Nest: Placed in hedges, scrubby, isolated little trees, thorn trees, thickets. The nest is large, loose, and bulky; composed of weed stems, grasses, cornstalks, rootlets, paper, etc.; thickly lined with chicken feathers.

Eggs: 4 to 6 ; grayish or yellowish white, marked and spotted with purple, light brown, or olive. Size $0.97 \times 0.73$.

IT is not easy, at a distance, to distinguish the Whiterumped from the more familiar California shrike; but while the former has pure white under parts, the entire plumage of the latter is tinged more or less with brownish, and the under parts are quite dingy, being covered with wavy hair-lines of brown. The range is different, but the two are likely to overlap somewhat in spite of the dividing line of the Sierra Nevada.

Both species indulge in the much censured habit of impaling their prey on thorns or on the barbs of a wire fence ; but this is largely from necessity when the catch is either mice or small birds, as the habits of the Shrikes in captivity have proved that they must have some such way of fastening raw meat before they can tear it. 
He does destroy numbers of small birds each year, and for this we condemn him; but, on the other hand, the good he does may outweigh the evil. Jerusalem crickets, grasshoppers, field mice, and lizards form the largest part of his diet, and it would be difficult to compute his value to the farmer.

Except for the difference in environment, the nesting habits of the White-rumped closely resemble those of the California Shrike. In fact, but for location, an expert can searcely distinguish the nest and eggs of the one from those of the other, and the

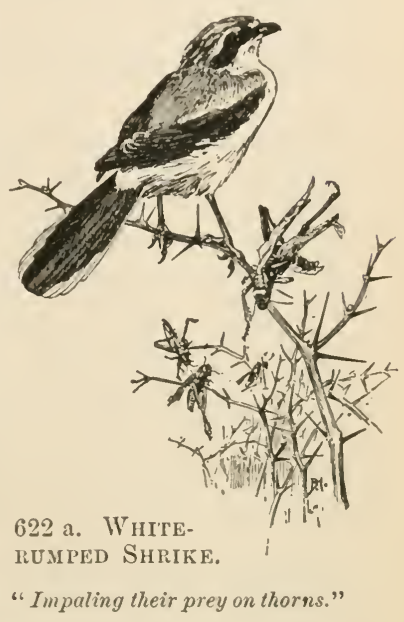
sets of different pairs of birds often differ as mueh as those of the two species.

622 b. CALIFORNIA SHRIKE. - Lamius ludovicianus gambeli.

Fanily: The Shrikes.

Length: 8.00-10.00.

Adults: Upper parts slate-gray, tinged with brownish; upper tail-coverts sometimes abruptly light grayish, or even white, same as the white-rumped shrike; undur parts dull white or grayish, darker on sides; breast usually distinctly undulated or narrowly barred with grayish, and sometimes tinged with pale brown.

Young: Similar to adults, but colors less distinctly contrastod.

Geographical Distribution: California, esprecially the coast district. California Brecding Range: Coast region from Red Bluff to San Diego. 
Breeding Season: April and May.

Nest: Usually in a scrubby tree; from 5 to 30 feet from the ground; bulky; made of coarse twigs, straws, grass, feathers, cotton, and wool,

Eggs: 4 to 7 ; gray, marked and spotted with purple, light brown, and olive. Size $0.97 \times 0.73$.

IN a scrubby tree or thorny bush the California Shrike builds her nest of whatever materials may strike her fancy. Usually the bulk of it consists of weed stems and rootlets; but an astonishing amount of trash, such as string, bits of lace, black ribbon, and feathers, were woren into one that especially interested me. The lace was recognized as belonging nearly half a mile away, and had probably been carried by the bird all that distance. Feathers which waved rakishly on the rim of the structure came from the chicken yard of the same ranch where the lace was originally owned. In place of the usual tough rootlets, palm fibre and yucca thread had been used with a large proportion of shredded bark and weed stems. The whole was lined with a felted mat of cow hair nicely padded into place on sides and bottom. Inasmuch as the bird was seen to bring this hair in small bunches and all this felting was done by him, the result was surprisingly smooth and compact. Both sexes worked busily at the building, being frequently at the nest together.

On May 17 the first egg was laid, and one each day thereafter until there were five. Twelve days were required for incubation, and on June 3 five naked nestlings were cuddled in a tangled mass in the soft cup. And now we had a fine opportunity to watch the hunt- 
ing of the so-called "Butcher birl." The fivorite perch was a telegraph wire, and from there swoops were made downward into the grass with startling swiftness. Not a movement in the meadow escaped him, not a cricket could jump but he saw it, even fifty feet away, and caught it at the first trial. For the first week the food was swallowed by the adults and given to the young in a partially digested form by regurgitation. Then came an intermediate stage in which they received fresh food bitten up by the adult. Ifter the nestlings were strong enough to help themselves at all, the insects were held firmly in the beak of the adult and pulled off, a bit at a time by the young bird. No food was hung up in the nest tree.

When the young Shrikes were fully fledged and had left the nest tree, they still followed the parents about with open mouths and quirering wings, begging for food until they were nearly five weeks old. They still tore bits from insects held in the beak of the adult or impaled on a barbed-wire fence, which was their farorite perch. When six weeks old, one of the young birds managed to eapture a grasshopper, and I saw him trying to impale it on the fastening of a telegraph wire insulator, watched by an adult Shrike two feet away.

Although usually silent except for a harsh note of alarm, both the ('alifornia and the white-rumper shrike have a love song strikingly at rariance with their reputation for wanton butehery. One can searcely credit the shrike with the tenderness expressed by the sweet warble that comes from the nest tree when the satiny 
gray mother bird is brooding the eggs. The harsh voices of both sexes soften to musical gurgles when they are near the young in the nest, and the cruel, bloodthirsty villain of popular bird lore loses the fierceness he is supposed to possess. The young Shrikes inherit the family traits of patience and silence, and even when hungry, cuddle down in unwinking stillness, evidently having fullest confidence that somehow their wants will be relieved.

\section{3 a. WESTERN MOCKINGBIRD. - Mimus polyglottos leucopterus.}

Family: The Wrens, Thrashers, etc.

Length: $9.00-11.00$.

Adults: Upper parts plain gray; wings and tail blackish; wings with white patch at base of primaries; wing-bars, white-tipped wing-quills, and tertials with whitish edgings; under parts white, tinged with grayish, more brownish in autumn.

Young: Upper parts more brownish, back indistinctly streaked or spotted with darker; breast spotted with dusky.

Geographical Distribution: United States (rare north of latitude $38^{\circ}$ ), from the Gulf of Mexico to the Pacific coast, and in Lower California. Californin Breeding Range: Chiefly in the San Diegan district, but also throughont the lower Sonoran zone to San Joaquin valley. Breeding Season: April, May, and June.

Nest: Of small twigs and weeds; lined with finer material and some-

times horsehair and cotton ; placed from 6 inches to 50 feet high, in thick bushes, hedges, vines, and trees.

Eggs: 4 or 5; pale bluish or greenish, spotted with reddish brown. Size $0.94 \times 0.71$.

The Western Mockingbird is to Southern California what the American robin is to the Eastern States, - the friendly dweller near the homes of men. From the fruit trees in the orchard, from the shrubs on the lawn, from the tops of the house chimneys, he pours "such a flood 
of delirious music that the woods and the streams stand silent to listen." No bird has been oftener written about. It would be difficult to say anything original coneerning him, but Mrs. Bailey's inimitable deseription is worth quoting:

"The Mocker almost sings with his wings. He has a pretty trick of lifting them as his song waxes, a gesture that not only serves to show off the white wing-patches, but gives a charming touch of vivacity, an airy, almost sublimated fervor to his love song. His fine frenzies often carry him quite off his feet. From his chimney-top perch he tosses limself up in the air and dances and pirouettes as he sings, till he drops back, it would seem from sheer lack of breath. He sings all day, and often - if we would believe his audiences - he sings down the chimney all night, and when camping in Mockerland in the full of the moon, you can almost credit the contention. A Mocker in one tree pipes up, and that wakes his brother Mockers in other trees, and when they have all done their parts every other sleepy little songster in the neighborhood - be he sparrow or wren - rouses enough to give a line of his song."

His nest, placed often in the hedgerows bordering the lawn, is presided over by his more quiet mate, who broods for fourteen days on the mottled blue eggs. There is no need to peek into the nest to ascertain whether those eggs have hatched, for his fussiness proclaims the event to all who eare to know. Ind now come busy days. Both male and female Mockers flit through the green like silent shadows hunting inseets 
under the leaves, earthworms on the ground, or berries in the garden. These are all swallowed first and delivered to the infant Mockers by regurgitation for the first few days, or until the babies' eyes open. After that, the number of earthworms, butterflies, etc. deroured by those nestlings rivals the story of the young robins who in twelve hours ate forty per cent more than their own weight. There seemis to be no limit to their appetite and scarcely any to their capacity. Even after they leave the nest and are nearly as large as the adults, they follow the overworked father about, begging with quivering wings. They are remarkably handsome youngsters, with their soft brownish coats and spotted breasts, well deserving the care and pride their fond parents bestow upon them.

\section{7 a. SLENDER-BILLED NUTHATCH. - Sitta carolinensis aculeata.}

Family: The Nuthatches and Tits.

Length: 5.00-6.10.

Adult Male: Top of head and nape blue-black; sides of head and under parts white; back bluish slate-color; wings and tail marked with black and white.

Adult Female: Top of head bluish gray; otherwise like malc.

Geographical Distribution: Western North America east through the

Rockies, south to Mexico.

California Breeding Range: Transition zone, except in humid coast belt. Brecding Season: April and May.

Nest: In natural cavities of oak trees or old woodpecker holes; lined with moss, short hair, and feathers, sometimes grass.

Eggs: 5 to 7 ; buffy white, thinly speckled with rusty and purple. Size $0.74 \times 0.53$.

PART way up the mountain-sides, on the clearings sparsely covered with large oak trees and surrounded by 
heary timber, the Slender-billed Nuthatch makes his home through the long summer days. When the winter storms threaten and food becomes scarce, he sometimes works his way leisurely down to a lower altitude where insect life is more easily found, but usually he remains all the year in the same locality. So protective is the coloring of these slate-eolored birds that, but for their nasal "yang, zang, henk-ah, henk-ah" (described by Mrs. Bailey), they might pass unnoticed by the easual observer. They travel head downwall round and round the trunks of the oaks, hunting in every crevice for larve and clinging to the under side of the large limbs as easily as if right side up.

The pairs remain together all the year round, and their housckeeping commences early in the spring with none of the grotesque demonstration so usual among birds. Quietly a cavity in an oak or a dead pine is selected and filled almost to the brim with feathers, fur, short hair, and moss by the united efforts of both busy worker's. By May 1 the nest is complete and the mother bird has begun her cares. She is a close sitter, seldom leaving the nest for food, but depending on the supply brought by her mate and only indulging herself in a wing-stretehing once or twice a day. The male is very attentive, going to the nest so often that one wonders when his own meals are eaten. As soon as the young are hatehed, which is twelve days after sitting begins, the female assists in the search for food and comes to the nest quite as often as the male. For the first few days the feeding is by regurgitation. 
728. RED-BREASTED NUTHATCH. - Sitta canadensis.

FamiLY : The Nuthatches and Tits.

Length : 4.12-4.75.

Adult Male: Top of head black; a white line over the eye and black line through the eye; upper parts bluish slate-color; tail with white patches on outer feathers; under parts whitish, washed heavily with bright red-brown.

Adult Female: Entire upper parts bluish slate-color; under parts paler and duller than male.

Young: Similar to female, but duller.

Geographical Distribution: Mountains of North America, south in winter to Southern United States.

California Breeding Range: Breeds irregularly along the higher Sierra Nevada in the middle and northern parts of the State.

Breeding Season: May and June.

Nest: In an old stub, usually within 6 feet of the ground; lined with shredded inner bark and vegetable fibre.

Eggs: 4 to 8 ; grayish white, sparsely speckled with red-brown. Size $0.60 \times 0.50$.

The Red-breasted Nuthatch is the same familiar slategray bird in California that he is in the oak groves of Illinois or the forests of Maine. In California he follows the footsteps of spring up into the mountains, and makes his nest in the natural cavities of dead trees, coming down to milder levels when the snow flies. Yet he is a hardy little fellow and loves the cold, and only the decrease of insect life induces him to seek a fatter larder elsewhere. The nesting habits of this species are essentially like those of the slender-billed nuthatch. 


\section{PYGMY NUTHATCH. - Sitta pygmaa.}

FaniLY: The Nuthatches and Tits.

Length: $3.80-4.50$.

Adults : Top of head olive-gray; nape and chin white; line through eye black; upper parts bluish slate-color; under parts pale grayish buffy, nearly white on upper breast.

Young: Similar, but wing-coverts edged with buff.

Geographical Distribution: Mountainous regions from British Columbia south to Mt. Orizaba, Mexico; from the Rockies to the Pacific.

California Breeding Range: Local in Transition zone, chiefly in the southern Sierra Nevada and in the Santa Cruz district.

Brecding Seasun: June.

Nest: In holes in trees, from 10 to 40 feet up; lined with wool, cattle hair, and feathers.

Eggs: 6 to 9 ; white, speckled with reddish. Size $0.54 \times 0.44$.

A Boot Tallac on Lake Tahoe, as at most points in the Sierra Nevada, these mites in gray scamper up and down the tall pine trees, upside down or right side up, as the case may be, - it is all one to them. In August and September, when the clans gather after nesting time, the trees seem to be literally alive with them. Their shrill "wit-wit" is varied by a whistled trill, and when all the flock is ealling at once the combined noise resembles that of a brood of young chickens. They move in crowds from tree to tree, running over the trunks and branches, searching every smallest crevice for bugs, and twittering a low sweet monologue. The flocks keep together all winter, and move down into the valleys as the cold weather comes on and the food supply grows smaller. In March the upward migration is begun again; but 
now the flocks separate, numbers dropping out on the way to nest in lower altitudes, and by the time the timber line is reached the birds are scattered into small companies of three or four. By June, nesting sites are chosen, - if, indeed, the same ones are not used each year, - and each little pair is well settled in housekeeping. At Lake Tahoe a hollow post several feet out in the water held a nest of these gray midgets, the entrance being a crevice scarcely large enough for a mouse. Both birds worked busily carrying feathers into this crevice until it seemed there must be at least a peck of them tucked away inside. Although I stood in a boat with hand resting on the post not a foot from their doorway, they came and went as unconcernedly as if no one were within miles of them; and when the young were hatched, the same winsome trust was displayed when an intruder visited the nest.

Another nest found, June 14, ten feet from the ground in a dead pine was also entered through a crevice; the birds displayed the same fearlessness, going inside with food, while the bird-lover stood on her horse's back and tried to make the opening large enough to admit a friendly though curious hand. The brave little bird would light on the trunk just abore the nest hole, and, rumning quickly down, dodge in when the fingers of the investigator were pulling at the crevice. Under such circumstances only a hard-hearted collector would persist in bothering the courageous parents. So, withdrawing to a short distance, she kept watch to learn what food was brought and how often. Both 
male and female were busy hunting some sort of white larvae that they obtained from an old stump. The adults did not swallow these, but carried them in their bills, - which convineed me that the nestlings were at least five days old. For my own observation proves that the young of perching birds (as well as Nacrochires and most Pici) are fed by regurgitation for four or five days, the length of time varying in different species and depending on the kind of food brought. Birds eating large insects are fed on raw food sooner than those feeding upon minute insect life, snch as ant eggss, gnats, ete., and secd-caters last of all.

In the case of the Nuthatches the entire brood left the nest, June 16, so that they must have been two weeks old when discovered. 'They were ferl by the parents for some time after their début, and most of the time were kept well "1 in the thick branches of a live pine tree, where we could hear but could not see them.

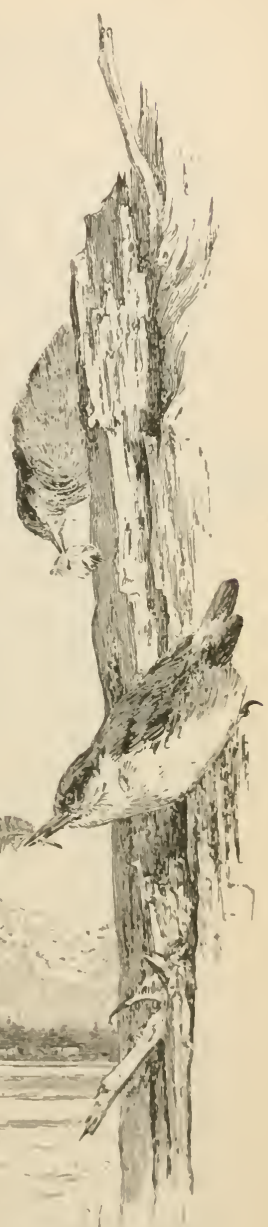


733. PLAIN TITMOUSE. - Bacolophus inornaius.

Family: The Nuthatches and Tits.

Length: $5.00-5.60$.

Adults: Upper parts olive-gray, becoming lighter and grayer on under parts ; belly nearly white.

Young: Upper parts tinged with rusty brown; under parts whitish.

Geographical Distribution: Pacific coast west of the Sierra Nevada, through California and Oregon.

California Breeding Range: Oak regions of upper Sonoran zone west of the Sierra Nevada.

Breeding Season: March and April.

Nest: In natural cavities of dead trees, or sometimes in old woodpeckers'

holes; lined with rabbit fur or feathers.

Eggs: 6 or 8 ; plain white. Size $0.64 \times 0.49$.

The tufted titmouse of the Eastern United States finds its California counterpart in the Plain Titmouse, an independent, aggressive little bird found among the live oaks of the foot-hills. He seldom enters the pine forests, but loves the sumny open slopes, where he wanders with small flocks of others of his species, searehing for insect life in a very businesslike way through the tall bushes and oak trees. His common note of "tsee-dayday" is not unlike that of the mountain chickadee, and occasionally he indulges in a whistled "peto, peto" that reminds one of his pretty Eastern cousin. But these are only two of a variety of notes the bird utters under various conditions.

The nest of this species is usually in a cavity of an oak tree limb, the entrance being through a knot hole well sheltered from the rain. To watch the development of the brood it is usually necessary to mutilate the tree, and so I have contented myself with observations 
made outside the nest. Both sexes share in the fun of nest-building, busily carrying short hair, feathers, and wool, and staying inside long enough to settle a much larger house. They work industriously for five or six days, until it seems as though at least a peek of trash had been tucked into the old oak tree. Then, after a day or so of play, the mother settles down to fourteen days of brooding in the dark nest hole. In a ease which I recorded she was fed by her mate at short intervals during all this long incubation, and many were the worms I saw him earry to her. He never entered the nest without first calling from outside, when she would answer and often come up to the door to be fed. We knew at once when the young had come out of the shells, for his exaggerated anxiety and comical airs of business told

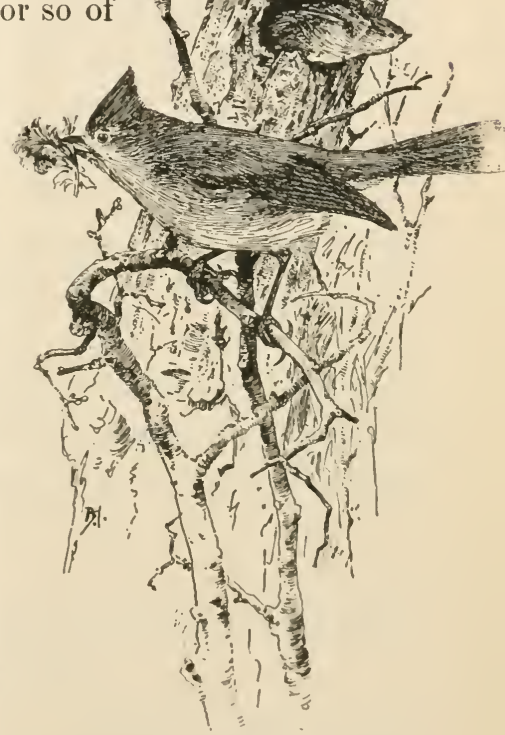

733. Platiy Tituouse. "Busily carrying short hair, feuthers, and wool.",

his secret. A listening at the doorway further confirmed this three days later. He now seolded at any approach to the nest and tried to win our attention to himself, while the female slipped in and out with food. My theory that most young birds are fed by regurgitation at first was 
confirmed in this case by the fact that, although I was within twelve feet of the nest whenever either bird entered it during that first day, not once was any food visible in the beak of either. After the fourth day the worms and insects carried were frequently projecting on each side of the small beak, but up to that time there had been none seen, though a careful watch was kept with both opera glasses and naked eyes. On the sixteenth day one of the young appeared in the doorway, but dodged back when I advanced a cautious hand. $\mathrm{He}$ was very like the adults, but somewhat browner on his head, and the under parts were clouded with light and dark gray. The crest was developing finely, and gave him a pompous look in funny contrast to his timid manner, as he raised it in surprise just before leaving the doorway. As my hand approached, the crest flattened and the little fellow seemed to crouch and slide down backward into the darkness.

\section{MOUNTAIN CHICKADEE. - Penthestes gambeli. \\ Fanul: The Nuthatches and Tits.}

Length: 5.00-5.75.

Adults: Throat and top of head black : white line over eye, black line through eye; sides of head white; upper parts gray; under parts grayish white, becoming dark gray on sides, washed with rusty.

Geographical Distribution: Western United States in Boreal and Transition zones from the Rockies to the Pacific coast, and from British Columbia to Lower California.

California Breeding Range: In Transition zone along the whole length of the Sierra Nevada.

Breeding Season: June. 
Nest: In an old woodpecker hole or natural cavity, $2 \frac{1}{2}$ to 17 feet from the ground; lined with cattle hair, fur, or wool.

Eygs: 5 to 9 ; white, sometimes spotted with rusty around the larger end. Size $0.6 n \times 0.41$.

"IT was a cheery chick-11-dee-dee that gave me my first introduction to this vivacious bird in the sierra, and when I later discovered a nest hidden securely in an old pine stub deep in the forest, I could not resist the impression that here indeed was contentment. Here, far from the habitations of man, and beside an abandoned trail which had long since ceased to re-echo human footsteps, had settled a pair of Mountain Chickadees. No matter how fared their neighbors, and with no time to gossip with the shy warblers of their domain, these little birds seemed unconscious of all else save their piny mansion.

"True, they were not fistidious, and had taken up housekeeping in old quarters; and their particular stub, with its deep-creased bark and rotten foundation, did not differ from a thousand other stubs which dotted the forest. But this stump, still capped by the winter's snow, was destined to become the arena of intense activity with the advent of spring.

" My first nest was found on .June 11, 1898, as Mr. L. F. Taylor and I were walking along the stage road. An old sporuce stub, about three feet higrh and nine inches through, stood near the road, and a two-ineh hole in its top led down into the darkness. On seraping the stub a series of hisses canc, forth clenoting young. We tore open one side of the stub and beheld a nest of nime young Chickadees rearly to fly. They scrambled up the 
side of the rough wall and three escaped into the brush. In plumage the young birds were counterparts of the adults. The male bird was calling near by, so we patched up the stub and continued on our way." 1

The above is the first
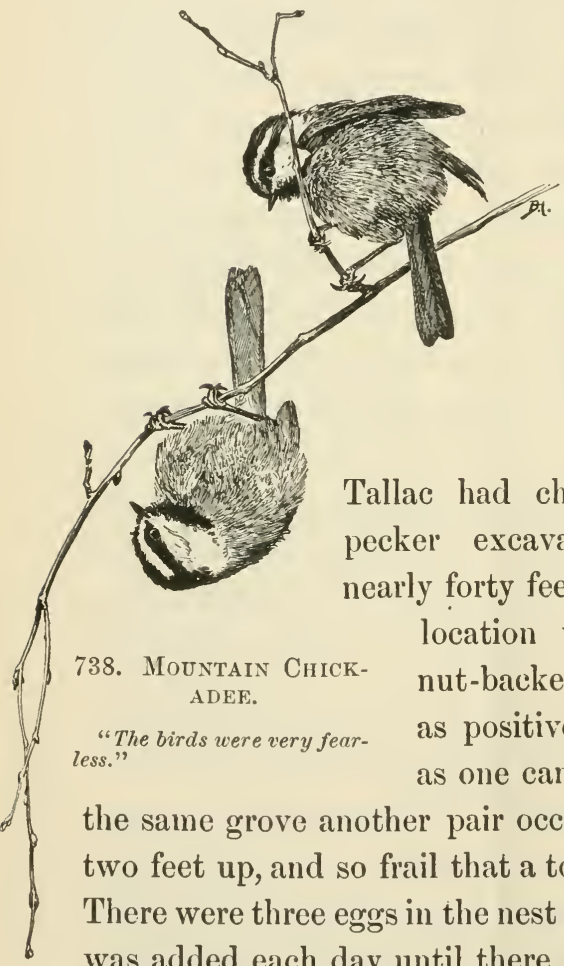
part of an excellent article on the Chickadee, too long to be quoted entirely.

The location of the nest of this species is usually less than four feet up; but one enterprising pair that I myself watched at Mt. Tallac had chosen a deserted woodpecker excavation in a dead tree, nearly forty feet from the ground. The location was that of the chest-

738. Mountain ChickADEE. less."

"The birds were very fearnut-backed chickadee, but I am as positive about the identification as one can be without a gun. In the same grove another pair occupied a hollow stub only two feet up, and so frail that a touch broke open the side. There were three eggs in the nest when discovered, and one was added each day until there were seven, when sitting began. In fourteen days the seven small Chickadees had broken the shells, and lay a wriggling mass of naked bird

1 Chester A. Barlow, in “The Condor,' 1901. 
life. We left the side partly open to watch the brood. The birds were very fearless, and allowed me to sit within a few feet of the nest while the young were fed. This enabled me to discover that the nestlings were fed by regurgitation until four days old, when fresh food was given. Whether or not the adult digested the food I do not know; but in every feeding for the first four days the insects were carried to the young in the throat of the adult, and forced up when needed, accompanied by a large amount of saliva.

The young Chickadees were slow in feathering, and remained in the stub nearly three weeks; then a spontaneous exit oecurred early one June morning. For fully two weeks longer the young were seen begging to be fed by their indugent parents, and showed little disposition to become self-supporting. Their plaintive "deedee, dee-dee" was uttered continuously when they were not asleep.

\section{1 a. CALIFORNIAN CHICKADEE. - Penthestes}

rufescens neglectus.

FamiLY: The Nuthatches and Tits.

Length: $4.50-5.00$.

Adults: Similar to chestnut-backed chickalee, but sides and flanks pale ashy gray, faintly washed with brownish.

Geographical Distribution: Coast region of California from Sur River northward.

Breeding liange: In redwood belt of coast district, from Monterey to Marin County.

Brecding Season: April. 
Nest: In deserted woodpecker hole, or in natural cavity in stub, from 2 to 10 feet from the ground; lined with cow hair, rabbit fur, wool, or moss.

Eggs: 5 to 9 ; white, sparsely specked with rusty. Size $0.63 \times 0.47$.

THE Californian Chickadee is confined to the coast region of California, and, Mr. Otto Emerson says, can always be found in the redwood belt. In habits it is similar to the ehestnut-backed chickadee, nesting rather higher up in the trees than the mountain variety.

\section{LEAD-COLORED BUSH-TIT. - Psaltriparus plumbeus.}

FAmily: The Nuthatches and Tits.

Length: $4.12-4.60$.

Adults: Upper parts bluish gray; sides of head brown; under parts gray, merging to white on middle of breast; belly washed with light grayish brown.

Geographical Distribution: Rocky Mountain district west to the Sierra Nevada, south to New Mexico and Arizona.

California Breeding Range: Desert ranges southeast of the Sierra Nevada.

Breeding Season: April.

Nest: Pensile; gourdlike in form; of plant down, white sage leaves, spider webs, small bits of lichens and moss; the whole carefully lined with small feathers. Entrance, small round hole in wall of nest near the top. Walls $1 \frac{1}{2}$ inches thick at bottom, but $\frac{3}{8}$ inch thick at top. Nest placed in low oaks and nut pines, 12 to 15 feet from the ground. Eggs: 4 ; white. Size $0.53 \times 0.40$.

THE Lead-colored Bush-tit is a common resident of the desert ranges southeast of the Sierra Nevada, feeding in the jumipers and nut pines, and usually to be seen in flocks.

Their constant twittering, though so faint, reminds one of the chatter of a flock of English sparrows, and 
the birds themselves, although so small, have all the independent airs of that pest. Some one has very aptly described them as "balls of gray down with a tail stuck in." Fascinatingly fluffy mites they are, busy all day long with their own affairs, ridding the trees of scales, insect eggs, bark lice, and many other injurious forms of insect life. They are constantly in motion, hanging head down under the slender twigs, chickadee-fashion, picking at every crevice in the bark and every fold of a leaf-bud, if perchance a bug lie hidden there, and many a tree owes its good condition to their industry.

The nesting habits of this species are rery like those of the Californian bush-tit. Among the underbrush of dry watercourses or on oak-covered hillsides you will find their gourd-like nests, usually pensile but often nestled among the thick twigs of a bunch of mistletoe. Wild blackberry vines, also, are favorite nesting sites. Wherever the pinkish gray cradle may swing, the jolly little housekeepers are friendly and fearless. Yon may watch them at a distance of three or four yards without producing the slightest interruption in their work. When the young are out of the nest and sitting like wee gray puff-balls in unwinking silence in the bushes, the adult will feed them when you are only two feet away; and fully fledged young may, with infinite patience, be coaxed to perch on twigs held in your hand.

These queer little gray clves endure cold that would kill many a larger birl, and are as lively in the winter as in the summer. Amost as soon as the last broor is reared, they join the flocks of their neighbors and forage 
fearlessly through the fall woods, until the spring calls them to commence nest-building again.

751 a. WESTERN GNATCATCHER. - Polioptila carulea obscura.

Family: The Kinglets, Gnatcatchers, etc.

Length: 4.00-5.50.

Adult Male: Upper parts dark bluish slate-color, lightest on rump,

bluest on crown. A blackish line over eye ; tail black, outer feathers edged with white; under parts grayish white.

Adult Female, and Young: Similar to male, but grayer; no black over eye; upper parts of young tinged with brownish.

Geographical Distribution: Western Texas, west through Arizona to California and Lower California, south to Mexico.

California Breeding Range: Locally through the Sonoran zone, except the humid coast belt.

Breeding Season: May.

Nest: In bushes, 3 or 4 feet from the ground; made of shreds of bark ;

lined with plant fibre and feathers, and covered with lichen.

Eggs: 4 or 5; whitish, wreathed and speckled with rusty brown and purplish gray. Size $0.57 \times 0.42$.

The Western Gnatcatcher is a common resident of the lower mountain altitudes throughont California, a part of those found here in the winter migrating to more northerly parts in the summer and the rest remaining to breed. Mr. Chamberlin writes of this species in "The Condor," March, 1901, as follows: "The name Guatcatcher is misleading as regards the diet of this species, for I have repeatedly seen one tackle a butterfly almost as large as himself, and bag his game too. I think, however, his food is largely made up of the eggs and larvæe of insects which are found on the under side of 
leaves and in the crevices of bark. Of the first few nests I saw being built none were finally occupied on their original sites. One pair near my camping place moved their nest and made it over three times before being satisfied to deposit eggs in it. Each time that the nest was nearly complete, the birds would discover a more suitable site, and then the work of tearing down would begin, and it would be moved piecemeal to the new place. Very thin strips of vegetable vellum and rotten bark-fibre made up the bulk of the nest. The edges at the top were drawn in, making the diameter of the opening less than that of the centre of the cavity. The outside was laced over with cobwebs and spangled over with lichens from the oaks, which were bound on with webs also. The selection of lichens varied considerably with the pairs of birds, some choosing dark brown ones with black backs, while others were paler or brighter, - the usual nest being pale green or silver-gray in color."

Mr. Chamberlin does not record the incubation or development of the broods, so I turn to my own records and find that a nest discovered in a low tree near San José, California, contained four eggrs on May 3. The mother was observed on the nest at every visit, and the male near by the tree. She was fearless and let me approach very near, almost near enough to put my hand on her. On May 10 the eggs had hatehed and four skinny pink nestlings, no larger than small grasshoppers, lay in the nest, - a helpless mass of wriggling legrs, wings, and neeks, ending in funny knoblike heads. They were fed by regurgitation until the feathers were well started, and 
even then the food was often chewed by the adult before it was given to the young.

The nest itself was a fairylike structure, not much larger than that of the hummingbird. When not busy hunting insects for his brood, the father flitted through the trees with a happy little song. It was a silvery warble, eminently in keeping with the tiny singer. His note of protest was a shrill "tzee, tzee, tzee," very like the call of the golden-crowned kinglet.

\section{BLACK-TAILED GNATCATCHER. - Polioptila californica.}

Family : The Kinglets, Gnatcatchers, etc.

Length: $4.15-4.50$.

Adult Hale: Crown black; upper parts dark slate-color; tail black; outer tail-feathers edged with white; under parts gray; belly washed with rusty.

Adult Female: Upper parts slate-color, merging to black on tail ; under parts gray.

Young: Like female, but tinged with brown.

Gcographical Distribution: Pacific coast of Southern and Lower California.

California Breeding Range: Local in the San Diegan district, northwest to Ventura.

Brecling Season: March, April, and May.

Nest: A compact, cup-shaped structure ; of vegetable fibre, sage leaves, plant down, and spider webs, lined with plant down and feathers. Placed near the ground in weeds, low bushes, or cactuses.

Eggs: 4 ; pale pea-green, thickly speckled with brownish red or rusty. Size $0.50 \times 0.45$.

Althougli this Gnatcatcher is a common resident in most parts of Southern California, its nesting habits are more or less difficult to observe. Only one nest of this species has ever come under my observation, and that 
was snugly woven in a low bush at San Diego. At first view it was difficult not to believe it the nest of the American redstart of the Eastern States, but closer examination revealed a wideness at the base and ornamentation of tiny curled sage-leaves and bits of lichen bound on with spider webs. It contained, May 10, four nestlings so nearly ready to fly that an attempt to investigate resulted in the sudden departure of the four in different directions. Nlthough the flight of each was short, quick, and fluttering, every one of them succeeded in getting out of sight among the thick green, and search revealed but one of the four. He was a bewitching little gray ball of feathers, with just a promise of the tail that should give him

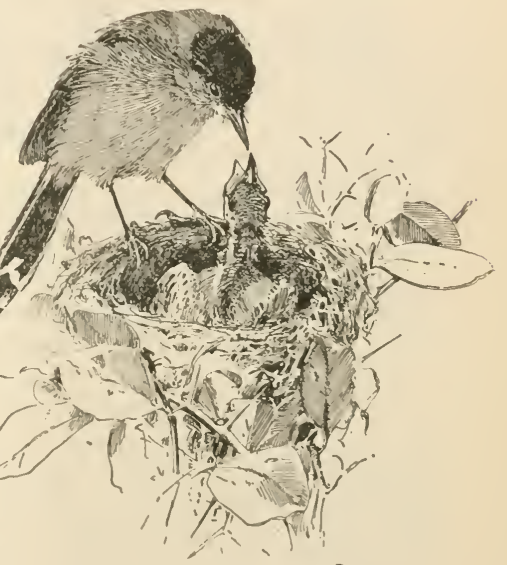

B.7.

753. Biack-tallen Gyatcatcher.

"IIc was a bevitching little gray ball of feathers." lis name. During the hour

that we were able to wateh him, he was fed seven times by the male, the food brought being small flies and green worms. The female was evidently with the rest of the brood, for she did not appear. The male seemed to have no fear of us, and eame each time with a little challenging note as if he were tempted to drive us away. A mockingbird, who eame near by to drink, was fiercely attacked and driven away by the plucky mite, single-handed. 


\section{PLUMAGE CONSPICUOUSLY BLACK AND WHITE}

\section{3 c. HARRIS WOODPECKER. - Dryobates villosus harrisi.}

Family: The Woodpeckers.

Length: $9.00-10.00$.

Adult ILale: Nape searlet; upper parts black, white stripe down the middle of the back; wing-coverts lightly spotted with white; outer primaries with white spots; outer tail-feathers white; under parts uniform gray, or pale grayish brown.

Adult Female: Similar, but with no scarlet.

Young: Like adult, but forehead spotted with white, and crown scarlet. Geographical Distribution: Pacific coast from Alaska south in winter as far as Monterey.

Breeding Range: In California, only the extreme northern part of the humid coast belt.

Breeding Secuson: April 15 to June 15.

Nest: An excavation in a dead tree.

Eggs: 4 to 5 ; glossy white. Size $0.98 \times 0.70$.

THE breeding range of this species, according to Major Bendire, is very limited and is co-extensive with its geographical distribution. It is a bird of the humid coast, Transition, and Canadian zones, only remaining resident in the northern part of California as far south as Humboldt Bay. In winter it wanders to Monterey along the humid coast belt. It corresponds in general habits to the hairy woodpecker of the north and east, which rids our orchards and forests of innumerable injurious larva, such as those of the boring beetle, etc. The food of the Harris consists of spiders, ants, other insects, and cocoons, besides larva, and sometimes acorns arid seeds.

It is one of the earliest of the woodpeckers to breed, the nest being completed in an old stump or dead tree as early as April. The nesting habits are described as 
identical with those of the hairy woodpecker; in the case of the latter, incubation lasts two weeks, the young remaining in the nest three to four weeks. Like all young woodpeckers, the nestlings are fed by regurgitation while in the nest, and are dependent on the parents for several weeks after leaving it.

393 d. CABANIS WOODPECKER. - Dryobates villosus hyloscopus.

Family: The Woodpeckers.

Somewhat smalier than the Harris woodpecker, and under parts white instead of gray ; otherwise exactly like the Harris.

Geographical Distribution: Sonthwestern United States.

Breeding Range: In California in suitable localities almost thronghout

the State, but chiefly south and east of the north humid coast belt.

Breeding Seuson: Mareh, April, and May.

Nest: An excavation in a tree, usually 12 to 18 feet from the ground.

E'gys: 3 to 6 ; glossy white. Size $0.96 \times 0.70$.

IT would be easy for a begimer to confuse this species with the Harris, and especial care must be taken in noting size, under parts, amel renge, for the Cabanis is rarely met with in the humid coast district.

Breeding in the mountains south and east of the coast belt, it oceasionally wanders down to the valleys in midwinter, probably seeking better food supplies. It is one of the earliest to commence nesting, fresh eggs having been taken near San Bernardino late in March. The long breeding season recorded in one locality indicates that two broods are raised. When brooding, it is rather fearless, devoted to nest and young, and refusing to leave until driven away. Then both adults remain near the 
collector, uttering cries of distress, scolding, and doing all that helpless birds can do for the protection of their young.

Like the Harris, the Cabanis is noisy, particularly during the mating season, when its loud drumming and its "kick-kick, whitoo, whitoo, 1) wit-wi-wi" may be heard all day long in the deep pine

way long in the deep pine

Both sexes share the labors of excavating, brooding the eggs, and feeding the young. Incubation lasts about fifteen days, and the young remain nearly four weeks in the nest, being fed most of that time by regurgitation. After leaving they are fed by the parents for at least two weeks, and usually return

393 d. CABanis

WOODPEC KER.

"Both sexes share the labors of excarating." to the nest at night to sleep.

Although the usual height of the excavation is from twelve to eighteen feet from the ground, Major Bendire records one as low as three feet and another as high as fifty feet.

The food of the Cabanis woodpeckers consists of larvæ and eggs of insects, berries, seeds, piñon nuts, pine seeds, 
and acorns. Major Bendire says he has often seen them pecking at haunches of venison hung in the open air, and picking up bits of fat around slaughter houses.

\section{4a. GAIRDNER WOODPECKER. - Dryobates}

\section{pubescens gairdneri.}

FaniLY : The Woodpeckers.

Length: $6.00-7.00$.

Adult Male: Forehead and stripe down the back white; nape scarlet;

upper parts black; wing-coverts lightly spotted with white; outer

tail-feathers white, barred with black; under parts gray.

Adult Fenale: Like male, but no scarlet on nape.

Young: Like male, but crown scarlet.

Geographical Distribution: From British Columbia to Southern California, east heyond the eastern slope of the Sierra Nevada.

Brcoding Range: Suitable localities as far south as Santa Cruz.

Brecding Season: May and June.

Nest: From 4 to 20 feet above the ground, in old stumps and dead trees. Eyys : 4 or 5 ; glossy white. Size $0.77 \times 0.58$.

THe Gairdner Woodpecker is the Western representative of the downy woodpecker of the Eastern States. An attempt has been made to divide this subspecies, restrieting the California range of the Gairlner to Del Norte and Siskiyou counties, and calling the species "Willow IVoodpecker" south of that locality. But in aceordance with Mrs. Bailey's "Mand Book," we shall consider the Gairdner Woodpecker to have a range "from British Columbia to Southern California." 'The willow woodpecker differs from the Giardner in being a trifle smaller, with lighter under parts and spotted tertials. (See Handbook of Birds of Western United States.) 
It is usually resident - and probably breeds - wherever found, although not very numerous in any one locality. Its nesting site is usually in deciduous trees, at a distance from four to twenty feet from the ground. The entrance hole is round, about an inch and a half in diameter; and the cavity excavated is from six to nine inches deep. Both male and female share in the work of excavating, and after the nest is finished, the male sometimes prepares a shallower one for himself in the same tree. Nesting begins as early as the middle of April in Southern California, and four weeks later in Sacramento County. Four to five glossy white eggs are laid, and for fourteen days both male and female share the cares of incubation. After the young are grown, they separate from the parents as soon as they can feed themselves, preparing shallow excavations for their own shelter in dead trees or rotting fence posts. Here they spend not only the nights but the stormy days of winter as well, feeding upon the larvæ of insects in the bark.

The call-notes of the Gairdner vary, being a low "pshir, pshir," when searching for food; a "tchee-tcheetchee," rapidly repeated, which is its commonest call; and a soft "kick-kick" uttered in the mating season.

397. NUTTALL WOODPECKER. - Dryobates nuttalli.

FAMILY: The Woodpeckers.

Length : 7.00 .

Adult Male: Crown black, sometimes streaked with white; occiput scarlet; hind-neck white; upper parts barred black and white; middle tail-feathers black; outer tail-feathers barred black and white; under parts white, spotted with black on sides. 
Adult Female: Like male, but with no scarlet on head.

Young: Like male, but nape black and crown red; under parts barred with black.

Geographical Distribution: Southern Oregon and California in Upper Sonoran zone, west of the Sierra Nevada and east of the humid coast belt.

Breeding Range: Same as Geographical Distribution.

Breeding Season: April and May.

Nest: In dead branches or beneath the bark of stumps.

Eggs: 3 to 6 ; white. Size $0.94 \times 0.69$.

THe Nuttall Woodpecker breeds west of the Sierra Nevada throughout the greater portion of California, being most abundant in the southern part of its range. In nesting it prefers the oak trees, digging a cavity eight inches deep, about twenty feet from the ground. Mr. Beck, of Berryessa, California, records it as breeding in the mountains east of Santa Clara County, and in one instance occupying a limb in a sycamore tree where a pair of red-shafted flickers had their nest. Occasionally it chooses elders, willows, and giant cactuses. Nesting commenees early in April, and after the pearly white eggs are laid both adults share in the incubation, which lasts fourteen days. The young remain in the nest three to four weeks, and after leaving return each night to sleep in it. Both parents defend their nest and young with great courage, the mother sometimes allowing herself to be taken on the nest rather than leave it. Their food consists of inseets, larve, berries, and fruit.

The call of the Nuttall Woodpecker is deseribed as a series of loud rattling notes entirely unlike those of any other woodpecker. In habits it resembles Gairdner's woodpecker; but its choice of locality is quite different, as it prefers a higher altitude and is seldom found along streams. 
399. WHITE-HEADED WOODPECKER. - Xenopicus albolarvatus.

Family: The Woodpeckers.

Length: 8.90-9.40.

Adult Male: Head, neck, upper part of chest, and patch on the wing, white ; nape bright scarlet ; rest of plumage black.

Adult Female: Similar to male, but with no scarlet.

Young: Similar to male, but scarlet on crown instead of on nape.

Geographical Distribution: Mountains of the Pacific coast, including both slopes of the Sierra Nevada, from Washington to Southern California.

Breeding Range: The Sierra Nevada and Cuyamaca mountains to Mt. Shasta.

Breeding Season: May.

Nest: 4 to 18 feet from the ground, in stumps.

Eggs: 4 to 7 ; crystalline white. Size $0.96 \times 0.75$.

THe range of the White-headed Woodpecker in California is restricted to higher mountain ranges from Oregon to Southern California. It is common in the fir forests of the Sierra Nevada from four thousand feet nearly to the summit, seldom descending to a lower altitude than three thousand feet. His conspicuous white head makes him recognized by the veriest tyro in bird lore. One would suppose this feature would make him an easy mark for hunters, but in reality there is an effect of protective coloring in the very sharpness of the contrasting black and white, - the one standing out so strongly in the light as to make the other seem part of the shadow and not of the bird.

This is emphatically a silent bird, particularly in the winter. Even during the breeding season in the Sierra Nevada, I have never heard it utter more than a sharp 
"hitt-hitt" as it chases its mate through the wood. The nest is usually in a dead pine or fir, seldom higher than twelve feet from the ground. The entrance is round, about one and a half inches in diameter, and the interior is from eight to thirteen inches deep. From four to seven white eggs are laid on a thin lining of sawdust made by the excavating. Both male and female brood during the fourteen days required for incubation. The young are fed by regurgitation at first, and afterwards upon the large black ants so numerous iri all the dead pine stumps. They remain in the nest nearly four weeks and, for at least ten days after leaving it, are fed and cared for by both parents, returning to the old nursery to sleep at night while the adults remain on guard outside.

Dr. Merrill, U. S. A., has studied the habits of this bird thoroughly, and written of it as follows: "I have rarely leard this Woodpecker hammer, and even tapping is rather mcommon. So far as I have observed,

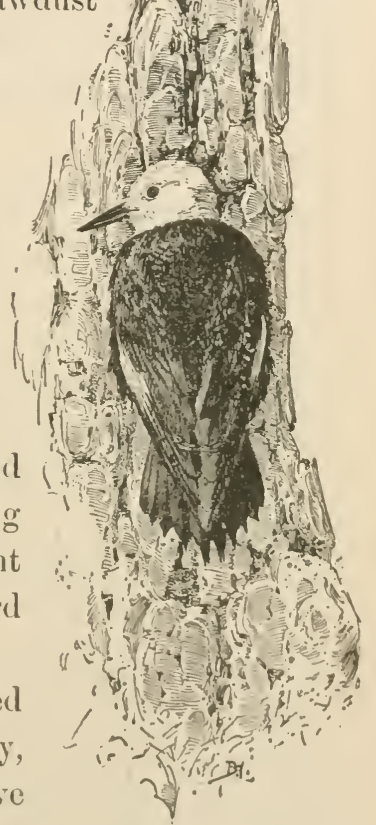

399. WHTTE-HEADEN

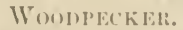

"Where the bark is thickest and roughesl." - and during the winter I watched it carefully, - its principal supply of food is olitained in the bark, most of the pines having a very rough bark, scaly and deeply fissured. 
The bird uses its bill as a crowbar, rather than as a hammer or chisel, prying off the successive scales and layers of bark in a very characteristic way. This explains the fact of its being such a quiet worker, and, as would be expected, it is most often seen near the base of the tree, where the bark is thickest and roughest. It must destroy immense numbers of Scaly tida, whose larvæ tunnel the bark so extensively, and of other insects that crawl beneath the scales of bark for shelter."

\section{ARCTIC THREE-TOED WOODPECKER.}

\section{Picoides arcticus.}

FAMILY: The Woodpeckers.

Length: 9.00-10.00.

Foot with three toes, two pointing forward and one backward.

Adult Male: Crown patch yellow ; upper parts iridescent bluish black; wings finely spotted with white; onter tail-feathers white; under parts white; sides barred with black; forehead and sides of head black and white.

Adult Female: Like male, but without yellow on crown.

Young: Like adult, but erown patch smaller; under parts brownish; upper parts dull black.

Geographical Distribution: Northern North America from the aretic regions through the Northern United States.

California Breeding Range: In the Sierra Nevada as far south as Lake Tahoe.

Breeding Season: May and June.

Nest: Usually in dead trees, 8 to 10 feet from the ground.

Eggs : 3 to 4 ; white. Size $0.95 \times 0.71$.

"THE Arctic Three-toed Woodpecker is essentially a bird of the pine, spruce, fir, and tamarack forests, and is rarely seen in other localities. It is generally a resident, rarely migrating to any distance, and probably breeds wherever found. . . . Its sharp shrill 'chirk, chirk' 
can be heard in all directions. It seems to feed entirely on such wood worms as attack spruce, pine, and other soft-wood timber that has been fire-killed. It never attacks a healthy tree, and is far more beneficial than harmful. . . . Like the hairy woodpecker, they are persistent drummers, rattling away for minutes at a time on some dead limb, and are especially active during the mating season in April. I have located more than one specimen by following the sound when it was half a mile away. . . May 10 I found a male busily at work on a pine stump only two and a half feet high and eighteen inches in diameter, standing within a few feet of the road, and close to a charcoal-burner's camp. On May 25 the cavity was found to be eighteen inches deep and was gradually enlarged toward the bottom. The four eggs it contained had been incubated four days. The female was on the nest, and uttered a hissing sound as she left it, and might easily have been caught, as she remained in the hole until the stump was struck with a hatchet." 1

Incubation lasts two weeks, and the young remain in the nest four to five weeks according to early or late hatching. They are fed by regurgitation for the first nine days and possibly longer, but adults have been seen carrying insects to the nest on the fifteenth day. When alighting with food the adult gives a low cooing call and is answered by a hissing clatter from the young that can be heard at some distance from the nest tree.

Where this bird occurs in California the local orni-

\section{Bendire.}


thologists have made it a subspecies of the Arctic Threetoed and call it Picoides arcticus tenuirostris, or Sierra Three-toed Woodpecker. It is like the Arctic in color and habits, but has a more slender bill. It is found in the northern Sierra Nevada as far south as Lake Tahoe.

\section{WILLIAMSON SAPSUCKER. - Sphyrapicus}

\section{thyroideus.}

FAMILY: The Woodpeckers.

Length: 9.00-9.75.

Adult Male: Upper parts, throat, and breast black; throat with a median stripe of bright red; rump and patch on wing-coverts white; quills finely spotted with white; sides of head striped with white; belly yellow.

Adult Female: Body barred with brown or black and white; rump white; head plain brown; chest with black patch; middle of belly yellow.

Geographical Distribution: Western United States, from the Rocky Mountains to the western slope of the Sierra Nevada ; winters in Southern California.

California Breeding Range: Along the Sierra Nevada from Shasta to the San Jacinto mountains.

Breeding Seeson: May 15 to July 1.

Nest: In large dead pines, 5 to 60 feet from the ground.

Eggs: 5 or 6 ; pure white. Size $0.97 \times 0.67$.

So unlike are the male and the female of this Wood pecker that for a long time they were listed as different species by ornithologists. The general effect of the male's coloring is black, that of the female brown; and unless one is forewarned or experienced, he is apt even now to look for another name when he first sees the female.

They nest commonly in the Sierra Nevada near Lake 
Tahoe and are not at all difficult to wateh. The site chosen for a nest is oftenest in the sheltered woods, where they excavate in the trunk of a dead tree. One that I watehed was situated about ten feet from the ground; standing on my saddled horse, I could reach into it but for one obstacle, - the relative size of the door and my hand. I was unwilling to eut away the wood about the door, so eontented myself with observing from a distance of fifteen feet. The father bird was especially fearless, and sat most of the time on the top of the nest tree, where he drummed oceasionally to reassure his mate in the nest. When I tried to put my hand into the eavity, both birds eame within six feet of me, uttering low angry ealls, and before I had fairly reseated myself in the saddle, the male had entered the nest. I could hear him reassuring the young, which all this time had kept up a tremendous hissing, after the manner of all birds borm in hollow trees. Is I sat there just far enough away to see well what was going on, both parents brought insects to the nestlings every ten minutes. These were usually butterflies, grasshoppers, or dragonflies; but the male frequently picked up the large ants that swarmed over a log I had broken open, and carried them to the nest. He was much more fearless than the female, - a trait so rare among birds that it deserves expecial mention.

In the same tree with this nest of the Williamson Sapsuckers there were a nest of the pygmy nuthatches on the other side of the tree and another of a bluebird a little lower down. The nuthatches were, if possible, 
even more courageous than the Sapsuckers, but the bluebirds flew far away.

The young Sapsuckers must have been fledged when I discovered the nest, June 10; for on the twelfth they came out of the nursery and flew away with their brown mother and black and white father into the deeper woods, where I lost sight of them. A plummet dropped into the nest hole told me it was nine inches deep. It was on the sunny south side of the tree, and several degrees hotter inside than the surrounding atmosphere. As is always the case with woodpeckers, every bit of excrement had been carried away while fresh by the parent, and the nest was as clean as if freshly excavated.

\section{5 a. NORTHERN PILEATED WOODPECKER.}

Phlootomus pileatus abieticola.

(Common Names: Cock of the Woods; Log Cock.)

FAMILY : The Woodpeckers.

Length: 16.00-19.00.

Adult Male: Head conspicuously crested; bill longer than head; top of head, crest, and malar stripe scarlet; chin and side of head pale lemon-color or white; a white patch on the wings; under wingcoverts white; rest of plumage dull brownish black; feathers of belly tipped with ashy.

Adult Female: Like male, but crown and malar stripe brown instead of red.

Youny: Crest salmon-colored, otherwise like female.

Geographical Distribution: Heavily wooded districts of North America,

from the Southern Alleghanies north to latitude $63^{\circ}$, west to the Pacific (Bailey).

California Breeding Range: Timbered areas in the northern part of the

Sierra Nevada as far south as King's River Cañon and Eel River. Breeding Season: May and June. 
Nest: Hole excavated in the trunk of a large dead tree, from 20 to 75 feet from the ground.

Eggs: 3 to 5 ; white. Size $1.40 \times 0.99$.

Throdghout the northern part of California in the forests of the Sierra Nevada, the handsome Pileated Woodpecker may be frequently heard, occasionally seen, but never watched unless you are going to live in his haunts months at a time for the especial purpose of making friends with him. But in the Yosemite Valley lie is the most conspicuous of all the birds, as well as one of the least shy. With slight trouble you may find the location of his nest in a tall live cedar fifty feet from the ground, and watch the pair as they care for their young. Here the mating season commences about the first of May, incubation lasts eighteen days, and the young remain in the nest nearly six weeks. It is not uncommon to find these nestlings still in the nursery the first week in July in the Yosemite forests. The parents are very devoted to their treasures whether they be eggrs or infant Woodpeckers, and the male rarely fails to stand on guard on a high perch ready to warn and defend should possible dangrer threaten. The method of feeding is like that of the flickers, hy regurgitation for the first two weeks or longer. 'The arlult comes with gular pouch full of food and aligrits at one side of the nest hole to rest a moment. Though he may have come noiselessly and from the other side of the tree, yet his approach is always heralded by a mowing-machine chorus from the young, plainly heard some yards away. If old enough, the queer-looking little heads are thrust out of the door- 
way, and the parent, inserting his long bill into the open mouth of a youngling, shakes it vigorously, thereby emptying the food from his throat into that of his offspring. Each in turn is fed in this odd fashion.

The newly hatched Pileated Woodpeckers are even homelier than young flickers. They have the sane ballshaped body with long, helplessly weak legs set very far back on it, and two long appendages that look like fat earthworms rather than like wings. Their in-

405 a. NORTHERN Pileated WoOdPECKER.

"After a few trials he
learns to hammer right merrily."

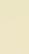


While you have been examining the young, - which, if you are a woman, must be lowered to you, - the parents have ceased to protest and are watching you in silence from behind a tree trunk a hundred feet or so away. After you have replaced the nestlings and left the immediate vicinity, the adult birds will wait an hour or more before they eome back to investigate the damage, and then it is the mother who finally ventures into the molested home to brood again, while the "Cock of the Woods" watches, as before, from a neighboring tree.

For a week or two after the young have left the nest, they follow their parents begging for food with ludicrous eagrerness; at this time the provender brought them consists of nuts, berries, ants, and the larve of beetles. These, especially the nuts, are often placed in a crevice of the bark, and the youngster is compelled to pick them out. After a few trials he learns to hammer right merrily and is ready to forage for himself. Unlike other woodpeckers, but like the flickers again, the Pileated is often seen eating ants on the ground or on a $\log$; henee his name of " $\mathrm{Log}$ Cock."

The call-notes of the Pileated IToodpecker are very like those of the flicker, but louler and flatter in tone, "kac-kac-kac-kac" and "wucker-wucker-wucker" being the most common. When the bird is much exeited, the note is a modification of both a loud and harsh "hikerhiker" rapidly repeated. Is it excavates a new nest every year, there are often fresh chips at the foot of the nest tree to the amount of two or three quarts. The eavity 
is from seven to thirty inches deep and about six inches wide at the bottom, unlined save for a small amount of chip-like sawdust. Like that of the flicker's nest, the doorway is quite as apt to be oval as round, and is from three to four inches in diameter. The eggs are from three to five, glossy, transparent white, and become opaque as incubation advances.

\section{7 a. CALIFORNIAN WOODPECKER. - Melanerpes formicivorus bairdi.}

FAMILY : The Woodpeckers.

Length: 8.50-9.50.

Adult Male: Upper parts, sides of head and chest iridescent black; chest streaked with white; crown red; feathers around base of bill black, bordered by band of white or yellow ; rump, wing-patch, and belly white.

Adult Female: Like male, but with red crown separated from the white or yellow forehead by a black band.

Young: Like adults, but colors duller.

Geographical Distribution: Mexico and western border of United States from Western Texas to California, and north along Pacific coast to Southern Oregon ; south to Lower California.

California Breeding Range: Suitable localities in lower Transition zone west of the Sierra Nevada.

Breeding Season: April 15 to July 15.

Nest: Cavity or excavation in trees, from 20 to 50 feet from the ground. Eggs: 4 or 5 ; glossy white. Size $1.00 \times 0.75$.

This is the Woodpecker most uniquely Western in all his ways. He belongs exclusively to the oak belt and can be found only where these trees are abundant. Not at all shy, he seems to the Eastern bird-lover to replace the redhead of the home forests, and his gay "wake-up, wake-up," is a welcome greeting from an old friend. Like the redhead, he is very emphatic in his manner of 


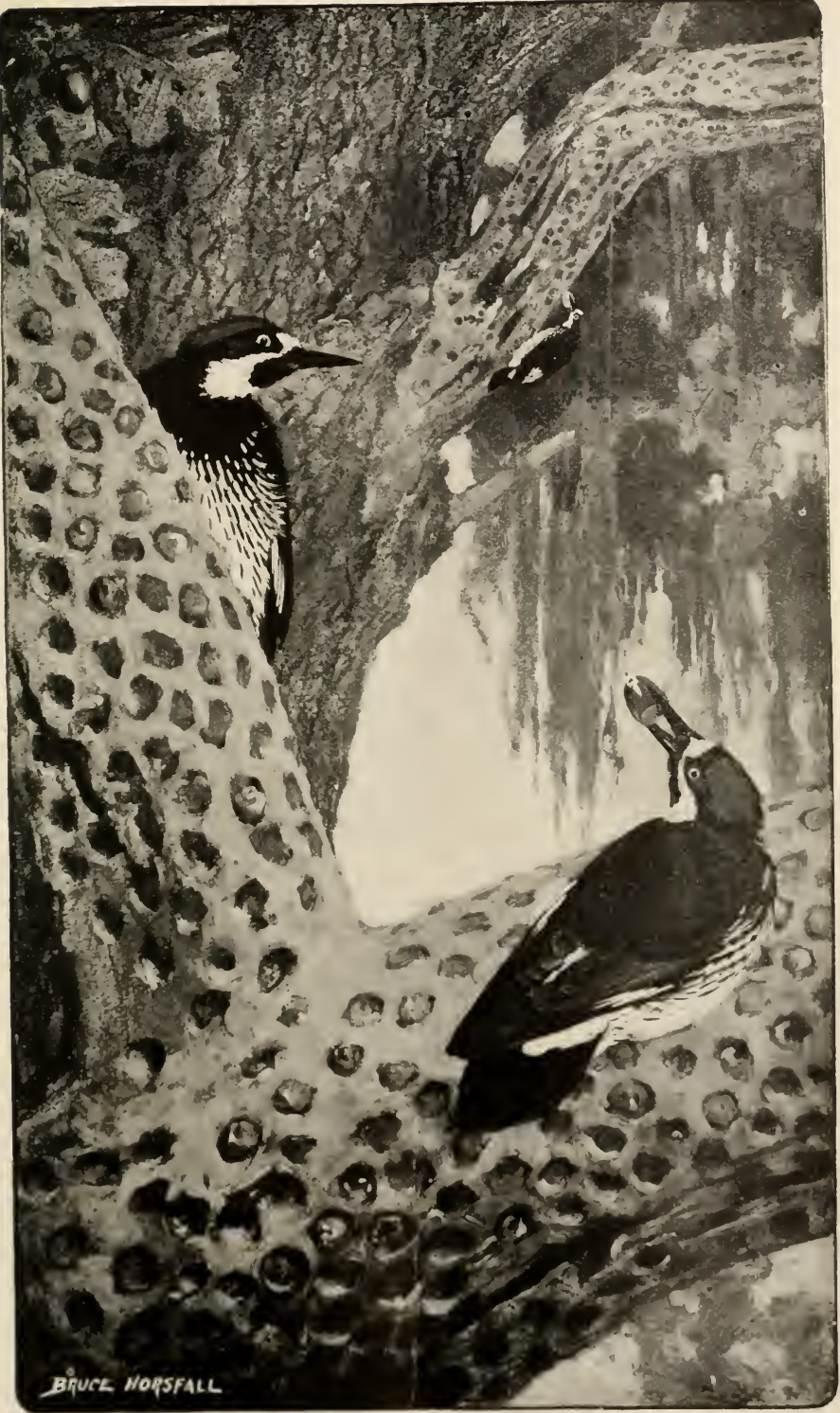

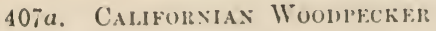



speech, emphasizing his conversation with ludicrous contortions of his body.

But his uniqueness lies in his habit of storing up food for the winter, according to the advice of King Solomon, - food in this instance meaning the cartridge-like acorns of the live oaks. For each one of these he chisels out a hole which is so exact a fit that once the nut is in, man requires a tool to get it out. Round and round a tree he goes, filling it as full of these acorns as the law allows, and not sparing the limbs until it is honeycombed from top to bottom. In front of the residence of Dr. David Starr Jordan at Palo Alto, stands one of these trees, a living monument to the industry of Melanerpes formicirorus bairdi.

Like the redhead again, he is a valiant defender of his property, - be it acorns, eggs, or nestlings. He is universally lord of all he surveys, fearing no bird of his own size and no quadruped of any size. He will fly furiously at a squirrel, and set upon a cat without the least hesitation, aiming directly for its eyes, provided puss is dangerously near his young. Though I have never found him quarelsome or tyrannical, I have frequently noticed that smaller birds scatter when he alights in their vicinity.

His nest is excavated in it live oak tree, usually on the under side of a large branch at some distance from the trunk, and from fifteen to twenty-five feet from the ground. Both male and female share in the labor of excavating the nest and in the incubation of the eggs. The cavity is usually about eighteen inches deep, fire 
inches wide at the bottom, and one and three-fourths inches in diameter at the entrance. Incubation lasts seventeen days, and the young remain in the nest about three and a half weeks. They are fed upon the larvæo of black beetles, grasshoppers, ants, and fruit. At certain seasons of the year this species is almost exclusively a fruit-eater, and at all times it prefers vegetable to animal food. Its call is a loud, clear two-syllable note, which it usually utters when perched on top of a stump, where it loves to sit and drum. It returns to the same nest tree year after year, but usually excavates a new cavity, frequently utilizing the old one as a shelter for the male on stormy nights.

\section{GILA WOODPECKER. - Melanerpes uropygialis.}

FAMILY : The Woodpeckers.

Length: About 10.00.

Adult Male: Head, neck, and under parts light grayish brown; middle of crown red; back, rump, and upper tail-coverts barred with black and white; middle of belly yellowish; middle and outer tail-feathers marked with white.

Adult Female: Like male, but no red on crown.

Young: Like adults, with colors duller and markings less distinct.

Geographical Distribution: Sontheastern California, southern part of Arizona and New Mexico, south through Lower California.

California Breeding Range : Around the Lower Colorado River, near Fort Yuma.

Breeding Season: May.

Nest: In excavations in trees or in giant cacti.

Eggs : 3 to 5 ; white. Size $0.96 \times 0.71$.

The range of the Gila Woodpecker in California is restricted to the sontheastern corner, bordering on the Lower Colorado River, in the vicinity of Fort Yuma. 
Here it breeds in small numbers, making its nest in cottonwoods, sycamores, and wherever possible in the giant eactus. In fact, Mr. Anthony asserts that its range is governed by the presence or absence of the giant cactus, in which it nests, and on the fruit of which it feeds.

In general habits it is like the Californian woodpecker, - talkative, noisy, and restless. "When flying from one point to another it usually utters a sharp shrill 'hiut' two or three times, resembling the common call of the phainopepla, and which may readily be mistaken for it. It is also more or less addicted to drumming on the dead tops of cottonwood, sycamore, and mesquite trees. Its flight, like that of most woodpeckers, is undulating rather than swift" (Bendire).

The food of the Gila Woodpecker consists of larvæ, grasshoppers, ants, beetles, the fruit of the giant cactus, and the berries of that species of mistletoe found on oaks and mesquite trees in that region. The same nest exeavation is used several years in succession. Major Bendire salys that incubation lasts about two weeks, and that both sexes assist in preparing the nest and brooding the eggs.

\section{WHITE-THROATED SWIFT, - Aeronautes}

\section{melanolencus.}

FamiL: : The Swifts.

Lenglh: $6.00-7.00$.

Adulls: Tail about half as long as wing, with stiff narrow feathers; upler parts blackish; throat, breast, wing-patch, and rump white; sides dusky or black. 
Geographical Distribution: Western United States, from the Pacific east

to Western Nebraska; from Washington to Lower Calilornia.

California Breeding liangc: Among the mountainous regions east of the

humid coast belt, and along the coast southward from Santa Cruz.

Breeding Season: June and July.

Nest: Glued to crevices of cliffs or walls of caves ; made of short twigs

and weed stems and soft vegetable matter; lined with a few feathers.

Eggs : 4 or 5 ; white. Size $0.88 \times 0.53$.

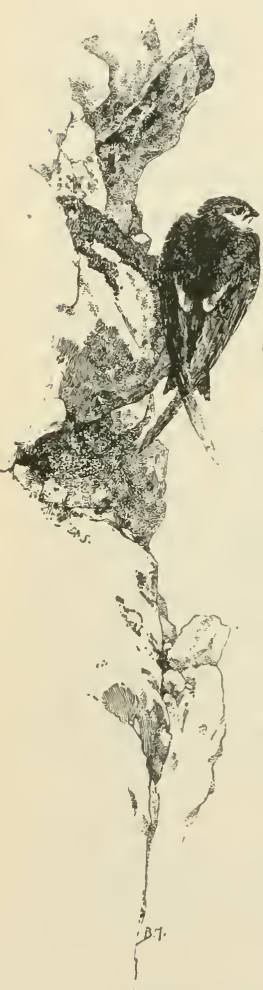

The IVhite-throated Swift is an abundant resident of Southern Cali-

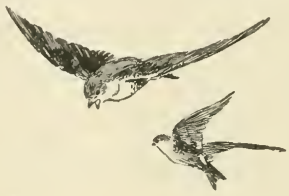

fornia, and may be seen in numbers in the vicinity of the Old

Mission at San Juan Capistrano, as well as in Los Angeles County and other localities. Its nesting site is the most inaccessible cliff of the regions where it is resident; consequently only a few nests have been investigated. The best account of one is given by Mr. W. B. Judson, of Los Angeles, where the nest was found. "It was situated about eighty feet from the top of a cliff and one hundred and twentyfive feet from the ground, in a cave about seven feet high, ten feet wide, and extending some seven feet in the face of the eliff. The nest was placed in a small hole in the roof of the cave, -

425. WHITE-THROATED SwIFT.

"Its nesting site is the most inaccessible cliff.", almost too small to get my hand in without enlarging it, - extending 
about a foot up in the rock, and then there was a small cleft in which it was placed. It was so firmly glued to the rock that it could not be pulled off without tearing it to pieces. The materials of which it was constructed felt soft and spongy; there were no sticks or twigs in it, and it was lined with a few feathers. Evidently it had been in use during more than one season, as the vegetable matter was quite disintegrated."

\section{8 a. WESTERN BLACK PHOEBE. - Sayornis nigri-} cans semiatra.

Family: The Flycatchers.

Length: $6.25-7.00$.

Adults: Entire plumage slate-black, except for white belly; onter web of tail-feathers and under tail-coverts white.

Young: Similar to adults, but wing-coverts tipped with light rusty.

Geographical Distribution: Pacific coast from Mexico to (1regon ; eastward nearly to Southrin Texas.

California Breeding Range: In lower Sonoran zone from latitude $28^{\circ}$ northward.

Breeding Season: April 15 to June 15.

Nest : A compact though bulky mass of mud mixed with dried grass, weed fibre, and hair; lined with soft feathers; attached to rocks, beams of buildings, or brilges.

Eygs: 3 to 6 ; white, sometimes finely speckled with reddish brown around the larger end.

The Black Phøebe resembles the Eastern phobe even more than does the Say. It builds about human habitations near water, and uses mud in the construction of its nest, which is on the same plan, though lacking the beanty, of that of the Eastern variety. Like the latter, it is greatly attached to a locality once used as a nesting site, and returns to it year after year, repairing the old nest 
or building a new one. The exterior of these nests is made of mud mixed with scraps of vegetable fibre and hair. Inside, it is lined with fine roots, strips of bark, hair, wool, and feathers. For some unexplained reason the nest of this species, like that of Say phobe and the Eastem phœbe, is infested with innumerable insects, which frequently cause the death of the young. This seems strange in the case of birds that splash in the water so much as do these. One of the first lessons taught the young is the delight of a bath in an irrigation ditch; to this wholesome recreation they are initiated when about five weeks old.

The food habits are those of all flycatchers, - a restless darting out into the air after a passing butterfly, or down for a grasshopper, and always back to the same perch. Nearly every insect with wings is seized by them with equal alacrity, and their capacity for eating is out of all proportion to their size. Especially is this true of the nestlings, to whom food is brought every two or three minutes and eagerly swallowed with no indications of surfeit. Possibly it is on account of this they develop so rapidly, for in fourteen days the weak naked babies becorne fully fledged Phobes, with a pretty call, not unlike that of their parents, but which, to imaginative ears, suggests "feed me, feed me!" And I may add that this is the interpretation put upon it by the father bird. At first the feeding is done by regurgitation, but when five days old the nestlings are fed on fresh insects.

As soon as they are ready to fly the male takes entire care of them, leaving the patient mother to repair the 
old nest and undertake the bringing up of a second family. He teaches the young to eatch food on the wing, just as the Arkansas and Cassin kingbirds teach theirs, and as I believe all flycatchers do, - by releasing a maimed insect in the air just in front of the hungry little one, who, forgetting fear, instinctively darts out to eatch it. It this the father gives a cheery note of triumph, which the nestling soon imitates and unconsciously begins to utter whenever he is successful in seizing his small prey. This and a low twitter during the mating season, and the conventional announcement of his name in a plaintive tone, are all the songs he ever sings.

475. BLAC K-BILLEI) MAGPIE. - Pica pica huulsonis

Family: The Crows, Jays, Magpies, etc.

Length: 17.40-21.75.

Adults: General plumage iridescent black, except belly and wingpatelses white; bill and naked skin of orbital regions black; tail long and graduated.

Foung: Head, neck, ete. dull black, without iridescence on crown.

Cícographical Distrihution: Midile and Western Nortl America, Alaska and Hudson Bay to Northern Arizona and New Mexico; east to Eistern Colorado.

Ereeding Rirnge: East of the Sierra Nẹvada, north to Shasta valley, south to Mono Iake.

Breding Season: $\Lambda_{\text {pril }} 20$ to July 1.

Nest: Globular; 2 feet in dianceter and 3 feet hich; made of sticks. inner walls of mul, lining of fine rootlets; entrance lıole on one siele : placer in small oaks, cottonwords, and pines, 3 to 20 feet from the grommi.

Eygs: 7 ; grayish, heavily and regularly bloteled with brown. Size $1.37 \times 11.89$.

To the tourist or sojourner from the East, the Magpie is one of the most interesting features of Western fauna, 
ranking with burrowing owls and prairie dogs. From the time one first catches a glimpse of these Magpies until one's face is set homeward, they are a fascinating study. Much handsomer and more intelligent than crows, they are comparatively less known. The average Westerner regards them as a nuisance, and I suspect he is not far wrong in this estimate, but, like their relatives the jays, they yet have something to commend them.

About Lake Tahoe the Black-billed Magpies abound; they build their nests in the young oaks as close to the dooryards as they are allowed. One pair that I watched had nested for six years in the same tree ten feet from a dwelling, and were almost as tame as chickens. They were tolerated on the ground that small rodents will not come where they are. While this theory is not entirely borne out by the facts, there is a grain of truth in it, for a magpie will watch the burrow of a ground squirrel like a terrier at a rat hole and pounce as swiftly on his victim. His curiosity knows no bounds, and any unusual appearance of the neighborhood he must investigate and talk over. An experiment of hanging bits of black, white, red, and yellow cloth on the bushes near the abode of magpies resulted in a curious selection of the yellow and white first and an apparent terror of the red. Repeated experiments seemed to prove that this color was repulsive to the birds, and for a long time I could not guess why, knowing that raw red meat was a favorite dainty. Finally, noticing how excited both birds became at the approach of some little Indian girls who lived in the fishing village and who were dressed in 
red calico gowns, I was forced to conclude that in some way the wise old birds associated that color with persecution by the children. It seems that the latter had played the old cross-string trick with red flannel, which had been promptly seized again and again by the birds, greatly to the delight of the tricksters, to whom the temptation to snare by this means became too great to be resisted. The feathered playmates learned to shun both the color and the children.

The nest in the oak tree was very bulky, and bore evidence of having been used for several broods. On or in a platform of sticks was a bowl of mud, lined with cattle hair and roofed with a dome-shaped mass of sticks. On opposite sides were entrance and exit, and through the former the tail of the brooding bird usually extended when she was on the nest. For eighteen days her beady black eyes could be seen at the exit, for scarcely ever was she absent, except when she went down to bathe, which was always once and sometimes twice a day. The male ferl her devotedly on a great variety of dainties, - crayfish, dead minnows, young squirrels, small snakes or lizards, big black crickets, and, alas! eggs and young of swallows. The latter were nesting in numbers in hollow piles of an abandoned pier near by, and wherever the opening was large enough the Magpie helped himself. Young chickens were also his victims.

On the day the young Magpies emerged from their shells, the mother joined her mate in stealthy journeys to and from the nest. Silently they slipped through the trees, but at the doorway of their home never failed to 
"talk" in low, gurgling tones as they fed and cared for the little ones. It was wonderful how those harsh voices became modulated for baby ears. Any approach to the nest on my part was received with a chorus of shrieks from both parents, defiant threats directed toward my eyes, and other unpleasantness ; but, fortunately, it being only eleven feet from the ground no great climbing was necessary. Surely such homely babies needed no violent defence from kidnapping! They were naked, dark greenish purple, with sightless knobs for eyes and long necks on which the dark skin hung in loose wrinkles. But to the doting parents none were ever more beautiful and none were more closely guarded. Crickets, other insects, and larvæ were crammed down their throats at the rate of forty-three in thirty minutes, - not much for them, but a goodly amount for the hard-working providers to catch and bring. Each one was carefully crushed, the crickets being deprived of their wings and legs before being given to the nestling. To watch these industrious hunters pursue their game in the wet grass near the lake or the dryer wood lots where near the rotting $\operatorname{logs}$ they found the huge black crickets, was fully as interesting as to see them feed the young. Though so dignified and stately when walking leisurely on the ground, they became ludicrously excited when in a hurry, and with long tail elevated swooped down upon the unfortunate insect with the air of one doing great deeds.

At the end of two weeks the nestlings were covered with the iridescent sheen of the adults, but their tails 
were as yet only promises. These developed with surprising rapidity, and when the mature age of three weeks was reached, were as long as babies could manage. For several days there had been restless little heads poking out of the doorways, and on the twenty-second day one youngster, assisted by much clamor on the part of the excited parents, hopped out and sat on a branch. I came too near for his comfort, and away he flew or blew, for his long tail refused to conduct itself in proper magpie fashion and filled with wind like a sail, pushing him helplessly before it. One parent followed his adventures, while the other remained to guard the three left in the nest. These were looking out with longing eyes. Thinking four babies too much for one mother to care for, I resolved to appropriate one of them. It proved a very amusing pet, crossing the continent with me, and eventually became one of the magpie colony at Lincoln Park, Chicago, where it still exists. While with us it learned to say a number of words quite distinctly, as well as to mimic the bark of a dog, the whine of a puppy, and the mew of a kitten; it was far more intelligent than my pet crow and no more mischievous than my blue jay. Family characteristies are prominent in the three.

476. YKLLOW-BILLED MAGPIE. - Pica nuttalli.

Family: The (rows, Jays, Magpies, etc.

Length : $16.00-18.00$.

Alults: Similar to black-billed magpie, but smaller and with bill and nuked skin of orbital region bright yellow. 
Geographical Distribution: California west of the Sierra Nevada, from' Sacramento south to Los Angeles.

Breeding Range: In the Sonoran zone west of the Sierra Nevada mountains, north to Red Bluff, south to Santa Paula.

Breeding Season: April, May, and June.

Nest : Similar to that of the black-billed magpie ; placed in oaks, sycamores, and willows, from 25 to 50 feet from the ground.

Eggs: 7 ; greenish gray, more or less marked with brown over the whole surface. Size $1.25 \times 0.86$.

The Yellow-billed Magpie is identical with the preceding species except in the color of the bill, which is yellow, varying from bright straw-color in birds found in central California to dull gravish buff in those inhabiting the northeastern portion. He is nearly two inches shorter than the black-billed, and smaller in proportion. His call-note also is less harsh and loud, being somewhat like "quee-quee-quee" instead of "chack-chack" or "quat-quat" of the larger species. The breeding habits are identical; a full description will be found under the preceding species. Much persecution is rapidly decimating this variety, and where it was abundant twenty years ago it is now scarce. Although much more restricted in its range than that of the black-billed, it is found in more thickly populated portions of the State about Sacramento valley and is a better known bird. It is this species that first arrests the attention of the tourist as the Eastern train pulls slowly into Sacramento.

Eminently social, like all their family, these birds have a certain esprit de corps which leads them to forage in bands, making common cause against an enemy or plotting wickedness together, talking incessantly as only they can do. 
487. WHITE-NECKED RAVEN. - Corvus cryptoleucus.

Family: The Crows, Jays, Magpies, etc.

Length: $18.75-21.00$.

Adults: Entire plumage iridescent black, with purplish lights, except the feathers of neck, which are white at base.

Geographical Distribution: Southwestern United States, principally in the lower Sonoran zone, from Texas to Sonthern California and from Southern Colorado sonth to Mexico.

California Breeding Range: Southern part of the State in lower Sonoran zone.

Breeding Seceson: Nay 6 to July 1.

Nest: Poorly constructed and somewhat larger than those of our common crow ; made of thorny twigs ; lined with eattle hair, rabbit fur, bark, grass, and moss; placed from 7 to 20 feet from the ground.

Eggs: 3 to 8 ; pale green, with longitudinal streaks and blotches of gray, brown, and lavender, extending from end to end of the egg, and partially hidden by spots and blotches of brown. Size $1.74 \times 1.19$.

To the careless observer the White-necked Raven differs from the American raven only in being more slender and slightly smaller, the white of the neek being at the base of the feathers and not conspicuous. In appearance and voice ats well as size, they resemble closely the common erows, though more than an inch longer. Their nests are placed in giant yueca, eactus, mesquite, or other low bushes, and oecasionally in oaks or willows. In structure they resemble the nest of a crow, being loosely thrown together of twigs and lined with hair from eattle. Old nests are repaired and used year after year, until they become excecelingly offensive from filth.

Incubation begins after the set of eggs is completed, and lasts twenty-one days, only one brood being raised each season. 
Like the crows, these Ravens feed upon insects and animal food as well as grain, coming close to the abodes of men in their search for it. When their appetite has been appeased, they will hide the remainder of the feast under a stone or a piece of bark, in a hole or in the ground, as do squirrels. By vigorous excavating with their bills a pit is dug, into which the superfluous dainties are tucked, and the whole is again covered with dirt, which looks as if it had never been disturbed. In some occult way the bird remembers just where each bit is hidden, and never fails to return for it.

Like the crows, also, they are found in large flocks; even at breeding season they are somewhat gregarious; but they are totally unlike the American ravens, in being easily tamed and in preferring the lowland deserts to the cliffs. In California they are found only in the southern and southeastern portions, and are nowhere very abundant.

\section{BOBOLINK. - Dolichonyx oryzivorus.}

Family: The Blackbirds, Orioles, etc.

Length: 7.00-8.00.

Adult Male in Spring: General plunage black; patch on hind-neck cream or buff; wing and fore part of back lightly streaked; scapulars grayish; rump and upper tail-coverts white.

Adult Female: General plumage yellowish brown, under parts paler; upper parts and flanks streaked with blackish; crown divided by a median buffy stripe.

Adult Male in Winter: Similar to adult female, but streaks on upper parts blacker.

Young: Similar to adult female, but more buffy, with necklace of faint dusky spots; flanks not streaked. 
Geographical Distribution: Generally throughout North America, and seems to be gradually reaching the Pacific coast, migrating to the West Indies and the valley of the Amazon.

Breeding Range: In Transition zone in open prairies locally, throughout its habitat.

Breeding Season: May 15 to July 1.

Nest; Of dried weeds and grasses; hilden on the ground among tall grasses or concealed in a depression.

Eggs: 5 to 7 ; dull or grayish white to redelish brown, irregularly spotted and blotched with browns and purples. Size $0.85 \times 0.64$.

Although at present only a rare fall visitant in California, there are evidences that the Bobolink of the East is moving westward with the great tide of civilization, and gradually forsaking the Itlantic coast to become a permanent resident of the Pacific States. There is no other bird quite like him or that can take his place in the heart of one who has heard his tinkling banjo-like song in the meadows cast of the Mississippi, -

"The rollicking, jubilant whistle,

'That Hows like a brooklet along."

While his demure brown sweetheart listens in the long meadow grass, Robert of Lincoln flies upward on quivering wings, exploding with melody, and the higher he Hies the more joyously he sings. It is a rhapsody on the glory of the June morning and the joy of loving.

His nest is securely hidden in the tangle of elover or wild grass, often placed in the hollow made by a cow's foot, sometimes woven among the clover stems and almost impossible to find. The mother bird broods alone for thirteen days, while Robert frolics gayly over the fields with others of his sex, always within call, but seldom or never feeding her. When the young are hatched, how- 
ever, he takes charge of them, and I have found him alone with a brood of seven nestlings huddled in a fence corner in Michigan. The young are born naked except for a scanty sprinkling of down, through which their skin is conspicuously visible. When feathered, they resemble the females, and by August first, when even Robert has doffed his gay suit, it is difficult to tell one nember of the family from the others. This is their travelling costume, and they start at once on their long journey south to
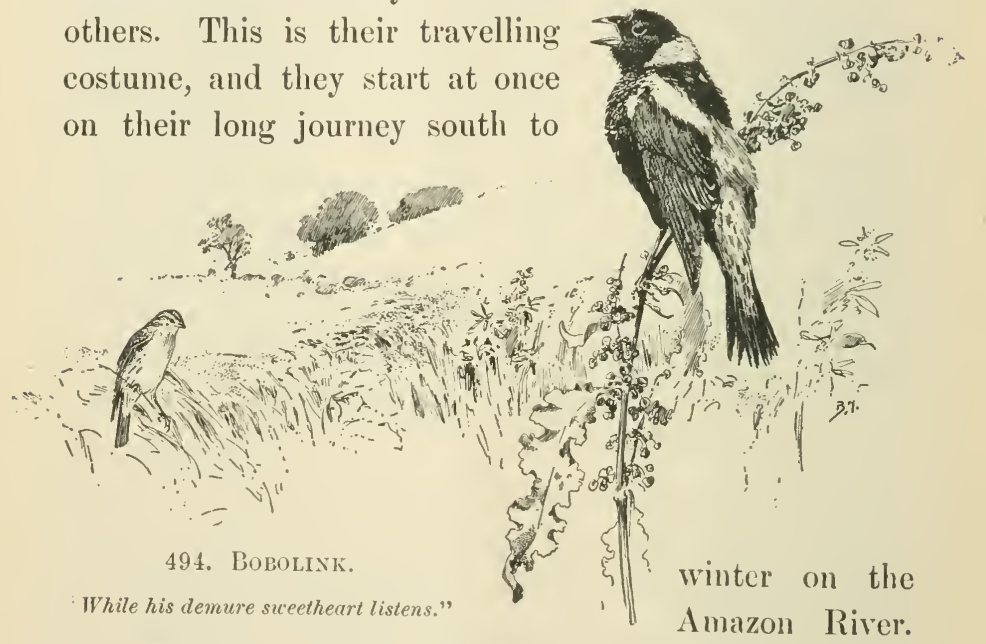

En route they are known as rice birds, and make havoc of the rice fields of the Southern States, so that farmers and sportsmen alike make war upon them, selling them as "ortolans" in Southern markets. In the spring they come north again, reaching the rice fields in April, when the tender shoots are a few inches high, and stop there a few days to pull them up before coming farther to their breeding grounds. At this season Robert has on his 
bright new wedding suit of buff, black, and white, and is called the "reed bird."

\section{8 a. SPURRED TOWHEE, - Hortulanus maculatus montanus.}

Family : The Finches, Sparrows, etc.

Length : 8.50-8.90.

Adult Wale: Head, neck, chest, and upper parts except rump black; rump grayish; white patch on outer tail-feathers; small white patches on wings; belly white; flanks çhestnut.

Adult Fernule: Similar to male, but brown in place of black; back indistinctly streaked.

Foung: Upper parts streaked black aud brown; inder parts rusty.

Geographical Distribution: Rocky Mountains, west to interior of Cali. fornia; north through Washington; south to Lower California and Mexico.

California Breeding Range: Upper Sonoran and Transition zones, east and south of the humid coast belt nearly throughout the state.

Breeding Seuson: June 1 to July 10.

Vest: Of bark, leaves, and small sticks; lined with crrass; placed on or near the ground in bushes.

Eygs: 4 or 5; pale greenish, finely speckled at the larger end. Size $0.88 \times 0.70$.

Remark: The San Diego towhee, $P . m$. atratus, is very similar to the spurred lowhee, but darker and with white markings more restricted.

The Spurred Towhee is very like the common towhee or chewink of the Eastern United States in coloring, except for the white mixed with the black of his back and wings. He is a eommon bird in the dense woods of the lower sierra Nevada mountains, breeding in the edge of the clearings, either on the gromul or a few feet up, in celar saplings and manzanita bushes. Often as I have seen them in a morning's trimp the spurred Towhee greatly outmumbered other birds, particularly if my way lay through the heary timber. 
His vocal efforts are somewhat different from the belllike notes of the Eastern species, and have been so well described by Mr. Keyser in "Birds of the Rockies" that I quote his words rather than attempt a description of my own :

"It is a cross between the song of the chewink and that of dickcissel. The opening syllabication is like dickcissel's; then follows a trill of no specially definable character. There are times when he sings with more than his wonted force, and it is then that his tune bears the strongest likeness to the Eastern towhee's. But his alarm call! It is no 'chewink' at all, but almost as close a reproduction of a cat's mew as is the catbird's well known call. Such crosses and anomalies does this country produce!

"On the arid mountain sides among the stunted bushes, cactus plants, sand, and rocks, this quaint bird makes his home, coming down into the valleys to drink at the tinkling brooks and trill his roundelays. Many, many times as I was following a deep fissure in the mountains, his ditty came dripping down to me from a spot far up the steep mountain-side - a little cascade of song mingling with the cascades of the brooks."

588 b. OREGON TOWHEE - Hortulamus maculatus oregomus.

Family: The Finches, Sparrows, etc.

Length: $8.00-8.60$.

Adult Male: Upper parts black, with white streaks on back concealed, and all white markings much restricted; small white round spots at tips of wing-coverts; white patches on outer tail-feathers less than an inch in length; sides dark reddish brown. 
Adult Female: Similar to male, but dark sooty brown in place of black on head, neck, chest, and upper parts ; sides deep reddish brown.

Young: Upper parts almost uniform dark brown; throat and chest dusky; neck streaked; under parts dark buffy.

Geographical Distribution: Pacific coast, from Southern California to British Columbia.

California Breediny Range: Humid coast belt as far south as San Francisco.

Breeding Season: May.

Nest: Of grasses and leaves; lined with finer grasses; placed on the ground or in bushes and stumps.

Eggs: 4 or 5; pinkish white or pale greenish, thickly speckled with cinnamon-brown. Size $0.94 \times 0.70$.

The Oregon Towhee which, south of Mendocino County, Mr. Grimnell has listed as the San Francisco Towhee, differs only slightly from the latter, but has a more restricted range in ('alifornia. In habits it resembles the common towhee.

The usual nesting site of this species is on the ground, in a tangle of ferns or grasses well shaded under low bushes; when, however, the proximity of enemies renders a ground nest dangerous, the birds wisely choose the top of a stump hidden among vines, or the thick branches of bushes. The same locality is sought by them year after year.

In the deep woods where the California partridge nests, it is not unusual to find the eggrs of that game bird in the nest of the Oregon Towhee. Mr. Cohen, of Alameda, records one Towhee nest four feet from the ground on a live-oak stub and containing four Towhee egras and fifteen eggs of the partridge. Another reeorded by him was on the ground, and contained three eggrs of the Towhee and eighteen of the partridge. The Towhee abandoned the nest after six partridge eggss were laid, 
leaving the partridge to rear the brood. Inasmuch as the Towhee eggs hatch in two weeks, the young being very dark colored and naked, while the partridge eggs require three weeks and the young are lively little balls of down able to run about as soon as dry, the sacrifice of the Towhee's brood is inevitable whenever the two are deposited in the same nest.

Mr. Anthony records finding an egg of this Towhee in the nest of a rusty song sparrow.

\section{LARK BUNTING. - Calamospiza melanocorys.}

Family : The Finches, Sparrows, etc.

Length: $6.12-7.50$.

Adult Hale in Summer : Entire plumage black or slaty, except for white patch on wings, and sometimes white marks on tail-feathers. Winter adult similar to summer female, except chin, wings, and tail black. Adult Female: Upper parts brownish gray streaked with dusky; white wing-patch smaller and tinged with buffy; tail, except middle feathers, spotted with white; under parts white, streaked on breast and sides.

Young: Similar to adult female, but more buffy; feathers of upper

parts bordered with buffy white; streaks on lower parts narrower. Geographical Distribution: Plains of Dakota and Kansas, west to

Rocky Mountains, north to United States boundary, south in winter to Lower California and New Mexico; occasional west of Rocky Mountains. Irregular in Southern California.

California Breeding Range: In San Diegan district. (Very rare.) Breeding Season: April and May.

Nest : Of grass and fine rootlets; lined with finer grasses and vegetable down ; sunk in the ground, or placed under a tuft of grass or weeds. Eggs: 4 or 5 ; plain pale blue. Size $0.85 \times 0.65$.

THE Lark Bunting, in form, size, and general habits of song and nesting, resembles the bobolink of the Eastern United States in such a way as to be frequently mistaken for that bird by careless observers. The dark plumage 
of the male, with his conspicuous white wing-patches and occasional white outlines on the tail, renders him a striking object as he shoots up from the grass like a rocket and whistles his merry song. This he does in true bobolink fashion, never pausing to catch his breath until, sliding downward through the air, he alights within twenty feet of his starting point and finishes the trilling begun in midair. Over and over, all day long, during the nesting time, he repeats this double aërial feat of flight and song. It is as if a sudden explosion of joy within him sent him skyward on wings of music. Its force spent, he flutters down to the quiet gladness of earth once more and soliloquizes sweetly on the wonder of it, as he swings on a low pereh.

Like the bobolink, too, he changes his summer plumage to a less striking suit of brown like that of his mate, before he starts on his fall trip to the plateaus of Mexico. His nest is deftly hidden in the weed clumps of a mountain meadow, and neither he nor the demure little mother bird will reveal its whereabouts. In this trait also he resembles the bobolink, for, instead of rising from the nest as the meadowlarks and some sparrows are apt to do, the Iark Bunting slips through the weeds for some distance before reaching her grass-lined cradle.

The baby Buntings are fed exclusively upon insect liet as long as they remain in the nest, and for some time after leaving it. They lisle in the cover of the grass and weeds until able to fly well, and at night they cuddle into the thick underbrush, like little quail, with both parents on gruard. Even after the first real flight it 
is not uncommon to find the family keeping together, and by September they have joined bands tlitting southward for the winter.

The call-note of this species is a clear, sweet whistle like an interrogative "who-ee?" and is heard oftenest during spring and fall, when the migrating flocks are feeding along the way. In quality it is not unlike the fall call of the bob-white, but much thimner in tone.

\section{PHAINOPEPLA. - Phainopepla nitens.}

Family : The Waxwings and Phainopeplas.

Length: 7.00-7.75.

Aclult Male: Plumage uniform glossy blue-black, except for white patch on inner webs of primaries; a long thin crest on crown. Winter plumage similar, but many feathers bordered with white.

Adult Female, and Young: Brownish gray, rather pale on under parts. Geographical Distribution: Arid region of Mexico and contiguous parts of

United States from Western Texas to Southern California. California Breeding Range: Arid lower Sonoran zone.

Breeding Season: May to July.

Nest: Saucer-shaped, rather compact ; of plant fibres, weed stems, twigs, and plant down; usually in pepper or oak trees, or bunches of mistletoe.

Eggs : 2 or 3 ; dull grayish white, thickly spotted with a neutral tint, dark brown and purple. Size $0.89 \times 0.69$.

If, when driving through the streets of Redlands or Riverside, you see a slender bird of iridescent black plumage with a striking black crest, feasting on the rosecolored berries of the pepper trees, or sailing through the air, his conspicuous white wing-patehes standing out like sails, be sure that it is the wonderful Phainopepla, one of the most interesting of Western birds. It is a common resident throughout Southern California, and 


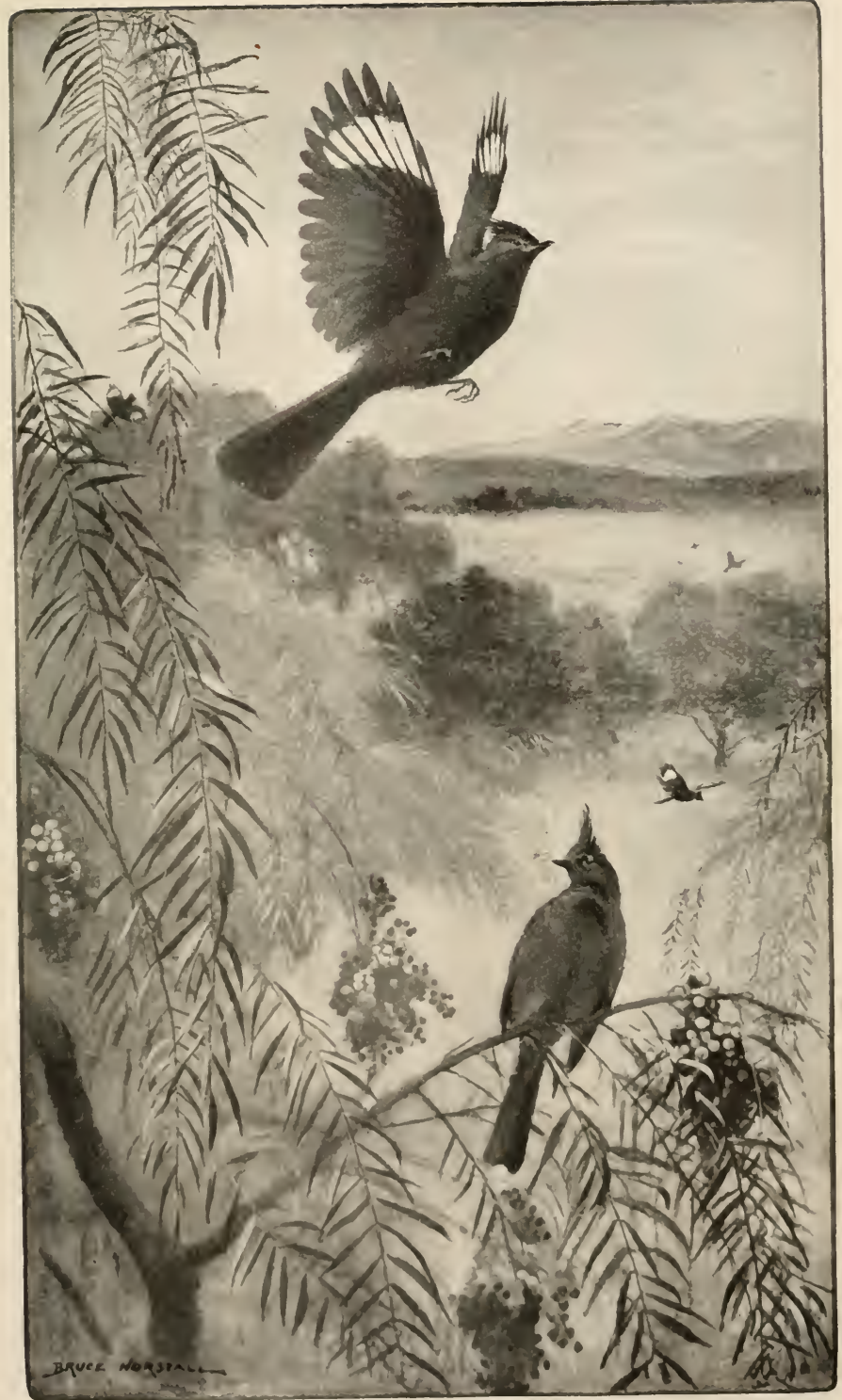

620. P'HANOI'EPLA

Phainopepla nitens 

may be studied in almost any locality from Pasadena to San Diego and eastward. Stragglers have been observed as far north as San José, Chico, and Marysville, but their usual haunts are the warmer regions of the southeastem part of the State. Here they nest in the oaks and mesquites, building a loose flat structure which once seen will ever afterward be easily identified. I believe that these birds, like the cedar waxwings, usually remain mated for life, but when the sumny May days come the male performs wonderful aërial gymnastics to win the admiration of the demure brown female. With a not unmusical prelude he springs into the air, performs a somersault much like a long-tailed chat, and comes tumbling back to his perch, where he alights easily and gracefully, not having ceased his song for a moment. The only notice his quiet mate takes of this is a slight elevating of her crest, as a haughty lady might raise her cyebrows. The male's fine erest is constantly erect, coekatoo fashion, as he continues his adulation. In fact, the only time I ever saw it lowered was when one of these handsome birds seemed to be scolding a female, whether his mate or not I do not know. He stood before her with erest down and head stretehed out on at level with his body, wings tight to his sides, uttering harsh notes and swaying from side to side in anger. As soon as she flew away he resumed his eating.

One pair which nested in an oak tree near Pasadena appeared suddenly in the neighborhood on the morning of May 16, and a few days later were discovered at work on a nest. A wateh was kept from a distance with field 
glasses, and while it was impossible to see how the weaving was done on account of the thick foliage, it was easy to ascertain that the male bird was the architect. Only once did the female drop down to the nest, and then she remained so long as to make it seem certain an egg was laid. However, the next day she was flying away over the valley with apparently no thought of family cares, and was not observed near the nest tree again until the third day after. Two days later sitting began. In this the male shared to a limited extent only. At least he remained at the nest, but whether or not he actually brooder the eggs I do not know, because a fear of causing the birds to desert prevented a watch at close range.

On the fourteenth day the male was observed visiting the nest very frequently, and an examination revealed two pinkish bits of bird life, naked except for a sprinkling of thin gray down on top of heads.and shoulders. There was nothing in their appearance to suggest the elegant form of their parents, and they might as well have been young sparrows. From that time on we obtained an intimate knowledge of their development by keeping watch under the tree. The intervals of feeding varied with the time of day. From four to six A. M. the shortest wait was five minutes and the longest seventeen. During the day as long as one hour sometimes intervened between the meals. Insects and berries were swallowed by the adults, who fed the young by regurgitation. In the case of the waxwings and Phainopeplas the process of regurgitation lacks the usual violent pumping motion, but consists of a quick eructation of the food from the throat into the bill. 
In twelve days the nestlings were growing quite a respectable coat of brownish gray like that of the female, and could be seen stretching their wings in the saucershaped nest so near the edge that they were in imminent danger of falling off. Their call was exactly like that of the young cedar waxwings, a prolonged "pee-eet," sweet and plaintive. The song of the adult is more remarkable for enthusiasm than musical quality, and his callnote is a shrill two-syllabled utterance in the harsh tones of a blue jay. Besides this he has a variety of conversational tones which remind one somewhat of the gentle wax wings.

In some localities the Phainopepla is ealled the black mockingbird, but he has not a single characteristic of the mockingbirl family, and certainly his rocal powers do not put him in that list.

\section{BLACK-THROATEI) GRAY WARBLER.}

Dendroica nigrescens.

\section{Fanuly: The Wood Warblers.}

Length: $470-5.40$.

Adult Male in Spring aurl summer: Head, throat, and chest black, except for broal white stripe above ear-eoverts, broad white malar stripe, and a yellow sjot over lores ; mper parts bluish gray, the back and sides streaked with black; breast and belly pure white; two white wing-hars; tail witl inner web of two onter feathers white.

Aclult femule in sprin! unel summer: Similar to male, but colors luller; crown usually grayish, often struked with black.

Adult Mule in Full and Irinter: Similar to summer male, but grav of upper parts tinger with brown, aml black markings restricterl, sometimes nearly olsolete.

Adult Fomule in Full and II inter: similar to summer female, but plu. mage softer and streaks on back ant ulyer tail-coverts wanting. 
Foung Male: Similar to adult winter male, but upper parts browner, crown brownish gray, except in frout and sides; streaks on back and upper tail-eoverts concealed; black of throat with white tips to feathers; under parts yellowish.

Young Female: Entire upper parts brownish gray, crown bordered with dusky; under parts brownish.

Geographical Distribution: In mountainous parts of Western United States, from Rockies to Pacific; north as far as British Columbia; south in winter to Mexico.

California Breeding Range: Along the sierra Nevada from San Bernardino mountains to shasta County.

Breeding Season: May and June.

Nest: Compact and eup-shaped; built of gray plant fibres ; lined with hair or feathers; placed in thickets or scrub oaks, or in pines, from 4 to 20 feet from the gromnd.

Eggs: 3 or 4 ; white, dotted with reddish brown and purple, chiefly at the larger end. Size $0.66 \times 0.52$.

Arrong the junipers of the San Bernardino mountains the Black-throated Gray Warbler makes his summer home. The green caterpillars, which some birds refuse and which on some trees seem to be poisonous, are his favorite food. His simple, rather thin little song comes from the sparse stunted growth of the foot-hills where he is busily at work hunting for his dimner, but the bird himself keeps behind the foliage and will not make friends. He seems to be more indifferent than shy, and to prefer the quiet of the thicket rather than gay dashes out into the sunlight. You may know him by the yellow spot in front of and just above the eye. Farther north this species is found frequenting the oak trees almost exclusively, though the nest is usually in a manzanita or hazel bush. In the spring these oaks are particularly infested with the green eaterpillars, and the Warblers never seem to tire of devouring the pests. They lean away over to peer under every leaf, or reach up to the 
twigs overhead, never missing one. Twenty of these worms is an average meal for a Black-throated Gray Warbler, and the total for a day must reach into the hundreds. When several of these busy workers hunt through a tree together, we may feel sure that it must be clean by the time they finish the task.

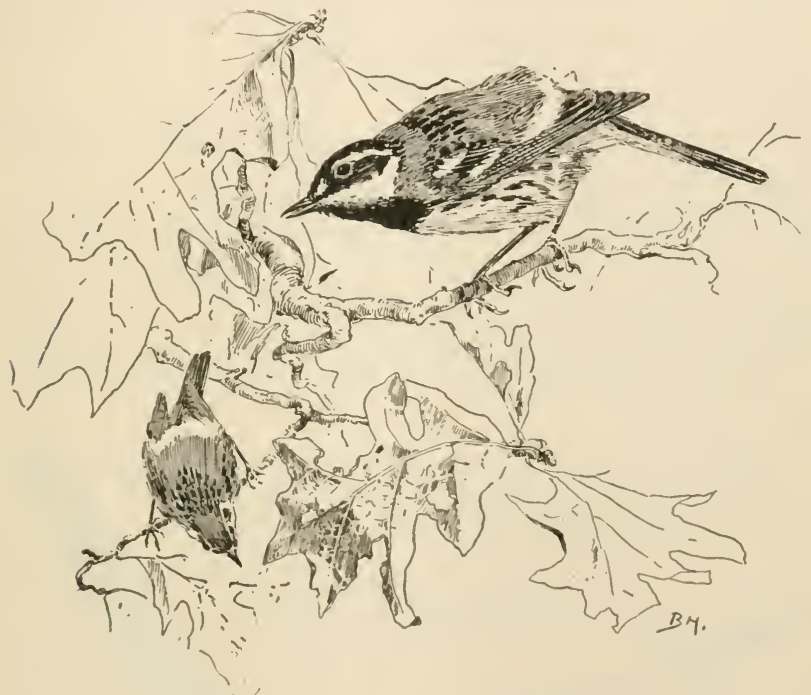

665. Black-throaten Gray Warbler.

"They lean away over to peer under every leaf."

Their common note is a sharp "chip," and their song is rich and very strong during the nesting season. One remarkable trait of these birds is the philosophical ealmness which they exhibit over any domestic catastrophe. When their nest is elestroyed by jays or other enemies, there is a quiet consulting togrether over the misfortune, 
and a beginning again in another bush. A very interesting description of the habits of this species has been given by Mr. Bowles in "The Condor" for July, 1902. The nesting habits resemble those of the yellow warblers.

\section{PLUMAGE BLACK OR IRIDESCENT BLACK}

422. BLACK SWIFT. - Cypseloides niger borealis.

Family : The Swifts.

Length: 7.00-7.50.

Adults: Tail sliglitly forked; entire plumage dusky, and grayish on head and neck; a black patch in front of the eye.

Young: Similar, but feathers tipped with whitish.

Geographical Distribution: From the Rocky Mountains west to the Pacific, and from British Columbia south to Lower California.

California Breeding Range: Irregular and local.

Breeding Season: June 15 to Angust 1.

Nest: On inaccessible cliffs ; made of straw, chips, and horsehair; lined with green leaves and paper.

Eggs: 5 ; white.

THE exact range of the Black Swift, or Cloud Swift, is not definitely known. It is found

breeding in various localities in California, but never

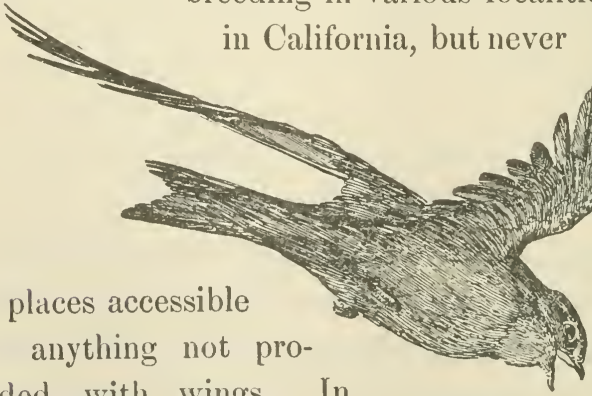

vided with wings. In the Sierra Nevada and the Coast Range of California it occurs

422. BLACK SWIFT.

"While flying swiflly through the air." 
locally in small numbers, nesting in colonies on the high perpendicular cliffs. Dr. Merriam reports it from Inyo County, California, and Dr. A. K. Fisher writes of it in the "Ornithology of the Death Valley Expedition" as follows: "The Black Swift was first observed at Owens Lake near Keeler, California, where a number were seen flying back and forth over the salt meadows. . . . When the flock left the marsh it rose high in the air and went in the direction of the cliffs in the Inyo Mountains, where a colony was evidently breeding."

In flight this species are even more rapid and graceful than the chimney swifts, rarely if ever alighting on the ground or in trees.

Their food consists of small insects caught in their large mouths while flying swiftly through the air.

486. AMERICAN RAVEN. - Coreus corax simuatus.

Family: The Crows, Jays, Magpies, etc.

Length: $21.50-26.00$.

sdults: Entire plumage iridescent black, with purple and green lights; feathers of the throat lanceolate, distinct from one another; feathers of the neck dull gray at the bise.

Geographical Distribution: From the Rocky Mountains to the Pacific; from Canada to Guatemala.

Brecding liange: sionthern C'aliformia and islands adjacent. Recorded north to Red Blnfl and Humbolit Bay.

Breedzny Seceson: March 15 to June 1.

Nest : Bulky structure; of conss sticks ; linel with bark, wool, or goats' hair; placed in trees or on eliffs according to locality, which is always inaccessible.

Eggs : 5 to 7 ; thickly spotted with brown, purple, and gray. size 1.92 $\times 1.27$.

Throvghour the coast district of California, "wherever tall bare cliffs rise from the valleys and deep, steep- 
walled cañons cut into the mountain ranges, the hoarse croaking of the Raven echoes back from cliff and wall." You may watch him soaring through the cañons or over the barren valleys with his mate, but to study his nesting habits at close range would require the cunning of a Mephistopheles. Two or three hundred feet above the valley, and from thirty to fifty below the top of the cliff, on a narrow ledge of rock, sheltered by the overhanging mass, is the place he has chosen to build his nest and rear his young. More inaccessible than an eagle's eyrie, few care to investigate it. Thus secure from human interference, year after year the pair return to it when the winter rains have given way to spring sunshine and all the birds of the air are seeking their mates. But the Raven, having chosen once, remains mated for life; and the nest, once built, serves for all his broods. A few more sticks to strengthen it, a little fresh wool or hair to line it, some strong new rootlets to keep the inner cup in shape, and the cradle is ready. In it are laid five, six, or seven large eggs, greenish, mottled with shades of brown, purple, and pinkish; and both the birds brood alternately until, in twenty-one days, the nestlings emerge from the shells. They are not handsome babies, being naked and of a sickly greenish hue, as if they had been long dead and had become mummified, but they are the objects of great devotion on the part of both parents. One or the other is constantly near them, on the lookout for danger, and ready to act as a decoy to any aspiring investigator. Meanwhile the other has slipped down to the valley or beach for food. It may 
be dead fish, or snakes, or lizards, or sinall mammals. $\mathrm{Or}$ it may be the eggs or nestlings of other birds; for the Raven is a camnibal as well as a thief. Young chickens from the farmyard, young quails from the valleys, or young gulls from the eliff are equally prized in the Raven menu. His appearance in any neighborhood creates as much consternation among the feathered folk as does a hawk, and with even more reason.

In about four weeks the young are realy for flight, and their deprerlations begin under the training of the adults. They learn to sit in watchful silence on the rock where the cormorant has her nest and at the first opportunity snatch the eggs or newly hatched young; to pick up. elams and drop them from a height on the stones, in order to break the hard shells; to trace dead Hesh by a sixth sense, and call their brothers to the banquet. They also learn to splash in the clear, cold water of the momntain stream or lake until every black feather stands ont for itself like a quill. When they rise so wet and shing from this bath in the early morning sunlight, they look like white birds, and they have fooled me more than once, until their loud, hoarse eroak from the far distance betrayed them.

Soon after the young are able to forage for themselves, the family usually disappears from the breeding locality to some valley where food is more easily obtaimable. Here, after a few weeks, they spparate, the youngsters going abont alone and the alult pair remaining torether. Throughout the winter and early spring they hanut the ranches of the more sonthern regions and interion valleys, 
walking with conical dignity over the ground, chasing each other merrily through the air, tumbling, somersaulting, and even trying to fly on their backs, according to Major Bendire. Their ordinary call is a loud "craackcraack " or a deep grunting "koerr-koerr." Occasionally during the early spring they attempt to sing in low gurgling notes a sort of monologue in monotone, as it were, but evidently expressive of their undying affection, and well understood by the mate for whose ears alone it is intended.

488. WESTERN CROW. - Corvus brachyrhynchos hesperis.

Fanily : The Crows, Jays, Magpies, etc.

Length: 17.00-21.00.

Adults: Entire plumage glossy black, with purple lights.

Geographical Distribution: Western North America, north to British

Columbia, except coast of Washington.

Breeding Range: In California, interior valleys, also coastwise locally. Breeding Scason: February 20 to June 1.

Nest: In trees, from 6 to 40 feet from the ground; bulky ; composed of

sticks and other coarse material; lined with fibre, grass, leaves, or

hair, the lining being well quilted together.

Eggs: 4 to 8; olive-green, irregularly marked with spots and blotches of brown and gray and sometimes lavender. Size $1.65 \times 1.15$.

North, south, east, or west, wherever found, the Crow is the same jolly black rascal. He may vary somewhat in size; his plumage may be duller, as claimed, on the Pacific Coast; he may forsake the tall trees and build on the ground, as he is said to do in British Columbia; but his well-known "caw, caw," has the same derisive inflection, and rooks present the same weird combination of black forms silhouetted against the 
evening sky. From these roosts at daylight each morning the entire company scatter over the country in search of food, undoubtedly covering many miles in their flight, but each one finding his way back to spend the hours of darkness in the additional safety that community gives.

As to the economic value of the Crow opinions differ. In California, acorns, beechnuts, berries of various shrubs and trees, seeds and all kinds of fruit, with insects such as locusts, black beetles, crickets, grasshoppers, spiclers, cutworms, angleworms, and injurious larve form a large part of his daily menu. In addition small manmals and snakes, frogs, lizards, snails, crawfish, fish, all kinds of dead flesh, and the eggrs or nestlings of other birds are his victims. It is very disheartening to become interested in watching some brood of song birds develop, and then to find some morning that the crow has made a breakfast on them. And the furmer who finds his cornfield ravaged or his young chicks devoured by a flock of the thieves feels a righteous anger in his heart against the spoilers. The fact that all feathered creatures are arrayed against him is proof to me that, from the bird-lover's standpoint, he does more harm than good.

The Califurnia species is said to build much nearer the ground than his Eastern relative, his nest being rarely over twenty feet up and from that down to five or six feet. My own records are, however, that nests lower than thirty feet are rare even in the $1 \mathrm{~T}$ est. The structure itself is identical with that of the Eastern erow, and 
is always surprisingly well lined and deeper than would naturally be judged from the side view. Eggs are laid in April most frequently, and, since incubation lasts nineteen or twenty days, the young usually make their appearance about the first of May. They are naked and blind, of an ugly greenish hue, and very repulsive to look at. Only one brood is raised in a season, and the remaining summer months are devoted to the training of these nestlings. At the end of two weeks they appear at the edge of the nest, looking out over the sunny slopes with unwinking blue eyes. From this time until they leave, when three and a half weeks old, they are very restless. Little wings are constantly stretched and flapped, uncertain little legs are trained to balance the heavy body, bills grow strong by tearing the food, and before the day for venturing out into the great unfriendly world has come, they have learned much. What yet remains for them to learn the adults will teach them day by day. Instinct plays a far smaller part in their cunning than we have long been taught to believe, and even in crow education it is the example of the adults that teaches the helpless young what to do and how to do it. Let anyone who doubts this course of training, or is inclined to consider that this opinion is founded on sentiment and not on science, watch the development of a family of young crows. 
495. COWBIRD. - Molothrus ater.

Fanily: The Blackbirds, Orioles, etc.

Length: Male 7.75-8.25; female 7.25-7.75.

Adult Male: Head, neck, and chest uniform brownish; rest of plumage glossy black, with a greenish reflection, changing to purplish on back. Adult Female: Plumage plain brownish gray, darker on upper parts, paler on chin and throat.

Young: Upper parts dull brownish gray, feathers bordered with pale buffy; under parts dull light buffy, broadly streaked with grayish brown.

Geographical Distribution: United States and more southern British

Provinces; south in winter to Southern Mexico. Irregular winter visitant in California.

Egys: 8 to 12. Deposited in nests of other birds; whitish, whole surface covered with brown specks and blotches, usually heaviest at the larger end. Size $0.88 \times 0.64$.

Amosg the great herds on the plains of the Middle West Cowbirds are found in great abundance. Perched on the backs of cattle, they search industriously for insects, and in the waterless regions may prove a great blessing to the poor ereatures tormented with heat and Hies. If so, it is the one thing to be said in commendation of a bird universally despised. Unmusieal, its only note is a sereeching call. It is the sneak of the feathered world and hated by all the rest. Too lazy to build for herself, the female lays her eggs in the most eonvenient nest whose owners happen to be away. Her ugly nestling is larger and grows finster than his adoptive brothers, and soon suceeds either in hoisting them ont of the nest, smothering them in it, or starving them by seizing all the food in spite of the parents' efforts to divide evenly. For every Cowbird reared a brood of 
song birds or insect-eating birds has been sacrificed, and Californians are to be congratulated that as yet the Cowbird is only an irregular winter visitant to the southeastern corner of their State.

\section{BREWER BLACKBIRD. - Euphagus cyanocephalus.}

FAMiLY : The Blackbirds, Orioles, etc.

Length: $8.75-10.25$.

Adult Male: Uniform glossy greenish black; head and neck purplish black.

Adult Female: Upper parts brownish slate; head and neck brownish gray, faintly glossed with purple ; wings and tail glossed with metallic bluish green ; under parts brownish gray faintly glossed with green. Young: Similar to female, but paler and withont gloss.

Geographical Distribution: Western North America, north to British Columbia; east to Minnesota and Nebraska; sonth to Lower California.

California Breeding Range: Below Boreal zone, nearly throughout the State.

Breeding Season: April 15 to July 1.

Nest: Placed in low trees or bushes, not over 8 fect from the ground; rather bulky ; made of sticks, plant stalks, grass, shreds of bark, dry grass, and moss, generally cemented with earth or manure; lined with fine rootlets, horsehair, and dry grass.

Eggs : 4 to 6 ; pale gray or greenish white, profusely blotched, marbled, streaked, and spotted with irregularly shaperl markings of brown and lavender. Size $0.96 \times 0.71$.

THE purple grackle of the East is replaced throughout California by the Brewer Blackbird, which closely resembles the Eastern species. It is a trifle smaller, with blue rather than purple iridescence on its black plumage, especially about the head and throat, but has the same conspicuous yellow iris as its kinsfolk. In habits these 
oirds differ from the other California blackbirds in being found less often in the lowland marshes or tule swamps. $\Lambda$ bundant throughout the State, they breed chiefly between the highest altitudes and three thousand feet above sea level. Their choice of a building site is varied. In Lower California they have been found nesting in pine; in western Oregon they sonctimes choose an old woodpecker's hole one hundred feet from the ground; while in the same State nests have been found on the ground, the rim being flush with the surface. At Del Monte a colony nested in the top of a group of tree yuecas, and at Tallac, on Lake Tahoe, I found them nesting on the rotten piles of an abandoned pier. In company with them were tree swallows; and one pair of feirless feathered mites, known as pygmy nuthatehes, had excavated a home in a leaning pile that towered above the rest. In a low, broken post that raised its crumbling top searcely two feet from the water a mother Blackbird brooded day after dar, entirely exposed to view, close to a pier where children played. Strangest of all, the post was the eustomary mooring place of a rowboat, the loop of rope being removed and replaced reveral times daily, and always rubbing the nest as it wats passed over. Yet the mother bird refused to leave it, and only flattened her body and erouched in terror as the rope was lifted. Ifter the little ones were hatehed, June 8, her distress increased, for now a careless move of the boatman might easily overthrow them into the water. One or other of the anxious parents sat on a splintered point of the post just over the nest and 
scolded from morning until night in loud "chacks," watching all who came and went in the vicinity.

Worms, slugs, black beetles, wingless crickets, grasshoppers, and dragonflies were given to the young at the rate of sixteen in twenty minutes, distributed among the four, - not so large an average as in the case of most young birds, but there was but one parent to forage. For the first three days, at least, the food was first swallowed by the adult and afterwards given to the young by regurgitation, but after that they were fed on the fresh insects.

The nestlings were a soft pinky gray when they first broke their shells, and the second day developed thin mouse-colored down on head and back. In five days their eyes opened, and the lines of submerged pinfeathers were plainly visible. On the twelfth day the little feathered ends had burst through the sheaths. And now began an alarming process of stretching and pecking and wriggling, - alarming because in this case it seemed as though the nestlings must be crowded out into the cold water below. But none of them ever was so crowded, and after nearly three weeks in the nest they flew out into some low bushes on the shore. Here they were fed by both parents for some days longer, being coaxed into the woods near by and cared for devotedly until they had learned to forage for themselves.

As soon as the young are able to take the trip the flocks of Brewer Blackbirds pass on to other feeding grounds. In August and September they are found in the high Sierra Nevada mountains and also on the ocean 
beach, so it seems to be a mere matter of caprice whether they go to the mountains or the seashore for the hot weather. Later they congregate for the winter in the interior valleys near the farms and stockyarls, where they pick up food like so many sparrows. In the spring they forage at the heels of the ploughman or among the herds.

Throughout the summer, fall, and winter their callnote has been a typical Blackbird "tchaak," uttered with a firt of the tail plainly showing displeasure. But when the rains cease and spring calls them to woo and win their mates, their little black throats ruffle with song. More energetic than musical, it may be; but heard as a chorus it is so full of enthusiasm as to make one forget its lack of harmony. The epithet of "wheelbarrow chorus," applied by Mr. Burroughs to the song of its Eastern kin, is just as appropriate west of the Rockies and fits the case exactly.

611 a. WESTERN MARTIN. - Progne subis hesperia.

FaniLy : The Swallows.

Length: $7.25-8.50$.

Adult Male: Entire plumage uniform glossy blue-black; wings and tail black; tail decidedly forkerl.

Adult Female: Upper parts duller and color less continuous ; forehead ani crown light gray ; feathers of back and rump conspicuously elged with grayish or pale brown; bend of wing and under coverts mottled profusely with whitish : anterior under parts and nuchal collar grayish white; belly and under tail-coverts white.

Young: Similar to :ulnlt female.

Greugraphical Distribution: Pactic eoast region, from Oregon south through California and Arizonis to Lower California. 
California Breeding Range: Chiefly in Transition zone, from latitude $40^{\circ}$ southward.

Breeding Season: June.

Test : Generally placed in eaves and cornices of buildings, or in boxes specially prepared for them; composed of a large variety of materials, - leaves, twigs, straws, string, rags, etc.

Eggs: 4 to 5 ; pure glossy white. Size $0.98 \times 0.73$.

THE Western Martin is in some ways less progressive than his Eastern relative, the purple martin, for he still builds largely in hollow trees. Instead of the familiar friend we know as circling over our lawns, nesting in bird boxes, or in holes under the house cornice, and so tame that we may lift the mother from her nestlings without frightening her, we find in the Western species a forest-loving bird. Occasionally these Martins are abundant about a town or farm building, but it is usually because some especial pains have been taken to attract them, and often because the first pair of birds were taken when young and have become domesticated. They are the same care-free, merry chatterers as the purple martin, circling on tireless wings throughout the swarms of insects in the air, turning, darting, and rising with marvellous grace and swiftness.

Besides small insects they are fond of beetles and butterflies, and doubtless they rid the farmer of many injurious pests wherever the birds can be induced to colonize. Under whatever circumstances they are found they are sociable little birds among themselves, never nesting in single pairs, and when together keeping up a sweet twittering song.

One looks at the nestling and at the egg in amazement that so much bird could ever have come from so 
small a shell. During the first week they double in weight every twenty-four hours, and at the end of four days, although still blind and naked, weigh as much as a eanary. Most of the food is given them by regurgitation so long as they remain in the nest. They are slow in developing, and do not fly until nearly four weeks old.

\section{PLUMAGE GREEN, GREENISH GRAY, AND OLIVE}

\section{BLACK-CHINNED HUMMINGBIRD. - Archilochus alexandri.}

Family : The Hummingbirds.

Length: Male 3.30-3.75; female 3.90-4.10.

Alult IKale: Upper parts metallie greenish; under parts whitish, washed with green on the silles; chin and throat velvety black, bordered below by a broad band, metallie purple, green, and blue.

Adult Female: Upper parts bronzy; under parts light grayish; tail much rounded, with middle feathers green, next two tipped with black, next three tipped with white.

Young: Similar to adult female, but feathers of the upper parts margined with buffy.

Gengraphical Distribution: Western Uvited States, east to Rocky Mountains, sonth over table-lands of Mexico.

Breeding liange: From British Columbia sonth to Lower California, and from the Pacific to the Rocky Mountains, chiefly in the upper Sonoran zone.

Brealing Serason: May 1 to August 15.

Nest: In trees or bushes, 4 to 7 feet from the ground; of buffy plant down covered with spider's web.

Eggs: 2 or 3 ; white. Size $0.50 \times 0.32$.

Ix some localities the Black-chimned Hummingbird is known as the Purple-throated Hummer, and this seems to describe him about as well as his more common name, for just below the black ehin is a band of iridescent 
purple that at once attracts attention as he sits sumning himself on a low twig. $\mathrm{He}$ is abundant throughout Southern California, but especially so at Tia Juana on the Mexican border and from there to San Diego, among the hills back from the coast. No very definite breeding range can be given him, for he is a capricious little creature, abundant in one locality and rare or unknown in another that seems in climate and surroundings to be

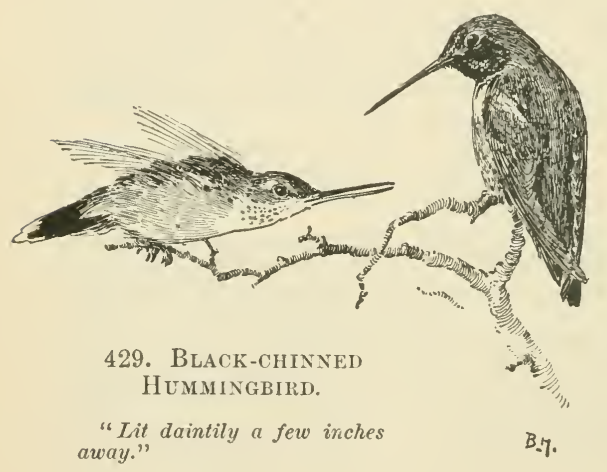
identical with the one he has chosen. Whether in the low hot valleys about the Colorado Desert, or in the Sequoia National Park at an altitude of nine thousand feet, he builds his home and rears his young in gay indifference to climatic conditions. Nor does he seem to have any especial favorites among the flowers; and this, I believe, is because his food is so largely insects. I have found him hovering over the bells of the Yucca more frequently than anywhere else, though at Tia Juana he was darting into the blossoms of the species of cactus so commonly domesticated by the Mexicans and used to brew a native drink. On one of these low plants a pair had built their nest in a crotch of the prickly leaves. It was composed of buffy plant down and covered with webs and something that looked like 
the thread of the Yucca. The mother was sitting; the nest was inside the garden fence; a fierce dog guarded the premises, and the Mexican family were away celebrating a church holiday. I could only admire from a distance, and, being unable to drive the mother from her post, did not ascertain whether eggs or young were the objects of her care. There was no question of identification, though Costa's hummingbird is more apt to build on cactus than this species. Another nest, found in the alders of a dry river bed, was quite unlike the first, and but for the father, who, contrary to hummingbird etiquette, sat within two feet of the brooding mother, I would not have attributed it to this species. The male was discovered first, and allowed me to walk up close to him before he took flight. In turning to follow him, I brushed against the branch on which the nest clung, and the female flew off just above my eyes. There were in the nest two newly hatched young, less than an inch long, and a third egg, probably a runt. The tiny cradle was woven of a pithy dark buff material that looked like the punk used by dentists, and was ornamented on the outside with willow buds. The question at once arose as to why this bird, building among the alder's, had not used the willow down for its nest, as had the one who built in the cactus. I diligent search failed to reveal the source of the building material, and although I have since found several nests composed of it, I do not know where it is obtained.

Like that of his Eastern cousin, the imby-throated, as well as four varieties of California hummers, the wooing 
of the alexandri is well worth watching. Should you spy a male, swinging sidewise back and forth through the air, pendulum fashion, look for the dainty little lady on a twig about three feet in front of and a little above him. So absorbed is she in watching and he in performing this curious aërial dance, that neither will notice you. Sometimes at its finish he will drop exhausted on any perch near and pay no further attention to her, but oftener I have seen her dart out into the sunlight as a signal for him to follow, and a merry chase through the blossoms followed. Once, as he sat resting after his graceful and apparently effortless swinging, the female flew toward him, lit daintily a few inches away, and quivered her iridescent wings. Instantly both birds were in the air apparently engaged in a mortal combat, and then he was back upon the perch like a flash of light, while she had disappeared. I have never seen the male Hummer assist at the nest building, and believe all the family cares are left to the female. She is larger and better equipped for labor than the brilliant little sprite who wooes her.

430. COSTA HUMMINGBIRD. - Calypte coste.

FAMILY : The Hummingbirds.

Length: Male 2.75-3.20; female 3.55-3.70.

Adult Male: Head and flaring ruff brilliantly burnished metallic amethyst violet, changing to blue and green ; rest of upper parts bronzegreen : under parts whitish; belly washed with green.

Adult Female: Upper parts bronzy green; under parts whitish; throat spotted with metallic purple.

Young: Sinilar to female, but duller and with feathers of the upper parts margined with buffy. 
Geographical Distribution: Lower California, Southern California, Arizona, and Western Mexico.

Breeding Range: In southern part of California, both east and west of the Sierra Nevada.

Breeding Season: On desert side of mountains, breeds in February; on the coast side, in May.

Nest: Of plant down or fine shreds of vegetable fibre; lined with feathers, and covered with lichen, bark, and leaves; fastened in place by spider web. On bushes, 1 to 6 feet from ground. Eggs: 2 ; white. Size $0.48 \times 0.31$.

The Costa Hummingbird is a haunter of the desert plains and barren mountain ranges of Southeastern California, where it nests in the branching cactus. On May 16 a nest containing one egg was discovered on a low branch of a willow five feet from the ground. The mother was brooding, and refused to leave until forced to do so. The next morning there were two tiny white eggs. Ineubation lasted thirteen days, the young emerging from the shell on the twenty-ninth. At first they were very tiny, naked, grayish bits of bird life with black skinny knobs for eyes, more like worms than hummingbirds; but they grew surprisingly fast, and at the end of the fourth day were eovered with yellowish white down on their backs and tops of their heads. By the sixth day this had spread to the wings and rump, the edges of the former began to show dark lines of needlelike points where the pinfeathers were eoming through. On the eighth day they had more than quadrupled in size, were darker in color, and were commencing to push pinfeathers through the down. On the twelfth day they seemed like miniature adults, for they wegre covered with greenish feathers, the hair-like down still sticking out in spots on the erown and back, but the plumage showing 
some glints of the metallic lustre of the adults. They began to sit up, preen their feathers, and stretch their ludierously small wings. On the seventeenth day one perched on the edge of the nest an hour, and that night the mother did not attempt to brood them, but clung meekly to the edge as close as they would allow her to come. Evidently they "resented being sat upon," like the ruby-throat described by Mrs. Olive Thorne Miller. They were fed entirely by regurgitation.

During this time the father bird had not once come near the nest, but on the seventeenth day an adult male hovered in the close vicinity and was repeatedly driven off by the nother. Within a week after that both youngsters had flown, but for many days thereafter were often found perching on small twigs in the sunshine, motionless, an hour at a time.

The nest was found to be much flattened from constant perching upon the edges, but was as clean as when newly built. The materials used were plant down ornamented on the outside with tiny bits of gray lichen and small dry leaves, bound with silk from cocoons. Inside it was lined with a few tiny feathers. It measured one and five-eighths inches across the top and three-quarters of an inch deep on the ontside, but less than threeeighths on the inside. This was after the brood had flown and, as mentioned before, it was much flattened. As we had not seen it built, we were unable to judge whether or not the male assists in the construction, but he certainly does not share in the incubation or care of the young. 


\section{ANNA HUMMINGBIRD. - Calypte annae.}

FAurly : The Hummingbirds.

Length: Male 3.40-3.60; female 3.80-4.15.

Adult Male: Top of head, throat, and ruff metallic pink, bronze, and green; upper parts and middle tail-feathers iridescent green; tail forked; under parts white, washed with green.

Adult Female: Hearl green, like upper parts; throat spotted with pink. Young: Similar to fenale, but tinged with brownish on upper parts.

Geographical Distribution: Central and Southern California, chiefly west of the mountains, Arizona, and Lower California. North as far as Yreka and Mit. Shasta.

California Breeding Range: Upper Sonoran zone west of the Sierra Nevada.

Breeding Season: January to June.

Test: From 8 to 30 feet from the ground; of thistledown and willow cotton ; lined with a few small feathers; coveres on the outside with moss, well covered with spider webs, with here and there pieces of lichens.

Eggs : 2; white. Size $0.50 \times 0.32$.

A Hummagino with a song would be somewhat of a novelty in the Fast, but in California it is so commonly met with that one soon forgets to wonder. The first time I heard the male Anna II ummingbird sing, he was perched upon a wire clothes-line and squeaking right merrily, "Te-nit, te-nit, te-wien, wieu, wien," repeating it over and over again. 'This chaming performance lasted most of one bright May morning in San José, and when later I discovered a little mate brooding on a nest in a climbing rose, I eonlel but fancy the song was for her benefit. One thing I know, he was "on gruard," for whenerer I rentured near the rose tree, he flew at me with a harsh liftle screech, sometimes right into my face. When I foumd him away from the vicinity of the 
nest he would allow me to come very close to him, so that I could almost touch him while he sat in unwinking silence like a bud on the moss rose, or a dead bird on a hat. The tiny green mother was no less courageous, and brooded unmoved while I watched not five feet away. When the little ones appeared they were very like all the small hummingbirds I had ever seen - naked except for thin down on back, about three-fourths of an inch long and with very short bills. I think our ruby-throat of the East could have mistaken them for her own but

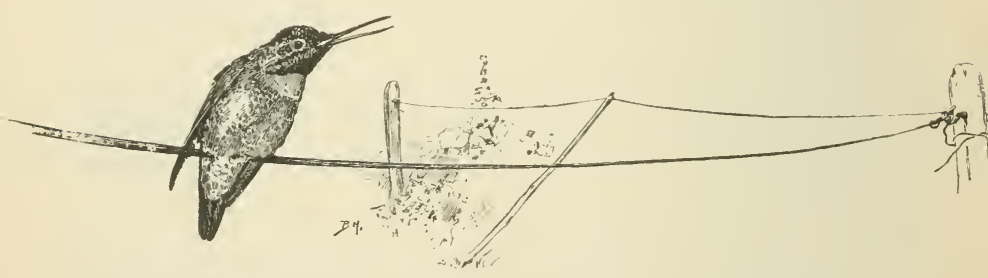

431. ANNa HemingBiRd.

" Lpon a wire clothes-line, and squeaking right merrily."

for the slightly lighter gray hue of the skin. They were fed each hour, and oftener, by regurgitation; the food given was small gnats and spiders.

It was astonishing how those babies grew! In two days they had doubled, and in four days trebled their original size. Dark, hair-like down began to show on crown, spine, and shoulders. In twelve days feathers were beginning to replace the down. In twenty-one days, just as the wing-stretching and restless wriggling threatened to upset the wee cradle, they popped out of the nest one day into the rosebush, sat there an hour 
or two, and ventured farther into the world of flowers. The mother still fed them, but now they seemed to help themselves from her bill rather than to have the food pumped or shaken into their throats. They now called in the squeaky tones of a young mouse, and the appeal never failed to bring the mother instantly to their side. Although I have been interested in several broods from start to finish, I have never seen one of the eggs hatch and eertainly never incubated one. Mr. A. W. Anthony has done both, and has deseribed the process so well that I quote it entire :

"A nest of this species [Anna Hummingbird] was found and transferred, eggrs and all, to my game bag. An hour later I was somewhat disgusted to find one of the eggs pipped, and was about to throw it away, when a movement on the part of the tiny creature in the shell suggested that I hatch the egg and find out how baby hummingbirds come into the world. So far there was but a pin point broken, and it was several minutes before the warmth of my hand produced another movement on the part of the prospective hummer. First a squirm and the point of the bill eame into view and was withdrawn; after a moment's rest there, a new system was adopted which consisted of a turning in the shell from right to left, and cutting a clean, smooth opening with the sharp horny tip on the upper mandible. This was hard work and required all the strength of the little mite, and frequent rests were necessary to recruit. The cutting was all done in the same direction, and after about ten minutes I was obliged to turn the egrg over in my hand in order 
to watch the proceeding, as by that time the opening had been cut about half-way around, bringing the chick's bill directly underneath and in the palm of my hand. When the shell had been cut four-fifths around, the chick succeeded in getting one claw hooked over the edge of the break, and, by one or two vigorous pushes, broke the remaining space, leaving in my hand two nearly equal parts of what had been a hummingbird's egg, and a squirming something that bore no resemblance whatever to one of the peerless members of the genus Calypte. The entire operation of hatching consumed about fifteen minutes."

\section{RUFOUS HUMMINGBIRD. - Selasphorus rufis.}

Favily : The Hummingbirds.

Length: Male 3.25-3.70; female 3.50-3.90.

Adult Male: Gorget intensely brilliant flame-color, with orange and green lights; rest of plumage reddish brown, with bronze-green iridescence on crown; a light band across the breast just below the gorget; tail-feathers rufous, with dusky mesial streaks.

Adult, Female: Upper parts reddish brown and bronze; under parts whitish, washed with red brown on the silles; tail-feathers reddish brown for basal half; millle pair green extending nearly to base ; the three outer feathers tipped with white and banded with blackish; belly white; flanks and under tail-coverts light reddish brown.

Young Nale: Similar to adult female, but upper parts light reddish brown and darker on rump; throat with a few bright metallic red feathers.

Young Female: Similar to young male, but rump green and throat dull green.

Geographical Distribution: Western North America, north to Alaska, east to Rocky Mountains, sonth through Mexico.

California Breeding Range: The Boreal zone of the central and northern Sierra Nevada.

Breeding Serson: March to August. 
Nest : In ferns, bushes, and vines, overhanging emhankments, and sometimes in trees; made of plant down, covered with mosses and lichens. Eggs: 2 ; white. Size $0.50 \times 0.33$.

The Rufous Hummingbird, also known as Cinnamon, Nootka, and Rufous-backed, is the most widely distributed of all the family in North America. It is found among the summer flowers of Alaska, and is common even above the timber line in the sonthern Sierra Nevada. Longitudinally it ranges from the east slope of the Rockies to the interior valleys of the sierras and in some places to the coast.

In Central California nesting begins in March, and the dainty structure of plant down, lined with cotton down and decorated profusely with fine mosses and bits of lichen, is placed on the horizontal limb of a tree or low bush. Farther north, Mr. Anthony has found it tucked away in unique places, - on dry roots of upturned trees; on the end of a tall fern leaf where other leaves, dropping over it, effectually hid it; in the long trailing vines overhanging embankments; on the sumuy sicle of railroad ents; and one little cradle had been built on top of a last year's nest, "a mere rim' being built to raise the sides, and a flooring being added to cover up a large pebble that could be plainly felt under the eotton lining."

Three years ago this species was not definitely recorded as nesting within the border's of California, but Mr. Grinuell now gives it as breeding in the Boreal zone of the eentral and northern Sierra Nevada mountains. I have found it in June at Lake Tahoe when there could be un mistake in idcntifieation, as both male and female 
were frequently seen in motion and at rest. A unique courtship that I saw was even more ardent than that of the Anna hummer. Like a brilliantly polished bronze pendulum, the gallant little lover swung in an arc of two yards' extent back and forth for fully three minutes before his coquettish sweetheart. Before he had ceased she darted out from her perch, and bill to bill they whirled far up in the air until they looked like big beetles. I think the flight must have taken them sixty feet straight up. Then back they came and alighted two feet apart on the same slender dead twigs. Four days after this, the nest was discovered on the branch of a low shrub in a very marshy place. It contained one egg June 11, and the little bronze mother had begun to brood. Her favorite feeding ground was twenty feet out on the marsh, where it was too wet for me to follow, but she seemed to be licking insects from a small whitish flower among the reeds. Both sexes were astonishingly fearless, following a little, four-year-old Indian girl back and forth, and evidently taking her red-gowned figure for an animated blossom.

Although so tiny, the male courageously attacked and drove away a Brewer blackbird that had chanced to alight in the bush containing the wee nest. This blackbird was nesting in a hollow post which stood in four feet of water fifty feet from the bush. His usual course in leaving his nest was over the hummer's bush, and the male seldom failed to dart out at him from his watch tower near by; but whether from natural pugnacity or from a genuine regard for the safety of his own treasures, 
I could not decide. The blackbird did not resent the assault, but seemed to endure it complacently, as the big man did his small wife's beating. Unfortunately I was not able to see the end of the inatter, as I left the locality on June 16, while the mother was still brooding.

This pair of hummingbirds did what I have seen no others do, - either they really bathed, or, going down to the surface of the water for small insects, they seemed to be bathing. There was no splashing, but they hovered a moment on the surface with rapidly beating wings, wetting their feet and bellies; then they flew away and lit on a sunny perch to preen.

\section{ALLEN HUMMINGBIRD. - Selasphorus alleni. \\ Family : The Hummingbirds.}

Length: Iale $3.25-3.30$; female 3.40 .

Adult Male: Back and crown bright bronzy green; under parts reddish

brown, lightest next to gorget; gorget brilliant flame-color, changing to oringe and green.

Adult Female: Similar to female rufous.

Gengrapleical Distribution: Coast belt from Monterey northward to British Columbia ; migrant through Southern California ; permanent resident on Santa Catalina Island.

California Breading liange: In the humil coast region from M[onterey north through the San Francisco Bay district; also on Santa Catalina. Breeding Seruson : February to August.

Nest: ('up-shaped, small in diameter and deep: made of plant down; covered with spider webs and bits of moss; placed on small twigs, weed stalks, and often on the seerl prils of the finc-leaved eucalyptus. Eggs: 2 ; white. Size $0.55 \times 0.35$.

THE Allen Hummingbird is only a summer resident of the United States, spending the winter months over the table-lands of Mexieo. It breeds wherever resident, and in California is found oftenest along the coast from 
Monterey northward. So far as I can ascertain, it is the only hummingbird resident on Santa Catalina Island, and it was the only species I found there. A nest of this species that I saw was built on the pendent twigs of the fineleaved eucalyptus. It was placed on top of a bunch of the seed pods and woven to them with fine spider web and silk from cocoons. Deeper and smaller around than any other I have seen, it measured a trifle less than one and a half inches in diameter and the same in outside depth. Inside, the cup was nearly an inch in depth. There was no lining, but the fibre of the white and buffy plant down composing it was more apparent and less compact than is usual in hummingbirds' nests. Outside, it was covered with bits of blossoms and strips of bark of hair-like fineness, making it so nearly the color of the grayish green seed pods that only an accidental discovery was possible.

These hummingbirds are nervous, pugnacious little mites, not tolerating any other species near them, and more or less quarrelsome among themselves; nor will the female allow her mate to come near the nest or feed at the same flower patch where she is feasting. They may be distinguished from the rufous by the bright metallic green of the back as well as by the difference in their breeding range.

Mr. Charles A. Allen, who discovered this species and in whose honor it has been named, writes of it: "Their courage is beyond question. I once saw two of these warriors start after a Western red-tailed hawk, and they attacked it so vigorously that the hawk was glad to get 
out of their way. And these little scamps were not satisfied even then, but helped him long after he had decided to go. Each male seems to claim a particular range which he occupies for feeding and breeding purposes, and every other bird seen by him encroaching on his preserve is at onee determinedly set upon, and is only too glad to beat a hasty retreat. During their quarrels these birds keep up an incessant sharp chirping and a harsh rasping buzzing with their wings, which sounds very different from the low, soft humming they make with these while feeding. . . . During the breeding season the male frequently shoots straight up into the air and nearly out of sight, only to turn suddenly and rush headlong down until within a few feet of the ground. The wings during the downward rushes cut the air and cause a sharp whistling screech as they descend with frightful rapidity, and should they strike anything on their downward course, I believe they would be instantly killed."

\section{CALLIOPE HUMMINGBIRI). - Stellula calliope.}

FaniLY: The Hummingbirds.

Length: Male 3.00 ; female 3.50.

Alult Male: Gorget pinkish purple, streaked with white; upper parts iridescent green; under parts white, washed with brown and green on the silles; tail-feathers ilusky.

Adult Femule: Upper parts bronzy green ; tail romuled ; tail-feathers, except the midile pair, tipped with white and banled with black: throat whitish, sometimes spotted eentrally with dull metallic purple. Young: similar, but under parts washed with redish brown and throat speetkled with darkish.

Geographiral /Nis/ribution: Mountainous regrions of Western North America, east to Rocky Mountains; suth through California, Arizona, and New Jlexico to Mexico. 
semble one closely. In fact, unless the bird be seen to fly off the nest or to it, the discorery of one of these dainty homes is almost impossible. One nest, now in the collection of Mr. William Brewster, at C'ambridge, Mass., is composed of fine moss and willow down, decorated with tiny shreds of bark, flakes of wood, and flakes of whitewash fastened securcly with cobwebs; it was placed on a knot in a rope hanging from the roof of a woodshed. The construction and materials minicked the rope and knot on which it was placed. Mr. Bryant records another, built on a projecting splinter of a woodpile at a height of two feet. Here, as seemingly under all circumstances, the bird had tried to imitate the surroundings, and to so place its home that it would be more or less protected by an overhanging branch, leaf, or some other object.

\section{9. (OLIVE-SIDED FLYCATCHER - Vuttallornis} berealis.

Finus: The Flyoutchers.

Length: $7.10-7.90$.

Alults: I juer parts lark-brownish slate, with darker shaft streaks on some of the feathers; comspicuous tuft of white cottony feathers on each side of rumly (grenerally ('uncealed by wings); under parts white through the middle from chin to crissum; the silles dark and somewhat struaked.

Foneng: Like allnlts, but wing-coverts tipped with brownish insteal of white.

Geopraphical Dis/ribution: Throngh the mountainous rengons of North Americu west of lincky Itommanus (o) Palcilic Coast ; north to Huilson Bay; south in wintur as fitr as P'ru.

Culffurnin lirediny liange: In Transition and lower Boreal zones througlont the State.

Breediny Sicuson: June 1 to August 1. 
Nest: Saucer-shaped ; of wiry materials ; fastened to horizontal branches of coniferous trees, 40 to 60 feet from the ground.

Eggs: 3 ; creamy, spotted at large end with brown and lavender. Size $0.90 \times 0.65$.

Although nowhere very numerous, the Olive-sided Flycatcher is found throughout the forest and mountainous regions of California. It prefers the edge of the timber to the dense wood, and stays along the course of streams or around small lakes in the higher altitudes. Like all flycatchers, it feeds on winged insects caught in the air, - moths, butterflies, dragonflies, June bugs, and beetles. Perched upon a dead branch, one of these birds will catch two dozen insects in as many swift dartings out into the air, always returning to the same lookout to eat them.

About the middle of May the females arrive from the South, and then the call-notes grow louder and merrier. Heard through the quiet hours of dusk or in the silence of a moonlight night, they are singularly like the plaintive notes of our rood pervee. But this is not all the song the little lover can sing, for when he goes a-wooing in the fresh coolness of the morning he trills a right merry lay. What though it be short and of limited range, the glory of the sumrise and the joy of love are in it. It is a beautiful world! He is glad to be in it, and as you listen you are glad to be in it too. When you hear this warble, you may know that somewhere in the top of a tall spruce tree a wee nest is being woven of fine hair-like rootlets, small twigs, and long green moss. Outside it will likely be covered with lichens, and inside lined with moss. So securely will it be woven to the 
horizontal limb on which it is saddled that a hard shake will not loosen it. You cannot see it from below, but the nervous little builders are sure to betray its location if you venture near. With tails wagging exeitedly and bills snapping with sharp elicks, all the while uttering a shrill "pip-pip-pip," they protest against your presence in their wood. About the middle of June, were you so ummindful of their wishes as to persist in climbing sixty feet to see, you would find three creamy eggs beantifully wreathed with brownish spots in the pretty green nest; but you would meet a warm reception from the furious parents. Were they half as dangerous as they are bold, you would never climb to a second nest.

They are equally intolerant of feathered intruders, especially if they be of their own species. Each pair seems to preëmpt a certain range from a fourth to a half mile in extent near the shore of a lake or along a stream, and on these preserves they allow no poaching. I believe they confine all their excursions to this territory so long as they remain in the same region. Only two things seem to be required in their breeding-ground, - coniferous trees and water. They are extravagantly fond of their morning bath, and are at it when the water is cold almost to freezing. To witness this one must rise with, if not ahead of the sun, for it is the first act of their waking hours. The young also are taught to enjoy a splash almost as soon as they learn to fly.

Only one brood is reared in a season, for they come north very late and leave again by the last of August to winter in the tropies. Incubation lasts about fourteen 
days, and the young remain in the nest two weeks longer, and in the same tree nearly a week after leaving the nursery. They are faithfully fed by both parents and taught to seize their food in the air, as do all flycatchers; and before the time comes when they must forage for themselves, they have learned the lessons necessary for their safety in the great forest.

464. WESTERN FLYCATCHER. - Empidonax difficilis.

Family : The Flycatchers.

Length: $5.50-6.00$.

Adults: Upper part grayish olive (more brownish in winter) ; wing-bars buffy; under parts yellowish, becoming bright sulphur-yellow on belly and under tail-coverts, and shaded with grayish brown across the breast.

Young: Similar, but upper parts browner, with wing-bars rusty buff, the sulphur-yellow of belly replaced by dull white.

Geographical Distribution: Western United States, north to Alaska; south in winter to Mexico ; east to the east slope of the Rockies; west to the Pacific.

California Breeding Range: In Transition and upper Sonoran zones throughout the State.

Breeding Season : May 1 to July 15.

Nest: In trees, under banks, in natural cavities, or about buildings, usually near water; made of rootlets, leaves, and moss ; lined with moss and feathers.

Eggs: 3 or 4 ; white, marked with brown and pale salmon. Size 0.69 $\times 0.51$.

THe breeding range of the. Western Yellow-bellied Flycatcher-known also as the Baird Flycatcher, or simply Western Flycatcher - extends through a wide latitude, from Alaska to Lower California. Eastward, it is found through the interior and southwest to the Rockies, but it is most common west of the Sierra 
Nevada in California. Throughout this extensive range the breeding season occurs some time between the first of May and the last week in July; and within that period each pair sometimes, but not usually, raises two broods. My own observations lead me to believe that in the same ${ }^{1}$ zone there is, in the case of all birds, a difference of about five days in nesting for every degree of latitude. This would make the season north of San Francisco from three to four weeks later than in the San Diegan district.

The Western Flycatcher is even less restricted in his selection of a building site than in choice of climate. On the ground among the roots of trees, up high on a tree branch, in the bottom of a deserted Hicker's hole, on a ledge of rock, he seems to follow no law but his own sweet will or that of his wee mate.

The notes on this Flyeatcher by Mr. Charles $\Lambda$. Allen, of Nicasio, California, seem to me well worth quoting. He says: "It is a very widely distributed species throughout this part of the state, both among the forests on the highest hills, where there is not a drop of water for long distances, and along the banks of brooks and streans in the lowlands; I have found its nests in all sorts of situations, - sometimes in a small tree, placed in the upright forks of the main stem: again, on the side of the stem where a small stub of a limb or some sprouts grew out; or in a cavity in a tree trunk; against an old stump, or a root which had been washed down during a flood in the middle of a stream ; among curled- 
up roots near the water, etc. I have found a number of nests, when fishing for tront, by flushing the bird from under a bank; and on stooping down and looking, I found the nest nicely concealed by the deep green moss, such as covered the surrounding stones. They always use this particular kind of moss, no matter where the nest is built. Oceasionally they nest in deserted woodcutters' huts, on outbuildings near cover, and a friend of mine has some large water-tanks in the woods back of his house, where for nineteen consecutive years these birds have built under the covered roofs of these tanks. I know of no place in this locality where they do not breed, excepting in very open country. Its song consists of a soft, low note. It shows much distress when its nest is taken, uttering then a low wailing note, like 'pee-eu, pee-eu,' and frequently flutters about the person taking it, snapping its mandibles together."

Mr. H. P. Lawrence gives the call-note as "weet-weet" or "per-teet-weet" uttered in jerky, spiteful accents. My own observations give still a third, "weet-weetweeter-eet," neither "spiteful" nor "plaintive," but a happy little love song sung early in the morning. The male is remarkably devoted to his mate, feeding her while she is brooding, and caring for her with the same devotion that he afterwards displays for his nestlings. And she receives this with the same pretty coaxing of wings by which the little ones beg for food. After the little ones are hatched, however, she works as hard as he to fill the ever-hungry mouths. Small insects, particularly water insects, are a favorite food, and one writer 
accuses them of eating newly hatched fish. The food is swallowed by the adults and afterwards given to the young by regurgitation until they are four or five days old.

\section{TRAILL FLYCATCHER. - Empidonax trailli. \\ Faмıц : The Flycatchers.}

Length: 5.S0-6.25.

Adults: Upper parts olive, darkest on head; wing-bars varying from brownish gray to white; eye-ring white ; under parts white, shaded with olive grayish on breast, and tinged with bright yellow on posterior parts; muler wing-coverts pale yellowish.

Foung: Similar to adults, but upper parts browner; under parts more distinetly tinged with yellow; wing-bars yellowish brown.

Geoyraphical Distribution: Western North America, from the Missis. sippi valley to the Pacifie; south in winter to Mexico.

California Breading Range: In interior valleys, to Sicramento and Honey Lake.

Breerline Serson: May 15 to July 15.

Vest : Deep, cup-shaped, bulky ; usually built between forks of an upright branch in bushes, near water, 1 to 18 feet from the ground; made of plant down, dry grasses, shreds of bark, etc.; lined with fibre, fur, down, and horsehair.

Eggs: 2 to 4 ; white or pinkish, spotted mostly at larger end with light brown. Size $0.73 \times 0.53$.

The Traill Flycatcher is a common summer resident in all suitable localities throughout the United States, but is distinetly a bird of the open country along the alder thickets of the river lands. It is restless and energetic, flitting about among the bushes but keeping out of sight exeept when a too enthusiastic sally after a passing insect betrays its whereabouts. But for this and a habit it has of calling out in a fretful tone at the approach of any person, it would never be noticed, so small is it and so well concealed by the waring leaves. Its notes 
are variously rendered as "pree-pee-deer" and "whuish, whuish," or " huip, huip."

Although so busy, this Flycatcher is never so occupied as to miss a chance of driving another bird, great or small, away from the special clump of alders which the pugnacious mite has preëmpted for his own. When there is no one else within scrapping distance, he contents himself with scolding his mate on the nest. Apparently nothing suits him from the time the nest site is chosen until the brood is reared. Capricious and variable, he places his nest anywhere that strikes his fancy, whether high up in the croteh of a sapling or close to the ground among heavy weed stalks. The materials used are fine, dry grasses, pine needles, plant down; and for lining, down and horsehair. About the middle of June both sexes may be seen bringing material to the chosen site, and too often one insists on scratching out the foundations laid by the other, until in this way a week is often consumed before the structure is complete. Only the mother bird broods in the beautiful nest; the male simply straddling the edge in masculine helplessness when left in charge, looking very wise but really quite useless so far as keeping the eggs warm is concerned. In twelve days queer naked bits of bird life fill the cradle, and now the small brown master is full of importance. They are hungry; away he darts for food, but the demand is ever greater than the supply. To satisfy those four open mouths means a trip every two minutes or oftener. No time has he now for scrapping or bullying his little wife. From early morn he must hustle, snatching time for a 
hastily swallowed bug en route if he can, going hungry if he must. Small wonder that he forgets to sing or even to scold, but becomes for the time a silent, selfabsorbed drudge in the workaday world.

\section{HAMMOND FLYCATCHER. - Empidonax hammondi.}

FaMiLY : The Flycatchers.

Length: 5.50-5.75.

Adults: Uprer parts olive, grayer anteriorly ; wing-bars light grayish or

tinged with yellow; outer tail-feathers edged with whitish; throat grayish; breast strongly shaded with olive; belly and under tail. coverts yellowish.

Geoyraphical Distribution: Western North America, east to the Rocky Mountains; north to the interior of Alaska; south in winter to

Mexico.

California Brecting Range: Through Transition and lower Boreal zones

from IIt. Shasta to San Jacinto mountains.

Breeding Season: June.

Nest : On a horizontal limb of a tree, 2 to 50 feet from the ground ; made of old weed stems, plint fibres, shreds of bark, plant down ; lined with grass, shreds of bark, plant down, hair, and a few feathers.

Eggs: 3 or 4 ; creamy white, sometimes lightly spotted with brown at the larger end. Size $0.70 \times 0.53$.

TuE Hammond Flyeatcher is the Western representative of the Chebec of the East. Unlike the latter, however, it is a shy dweller of the mountains, nesting oftenest, in the higher altitudes, from five thousand to ten thousand feet.

Instead of the merry little note which has given the Eastern species its nickname, the Hammond Flycateher gives only a low, indistinct whistle and a soft "peet." Building in the higher branches of the coniferous trees, 
it is a most difficult bird to observe during the nesting season.

The food of hammondi consists of insects, which it catches by darting from its perch. In sharp contrast to the restless energy so characteristic of its family, it will sit motionless for a long time upon this perch, Micawberlike, waiting for something to turn up. It is comparatively little observed, and is accounted rare, but I believe this is due more to its retiring habits and silence than to any special scarcity of individuals. It is certainly not uncommon in the higher valleys of the Sierra Nevada in June, and would, I believe, allow some investigation of the nesting habits without deserting the brood, for the parents are very devoted.

\section{WRIGH'T FLYCATCHER. - Empidonax wrighti. FamiLY: The Flycatchers.}

Length: 5.75-6.40.

Adults: Similar to Hammond flycatcher, but upper parts grayer ; under parts whiter ; throat often whitish; outer web of outer tail-feathers abruptly paler than inner web.

Geographical Distribution: Western United States, east to the east slope of the Rocky Mountains; south to New Mexico; migrates to Lower California and Mexico.

California Breeding Range: Along the Sierra Nevada, south to Mt. Whitney.

Breeding Season: June 15 to July 15.

Nest: Shaped like an inverted cone ; in hazel, dogwood, or other shrubs ; fastened to the twigs or against the trunk of bush or sapling, 2 to 18 feet from the ground; made of plant fibre and strips of bark; lined with feathers and hair.

Eggs: 3 to 5 ; dull white, unspotted. Size $0.65 \times 0.50$.

Amovg the pines and aspens that fringe the mountain brooks, this dull-colored Flycatcher hides its nest. As 
soon as spring fever stirs in his veins, he seeks his favorite haunts and flits about, a gay bachelor, among the buckbush and willows for a week or so before his sweetheart appears on the scene. After her arrival fully two weeks are squandered in the frivolities of courting before the more serious business of housekeeping is begun, but you may be sure he has had his eye on a special cosy fork of a branch, and that he will not allow any other householder to "jump his claim." Then one sunny day about the tenth of June, you will see him bring a bunch of plant fibre and, placing it in the chosen crotch, jump on it and pack it into place with feet and bill. He has worked hard to get it, tugging with all his little strength to loosen some of it, which is the inner bark of the willows, and ehewing it back and forth in his beak to render it fine and pliable. After the first bit has been put in place the female does the shaping and weaving, while the male brings the material. When the foundations and walls are completed, a warm lining of feathers is tucked and wadded carefully inside the small structure, and the cradle is ready. The thickness of this lining varies with the altitude and location, being thicker in higher or more exposed localities, while in some instances I have found nests with scarcely any lining and comparatively thin walls, on the sunny side of a cañon. These thinly built nests were invariably in pines and close to the trunk, and further from the ground than the heavier ones. Of the latter, several particularly warm ones were in willows and aspens and were lined with both wool and short hair from cattle or deer. Of 
four nests in one locality, one was two and a half feet from the ground in a manzanita bush, one four feet in a very exposed crotch of an aspen sapling at the edge of a grove, one was nicely hidden about five feet up in a young pine, and one was eleven feet from the ground, also in a pine tree. All were commenced at about the same time, and the first egg was laid in two of them the same day. In one of the others incubation had begun on the day on which the second egg was laid in the other two. The higher nest was watched less closely, but the brood of two nestlings were seen on the edge of the nest at the same time that those in the lower nest had made up their minds to fly; so there was not more than three or four days' difference in the ages of the four broods. The nests were all within a radius of a quarter of a mile or less, and were similar in material and construction; but those in the pines were almost an inch shallower than those in the bushes.

During incubation, which lasted thirteen or fourteen days in two cases, the male was frequently found on the nest, not merely guarding but brooding. When not thus oecupied, he flitted restlessly through the bushes, bringing insects to his mate, not spending one moment in idleness except to take a sumbath, and his cheery twitter could be heard all day above the music of his more ambitious neighbors. As soon as the young Flycatchers were out of the shell, he redoubled his efforts and seemed to do much more than half the feeding. For the first few days this was by regurgitation, but later fresh food was given to them. Small wonder that with four such 
voracious appetites to satisfy he came and went in preoccupied silence. In two weeks the babies had filled the nest to overflowing and were fairly crowded out of it. Then the trials of the father bird really began, for they tagged him from twig to twig with open mouths and quivering wings. In vain he tried to swallow a bite himself. Often he seemed to hesitate between the demands of his own hunger and the entreaties of his already too full fledglings, but he usually sacrificed himself to them. In every instance the mother helped faithfully, and in one case she alone fed a nestling almost as large as herself, at the rate of six bugs in three mimutes. Sometimes she liberated one in front of him, in an effort to teach him to hunt for himself, but he was the only young Flycatcher I have ever seen refuse to try to catch an insect; he would not budge. This little comedy was played all one day, and early the next morning the worn and weary little mother was seen alone, no trace of the overgrown youngster could be found, nor did she seem to care. She called restlessly awhile, but about noon began to enjoy life with the rest of her kin and to forget the cares of yesterday.

\section{NORTHERN VIOLET-GREEN SWALLOW:}

T'achycineta thalassina lepida.

Famus: The swallows.

Length $=4.75-5.50$.

Adult Male : T'op of head, hind-neck, lnck, and seapulars rich green, eithr. the heal, ueck, or clorsal region, or hoth, usmally tinged with bronz. or purple; rump and upper tail-coverts violet, shacled with purple; wing-evverts violet, edged with greten ; a white patols on each 
side of rump, often close enough to form a band; under parts white ; ear-coverts and line above posterior half of eye pure white.

Adult Female: Similar to male, but smaller and duller; ear-coverts and hivd-neck dull grayish.

Young: Upper parts entirely dull brownish slate; feathers of under parts grayish beneath the surface.

Geographical Distribution: Western United States, east to the Rocky

Mountains, sonth in winter to Costa Pica, north to Alaska.

California Breeding Ricunge: In Transition zone nearly throughont the

State.

Breeding Seasm: May and June.

Nest : In cliffs, hollow trees, under eaves of houses, etc.; made of dry grasses; lined with feathers.

Eggs: 4 or 5 ; pure white. Size $0.74 \times 0.52$.

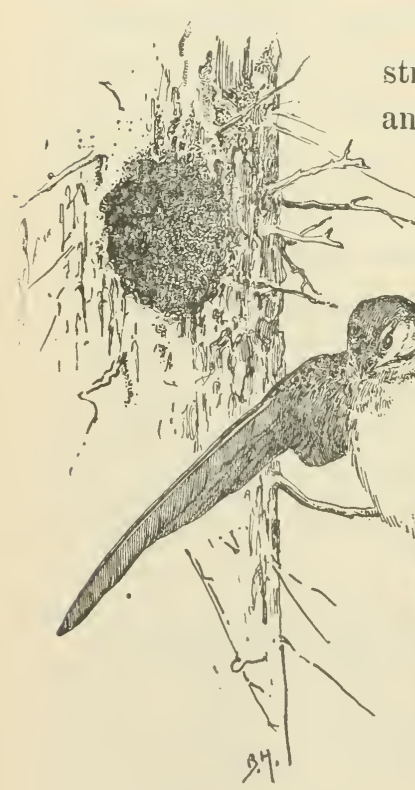

615. Northeri VioletGREEN SWALLOW.

"It is a lover of pine uoods and mountain forests."

The Violet-green Swallow is a strikingly beautiful bird both in form and coloring. Although its plumage lacks somewhat of the lustre of the other swallows, the bright green-and-violet effects of the upper parts render it unique among its kind. It is a lover of pine woods and mountain forests, but where these are scarce, it makes its home among the bare cliffs, nesting in crevices in the rocks. In

California all of the nests I have found have been in deserted woorlpecker excavations which the Swallows had filled with feathers and bits of grass. 
The young are naked when hatched, but feather into a soft mottled gray with glints of blue and green on the upper parts and the under parts nearly white. They are fed on small insects by regurgitation.

\section{7 a. WESTERN WARBLING VIREO. - Vireo sylua gilla snainsoni. \\ Family: The Vireos.}

Length: $5.00-5.50$.

Adults: Upper parts olive grayish; top of head dull ash-gray ; rump and upper tail-coverts pale olive-green; white streaks through eye; wings and tail plain dusky brown ; sides of head pale brownish ; under parts dull white, tingerl with olive yellow.

Youny: Top of heal and hinl-neck very pale grayish buff; lores and superciliary region white; rest of upper parts huffy, wings with buffy bars; under parts pure white, except for yellowish under tail-coverts. Geographical Distribution: Western North America from Great Slave Lake to Mexico.

Californic Breeding Range: 'Through upper Sonoran and Transition zones.

Brecling Scason: May and Iume.

Nest: A strong, durable basket, made of bark strips and fine grasses on

the inside; suspended by the brim from forks of horizontal branches. Eygs: 4 or 5; white, spotted, with reddish brown and lilac around the larger end. Size $0.70 \times 0.55$.

Тнв soft green plumage, unstreaked above and merging to greenish white below, is so characteristic of the Vireo family as to win for them the name of Greenlets, which to the non-scientific observer seems quite as appropriate as Vireo. They are small birds, so nearly the color of the leaves as to be observed with diffieulty, except for their friendly habit of stopping to chat with you awhile at close range. Each different species has a different remark to make, but whatever is said you are sure 
to understand and translate into human speech. Mrs. Eckstrom says: "Few birds are easier to tell by their music and harder to tell without it than the Vireos. By all means put their song into words." The song of the Warbling Vireo is a quaint, cheery melody whistled all day long until chill autumn rains drive him to a warmer climate. He is a mountain-lover, choosing the aspens and oaks of the Sierra Nevada rather than the lowland thickets. If he condescends to build in a city park, his nest will swing as near the top of the tallest tree as he can find suitable twigs to hold it. Usually it will be at the edge of a stream, or near an open space. In the fall this bird becomes very friendly, coming into the orchards and gardens to hunt busily among the leaves for small caterpillars. At this time he is fond of the cornel berries that grow along mountain brooks, and occasionally condescends to eat mistletoc, though he prefers insect food.

629 a. CASSIN VIREO. - Lanivireo solitarius cassini.

FAMILY : The Vireos.

Length: 5.00-5:60.

Adults: Top and sides of heal dark gray, blending to white on the throat; clearly defined white eye-ring and loral streaks; back dull olive-green; wings with two clear white bands; under parts clear white, tinged with yellow and olive on sides and flanks.

Young: Upper parts dull grayish brown; under parts dull buffy.

Geographical Distribution: Western United States, chiefly on the Pacific coast in summer ; east to New Mexico, and south to Mexico in winter. Culifornia Breeding Range: Along the Sierra Nevada. Breeding Season: May, June, and July. 
Nest : Made of dry leaves, cocoons, and spider webs ; lined with grass and bark; hung in thickets, bushes, oaks, and alders.

Eggs: 3 or 4 ; white, sparsely speckled with burnt umber. Size $0.80 \times$ 0.58 .

The Cassin Tireo is more common along the Sierra Nevada than through the valleys, and is most abundant in the coniferous forests half-way up the mountains. Here its characteristic song, "Mary, Mary, Mary! look up here!" bears so close a resemblance to that of the yellow-throated vireo of the Eastern States as to make it seem like the same bird.

His beautiful basket nest will be swung from the branches of an oak or spruee, and, so long as the little green mother is brooding, his happy warble will ring from the nest tree begging her in tenderest tones to "look up here!" At ślippery Ford on the Lake Tahoe road, one of these little singers followed me from tree to tree, whenever I was within fifty feet of his nest, singing from the lowest twigs a foot or two above my head and peering down at me euriously as he repeated his quaint imvitation. Ilis nest was only six feet from the ground and, June 3, contained four egrgs. Sitting began that day, and two days later both nest and contents had disappeared and, with them, the happy singer and his mate, probably into a collecting basket. I searched for them diay after day, but found no trace of them in the neighborhood. Another pair of the same species were finishing their nest in a tree not far from the hotel, and it, like the first, was decorated with white cocoons until it looked almost like a hornet's nest among the green leaves. 'These birls, although building nearer 
a dwelling, were less confiding than the first pair, and the male tried many little wiles to coax intruders away from his nest, though there were as yet no eggs in it.

The nest-making of the yellow-throated vireo has been so finely described by Mr. Hutchins in "Bird Lore," August, 1902, and so exactly resembles that of the Cassin Vireo, that I quote from it:

"The birds built the rim of their nest stout and strong, twisting the web about the twigs over and over upon itself where it stretched from twig to twig, till I wondered at their patience and ingenuity. Inside and outside the little heads would reach, with the prettiest turns and curvetings imaginable, till, as the nest grew deeper, the work was done more and more from the inside. Then it was gathered together at the bottom with side joined to side. When this part of the work first took place, the nest seemed to be strangely lacking in depth, and had an unshapely look altogether. But this was the point where the full revelation came to me of how the deepest part is shaped. I saw the bird at this stage inside the nest raise her wings against the upper rim and the twigs which held it, and strain with her wings upward and her feet downward till the nest grew so thin I could see through it in places. Then they began weaving in more material to thicken and strengthen sides and bottom where these had become thin and weak through stretching. This was done many times until proper depth and thickness were both secured." 


\section{GREEN, GREENISH GRAY, AND OLIVE 451}

\section{HUTTON VIREO. - Vireo huttoni.}

FAMiLY : The Vireos.

Length: $4.25-4.75$.

Adults : Lores and eye-ring dull whitish ; upper parts plain olive-brown; green on rump, wings, and tail ; narrow white wing-bars ; under parts dull whitish, tinged on sides with olive-yellow.

Young: Similar, but upper parts lighter brown, sides of head buffy brown ; under parts paler.

Geographical Distribution: California.

California Breeding liange: West of the Sierra Nevada in upper Sono. ran and Transition zones.

Breeding Season: March to June.

Nest: Neat, compact structure; made of fine vegetable fibres, bits of paper, and grasses ; covered on the outside with moss, and lined with grasses; placed in trees, from 8 to 10 feet from the ground.

Eggs: 4 ; white, finely dotted with reddish brown, especially at the larger end. Size $0.69 \times 0.51$.

Is the valleys and foot-litls of California the Hutton Vireo builds its nest among the branches of the serub oaks. In the materials used it is quite unlike any vireo nest found in the Eist, for moss forms a large part of its composition. Sometimes the external adormment alone consists of bits of moss woven in with shreds of spider web; but oecasionally the entire nest will be so draped as to look like a bunch of moss tangled at the fork of a light branch, and will deceive the eyes of an expert collector. But the bird himself has no talent for misleading you. His clear, emphatic warble tells you where he is and what he is doing ; for, in the tenderest phrasing of it, there comes an undertone of business, and sure enough he is prosiacally hunting his dimner while singing between mouthfuls. Under every one of the green 
leaves he peers with unabated interest, searching carefully for the small worms of which he is so fond. His slender bill, with the hook at the end and bristles at the base, reminds one of the flycatchers, but surely this phlegmatic plodder could never belong to the restless, darting, nervous flycatcher family.

Both the male and the female work busily at the building of the nest. Beginning at the top, they weave moss and fibre over and around the supporting twigs, leaving loose ends to be caught into the walls and bottom of the structure. The work is all done from the inside until the walls are firm, and then bits of the external decoration are carefully tucked on.

The brooding is all done by the female, while the devoted master of the household sings early and late from a perch in the same tree. This habit of singing so near the nest is characteristic of all the vireos, but is rare among other birds. He also feeds her very often during the day, and, as soon as the young appear, takes more than his share of the labor of caring for them.

Only ten days are required to incubate the eggs of the vireos, and one of my own records says seven for Hutton Vireo. All vireo nestlings are born naked except for the hair-like down that waves thinly on head and back. In this bird family it is even less perceptible than in most young birds, almost requiring a microscope to discover it. They are fed by regurgitation for five days and, after that, the food is usually reduced to pulp before being given to them. It consists almost entirely of small tree-worms, green and white, the latter some- 
times seeming, by their whiteness, to be fruit worms. The intervals between feeding are unusually short, ranging from three minutes to half an hour.

\subsection{LEAST VIREO. _ Vireo belli pusillus. \\ Fanily: The Vireos.}

Length: 4.80-5.25.

Adults: Upper parts plain gray, tinged with olive-green on rump, wings, and tail ; wings with one or two narrow bars ; lores gray and white; under parts white; sides tinged with olive-gray and pale yellow.

Young: Lores entirely white; top of head and hind-neck pale brown; back dull green.

Geographical Distribution: Southern and Central California, Lower California, and Arizona.

Culifornia Breeding Range: Northern San Joaquin-Sacramento valley to Saeramento.

Breeding Season: April and May.

Nest: In bushes and thickets; made similar to that of the other vireos. Egys: 3 or 4; lightly dotted with brown, especially at the larger end. Size $0.69 \times 0.48$.

THe Least Vireo is a bird of the warm valleys and foot-hills, frequenting the alder thickets along the wet bottom lands and following the spring into the foot-hills or more northern valleys to nest. It is a tiny mite in grayish green, and scarcely distinguishable from the foliage as it hunts through the bush for insects. Its semi-pensile nest is fistened to the slender twigs of the willows as close to water as it can get. This is not because of its fondness for bathing, but beeause of the abundant insect life found in wet places. While not a great musician, the Iscast Vireo calls enthusiastically early and late from the cover of the bushes, showing at times decidedly imitative qualities not possessed by any of its family exeept the white-eyed vireo. 


\section{GRAY VIREO. - Vireo vicinior.}

Family: The Vireos.

Length: 5.60-5.75.

Adults: Similar to least vireo, but lores and eye-ring entirely white; wings brownish, with wing-band indistinct or wanting.

Young: Similar to alults, but upper parts with brownish tinge and wing-bar buffy white.

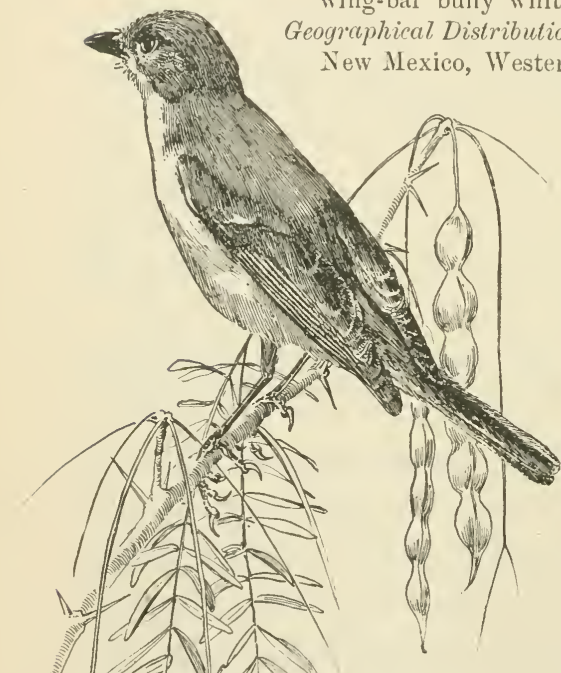

: Southern California, Arizona, Texas, and Mexico.

California Breeding Range: Southern California along the San Bernardino mountains.

Breeding Season: March to June.

Nest : Nade of coarse dry grasses and shreds of bark ; lined with finer grasses; placed in thorny bushes or trees, 4 to 6 feet from the ground.

Eggs: 3 or 4; white, thinly spotted with reddish brown, chiefly at the larger end. Size $0.72 \times 0.53$.

THE level mesas and the wide cañons of Southern California are the haunts of the Gray Vireo. Lacking the calm patience of its family, this species hunts nervously among the scant foliage for food, flying restlessly from one clump of the sparse growth of brush to an-

634. Gray Vireo.

"The best songster of all other and singing its quaint roundelay the rireos." whenever it stops long enough to do 
so. It is much the best songster of all the vireos, and its melody has a clear, liquid quality, at times melting with a tenderness strangely in contrast with its abrupt motions. Rarely does it wander higher than the tops of the scrubby growth of the rocky hillsides, and it comes fearlessly into view. The basket-shaped nest is swung from a mesquite or thorn bush usually within five feet of the ground, and, except for the overhanging leaves that shelter it from the sun, there is nothing to conceal it from the observation of every passer.

\section{6 a. LUTESCENT WARBLER. - Vermixora celata lutescens.}

Famil: The Wood Warblers.

Length: 4.20-4.45.

Adult Hale: I'pler parts bright olive-green, brighter on rump; sometimes tinged witl gray, especially on heal; orange crown patch concealed by grayish olive tips of feathers, except in midsummer plumage; eye-ring and supereiliary yellow ; under parts bright greenish yellow, streaked with dull olive.

Adult Female: Crown patch duller and sometimes obsolete.

Young: In first plumage; "pler pruts olive-green; wing-hars paler or buffy ; under parts buffy, shaded with olive on chest, siles, and flanks. Goographical Inistribution: I'acific const from Alaska to the mountains of Lower California and Western Mexico in winter; migrates east. ward to Coloralo, Arizonil, ete.

Culifornia Breseling liange: Sonthwarl along the Pacific Coast Range to the mountains of Sonthern ('alifornia.

Breeding Śruson: May 15 to June 15.

Nest: On the ground, often (oncereleul by tall grass or lushes; eomposed of dry grasses, rootlets, and moss, lined with a few horsehans and finc fibres.

Eygs: 4 or 5; white or creamy, finely squekled with purplish gray and cinnamon-hrown, chicfly at the larerer enel. Size $0.65 \times 0.46$.

WiTu the spring sunshine comes the Lutescent Warbler on his way from the sonth to the monntain ranges 
of California, where he will spend the summer ; and as he loiters along the way hunting for insects among the golden tassels of the oaks, we are charmed with his dainty grace and soft sweet twitter.

All day long he flits about throngh the oak trees, leaning away over the tips of the boughs to investigate a spray of leaves, or stretching up his pretty head to reach a blossom just above him; now clinging head downward underneath a spray, or hovering under the yellow tassels as a bee hovers beneath a flower. But the everlasting hills are calling him, and day by day he goes nearer to them, higher and higher up the range until his own particular thicket is reached, where he can hide his pretty nest and rear his young. And now, from swinging in the tops of the oak trees, he comes down to a snug corner under the thick shrubbery and weaves a cradle of weeds, bark, moss, and grass, lining it with hairs and rootlets. Each one of these rootlets must be pulled off separately, a task as great for his small strength as the uprooting of a sapling would be for a man, yet the average nest requires very many of them. A nest found near Rowardennan, May 26, contained three nearly fledged young and two infertile eggs. It was a typical nest, except that a large amount of moss was used in its construction and only a few rootlets. The location was also somewhat singular, it being squeezed between a stone and a clump of weeds and lying partly under the overhanging stone. There was, of course, no way of determining the age of these nestlings, but the under parts were still somewhat bare when they scrambled out of the nest the 
next day. Another nest in the locality, half a mile from the first, contained four fresh eggs. This was a foot from the ground, in a bush, and, but for the unmistakable identification, would never have been placed in the same list as the first nest, for there was not a spear of moss in it and it was lined entirely with rootlets. After accidental discovery it was found to be in plain sight from the path.

646 b. DUSKY WARBLER. - Vermirora celata sordida.

FAMILY: The Wood Warblers.

Length: 4.70 .

Adults: Similar to the lutescent warbler, but colors much darker.

Geographical Distribution: Santa Barbara Islands, California, and the mainland after the breeding season.

California Breeding Range: San Clemente, Santa Catalina, and other Santa Barbara Islands.

Breeding Season: About June 1.

Nest and Egys: Similar to those of the lutescent warbler.

The Dusky Warbler seems to be an island form of the lutesecnt warbler. It is a common resident of Sauta Catalina Island and others of the Santa Barbara group, breeding in the sparse growth of brush on the steep sides of the mountains. On Santal Catalina the nests are commonly on the gromend at the foot of a weed stalk, but one was found in a crevice of the cavity left by a small landslide of the preceding winter. They are especially abundant in the vicinity of the Isthmus. Early in the fall flocks of these Warblers fly eastward to the mainland, striking it a little south of Sim Pedro and continuing 
east as far as San Bernardino. They are abundant at Los Angeles in August, but disappear entirely in the fall and do not reappear until the next year.

\section{8 a. WESTERN GOLDEN-CROWNED KINGLET.}

Regulus satrapa olivaceus.

FAmiLY: The Kinglets, Gnatcatchers, etc.

Length: $3.15-4.55$.

Adult Male: Crown orange, surrounded with yellow and edged on front and sides with black lines; upper parts olive, greenest on the rump; two whitish wing-bars; under parts buffy whitish.

Adult Female: Similar, but crown lemon-yellow.

Young: No yellow on crown; under parts tinged with pale brownish gray.

Geographical Distribution: Pacific coast of North America, from California northward; south in winter to Guatemala.

Breeding Range: Breeds sparingly on the high Sierra Nevada southward nearly to Mt. Whitney.

Breeding Season: July.

Nest: A ball of green tree moss; fastened to end of pine branch; lined with feathers and short hair.

Eggs: 5 to 10 ; pale buffy, speckled with buff. Size $0.56 \times 0.44$.

The Western Golden-crowned Kinglet is a common winter bird in the coast regions and elsewhere in California west of the Sierra Nevada. He is such a fearless, happy little chap, with his crown of bright orange and his plump green body, that one is instinctively drawn to him and comes to regard his merry "zee-zee-zee" as an attractive sound in the woodland chorus. He will allow you to come within a few feet of him and meets all your friendly advances with charming trustfulness. This sociability is only for the winter, however, when he has the companionship of his fellow-kinglets for moral support 
and frolics through the oaks in flocks, busily searching under every leaf for insect food. It is quite a different matter in the high forests of the Sierra Nevada where he goes to rear his brood. There he is shyest of the shy, keeping mysteriously in the tops of the tall firs and giving you only a tantalizing glimpse now and then. One female that I watehed, or tried to watch, was evidently constructing a nest, for she could be seen fluttering about with her bill filled with nesting material of some sort, and carrying it always to the same tall spruce with a comical air of business. On all these trips she was accompanied by the male, who eame and went with her, but never, that I could see, brought any load himself. Whenever she dropped down to where she was building her nest anong the thick branches, her mate perched ligher in the same tree and warbled in continuous low, sweet song, every now and then diuting out, flycatcher fashion, after an insect - which he greedily ate. 'The song opened with a high-keyed, clear crescendo in tone and volume, diminishing rapidly as it ran down the seale, and was repeated over and over without much varriation, like the song of a canary.

749 (part). WISTERN RLBBY-(ROWNEI) KINGLET.

liegulus calendula cineraceus.

Fanus: The Kinglets, Gnatcatchers, etc.

Lenegth: 4.00-5.110.

Adult Mule' Brichlit crimson erown patch, more or less concealed ; upper farts grayish olive, greener on rump; two nartow white wing-hars; unler parts gratyish white, sometimes tinged with greenish.

Adult Fomale, and Foung: Similar, hut lacking the crimson crown patch. 
Breeding Range: Boreal zone of United States and Northern Mexico, in Rocky Mountains, Sierra Nevada, and mountains of Arizona. Breeding Season: May and Juue.

Nest: Bulky; semi-pensile ; woven of shreds of bark and moss; lined with hair and feathers; placed in pine or spruce tree, 15 or 20 feet from ground.

Eygs : 5 or 6 ; buffy, lightly spotted around larger end with pale brown.

Althovgh Mr. Grinnell states that the Ruby-erowned Kinglet breeds "in the Boreal on the sierras south to San Jacinto mountains," he does not say, as he might with truth, that it is rare and very hard to find. The nest is hung so high, usually in the branches of a tall spruce, that only an expert climber can hope to peep into one. Such was Mr. H. F. Bailey, of Santa Cruz, who, May 15, 1901, discovered a Kinglet carrying nesting material and watched her, although he could not at first see the nest. Jume 6 , three weeks later, he climbed the tree in which he had seen the bird at work, and found the nest thirty fect up and only six or eight feet from the apex. "It was beautifully made, pyriform in shape, with the small end downward, about six inches long, and five inches through at the thickest part. The cup was very deep and the rim very much contracted, inclosing a spherical space with a small opening at the top. The material used in construction was moss, fur, and silky, fibrous substances woven compactly together. The lining was of hair and feathers. Some of these latter were woven into the rim, the stems firmly secured and the free tips curling inward until they met, thus forming a curtain over the contracted opening and completely inclosing the interior. A very warm house was 
GREEN, GREENISH GRAY, AND OLIVE 461

the result. The number of eggs was seven, ineubation slightly advanced, ground color light buff - almost white - with numerous fine, pale, brown spots, so pale as to be indistinguishable, thickest near the larger end. The effect is as if a fine layer of dust had settled on the eggrs."

The usual call of a Ruby-crowned is a sharp thin whistle, unmistakable when once heard. On migrations this is his only note, but at nesting time he has a twittering warble of three motes repeated over and over. This camnot be heard so far as his whistle, but is soft and

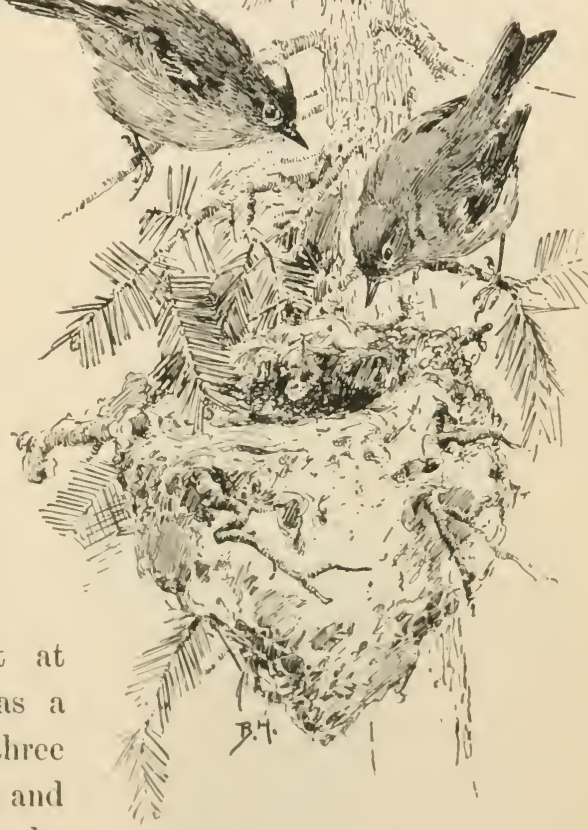

749. RuBY-chownel) fincilet. "Only an experl climber can hope to peep into one."

sweet. It is ocensionally heard late at night when the wind sweeps through the pine boughs and rouses the little sleepers. 


\section{RED CONSPICUOUS IN PLUMAGE}

403. RED-BREASTED SAPSUCKER. - Splyyrapicus ruber.

Family: The Woodpeckers.

Length: 8.50-9.25.

Adults: Entire head, neck, and upper breast red, sometimes lightly striped on sides of head with black and white; rest of upper parts black, barred with white; under parts dark gray or yellow.

Young: Duller, head and breast purplish brown instead of red.

Geographical Distribution: Pacific coast district north to Alaska, south to San Bernardino mountains.

Breeding Pange: The Transition and Boreal zones throughout its Califurnia range.

Breeding Seuson: Mlay 15 to June 15.

Nest: A gourd-shaped cavity, from 6 to 10 inches deep; in a live aspen tree, 15 to 25 feet from the ground.

Eggs: 5 or 6 ; white. Size $0.91 \times 0.71$.

Tне Red-breasted Sapsucker is a common summer resident in the Sierra Nevada from Mount Shasta to the San Bernardino mountains. When the cold of winter drives it from the higher altitudes, it migrates irregularly westward through the valleys to the coast.

Among the fir forests of the Sierra Nevada it is conspicuous and frequently met with, and may be heard at a distance of two hundred yards, beating its rattling tattoo for hours at a time. When alone, it is very noisy, but as soon as it suspects your presence, it becomes silent and dodges behind the tree trunk, slipping away as soon as you look in another direction. In the vicinity of Lake Tahoe the mating was arranged and excavation for the nest was begun by May 23. When first observed, the cavity seemed to be about four inches deep, below the first limb of the live aspen tree they had selected for 
a home, and in six days it was complete. It was, as I afterwards ascertained, nine and a half inches in depth. This pair were not so shy as most of those I had watched; after the excavation was partly accomplished, they kept on at their work when I was in full view, though discreetly keeping my distince. The male was advisory counsel and defender, but candor compels me to armit that he allowed Madam to do more than her share of the hard work. He was always near, keeping an eye on me and looking into the small doorway to note progress when his mate had Hown away for food, but only three times did I catch him making the chips fly limself.

I thought sometimes he

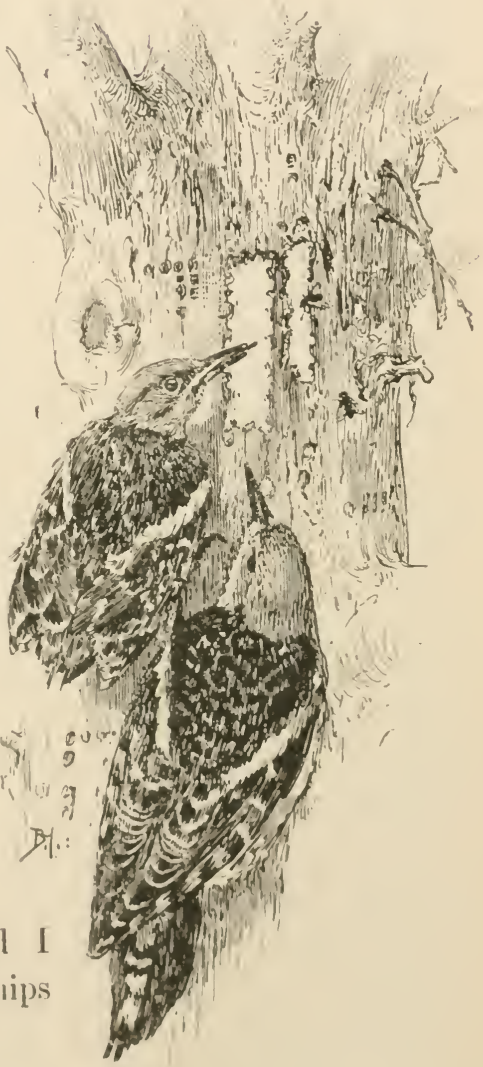
seened stupefied with the sap he ham been drinking. This is not an uncommon

103. RED-BREASTFI SAPLCKFK.

"The mother watched the attempt to "lrink the suert syrup." 
occurrence with his Easteru cousin, the yellow-bellied sapsucker, who sometimes becomes so intoxicated on the sap of the mountain ash that he will allow himself to be picked up by the hand of a quiet observer. But the Red-breasted is more cautious, and knew instinctively just when my glasses were turned toward him or when I moved hand or foot. I say "instinctively," for oftentimes I knew he was behind the trunk where he could not see me, and yet the most noiseless movement brought him inquisitively into view. So long as he was on guard the female worked without fear, but when he left on a foraging expedition, she usually became restless and shortly afterwards flew away also.

Incubation began Nay 30, and lasted fifteen days. The young were fed by regurgitation for the first two weeks. As in the case of most other woodpeckers except the flicker, I know this by closely watching the adults as they come to the nest. As soon as the bottle period is over, the food can be seen in their bills. After the first week, some few species, like the flicker, feed by regurgitation, from the doorway, in full view of the world.

The young Sapsuckers left the nest on the seventh of July, and clung to the nest tree for three days. Here they were initiated by both parents into the mysteries of sapsucking. A hole having been bored in front of each, with grotesque earnestness the mother watehed the attempt to drink the sweet syrup. During this time both insects and berries were brought to them by the adults, in one hour one youngster devouring twelve insects that looked like dragonflies. 
This species is said never to girdle the trees as does the Eastern variety, and to be far less harmful.

408. LEWIS WOODPECKER, - Asyndesmis lenisi.

FAMILY : The Woodpeckers.

Length: $10.50-11.50$.

Adults: Upper jarts, lower tail-coverts and thighs uniform dark metallie greenish ; face dark crimson; chest and collar round back of neck grayish; under parts, sides, and flanks pinkish red, with plu. mage coarse and hair-like.

Young: Like adults, but without red on head and without collar ; under parts more grayish than pinkish.

Geographical Distribution: Western United States, from the Black Hills and Rocky Mlountains to the Pacific.

Californic Breeding Range: Along the Sierra Nevarla south to Fort Tejon; also in the valleys of the Salinas and the Sau Benito. Breeding Season: May and June.

Nest: Exeavations made mostly in pines and dead stumps, from 8 to 100 feet from the ground.

Eggs: 5 to 9 ; white. Size $1.03 \times 0.80$.

THE Lewis Woodpecker, although so handsome, is the most silent and stupid of all its race. Making no attempt to defend its nest, it will sit on a limb of the tree and look on while its home is rifled, uttering no sound and seeming not to care. It uses the same excavation year after year, and will sometimes lay a second set of eggs in the same hole from which the last has just been stolen. The nest is usually high in a tree, and is sometimes thirty inches decp with an entrance two and a half inches in diameter. In summer this Woodpecker is resident in ecrtain localities along the Sierra Nevada south to Fort Tejon, and breeds in the open country along this range. In the winter it may be found nearly throughout the state. 
In the summer its food consists of grasshoppers, large black crickets, wood ants, larvæ, wild strawberries and raspberries, cherries, acorns, pine seeds and juniper berries. Where grasshoppers and Mayflies abound, it will gather these insects and stick them into cracks in the bark to be eaten later.

Unlike most woodpeckers, this species have the habits of the flycatcher, darting out to catch an insect on the wing and returning to the perch on the top of a dead pine tree. The young remain in the nest three to four weeks, and are fed upon insects and fruit by the parents for some time after leaving.

After the breeding season is over the Lewis gradually makes his way with his young into the higher mountain forests, where they remain in flocks until the cold weather of late September sends them toward the valleys.

\section{VERMILION FLYCATCHER. - Pyrocephalus rubinus mexicanus.}

Family : The Flycatchers.

Length: 5.50-6.25.

Adult Male: Head of male with crest ; upper parts, except top of head, brownish gray, darker on wings and tail; crown and uuder parts bright scarlet.

Adult Female: Upper parts brownish gray ; under parts whitish ; breast streaked with grayish; belly tinged with pale red or salmon.

Young: Upper parts grayish, feathers edged with whitish; under parts whitish, streaked across the breast.

Geographical Distribution: Mexico, Southern and Lower California to Central America, north to Southwestern Utah and Nevada.

Breeding Range: If at all in California, this flycatcher breeds in the vicinity of the Colorado River near Fort Yuma. Breeds in Utah, Arizona, New Mexico, and Southwestern Texas. 
Breeding Season: April to July 16.

Nest: Shallow and loosely constructed; saddled on a horizontal fork 6 to 50 feet from the ground; made of twigs, small weed tops, plant fibre, empty cocoons, spider webs, and plant down; lined with feathers, hair, wool, fur, and plant down.

Egys: 2 to 3 ; cream or buff, marked most heavily about the larger end with irregular blotches of brown, drab, and lavender gray. Size 0.71 $\times 0.53$.

IT is most unfortumate that this brilliant bit of bird life occurs in California only as a winter visitor. During the weeks from November to March it is more or less common throughout the southern part of the State, especially that portion along the Lower Colorado River, but it is neither so jubilant nor so fiscinating as when in its own chosen haunts it wooes its pretty mate. One must eross to the Arizona side of the river and ride some miles castwarl, to find it really abundint, but the enthusiast will be well

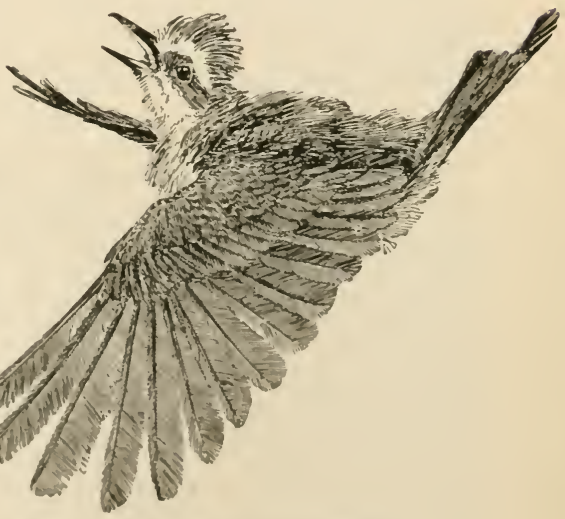

471. Vermilos Flycatcher.

"Pouring out his joy."

repaid. Here, among the mespuite trees, like scarlet blossoms suddenly taken wings, the dashing males chase each other and engage in brilliant combats.

These feathered warriors have tempers as fiery as their breasts. Early in March they arrive from the south or west, and a week later are joined by the females. So 
slyly, so quietly do these demure brown ladies slip into the gay company that, but for the curious antics of their ardent swains, you might not notice their advent. The little cavalier can no longer contain his delight. From a branch where he has been sitting, one will shoot suddenly straight upward, like a fiery spark against the evening sky. There, high in the air, he poises on vibrating wing, with every feather fluffed out, crest raised, and tail quirked up over his back, all the time pouring out his joy in bubbling nusic. Just as you are sure he will explode with the rapture of it, down he comes, lightly as an autumn leaf. It is his wooing, and somewhere among the green leaves his sweetheart is watching.

One such aërial serenade had quite an unlooked-for ending. Evidently the performer had chosen his arena without properly surveying the neighborhood; for, as he hovered in the air only four feet away from an oak tree limb where sat an Arkansas kingbird, the latter, conceiving this to be a direct challenge and ever ready for a scrap, darted out at him with indescribable fury. The result was a kaleidoscopic mingling of yellow, red, and brown tumbling earthward, the birds fighting as they fell. The Vermilion had been taken by surprise, and was no match for his antagonist, but he fought gallantly. As he landed on his back on the ground, with feet and bill still eager to finish, the kingbird rose a few feet above him, poised over him as a hawk over a field mouse lair, hesitated, and for some occult reason flew back to his own perch. His honor had been vin- 
dicated, his rights enforced, there was no fun in scrapping with a vanquished foe; so magnanimously he withdrew from the field. Left alone, the little Vermilion wriggled over right side up, and sat panting but still full of fight. Evidently he did not know when he was beaten. His beady eyes flashed fire, his crest quivered, his wings were spread and his tail raised, while every individual feather bristled with impotent rage. A small brown bird, evidently his mate, flew down near him uttering low chirps. With the unreasonableness of his sex, he turned like a flash upon her and angrily drove her away. After a few moments of rest he was apparently as gay as ever, and was off again on his wooing, no whit less ardent for his defeat.

His nest was discovered in process of construction nine feet from the ground in the mesquite in which his mate had been hiding. It was a shallow affair of small twigs, fine grasses, vegetable fibre, plant down, and weblike stuff probably from a spider's nest or a cocoon. Inside a thin lining of plant down was matted neatly about. On April 24 the first egg was laid, and one each day thereafter until there were three. Twelve and a half days were required for incubation, and during this time I never saw the male nearer to the nest than six feet. The almost naked nestlings were salmon-pinkish; and, as in the case of most newly hatched birds, the eyes were covered with a membrane. On the fourth day this parted in a slit, griving them a comical, half-awake look, while grayish down stood out thickly on the crown and along the back. On the tenth day they were fairly 
feathered, but remained in the nest until the fourteenth and sixteenth days, when one and two, respectively, fluttered out on untried wings. The father took charge of the one that left home first, while the patient mother fed and coaxed the lazy ones. These were finally started into flight by a little judicious jiggling of the nest branch on the part of a less patient observer.

The call of the Vermilion is a characteristic loud and constantly repeated "peet, peet," or "peet-ter-weet." The song is a clear twittering remarkable only for its joyous enthusiasm.

\section{8 e. SAN DIEGO RED-WINGED BLACKBIRD.} Agelaius phoniceus neutralis.

FAMiLY : The Blackbirds, Orioles, etc.

Length: 7.85-9.00.

Adults: Similar to Sonoran red-winged, but smaller; female darker, with upper parts less conspicuously streaked, while under parts are more so.

Geographical Distribution: Great Pasin district of United States, south through Southern California.

California Breeding Range: Locally in the interior and southeru part of the State, chiefly in San Diegan district.

Breeding Season: April 15 to May 25.

Nest and Eggs: Similar to those of the Sonoran red-wing.

The Red-winged Blackbird of the East is, in California, divided into three subspecies, - the Sonoran, which occurs only along the Colorado River in the extreme southeastern corner of the State; the San Diego, which is common locally throughout the interior and southern districts, breeding wherever found, but most abundant 
in the San Diegan district; and the Northwestern, found in the northern counties. The habits of the species are identical, for all are marsh-loving birds, building their nests among the rushes or bushes along the edge of the water. All the summer, fall, and winter the San Diego Red-wings frolic and feed in large flocks, wandering over the farm lands of the valleys and piping their gay "konkaree" from all the fruit trees. At this time their food consists of insects that are injurious to fruit trees and the farmers' crops, for they glean alike in the orchard and behind the plough, picking up not only adult insects, but the larva and eggs. Grains of all sorts and seeds are also part of their diet, yet the small harm they do is greatly overbalanced by the goud they accomplish. When nesting time comes they are off to the marshes and sloughs. Here they nest in large colonies, sometimes numbering hundreds, the nests so close together that the young birds can almost hop from one to the next. After the manner of the yellow-heads, the male Red-wings take small share in nest building or brooding. In the Fast this bird is not infrequently a victim of the parasitic cowbird egg, and when this happens the brood is abandoned or a second nest is constructed on top of the old one. Occasionally these donble-decker affairs are a foot high with one half-incubated brood walled securely into the lower part and a second reared above it. Nests built on the edges of the marsh or near the open water are always much deeper and more securely fastened to the rushes than those placed in more sheltered locations, as if the wise little architects knew the greater strength 
necessary to resist the force of wind and wave. The newly hatched young Red-wings are just the color of a ripe apricot, and entirely naked. In a few days dark lines of embryonic pinfeathers show along each side of

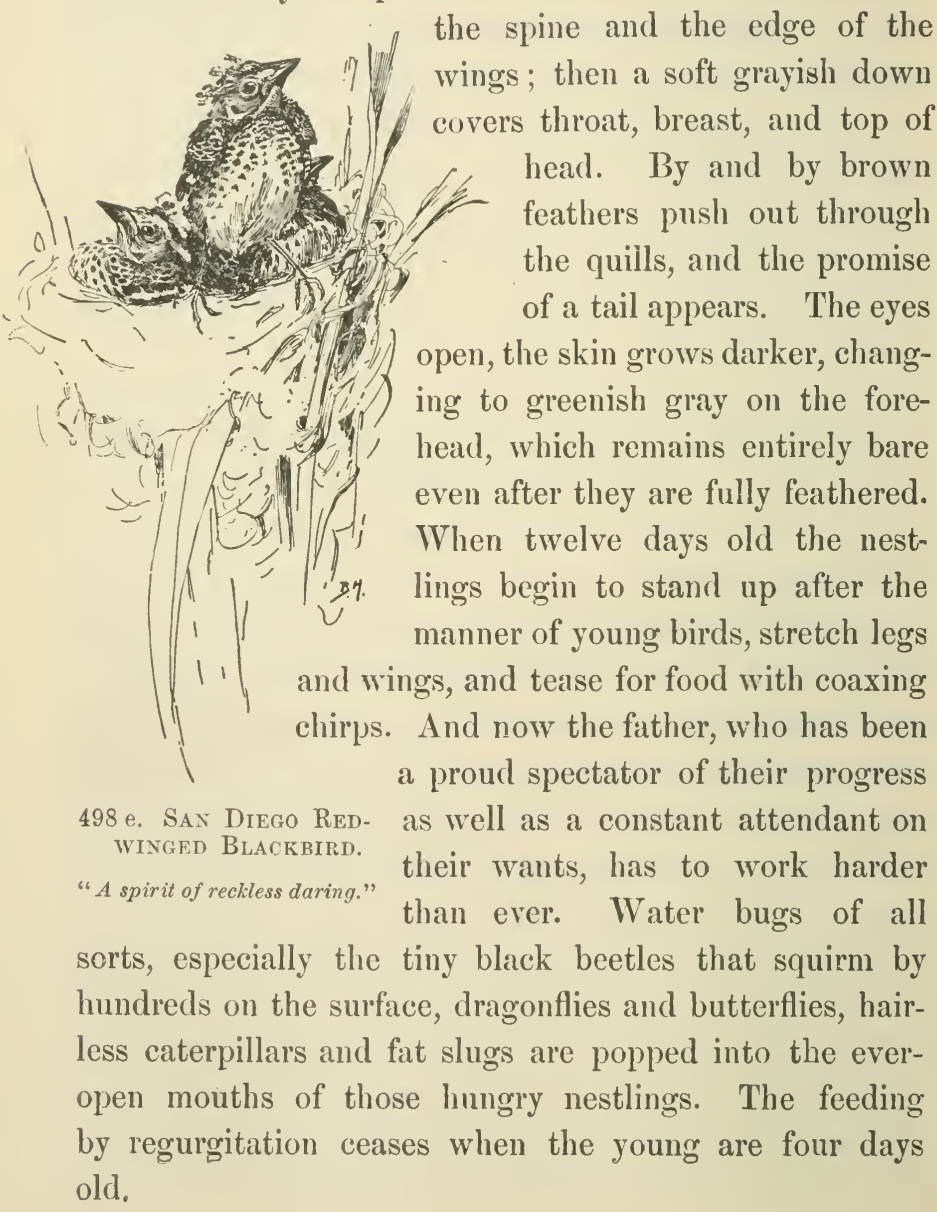


There is a spirit of reckless daring inherent in every young blackbird, and the Red-wings are no exception. One of these bald-headed babies balancing himself gingerly on the edge of the swaying nest is a comical sight on a calm day, but fumnier still when the wind blows. How tightly his tiny claws grasp the stout rushes, as he bobs this way and that in a desperate struggle to keep right side up! How curiously those in the nest watch his gyrations! Occasionally a second and a third will climb out beside him, and that means that something is sure to happen. Too often it is a tumble for all three back into the nest, or a less lucky tip out into the rushes.

As soon as their wings are strong enough for short flights, the wise parents coax them back to the safer feeding ground of the orehard or farm, where day after day they pick up bugs, and night after night roust side by side with hundreds of other Red-wings in the shelter of the trees.

\section{8 a. SONORAN RED-WINGEI) BLACKBIRD.} Agelaius phaniceus sonoriensis.

Family : The Blackbirds, Orioles, etc.

Length: Male 8.15-9.35; fermale 6.80-7.86.

Adult Male: Uniform black, except for rell and buffy or whitish shoulder patehes.

Adult Female: Plumage not so glossy as the unale's; upper parts more or less streaked with dusky; top of head and fore part of back dark brown, with buffy median crown stripe aud superciliary; shoulders faintly tinged with red; under parts broadly streaked with dusky and whitish; chin and throat more or less tinged with buffy or pinkish.

Geogruphical Distribution: From the Lower Colorado valley in Soutbern Californis and Arizona south to Mexico. 
Breeding Range: Southeastern portion of State along Lower Colorado River.

Breeding Season: April to June.

Nest: Usually built in reeds or bushes, near the ground, and sometimes in a clump of grass; made of rushes or sedges; lined with finer grass. Eggs : 3 to 5 ; light blue, marbled, blotched, and clouded with light and dark purple and black. Size $1.00 \times 0.75$.

\section{BICOLORED BLACKBIRD. - Agelaius gubernator californicus.}

Family : The Blackbirds, Orioles, etc.

Length: Male $7.80-8.60$; female 6.90-7.50.

Adult Mole: Plumnage black, red shoulder patch; middle wing-coverts buffy or brownish at the base, but concealed by black tips.

Adult Female: Nearly uniform dusky and streaked; chin and throat pale buffy or pinkish, the latter marked with triangular spots of dusky.

Geographical Distribution: Valleys of California and Western Oregon, south into Mexico.

California Breeding Range: Locally in the interior valleys west of the Sierra Nevada.

Breeding Season: April to July.

Nest : Placed on tufts of marsh grass or weeds, from 1 to 3 feet above the water ; marle of grasses and strips of bark; lined with grass and sometimes horsehair.

Eggs: 2 to 4 ; light bluish green, generally marbled, spotted and streaked with brown, black, and purple. Size $1.00 \times 0.68$.

THE Bicolored Blackbird is similar in all his habits to the red-winged. His nest differs only in the bark and horsehair used in construction, and the shallower cup. Like all blackbirds, he loves wet meadows and marshes near open water, and during the breeding season is found in these localities. For the rest of the year he roves in company with the Brewer blackbirds over the valleys of the interior west of the Sierra Nevada 
mountains. His call-note is a loud metallic "konkaree" that can scarcely be distinguished from that of the redwing.

500. TRICOLORED BLACKBIRD. - Agelaius tricolor.

FaniLY: The Blackbirds, Orioles, etc.

Lenyth: Male 8.00-9.05; fermale 7.10-7.85.

Adult Male: Glossy blue-black with silky plumage; shoulder patches dark red, bordered with white (tinged with buff in winter).

Adult Female: Plumage silky texture ; upper parts dusky, with greenish lustre ; crown streaked ; scapulars and interscapulars with grayish edgings; wings with grayish and white bauds; throat and chest. streaked; remainder of under parts dusky.

Young: Similar to female, but browner, and under parts finely streaked ; wings with two bands.

Geographical Distribution: Valleys of the Pacific coast from Southern California to Western Oregon.

California Breeding Range: Locally in the interior valleys west of the

Sierra Nevada, from MIt. Shasta to San Diego ; east to Lake Tahoe. Breeding Seuson: May to July.

Nest and Egys: Similar to those of the Soworan red-wing.

THE Tricolored Blackbird is a common resident of the interior valleys west of the Sierra Nevada from Mount Shasta to San Diego. In the vicinity of Lake Tahoe these birds stray across the crest, but not in the numbers in which they are found westward.

They breed in large colonies in the tule marshes and wet meadows, oftentimes placing the nests in trees or bushes after the manner of the red-wing. "Mr. Henshaw found a colony of these birds nesting in a dry pasture in a patch of nettles and briars covering between three and four aeres in the Sinta Clara valley, California. The nettles grew so dense and high (twelve feet) that he found it almost impossible to force his way into 
their midst. Two hundred pair were here congregated to rear their young, and the odor could only be compared to that of a cormorant rookery. Nearly every bush had several nests." ${ }^{1}$ This was in 1875. I doubt whether such a patch of wilderness could be found in Santa Clara County at present, but the birds still nest there in smaller numbers. I have never found more than from ten to twenty nests in one place.

The nests can be told from those of the red-wings only by their looser construction and their shallowness. The newly hatched nestlings are exactly like those of the red-wings and are fed and cared for in the same manner; even when a month old they can scarcely be distinguished from their more common Eastern relatives.

\section{5 b. CALIFORNIA PINE GROSBEAK. - Pinicola enucleator californica.}

Family: The Finches, Sparrows, etc.

Length: Male 7.75 ; female 7.40-7.95.

Adult Male: Upper parts pale vermilion; head tinged with pinkish and yellow ; scapulars light gray; wings and tail dusky ; feathers tipped with whitish; under parts light gray; entire plumage gray beneath the surface.

Adult Female: General plumage light gray ; top and sides of head, back of neck, and middle of breast bright tan-color; upper tail-coverts tinged with light yellow.

Young: Similar to female, but brownish gray, with brownish and grayish edgings to wings and tail.

Geographical Distribution: Boreal zone on the central Sierra Nevada; north to Placer County; south to Fresno County.

Breeding Range: Coextensive with its habitat.

1 Bendire's "Life Histories," p. 457. 
Breeding Season: May and June.

Nest: Flat, thin structure composed of rootlets and twigs, lined with finer roots, usually placed in coniferous trees.

High in the Sierra Nevada range where, all the year long, the crevices and sunless nooks hold patches of snow, where the dark hemlock forests cover the mountain sides with their shadows, the Pine Grosbeak finds temperature, food, and breeding grounds exactly to his liking. Nor when the storms of winter howl through the pines does he go far to seek a warmer climate. He seems fairly to revel in the swirling clouds of snow, and, until driven by hunger to seek food lower down the mountain, he will stay in his favorite haunts. On the edge of a snowrlrift you may see him picking up the wind-blown seeds and frozen insecr life

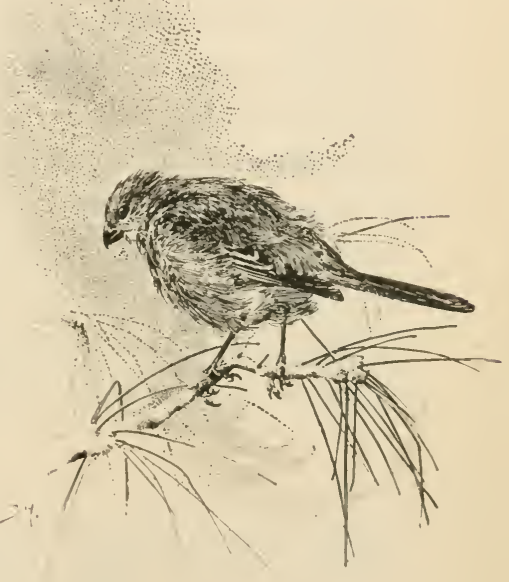

515 b. Califoria Pixe Grosbeak.

"He seems fuirly to revel in the swirling clouls of snow."

that come there no man knows how. When the summer suns have warmed the mountains, he whistles most musical love songs as he frolies through the trees with his mate. It all times, exeept the few weeks of the breeding season, he is fomm in company with others of his kind, both male and female. Early in May the 
flocks separate, each pair going to its chosen nesting site in the furry hemlocks, and house-building begins. Both sexes carry material and weave the walls of the home, which is well hidden and securely fistened among the thick branches. It is very difficult to discover even when you have located the tree, and the birds themselves, although not shy, are wary about disclosing this secret. So the bird-lover must be content with lying under the hemlocks and watching the pretty rose-colored male carrying food to his mate through the days of incubation; and listening to his liquid trilling, as the setting sun tinges his breast with a deeper rose, or as at four $\mathbf{\Lambda}$. Mr. he greets another blue day. He makes a welcome bit of color in the sombre woods, and delicious music in their silence. Unless you hear his rival, the Townsend solitaire, who frequents much the same haunts, you are quite ready to call him the musician of the monntain tops.

\section{7 a. CALIFORNIA PURPLE FINCH. - Carpodacus} purpureus californicus.

Fanily : The Finches, Sparrows, etc.

Length: 5.50-6.25.

Adult Male: Upler parts dark madder-pink, elear on rump, deeper and brighter on top of head; back streaked with dusky; middle of belly and lower tail-coverts white; remainder of under parts light rosepink with sides and flanks strongly tinged with brownish and streaked with darker.

Adult Female: Upper parts grayish olive, heavily streaked with brown; under parts ashy white, finely streaked; sides of head with two distinct brownish stripes, one on ear-coverts, the other on each side of throat, - the two separated by a whitish stripe. 
Young: Similar to adult female, but colors duller, markings less distinct, and edgings of wing-feathers more buffy.

Geographical Distribution: Pacific coast of United States, from Southern California to British Columbia.

California Breeding Range: Upper Sonoran and Transition zones west of the Sierra Nevada range.

Breeding Season: May and June.

Nest: A flat thin structure; made of fine rootlets and grasses ; placed on the horizontal limbs of trees.

Eggs: 2 to 4 ; greenish blue, finely speckled on large end with dark brown and black. Size $0.75 \times 0.55$.

The California Purple Finch is one of those species which indulge in a semi-annual vertical migration. Spending the winter among the lowlands, feeding through the valleys in small flocks, as soon as the snow begins to melt in the mountains, they work their way slowly to the higher levels. And the fruit-growers are not sorry to see them go, for during their brief stay through the winter months they have eaten the buds of the deciduous trees, doing incalculable harm to the erops.

Half-way up the mountains, at an altitude of from three thousand to five thousand feet, they find suitable breeding grounds in the yellow pines, oaks, and redwoods. The nest is built usually on a horizontal branch, and is composed of wiry grass and fine rootlets woven into a shallow eup and lined with wool or horsehair.

Incubation lasts thirteen days; and, so far as I have observed, the male does not brood upon the egrss, although he does take charge during the absence of the female.

The song of the Purple Finch is a pleasing warble kept up during most of his waking hours in the breeding 
season. The call-note is a chirp not unlike that of the English sparrow, but somewhat softer.

\section{CASSIN PURPLE FINCH. - Carpodacus cassini.}

Fanily: The Finches, Sparrows, etc.

Length: $6.50-6.95$.

Adult Male: Upper parts pinkish brown, clearly streaked with dark brown; top of head bright erimson; rump subdued rose-pink ; throat and breast pale rose-pink; belly white; sides tinged with pinkish; lower tail-coverts conspicuously streaked with dusky; wing-feathers edged with reddish.

Adult Female: Upper parts olive-gray; under parts white ; entire plumage conspicuously streaked with dusky.

Young: Similar to adult female, but streaks on lower parts narrower and less conspicuous, and wing-edgings more tawny buff:

Geographical Distribution: Western United States, worth to British Columbia, east to Rocky Mountains, sonth to Mexico.

California Breeding Range: Lower Boreal zone from Mt. Shasta to Los Angeles County; also Inyo Mountains and White Mountains.

Breeding Season: Мay and June.

Nest: Flat and thin; composed mostly of rootlets and grasses; lined with moss and cotton; placed near the tops of young pines, on horizontal branches.

Eggs: 2 to 4 ; light bluish green, dotted around the larger end with slate, lilac, and dark brown. Size $0.84 \times 0.62$.

Flocks of Cassin Purple Finches are met with along the entire high Sierra Nevada from Mount Shasta southward. The winter storms only drive them a little lower down to the shelter of the brush, or in severe seasons to the foot-hills; but even then it is not uncommon to find a small flock huddled under a fallen tree for shelter and trying to brave it out in the snow. With the returning spring the flocks go back to their pine-eovered haunts in the higher altitudes. 
The saucer-shaped nest of this species is placed in the top of a tall fir and is nearly always inacessible. Twelve days are required for incubation, and as soon as the young are able to care for themselves the brood and adults move higher up the mountain in the wake of summer.

The song of the Cassin Finch is rich and melodious, of a softer quality than that of the California purple finch, but less varied. Its call-note is a clear " cheep."

\section{HOUSE FINCH, OR LINNET. - Carpodacus mexicanus frontalis.}

Fanily: The Finches, Sparrows, etc.

Length: 5.75-6.25.

Adult Male: Upper parts brownish gray, tinged with carmine; back faintly streaked; forehead, snperciliary, and rump rose-pink or carmine; throat and breast reddish; belly whitish, sharply streaked with brown.

Adult Female: Upper parts grayish brown, faintly streaked; under parts white, broadly streaked.

Young: Similar to female; upper parts more distinctly streaked; under parts less distinctly streaked; wing-coverts tipped with buffy.

Gcomprophical IDistribution: Westem I'nitenl States from Rocky Mountains to Pacilic coast; from Oregron to Mexico.

California Brealinul liange: ('hicfly below Transition zone, in suitable localities throughout the state.

Breeding Seftsm: April, May, and June.

Nest : A compactly woven cup; composerl of grass and vecretable fibre: placed in evergreens, palms, and other trees and shrubs abont the house.

Eggs: 3 to 6 ; pale blue, nearly white, thinly speekled with black. Size $0.80 \times 0.55$.

The House Finch is popularly known throughout California as the Linnet, and is one bird for whom the 
residents have little praise. So numerous are these birds and so destructive to fruit that a continual ivarfare is waged against them by poison and by gun. Hundreds are sold in the bird-stores annually, sometimes at the low price of twenty-five cents each. But to the newcomer and the tourist the pretty pink-breasted songsters are one of the attractive features of the garden, where they take the place of the robin of the East. No bird is more tame or more confiding. In the rose that clambers over your window, or the evergreens on the lawn, he will build his nest, absolutely refusing to believe that he is not wanted. His happy song wakens you in the morning and is the last to cease at night, and when his pretty brown sweetheart is listening, his little pink throat ruffles and swells with the torrent of music. Then he sings on the wing in rocket-like bursts of melody, and executes wonderful gyrations for her sole benefit. A moment later they are off together over the roses looking for a place to hide the tiny home. The choice is varied. A palm tree, a vine at the kitchen door, a nook in the chicken yard, the top of an open-air pantry, the inside of a hat put up for a scarecrow, or a shoe flung into a tree in childish sport, are each and all eligible building sites. After weaving the nest out of grasses usually mixed with pine needles and a few feathers, the little brown mother broods for thirteen days, assisted by her mate at long intervals. The babies are naked, except for a scant bit of down on head and back, and are of a pinkish gray color. Like most young birds, they are born blind and do not open their eyes until the 
fourth or fifth day. They feather very rapidly, and on the fifteenth day are on the edge of the nest ready for their début. It is at this time that the domestic cat and the small boy collecting for the bird-store get in their deadly work. Were the robins of the East no better protected than are these feathered citizens of California, they would soon become only a legend to tell our grandchildren.

I have watched the Finches feed their young, by regurgitation at first and later with fresh food, and very rarely do they bring fruit to the nest. Seeds of various weeds and small green caterpillars formed the larger part of the diet, at least of the nestlings. In spite of their bad name, I believe they will some day be proved to have accomplished a fair amount of good to offset the evil charged against them, if in no greater way than by eating the seeds of injurious weeds.

521 (part). BENDIRE CROSSBILL. - Loxia currirostra bendirei.

Family : The Finches, Sparrows, etc.

Length: $6.80-7.25$.

Adult Irale: Plumage dull red; brighter on rump; wings and tail uniform dusky; feathers of back indistinctly streakerl.

Adult Female: Plumage olive, varying in shade from a grayish to a yellowish cast.

Young: Plumage light olive; umlır parts lighter, streaked all over, except on wings and tail, with dusky.

Geographical Distribution: In the momitainous parts of the Sontliwestern United States from Western Kansas, Colorado, and Arizona, south through highlands of Mexico.

Californiu Breeling liange: Locally in the central Sierra Nevada. 
Breeding Scason: March and April.

Nest: Of spruce twigs, shreds of soft bark, etc.; lined with horsehair, fine rootlets, etc.; rather flat; placed in coniferous trees.

Eggs: 3 or 4; pale greenish, spotted and dotted about the larger end with shades of brown and lavender. Size $0.75 \times 0.57$.

Wherever in the Sierra Nevada you find pine cones in plenty, look for the Crossbills. From Placer County to Mount Whitney they are more or less common dur-

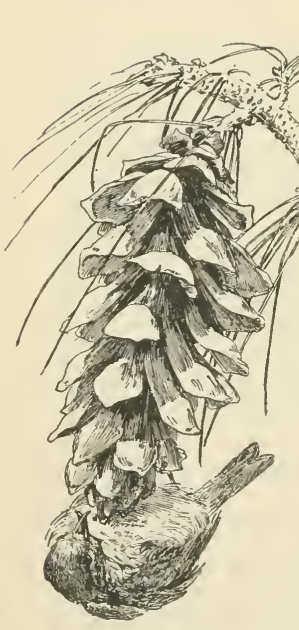

521 a. MEXICAN

Crossbill.

"Head down, chick:adee fashion." ing the sunmer. We use this phrase advisedly, for never were birds more capricious in the choice of feeding and nesting grounds. If here one season, as likely as not next year will find them miles away. But because you may not have seen them, do not decide that they are not near. One hundred feet away a flock of twenty to fifty may be feasting in the tree tops and not one elsewhere. Or you may hare them as neighbors to-day, and to-morrow find no trace of one. In the winter this is even more true, for they straggle irregularly over the central part of the State even as far south as Pasadena. At Monterey they are irregular summer visitants; and since they are without established laws as to breeding range, they may even be found breeding there. The nest is placed on the horizontal branch of a coniferous tree, usually about twenty feet from the ground, at:l both sexes assist in its construction. From the euri- 
ously twisted shape of the bill one would expect them to have some trouble in carrying twigs to it, but they manage very well. Instead of picking up from the ground the twigs needed, they wisely prefer to pull them from the tree, selecting brittle, dead limbs. In procuring the fine rootlets with which the nest is made, their awkward bill is an advantage. It is a great advantage, also, in prying open the pine cones and dexterously extracting the seeds. In doing this they frequently hang, head down, chickadee fashion, or climb over the cones by means of beak and claws. It has been a question how and on what the very young Crossbills are fed. Regurgitation would seem to be impossible in their case. Fortune has nerer farored me in watching a brood develop, for in every instance the eggs were "collected," either by a small boy or a squirrel, before they hatched.

The only somuds I have ever heard a Crossbill utter are the "kimp, kimp," always described in connection with them, which sounds like the crackling of the cones, and a twittering conversation early in the morning when the mate is on the nest. They are fond of water, and bathe early and late.

BLUE OR METALLIC BLUE CONSPICUOUS IN PLUMAGE 478 e. GRINNELL, JAY. - Cyanocitta stelleri carbenacea.

Fanur: The Crows, Jays, Magpies, ete.

Length: : 12.00-13.00.

Adulls: Head (including conspiruous crest), neck, and back dull black; wings and tail purplish blue, harred with black; under parts hlue.

Young: Similar to adults, but with duller nud less conspicuous matrings. 
Geographical Distribution: Const of California, from Monterey to the Columbia River east in Oregon to the Cascades.

Breeding Range: Transition zone south through humid coast belt to

Monterey.

Brceding Season: April and May (a few rare records in March).

Nest: Usually placed in fir trees 30 to 55 feet from the ground, some-

times in other trees or vines; made of twigs, moss, and dry grass, well cemented with mud; lined with fine roots.

Eggs : 3 to 5 ; dull, pale, bluish green, spotted and blotched over the entire surface with brown and lavender. Size $1.24 \times 0.92$.

"There are many handsome blue jays, but the stelleri in its numerous forms, with its blue body and high crest, is one of the lords of the race, fittingly associated with the noblest forests of the West" (Mrs. Bailey).

The Steller Jay is variously subdivided in California. The form known as the Coast Jay is usually resident wherever found, and is common in California along the coast from Oregon as far as the southern boundary of Monterey County. In the vicinity of Monterey and Pacific Grove these Jays are very abundant. Some one has called them the "policemen of the woods," but brigands would be a much more fitting cognomen. Flying in bands with jolly good fellowship, they are the torment of the more peaceful woodland divellers. Nowhere are they welcome. The appearance of one is the signal for the more fearless of the small birds to sally out en masse and drive them away; for right well these helpless woodfolk know that here is a monster who will, if he can, devour both their eggs and their nestlings. His mimicry of the notes of various birds of prey strikes terror to the mother birds brooding the young and to the father on guard near by. Small wonder he is hated. 
And yet a Blue Jay can be gentle, and few birds are so devoted to mates or young. Two robins may quarrel, two orioles often do, but Blue Jays never. If a young Jay is taken from one nest and placed in another, he receives the same treatment from his foster parents that their own young do; but these same Blue Jays will 'bring the nestlings of other birds for him to eat.

Their ordinary call-note is very discordant, but I have heard them sing their love songs at four A. Mr., when no one was supposed to hear but the mother bird on the nest in the tall pine tree. Those critics who write learnedly of bird songs, putting them into notes on a scale, may not speak of this elear, low conversational warbling as "music," but it is the outpouring of a great joy, blessing alike the singer and

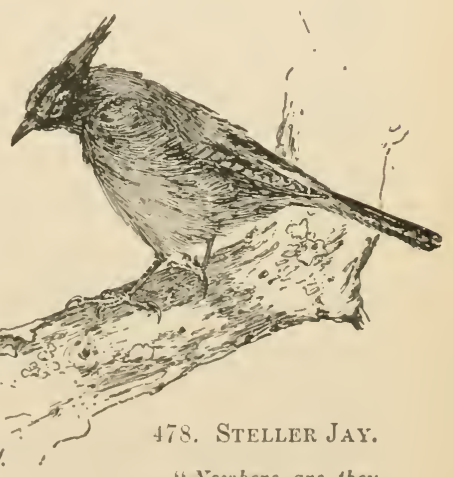

"Nouhere are they welcome." the one who hears.

In the vicinity of Monterey, nest-building usually begins early in April, and for ten days the male brings twigs, rootlets, moss, and grass, with mud enough to eement them well together. These the female weares into a cup-shaped affair quite unlike the flat platform of twigs made by our Fastern jays. It is oftenest lined with pine neelles or rootlets, but oceasionally short hair from cattle or deer is found in it. Ineubation lasts six- 
teen days, and during this time, although the male is frequently left in charge of the nest, I have never seen him attempt to brood the eggs, as the mother does. He will perch on the side of the nest, look at the contents with head cocked sidewise in a comical mixture of pride and masculine helplessness in the care of infants. He knows something is necessary to keep the wonderful treasure warm, but just how to go about it is a puzzle. But when those four dull eggs have become a nest full of queer-looking babies, he knows exactly what to do. They are hungry, and who can feed them so deftly as he? So, from dawn to dusk, he is hustling in true Western fashion for bugs of all sorts and varieties, for fruit and berries. Later he will show these same nestlings how to extract an acorn from the store of the C'alifornia woodpecker, how to crack a pine nut, how to hold a piece of meat in their strong claws and tear off bits of it, how to dash into the ice-cold water and enjoy the morning plunge, how to shake each little feather and dry and comb it into place again, how to frolic among the tall pine trees or over the sand dunes following the leader, how to hide motionless in the shadows when the hawk flies by, and, alas! how to wait until helpless nestlings are left alone and then sneak up and steal one. All this and more will they learn of the lore of the woods, which every wild creature must know if he would live. That most of these habits are acquired only by imitation is thoroughly proven by the helplessness of those birds which have been taken from the nest when young and raised in captivity. Although liberated as 
soon as they are fully fledged, they seldom learn to hunt their food until tanght patiently and slowly by their captors; and they never acequire the caution necessary for their self-preservation in a wild life.

\section{8 a. BLLE-FRONTED JAY. - Cyanocitta stelleri}

$$
\text { frontalis. }
$$

Fanily: The Crows, Jays, Magpies, etc.

Length : $11.75-13.00$.

Lldults: Heall, neck, and back brownish slate; crest blue; forehead streakel with blue; wings and tail dark blue, and barred; rump and under parts dull turquoise.

Geographical Distribution: Both slopes of the sierra Nevada, from Fort

Crook south to Lower California. Westward to the interior valleys in winter.

Culifornia Breeding Runge: Sonthern coast ranges and Sierra Nevada from Mlt. Shasta to Lower California. Breeding Season: April 20 to July 10.

Nest: Usually in a fir tree, from 6 to 50 feet above the ground, sometimes placed in natural cavities of trees and shrubs; made loosely of sticks or stems of weeds; lined with fine roots and grasses. E'ggs : 3 to 5 ; like those of the steller jay.

The Blue-fronted Jay constitutes one of the subdivisions of the Steller jay. Along the Sicrra Nevada from Mount Shasta sonth it breeds more or less abundintly, wandering irregularly to the coast in the winter. In general habits it is like the coast jay, and the deseription of nesting habits will be found nuder that species. In some localities, however, it is found nesting in cavities in trees. It Julian, C'alifornia, Colonel Goss obtained a number of nests from hollow trees at a distance from the ground of four to fifty fect. It also builds in snowsheds of the Canadian Pacific Ratilruad in the Sierra 
Nevada. As in the case of the coast jay, eggs and young of other birds form a part of the menu of the Bluefronted, together with acorns, piñon nuts, insects, and fruit.

481. CALIFORNIA JAY. - Aphelocoma californica.

Family : The Crows, Jays, Magpies, etc.

Length: $11.50-12.25$.

Adults: Upper parts blue; back and scapulars brownish gray ; sides of head grayish black; under parts white, washed with bright blue on sides of chest, middle portion being streaked with blue and brown; white superciliary stripe very distinct.

Young: Nearly uniform rusty black; head tinged with blue; throat white, mustreaked; chest brownish gray; belly white.

Geographical Distribution: Pacific coast of United States, from northern Oregon to Lower California ; east to Western Nevada.

California Breeding Range: Upper Somoran zone, west of Sierra Nevada, south to Lower California.

Breeding Season: April to June 15.

Nest: Usually found in low bushes or thickets, though sometimes in a tree, from 3 to 30 feet from the ground; a platform of interlaced twigs, moss, and dry grass supports the nest proper, which is made of rootlets mixed with horsehair.

Eggs: 3 to 6 ; buffy or green, varying in shade, blotehed with brown. Size $1.08 \times 0.80$.

To one accustomed to the handsome blue jay of the East or the still more splendid Steller jay of the West, the "flat-headed" California Jay presents a far less attractive appearance. Nor does he improve upon acquaintance; for, as one becomes aware of all his iniquities, his crestless head seems the typical low forehead of a villain. He is one of the greatest trials a bird-lover must encounter, and I know no reason why the law should protect him to the destruction of our 
beloved birds of song and beauty. Were he of benefit to the farmer or the fruit-grower, no word of dispraise would I offer; but he not only robs them, but also destroys annually liundreds of feathered creatures which, living upon the harmful insects, would be of great assistance in preserving the crops. No hawk is more destructive to small birds than is he. Ruthlessly he robs every nest in his vicinity that is left unguarded long enough for him to carry off eggrs or young. Not content with this, he pulls down and breaks up the nest itself. Usually he prefers the newly hatched babies to the raw albumen, and waits for the

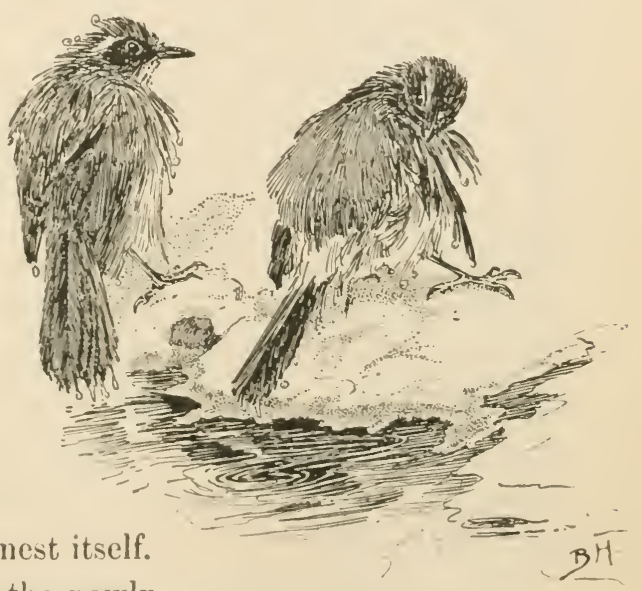

481. Califoriata thy.

"The colder the better." incubation to be finished. I have seen him sneaking around the nest of a pewee day after day until the eggrs hatched, when he at once marle a breakfast on the nestlings, - in this ease calmly disregarding the frantic eries of the poor little mother. When, however, he must ravage the home of a hird of his own size, he either calls all his kin to help, or comes, like the villain he is, when both the parents are away. 
About the farms and henhouses he is even a greater pest, eating thie eggs and occasionally killing the newly hatched chicks. Foraging in bands, these Jays destroy quantities of fruit of every variety and pull up the young sprouts of wheat. In short, there seems to be no limit to the Jay's mischief, and nothing too bad to say of him. In addition to all this, every bird-student sooner or later comes to feel a personal grievance against him, for seldom or never does one of these pests fail to discover your presence in a wood and to give warning of it far and wide to everything that flies. As long as you stay, so long will he, perched on the tallest tree-top, sit screaming, "Here she is! here! here!" in open defiance of your wish for quiet or concealment. Every bird in the forest knows and hides. Observation is impossible, and with unspoken malerlictions on his little flat blue head you sadly trudge on to another wood. Fortunate indeed are you if he does not collect a band of his fellows and follow you.

There is another side of this story. In spite of ourselves we are forced to admire his dashing courage and gay nonchalance, his devotion to his kind, and his care for his young. There is something uncanny in the wisdom with which these Jays band together for defence or offence. Although so quarrelsome with other birds, they never molest each other, nor do they kill an injured one of their kind, as robins do.

Their nests are placed in low bushes or thickets, or on the horizontal branch of an oak, seldom more than ten feet from the ground, and usually near water. This last 
requisite scems to be necessary for their existence in other ways than for drinking. Early every morning every adult Jay takes a cold bath, the colder the better; but the water must be clear. A tremendous splashing is followed by a long, careful preening of the feathers, which frequently occupies fifteen minutes or longer. Long, close watching has led me to believe that, except where there are youmg in the nest to be fed, this toilet is made before any hunting is done for breakfast.

The male assists in the nest-building, but not in the incubation. The latter requires fourteen days. The mother during the brooling time plunges down to the water once or twice a day, returning to her eggs with feathers still damp, fusses about as if turning them before settling down upon them, and in a moment rises up and fusses again. This may be only for her own greater comfort, but I have woudered whether the moisture was necessary for the egrgs. As soon as they hateh she ceases to bathe in this way, and, devoting her time to obtaining food, becomes dishevelled and rusty-looking.

One of the first lessons the young Jays learn is to love the water. It requires some coaxing for the first splash, but they seem to take to their bath as do little ducks, and to find it just as necessiry as foorl.

492. PIÑ()N JAY. - Cyanocephalus cyanocephalus.

Fanus: The Crows, Jays, Magpies, ete.

Lrngth: 10.00-11.75.

Adults: putire plumage grayish hlue, brighter on heml ; thront bright blue, with white streaks; head not crested; bill cyliudrical. 
Young: Uniform dull grayish blue, lighter beneath.

Geographical Distribution: Platean regions of Western North America, from the Pocky Mountains west to the Pacific coast ranges, north to British Columbia, south to Lower California, Texas, and Mexico.

California Breeding Range: In the piñon belt of the desert ranges, southeast of the Sierra Nevada and locally along the whole length of the Sierra Nevada from Mt. Shasta to the San Bernardino mountains.

Breeding Season: March 15 to May 15.

Nest : 5 to 12 feet from the ground; deep, bulky and compact; composed of piñon, sagebrush, shreds of bark; lined with fibre, rootlets, and dry grasses thoroughly woven together.

Eygs: 3 to 5; bluish white, entirely covered with fine specks of brown, and sometimes with larger spots and blotches at the larger end. Size $1.19 \times 0.87$.

The Piñon Jay is also called Nutcracker, Blue Crow, and Piñario by the Mexicans, in reference to its fondness for the nuts of the variety known as piñon. It is a haunter of the piñon-covered foot-hills, and scarcely ever roves into the higher coniferous forests. Eminently social at all times, it is found in flocks of hundreds feeding upon the ground after the fashion of blackbirds, and like them constantly in motion, - those in the rear flying over those feeding ahead of them and alighting in front of the flock. In this way they progress from place to place, and collectors who know this peculiarity hide along the route to wait for a good shot. Their constant chatter can be heard a long distance, and betrays their approach. They are occasionally seen in company with Clarke nutcrackers in the piñon groves; but, although they are great rangers, here to-day and gone to-morrow, they do not follow the latter in their vertical migration to the high altitudes, nor are they commonly found north of latitude $40^{\circ}$. 
In the summer grasshoppers, insects caught on the wing, and fruit form their bill of fare. They seem to lack the camnibalistic tendencies of their family, and do not, so far as I have observed or can learn, meddle with the broods of other birds.

The call-notes of the Piñon Jay are as varied as those of the Eastern jay and very like them in character. A harsh "j-a-a-h," a guttural chuck, and some soft, low notes uttered at the nest to mate or young are the sounds most characteristic.

Late in March or early in April they commence to build their bulky nests in full view, on the horizontal limbs of a nut pine or a juniper tree, usually within ten feet of the ground. The framework consists of twigs of juniper, nut pine, or sagebrush, and is lined with fine rootlets, bark shredded very fine, and moss or grass. Both sexes share in the incubation, which lasts sixteen days. In devotion to mate and young they rival the nutcrackers, and feed the nestlings long after they are able to provide for themselves. Like young nuterackers, they are born naked, but are greener in hue. They remain about the same length of time (twenty-two days) in the nest, and learn to extract the sweet kernels of the piñon muts before they leave it. They are also fed quite as fully on grasshoppers from which legs and wings have been carefully removed. As soon as able to fly they unite with other families in large flocks, and forage from place to place with the roving habits of their species. 
597 a. WESTERN BLUE GROSBEAK. - Guiraca coerulea lazula.

Family : The Finches, Sparrows, etc.

Length: 7.00-8.00.

Adult Male: Plumage plain bright blue, with two brownish wing.

bands; under tail-coverts with white borders.

Adult Female: Plumage grayish brown, tinged with blue.

Young: Similar to adult female.

Geographical Distribution: Western United States, north to Colorado,

California, etc. ; south throughout Mexico.

California Breeding Range: In lower and possibly upper Sonoran zone, recorded from Owens valley, through the San Joaquin-Sacramento basin, to Marysville.

Breeding Season: May 15 to July 15.

Nest : A deep, cup-shaped structure; compactly built of dried grasses, plant fibre, etc.; placed in bushes and tall weeds.

Eggs: 3 or 4 ; plain pale greenish blue or bluish white. Size 0.87 $\times 0.63$.

The Western Blue Grosbeak is a more difficult bird to observe than either the black-headed or the rosebreasted Grosbeak. He loves the thickets and brush of the valleys, seldom going higher than the foot-hills. The male, in plain winter garb, has been mistaken for a female cowbird by amateurs, but one glance at the bill should correct such a mistake. In the glory of his summer blue he is instantly recognized. His song is somewhat misleading, for although the same sweetly whistled turns so characteristic of the Grosbeak song abound in it, the tone quality is thinner and less mellow than that of the black-headed. Nor does he sing so continuously as the latter; perhaps because the days are shorter in the cañons, where he loves to stay, and he must put in more time eating. 
But if not so fine a singer, the Blue Grosbeak is a much better nest-builder than any other member of his family. And this work is well worth patient watching. After much consulting together, the pair agree upon a site, and the founclation of heavy grasses and weed stalks are scratched into place. A pair that I watched, after trying one eroteh, deliberately selected another, and removed the material to the new site. Nor could I find out what influenced the choice, unless there was something in the shape that was not quite comfortable to the little mother. Both male and female carried material, and moukled it into form by turning about in it and tucking the unruly ends in with their bills. It the end of the fifth day the compact, rather deep affair, lined with plant fibre and fine grasses, was ready for use ; and on the seventh day it contained one egg. An egg was laid each day until there were four; then incubation began.

The Blue-headed Grosbeak is a model father. Day after day found him on the nest. By some mysterious signal he knew when Madam was ready to leave, and never failerl to appear just as she flew off, though my dull ears caught no signal between them. Then, pausing a moment on the edge of the nest, he would survey the treasures with a comieal air of wisdom. Having satisfied himself that all was as it should be, he settled down, rather awkwardly, but with less fuss than the female ever could suceed in doing.

After fourteen days of waiting, four wriggling, naked nestlings filled the cridle and ate as surely no other 
young birds ever have done. There was scarcely a moment when one or the other of the parents was not bending over the nest offering food to the wide-open yellow mouths of the offspring. For several days this was given entirely by regurgitation. The adults had a habit of flying down the cañon to their feeding grounds, about a hundred yards away, and I never succeeded in finding out what they brought back. Oftentimes what looked to be the gauzy wings of a dragonfly stuck out on one side of the bill; at other times the food looked like grasshoppers or crickets, but I cannot be sure what it was. When ten days old, the young were feathered in soft tints of grayish brown, with a hint of blue on head and shoulders. But the constant surveillance had made them uneasy; as soon as possible they escaped from it by disappearing from the locality the sane day that the little ones flew from the nest, and a diligent search failed to discover their whereabouts.

\section{LAZULI BUNTING. - Passerina amœna.}

Family : The Finches, Sparrows, etc.

Length: 5.00-6.25.

Adult Male: Head, neck, and upper parts turquoise blue; the back darker and duller; wings with two white bars; breast and sometimes sides washed with brownish; remainder of under parts white.

Adult Female: Upper parts grayish brown, with blue on rump; back more or less streaked; wing-bars dull whitish; lower parts pale dull buffy, deeper on chest, and fading to white on belly and lower tailcoverts.

Young: Similar to adult female, but without blue tinge on rump; chest and sides streaked.

Gengraphical Distribution: Western United States, east to Great Plains and Kansas; south in winter to Western Mexico. 
California Breeding Range: Below Boreal zone, nearly throughout the State.

Breeding Season: Mlay and June.

Nest: Of fine strips of bark, small twigs, grasses; Jined with hair; placed in trees or bushes a few feet from the ground.

Eggs: 3 or 4 ; plain bluish white or light bluish green. Size $0.75 \times$ 0.58 .

Although the Lazuli Bunting is found on the higher Sierra Nevada, his best loved haunts are the lower momtain thickets and the chaparral-covered foot-hills. While the showily plumaged male flies through the open, from tree-top to tree-top, his little brown mate keeps well within the cover of the bushes, zigzagging her way through the chaparral like a shy sparrow. From the plains to the Pacific this species replaces the indigo bunting of the East.

The song of the Lazuli is loud, sweet, and merry, but is chiefly remarkable for the fine enthusiasm of the singer. Long after the other birds, worn out by family cares, have ceased their music, this blithe "little boy blue" carols his jolly roundelay from the top of a tall tree as gayly as though there were no such thing as work in the world. For this we lore him. Yet snugly hidden among the bushes is the eup-shaped nest, where in the June days his mate brooked over the pretty nestlings, and where he was kept busy hunting bugs for the hungry mouths; and there-may have been a second brood to be looked after, as there often is in the Bunting family. It any rate, he has had his full share of labor in nest-building, ineubating, guarding, and feeding, and has come out of it without losing one iota of enthusiasm in the joy of living. 
Baby Buntings are very like their newly hatched sparrow cousins. The thin hair-like down on their heads and shoulders is soon replaced by soft brownish feathers; the broad flat bills take form and comeliness; their funny little elbows become hidden in the wing plumage, and every day sees them stretching up to fly. They usually leave the nest when fifteen days old unless the début is hastened by meddlesome fingers. Up to this time they have been fed on insects, by regurgitation at first, then fresh food is given them, the frequency of meals depending somewhat on the location and the time of day. Early in the morning, after a night of fasting, all young birds are fed as frequently as it is possible for the parents to bring the food; and young reared upon insect diet seem to require more frequent meals than those whose bill of fare consists of seeds. In the case of one brood of young Buntings, the meals were brought every eight minutes from four to five A.M., until their little crops swelled out like marbles. Through the semitransparent skin I could see enough of the contents to be sure of their menu after they were five days old.

613. BARN SWALLOW. - Hirundo erythrogastra. Family. - The Swallows.

Length: $5.75-7.75$.

Adults: Tail forked for about half its length, outside feather tapered to point. Upper parts glossy metallic blue; forehead dark brown; wings and tail changeable purple and green ; outer two tail-feathers, marked with large whitish spots; under parts rusty brown, darkest on throat. Young: Fork of tail shorter; upper parts lighter in color; under parts dull brownish buffy. 
Geographical Distribution: Whole of North America, migrating to Cen. tral and South America.

California Breeding liange: Chiefly coastwise in more uorthern portions, but local elsewhere throughout the State.

Breeding Season May and June.

Nest: A cup or bowl-shaped structure; made of pellets of mud mixed with straws, etc.; lined with feathers; attached to the side or roof of a cave, or to timbers in barns or other buildings.

Eggs: 3 to 4 ; speckled with brown and lavender. Size $0.68 \times 0.50$.

Although choosing to live in a stable loft, the Barn Swallow is an aristocratic-looking bird, his long forked tail giving him an air of elegance unrivalled by any of his comely relatives. Among a family remarkable for their swift, graceful flight he has no superior. Circling low over the earth in search of the insects that live in moist places, or fluttering like a huge butterfly at the edge of a puddle as he gathers mud for his little nest, his is indeed the "poetry of motion."

On the inside of the barn, among the rafters of the roof, is his cup-shaped nest made of alternate layers of mud-pellets and hay. Once during the long afternoons of late spring time I watched these little masons build. Male and female brought mud in their beaks and plastered it to the rongh boards. Then long wisps of hay and bits of hair were carricel and tucked into place with much poking and patting of the bill. Feathers of all sorts were stuck in promiscuously, until the whole looked as much like a ruffled, headless, Shanghai chicken as like a nest. Some naturalists assert that saliva is mixed with the mud to make it sticky, and it seems to me this must be, for the nest is much firmer than that of the eave swallow and can be taken down intact. 
In several nests, May 20, when the watch began, the young were nearly ready to fly, and their little heads were stretched over the edge as if they were trying to gather up courage to make the dive. In other cases the broods were much later. Incubation required twelve days, and in this the male shared equally with the female, seeming fully as much at home on the nest as did she. It was delightful to see them sit side by side on the edge, turning their little blue heads sidewise as they peeked into the cradle and talked it all over together in low sweet twitters. And when the nestlings were finally hatched, one need not climb to discover the fact, for the busy importance of the happy housekeepers told all who had eyes to see. The young were fed by regurgitation until two weeks old, and then the diet was varied by an occasional large insect that looked like a bluebottle fly.

\section{WHITE-BELLIED SWALLOW, OR TREE SWALLOW. - Tachycineta bicolor.}

FAMiLY. - The Swallows.

Length: $5.00-6.25$.

Adult Male: Upper parts iridescent steel blue ; lores deep black ; wings

and tail blackish, slightly tinged with greenish; under parts pure white.

Adult Female: Similar to male, but upper parts duller.

Young: Upper parts dull brownish slate.

Geographical Distribution: Whole of North America, migrating in winter to the Gulf States and West Indies.

California Breeding Range: Chiefly in upper Sonoran zone, west of the

Sierra Nevada.

Breeding Season: May, June, and July. 
Nest: In holes, excavations, natural cavities, etc.; made of grasses and straw ; thickly lined with feathers.

Eyys: 4 to 7 ; pure white. Size $0.75 \times 0.53$.

EARLY in July the Tree Swallows begin to gather in flocks; and, from that time until they start on their southern migration, innumerable multitudes of them are to be seen flying over the open country. They sit in crowds on telegraph wires or any available perch, gathering late in the afternoon and, when near water, circling over it in an endless game of "Follow the Leader." They dip daintily, each one in turn, rise, circle, and dip again, just brushing the surface with a light splashing, until the shadows of evening fall and it is too dark to watch them longer. In almost any seetion of the United States they are the swallows best known, at least to city folk, and are, I believe, the ones whose return migration has been celebrated in the old song.

They still adhere to the old habits of nesting in hollow trees, only a small portion having been indueed to try the boxes put up for them by bird-lovers. Undoubtedly they will in time accept this substitute and become as changed in their environment as are the eare and barn swallows; but no one can wonder that they love the forest best and are loath to leave it. At Lake Tahoe we found them nesting in the oll piles of the deserted pier, in company with the Brewer blackbirds. They entered the nesting cavities, which were usually two to five feet above the water, by a knot-hole or erevice in the wood. One nest whose brood I watched develop was so filled with feathers that they waved in the doorway, ealling 
the attention of all passers-by. Near this nest a pair of pygmy nuthatches were occupying a small hollow near the top of a pile, entering by a knot-hole too small for a mouse. Both they and the swallows were remarkably fearless.

The incubation of the swallow's eggs lasted thirteen days, both sexes sharing alike in it. We knew this because one would fly in as soon as the other left; but they looked so exactly alike that it was impossible to distinguish one from the other. The newly hatched nestlings were naked, pink, and not unlike a tangle of earthworms. In ten days they were feathered. At this time so fearless were the parents that they did not leave the nest at our approach and, on the last visit, one of the parents allowed herself to be lifted from her brood rather than desert them. This was remarkable in contrast to bank swallows, which are excessively timid; but it was very like the brave little eave swallows and the martins.

For the first ten days of their existence the young Tree Swallows were fed by regurgitation, at intervals varying from five to thirty minutes according to the time of day. During the early morning hours - from four to six - the meals were most frequent. At this sunrise time, also, the adults frolicked over the water, catching inseets, skimming the lightest spray of the waves with a splash in the sparkling ripples, and twittering merry greetings as they passed each other. 


\section{WESTERN BLUEBIRD. - Sialia mexicana occidentalis.}

Family: The Thrushes, Solitaires, etc.

Length: 6.50-7.12.

Adult Wale: Upper parts dark blue and brown ; throat purplish blue; breast bright chestnut; under parts brown, washed with purplish blue.

Adult Female: Upper parts brownish gray; blue on rump and tail.

Young: Gray, mottled and streaked with white, darkest on upper parts. recgraphical Distribution: Transition zone of Pacific coast from Britis:h

Columbia south to central California, east to Western Montana.

Culifornia Breeding lunge: Local in upper Sonoran zone and throughout Transition zone.

Breediny Seuson: April, May, and June:

Nest: In old woodpecker holes or in cavities of pine trees, usually rather high.

Eggs: 6 ; light blue. Size $0.81 \times 0.67$.

Is coloring, the Western Bluebird is the counterpart of the bluebird of the East, but he is much more shy, seldom coming close to houses or nesting near the homes of men. He is a resident throughout the foot-hills and lower mountains, coming down to the valleys in winter. I lave found him oftenest along country roadsicles or in the edge of the woods, and have seldom seen him within the borders of a town even in the winter. This Bluebirl, like the mountain species, has the flycateher habit of darting down from a pereh for insects, and often hunting through the grass for them and flying back to the perch to eat. Crickets, moths, grasshoppers, caterpillars, ants, and weevils form the large part of his diet, varied with fruits.

His song is clear and mellow, - three notes repeated 
over and over while perching, never on the wing. Except in the location of the nest, this bird is like the mountain bluebird in breeding habits, which have been fully described under that liead.

\section{MOUNTAIN BLUEBIRD. - Sialia currucoides.}

FAnILY : The Thrushes, Solitaires, etc.

Length: 6.50-7.90.

Adult Iale: Upper parts brilliant light-blue; under parts pale turquoise blue. Winter plumage slightly duller.

Adult Female: Upper parts gray, wings and tail bright turquoise blue ; under parts soft light-brown, washed with blue.

Young: Grayish, indistinctly streaked or mottled with white; wings and tail blue.

Geographical Distribution: From Great Slave Lake south to New Mexico, and from the Plains to the Pacific.

California Breeding Range: On the higher Sierra Nevada, from Mt.

Shasta to the San Bernardino mountains. Breeding Season: May, June, and July.

Nest: In old woodpecker holes or in natural cavities of dead trees. Eggs : 5 to 7 ; pale turquoise blue. Size $0.85 \times 0.63$.

THE exquisite coloring of the Mountain Bluebird renders him easily the most beautiful of all Californian birds. No words can deseribe his brilliancy in the breeding season, as he flies through the sunny clearings of the higher Sierra Nevada, or sits like a bright blue flower against the dark green of the pines. In the winter the brilliant blue of his plumage is dulled by brownish, but even then he is glorious. All through the State east of the humid coast belt these birds wander during the winter in small flocks, looking like big blue butterflies, as they hover fifty feet above the earth. At this time they have all the habits of flycatehers; I have seen them 
at San Diego flying out after insects, or skimming the air like swallows, and hovering like hummingbirds. They have a pretty fashion of quivering their wings a moment as if loath to close them.

Their song is a sweet clear "trually, tru-al-ly," like that of the Eastern species, and a mellow warble. High up in the mountain meadows, where these bits of azure nest, they are usually seen only in pairs, and are frequently the only pair in the neighborhood, and here their feeding habits are those of the thrushes once more.

Both male and female carry material to the old tree which they have selected for a home. Usually the cavity chosen is one excavated the previous year by a woodpecker, but sometimes a natural hole in a dead tree or a crevice about a house is selected. In any case it is nearly filled with dried grass and feathers. Fuurteen days are required for incubation, and in this the male often, but not always, shares. When not on the nest himself he brings food to his mate, calling to her in sweetest tones from the outside before entering the doorway. The newly hatehed young are of the usual naked pinkish gray type, looking as like tiny new-born mice as birds. On the second day down begins to appear in thin hairs on head and back; on the fourth or fifth day the eyes show signs of opening; on the sixth day they open, and the down is well spread over the bodies.

Up to this time they have been fed by regurgitation, the adult swallowing each bit first to moisten or crush it; but from the fourth day on fresh food is given occasionally, and from the sixth or serenth day all the food 
given is in the fresh state, not regurgitated. Crickets, grasshoppers, beetles, butterflies, and worms are their menu, with a few berries. The young Bluebirds double in weight every twenty-four hours for the first week, and in twelve days are growing a respectable crop of feather's, though the bare skin is still distressingly visible. Their breasts gradually take on the soft, mottled light and dark, and the upper parts have a hint of blue among the grayish brown on the wings and tail. One would suppose this blue on the upper parts would be too conspicuous, but when the youngsters leave the nest and perch on the soft gray of the dead trees, they become almost invisible in the strong sunlight.

\section{YELLOW OR ORANGE CONSPICUOUS IN PLUMAGE}

497. YELLOW-HEADEI) BLACKBIRD.

Xanthocephalus xanthocephalus.

Fanily: The Blackbirds, Orioles, etc.

Length: Male 8.60-10.10; Female 7.50-8.30.

Adult Male in Summer: Plumage uniforin black, except yellow or orange head, neck, and chest, and white patch on wings.

Adult Nale in Winter: Similar, but yellow feathers on top of head tipped with brown.

Adult Female: Dark grayish brown, throat and chest dull yellow; breast mixed with white.

Foung Male in First IV inter: Similar to female, but larger, and deeper colored.

Young: (Nestling) General color pinkish brown; upper parts indistinctly streaked with lighter beneath; wings and tail blackish.

Geographical Distribution: Western North America from British Colmmlia south to Mexican table-lands; east to Wisconsin, Indiana, and Texas.

California Breeding Range: Interior valleys, east of the humid coast belt. 
Brecding Season: May 15 to July 1.

Nest: Like an inverted cone in shape; fastened to the upright tules, from 1 to 2 feet above the surface of the water; the outside is composed of coarse marsh-grass and fine tules woven together; lined with fine grass and pond weeds and occasionally plant down.

Eygs : 3 to 5 ; greenish white, evenly blotched and speckled with browns and gray. Size $0.71 \times 0.53$.

Is suitable localities throughout California, as elsewhere in the United States, the Yellow-headed Blackbird breeds abundantly. The interior valleys east of the Coast Range are his favorite haunts; there, except during the nesting season, he may be found picking up insect food in the newly harrowed ground. Grasshoppers, big black wingless crickets, all sorts of marsh insects, and the larve and eggrs of beetles form his bill of fare ; and much does the farmer owe to his good services. When the winter rains have ceased and the warm spring sunshine floods the valleys, the large flocks of these handsome birds leaving the farms and fruit ranches betake themselves to the tule marshes, where their noisy wooing can be heard far and wide. While the male rocks and sings on the tall reeds, the soberly gowned female is busy building a nest among the swaying rushes. First she brings heavy, wet pond-weed and marsh-grass, and with it winds several of these together, weaving it in and out and making a firm support for the superstructure. Bits of dried rushes and last year's tule are twisted in to form the walls, which are then warmly lined with the finer marsh-errass and pond-weed. No feathers or other animal matter are used in it, but oceasionally a little plant down, as if the blossom had ripened after having been caught aecidentally in the weaving. 
No help has the mother bird had from her mate in this labor, except the encouragement of his cheery song as he swung always in sight of her, ready to join her the moment she left her work. In a few rare instances I have

497. YELLOW-HEADED BLACKBIRD.

\section{"Beseechingly from the} cradle."

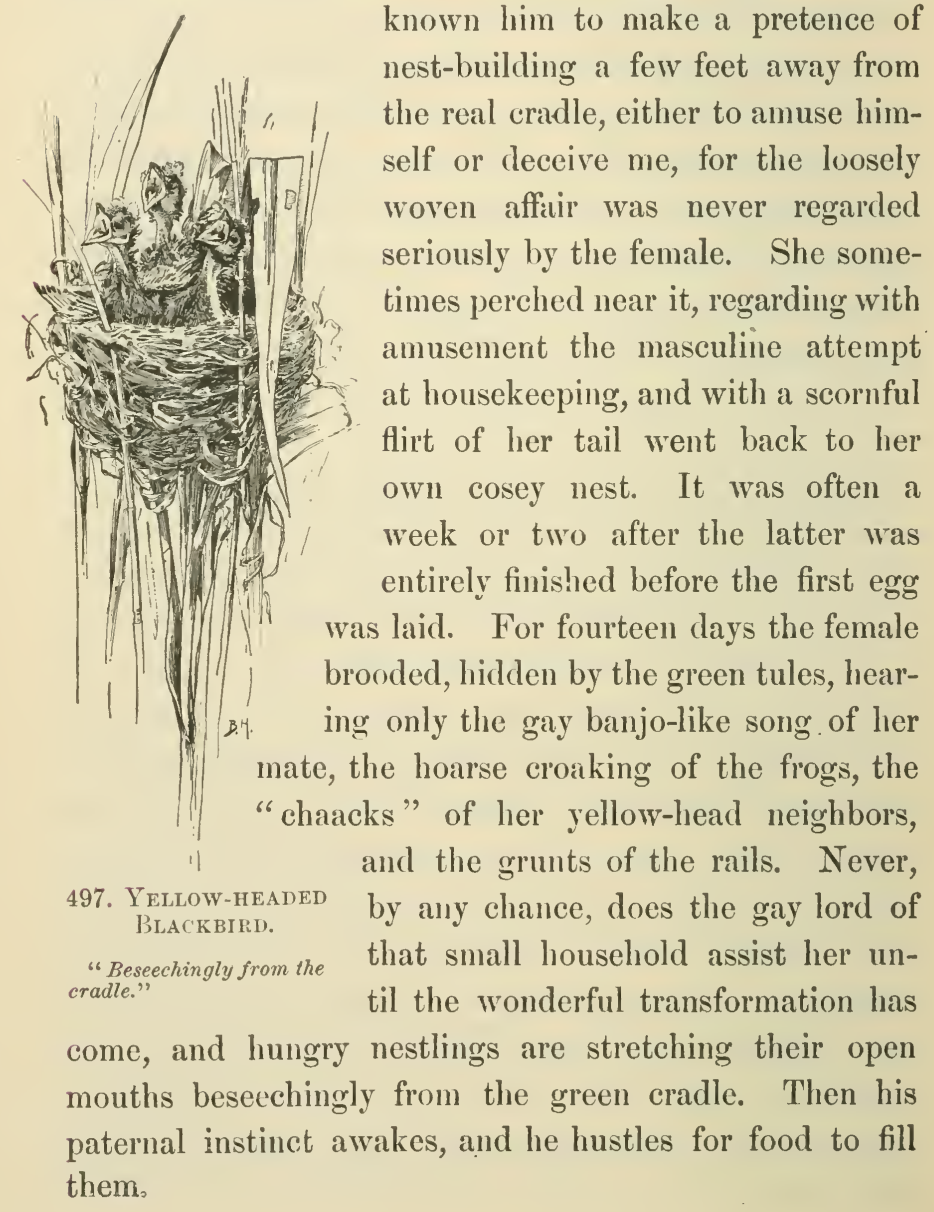

known him to make a pretence of nest-building a few feet away from the real cradle, either to amuse himself or deceive me, for the loosely woven afficir was never regarded seriously by the female. She sometimes perched near it, regarding with amusement the masculine attempt at housekeeping, and with a scornful flirt of her tail went back to her own cosey nest. It was often a week or two after the latter was entirely finished before the first egg was laid. For fourteen days the female brooded, hidden by the green tules, hearing only the gay banjo-like song of her come, and hungry nestlings are stretching their open mouths beseechingly from the green cradle. Then his paternal instinct awakes, and he hustles for food to fill them.

by any chance, does the gay lord of that small household assist her until the wonderful transformation has chs of her yellow-head neighbor's, and the grunts of the rails. Never, 
From the very first they are fascinating, pinkish salmon babies, without feathers or down, except a very little patch on the head and shoulders, and a thin dark strip on either side of the back. Developing very rapidly on the diet of water-snails, slugs, and slimy water larvæ of all sorts, on which they are fed by regurgitation at first, they soon become handsome enough in their soft brown coats to delight any father's eyes. Their bills change from buff to black, and the inside of the throat becomes an exquisite rose-pink. Nor are their heads bare, as is the ease with young red-wings. In two weeks or sixteen days after hatehing they are ready to leave the nest, and now it is the father who coaxes them step by step back through the rushes to the safer meadow and teaches them how to find their own food. As soon as they learn this they become very independent and, leaving their parents, join flocks of other young Yellow-heads, who, with a few adults, keep togrether the rest of the summer and through the fall and winter. They seatter over the valleys, wherever the food supply tempts, chattering, frolicking, and gradually doming adult plumage until, when spring calls again, they are off en musse to marshland.

\section{1 b. WESTERN MEADOWLARK. - Sturuella neglecta.}

Famis: The Blackbirds, Orioles, etc.

Length.: Male 8.31-10.14: Female 7.74-9.00.

Adult . Vale: Upper parts grayish brown, strenked and harred witl bulfy, white, and black; crown with median buffy white stripe; lores yel- 
low ; superciliary buff; middle of tail heavily marked with black; tertials, rump, and tail heavily barred; outer tail-feathers white; under parts bright yellow, with black crescent on breast and black spots on sides; flanks and lower tail-coverts white. Adult Female: Similar, but lighter colored.

Young: Colors much duller, with less distinct markings; crescent on chest faintly marked.

Geographical Distribution: Western United States, from Wisconsin, Illinois, and Texas to the Pacific; north to British Columbia; south to Lower California and Mexico.

California Breeding Range: Suitable localities throughout the State. Breeding Season: April.

Nest: On the ground, usually at the foot of a bunch of grass; made of grass, loosely covered over.

Eggs: 3 to 7; white, spotted irregularly over the entire surface with brown and purple. Size $1.10 \times 0.90$.

The Western Meadowlark differs from the Eastern species chiefly in the quality of its song, in which it greatly excels the latter. The wild sweet notes have a carrying quality, and at the same time a liquid mellowness that is peculiarly in harmony with the wind-swept prairies of the West. It is also longer, more varied, and more sustained than the song of the Eastern species. Major Bendire compares it to the "matchless, clear, tinkling utterances of the finest of our Western songsters, Townsend's solitaire." Its alarm notes differ somewhat also, being less harsh, more a remonstrance than a scold.

Of a somewhat paler plumage than the lark of the East, it is closely allied in habits, living in the open meadows and clearings along streams. Down among the tangled grass of the lowland prairie it builds its nest, - a snug little hollow in the soil, lined with dried grass and often roofed with the same. Both male and female assist in moulding the nest and in the cares of 
incubation. This lasts thirteen days, and the young remain in the mursery twelve days longer, leaving it before they are able either to fly or to perch. Yet so protective is their coloring and so jealously dues the long grass guard its secret that, search as you may within a circle where you know they are hidden, you will not find one of them. For two weeks longer they remain with their parents, learning to hunt grasshoppers, beetles, and crickets, to hide in the shadow of a green tuft, to bathe in the shallows at the brook's edge, and last of all, to perch in low bushes at night with others of their kind. As soon as they have mastered these things, they are able to provide for themselves and are abandoned by the parents. I have a theory that the young of each year go some distance south in companies guided by one or two adults, returning either the next spring or the second season. Some species of birds do not mature fully until two years old, and this seems to be true of Meadowlarks.

Meanwhile the parents have begun preparations for rearing another brood in the same meadow, but not the same nest. The sun being hotter, this second cradle is more carefully sheltered from its rays by the pulling over of the surrounding grass, and sometimes a runway is made to it, extending four or five feet away. By this the old birds enter and leave the nest proper.

Dr. Cones, in "Birds of the Northwest," writes of some peculiar habits of the IV estern Meadowlark as follows: 
"In April before pairing, hundreds used to frequent daily the parade ground of Fort Randall, where, as the grass was yet scarcely sprouted, good opportunity was offered of observing their characteristic habit - one not so generally known as it should be, since it is related to the peculiar shape of the bill. The birds may be seen scattered all over the ground, busily tugging at something; and on walking over the scene of their operations, the ground, newly softened by the spring thaw, is seen to be riddled with thousands of little holes, which the birds make in search of food. The holes are quite smooth, - not a turning over of the surface of the ground, but clean borings like those made by sinking in the end of a light walking stick, just as if the birds had inserted their bills, and then worked them about till the holes were of sufficient size. Whether they bored at random or were guided by some sense in finding their prey, and what particular object they were searching for, I did not ascertain; but the habit was so fixed and so continually persevered in as to attract general attention."

To this Major Bendire adds his opinion, based on close observation, that they were feeding upon the eggs of the locust, which are deposited just below the surface of the ground.

\section{SCOTT ORIOLE. - Icterus parisorum.}

FAMiLY : The Blackbirds, Orioles, etc.

Length: 7.70-8.50.

Adult Male: Uniform black, except white and yellow markings on wings and tail, and bright yellow belly, shoulders, and posterior parts of back; the rump and upper tail-coverts, usually tinged with olive. 
Adult Female: Upper parts olive-green, yellow on rump and onter tailfeathers ; two white wing-bars; under parts greenish yellow.

Young: similar to adult female, but under parts less yellow, and breast brownish; wing-bar yellow, and all wing-feathers tipped with white; tail tipped with yellow.

Geographical Distribution: Western Texas to California, and from southern parts of Utah and Nevada south to Lower California.

Califormia Breeding Range: In desert regions southeast of the Sierra Nevada.

Breding Season: Nay to June 15.

Nest: A pouch-shaped affair; woven of string, grass, and yucca fibre ; hung under yucca leaves or in other low trees.

Eggs: 2 to 4 ; light blue, marked with brown and gray. Size $0.96 \times$ 0.68 .

Where the tree yuceas grow, the Scott Oriole makes his home. His brilliant lemon and black plumage and merry song are a weleome bit of life in the arid desert regions of Southeastern California. There, in the cool of the morning, or when the intense heat of noonday beats down from the cloudless sky and up from blistering sand, and all the other birds are still, he pipes his clear, sweet roundelay. Even when worn with the cares of a family of two he sings - less often perhaps and less rapturously than when the spring called him to woo his mate, but still with a bubbling overflow of joy. I little way up the valley is his nest, swung under the swordlike leaves of the yueca and securely fastened with its coarse, thread-like fibre. Here, concealed by the dead leaves, the mother bird sits all day long for two weeks, and keeps the eggs warm, often singing softly to herself the same sweet lullaby. Her devoted mate feeds her and stands guard on a neall-by tree, but I have never seen him attempt to get into the nest to take her place when she is absent. He will peer into it with ludicrous 
earnestness, evidently not daring to attempt the dangerous task of brooding, lest his bungling should be disastrous. As soon as the naked pink nestlings have emerged from the
shells and opened their wide bills
for food, his cares begin. And they
know no end until four
weeks later, when all have
learned to care for them-
selves. Oriole nestlings in
general are proverbial cry-
babies, and Scott Orioles are
no exception. Insects of
all sorts in all stages of 


\title{
505 a. ARIZONA HOODED ORIOLE. - Icterus
}

\author{
cucullatus nelsoni.
}

Famil: The Blackbirds, Orioles, etc.

Length: Male 6.90-7.80; female 6.90-7.30.

Adult Male: General plumage saffron-yellow; black patch on throat, extending in front and under the eyes; a band across the fore part of back; tail and wings black, the latter with two white bars and white elgings; tail tipped with white.

Adult Female: Upper parts olive-green, slightly tinged with gray on back; wings olive-brown, with two white bands ; under parts plain dull yellow.

Young: Similar to female, but with throat patch as in the male.

Geographical Distribution: Western Mexico and Lower (alifornia, north

to New Mexico, Arizona, and west of the Sierra Nevada in Southern California; north to Santa Barbara.

Breeding Runge: Coast district of Southern California, north as far as Santa Barbara.

Breeding Season : April 20 to July 1.

Nest: Basket-shaped; of green wiry grass and sometimes dry yucca fibres; oecasionally lined with willow down, wool, or horsebair; securely fastened with twigs and semi-pensile, at various heights from 12 to 40 feet from the ground.

Eggs: 3 to 5; speckled with brown, and having zigzag markings. Size $0.58 \times 0.62$.

DoDgIxG about among the dull green, the Arizona IIooded Oriole makes a gay bit of color, like a brilliant blossom in the acres of chaparral that abound in the Sim Diegan district. His orange breast rivals the poppies in its gorgeoms hme, and his songr fills the air with music. In all his ways he is much more like the orehard oriole of the Eist than like any of the Western species. His protest is the same harsh "scratck." His call-note is the same clear whistle, and his song has the same joyous sweetness. Like the orchard oriole, he haunts the heavy 
foliage, flitting through the open only en route to a fresh pasture. Restless, shy, ever on the move, searching for caterpillars on the under sides of the leaves chickadee fashion, picking in the crevices for larvæ like a nuthatch, and snapping up grasshoppers with a little jump as do young meadowlarks, he is usually to be found within twelve feet of the ground.

His wooing is as ardent as the brilliant plumage would typify. Rivals not a few he fights, and to the victor belongs the spoil, whether she will or no. With song or with harsh scolding note he wooes or threatens, giving her no peace until his suit is accepted. Then both gather material for the characteristic nest, which the female weaves. It is hung on the under side of a fanpalm leaf or in low trees or bushes, sometimes in a bunch of mistletoe, sometimes in willow or gum trees, and in one instance, at Monrovia, California, it was hung to a banana leaf. In material used it differs radically from all the other oriole nests in California, for instead of gray or brown plant fibre, horsehair, string, shavings, and other grotesque accessories, it is built of green grass and the moss from the trees. It is sometimes stiffened with yucca fibre, but the prevailing color is invariably green, as in the nest of the orchard oriole; hence it is exceedingly difficult to discover among the green leaves. By the time it has turned yellow the brood has flown. Not so deep nor so pensile as that of the other Californian varieties, it swings like a little basket from the slender support, or is secured by upright twigs to which its walls are fastened. In Texas the bird often hollows 
out a snug nursery for itself in a ball of the tree moss. In this case, or when fastened to the under side of a palm leaf, a small opening is left as an entrance for the female.

Incubation lasts thirteen days, and in this the male takes no part. His duty is to sing from a concealed perch near by and bring tidbits to the mother bird as she broods. If you listen elosely and patiently, you may hear her imitate his song in low tones of sweet soliloquy.

The young Orioles are born naked except for flecks of down on the crown and along the back. They are fed by regurgitation for four or five days. The eyes open on the fourth day, and pinfeathers soon begin to darken the skin. In two weeks' time the nestlings are fully fledged, looking much like the mother, and are ready for their début. Nevertheless they are very helpless, and are fed and cared for by both parents for some time after leaving the nest. The food of this species consists almost entirely of insects, and great is the debt of the farmers to their good services.

\section{BULLOCK ORIOLE. - Icterus bullocki.}

$$
\text { Fammis, - The Blackbirds, Orioles, etc. }
$$

Length: 7.50-8.60.

Adult Male: Under parts, sides of neck, whole malar region, forehead, and distinct superciliary stripe yellow or orange; narrow throat patch, erown, back of neek, back, and stripe through the eye black; wings with white patch and exlgings; tail mostly yellow, but the midlle ferathers and the tips of others blatk.

Adult Frmale: Upper parts olive grayisis, strenkerl with black on lanck, but ehanging to live yellow on rump and tail : top of lead and hind. 
neck yellowish olive, becoming brighter yellow on forehead and superciliary region; wings with white bands; under parts lemon-yellow, fading to gray on belly; throat usually with more or less of black.

Young: Similar to female, but colors duller; no black on throat, and yellow sometimes almost wanting.

Geographical Distribution: Western North Ainerica, north to British Columbia, east to and including the Rocky Mountains; south in winter to Mexico.

California Breeding Range: Chiefly in the upper Sonoran zone throughout the State.

Breeding Season: May and June.

Nest : Fastened at sides and rim to branches of the birch, alder, cottonwood, poplar, and often to bunches of mistletoe growing on cottonwood trees; placed from 6 to 40 feet from the ground; made of vegetable fibres, horsehair, and inner bark woven together; lined with horsehair, down, and wool.

Eggs : 3 to 6 ; grayish or bluish white, or pale buffy, marked with irregular fine hair lines. Size $0.89 \times 0.64$.

THE handsome Bullock Oriole fills the same niche in the country west of the Rocky Mountains that the equally handsome Baltimore oriole occupies in the Eastern States. Like the other two species found in California, it is only a summer visitant, arriving in March and going back to its winter haunts in late September. Like the Baltimore oriole, it loves the open country of the interior valleys, and the margins of streams fringed with alder ; it is never found in the deep forests or the higher altitudes, and seldom or never strays across the Coast Range into the humid coast region.

Its call-notes and song resemble those of the Baltimore, but have less sweetness and variety. Where the latter whistles half a dozen variations on his original theme of five notes, the Bullock is content to repeat the same phrase with few modifications. Nor have I ever heard him give the love song that is poured out by the Balti- 
more with such tenderness just at dawn when his mate is on the nest.

In nesting habits it resembles its Eastern relative, - weaving a pensile bag-like affair of wild flax and plant fibre stiffened with horsehair and lined with plant down and fine moss. This is a typical nest, but string, bits of rag, and colored wool are often used also. The whole is fastened securely around the rim to the finer twigs of alder, eucalyptus, oak, juniper, or pepper. About San José, California, I have found it oftenest in pepper trees. In Texas and elsewhere it is said to hang its cradle in the bunches of mistletoe; it may do this among the foothills, also, but it does not choose this site by preference. Most of the nests hang within fifteen feet of the ground, but I have found them forty feet up from the base of a tree on a steep slope. Nlthough this species less frequently use the nest a second season than do the Baltimores, they have a curious habit of building a sceond close beside the first and often fastened to it. There is no way of ascertaining whether or not it is the same pair who come back to their favorite location and build this addition to their old home, and in bird lore it is never safe to hazarl a guess. Never having seen a male oriole of any species attempt to brood either the egrgs or the young, I an convineed that in every case the fourteen days of incubation of this species is the task of the female alone. Her mate is always within calling distance, keeping a vigilant watch for squirrels, crows, and jays; and should any one of these enemies appear, not only he but the mother bird, joined by all the orioles and blackbirds 
within hearing, will fly at the intruder and effectually banish him from the vicinity. When newly hatched, the young orioles are naked, pink babies with little tufts of thin white down on head and back. For nearly a week after they are feathered the down waves rakishly on either side of the crown and abont the shoulders, gradually wearing off as they brush about through the bushes.

Like all oriole babies, these demand the constant attention of both parents, crying loudly for more the moment their mouths are emptied of the last mouthful, not in the least trying to help themselves, but following the adults about for a week or two after leaving the nest. No wonder that, worn out by unremitting care of this first brood, the parents have neither the strength nor the time to undertake a second in the same season. I believe the families usually keep together until late in August, when the males join flocks of their own sex for the September migration southward.

In "The Condor" for July, 1901, the following statement with regard to the food habits of this Oriole is worthy of special note: "The chief food of the Orioles consists of insects and injurious caterpillars. . . . They are particularly fond of a small green caterpillar that destroyed the foliage of the prune trees a few years ago. The Orioles are often seen in the berry patches, but they are usually in search of insects, as is proven by an examination of a great number of stomachs." These facts regarding the food habits of our song birds are of great value to the bird-lover, but even more so to the farmer. Naturally he will protect any species which is proven beneficial to his crops. 


\section{4 a. WESTERN EVENING GROSBEAK. - Hesper-} iphona vespertina montana.

Family: The Finches, Sparrows, etc。

Length: Male 6.70-7.30 ; female 6.50-7.30.

Bill: Large and heavy.

Adult Male: Upper parts yellowish olive, shading to yellow on rump; forehead and superciliary bright yellow; crown, tail, and wings black, the latter with large white patches; under frarts greenish yellow, shading to lemon-yellow on under wing and tail-coverts.

Adult Female: General plumage yellowish or yellowish brown; throat bordered on each side by a dusky streak; whitish patches on wings ; under parts light gray.

Young: Similar to female, but color duller and more brownish, with markings less sharply defined.

Geographical Distribution: Western North America, from the Pacific coast eastward to the Rocky Mountains; south to Mexico.

California Breeding Range: Local in the high Sierra Nevada from MIt. Shasta to the Yosemite valley.

Breeding Season: May 1 to June 15.

Nest: A comparatively slight structure ; composed of small sticks, roots, and sometimes lichens; lined with finer roots; placed in coniferous or willow trees, from 12 to 50 feet from the ground.

Eggs : 3 or 4 ; green, blotehed with light brown.

Lixen against the dark green of the pine tree in the golden glow of sunset, as he settles for his night's rest, the Evening Grosheak is a bird of striking beauty. Seen flying across the open when the first rays of the rising sun flash on the yellow of his breast, brightening and deepening its pale lemon to a color like grold, while his elear whistle calls through the dewy air, he is a joy forever. Daintily eating the maple buds or the young shoots of the juniper tree, stopping ever and anon to pipe his wild, free song that has in it the breath of the pine 
woods and the silver cadence of the mountain brook, he is " an April poem that God has dowered with wings."

He is seldom or never alone, but travels with a merry band of his fellows, from the southern valleys where he feeds in winter to the northern mountain heights. There among the pine forests where the yellow lichen clings to the rugged trunks, he will build his nest and rear his brood. And now you discover the reason for his greenish yellow coloring; for, as he flits here and there among the lichen tufts, picking up bits to line or decorate his nest, you are struck with the way in which he becomes invisible. So, in cases where the lichens are used in the nest-building, it is difficult to tell whether or not the bird is brooding. The lichens are seldom used, however, unless the nest is placed in a fir or pine tree. When built in a willow, rootlets and finely shredded strips of bark take its place. Whether this material is chosen because of convenience or with an eye to protective coloring no one may say, but I believe it is only a matter of whatever is most easily obtained. Both sexes assist in the nest-building and in gathering material, which is moulded into shape by a turning about of the bird's body after the manner of the blackheaded grosbeak. The only nest I have ever seen was entirely inaccessible, in the top of a fir tree at least thirty-five feet from the ground. The tree stood on the side of a cañon, and it was possible from a point above it and a hundred feet away, by means of field glasses, to watch the birds at work. But at this distance one could only observe in a very unsatisfactory degree and 
could gain few facts that are sufficiently definite to be recorded. I know that the female was on the nest and the male always somewhere in the vicinity every time I looked during a watch of fifteen days. After that, both flew back and forth with food, but I was entirely unable to tell what the menu might be, except in one 'ease, where the male alighted a moment near me with a caterpillar (not the hairy kind) in his beak, and theu flew straight to the nest.

On the fifteenth day after I first observed the parents carrying food, the nest-tree was deserted and not a glimpse could I catch of young or old. This was at a height of seven thousand feet in the Sierra Nevada, and I fancied they had gone to the lower altitudes to feed upon the buds of the deciduous trees and in the fruit ranches of the foot-hills. With the solitude of the forests the Grosbeik leaves his quaint, sweet song. Henceforth, until spring calls him back to the breeding grounds, he will utter only the single whistled note, and no one who hears shall guess that he can sing.

529 b. WILLOW G(OLDFINCH. - Astragalinus tristis salicamans.

Funcy: The Finches, Sparrows, etc.

Length: 4.08-1.82.

Adult Male: (ieneral boly plumage yellow, in sharp contrast to black foreheal, crown, lores, wings, and tail ; wings with faint white elgings; tail-feathers with white patelues.

Adult Female: Ijuer parts dark olive-brown, sometimes tinged with olive gresuish; wings aml tail dull blackish brown, with mnrkings similar to male; throat dull greenish yellow, remainder of under parts dull grayish, more or less tinged with yellow. 
Young: Plumage darker in tone than that of the adult.

Geographical Distribution: Pacific coast from Washington to Lower California.

California Breeding Range: Chiefly in the upper Sonoran zone, from Shasta valley to San Diego.

Breeding Season: May to July.

Nest : A compactly woven cup-shaped structure; composed of plant

fibre; lined with down and other soft materials; placed in tall bushes or low trees.

Eggs : 3 to 5 ; bluish white. Size $0.65 \times 0.52$.

The Willow Goldfinch of California is in form, color, and habits so exactly like the goldfinch or "thistle-bird" of the East that one wonders why Western ornithologists have made a subspecies of him. His shorter wings and tail and his smaller black cap are the only points of difference. Although he is resident wherever found, he changes his bright yellow and black plumage in the fall to a more sober garb of dark olive and black, and in his new suit is not always recognized as an old friend. In the spring, likewise, when the olive has given place to the gold, you hear it said, "The wild canaries have come back again," when they have really been there all the time. His happy call has been interpreted as "perchic-o-ree, per-chic-o-ree," and fits well with the gay undulating flight of the little songster. In addition to this he has a merry twitter that might be called a song. When the thistles bloom, he commences his housekeeping, building an exquisite cup-shaped nest in the fork of a willow, so low that one may with small exertion peep into it. It is beautifully lined with a compact felting of thistle-down and moulded smoothly on the edges with wonderful skill. The two pale blue eggs are brooded by the mother for ten days, and then the 
naked pinky nestlings require all the care of both parents. They are beauties, to the eyes of one who loves bird babies, being perfect in form although so tiny. Their eyes open in a few days, and feathers begin to show along each side of the back and on the edges of the elbows. In ten days they have begun to look charmingly like their devoted mother, with coats of soft olive and brown. It is exactly the right color for nestlings, and when they have left the cradle and sit motionless for hour's among the green leaves, they are invisible to all eyes but those of the parents.

Like the young of all seed-eating birds, they learn to forage for themselves much sooner than do those whose food requires skill to catch. Almost as soon as they can balance themselves the Goldfinch babies eling to the top of a thistle or a bunch of goldenrod, helping themselves to the seed an independently as any of the adults. But when father or mother alights near, the little wings begin to quiver and the bill opens expectantly, even though the little crop be too full to hold more.

Goldfinch nestlings, like very many others hitherto unsuspected, are fed by regurgitation. The adult comes to the nest with his crop conspicuously loaded, and soon transfers the contents to the empty crops of the young, which at once show the change. The food brought is thistle seed from which the down has been carefully plucked, leaving only the small brown part. When full of this the naked crops are distressingly sugrgestive of a flaxseed poultice. 


\section{CALIFORNIA GOLDFINCH. - Astragalinus psaltria hesperophilus.}

Family: The Finches, Sparrows, etc.

Length: $4.00-4.50$.

Adult Male: Upper parts olive-green ; crown, wings, and tail black, with inner webs of tail-feathers white; under parts entirely deep lemon-yellow.

Adult Female: Upper parts grayish olive-green; under parts light greenish yellow; wings and tail dull black.

Young: Similar to female, but tinged with buffy, and wing-coverts tipped with buff.

Geographical Distribution: Southwestern United States, north to Oregon, east as far as Utah, south to Lower California, and Southwestern New Mexico and Northern Sonora, Mexico. In winter to Cape St. Lucas. Californic Breeding Range: Chiefly below Transition zone nearly through the State.

Breeding Season: May to August.

Nest: A small, compact felted mass of vegetable fibre, moss, grasses, leaves, and fine bark; lined with plant down and sometimes with thistle-down; placed in trees and bushes, from 3 to 40 feet from the ground.

Eggs: 5 to 6 ; pale bluish or greenish white. Size $0.63 \times 0.45$.

THE Arkansas Goldfinch differs from the "willow" chiefly in its habitat, being a bird of the orchard and garden as well as of the wooded highway. It is found in the mountains along the edges of clearings to a height of six thousand feet. In breeding habits it resembles the willow, commencing its nest when the thistle-down is at hand for lining and the seeds for food for the nestlings. Except in the breeding season, it is found in small flocks, feeding upon the seeds of weeds or plants, and to a limited extent upon berries and haws. Along the edge of a country road in the fall, the weed tops blossom with these merry songsters, who fly up as you come near, only 
to alight again a few feet farther on, singing the same gay "perchicoree, per-chic-o-ree" as do their Eastern kinsfolk.

\section{LAWRENCE GOLDFINCH. - Astragalinus lanrencei.}

Fanily: The Finches, Sparrows, etc.

Length: $4.50-4.70$.

Adult Mule: Upper parts browuish gray (the baek sometimes tinged with olive-green), changing to bright greenish yellow on rump and wings; crown, face, and throat black; median under parts yellow; lateral under parts light brownish-gray, becoming white on tailcoverts and middle of belly.

Adult Female: Similar to male, but colors duller, and without black on head or throat.

Young: Similar to female, but duller and lower parts indistinctly streaked.

Geographical Distribution: California west of the Sierra Nevada ; southeastward in winter to Arizona.

California Breenting liunge: Local in upper and lower Sonoran zones west of the Sierra Nevalla, as fir north as Chico. Recorded from Ventura County and sim Gorgonia Pass.

Breeding Season: $\Lambda_{1}$ ril, May, and June.

Nest : Composed of wool, fine grasses, down, and feathers, closely wov'n togrether; lined with long hair; placed on extreme end of the limb, of a live oak tree. Sometimes the nest is composed entirely of grasses.

Eggs: 4 or 5 ; pure white. Size $0.12 \times 0.44$.

THE Lawrence Goldfinch is a haunter of the eañons and the lower range of pine forests. I ike the Arkansas and willow goldtinches, it is fommd in small tlocks feeding on the seeds of weeds and flitting from one foragring ground to another in the winter days. Farly in April it secks its breeding places in the foot-lills, where, securely hidden from prying eyes in the unfrequented cañons, it 
rear's its brood. By November it comes down to the lowlands, driven probably by lack of food supplies fully as much as by the cold weather.

\section{LOUISIANA TANAGER, OR WESTERN TANAGER. - Piranga ludoviciana. \\ Fanily: The Tanagers.}

Length: $6.75-7.75$.

Adult Ilale: Head and neck red, brightest on crown ; back, scapulars, wings, and tail black; the wings with two broad yellow bands; rump, upper tail-coverts, and under parts bright yellow. Winter plumage like female.

Adult Female: Upper parts olive-green ; back and scapulars grayish; wing-bars dull light yellow ; under parts pale grayish yellow, becoming bright yellow under tail-coverts.

Young: Similar to adult female, but paler beneath; upper and lower parts indistinctly streaked with dusky.

Geographical Distribution: Western United States; straggles eastward in migration to the Atlantic States.

California Rreeding Range: Chiefly in Transition zone along the entire length of the Sierra Nevada.

Breeding Season: April to July.

Nest: Thin, saucer-shaped structure; made of bark strips and grass stems; lined with rootlets and horsehair; usually placed on the horizontal limb of a tree, preferably an evergreen, about 15 to 30 feet from the ground.

Eggs: 3 to 5; light bluish green, lightly speckled with browns and purples, chiefly at the larger end. Size $0.95 \times 0.65$.

WHEN Louisiana stretched across the continent from the Mississippi River to the Pacific Ocean and north to British America, the most beautiful bird within its borders became known as the Louisiana Tanager. This appellation has long since ceased to be appropriate, for the bird is only a rare migrant in the State whose name it bears, and its centre of abundance is in the Rocky Moun- 
tains. Here and in all the Wrestern monntains it breeds in the coniferous forests. In the Sierra Nevada the Tanagers are among the birds most commonly observed, and in May the buffalo berries near Pyramid Lake fairly blossom with them. Early in the morning the rather monotonous song rings clearly from the top of the tall pines, and a dash of yellow tipped with red and black appears against the dark green of the trees or the blue of the sky. The song is very like that of the Eastern tanagers, but less musieal, having a shrilhess and flatness of tone that are not pleasing to the ear. Its call-note is short and incisive and has been rendered as "pitic, pitictic."

The nest of this brilliantly plumaged bird is commonly placed on a horizontal branch of a fir or pine, and is so concealed by the foliage as to be practically invisible from below. Unlike the scarlet tanager of the East, it constructs a carelessly woven saucer-shaped affair, so shallow in some instances that a hard wind storn would throw the contents out were not the mother brooding over them.

Ineubation lasts thirteen days, and is performed by the mother birl alone, the male rarely if ever going to the nest until the brood are hateherl. Is soon as the nestlings are ont of the shell, however, he assumes his full share of the labor of feeding them. In the ease of one brood at slippery ford in the sierra Nevada, the male brought fifteen large insects and countless smaller ones in the half hour between half-past four and five one June morning. During most of the day the trips to the 
nest with food averaged ten minutes apart. The longest period of fasting was twenty-three minutes, and the shortest one and one-half minutes. Usually one can tell what food a nestling has swallowed by looking closely at its distended crop, as the contents are visible through the

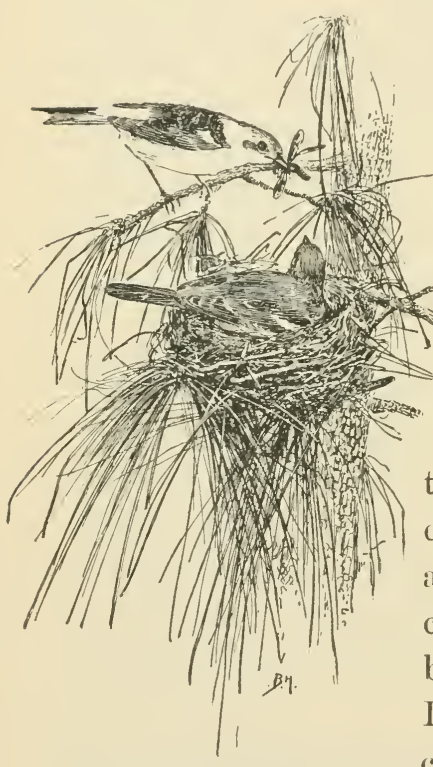

607. LOUISIANA TANAGER.

"A dragcnfly had been captured for brealifast." nearly transparent skin. But these young Tanagers were twenty feet from the ground in a slender fir, and I could not examine them; consequently I could judge of the menu only by the foraging of the alult, and by what I saw sticking out of his bill. When he darted out into the air and back again in flycatcher fashion, I knew he was after a small insect. When he came from the bushes with a bunch on either side of his beak, I was sure he had picked up a caterpillar; when wings of gauzy texture projected on ono side of the mandibles and a long black body on the other, I made a Yankee guess that a dragonfly had been captured for breakfast.

As soon as the nestlings were able to fly they came down to the cover of the lower brush and fed in company with their parents. We knew this by the anxiety of the adults and by their efforts to lead us away from 
the immediate vicinity when we stumbled into it, but long and patient search revealed only one of the young birds. He was sitting on a low bush, looking as solemm as a young owl, and allowed us to go close to him. Except for size he looked like a goldfinch nestling and was no more timid than the latter. The adults moved anxiously through the branches over our heads uttering plaintive calls of fear and low purring notes of remonstranee with us or of reassurance to the young. I am eonrinced that but for their excitement he would have known no fear.

Later, in August, small flocks of young Tanagers were seen, in company with vireos, feeding among the pine trees and evidently gathering for the fall migration. They were following the flycitcher fashion of catching insects on the wing, begiming when the sun tonched the tops of the trees and moving downward as the day advaneed and the insect life neared the ground awoke to activity. In like imanner they retreated to the tree tops as the shadows fell in the afternoon.

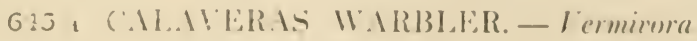 rubricupilla gulluralis.}

Finu, : The Wood Warblers.

\section{Lingth: 4.75 .}

Alult .Male: 'Top of heal griy, whth chestunt erown pateh; white eye-

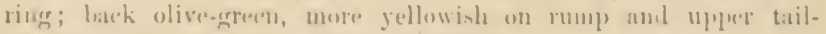
coverts: moler jarts rich lurientit yediow.

Adult Femule: Similar, lut duller ; little or no ehestumt on crown.

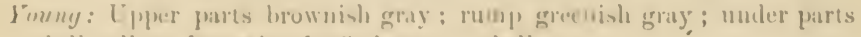
dull yellow, breoming hutly lirown on belly.

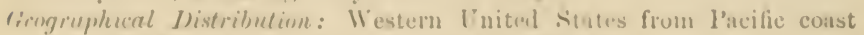
(o) liwehy Monntaius; south in winter to Mexiro. 
California Breeding Range: Along the Sierra Nevada from Mt. Shasta south to Mt. Whitney.

Breeding Secron: May and June.

Nest: On the ground; composed of leaves, bark strips, and weed stems ; lined with finer materials of the same kinds.

Egys: 3 to 5; white, spotted with reddish brown and lavender, in a wreath around the larger end. Size $0.64 \times 0.45$.

The Calaveras Warbler may be said to correspond to the Nashville warbler of the Eastern States. In California it is a haunter of the brush-covered hillsides, hiding shyly in the scrubby undergrowth and singing from the concealment of the deer brush and chaparral. Mr. Chester 1. Barlow writes briefly in "The Condor," November, 1901, of its occurrence in the Sierra Nevada: "Although the species is fur from rare in numbers, it appears that but comparatively few of its nests have been taken; but this is not strange when we consider the nature and extent of the country selected for nesting sites. It is usually by the merest chance that a nest is discovered, as successful a method as any being to beat through the 'mountain misery' in the vieinity of where the male bird is found singing. On June 9, 1899, I flushed a Caliveras Warbler from her nest in tarweed beneath a small cedar at Fyffe, California, at which date the nest held five half-grown young. On June 10, 1901, at Slippery Ford, California, a nest was found built among an accumulation of dry black oak leares beneath a deer brush on the side of a gulch. It contained five eggs, two-thirds advanced in incubation." 
652 c. CALIFORNIA YELLOW WARBLER. - Dendroica astiva brensteri.

Fanil: The Wood Warblers.

Length: $4.50-5.25$.

Adult Wrule: Upper parts bright yellowish olive-green, brightest on rump; forehead bright yellow; front of crown sometimes tiuged with orange; wing-feathers edged with yellow; under parts yellow; breast and belly streaked with rufons.

Adult Female: Upper parts yellowish green, darker than in the male: lighter on forehead and rump; under parts pale ant duller, usti:lly. unstreaked.

Young: Similar to adult female.

Geographical Distribution: Pacifie coast region, from Lower California north to Washington. Possibly farther sonth in winter.

California Breeding Ranye: In upper Sonoran zone chiefly, and elsewhere throughout the State.

Breeding Season: April, May, and June.

Nest: Compract eup-shaped structure ; made of grayish plant-fibre, spider webs, etc. ; lined with lown and feathers ; placed in bushes or trees. Eggs: 2 to 6 ; bluish white, spotted usually in wreath around the larger end, with brown, black, and lilac gray. Size $0.66 \times 0.4$ s.

The Yellow Warbler of California is the yellow warbler of the Eist, the "summer yellow bird" of the Massachusetts firmers, sometimes erroneously called the wild cinnty, and its "wee-chee-chec-chee-cher-wee" lings as joyously from the chaparral as from the wild rose and the blackberries. Next to the robin and the bluebird, it is the bird best known to the country children, who find its nest in the hazel bushes on the way to school. In California it is somewhat more shy and less apt to come into view from every roadside thicket.

The nest is an exquisitely moulded cup lined with plant down that has been felted until it is like shining white satin; even the rim presenting a smoothly rolled 
appearance. It is placed in an upright crotch of a low bush with little attempt at concealment. One little nest that we found had two of the leaves fastened down over it in the weaving, probably by accident, and they formed a complete shelter and protection from the wind. The female flew in at one side and usually sat facing the opening, perfectly concealed, yet seeing all that occurred around. But the typical Yellow Warbler nest is built with an eye to sunshine and fresh air and recklessly exposed to the gaze of every passer-by.

The small bluish eggs, wreathed with minute brown spots at the larger end, are very like the eggs of the German canaries, and I have placed them under a sitting canary hen for hatching. The only drawback was that they hatched in twelve days, which was two days sooner than those of their adoptive mother, and caused her to throw them out of the nest and go on sitting on her own eggs. Under normal conditions they hatch under their own mother in twelve days, and sitting is never begun until the full complement is laid, so that the whole brood emerge from the shell on the same day. At first, like most young birds, they are naked except for sparse down on the head, but at the end of a week they have pinfeathers on wings and tail and thin down on the other parts of the body. In another week the feathers have burst their sheaths, and the nestlings are the prettiest things in the wood. They are fed upon insects by regurgitation for the first few days, and later upon the fresh food. 


\section{YELLOW-RUMPED WARBLER, OR MYRTE WARBLER. - Dendroica coronata.}

Fanily: The Wood Warblers.

Length: 5.65 .

Adult Male in spring and Summer: A yellow patch on the erown, rump, and either side of the breast; "uper yalts bluish gray, streaked with black; two white wing-bars; tail black, with gray edgings; outer pair of tail-feathers with large spots of white; throat white; breast and upper belly heavily marked with black; lower belly white.

Adult. Female in spring and summer: Similar, but smaller, and colors duller; upper parts browner; breast simply streaked with black.

Adult Wule in Full and Winter: Unper parts grayish brown, streaked with black on back and scapulars; yellow crown patch eoncealed by brown tips of feathers; throat and chest bufly brown ; chest streaked with black; yellow patches obscured; black patches with white edges to feathers.

Adult Female in Full and Winter: Similar to winter male, but smaller; upper parts browner, yellow erown patch restricted or obsolete; uniler parts pale buff-hrown in front and on sides; centre of breast and belly yellowish white; yellow brenst patches indistinet.

Young: Similar to adults, hut no yellow anywhere excejt sometimes on rump; whole plumage thickly streakel above and below.

Geographical Distribution: North America, chiefly east and north of Rocky Mountains; rare west, except along the Pacific coast; south in winter to Milllle States, West Indies, and Panama.

Breeding Range: Britislı Columbia and Alaska.

Brording Srason: June 15 to July 15.

Nest: Of vegetable fihres; linel with mosses, feathers, and hair ; placed in coniferous trees, 5 to 10 feet from the ground.

Eygs. 3 to 6 ; white, spotterl chinfly arouml larger end with brown and lilac. Size $0.70 \times 0.52$.

The Yellow-rumped Warbler differs from the Audubon warbler in having a white throat. Both species are very like the Myrtle Warbler of the Fast, and Mr. Girimell lists the Yellow-rumper in California as the "Alaska Myrtle Warbler," while Mrs. Bailey calls it "the Eastern 
representative of the Audubon warbler" because its range is extended eastward to the Rocky Mountains. But it certainly seems more like a Western representative of the Myrtle Warbler, with its white throat and its early migration. East and West it is one of the first of its family to start for the breeding grounds in the spring.

\section{AUDUBON WARBLER. - Dendroica auduboni.}

Fanily : The Wood Warblers.

Length: 5.12-6.00.

Adult Male in Spring and Summer: Throat and rump yellow ; upper parts bluish slate, streaked with black; large white patches on wingcoverts; tail black, with patch of white; under parts with patches of white, yellow, and black.

Adult Female in Spring and Summer: Similar, but colors duller, and with less black on under prarts; upper parts tinged with brown; yellow crown patch restricted and partly tipped with brownish gray; wing-bands narrower; chest and sides grayish, marked with black; color-patches restricted.

Adult Male in Fall and IVinter: Duller and browner than summer males.

Adult Female in Fall and IVinter: Similar to winter male, but smaller and duller.

Young: Upper parts streaked dark and light brownish gray; under parts light and streaker.

Geographicul Distribution: Western North America, north as far as British Columbia; east to eastern base of Rocky Momntains; winters in valleys of W"estern United States, and sonth to Guatemala.

California Breeding Range: In Transition zone along the Sierra Nevada from the San Bernardino mountains to Shasta County.

Breeding Scason: May and June.

Nest: Usually in pines or spruces, 4 to 5 feet from the ground; com-

posed of shreds of bark, pine needles, and fine rootlets; lined with hair and feathers.

Eggs: 4 or 5 ; greenish, speckled with black, brown, and purple. Size $0.67 \times 0.52$.

Mrs. BArler calls this bird "the whirligig of perpetual motion," and the name fits. A flash of yellow, black, 
and white flits through the clearings in the Sicrra Nevada and you are conscious that an Iudubon Warbler has flown by. He lias all the tricks and manners of a flyeatcher, darting out after insects or dodging about among the tree tops, always in a hurry, always in a mad chase for something to eat. Tuless you go to his summer liaunts in the Sierra Nevada you will not see him at his best, for the "winter visitant" of the valless wears a more sober plumage of dull brown streaked with black and only a little yellow visible. In his breeding grounds among the pines and spruces of the mountains lie is a brilliant, lıappy-go-lucky little chap, not at all shy, but is so absorbed in his own busy life as to care little who watches him. The four nests I have

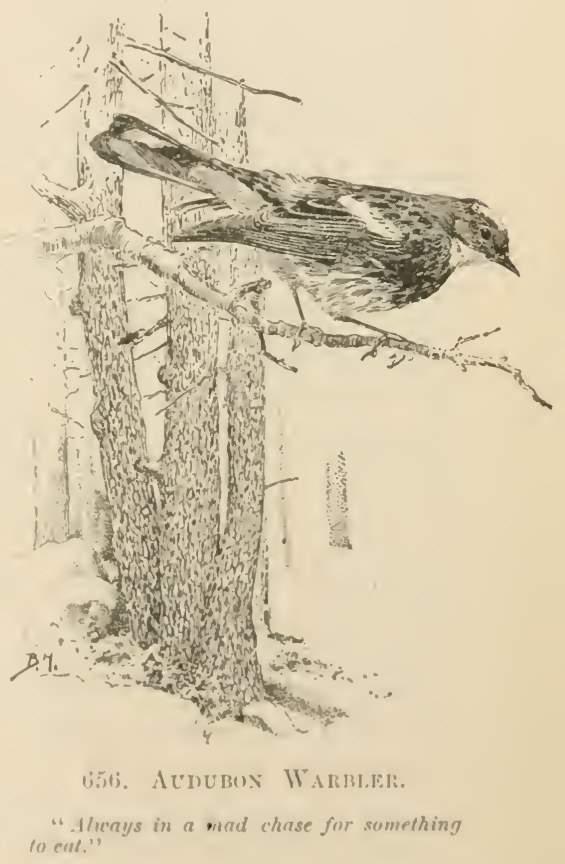
found were all near Tallate on lake Tahoe, and were all in young spruce trees, within five feet of the crromed, along a frequented path. ()II June 15 one contained young a weok old, and three held egrgs in rarious stages of incubation. The pair whose young had hatehed so early 
were very friendly, feeding them without much fear while I sat within three or four feet of the nest and on a level with it. They usually came with nothing to be seen in their beaks, but the insect food they had gleaned and carried in their own throats was regurgitated into the throats of the young. When the latter were five days old the mother bird, for the first time, brought an insect large enough to be seen, and crammed it into the open bill of one of the nestlings, and from that time on most of the food brought was eaten by the young while fresh.

In the brood whose incubation was closely watched, I found that twelve days elapsed between the laying of the last egg and the advent of the young. The female did most of the brooding; the male was found on the nest only once, but was usually perehed on a neighboring tree warbling his enthusiastic little song, "chereecheree-cheree-cheree." $\quad$ fter the young were feathered enough to leave the nest, - which occurred when they were two weeks old, - the male forgot to sing and became a veritable family drudge with the brood ever at his heels clamoring for food.

\section{TOWNSEND WARBLER - Dendroica townsendi.}

\section{FAMILY : The Wood Warblers.}

Length : 4.90-5.30.

Adult Male in Spring and Summer: Head and throat black, with bright. yellow superciliary and malar stripes; breast bright yellow; belly and under tail-coverts white; the latter, also sides and flanks, broadly streaked with black; back bright olive-green, with black arrow-point 
streaks; wings and tail blackish; two white wing-bars, tail with small white spots at end of lateral feathers.

Adult Femule in Spring and summer: Similar to winter male, but black streaking of upper frarts and sides restricted or obsolete; crown sometimes blackish; throat often blotehed with black.

Adult Male in Fall and IV znter: Similar to smmmer male, but llack olscured; crown and hind-neck with olive-green edges to feather's : cheek patch with olive-green tips to feathers; throat lemon-yellow; chest and sides spotted with black.

Adult Female in Full and Winter: Similar to summer female, but npper prarts, sides, and flanks brownish, with streaks of upper parts indistinet.

Young Male: Similar to adult winter male, but streaks on crown and back obsolete, and yellow of throat paler.

Young Female: Similitr to arlult winter female, but yellow fraler and markings less distinet.

Geoyraphisal Distribution: Western North America, chiefly near the Pacifie coast, north to Alaska; migrating east to Rocky Mountains. and south in winter to Guatemala.

Breeding Range: In the pine forests, from Oregon to Sitka.

Breeding Season: June.

Nest: Compract, cup-shaped; made of gray plant fibres; lined with feathers, placed in bushes or trees.

Eggs: 3 or 4; white, spotterl mainly about the larger end with brown and lavender. Size $0.64 \times 0.53$.

Mr. Grincelu says: "The Townsend Warbler oceurs in California as a winter visitant in the Santa Cruz, and sparingly elsewhere west of the Sierra Nevada; oceurs more willely during migration."

It is one of those tantalizing $W$ arblers who persist in staying in the tops of tall trees, where they dodge in and out among the foliage in a most exasperating way. But, in spite of all difficulties, if the "Wrabler madness" has taken possession of you, a day of neek-breaking study will comnt for nothing as arainst the possihility of identifying a species muknown to you, and tomensendi offers unparalleled opportunities in this line. 
The common note of this species is a high-keyed "tseep." The song is very short, and heard from below is scarcely more musical than that of a grasshopper sparrow.

\section{HERMIT WARBLER. - Dendroica occidentalis. Family: The Wood Warblers.}

Length : $4.70-5.25$.

Adult Male in Spring and Summer: Top and sides of head bright yellow, the occiput, and sometimes the erown, spotted with black; throat black; under parts white, sometimes streaked on sides; nape olivegreen streaked with black; rest of upper parts gray, washed with olive-green and streaked with black; wings and tail black; two white wing-bands; tail with the two onter feathers on each side mostly white.

Adult Female in Spring and Summer: Similar to winter male, but forehead and crown more or less mixed with yellow ; body more olive ; dusky patch on throat and chest.

Adult . Iale in Full and Winter: Similar to summer male, but the yellow of crown and occiput more or less obscured; black streaks of back mixed with gray, and black throat pateh specked with white.

Adult Female in Fall and Winter: Upper parts olive-gray; crown with traces of yellow; under parts brownish white.

Young: Upper parts plain ash-gray ; under parts brownish gray, except that the belly and under tail-coverts are white.

Geographical Distribution: Western United States, chiefly near Pacific coast; migrating east to Rocky Mountains, and south in winter to Guatemala.

Californic Breeding Range: In Transition zone along the Sierra Nevada from Mt. Shasta to Mt. Whitney.

Breeding Season : June.

Nest: Of fibrous stalks of plants, fine dead twigs, lichens, and pine needles, bound with cobwebs, and woolly materials; lined with soft inner bark and hair; placed in coniferous trees, from 25 to 40 feet from the ground.

Eggs : 3 ; dull white or grayish green, spotted or blotched with lilac, gray, or brown, chiefly around larger end. Size $0.67 \times 0.47$.

WhILE a fairly common bird along the lower Sierra Nevada from Mount Shasta southward, the Hermit 
Warbler is comparatively little known. Its shyness and its quiet way of slipping from tree to tree, keeping well out of reach in the conifers, makes any extensive observation of its habits difficult. On the Placerville-Tahoe stage route,

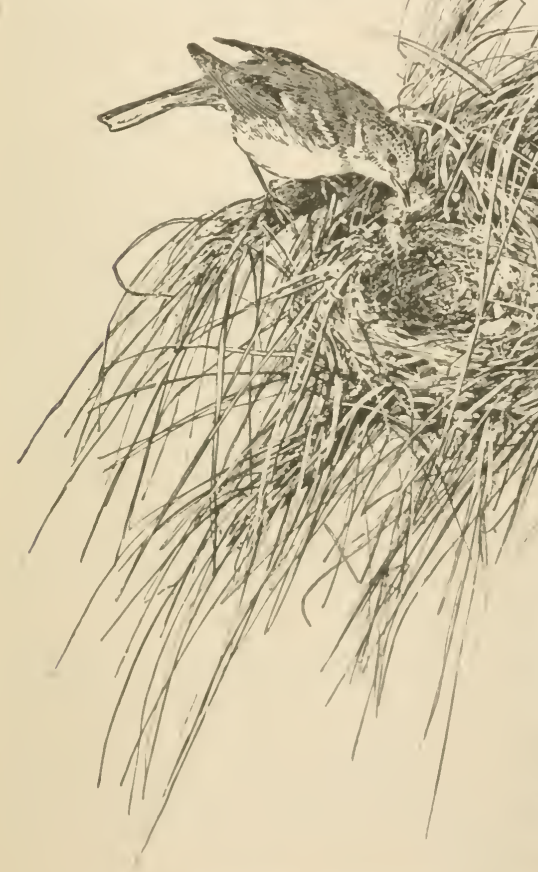

I heard this bird sing and caught tantaliziing glimpses of him in the tops of the manzanita and deer brush alomg the road-

669. HFRMIT WARBI.FR.

" I"ith her beak full of colurebs." sicle: but. seemingr to know intuitively whenever we made a stop to study him, he would instintly end his thin little song and ranish among the green leaves. 
On June 8, after quiet hiding and patient watching, we saw a female of this species fly away with her beak full of cobwebs which trailed nearly two inches, and alight on a tall cedar not ten feet from the travelled stage road; but the tree was so difficult to climb that we could not investigate it. In a moment she flew out of it, empty-mouthed, and further waiting for her second visit was fruitless. Meanwhile her mate had devoted himself to hunting for insects under the leaves of the deer brush, and seemed equally oblivious to her presence and her absence. I fancied him a self-centred mite because, when she alighted beside him, coaxing with a pretty chirp as nestlings do, he fed her in a matter-offact fashion and resumed his own meal. Long, careful searching in this and other places failed to reveal any nest, although it is certain there was one in process of construction near by. Mr. Barlow found one, and, after "collecting" the female, discovered there were young in the cradle. These were promptly cared for by the male, who fed and brooded them.

Mr. Bowles describes the song of this bird as "zeeglezeegle-zeegle-zeek," but to me it sounded more like "jiggle-jiggle-jiggle-jig." Although not loud, it has a carrying quality which at once arrests attention. The eall-note is a sharp "tseet." 
680. MACGILLIVRAY WARBLER. - Oporornis tolmici.

Fanily : The Wood Warblers.

Length: 5.00-5.75.

Adult Male: Head, throat, and breast slate-gray ; throat feathers margined with gray; rest of under parts yellow; lores black; a distinct white spot on each eyelid; back olive-green, sometimes merging to grayish olive.

Adult Female: Similar to male, but crown, hind-neck, and sides of head and neck mouse-gray, fading to grayish white on throat and breast.

Young: Similar to adults, but plumage softer ; throat, chest, and spots on eyelids yellowish; streak over lores pale yellow.

Geographical Distribution: In the mountainous regions of Western North America, from the east slope of the lockies to the Pacific, north to British Columbia, south in wiuter to Panama.

California Breeding Range: Throngh Transition zone along the Sierra Nevada from MIt. Shasta to the San Bernardino mountains.

Brceding Sroson: May 15 to Jume 15.

Nest: Of dried grasses; lined with finer grasses and horsehair; placed in weeds, bushes, or low shrubs, 1 to 6 feet from the ground.

Egys : 3 to 5 ; ereamy white, marked near the larger end with spots and pen lines of dark brown and lilac gray. Size $0.72 \times 0.52$.

Is the chaparral and underbrush; in ravines where small brooks wind in and out, their borders fringed with thick bracken; on the scrubby hillsides, - the Macgillivray Warbler hides shyly among the low foliage, or sings an odd little trill as you pass. These are his chosen haunts, and here among the ferns he will build a dainty nest so carefully hidden and so closely guarded that only by accident can you discover it. And if you do chance to locate it and part the ferns the least bit to peer into it, unless the ergos are nearly ready to hateh they will be abandoned by the timid Warblers and your opportunity to see a brood develop will be lost. Under these eireumstinces it is small wonder that little is 
known concerning the nesting habits of this species, so far as the time of incubation and the rearing of the young are concerned. One nest, found near San José, June 2, and containing young about six days old, was visited daily with no disastrous results, but this is only a partial success among a long list of failures. In this case the parents were so shy that they refused to go to the nest with food while an observer was in sight, and the field glasses could reveal nothing sufficiently accurate to be recorded. The nest was nicely hidden in a clump of weeds on the edge of a small brook and within five inches of the ground. A jump across the brook almost into it resulted in its discovery. When watched, the adults alighted at some distance from it and dodged from clump to clump and through the weeds until they reached the spot where it lay. Close observation failed to record accurately how often they went with food, so slyly did they slip through tangles and open like small gray mice; the crops of the nestlings, examined immediately after feeding, bulged with insect food dark in color. They left the nest after four days' watching, and were probably less than ten days old.

681 c. PACIFIC YELLOW-THROAT. - Geothlypis trichas arizela.

FamiLY : The Wood Warblers.

Length : 4.70-5.75.

Adult Male: Forehead and sides of head black, bordered above with white, sometimes tinged with yellow ; rest of upper parts plain olivegreen; under parts yellow. In winter washed with brown.

Adult Female: Upper parts olive-brown, without black, ashy, or white ; 
crown sometimes washed with reddish brown, tail with greenish; under parts yellowish white.

Young: Similar to adult male, but black mask less distinct.

Geoyraphical Distribution: Pacifie coast from British Columbia to Lower California; east to the Cascades and Sierra Nevada; south in winter through Lower California and Mexico.

California Breeding liange: In the San Diegan district, northwest to Santa Barbara, and possibly northward.

Breeding Season: May and June.

Nest : On or near the ground, among weed stalks ; cup-shaped ; of grass. Eygs : 4; white, finely speekled with brown.

Mingling with the song of the yellow-headed blackbirds and the tinkling music of the marsh wrens, the clear "wichity, wichity, wichity," of the Yellow-throat rings from lowland marsh in the warm May sunshine, telling the world that spring and nesting time have come. If you follow the song to its sumree, you may catch a glimpse of a black-masked little head, flanked by bright yellow, peeking at you with bewitching curiosity, - curiosity mixed with fear, however; for, as soon as discovered, the head is quickly withdrawn, and only a moving of the leaves tells where the singer has hidden himself. But you have seen enough to make you curious in your turn, and to induce you to attempt to pursue the fascinating flash of yellow and green. In a moment more you see him agrin, it small greenish bird scrambling for dear life through the tules or mulerbrush, turning his odd little face constintly to keep watch of you, or flying over a small open space to dive hurredly into the shelter of the thicket. From clump to clump he flits until, when he has led you far enough from his nest, he doclges down to the thickest tangle of marsh grass and hunts for his dinner of insects while you hunt in vain for him. With 
all this hiding he is not particularly shy, and you feel inclined to set him down as a clever little tease who has purposely led you a chase for his own amusement. Throughout the long summer days his cheery, energetic song floats over the wet meadows and out from the blackberry tangles or the tule swamp. Neither the heat nor the cares of a family diminish his ardor one whit. He even springs into the air in the exuberance of joy, performing chatlike gymnastics to his own merry music.

On the bulky nest, snugly hidden low in the bushes or long marsh grass, his plain little mate sits brooding for twelve days, unrelieved by the dapper singer. It is possible that he may feed her, but I have never been able to catch him at it. The female slips noiselessly, without protest, away through the underbrush at the first approach to her nest, and scolds at you from a safe distance, while the male, bold enough when danger threatens, comes nearer, calling, "quit, quit, quit."

You are certain to know when the eggs have hatched by the storm of "quits" that greets your approach, for the Yellow-throat is a devoted parent. Tirelessly he hunts through the wet sedge for insects, swallowing them himself first, and feeding the nestlings with the partly digested food until they are able to take it fresh from the field. And long after the young are feathered and out of the nest, they follow the adult about, refusing to help themselves, coaxing to be fed, until you wonder he has any strength left to sing. The female takes a full share of this labor, but is less often seen because more shy. 
683 a. LONG-TAILED CHAT. - Icteria virens longicauda.

Fanily: The Wood Warblers.

Length: $7.00-8.00$.

Alults: Upper parts olive-gray ; superciliary, eye-ring, and malar stripe white; lores and line under eye deep black ; throat and breast bright yellow ; belly and under tail-coverts white.

Young: Uper prarts plain dull olive-gray ; lores gray ; throat whitish ; chest, sides, and Hauks grayish; rest of under parts white.

Gcographical Distribution: Western United States, east to Great Plains ; south in to Nlexico.

Californin Breeding Range: ('hiefly in upjer Sonoran zone, west of the Sierra Nevada.

Breeding Scason: May.

Nest : Of dry leaves, grasses, and strips of bark ; lined

with finer grasses; placed in thickets and brambles

of low undergrowth, from 2 to 5 feet above the ground.

Eggs : 3 or 4 ; glossy white or piukish, speckled and spotted with shades of brown, which are heaviest at the larger end. Size $0.92 \times 0.70$.

"Is the odd jumble of whistle, chucks, and caws uttered by one bird in that copse youder, or by half a dozen birds in as matny places? Approach cantiously and perhilps you may see him in the air, - a bunch of feathers twitched downward by queer, jerky notes which animate it. One miglit suppose so peculiar a performance would occupy his entire attention, but never-

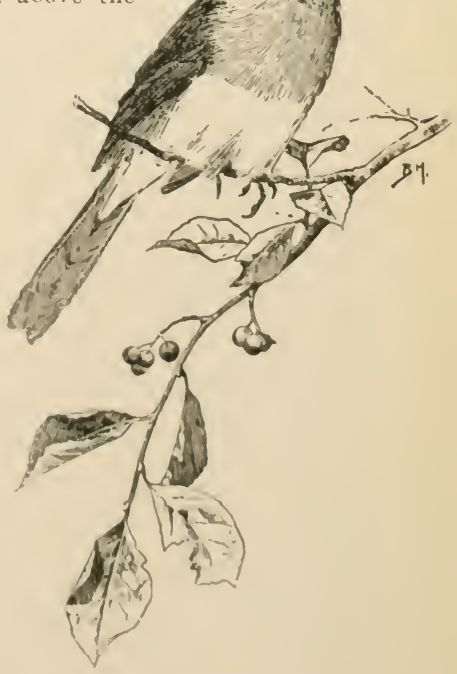

683 a. LoNg.talled Cihat.

"Where hr whislled and sang from daen until dark." 
theless he has seen you. In an instant his manner changes, and the happy-go-lucky clown, who a moment before was turning aërial somersaults, has become a shy, suspicious haunter of the depth of the thicket, whence will come his querulous 'chut, chut' as long as your presence annoys him." 1

This perfect description of the tricks and manners of the chat is the best means of identifying the species. Birds with olive-green backs and yellow under parts are common enough, but one that combines the qualities of a Punchinello with the grace of a professional gymnast is rare. To the chat, life is one long joke.

"His coming in the spring is like the arrival of a brass band. ... When not whistling, or scolding like an oriole, calling like a cuckoo, or piping like a shrill-voiced rock squirrel, he will bark like a dog." 2

It is hard to believe this of a bird not much larger than a sparrow and belonging to the family of warblers. But no words can describe his antics, though nearly every writer on birds has tried. Mr. Bradford Torrey and Mrs. Bailey have succeeded better than any others in interpreting this eccentric clown of the bird world.

Most of his aërial gymmastics are for the benefit of his demure sweetheart, who rarely indulges in such foolishness herself. $\mathrm{He}$ is like the small boy who must turn handsprings to show off.

One of these birds that built his nest in a willow thicket near Pasadena took his full share of nest-building, and would bring the material soberly enough, give it to

$$
1 \text { Chapman. }
$$

2 Bailey. 
the female, who seemed to do all the weaving, start out for more, and "straightway forgetting what manner of man he was," end in one of these eurious song flights. Usually, however, he came with strips of bark or leaves and looked on with conversational chucks that I guessed rather than heard, is most of my observing of hin was done through the field glass. After the beginning of incubation, which lasted fourteen days, he paid little attention to either the mate or the nest during the midlle of the day, but frequented a thicket fifty yards away, where he whistled and sang from dawn until dark, but as soon as the egrgs had hatched he was all devotion. At this time it was possible to watch from a concealed position, and to keep a record of his visits to the nest with food. On one day, which seemed to be a fair average, when the young were eight days old, they were ferl twenty times between five and six $\mathbf{~}$. M., eight times between nine and ten A. M., cleven times between three and four P. Mr., and seventeen times between five and six P.M. For the first four days there was no visible food in the bill of the adult, and the feeding seemed to be by regurgitation. After that, parts of insects could be seen protruding from his bill, and were given to the yomm in a fresh state. Bectles, grasshoppers, and butterflies were all in the dietary, and were brought indiscriminately ; but hairless caterpillats seemed to be the favorite food. The alults are said to eat berries, but I saw none brought to the nest for the young. 
685 b. GOLDEN PILEOLATED WARBLER. - Wilsonia pusilla chryseola.

Family: The Wood Warblers.

Length: $4.25-5.10$.

Adult Male: Upper parts bright yellowish olive-green ; crown glossy blue-black; under parts bright yellow ; forehead sometimes orangeyellow.

Adult Female: Similar to male, but back of crown usually indistinct, being concealed by olive wash.

Geographical Distribution: Western North America, chiefly along or near the Pacific coast; north to Southern British Columbia; south in winter to Northwestern Mexico.

Breeding Season: April 15 to July 2.

Nest: Of leaves, bark strips, weed stems, vegetable fibres, and rootlets; lined with finer grasses; placed in thickets and blackberry vines, on or near the ground.

Eggs: 2 to 4; white or creamy white, speckled with reddish brown and lilac gray, often in the form of a wreath around the larger end. Size $0.60 \times 0.48$.

Is the warm spring days comes the handsome little Pileolated Warbler, with his long title of Western Black-capped Flycatching Warbler. He is a common migrant throughout the valleys of California, and flits over the underbrush like a big yellow butterfly; hut, as nesting time approaches, he withdraws to the mountains, and is seen on the lowlands no more until fall. Not shy, he watches you with quite as much interest as you observe him, calling saucily from his low perch, and readily answering to an imitation of his "seep see." If you are motionless and coax long enough, he will even alight on a spray of chaparral held in the hand. In movements he is an odd little mixture of flycatcher and hummingbird, darting out for a passing insect, or hover- 
ing on whirring wings to pick one from the under side of a leaf so swiftly the eye can scarcely follow him. His song reminds one of the tinkle of a brooklet in its merry, rather metallic melody, and is a distinct note in the medley of spring music.

Like his Eastern relative, the Wilson warbler, the Pileolated builds his nest close to the ground in a swampy willow thicket, and is not infrequently a vietim to the marsh rats and smakes. The first brood is usually hatched early in May, and is fed by regurgitation by both parents until four or five days old, when the usual food of small insects and little green worms is given to them in the fresh state. As soon as their nursery days are over, the male

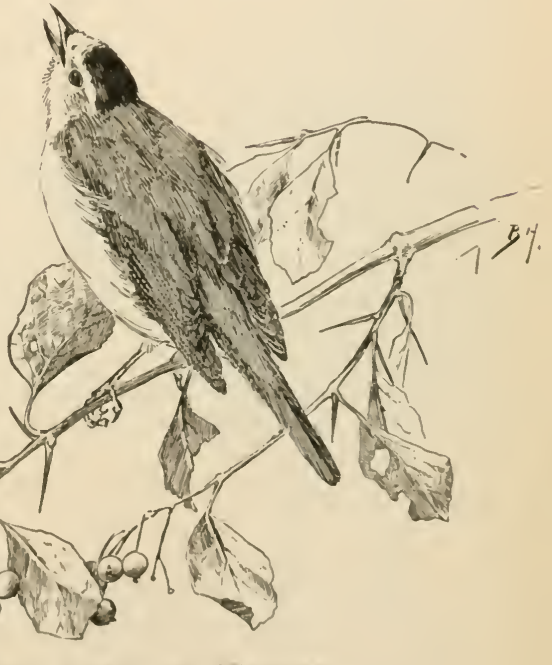

6S5) a. Pillelated Warbler.

"His song remimuls one of the tinkle of a brnoklet."

takes entire charge of the nestlings, feeding them for ten days or two weeks longer.

For the seeond brood a locality slightly higher up the mountain may be chosen, but oftener the little mother builds her second nest within a hundred yards of the first, eommencing it alone, while the male is still oecu- 
pied with the first series. Incubation lasts twelve days, and is, I think, attended to solely by the female, although the male is frequently at the nest both to feed her and to watch over - but not brood - the eggs.

\section{VERDIN. - Auriparus flaviceps.}

FamiLY: The Nuthatches and Tits.

Length: 4.00-4.60.

Adult Male: Crown bright olive; forehead sometimes orange; rest of head, neck, and breast yellow; upper parts gray, with red-brown patch on shoulders; under parts whitish.

Adult Female: Sinilar to male, but enloring duller.

Young: Upper parts gray, tinged with brownish; no yellow, and no chestnut shoulder patches; under parts white.

Geographical Distribution: From Southern Texas to the Pacific, and from latitude $38^{\circ}$ to Mexico and Lower California.

Californic Breeding Range: Local in the desert regions of Southeastern

California along the Colorado River district.

Nest : Large, retort-shajed or globular ; composed externally of thorny

twigs and stems interwoven; thickly lined with weed stems and

feathers; a small round entrance at one side; placed in bushes or low trees.

Eggs : 3 to 6 ; pale bluish white, speckled with red-brown. Size 0.59 $\times 0.43$.

The Yellow-headed Bush-tit, or Verdin, occurs most abundantly in California at the extreme southeastern corner bordering on the Colorado River. He is a tiny mite, not so large as the Rivoli hummingbird, which lives in the same district, across the river, in Arizona. But although so small a bird, the Verdin has most remarkable traits, and is the most fascinating of all the California birds. From his wee yellow throat he pours such a flood of music that you scarch eagerly for the singer, and can hardly credit your senses when you find 
him scarcely bigger than your thumb; you have been looking for something the size of an oriole at least. But there he sits, as perky as if he were of respectable size, and sings the ditty over again to prove that he can do it. And when you first find his nest, the wonder grows. Surely such a mite will build a dainty house like that of the hummingbird. But not so! A retort-shaped affair, ludicrously out of proportion to the diminutive arehitect, is woven of twigs and stems, each one a heavy load for the little builders, and lined to bursting with feathers and flowerstems. It is at least twenty times the size of the mother bird who broods in it, and we do not wonder that it is used summer and winter so long as the walls remain firm. One would suppose this one nest were large

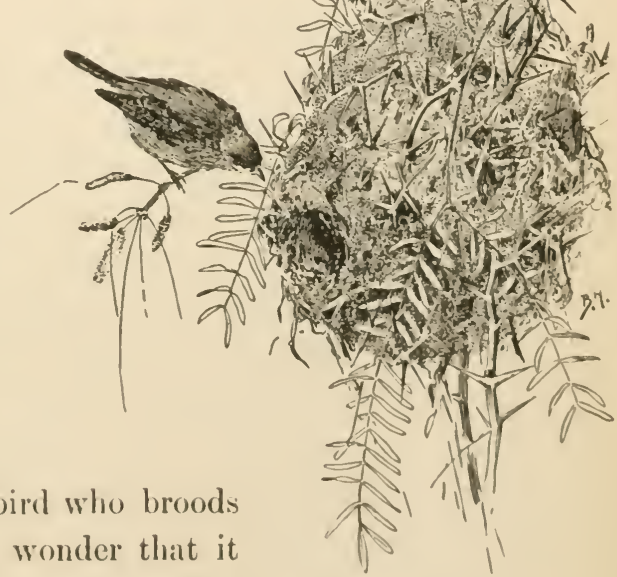

746. VERIIN.

"A relurt-shaped afjuir." enough to hold both master and mistress of the household; but, as if his industry knew no bounds, the male constructs his own apartment in the same neighborhood and oceupies it all winter alone. I believe that the female constructs her own winter nest, and also 
the breeding nest in cases where the winter nest is not used for that purpose. The architecture of the two is somewhat different in those I have observed, the nest built by the female being larger, more carefully lined, and with a decided hollow in the centre of the bedding material as if to keep the babies from rolling out. The nest of the male was simply a hollow gourd-shaped affair with little or no lining, and might pass for a dummy nest such as there is reason to believe he does occasionally build. Every nest found had a neck-like entrance extending downward and ending in a round hole. They were all located in mesquite thickets within six feet of the ground, and most of them were easy to watch. In ten days after the last bluish white egg was laid, there were three infinitesimal bits of naked bird life, huddled tightly together in the middle of the feather-lined hollow. A slit carefully cut at this time and fastened shut after each observation enabled me to keep an exact record of the development of the brood. Although I could not watch the mother feeding the young, I am positive it was done by regurgitation, for she would eat as unconcernedly as if merely occupied with her own dinner, and fly at once with apparently enıty mouth into the nest, emerging shortly to repeat the performance. During the first five days the male was not seen to go into the nest, but sang right merrily near by. After that time the young began to make themselves heard in hungry cries, and he began to carry food to them, which we could see in his bill. This food consisted almost exclusively of small green worms, and eggs 
and larve of insects. The young Verdins remained in the nest quite three weeks, and long after their début they returned to the nursery every night to sleep. The usual note of the adult Verdins is a chickadee-like "tseetu-tu" uttered while hunting, chickadee fashion, among the terminal buds and under the leaves for their insect food, and this the nestlings minic in two syllables as soon as they leave the nest, _ " tsee-tee, tsee-tee." It is a cry of hunger, and never fails to bring the parent with food. 



\title{
SUPPLEMENTARY LIST OF CALIFORNIA BIRISS
}

\author{
CORRECTED TO JANUARY 1, 1909, BY \\ HARRY C. OBERHOLSER
}

The following list contains all additional species and subspecies which occur, even accidentally, in California, and has been compiled from all available sources.

2. Holbotl Grebe. Colymbus holballi. Rare milwinter visitant coastwise.

3. Horned Grebe. Colymbus auritus. Rare midwinter visitant - aloms the coast and on inland lakes.

17. Paroqué Acklet. Phaleris psittucula. One record of tive specimens.

35. SkUA. Megulestris shuu. One record hy G. N. Lawrence.

36. PuMARINe JAEgER. Stercorarius pomarinus. Migrant coastwise.

38. Loxg-TaIled JaEger. Stercorarius longicaudus. One record by L. M. Loomis.

$40 a$. Pacific Kiтtiwake. Rissa tridactyla pollicaris. Rare winter visitant coastwise.

42. Glaucous Guls. Larus hyperboreus. Rare winter visitant alorg the coast.

55. SHort-BILled Guld. Larus brachyrhynchus. Winter visitant coastwise.

56. MEw Gull. Larus canus. Winter visitant coastwise.

62. Sabive Gull. Vemu sabimi. Rare migrant.

64. Caspian Terx. Hydroprocne cusplia. Rare winter visitant along the coast.

66. Elafant Terx. S'terma eleguns. Fall and winter visitant.

71. Arctac 'Ters. Sternu puralisan. Rare migrant.

91. Pisk-footen sinisrwater. I'uffinus criatopus. Summer and fall visitant alongr the coust. 
96. Slender-billed Shearwater. Puffinus tenuirostris. Midwinter visitant.

96.2. New Zealand Shearwater. Puffinus bulleri. One record by L. M. Loomis.

97. Black-talled Shearwater. Priofinus cinereus. One record by G. N. Lawrence.

102. Pintado Petrel. Daption capensis. One record by G. N. Lawrence.

105. Fork-tailed Petrel. Oceanodroma furcata. Irregular visitant.

108.1. Socorro Petrel. Oceanodroma socorroensis. Vicinity of San Diego in summer.

129. American Merganser. Mergus americanus. Fairly common locally in summer.

130. Red-breasted Merganser. Mergus serrator. Common winter visitant coastwise.

131. Hooded Merganser. Lophodytes cucullatus. Fairly common fall and winter visitant in the interior.

132. Mallard. Boschas platyrhynchos. Common resident locally.

135. Gadwall. Chaulelasmus streperus. Fairly common resident.

136. Widgeon. Mareca penelope. Recorded from Eureka.

137. BaldPate. Mareca americana. Abundant winter visitant locally.

138. European Teal. 'Nettion crecca. Recorded by J. G. Cooper only.

139. Green-winged Teal. Nettion carolinense. Abundant winter visitant locally.

140. Blue-winged Teal. Querquedula discors. Rare.

141. Cinnamon Teal. Querquedula cyanoptera. Summer visitant.

142. Shovetler. Anas clypeata. Winter visitant.

143. Pintail. Dafila acuta. Abundant winter visitant, a few remaining to breed.

144. Woop Duck. Aix sponsa. Common resident.

146. Redhead. Nyroca americana. Common resident locally.

147. Canvas-Back. Aristonetta valisineria. Common winter visitant locally.

148. Scaup Duck. Marila marila. Fairly common winter visitant. 
149. Lesser Scaup Dock. Marilu affinis. Common winier visitant enastwise.

15). Riscr-Necked Duck. Nyrocu collaris. Rare.

151. AMERICAN GOLDEN-EYE. Clungula clangula americana. Winter visitant coastwise.

152. Barrow Goldex-eye. C'lungulu islandica. Rare.

153. BuFfle-HEAD. Churitonethe ulbola. Winter visitant.

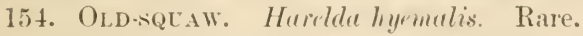

155. Harlequin Deck. Histrimicus listrionicus. Fairly common summer resident.

162. King Eider. Somuteria spectubitis. One record by H. W. Henshaw.

163. American Scoter. Oidemia americana. Rare.

165. White-Winged Scoter. Oidemiı deglandi. Winter visitant.

166. Straf Scoter. Oidemiu perspicillata. Common winter visitant.

167. Ruddr Duck. Erismatura jamaicensis. Common resident locally in the interior.

169. Lesser SNow Goose. Chen hyperbomea hyperborea. Common winter visitant.

169.1. BuUE Goose. Chen ccrulescens. One record by Belding.

170. Ross Sxow froose. Exanthemops rossi. Fairly common winter visitant.

$171 \%$. American White-fronten Gouse. Anser alhifrons gumbeli. Coumuon winter vixitant.

172. Caxada Goose. Brunta canadensis canadensis. Farir! common midwinter visitant.

172a. Hстснаxis Goose. Brantr cumedensis hutchinsi. Winter visitant.

172b. White-chesken Goose. Brantu cremedensis accidentulis. Winter visitant, breeling mortheast of the sierras.

17: c. Cackuxg Goose. Brentre centedensis minima. Winter visitant.

174. Beack Brant. Bronta nilricuns. Mielwinter visitant constwise.

176. EMperor Goose. Philacte crnagica. Rare.

178. Fenvous T'ree Diek Mendroyeme biculor. Common summer resident in the Sin Joapuin-sacramento valley.

188. Woon I BIs. Mycteria americame. Irregular visitant.

210 (part). Southere ('aliforiala Ciapper Railo Rullus levipes. Resident throughout somthern California. 
215. Yellow Rail. Coturnicops noveboracensis. Rare visitant.

222. Red Phalarope. Phalaropus fulicarius. Migrant coastwise.

223. Northern Phalarope. Lobipes lobatus. Migrant coastwise.

234. Knot. Tringa canutus. Casnal migrant.

239. Pectoral Sandpiper. Pisobia maculata. One record by J. G. Cooper.

240. White-rumped Sandpiper. Pisobia fuscicollis. One record by $\mathrm{W}$. E. Bryant.

241. Batrd Saxdpiper. Pisobia bairdi. One record by J. Mailliard.

249. Marbled Godwit. Limosa fedor. Migrant coastwise. 255. Yellow Legs. Totanus flavipes. Two records.

$256 a$. Western Solitari Saxdpiper. Helodromas sultitarius cinnamomeus. Migrant.

258 a. Western Willet. Catoptrophorus semipalmatus crassirostris. Migrant coastwise; occasional winter visitant.

272. American Goldex Plover. Charadrius dominicus. Rare migrant.

274. Semipandated Plover. Egialeus semipalmatus. Migrant coastwise.

276. Little Ring Plover. Égialitis dubia. One record by R. Ridgway.

280. Wilson Plover. Ochthortromus wilsonius. One record by A. M. Ingersoll.

282. Surf Bird. Apluiza virguta. Rare migrant.

283. Turnstone. Arenaria interpres interpres. Migrant along the coast.

283.1. Ruddy Tunnstone. Arenaria interpres morinella. Migrant coastwise.

286.1. Frazar Otster-catcher. Hrematopus frazari. Rare.

292 $b$. San Pedro Partridge. Oreortyx pictus confinis. Extreme southwestern part of State.

300 c. OREgon RufFed Grouse. Bonusa umbellus sabini. Resident from Cape Mendocino northward.

308 a. Columbian Sharp-tailed Grouse. Pedioecetes phasianellus columbianus. Resident in the northeastern corner of the State.

319. White-Winged Dove. Melopelia asiatica. Rare visitant to southeastern portion of California. 
320 a. Mexican Ground Dore. Chremepelia passerinu pullescens. Rare.

334 a. Western Goshawk. Astur atricupillus striatulus. Rare resiclent in northern part of State.

340. Zoxe-talled Hawk Buteo abbrericatus. One record by J. (i. Cooper.

347 a. Adericax Rovgh-Legged Hawk. Archibuteo layopus sanctijohannis. Rare winter visitant.

35\% a. Black Merlix. Falco columburius suckleyi. Rare winter visitant to northern portion of State.

358. Richardson Merlix. Fulco columbarius richurdsoni. One record by H. W. Henshaw.

369. Spotted OwL. Syrnium occidentale, Fairly common renjdent of the Sim Diegan district.

370. Great Gray Owl. Scotiaptexnebulosa. Rare winter visitant in northern part of State.

372. Saw-whet OwL. Glanx acadica acadica. Eleven records as winter visitint.

3i4. Flayjluated Screech OWL. Itus flammeolus flammeolus. Two recorils.

$374 u$. DWARF SCREeCH OWL. Otus fammeolus iduhoensis. Sisceral recorils.

375 a. Pallid Horned OwL. Bubo virginiunus pallescens. Desert regrion of the southeastern part of the State.

375 e (part). California Horved Owl. Bubo virginianus icelus. Fairly eommon resident of the humid coast belt from Siunta Barbarat north to San Francisco Bay.

376. Snowy OwL. Nycten nyctea. Liare winter visitant.

379 a. Califorvia Pyom OWr. Glaucidium gumma ialiformicum. Const region south to Monterer.

381. ElF OWL. Micropallas whituegi. One recorl l,y R. Rislsway and one hy L. II Lommis.

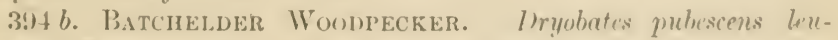
curus. Rare; possibly only a winter visitant.

394 . WILLow Woonl'Ecker. Mryobutes pubesensturuti. Resdent in Upper Sonoran and Transition zones in mont localities.

396. Texas Woonpecker. IMryubutes sculuris bairti. Fairly (ommon in desert region southeast of the Sirrrats.

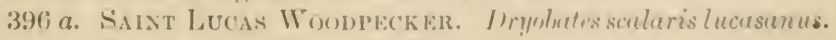
Recorded from western Riversirle C'ounty. 
$402 a$. RED-NAPED SAPSUCKER. Sphyrapicus varius nuchalis. Winter visitant to southern part of State.

$403 a$. Northern SAPSUcker. Sphyrapicus ruber notkensis. Coast belt to Monterey in winter.

412 a. Northern Flicker. Colaptes auratus luteus. Occasional winter visitant.

$413 a$. Northwestern Flicker. Colaptes cafer saturatior. Winter visitant in north end of State.

418 a. Poorwill. Phalcenoptilus nuttalli. Resident in desert regions of southeastern portion.

420 a. Western Nighthawk. Chordeiles virginianus henryi. Summer visitant in desert regions.

444. Common KingBird. Tyrannus tyrannus. Rare summer visitant.

456. Рнаве. Sayornis phabe. One record hy H. S. Swarth.

464.1. Saint Lucas Flycatcher. Empidonax difficilis cineritius. Summer resident in San Diego County.

469.1. Gray Flycatcher. Empidonax griseus. Summer resident in central portion of State along Boreal Zone ; winters in Sin Diegan district.

$474 e$ (part). California Horned LaRk. Otocoris alpestris "mmophila. Deserts of southeastem California.

$474 i$. Duskr Horned Lark. Otocoris alpestris merrilli. North. eastern part of State.

$474 j$ (part). Tuma HoRned LARK. Otocoris alpestris leucansiptila. Extreme southeastern corner of State.

$474 \mathrm{~m}$. IsLAND HORNED LARK. Otocoris alpestris insularis. Common resident on the Santa Barlsara Islands.

480. Woodhodse Jay. Aphelocoma woodhousei. Resident along the desert ranges east of the Sierra Nevada.

$481 b$. Belding JAY. A phelocoma californica obscura. Sonthern coast district.

481.1. Santa Cruz Island Jay. Aphelocoma insularis. Resident on Santa Cruz Island.

485 a. Gray Jay. Perisoreus obscurus griseus. Northern Sierra Nevada.

498f. Northwestern Red-winged Blackbird. Agelaius phoniceus caurinus. Recorded by R. Rirlgway from Mendocino County in May.

519c. San Clemente House Finch. Carpodacus mexicanus clementis. Resident on all the Santa Barbara Islands. 
528. Redpoll. Agiothus linaria linaria. One record by J. M. Willard.

$540 b$. Oregon Vesper Sparrow. Poocetes gramineus affinis. Winter visitant.

542. Sandwich SPARRow. P'usserculus sandwichensis sandurchensis. Rare visitant.

549.1. Nelsox Sparrow. Ammuspizu caudacutu nelsoni. Two recorrls.

553. Harris SPARRow. Zonotrichia querula. One record hy IV. O. Enerson.

5ir. White-throated Sparrow. Zonotrichia allicollis. Rare visitunt.

559 $a$. Westers Tree SPARROW. Śpizella momticola ochruen. One record by Feilner.

567. Suate-coloren Junco. Junco hyemalis hyemalis. Rare winter visitant.

567 b. Shufeldt Juxco. Junco oreganus shufeldti. Winter visitant.

569. GraY-headed Juxco. Junco cuniceps. One record ly W. B. Judson.

573 a. Desert Black-throated śparrow. Amphispiza bilineata deserticola. Summer visitant.

574.1 b. Califorvia sige siparrow. Amphispiza nerudensis canescens. Desert region of sontheastern part of State.

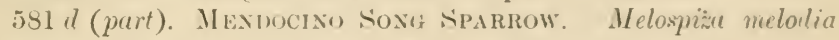
cleonensis. Resilent in north humil const belt.

$581 d$ (part). Santa Crez song Sparrow. Melespiza melotin suntacrucis. Resident in the Sintin r'ruz district.

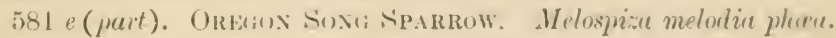
Winter visitaut.

581 h. Saxta liarbara siong siparrow. Melospiza melodia grelminu. Resilent on Siuntal Parbara and santa ('ruz lslands.

5sli. Six Clamexte Sova Sparrow. Melospiza melodia dementor. Resident on sim C'lemente, San Mignel, amd simta Rosil Islituls.

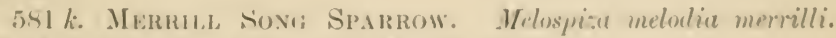
Winter visitant ; also breeds in shasta ('ountr.

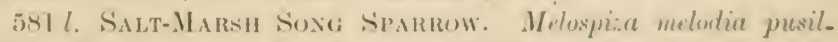
luk. Resielent in the sim Francisen Bay renginn.

581 m. Sax 1)hego Sowa Sparrow. Melospiza melodia cooperi. Reailent in the San Diegan district.

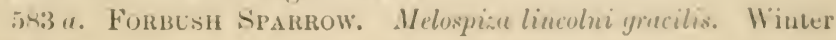
visitant. 
585. Fox Sparrow. Passerella iliaca iliaca. Rare visitant. $585 a$ (part). Shumagin Fox Sparrow. Passerella iliaca unalaschcensis. Pare winter visitant.

$585 a$ (part). Kadiak Fox Sparrow. Passerella iliaca insularis. Winter visitant.

$585 a$ (pait). Yakutat Fox Sparrow. Passerella iliaca meruloides. Winter visitant.

585 a (part). Soоty Fox Sparrow. Passerella iliaca fuliginosa. Winter visitant as far south as San Francisco.

585 c. Slate-colored Sparrow. Passerella iliaca schistacea. Summer resident.

$588 b$ (part). San Francisco Towhee. Hortulanus maculatus falcifer. Coast belt south to Monterey County.

588 c. San Clemente Towhee. Hortulanus maculatusclementa. Resident on San Clemente and other Santa Barbara Islands.

$588 d$. SAN Diego Towhee. Hortulanus maculatus megalonyx. Coast district of Southern California.

592. Abert Towhee. Hortulanus aberti. Southeastern corner of State.

594. Arizona Prrrhuloxia. Pyrrhuloxia sinuata sinuata. Recorded only at Fort Yuma.

595. Rose-breasted Grosbeak. Hedymeles ludovicianus. Two records.

618. Bohemian Waxwixg. Bombycilla garrula. Recorded from Lassen, Plumas, and San Bernardino Connties.

621. Northern Shrike. Lanius borealis. Midwinter visitant in northern part of State.

622 c. Island Shrike. Lanius ludovicianus anthonyi. Resident on Santa Catalina and Santa Cruz Islancls.

622 d. San Clemente Shrike. Lanius ludovicianus mearnsi. San Clemente Island.

625. Yellow-Green Tireo. Vireosylva flavoviridis. One record by W. W. Price.

629 b. Plumbeous Tireo. Lanivireo solitarius plumbeus. One record by $\mathrm{H}$. W. Henshaw.

632 (part). Oberholser Vireo. Vireohuttoni oberholseri. Western San Diego County, north in the interior to the San Joaquin valley.

636. Black-Axd-White Warbler. Mniotilta varia. Rare migrant.

646. Western Orange-Crowned Warbler. Vermivora celata orestera. Rare migrant. 
647. Tennessee Warbler. Vermivora peregrina. One record by J. Grinnell.

652b. Alaska Iellow Warbler. Dendroicu astiva rubiyinosa. Migrant.

654. Black-throated Blue Wirbler. Dendroica corulescens cerrulescens. One recoud by W. E. Bryant.

657. Magxola Warbler. Dendroia megnoliu. Rare migrant.

672. Pala Warbler. Dendroica pelmurum palmarum. One record by W. O. Emerson.

675 a. Grixyell Water Thrush. Séurus noveboracensis notubilis. One record by L. Belding.

$681 a$. Western Yellowthroat. Geothlypis trichas vecilentulis. Summer visitant.

$681 c$ (part). San Diego Yellowthroat, Geothlypis trichus scirpicola. Extreme sonthern coast district.

681 e. Salt-Marsh Yeliowthroat. Geothlypis trichas sinuose. Resiclent at San Franciseo Bay.

687. American Redstart. Setopherye ruticillu. Two records by W. O. Emerson and L. Belling respectively.

704. Catbind, Inumetella curolinensis. One record by C. H. Townsend.

718. Bendire Thrasher. Torostoma bendirei. Occurs only in desert rerions of southeastern California.

715 (part). SAN Nicolas Rock Wren. Sulpinctes obsoletus pulverius. San Nicolats lskincl.

$719 a$ (part). SAx JoAQlin WREx. Thryomanes bruicki itrymocus. Revident in central part of state.

$719 a$ (part). SANTA ('Rl\% lsLaxi) WREx. Thryomumes bewicki nesophilus. Revilent on Santa Cru\% and santa Rosit Islamils.

719 b. Desert Wrex. Thryomanes bruicki eremuphilus. Resident along desert ranges in southeastern part of state.

719 l. SAx Dieso Wrex. Thryomanes beurich charienturus. Resiclent in Sam Diegran district.

719.1. San Clenexte: Wrex. Thrymumes bruirhi lencuphrys. Resident on San Clenente Islanul.

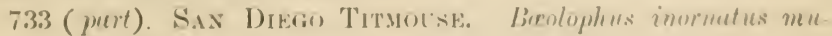
rinus. Southern Califoruia.

73:3a. Gray Titsoeses. Becolophus inornatus grisens. Resident along the desert ranges.

73ra. San Diego Chickanee. Penthestes gumluli baileme Southern part of State. 
741 b. Barlow Chickadee. Penthestes rufescens barlowi. Coast range of Central California.

$742 a$. Pallid Wren-tit. Chamcea fasciata henshawi. Interior districts of California.

742 b. Ruddy Wren-tit. Chamoea fasciata rufula. Central coast districts of California.

743. Bush-тiт. Psaltriparus minimus minimus. Entire coast district.

749 (part). Ruby-crowned Kinglet. Regulus calendula calendula. Winter visitor; perhaps resident in northern coast region.

749 a. Sitka Kinglet. Regulus calendula grinnelli. Winter visitant.

752. Plumbeous Gnatcatcher. Polioptila plumbea. Resident locally in the desert region of southeastern part of State.

758 a. Olive-BAck Thrush. Hylocichla ustulata swainsoni. Rare transient.

759. DWARf Hermit Thrush. Hylocichla guttata guttatu. Winter visitant.

759 (part). Monterey Hermit Thrush. Hylocichla guttata slevini. Ceutral coast district in summer.

763 a. Alaska rarifed Thrush. Ixoreus novius meruloides. Winter visitor.

$767 b$. San Pedro Bluebird. Sialia mexicana anabelae. The entire State, except northern coast region. 


\section{N D E X}

Accipiter cooperi, 143

velox, 142

Actitis macularia, 72

Echmophorus occidentalis, 82

Egralitis montana, 113

nivosa, 78

vocifera, 77

Aëronautes melanoleucus, 379

Agelaius gubernator californicus, 474

phoniceus neutralis, 470

tricolor, 475

sonoriensis, 473

Aimophila ruficeps, 239

Albatross, Black-footed, 17

Short-tailed, 18

Allen II ummingbird, 429

American Avocet, 60

Barn Ow], 166

IBittern, 90

Black Tern, 46

Coot, 107

Crow, 408

Dipper, 264

Eared Grebe, 84

Egret, 94

l.ong-eared Owl, 168

()sprey, 163

I'ipit, 262

liaven, 405

White Pelican, 53

Ammodramus beldingi, 217

rostratus, 218

sandwichensis alaudinus, 215 bryanti, 21\%;

savaunarum bimaiulatus, 219

Ampelis cedrorum, :2:!!

Amphispiza belli, 236

Ancient Murrelet, 7
Anna Hummingbird, 423

Anthony Green Heron, 96

Towhee, 250

Anthus pensilvanicus, 262

Aphelocoma californica, 490

Aquila chrysaëtos, 154

Archibuteo ferugineus, 153

Arctic Three-toed Woodpecker, 368

A rdea candidissima, 95

egretta, 94

herodias, 93

virescens antlionyi, 96

Ardetta exilis, 91

Arenaria melanocephala, 80

Arizona Hooded Oriole, 517

Arkansas Goldtinch, 528

Kingbird, 318

Ash-throated Flycatcher, 324

Ashy I'ctrel, 24

Asio accipitrinus, 169

wilsonianus, 168

Astragalinus lawrencei, 529

psaltria, 528

trist is salicamans, 525

Audubon Hermit Thrush, 307

Warbler, 538

Auklet, Cassin, 6

Rhinoceros, 5

A uriparus flaviceps, 554

Avocet, American, 60

Bamo Cormorant, 52

Balil liagle, 15t;

Band-tailed l'igeon, 130

Bauk Swallow, 3:34

Barn Swallow, 5(x)

Belding Marsh Sparrow, 217

Bell Sparrow, $2: 36$

Belted Kinglisher, 313 
Bicolored Blackbird, 474

Bittern, American, 90

Least, 91

Black-bellied Plover, 76

-billed Magpie, 383

-chinned Hummingbird, 417

Sparrow, 230

-crowned Night Heron, 97

-footed Albatross, 17

-headed Grosbeak, 253

-necked Stilt, 62

Oyster-catcher, 81

Petrel, 23

Rail, 104

Swift, 404

-tailed Gnatcatcher, 358

-throated Gray Warbler, 401

Turnstone, 80

-vented Shearwater, 20

Blackbird, Bicolored, 474

Brewer, 412

San Diego Red-winged, 470

Sonoran Red-winged, 473

Tricolored, 475

Yellow-headed, 508

Blue Crane, 93

-fronted Jay, 489

Bluebird, Mountain, 506

Western, 505

Bobolink, 390

Bonaparte Gull, 42

Bonasa umbellus sabini, 126

Botaurus lentiginosus, 90

Brachyramphus hypoleucus, 11

marmoratus, 10

Brandt Cormorant, 50

Brewer Blackbird, 412

Sparrow, 228

Bryant Marsh Sparrow, 216

Bubo virginianus pacificus, 173

Bullock Oriole, 519

Bunting, Lark, 396

Lazuli, 498

Burrowing Owl, 175

Bush-tit, Californian, 298

Lead-colored, 354

Buteo borealis calurus, 147

lineatus elegans, 149

swainsoni, 150
Cabaxis Woodpecker, 361

Cactus Wren, 276

Calamospiza melanocorys, 396

Calaveras Warbler, 533

Calidris arenaria, 68

Califoruia Brown Pelican, 55

Clapper Rail, 99

Cuckoo, 185

Gull, 39

Jay, 490

Murre, 13

Partridge, 118

Pine Grosbeak, 476

Poorwill, 192

Purple Finch, 478

Screech Owl, 171

Shrike, 337

Vulture, 134

Californian Bush-tit, 298

Chickadee, 353

Creeper, 293

Thrasher, 270

Towhee, 248

Woodpecker, 376

Calliope Hummingbird, 431

Calypte anna, 423

costæ, 420

Cañon Wren, 281

Carolina Rail, 102

Carpodacus cassini, 480

mexicanus frontalis, 481

purpureus californicus, 478

Cassin Auklet, 6

Kingbird, 322

Purple Finch, 480

Vireo, 448

Cathartes aura, 136

Catherpes mexicanus conspersus, 281

Cedar Waxwing, 259

punctulatus, 282

Centrocercus urophasianus, $12 ;$

Ceophlœus pileatus abieticola, 372

Cepphus columba, 12

Cerorhinca monocerata, 5

Certhia familiaris occidentalis, 293 zelotes, 293

Ceryle alcyon, 313

Chrtura vauxii, 317

Chamæa fasciata, 296 
Chamæa fasciata phæa, 302

Chat, Long-tailed, 549

Chestnut-backed Chickadee, 301

Chickadee, Californian, 353

Chestnut-backed, 301

Mountain, 350

Chondestes grammacus strigatus, 2.21

Chordeiles acutipennis texensis, 197

virginianus, 194

Cinclus mexicanus, 264

Circus hudsonius, 139

Cistothorus palustris paludicola, 289

Clarke Nutcracker, 329 plesius, 292

Cliff swallow, 256

Coast Wren-tit, 302

Coccothraustes vespertinus montanus, 523

Coccyzus americanus occidentalis, 185

Colaptes cafer collaris, 188

Columba fasciata, 130

Colymbus nigricollis californicus, 84

Condor, 134

Contopus borealis, 433

richardsonii, 202

Cooper IIawk, 143

Coot, American, 107

Cormorant, Baird, 52

Brandt, 50

Farallone, 48

Corvus americanus, 408

corax sinuatus, 405

cryptoleucus, 389

Costa Hummingbird, 420

Cowbird, 411

Crane, lilue, 9:3

Sandhill, 98

('reeper, Californian, 293

Sierra, 2933

('rissal Thrasher, 274

Crossbill, Mexican, 483

(row, Auserican, 408

C'uckon, C'ulifurnia, 185

Curlew, Iludsonian, 75

Jack, 75

Long-billed, 73

sickle-billed, 73

Cyanocephalus cyanocephalus, 493

Cyanocitta stclleri, 485
Cyanocitta stelleri frontalis, 489

Cyanospiza amœna, 498

Cypseloides niger borealis, 404

DARk-BODIEn Shearwater, 21

Dendragapus obscurus fuliginosus, 124

Dendroica astiva, 535

auduboni, 538

coronata, 537

nigrescens, 401

occidentalis, 542

townsendi, 540

Desert Horned Lark, 204

Song Sparrow, $2 \notin 0$

Sparrow Hawk, 161

Diomedea albatrus, 18

nigripes, 17

Dipper, American, 264

Dolichonyx oryzivorus, 390

Dotted Cañon Wren, 282

Dove, Mourning, 132

Dowitcher, Long-billed, 63

Dryobates nuttallii, 364

pubescens gairdnerii, 363

villosus harrisii, 360 hyloscopus, 361

Duck Hawk, 158

Dusky Poorwill, 192

Warbler, 457

Dwarf Hermit 'Tlırush, 309

EAgit., Bald, 156

Golden, 154

Egret, American, 94

Elanus leucurus, 138

Empidonax difficilis, 436

hammondi, $4+1$

traillii, 439

wrightii, 442

Eremnetes nccidentalis, $6 \pi$

Fatco columbarius, 159

mexicanus, 145

peregrinus anatum, 15s

sparverius deserticola, 161

Falcon, Prairie, 145

Farallone Cormorant, 48

ferruginous Rongh-leg, 15:3

Finch, Califoruia Purple, 478

Cassin Purple, 480 
Finch, House, 481

Pine, 211

Fish Hawk, 163

Flicker, Red-shafted, 188

Florida Gallinule, 105

Flycatcher, Ash-throated, 324

Hammond, 441

Olive-sided, 433

Traill, 439

Vermilion, $466^{\circ}$

Western, 436

Wright, 442

Forster Tern, 44

Fregata aquila, 26

Fulica americana, 107

Fulmar, Pacific, 19

Fulmarus glacialis glupischa, 19

Gairdner Woodpecker, 363

Gallinago delicata, 111

Gallinula galeata, 105

Gallinule, Florida, 105

Gambel Partridge, 122

Sparrow, 224

Gavia imber, 27

lumme, 31

pacifica, 30

Geococeyx californianus, 181

Geothlypis tolmiei, 545

trichas arizela, 546

Gila Woodpecker, 378

Glaucidium gnoma, 178

Glaucous-winged Gull, 32

Gnatcatcher, Black-tailed, 358

IVestern, 356

Golden-crowned Sparrow, 225

Eagle, 154

Goldfinch, Arkansas, 528

Lawrence, 529

Willow, 525

Gray-crowned Leucosticte, 209

Vireo, 454

Great Blue Heron, 93

Greater Yellow-legs, 69

Grebe, American Eared, 84

Pied-billed, 86

Western, 82

Green-tailed Towhee, 251

Grosbeak, Black-headed, 253
Grosbeak, California Pine, 476

Western Blue, 496

Western Evening, 523

Grouse, Oregon Ruffed, 126

Sage, 127

Sooty, 124

Grus mexicana, 98

Guillemot, Pigeon, 12

Guiraca cærulea lazula, 496

Gull, Bonaparte, 42

California, 39

Glaucous-winged, 32

Heermann, 41

Herring, 37

Ring-billed, 40

Western, 34

Gymnogy ps californianus, 134

HæMatopus bachmani, 81

Haliæëtus leucocephalus, 156

Hammond Flycatcher, 441

Harris Woodpecker, 360

Hawk, Cooper, 143

Desert Sparrow, 161

Duck, 158

Fish, 163

Marsh, 139

Pigeon, 159

Red-bellied, 149

Sharp-shinned, 142

Swainson, 150

Heerman Song Sparrow, 243

Heermann Gull, 41

Heleodytes brumneicapillus, 276

Helminthophila celata lutescens, 455 sordida, 457

rubricapilla gutturalis, 533

Hermit Warbler, 542

Heron, Anthony Green, 96

Black-crowned Night, 97

Great Blue, 93

Snowy, 95

Herring Gull, 37

Heteractitis incanus, 71

Himantopus mexicanus, 62

Hirundo erythrogastra, 500

House Finch, 481

Hudsonian Curlew, 75

Hummingbird, Allen, 429 
Hummingbird, Anna. 423

Black-chinned, 417

Calliope, 431

Costa, 420

Rufous, 426

- Hutton Vireo, 451

Ilydrochelidon nigra surinamensis, 46 Hylocichla guttata auduboni, 307 nana, 309

ustulata, 306

Ists, White-faced Glossy, 88

Icteria virens longicauda, 549

Icterus bullocki, 519

cucullatus nelsoni, 517

parisorum, 514

Interior Tule Wren, 292

Intermediate Sparrow, 224

Ixoreus navius, 311

Jack Curlew, 75

Jaeger, Parasitic, 16

Jay, Blue-fronted, 489

California, 490

Oregon, 327

Piñon, 493

Steller, 485

Junco hyemalis oregonus, 333

pinosus, 234

thurberi, 231

Oregoll, 333

I'oint P'inos, 234

Sierra, 231

Thurber, $2: 31$

Kaeding Petrel, 22

Killdeer, 77

Kinghird, Arkansas, 318

Cassin, 322

Kinglisher, Belted, 313

Kinglet, Ruhy-crowned, 459

Western (iolden-crowned, 458

Kite, White-tailed, 138

LAxics ludovicianus excubitorides, $336 ;$

Large-billed Sparrow, 218

cambeli, $3: 37$

Lark Bunting, 396
Lark, Desert IJorned, 204

Mexican Horned, 208

Pallid Horned, 204

Ruddy Horned, 208

Streaked Horned, 209

Sparrow, Western, 221

Larus argentatus, 37

californicus, 39

delawarensis, 40

glaucescens, 32

heermanni, 41

occidentalis, 34

philadelphia, 42

Lawrence Gold finch, 529

Lazuli Bunting, 498

Lead-colored Bush-tit, 354

Least Bittern, 91

Sandpiper, 65

Tern, 45

Vireo, 453

Leconte Thrasher, 273

Leucosticte, Gray-crowned, 209

tephrocotis, 209

Lewis Woodpecker, 465

Lincoln Sparrow, 244

Linnet, 481

Long-billed Curlew, 73

Dowiteher, 63

-tailed Chat, 549

Loon, 27

Pacilie, 30

Red-throated, 31

Lophortyx californicus, 118

rallicola, 120

gambeli, 122

Louisiana Tanager, 5:30

Loxia curvirostra strick landi, 48:3

Luıda cirrhata, 3

Lutescent Warbler, 455

Macgilliviuy Warbler, 545

Macrorhamphus scoloplaceus, 6.3

Magpie, Black-billetl, 383

Yellow-billed, 387

Man-o'-W ar Bird, 26

Marbled Murrelet, 10

Marsh IIawk, 139

Martin, Wistern, 415

Meadow Oxeye, 65 
Meadowlark, Western, 511

Megascops asio bendirei, 171

Melanerpes formicivorus bairdi, 376 torquatus, 465 uropygialis, 378

Melospiza lincolnii, 244 melodia fallax, 240 heermanni, 243 montana, 242 morphna, 244 samuelis, 243

Merula migratoria propinqua, 309

Mexican Crossbill, 483

Horned Lark, 208

Mimus polyglottos leucopterus, 340

Mockingbird, Western, 340

Molothrus ater, 411

Mountain Bluebird, 506

Chickadee, 350

Partridge, 114

Plover, 113

Song Sparrow, 242

Mourning Dove, 132

Mud-lien, Red-billed, 105

Murre, California, 13

Murrelet, Ancient, 7

Marbled, 10

Xantus, 11

Myadestes, townsendii, 303

Myiarchus cinerascens, 324

Myrtle Warbler, 537

Nighthawk, 194

Texan, 197

Northern Pileated Woodpecker, 372

Violet-green Swallow, 445

Nucifraga columbiana, 329

Numenius hudsonicus, 75

longirostris, 73

Nutcracker, Clarke, 329

Nuthatch, Pygmy, 345

Red-breasted, 344

Slender-billed, 342

Nuttall Sparrow, 225

Wood pecker, 364

Nycticorax nycticorax nævius, 97

OCEANODROMA homochroa, 24

Kaedingi, 22

melania, 23
Olbiorchilus hiemalis pacificus, 287

Olive-sided Flycatcher, 433

Olor buccinator, 57

columbianus, 56

Oregon Jay, 327

Junco, 333

Ruffed Grouse, 126

Towhee, 394

Oreortyx pictus, 114

Oreospiza chlorura, 251

plumiferus, 115

Oriole, Arizona Hooded, 517

Bullock, 519

Scott, 514

Oroscoptes montanus, 268

Osprey, American, 163

Otocoris alpestris chrysolæma, 208 leucolæma, 204 rubea, 208 strigata, 209

Ouzel, Water, 264

Owl, American Barn, 166

Lorig-eared, 168

Burrowing, 175

California Screech, 171

Pacific Horned, 173

Pygmy, 178

Short-eared, 169

Ox Bird, 66

Oxeye, Meadow, 65

Oyster-catcher, Black, 81

PACific Fulmar, 19

Horned Owl, 173

House Wren, 285

Loon, 30

Yellow-throat, 546

Pallid Horned Lark, 204

Wren-tit, 296

Pandion haliaëtus carolinensis, 163

Parasitic Jaeger, 16

Parkman Wren, 285

Partridge, California, 118

Gambel, 122

Mountain, 114

Plumed, 115

Valley, 120

Parus gambeli, 350

inornatus, 348 
Parus rufescens, 301

Passadena Thrasher, 272

$$
\text { neglectus, } 353
$$

Passerella iliaca megarhyncha, 247

stephensi, 248

unalaschcensis, 245

Pelecanus californicus, 55 erythrorhynchos, 53

Pelican, American White, 53 California Brown, 55

Perisoreus obscurus, 327

Petrel, Ashy, 2!

Black, 23

Kaeding, 22

Petroclselidon lunifrons, 256

Pewee, Western Wood, 202

Phainopepla, 398

$$
\text { nitens, } 398
$$

Phalacrocorax dilophus aibociliatus, 48

pelagicus resplendens, 52 penicillatus, 50

Phalænoptilus nuttalli californicus, 192

Phalarope, Wilson, 58

Phobe, Say, 199

Western Black, 381

Pica nuttalli, 387 pica hudsonica, 383

Picoides arcticus, 368

Pied-billed Grebe, 86

Pigeon, Band-tailed, 130

Guillemot, 12

llawk, 159

Pileolated Warbler, 552

Pine Fiıch, 211

Siskin, 211

Pinicola enucleator californica, 476

Piñon Jay, 493

Pipilo fuscus crissalis, 248 senicula, 250

maculatus megalony $x, 393$

Pipit, American, 262 oregonus, 394

Piranga ludoviciann, 530

Plain Titmouse, 348

P'legadis guarauna, 88

I'lover, Black-bellied, 76

Mountain, 113
Plover, Snowy, 78

Plumed l'artridge, 115

Podilymbus podiceps, 86

Point Pinos Junco, 234

Polioptila cærulea obscura, 356 californica, 358

Poœecetes gramineus confinis, 213

Poorwill, California, 192

Dusky, 192

Porzana carolina, 102 jamaicensis, 104

Prairie Falcon, 145

Progne subis hesperia, 415

Psaltriparus minimus californicus, 298 plumbeus, 354

Ptychoramphus aleuticus, 6

Puffin, Tufted, 3

Puffinus griseus, 21 opisthomelas, 20

Pyginy Nuthatch, 345 Owl, 178

Pyrocephalus rubineus mexicar'us, 466

RaIL, Black, 104

California Clapper, 99

Caroliua, 102

Virginia, 101

Rallus obsoletus, 99 virginianus, 101

Raven, American, 405

White-necked, 389

Recurvirostra americana, 60

Red-backed Sandpiper, 66

-bellied Hawk, 149

-billed Mul-lien, 105

-breasted Nutlatch, 344

Silpsucker, 462

-shafted Flicker, 188

-tailed Hawk, Westeru, 147

-throated Loon, 31

Regulus caleudula, 45!?

satrapa olivaceus, 458

Rhinoceros Auklet, 5

Ring-billed Gull, \&!

Riparia riparia, 334

Rinad-runtuer, 181

Robin, Western, 309

liuck Wren, 279 
Rough-leg, Ferruginous, 153 -winged Swallow, 258

Royal Tern, 43

Ruby-crowned Kinglet, 459

Ruddy Horned Lark, 208

Rufous-crowned Sparrow, 239

Hummingbird, 426

Russet-backed Thrush, 306

Rusty Song Sparrow, 244

SAGE Grouse, 127

Sparrow, 237

Thrasher, 268

Salpinctes obsoletus, 279

Samuels Song Sparrow, 243

San Diego Red-winged Blackbird, 470

Sanderling, 68

Sandhill Crane, 98

Sandpiper, Least, 65

Red-backed, 66

Spotted, 72

Western, 67

Sapsucker, Red-breasted, 462

Williamson, 370

Say Phœbe, 199

Sayornis nigricans semiatra, 381 saya, 199

Scolecophagus cyanocephalus, 412

Scott Oriole, 514

Selasphorus alleni, 429 rufus, 426

Sharp-shinned Hawk, 142

Shearwater, Black-vented, 20 Dark-bodied, 21

Short-eared Owl, 169 -tailed Albatross, 18

Shrike, California, 337 White-rumped, 336

Sialia arctica, 506 mexicana occidentalis, 505

Sickle-billed Curlew, 73

Sierra Creeper, 293

Hermit Thrush, 307

Junco, 231

Siskin, Pine, 211

Sitta canadensis, 344 carolinensis aculeata, 342 pygmæa, 345

Slender-billed Nuthatch, 342
Snipe, Wilson, 111

Snowy Heron, 95

Plover, 78

Solitaire, Townsend, 303

Sonoran Red-winged Blackbird, 473

Sooty Grouse, 124

Sora, 102

Sparrow, Belding Marsh, 217

Bell, 236

Black-chinned, 230

Brewer, 228

Bryant Marsh, 216

Desert Song, 240

Gambel, 224

Golden-crowned. 225

Heerman Song, 243

Intermediate, 224

Large-billed, 218

Lincoln, 244

Mountain Song, 242

Nuttall, 225

Rufous-crowned, 239

Rusty Song, 244

Sage, 237

Samuels Song, 243

Stephens, 248

Thick-billed, 247

'Townsend, 245

Western Chipping, 227

Grasshopper, 219

Lark, 221

Savanna, 215

Vesper, 213

White-crowned, 222

Speoty to cumicularia hypogæa, 175

Sphyrapicus ruber, 462

thyroideus, 370

Spinus pinus, 211

Spizella atrigularis, 230

breweri, 228

socialis arizonæ, 227

Spotted Sandpiper, 72

Spurred Towhee, 393

Squatarola, 76

Steganopus tricolor, 58

Stelgidopteryx serripennis, 258

Steller Jay 485

Stellula calliope, 431

Stephens Spar row, 248 
Stercorarills parasiticus, 16

Sterna antillarum, 45

forsteri, 44

maxima, 43

stilt, Black-necked, 6:2

Streaked Horned Lark, 209

Strix pratincola, 166

Sturnella magua neglecta, 511

Swainson Hawk, 150

Swallow, Bank, 334

Barn, 500

Cliff, 256

Northern Violet-green, 445

liougl-winged, 258

Tree, 502

White-bellied, 502

Swan, Trumpeter, 57

Whistling, 56

Swift, Black, 404

Vaux, 317

White-throated, 379

Synthliboramphus antiquus, 7

TAcurcisfes bicolor, 502

thalassina lepida, 445

Tanager, Louisiana, 530

W'estern, 530

Tattler, Wandering, it

Term, American Black, 46

Forster, 44

l.east, 45

lioval, 43

Texan Nightlawk, 197

Thick-billed Syarrow, 247

Thrasher, C'alifornian, 270

C'rissul, 2it

Leconte, 273

l'asadena, 2i:2

Sage, $21 ; 8$

Thrush, Andubon Ilermit, 307

Dwarf Hermit, 309

liusset-backed, 3ufi

Sierra Hermit, 307

Varied, 311

Thryomanes bewickii spilurus, $2 \mathrm{st}$

Thurber Juneo, 2:31

'Titmonse, Jhin, 348

Totauus melanoleucus, 69

Towhere, Anthony. 25t)
Towhee, Californian, 248

Green-tailed, 251

Oregon, 394

Spurred, 393

Townsend Sparrow, 245

Solitaire, 303

Warbler, 540

Toxostoma erissalis, $2 \pi t$

lecontei, 273

redivivum, 270

pasadenense, 272

Traill Flycatcher, 439

Tree Swallow, 502

Tricolored Blackbird, 475

Tringa alpina pacifica, 66 ; minutilla, 65

Trochilus alex:mdri, 417

Troglodytes aëdon parkmanii, 285

Trumpeter Swan, 57

Tufted P'uftin, 3

Tule Wren, 289

Turkey Vulture, 136

Turnstone, Black, 8)

Tyrannus verticalis, 318

vociferans, $32: 2$

Uıia troile Californica, 13

VAldeY Partridge, 120

Varied Thrush, 311

Vaux Swift, 31T

Verdin, 554

Vermilion Flycatcher, 466

Vigors Wren, 284

Vireo, Cassin, \&\$S

grilvus, 447

Gray, 454

[1utton, 45]

huttoni, t5)

least, 45is

pusillus, tisis

solitarius can-mii, $\$+8$

vicinior, fist

Warbling, $+4 i$

Virgina Rail, 101

Vulure, Californiu, l:34

Turkery, 1isti

Wasur.usc: Tutuler, 71

Warbler, Audubon, 53. 
Warbler, Black-throated Gray, 401

Calaveras, 533

Dusky, 457

Hermit, 542

Lutescent, 455

Macgillivray, 545

Myrtle, 537

Pileolated, 552

Townsend, 540

Yellow, 535

Yellow-rumped, 537

Warbling Vireo, 447

Wrater Ouzel, 264

Waxwing, Cedar, 259

Western Black Phœbe, 381

Blue Grosbeak, 496

Bluebird, 505

Chipping Sparrow, 227

Evening Grosbeak, 523

Flycatcher, 436

Gnatcatcher, 356

Golden-crowned Kinglet, 458

Grasshopper Sparrow, 219

Grebe, 82

Gull, 34

Lark Sparrow, 221

Marsh Wren, 292

Martin, 415

Meadowlark, 511

Mockingbird, 340

Red-tailed Hawk, 147

Robin, 309

Sandpiper, 67

Savanna Sparrow, 215

Tanager, 530

Vesper Sparrow, 213

Winter Wren, 287

Wood Pewee, 202

Whistling Swan, 56

White-bellied Swallow, 502

-crowned Sparrow, 222

-faced Glossy Ibis, 88

-headed Woodpecker, 366

-necked Raven, 389

-rumped Shrike, 336

-tailed Kite, 138

-throated Swift, 379
Williamson Sapsucker, 370

Willow Goldfinch, 525

Wilson Phalarope, 58

Snipe, 111

Wilsonia pusilla pileolata, 552

Woodpecker, Arctic Three-toed, 368

Cabanis, 361

Californian, 376

Gairdner, 363

Gila, 378

Harris, 360

Lewis, 465

Northern Pileated, 372

Nuttall, 364

White-headed, 366

Wren, Cactus, 276

Cañon, 281

Dotted Cañon, 282

Interior Tule, 292

Pacific House, 285

Parkman, 285

Rock, 279

Tule, 289

Vigors, 284

Western Marsh, 292

Western Winter, 28 '

Wren-tit, Coast, 302

Pallid, 296

Wright Flycatcher, 442

Xanthocephalus xanthocephalus, 508

Xantus Murrelet, 11

Xenopicus albolarvatus, 366

YELlow-BILled Magpie, 387

-headed Blackbird, 508

-legs, Greater, 69

-rumped Warbler, 537

-throat, Pacific, $5+6$

Warbler, 535

ZAмelodia melanocephala, 253

Zenaidura macroura, 132

Zonotrichia coronata, 225

leucophrys, 222

gambelii, 224

nuttalli, 225 


\section{THE YOUNG BIRDS OF ILLINOIS}

MRS. WHEELOCK'S EARLIER WORK

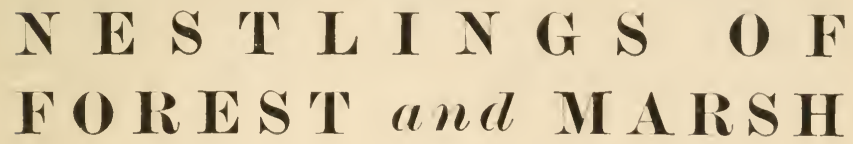

BY

IRENE GROSVENOR WHEFI,OCK

Author of "Birds of California"

Beantifully illustrated with twelle full-page photograrares and about fifty alicate half-tones in the text from origimal photogreples.

'This rolume is a capital one for the lorer of things out of doors, of the woods and the fields, and particularly of the birds, and will furnish abundant suggestions for original field work.

"Her studies have been made in the vicinity of Chicago, and she has evidently had unusually good opportunities to observe certain species - opportunities of which she has availed herself so effectively that her book rontains much that is novel."-Bird-Lore, New York.

"The numerous illustrations of nests and nestlings add greatly to the realism of her graphically related experiences in the field, and combine with the text to render her book especially attractive as a popular contribution to the life history of some of our commoner birds." - The A $u k$, New York.

"Mrs. Wheelock would seen to have the magic touch in taming the shyest and rarest. She has a host of incidents at command and illustrates her pleasant narrative with many illustrations direct from nature. The volume is a delightful addition to the library of the bird student and lover."-I'hiladelphia Publir Leslyer.

A. ('. MCCLURG E COMI'ANI, PUBtishers 


\section{BIRDS of THE ROCKIES} WITH CHECK LIS'T OF COLORADO BIRDS BY

\section{DR. IEANDER S. KEYSER}

Author of "In Bird Land"

With eight full-page biral portraits (four in color) by Louis Agussiz Fuevtes; thirty-three text aravings by Bruce Horsfull; eight photographic vieus of momtain scenery showing the habitats of the birds, and an elabovite index.

In Mr. John Burroughs' recent paper in The Atlantic Monthly, on "Real and Sham Natural History," he said: "Mr. Leander $\mathrm{S}$. Keyser's 'Birds of the Rockies' tells me just what I want to know about the Western birds - their place in the landscape and in the season, and how they agree with and differ from our Eastern species. Mr. Keyser belongs to the noble order of walkers and trampers, and is a true observer and bird-lover."

" The book is beautifully illustrated. . . . Mr. Keyser is an intelligent observer and has a good general knowledge of his subject. ... A book that is well worthy of extended sale, and which occupies a hitherto somewhat neglected field in the list of popular bird books." - Dr. J. A. Allen, in The Auk, New York.

" Mr. Keyser abandoned himself to the fascination of bird-study on plains and foothills, mountain parks and peaks, and his recountal of his experiences cannot fail to arouse the spirit of desire in the minds of those who follow his pages. The book possesses scientific as well as literary value."-Frank 1I. Chapman, in Bird-Lore, New York.

\section{PIRICE, \$1.50}

A. C. McClutg E COMPANy, Pubishers 





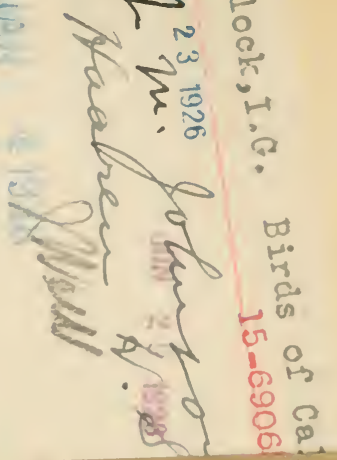


AMNH LIBRARY 